



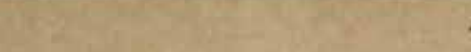




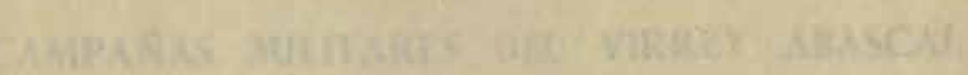





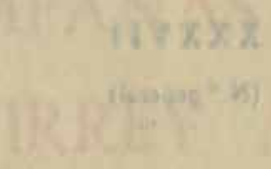

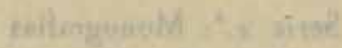

134.4

CAMPAÑAS MILITARES DEL VIRREY ABASCAL

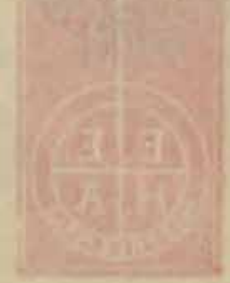


PUBLICACIONES DE LA

ESCUELA DE ESTUDIOS HISPANO-AMERICANOS

DE SE VIL L A

\author{
XXX X I I \\ (N. ${ }^{\circ}$ general) \\ Serie 2.": Monografías \\ N. ${ }^{\circ}$ I I
}

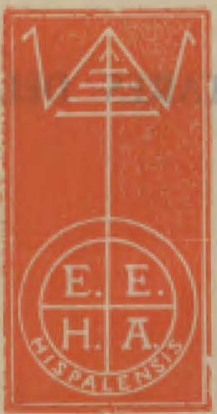

Las noticias, asertos y opiniones contenidas en este trabajo, son de la exclusiva responsabilidad del autor. La Escuela de Estudios Hispano-Americanos sólo responde del interés científico de sus publicaciones. 
FER A NDO DÍAZ VENTEO

\section{LAS CAMPAÑAS MILITARES DEL VIRREY ABASCAL}
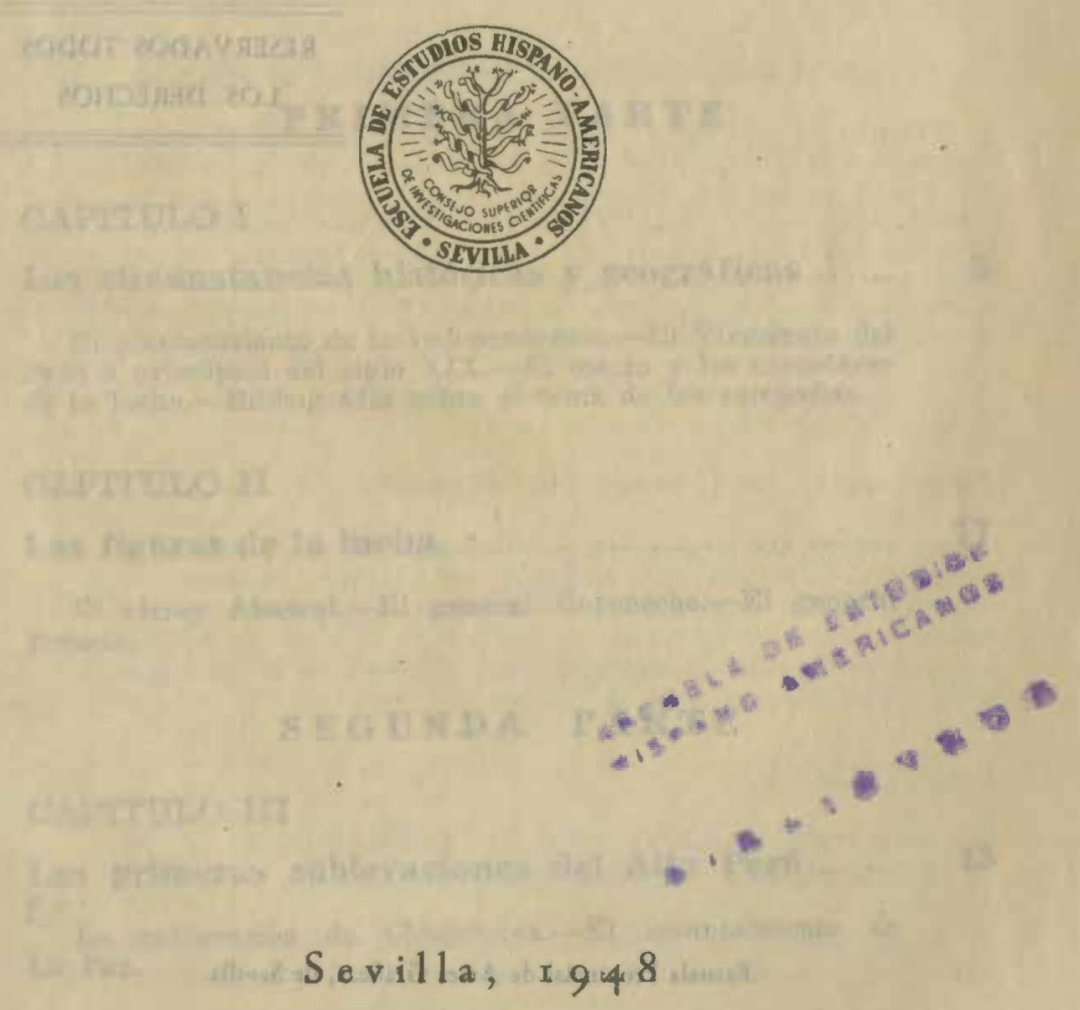
0. Primera edición; junio de 1948 .

Con doce ilustraciones.

\section{3ЯATIIIN. 2AЙA9MAD 2A.

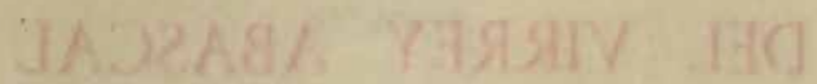

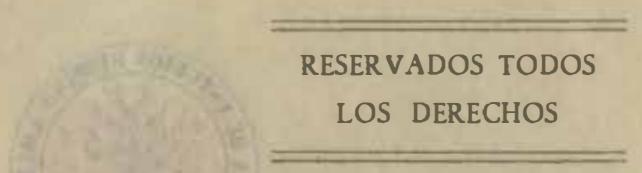

Escuela Provincial de Artes Gráfiçs, de Scvilla. 


\section{N D I C E}

\section{PRIMERA PARTE}

\section{CAPITULO I}

Las circunstancias históricas y geográficas... ...

El planteamiento de la Independencia.-El Virreinato del Perú a principios del siglo XIX.-El teatro y los caracteres de la lucha.-Bibliografía sobre el tema de las campañas.

\section{CAPITULO II}

Las figuras de la lucha... ... ................ 17

El virrey Abascal.-El general Goyeneche.-El general Pezuela.

\section{SEG U N DA PARTE}

\section{CAPITULO III}

Las primeras sublevaciones del Alto Perú... ...

La sublevación de Chuquisaca.-El levantamiento de La Paz.

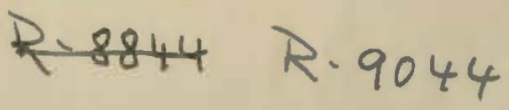




\section{CAPITULO IV}

Las revoluciones de Quito... ...............

Creación de la Junta de Quito.-La noticia de la revolución en Lima.-Medidas de Abascal.-La expedición de Arredondo.-Cambio de conducta de los quiteños.-Entrada de Arredondo en Quito.-Manejos de Cucalón.-Motín del 2 de agosto de 1810.- Junta del 5 de agosto.-El comisionado Montúfar: creación de la nueva Junta de Quito.-Actitud de Abascal.-El Presidente Molina en Guayaquil.-Preparativos hostiles.-Fracaso de la misión de Villalba en Quito.-Misión de Bejarano.-Comienzo de la lucha.-Ataque quiteño a Cuenca: reacción de los conquenses.-Abascal critica a Molina.-La lucha en el Norte: encuentro del río Palacé.Heroica resistencia de Tacón.-Nuevos preparativos de Molina.-Combates con los quiteños.-Desórdenes en Quito.Expedición de Montes: ocupación de Quito.-Fin de la revolución.

\section{CAPITULO V}

La invasión del Alto Perú: Cotagaita y Suipacha.

Triunfo de la Revolución en Buenos Aires: eel Ejército auxiliador» del Alto Perú.-La organización de la defensa del Perú: planes de Abascal.-La conspiración de Córdoba y el fracaso de Liniers.-El crrer de Nieto.-Creación del Ejército del Desaguadero.- La expedición de Balcarce.-Contratiempo de Ramírez: Aroma.-Cotagaita. - Suipacha.Ocupación del Alto Perú por los argentinos.-Acuerdo entre los realistas y el Cabildo de La Paz,- La conducta de Castelli.

\section{CAPITULO VI}

La ofensiva de Goyeneche: Huaqui... ............

La región del Desaguadero.-Posición de las fuerzas de Goyeneche.-Intento de dimisión del General.-Ideas de Abascal sobre la situación.-Incidentes entre realistas y porteños.-Negociaciones de Castelli y el Cabildo de Lima: conclusión del armisticio.-Su anulación.-Batalla de Huaqui.- ¿Fué Huaqui una infracción del armisticio?

\section{CAPITULO VII}

La segunda sublevación de Cochabamba y la pacificación del Alto Perú................

Consecuencias de la batalla de Huaqui.-Avance de Goyeneche por el Alto Perú: instrucciones de Abascal.-Bata- 
lla de Sipe-Sipe y ocupación de Cochabamba.-Nueva amenaza en el Alto Perú: la sublevación de indios en La Paz.Avance realista hasta Tupiza -Segunda sublevación de Cochabamba.-Situación de las fuerzas de Goyeneche.-La lucha en la frontera argentina: la seeunda batalla de Suipacha.-Repercusión en Lima del armisticio de Elío con la Junta de Buenos Aires.-Planes de Abascal ante la nueva sitųąción.-Campaña contra Cochabamba: acción del Queñual.-Ocupación y pacificación de la ciudad.

\section{CAPITULO VIII}

La expedición al Tucumán... . . . . . . . . . . . .

Situación apurada de Abascal: sus medidas para hacer frente a la crisis.-Avance de Tristán hacia Salta.-Acción del Río de las Piedras: sus tres etapas.-El plan de Tristán.-Batalla del Tucumán: retirada realista.-Consecuen- cias de la batalla: sublevación de Salta.-Fracaso de la expedición al Tucumán.-Medidas y plan de campaña de Abascal.-Quejas de Goyęneche.-Intentos de negociación: la misión de Pớrì en Lima.

\section{CAPITULO IX}

\section{La batalla de Salta y la sustitución de Goyeneche}

El repliegue de Tristán a Salta.-Valor estratéfico de esta provincia.-Preparativos argentinos.-Incompatibilidad de Goyeneche con Ramírez.-Batalla de Salta: capitulación de Tristán.-Goveneche evacua Potosí.-Sorpresa de Abascal: censura del plan de Goyeneche.-Junta de Guerra de 1 de abril de 1813 en Lima.-El cese de Goyeneche como jefe del ejército del Alto Perú.-Junta de Guerra de 8 de abril de 1813 en Lima.-Tirantez de relaciones entre Absscal y Goyeneche.

\section{CAPITULO X}

\section{Pezuela al frente del ejército: Vilcapugio y Ayo-} huma... ...........................

Junta de Guerra de 25 de abril de 1813 en Oruro.-La situación del ejército pintada por Ramirez.-Junta de Guerra de 6 de mayo.-Goyeneche entrega e! mando del ejército a Ramirez.-Actitud de los jefes.-Henestrosa, designado para el mando de las fuerzas del Alto Perú.-Inconvenientes para su marcha.-Henestrosa es sustituido por Pezuela.-Ramirez, jefe interino del ejército: motín del 10 de mayo.-Avance a Sorasora y Condocondo.-El viaje de Pezuela: sus ideas 
sobre la situación militar-Ramírez se retira a Challapata. -Pezuela, al frente del ejército.--Vilcapugio.-La sitaación subsiguiente a la batalla.-Ayohuma.-Consecueincias de ambas batallas.

\section{CAPITULO XI}

La liberación del Alto Perú: Wiluma... .........

La retirada argentina después de Ayohuma.-Nuevo carácter de la guerra en el Alto Perú.-Expedicí́n contra Cochabamba. - La campaña contra Arenales. - Belgrano abandona el mando del ejército argentino.- San Martín sucede a Belgrano.-Avance de Ramírez hacia Salta: expediciones de reconocimiento.-Se agrava la situación: rendición de Montevideo y sublevación del Cuzco.-Rondeau sustituye a San Martín: preparativos argentinos.-Negociaciones de Pezuela con Rondeau: engaño del coronel Rodríguez.-Repliegue de Pezuela.-Arenales ocupa Cochabamba. - Incertidumbre de Pezuela.-Cambic de destino de la expedición de Morillo: sus consequencias.-Examen de la situación por Pezuela.-Encuentro de Venta y Median-Ofensiva realista.-Batalla de Wiluma: sus consecuencias.

\section{CAPITULO XII}

La revolución de Chile: Rancagua... ... ........

Situación política de Chile al comenzar la revolución.Triunfo de la revolución.-Enerhistad entre los partidos:" escisión en el bando revolucionario.-Actitud de Abascal.Expedición de Pareja: encuentro de Yerbas Buenas.-Retirada de Pareja a Chillán.-Fracaso de Carrera ante la ciudad.-Cambios operados en el eampo chilleno.-Expedición de Gaínza: instrucciones de Ábascal.-Avance de Gaínza sobre Santiago: su retirada a Talca_-La misión de $\mathrm{Hy}$ lliar.-Negociaciones de Gaínza con O'Higgins. - Tratado de Lircay.-Gaínza, desautorizado por Abascal.-Expedición de Osorio: instrucciones del Virrey.-Triunfo de Carrera en Santiago: acuerdo con O'Higgins.-Osorio ante Rancagua: derrota chilena.-La desobediencia de Osorio.-Situación de Chile después de la victoria realista.

Fuentes y bibliografia... $\ldots \ldots \ldots \ldots \ldots, \ldots \ldots$ 


\section{PRIMERA PAR TE}


उTY 


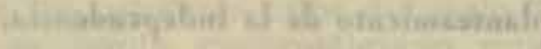

\section{CAPITULO I}

\section{CIRCUNSTANCIAS HISTÓRICAS Y GEOGRÁFICAS}

Antes de iniciar el estudio monográfico de las campañas militares del virrey Abascal, juzgo indispensable trazar un cuadro de conjunto sobre las circunstancias históricas y geográficas dentro de las cuales se desarrollan dichas campañas. Sin esa previa exposición general, los hechos bélicos que voy a exponer no podrian ser exactamente valorados, ni, en algún caso, objeto de adecuada comprensión.

Toda guerra no es sólo un conjunto de batallas. Responde a determinados fines o motivos, y debe las peculiaridades de su planteamiento y desarrollo a especiales circunstancias politicas, económicas, geográficas y cronológicas. Por tanto, en el caso de que voy a ocuparme, será necesario penetrar el sentido general de las guerras de Emancipación, el escenario geográfico sobre el cual se desarrollan, y los medios con que cuenta Abascal para mantener la lucha.

El empeño resultaría arduo si pretendiese en estas páginas revisar el problema de la Independencia Hispanoamericana, tan complejo, o investigar la situación del virreinato peruano a principios del siglo XIX, 
cosas ambas a mi juicio necesarias, pero que estarian aquí fuera de lugar. Me limitaré por lo tanto a esbozar un ligero resumen, sin más pretensiones que la de servir de introducción al tema del libro; y encuadrarlo en el conjunto de hechos históricos de que forma parte.

\section{El planteamiento de la Independencia.}

Hoy está claro que la Independencia fué un problema típica y netamente español. En su génesis, no juega un papel decisivo la ideología de la Enciclopedia -que echa raíces en América (1), mas no pasa de informar la mentalidad de una minoria revolucionaria, pero sin fuerza-, sino las doctrinas tradicionales españolas (2). En su desarrollo, tampoco es factor esencial la ayuda proporcionada a los sublevados por Inglaterra y Estados Unidos, aunque no carece de importancia ni en el aspecto militar ni en el diplomático.

El hecho de la Emancipación es, con palabras de Santiago Estrada, «la muerte del Imperio, o si se prefięre, la muerte del ideal que informó al Imperio» (3). Responde a un problema general del conjunto político hispano, nunca a cuestiones exclusivas de las provincias ultramarinas, donde se desarrolla. En este sentido, ni ciertas reformas de Carlos III que pudieron herir sentimientos de los criollos, ni una serie de cuestiones sociales o económicas que podían enfrentar a

(1) BASTERRA, Lo8 navios de la Ilustración. Caracas, 1925; pág. 91. - GARCIA ESCUDERO, Un viraje en la interpretación de ta Independencia americana, en Revista de Estudios Polfticas. Madrid, V, núm. 10, 1943; pág. 473.

(2) GIMENEZ FERNANDEZ, Manuel. Las doctrinas populistas en la independencia de Hispanoamérica. Escuela de Estudios Hispano-Americanos. Sevilla, 1947. - La población americana mostró clara y espontáneamente en diversas acasiones su repulsión a las ideas revolucionarias extranjeras,

(3) FSTRADA. Santiago. ..., Y la casa fué destruida. Revista Sol $y$ Luna, núm. 5. Buenos Aìreś, 1940; pág: 46. 
éstos con los españoles peninsulares, deben considerarse como factores determinantes de la Independencia; en todo caso, actuaron con más o menos fuerza para acelerarla o consolidarla (4).

La Emancipación tiene raíces más hondas. Imperio tan diversificado como el español, se mantuvo gracias a una estrecha unidad de ideales, y había de disgregarse tan pronto esta unidad se rompiera. En el orden político, ese ideal común era la monarquia; durante los primeros años del siglo XIX, dicha institución se habia desprestigiado mucho en España, mientras que en América, más apegada a las tradiciones y de ambiente más conservador, estaba muy vivo el sentimiento de fidelidad al monarca y repulsión a las doctrinas liberales difundidas en la Metrópoli.

La invasión francesa de 1808 fué coyuntura para que esta dualidad de tendencias politicas se manifestara. Los españoles se encontraron sin rey, solos contra el enemigo; en los primeros momentos de la resistencia se hicieron con el poder hombres que, a los ojos del pueblo, estaban libres de responsabilidad en los hechos acaecidos durante los veinte últimos años; y eran, en su mayoría, liberales que se habian mantenido forzosamente alejados del gobierno. En América el entusiasmo popular hacia Fernando VII es más hondo y sincero; también se constituyen Juntas como las de la Península, para defender los derechos del monarca y ayudar a la lucha contra los franceses; pero esas Juntas, sancionadas por la voluntad popular expresada en los Cabildos abiertos, se forman a base de los elementos más conservadores del país.

En consecuencia, metrópoli y provincias americanas se hallan ideológłcamente enfrentadas. Los americanos quieren sacudir la autoridad de los liberales peninsulares. Su posición descansa en argumentos clarísimos: las Indias son un dominio personal y directo del rey, que las gobierna por delegación en autoridades que él nombra, y que cesan de serlo apenas

(4) Cfr. LEVENE, Ricardo. Leccionas de Historia Argentina, tomo I, Buenos Aires, 1934 ; pág. 415.-CAILLET-BOIS, R., Ensayo sobre el Río de la Plata y la Revolución francesa, Buenos Aires, 1929; pág. 115. 
dejen de depender del monarca; obligado éste a desaparecer contra su voluntad y sin dejar sucesión legítima, las Indias no están obligadas a aceptar ningún otro poder; el de las Juntas de España, en situación caótica y controladas por liberales, no tenía por qué ser acatado en Indias, juzgando con el más recto, puro y tradicional criterio hispánico (5).

Solo más tarde el españolismo de esta postura se cesvirtúa y llega por último a convertirse en antiespañolismo total; paralelamente, el acusado sentimiento monárquico cede en lenta progresión ante gérmenes de republicanismo casi insignificantes en los primeros momentos (6). Una serie de factores externos e internos cooperan a ahondar diferencias y a hacerlas más graves: el hecho de ser declaradas en rebeldia las provincias americanas, la influencia ideológica de la Revolución, las ideas políticas y económicas de los ingleses, hábilmente difundidas entre los insurgentes, el fracaso de gestiones para dar un trono americano a personas de la familia de Borbón, las ventajas sociales y económicas que encuentran los criollos en el nuevo estado de cosas, etc. Cuando Fernando VII vuelve a ocupar el trono de España, han ido surgiendo diferencias muy hondas, no quedan muchas posibilidades de arreglo, y las que existen son mal utilizadas. Así se explica la aparente paradoja de que los pueblos sublevados para defender derechos de su rey, terminen en repúblicas independientes.

En 1810, pocos americanos estaban en condiciones de prever el desenlace del drama (7). Algunos gobernantes españoles en Indias, apreciaron con clara visión las últimas posibilidades de la lucha (Abascal entre ellos); en el momento de actuar, algunos pecaron de irresolución o cobardía; otros, enfrentados a los grupos sociales más capaces, carecieron de me-

(J) L La Revolución de $1810 \ldots$ se inspira en gran parte en los postulados de los juristas indianos». (LEVENE, R., Introducción a la historia del Derecho Indiano,.Buenos Aires, 1924; pág. 42).

(6) LEVENE, R., Intentos de independencia en el virreinato del Río de la Platé, on Historia de la Nación Argentira por él dirigita, tomo $V$, secc. 1.a, Buenos Aires, 1841; pág. 456.-CANTER, J., ob. y rol. eits.; pág. 206.

(7) ESTRADA, ob. cit., pág. 47. 
dios para imponerse; y en general, donde las autoridades fueron enérgicas desde el principio o contaron con algùn apoyo, organizaron la resistencia.

Las autoridades peninsulares, en cambio, se mostraron incapaces de vislumbrar la transcendencia de los hechos, y sólo a última hora comprenden que es decisiva la lucha planteada; aun entonces, sus medidas resultan torpes o ineficaces. Intentan al principio atraerse a los americanos autorizándoles a enviar representantes a las Cortes de Cádiz, tras una declaración teórica de su igualdad de derechos con los españoles. El resultado fué contraproducente, porque los diputados americanos, en general, ayudaron desde la metrópoli a los insurgentes y entorpecieron la labor de las Cortes (8). Igual suerte corrió un segundo intento realizado al promulgarse la Constitución de 1812, que fué lanzada a América y rechazada por los americanos, dueños ya de muchas libertades para aliarse por este precio al régimen liberal.

Fracasados estos intentos, las autoridades peninsulares se deciden a emplear las armas. Se preparan expedieiones bélicas, de las que unas no llegan a América y otras resultan ineficaces; los gobernantes indianos se hallan, en consecuencia, prácticamente solos para luchar contra los sublevados, y ha de reconocerse que, pese a ello, lo hicieron sin vacilaciones, con verdadero heroismo.

\section{El virreinato del Perú a comienzos del siglo XIX.}

El virreinato del Perú sufrió a lo largo del siglo XIX una transformación completa. Su enorme territorio jurisdiccional quedó reducido a límites comparativamente exiguos; su vitalidad económica disminuye en proporciones alarmantes; sus problemas

(8) VALLE Y BERLUCEA, E. del, Los diputados de Buenos Aires en las Cortes de Cádiz, Buenos Aires, 1912; págs. 81-85. 
sociales estallan con violencia en disturbios internos, en general de poca importancia, pero graves en el caso de la revuelta de Tupac Amaru. Al finalizar la décimooctava centuria, el virreinato padece todavía las consecuencias desastrosas de una aguda y completa crisis, que tuvo su apogeo en los años 1776 a 1782 , y cuyos factores determinantes fueron de tipo externo e interno.

Los primeros son consecuencia de necesidades politicas de orden internacional, que obligan a Carlos III a efectuar una completa reestructuración de sus dominios surindianos, con vistas a una mejor defensa estratégica de aquel Continente. Ya en 1739 eran segregados del Perú los territorios de Quito y Nueva Granada, erigidos en virreinato independiente; se trataba de establecer así un centro político fuerte, vigía del istmo de Panamá, de cara al Atlántico y al Pacífico. En 1776, mediante una nueva amputación de territorios al viejo virreinato, era creado el de Buenos Aires; los problemas de límites con Brasil se zanjaban de una vez; la desembocadura del Plata, el mejor lugar de penetración al interior del Continente, se cerraba a toda amenaza extranjera; el triángulo Buenos Aires-Malvinas-Montevideo, se constituia como excelente base para el dominio del Atlántico Sur. Poco después Chile, capitanía general ya por completo independiente de Lima, era nuevo bastión defensivo del Pacífico, guardando el acceso a dicho Oceano por el estrecho de Magallanes.

Quedaban así las Indias meridionales, antes punto tan vulnerable del Imperio, en condiciones defensivas bastante buenas, indispensables para un ventajoso planteamiento de la lucha contra Inglaterra, objetivo esencial en el reinado de Carlos III (9). Mas el enorme esfuerzo económico que representaba este poner en pie de guerra un Continente, vino a gravitar de un modo insoportable sobre la economía peruana.

La inclusión de Guayaquil en el virreinato de Nueva Granada rompe, o al menos entorpece, el fun-

(9) RODRIGUEZ CASADO, Vicente, Politica exterior de Carlos 111 en torno al problema indiano; en Revista de Indias, Madrid, n. ${ }^{\circ} 16$, págs. 227-266. 
cionamiento del eje comercial Callao-Guayaquil, sin que las ulteriores leyes sobre comercio intercolonial remedien este hecho más que en parte. El pobre desarrollo económico de la región del Plata no permitía sostener los gastos militares que su defensa requirio; por eso, tratando de proporcionar recursos al virreinato bonaerense, es agregado a sus territorios el Alto Perú, y Buenos Aires es objeto de un acusado proteccionismo económico (libre internación, excepcionales medidas aduaneras, etc.), que altera por completo la situación anterior; todo va en daño del Perú, cuyo erario había sido el más rico de América, y cuyos mercaderes monopolizaban secularmente el papel distribuidor en el comercio exterior del Continente (10). Las leyes de libre comercio acaban de descentralizar éste con la habilitación de numerosos puertos al tráfico intercontinental, y son causa de que Lima pierda los últimos vestigios de su antigua preponderancia económica (11).

Perú resultaba así el único perjudicado en un reajuste general que se hizo, por añadidura, a su costa. $\mathrm{Su}$ erario hubo de financiar gastos militares de todo el Continente, con remesas que suman muchos millones de pesos, hechas desde Lima a las plazas fortificadas chilenas, a Guayaquil, a Panamá, a Guatemala, y sobre todo a Buenos Aires. Hubo además de costearse amplias movilizaciones bélicas, hechas en el virreinato ante posibles amenazas exteriores, en ocasión de guerra contra Gran Bretaña, y sobre todo, ante el peligro interior que supuso la revuelta de $\mathrm{Tu}-$ pac Amaru, que trastorna por varios años la vida económica de muchas provincias del virreinato.

En la crisis a que me refiero actuaron también una

(10) CESPEDES DEL CASTILLO, Guillermo; Lima y Buenos Aires (Repercusiones económicas y políticas de la creación del virreinato del Plata), Escuela de Estudios Hispano-Americanos, Sevilla, 1947.

(11) En el día, Chile se surte directamente, así por el Cabo como por Buenos Aires, * Guayaquil ha establecido su comercio directo con Cádiz...) (UNANUE, Hipólito; Guía política, eclesiástica y militar del virreinato del Perú para ol año de 1794; pág. 146). Lima había perdido, en 1794, incluso su importancia como centro mercantil de las regiones del Pacífico. 
serie de factores internos, menos aparentes, pero asimismo graves. No sólo el comercio fué en progresiva decadencia. La minería, afectada por problemas técnicos de explotación que no logró ver resueltos, y por el rendimiento cada vez menor de la mina de Huancavelica, se hallaba muy decaida. Empleados en las minas los indios, la agricultura atraviesa una alarmante escasez de mano de obra, no salvada con suficientes importaciones de esclavos negros. El problema social de los indios ofrecia negras perspectivas.

Por fortuna, durante los años en que esta crisis reviste caracteres más agudos, se efectúa en el Perú la visita general de 1777-1785, decretada con el fin de resolver dicha situación. A cargo de Areche y Escobedo, que sucesivamente la desempeñaron, corrió el establecimiento de una serie de reformas administrativas, hacendisticas y económicas y el desarrollo de una ingente labor de gobierno (12). Para la rápida y mejor administración de justicia, fué visitada la Audiencia de Lima y creadá la de Cuzco; trató de mejorarse el goblerno provincial suprimiendo los abusivos repartimientos forzosos a los indios, y sobre todo con la aplicación del sistema de intendencias; la $\mathrm{Ha}-$ cienda virrelnal fué reorganizada y enriquecida, más que por el aumento de impuestos, gracias a la racionalización de ellos y a un profundo sareamiento en el manejo de fondos y en el personal encargado de efectuarlo; para resolver la decadencia de las industrias extractivas, fueron creados Tribunales de Minéria-con el fin de mejorar la técnica de explotación-y Bancos de Rescate, al objeto de remediar la pobreza de los mineros; de haberse podido llevar a la práctica, el plan de Escobedo para facilitar a los indios campesinos ganado, aperos de labranza, etc., hubiera logrado su finalidad de dignificar a esa clase social por el trabajo, y conseguir una importante intensificación de cultivos, necesaria para el mejoramiento general de la agricultura; el comercio obtuvo, en compensación a muchos males, ciertos alivios tributarios.

Labor tan intensa y amplia, permite salvar al Perú

(12) CESPEDES, Guillermo; ơb. cit.; págrs. 156 y ss. 
la fase más crítica de su situación, pero resulta por completo insuficiente para resolverla de un modo satisfactorio y definitivo. El erario virreinal, gravado hasta 1784 por enormes gastos militares originados por la gueria contra Gran Bretaña y la sublevación de Tupac Amaru, no pudo rehacerse; en 1792 el presupuesto anual continúa siendo deficitario (13), y crecidas deudas no podían ser amortizadas. La economía general del virreinato, tampoco logra restablecer su equilibrio: Charcas, la zona más rica del Continente, fué arrebatada al Perú no sólo como territorio productor de enormes riquezas, sino hasta como mercado comercial, ahora en manos de los comerciantes bonaerenses; el atraso de la agricultura impidió la conversión de la tradicional economía minera deI virreinato en economia agrícola, como empezaban a exigir las circunstancias (14).

Perú entra asi en el siglo ẊX, con sólo el recuerdo de su antigua opulencia; otrora centro político y económico de todas las Indias meridionales, es ya una zona de importancia secundaria, lugar excéntrico en el conjunto del Imperio. En cambio, conserva todos sus antiguos problemas politicos y económicos, por añadidura agravados. El problema de los indios, aun bajo el peso de la reciente convulsión interna que ocasionara, no ha podido ser resuelto. Idéntico estado ofrece la situación de la minería, base del conjunto económico virreinal: «la pobreza de los que ordinariamente abrazan la carrera de las minas, su falta de luces y conocimientos para dirigir las labores y sus beneficios, son otros tantos obstáculos que han impedido su adelantamiento y progreso», reconoce el virrey Abascal (15). El libre comercio descentralizando el tráfico de Lima, y la incorporación de Charcas al Plata (seguida de unas leyes aduaneras encaminadas a desvincularla económicamente del Bajo Perú), acabaron con la prosperidad de los mercaderes peruanos.

(13) UNANUE, ob. cit., pág. 14.

(14) CESPEDES, ob. cit., pags. 173 y ss.

(15) ABASCAL, Memoria de Gobierno, editada por V. RODRIGUEZ CASADO y J. A. CALDERON QUIJANO; Escuela de Estudios Hispano-Americanos, Sevilla, 1944; vol I, pág. 181. 
Si la administración públíca era difícil, los encargados de realizarla no eran modelos de eficiencia. La visita general logró mejorar los funcionarios sólo en parte y de un modo pasajero; pudo más la tradicional inmoralidad e inutilidad de la burocracia limeña, tan numerosa como inoperante, y en ocasiones corrompida. Abascal se lamenta de «la morosa y descuidada ejecución de lo que se manda, a punto de ser menos embarazosas las resoluciones que el cumplimiento de ellas, pues aunque hay ministros y copia de subalternos a quien encargarlos, corren la peor suerte si por desgracia el tropel de otros negocios hace que el virrey los pierda de vista o de su memoria» (16). El Intendente de Huancavelica exponia en 1811: "De las siete horas de trabajo y precisa asistencia que con tanta eficacia manda el articulo 217 de la Real Ordenanza de Intendentes, no se cumple ni en la mitad...: de esta negligencia y abandono nace esa multitud de manos que para cada cosa tenemos» (17).

Tal situación no era más que la faceta burocrática de un estado general de relajación en toda la sociedad, que alcanzaba incluso al clero: «Los curas no observan la residencia, y están fuera de sus curatos todo el tiempo que les acomoda, ocupados en cosas muy ajenas a su estado. Los religiosos no conocen la vida en común, y cada uno vive y come donde quiere» (18). A la altura de estas circunstancias, el ejército virreinal era escaso, y se hallaba falto de cuadros de mando, desorganizado y mal disciplinado.

Con tales medios económicos, políticos y bélicos, inicia el Perú su lucha contra los insurgentes. Estos se hallaban dentro y fuera del virreinato; dentro, no faltaron sublevaciones independizantes, más esporádicas y sin verdadero arraigo en el pais; la sociedad peruana conservaba una honda tradición española, estaba muy identificada con la metrópoli. Encontró

(16) ABASCAL, Memoria, tomo I, pág. 115 de la ed. cit.

(17) Archivo General de Indias, Lima, 1116; Copia del in. forme sobre los medios propuestos para acudir a las atenciones del Erario, por el Intendente de Huancavelica don Lázaro de Riberas. Huancavelica, 14 diciembre 1811.

(18) Ibid. 
la causa realista tan profundo eco, Abascal poseyó tan grandes cualidades de energia y habilidad, que el Perú vuelca su esfuerzo en pleno contra los sublevados del exterior, y con pobres medios materiales vence primero y resiste después durante años, rodeado de territorios enemigos y sin ayuda de la metrópoli. Sin divergencias y escisiones internas que existieron en el bando realista, el Perú se hubiera mantenido todavia mucho más tiempo.

\section{El teatro y los caracteres de la lucha.}

La cordillera andina presta cierta homogeneidad natural a todo el sector sudamericano del Pacífico, homogeneidad acentuada hasta el máximo en lo que se refiere al tramo que los geografos designan hoy como región natural de los Andes tropicales secos, que abarca aproximadamente desde Piura al Norte hasta Tarapacá al Sur. El Bajo y el Alto Perú constituian, pues, una clara unidad geográfica, fraccionada en sectores no transversales, sino longitudinales: la costa, la sierra y la montaña.

El Alto Perú se articula perfectamente al Bajo Perú (a través de la región del Desaguadero y del Lago Titicaca), y a la cuenca del Plata por las provincias de Salta y JuJuy. No es de extrañar que, desde comienzos de la guerra civil, ambos contendientes trataran de poseer tan importante región de paso: los argentinos, con ánimo de unirla a su causa $y$, en el momento oportuno, utilizarla como trampolín para invadir el Bajo Perú; los realistas, para servirse de ella como glacis defensivo; y ambos, con el deseo de aprovechar sus grandes riquezas. $L a$ guerra de la Independencia-ha escrito Julio Méndez (19)-no se redujo a otro empeño que el de poseer militarmente el Alto Perú para resolver el éxito de la lucha».

(19) Cit. por D'AVIS, Julio Alberto, El Estado boliviano y la unidad peruana, Cochabamba, 1944; pág. 283. 
Que a ambos bandos interesaba su posesión, lo demuestra el número de invasiones que sufrió a lo largo de la guerra, de una y otra parte. Sin embargo, «los hechos demostraron a través de todas las campañas... que el camino del Norte fué siempre fatal para uno $u$ otro adversario, cada vez que intentaron llevar sus operaciones profundamente hacia el enemigo, pues entonces las ofensivas fracasaron..., porque los ejércitos se alejaban demasiado de sus bases de operaciones, y la falta de recursos, la naturaleza del suelo o la hostilidad de las poblaciones, no permitían la creación de bases intermedias. Además, mientras las líneas de comunicaciones del que llevaba la ofensiva se alargaban exageradamente, las del adversario se acortaban en la misma proporción: (20).

¿No era posible otra ruta para buscar al enemigo, un campo de operaciones más resolutivo que la meseta charqueña, agreste, inhóspita, sin recursos naturales para sostener a un ejército, excelente para resistir y mala para atacar? La había, efectivamente, y cuando por fin uno de los bandos se decide a utilizarla, el resultado es inmediato y brillante: el mar. «Una característica geográfica de los países andinos es la existencia de dos líneas de unión que se prolongan paralelamente a la arista de los Andes: una interior, por entre los valles angostos y discontinuos; y otra exterior, el mar... La primera es la línea de resistencia, que cuenta con elementos de defensa, que presta estabilidad económica a la población y que sirve de asiento a las grandes aglomeraciones urbanas y a los centros de la dirección política. La segunda línea en cambio, fácil a la circulación, articulada con la zona costera por una serie de escotaduras y accidentes geográficos, es la linea de ataque, merced a la cual en un momento dado pueden concentrarse grandes efectivos navales frente a cualquier punto de la costa, con posibilidad de invadir el territorio de Oeste a Este» (21).

(20) LOZA, Emilio, Yatasto, Tucumán y Salta, vol. II, secc. 2. ${ }^{\mathrm{a}}$ de la Historia de la Nación Argentina; pág. 529.

(21) BADIA MALAGRIDA, Carlos, El factor gengráfico en la política sudamericana, Madrid, 1919; pág. 241. 
En efecto, los argentinos vieron rechazadas todas sus ofensivas a.través del Alto Perú; el río Desaguadero se mostró eficaz escalón de resistencia, y cuando los realistas llegaban a Salta y Jujuy, Tucumán se veía expuesto a una fácil invasión. Los ejércitos peruanos, al principio más numerosos y siempre mejor organizados que los insurgentes, estuvieron en todas partes a la vez para resistir, y lanzan hasta el último momento ofensivas terribles; sólo podría tachárseles de cierta indecisión, debida a la escasez de elementos con que siempre hubieron de actuar; no explotaron sus éxitos, porque sin recibir contingentes de tropas peninsulares - que no llegan-carecian de efectivos para llevar a cabo cualquier acción resolutoria.

Sin embargb, parecia que no iban a ser vencidos, hasta que los insurgentes obtuvieron el dominio del mar. Para los realistas era fundamental la libertad de comunicaciones con España, posibles sólo en la ruta del Cabo de Hornos, desde el momento en que la revolución triunfa en Nueva Granada; en el apostadero del Callao apenas había buques de guerra, que tampoco llegan de España ni pueden ser construidos en Perú por falta de medios incluso para mantenerlos. De este modo, San Martin ganaría la partida apenas emprendiera el ataque por el mar, lograse dominarlo y establecer un sólido bloqueo. Faltos de toda ayuda y sin esperanza de recibirla, los soldados realistas resisten hasta el fín; aun así fué ardua tarea derrotarlos, pese a que las desavenencias políticas entre sus Jefes acortaron en gran parte el plazo de su resistencia.

\section{Bibliografía sobre el tema de las campañas.}

Siendo tan copiosa la existente sobre temas de la Independencia, las campañas militares llevadas a cabo por las tropas realistas en América del Sur durante el gobierno del virrey Abascal, no han sido objeto de un estudio concreto y detenido. Por supuesto, se trata de ellas en una serfe de obras más o menos amplias. Las de tipo general, que tratan en conjunto el desarrollo completo de la Emancipación, no hacen más que re- 
ferencias necesariamente someras a las campañas que van a ocuparme.

Mayor utilidad ofrecen un grupo de historias nacionales de los paises donde tuvieron lugar esas luchas. En las del Perú, es por cierto donde menos datos se hallan sobre la figura de Abascal y su actuación bélica; la conocida «Historia del Perú bajo los Borbones», de Lorente, resulta anticuada y muy superficial; el libro de Vicuña Mackena, sobre la Independencia del Peru, tampoco plantea ni resuelve muchos problemas; «La gesta emancipadora del Perú», por J. M. Valega, expone sin ilación las conspiraciones insurgentes desarrolladas en el Perú, refiere por encima la labor de Abascal, y Juzga - muchas veces torcidamente- la actuación española en el virreinato. La «Historia del Ecuador», de González Suárez, algo anticuada, es todavia apreciable. Respecto a Chile, cabe cltar el libro de Edwards, más al dia que la Historia de Barros Arana, bien documentada y enjuiciada. Las historias nacionales argentinas, más recientes y útiles a nuestro objeto, son la de Monferini y la que dirige Ricardo Levene; ésta, aún no terminada de publicar, se refiere a Abascal y los realistas, sólo para completar el cuadro de su tema.

Todas las historias nacionales enjuician, como es natural, nuestro tema desde el punto de vista particular y nacional de cada pais, y aunque lo traten con menos rapidez que las obras generales, dan noticia parcial y aislada de las distintas campañas.

Unica referencia monográfica a ellas, es la obra de Herreros de Tejada sobre «El Teniente General D. José Manuel de Goyeneche, conde de Guaqui»; hecha con cuidado, lujosamente editada, dista, como su titulo indica, de agotar el estudio de las campañas, y reviste tonos de franca apologia hacia el biografiado.

Todo lo expuesto hace comprensible que el presente libro se haya elaborado, de un modo directo y casi exclusivo, sobre fuentes documentales; al final indico cuáles son y su procedencia. Sólo me resta aqui manifestar mi gratitud a las ilustres personas que me han franqueado amable acceso a los archivos particu- lares cuyos fondos utilizo ampliamente. 


\section{LAS FIGURAS DE LA LUCHA}

\section{El virrey Abascal.}

«He sabido la polvareda que ahi se ha levantado contra mí; me importa poco, porque la gloria de haber sido el único punto de apoyo que ha sostenido y sostiene a esta América del Sur, nadie me la puede obscurecer: no habrá un hombre de bien que por término ninguno sea capaz de tachar mi conducta pública ni privada... (1). Así escribía el Virrey Abascal a propósito de la campaña promovida contra él en las Cortes de Cádiz por los diputados americanos. Y no cabe duda de que el viejo gobernante llevaba razón. A pesar de tales insidias contra su persona y su labor de gobierno, su nombre ha quedado como el de uno de los más sagaces Virreyes que el Monarca español

(1) Archivo Abascal. Minuta de carta del Virrey Abascal, sin dirección. Lima, 23 de septiembre de 1811. 
enviara a los dominios americanos. Ya por sí solo bastaría para honrar su memoria el hecho de haber sido el único punto de sostén de la autoridad real en toda América del Sur cuando aquélla parecia a punto de derrumbarse; pero aun hay que añadir otras cualidades personales que lo definen como hábil político y gobernante experto, y que hacen de él uno de los hombres más completos entre todos los que ocuparon el mando en América del Sur (2).

Por ahora sólo he de limitarme a una exposición general que sirva para definir el criterio y la actitud del Virrey en relación con los acontecimientos del periodo que se estudia. Dejo para otra ocasión la labor, ya casi ultimada, de hacer un estudio completo de su persona y de su gestión al frente del Virreinato.

Don José Fernando de Abascal y Sousa, nació en Oviedo el 3 de junio de 1743. Dedicado a la carrera militar, intervino en la batalla de Argel de 1775, y en la ocupación de la Colonia del Sacramento. Destinado posteriormente a Guba, como Teniente del Rey, se dedicó a fortificar la Habana, de donde pasó a Guadadalajara, como Presidente de la Audiencia. Ascendido a Mariscal de Campo, fué nombrado Virrey del Río de la Plata, cargo que no llegó a ocupar por haber recibido antes el nombramiento de Virrey del Perú. En su marcha a este territorio fué detenido por los ingleses y conducido a Lisboa, en donde consiguió ser canjeado. Vuelto a América, desembarcó en Buenos Aires, y desde alli, a través del Continente, se dirigió a Lima (3).

A su llegada al Perú con el nombramiento de virrey de aquellos territorios, los encontró en la situación expuesta más atrás; pero el viaje a través del Continente desde Buenos Aires a Lima, le sirvió para

(2) Son curiosos a este reapecto los debates iniciados en mar$z 0$ de 1811, en los que el diputado americano Morales Duárez propone el relevo de Abascal, y en los que el Virrey recibió el calificativo de evinósos, lanzado por uno de los dipatados. Al fín, la Regencia se pronunció por la continuación de Virrey en su puesto.-Vid. VILLANUEVA, J. Mi viaje a las Cortes. Madrid, 1860. Págs. 196 y 200.

(3) MENDIBURU, M. Diceionario Historico-Biográfico del Perú, Lima, 1931. Tomo I. Págs. 58-50. 
conocer personalmente la verdadera situación del Virreinato y apreciar los recursos de aquellas tierras, a los que tanto partido hubo de sacar más tarde.

Las dificultades para el Virrey comenzaron cuando llegaron a Lima las noticias de la abdicación de Carlos IV en Napoleón, después de los sucesos de Bayona y de la entrada de las tropas francesas en la Península. Existian en aquel momento tres pretendientes a la soberanía sobre los territorios americanos. Por una parte se hallaba el Rey José, que ocupaba entonces el trono español; frente a él las Juntas organizadas en las provincias, que sostenian como único y legítimo Rey de España a Fernando VII, y aparte de éstos, pero con bastante interés en sacar provecho de la situación, la Infanta Carlota Joaquina y la Corte del Brasil. Los tres pretendientes enviaban emisarios a Lima con el objeto de obtener la adhesión del Virrey del Perú. Los dos primeros pedian un reconocimiento total de sus derechos con el consiguiente sometimiento, y la tercera solicitaba la regencia de las colonias americanas hasta la vuelta de Fernando a España. En semejantes circunstancias, la decisión sobre tal problema era de la más extremada gravedad (4).

Sin embargo, Abascal era hombre de profundas convicciones monárquicas y de arraigado amor a su Soberano. No cabe pensar, por tanto, que en algún momento se hallase dispuesto a reconocer a José como Rey de España. Antes al contrario, recibidas las noticias de los sucesos de la Península, determinó, de acuerdo con el Cabildo, adelantar la fecha de la proclamación de Fernando VII, que ya se preparaba antes, y se había fijado para el dia 1 de diciembre de 1808, sustituida entonces por el 13 de octubre, en que efectivamente se llevó a cabo (5).

Ha corrido la leyenda, fundada en un escrito de

(4) Sobre el envío de los agentes franceses al Perú. Vid. RODRIGUEZ CASADO, V.: Estudio preliminar cit. Págs. LXXXIXXCIII.

(5) Cuando estaba acordada la fecha de proclamación de Fernando. VII, se recibieron noticias por un embarcación que llegó al Callao, procedente de Valparaíso, enviada por el Presidente de Chile, de lo ocurrido en España. El 7 de octubre se recibió la mis- 
J. A. de Lavalle, de que el Virrey tuvo un momento de duda al recibir las noticias de España (6). Según dice el historiador limeño, por la mente de Abascal pasó por un instante la idea de proclamarse Rey del Perú e independizarse de España. Sin embargo, tal afirmación no pasa de ser una leyenda sin el menor fundanıento histórico (7). Ciertamente, de haber existido este proyecto, seguramente hubiera tenido éxito. Abascal se había hecho querer no sólo de los limeños, sino también de todos los peruanos. $Y$ es lógico pensar que a su reino americano se hubiesen unido todos los territorios que se sublevaron dos años más tarde. Con ello, seguramente la independencia de América se hubiera llevado a cabo muchos años antes y sin derramamiento de sangre, puesto que no hubiera encontrado otra resistencia que la que le opusiera la Corte del Brasil, en realidad poco eficaz. Pero tal proyecto no existió, como lo demuestra la posterior conducta de Abascal, pues como se verá, el Virtey

ma noticia por la vía de Arequipa, enviada por el Vỉrrey de Buenos Aires, juntamente con un pliego de Murat, en el que se titulaba lugarteniente general del Reino; ademús venía un oficio de Goyeneche, enviado de la Junta Central, dándole cuenta del objeto de su comisión, y otro del Virrey del Río de la Plata en el que le comunicaba lo ejecutato en Buenos Aires. Inmediatamente convocó una Junta en su Palacio, a la que asistieron los Ministros de la Audiencia, el Arzobispo, los Alcaldes y Regidores, en la que se adelantó la fecha para el día 13 de octubre, como se efectuó, previo acuerdo con el Cabildo. Asimismo se enviaron noticias a los Presidentes de Quito, Chile y Guatemala y a los Virreyes de Santa Fe y Buenos Aires, para uniformar las medidas. Poco después se publicaba en Lima un bando del Virrey en el que declaraba la guerra a los franceses. (A. G. I. Lima, 736; CParte que envía Abascal a la Serenísima Junta Suprema de Gobiemo de Sevilla». Lima, 8 de noviembre de 1808. Y también Lima, 192; Copia de acta del Acuerdo celebrado en Lima el 8 de octubre de 1808 , bajo la presidencia del Virrey).

(6) LAVALLE, J. A., A bascal. Rev, de Buenos Aires, 1864. Tomo V. Pág. 346.

(7) Después de haber consultado prolijamente y con detenimiento la documentación guardada en el Archivo de Indias, y en los particulares del Virrey y del Conde de Huaqui, no ha legado a mis manos ningún documento que refleje, siquiera remotamente, tal proyecto de Abascal; como parecería lógico, de haber existido. Es de esta misma opinión HERNANDEZ ALFONSO, El Virreinato del Perí. Madrid, 1945. Pág. 221. 
no sólo no faporeció la Independencia, sino que la retrasó notablemente, y de haber podido llevar a cabo sus planes, la emancipación americana hubiera sufrido un golpe mortal.

La actitud de la Infanta Carlota Joaquina también causó hondas preocupaciones en Lima. Tras sus proposiciones de aceptar la regencia de aquellos territorios mientras durase la ausencia de Fernando VII, podian esconderse los proyectos de la Corte de Portugal, nunca disimulados, de engrandecer su imperio colonial americano a costa de España. Más adelante, con ocasión de estudiar la figura de Goyeneche, se podrá apreciar más extensamente, aunque sólo en sus líneas generales; la política de la Infanta respecto a las colonias españolas. Por ahora, para lo que nos interesa, basta adelantar que el Virrey, con gran habilidad politica, logró deshacer sus proyectos sin llegar por eso a un rompimiento con la Corte del Brasil; antes al contrario, cuando tuvo lugar la sublevación de Buenos Aires, consiguió el apoyo de las tropas portuguesas en la Banda Oriental (8).

(8) Abascal pudo pasar por momentos de dificultad cuando, al mes de proclamado Fernando VII, comenzó la propaganda de lá Infanta a inundar el Virreinato, haciendo correr la notieia de que el Infante D. Pedro Carlos de Borbớn y Braganza iría poco después a hacerse cargo del Gobierno del Perú en nombre de Carlos IV, ayudado por el Almirante inglés Sir Sidney Smith. Pero el Virrey no vaciló un instánte; antes al contrario, obligó a marcharse al buque inglés portador de tales noticias, y contestó enérgicamente a la Infanta haciéndole ver que no estaba dispuesto a aceptar otro Soberano que Fernando VII. Con esto se pueden considerar fracasadas definitivamente las tentativas de la Corte del Brasil para atraerse al Perú. (Archivo Abascal. Minuta de carta de Abascal a Jovellanos. Lima, 14 de marzo de 1810.-A. G. I. Lima, 738. Oficio reservado de Abascal a don Martín de Garay, y ABASCAL, Memoria, Tomo I, Págs. 481-484).

No es de extrañar, por tanto, que poco después la Infanta procurara la remoción de Abascal del cargo de Virrey y que escribiese a la Junta Central en los siguientes términos: eLa conducta de este Virrey no parece ser bastante arreglada, y cuando no sea por otra cosa que por la negligencia con que mira las funciones de su ministerio, dejándolas todas al venal capricho de su secretario Simón do Rábago, sería muy conveniente a las justas intenoiones de mi hermano Fernando, a las Vuestras y a los deseos de los habitantes de sana intención de Lima, el que fuese relevado de su empleo y tomada la más exacta residencia de todo el tiempo de su 
Se ha dicho más atrás cómo la entrada de las tropas francesas en España y la desorganización que en la Peninsula produjeron, fué la causa ocasional que hizo estallar los movimientos revolucionarios en toda América. Por supuesto que en todos los gobiernos del Continente hubo un momento de desorientación, producido por la perplejidad en que se encontraron las autoridades españolas, y este momento de duda fué el que, con gran habilidad, supieron escoger los americanos para apoderarse de los resortes del mando. En la mayor parte de los casos, su éxito fué debido, entre otras razones, a la pugna que en casi todos los territorios existia entre el Virrey y el Cabildo. Por regla general, el Cabildo era el órgano representativo de las tendencias revolucionarias frente al Virrey, que representaba el antiguo régimen. En Lima, sin embargo, las circunstancias variaban notablemente: la posición de los peruanos ante la cuestión de la Independencia, era bastante distinta de la de los restantes americanos. Pues bien, esta actitud del Cabildo fué aprovechada al máximo por Abascal. En primer lugar consiguió que se aceptase como Rey a Fernando VII y que se reconociese a la Regencia antes de que surgiera la menor discusión de sus derechos, con lo cual evitaba toda duda y se colocaba a su lado al Cabildo, que se encontró así identificado con el Virrey. Por tanto, desde el momento en que no habia discrepancias entre ambos, y con todos los resortes del poder en manos de Abascal, no habia lugar para que los descontentos que pudieran existir exteriorizasen sus ideas con éxito. La energía del Virrey ya se habia puesto de manifiesto al enviar auxilios a Buenos Aires cuando sufrió el ataque de los ingleses, y últimamente habia dado a entender que se hallaba dispuesto a mantener integro el territorio de su mando para Fernando VII. $Y$ si a esto se une la casi completa inexistencia de elementos revolucionarios en el interior, encontramos perfectamen-

administración...> (Carta autógrafa de la Infanta Carlota Joaquina al Presidente y Vocales de la Junta Central. Río de Janeiro, 15 de julio de 1809. Publ. por Julián María RUBIO: La Infanta Carlota Joaquina. Madrid, 1920. Pág. 224). 
te explicada la actitud del Perú, en el momento de plantearse el problema de la Independencia.

Poco después de salvado el primero obstáculo, representado en la proclamación de Fernando VII, surgió una seria difícultad para Abascal con las sublevaciones de Chuquisaca y La Paz. El viaje del enviado de la Junta Suprema para dar a conocer en las colonias la realidad de España fué, al parecer, bastante fructífero. A su paso por las ciudades recibia la adhesión de todas ellas a la persona de Fernando VII; pero no supo o no pudo lograr el reconocimiento de las personas que representaban al monarca, entonces prisionero en Francia. No es, pues, extraño que en el momento en que se corrieran las voces de que los gobernantes españoles no eran los legitimos representantes del Rey, por considerársele caducados sus poderes, surgiese la protesta contra ellos. Y esto tuvo lugar por primera vez en la ciudad de Chuquisaca, en donde, después de haber reconocido al Rey, se difundíó la especie de que el Arzobispo y el Presidente de la Audiencia pretendian entregar el territorio del Alto Perú a la Infanta Carlota Joaquina. En consecuencia, se originó la sublevación de dicha ciudad, a la que siguió pronto la de La Paz y cuyas circunstancias se examinarán más adelante.

El propósito de los revolucionarios de La Paz y Chuquisaca era claramente separatista, e inmediatamente que tuvo noticias de tales acontecimientos se dispuso el Virrey del Perú a atajarlo antes de que se corriese a su propio Virreinato, o a las demás provincias altoperuanas, que gozaban fama de inquietas. Esta región, como se recordará, formaba parte del Virreinato del Rio de la Plata, pero Abascal, dándose cuenta de la facilidad con que se podía propagar la sublevación al Perú, se puso en contacto con aquel Virrey y envió al efecto una expedición al mando de Goyeneche, que acabó pronto con el movimiento.

Este fué el primer paso dado por Abascal contra la Independencia americana, y a partir de ese momento no cesa ya de luchar contra ella hasta su relevo. No había acabado aún de someter a las ciudades, altoperuanas, cuando se insurreccionó Quito, con la formación de la primera Junta, y también hubo de acudir allá a someterla; entretanto, Buenos Aires en- 
vió sus tropas al Alto Perú y entonces es cuando comenzó la verdadera lucha que habia de durar quince años.

La instalación de la Regencia fué el momento aprovechado por los porteños para realizar sus proyectos revolucionarios. El 25 de mayo de 1810 llegan a Buenos Aires las noticias de dicho acontecimiento y entonces tiene lugar la creación de la Junta, que recoge en sí todo el poder de que se despojaba al Virrey. Los avisos de lo ocurrido en aquella capital llegan pronto a Lima, como asimismo los rumores de que los revolucionarios, depuesto el Virrey, y hechos dueños de la ciudad, preparaban una expedición a las provincias del Norte. La posición de Abascal ante tales hechos se manifiesta claramente. Para el Virrey del Perú, lo ocurrido en Buenos Aires es el comienzo de todos los males que se suceden desde entonces sin interrupción en América; el ejemplo dado por esta ciudad podía producir graves trastornos en el orden de cosas existente en el Continente. Pero no paraban ahí; pues triunfante la revolución en la capital, abrigaban ahora los porteños el propósito de extenderla a las provincias del Norte, con lo cual se corria el peligro de que llegase la expansión revolucionaria hasta las fronteras de su propio Virreinato. Y no sólo eso, sino que pretendian imponerla con la punta de las bayonetas; Abascal no iba a mantenerse indiferente (8):

Según se podía desprender de las recientes ocu-

(9) Para Abascal, Buenos Aires fué el centro de donde partió la idea de la independencia al resto del Continentè: c...las semillas de independencia se habían ésparcido en Buenos Aires por muchos aventureros de que se inundaban sus provinciais a la entrada de los ingleses en el Río de la Plata: que esta halagüeña esperanza sedujo y dispuso los ánimos de muchos incautos y ambiciosos; y que la conducta en todo uniforme que se ha observado por los revoltosos de todas partes, es una fuerte persuasión para que el projecto que nació en Buenos Aires se hiciera después extensivo a todo el Continente; pero que jamás hubiera pusado, a mi ver, de las clases de simples proyactos si aquella capital no bubiese alentado con su ejemplo de insubordinación y falta de respeto a las autoridades y si las descracias de la Península no les hubiesen persuadido que podría verificarse todo sin la menor contradiccións. (Memoria, Tomo II. Pág. 63). 
rrencias de Chuquisaca y La Paz, no parecía dificil que a la llegada de un ejército argentino proclamando la libertad de las provincias del Alto Perú, cundiese la sublevación por todas ellas. Y como es lógico pensar, si los revolucionarios triunfaban tan fácilmente en este territorio, no se contentarían con detenerse en las fronteras del Perú, hallándose el Virreinato en tan deficiente estado defensivo. $O$ aun en el caso de que no se atrevieran a penetrar por las armas, cabia la posibilidad de que procurasen infiltrar sus ideas con una abundante propaganda.

He aqui, pues, las razones que mueven a Abascal a cerrar el paso a los argentinos previa la incorporación al Virreinato de las provincias altoperuanas. De este modo, conseguía un objetivo múltiple, pues a la par que lograba que la lucha se desarrollase en la frontera sur de Charcas, en el punto más alejado del Perú propiamente dicho, evitaba que en el caso de una derrota se viese invadido el Virreinato por los enemigos, con lo que se hubiera hecho mucho más difícil su defensa, y el resultado final, más dudoso. Por otro lado, y esto es de una importancia fundamental para explicaros en gran parte el curso de la lucha, lograba asi arrancar a los argentinos los extraordinarios recursos del Alto Perú, decisivos para mantener la guerra.

Desde entonces la lucha contra los argentinos polarizó de tal modo la atención de Abascal, que se convirtió en el punto central de su labor de gobierno. A ella se supeditaron todas las demás actividades, y a su disposición se pusieron todos los recursos del pais.

Sin embargo, Abascal era un hombre que calculaba las consecuencias de sus actos. Por eso, ahora se da cuenta de que la guerra supondría la total ruina del Perú, tanto mas cuanto que a la vez tenia que acudir en auxilio de la Metrópoli en su lucha contra los franceses, lo cual significaba que no sólo tendria que mandar ayuda económica a España, sino que no podria recibir ninguna desde la Península, con las consecuencias que de ello se derivaban. Esa es la razón por la que intentaba en todo momento hallar una solución pacifica al conflicto antes de acudir a las armas. Es la solución que busca al principio de la lucha, antes incluso de ocurrir el primer choque entre 
las fuerzas contendientes, y más tarde, cuando se volvía encarnizada. Debe, por tanto, quedar bien claro que las diferentes proposiciones que Abascal pudiera hacer para llegar a un acuerdo con sus enemigos, signifieaban por su parte solamente un deseo sincero de acabar la guerra para prevenir el desenlace que a la larga prévela en su imaginación, y para acudir en socorro de su patria. Ahora bien, para el Virrey no cabia más que un modo de llegar a la avenencia, que era el reconocimiento de Fernando VII por parte de los sublevados. Claro está que era dificil llegar a un acuerdo en tales condiciones, pero no podia transigir. Consciente de su dignidad y de la justicia de la causa que defendía, su conciencia no le permitía ceder en este punto fundariental, no sin que se diese cuenta de que la continuación de la lucha en las condiciones en que hasta entonces se habia desarrollado, conducía fatalmente a la independencia de los paises ámericanos; pero no pođtia hacer más; el resto habian de hacerlo desde la Península (10).

Es curioso observar, sin embargo, cómo planteada la situación de modo que no cabia ya la posibilidad de arreglo pacífico, aislado el Virreinato de los demás paísès americanos, en casi todos los cuales habia triunfadio la retolución, logré Abascal no sólo evitar que ésta se propagase al Peru, sino contrarrestar con verdadera eficacia a los sublevados; y. lo que es más notable, identificar a los peruanos con la causa realista, de tal forma, que afué debido a su obra que los tradicionalistas del Alto Perú y los es-

(10) Así expresa el Virrey esta actitud suya, confirmada déspués por los hechos: «Las proposiciones más ventrjosas a nónbore del Góbierno pars un acomodamiento ractonal y jústo; los induItos y protestas de perdéa; las que de una y otra especie han recibido en pxoclamas $y$ ofieios feiterados, sin exceptuar promesas de premios, fuérón las primeras armas de que se usó al principio de los movimientós en una $\bar{y}$ otra párte de las provincias conmovidas, con sólo la calidad de reconocer al Gobiemo de Jispana, reponiendo las autoridades que dela istya propis y sin causa ni título soficiente habían removidos: (Mernoria, Tomo I. Pág. 3). Eq cuanto a las ideas de Abascal sobre, las causas, de la independencia y sus posiblês remedios, vid. el Estudio preliminar a su Memorią, de RODRIGUEZ CASADO, V. PGags. XCV-CXII. 
tandartes que lleyaban escritos Rey y Fe, sobrevivieran a la batalla de Ayaclicho (11).

Can esto llegamas a lo más trascendental de la labor de Abascal al frente del Virreinato. Generalmente se ha ensalzado su gobierno por las campañas realizadas contra la revolución, por las construcciones y los adelantos llevados a cabo en el país; pero no se echa de ver que, aparte de todo eso, la gran eficacia de su labor, y en donde demostró más habilidad política, fué en £u empeño de dar una base americana a la contrarrevolución, 0 , dicho de otro modo, en conseguir la formación de un partido americano criollo realista para hacer frente a los partidarios de la Independencia.

Ya he hablado más atrás de la actitud y de las ideas de los peruanos ante el conflicto planteado, Sin embargo, estas ideas podian sufrir modificaciones, para evitar lo cuizl, el Virrey actuó con rapidez y habilidad, y de tal forma, que, antes de que sus súbditos se percatasen de la trascendencia de sus medidas, se encontraron ligados y comprometidos con la causa realista. En primer lugar apravechó la estancia de Goyeneche en el Virreinato. A los ojos de los americanos, ninguno como él podía sepresentạr más cabalmente los derechos de Fernando VII, ya que había yenido de España precisamente a hacerlos patentes en América y a dar a conocer que la situación de España era una cosa transitoria a la que pronto se le encontraría una solución adecuada. Por otrarparte, Goyenéche era americano y podía venir muy bien a las planes que se proponia Abascal. Encabezada la contrafrevalución por un americanps que además por aquel entonces pçupaba la Presidencia del Cuzco, se daba el primer paso en ese sentido, A su lado colocó otros jeffes, también americano, como Tristán, primo del general, Picogga, Lombera. Valdés, etc., lo que, unido al prestigio de que ciertamente gozaba Goyeneche, hizo que fuera adquiriendo popularidad la causa por él representada. Se completó su proyecto con la creación del ejército peruano, puesto que así se puade llamar, sin exageración, a la labor realizada

(11) ESTRADA, Santiago de. Qp. cit. Pág. 48. 
entre Abascal y los jefes americanos a sus órdenes. Todos estos oficiales, agradecidos a la persona del Virrey, contentos de tener a su frente a un americano de nacimiento, y viendo en el triunfo de la causa revolucionaria el total trastorno del orden de cosas existentes en el Perú, se dedicaron con ardor a infundir sus ideas a los soldados, todos americanos, y en gran parte cuzquenos, que tenian especial devoción a su Presidente.

El resto de la obra lo hicieron los propios argentinos. Ya tendremos ocasión de examinar su conducta en las diversas ocasiones en que ocuparon el Alto Perú, el punto más próximo al virreinato hasta donde llegó la marea revolucionaria. No está de más, sin embargo, anticipar que su comportamiento dejó tanto que deséar, que el propio José María Paz, uno de los jefes de las tropas porteñas, lo reconoce así, cuando dice: : forzoso es decir que la aristocracia del Perú nos era desafecta desde que Castelli, con poquísimo discernimiento, la oferidió, provocando los furores de la democracia. Creo hasta ahora que ésta ha sido una de las causas que han hecho del Perú el último baluarte de la dominaeión española y el taller de esos ejércitos que volaron a todas partes para conservarla y extenderIa» (12).

Por tanto, t plan de Abascal estaba logrado. Contaba con el ejército peruano, con la aristocracia, y, en general, con las simpatias de todos los habitantes del Virreinato. Muy bien podía considerarse, como él mismo decia, único punto de apoyos que sostenía a Amériea. Si a pesar de todo no consiguió vencer totalmente a sus enemigos, la culpa no fué suya. Su obra constituyó un verdadero triunfo, tanto mayor cuanto que sobrevivió a su persona y logró hacer del Perú el centro, no sólo de la resistencia, sino de las ofensivas españolas hasta 1824 (13).

(114. PAZ; J. Maria. Memorias póstumas. Madrid, s. a. Bibl. Ayacucho. Págs. 145-146.

(13) Es característica, y nada nos muestra mejor lo relevante de su figura, la unanimidad que existe en todos los autores al enjuiciar la labor de Abascal al frente del Virreinato. Individuo tan 


\section{El general Goyeneehe.}

El aspecto más interesante de la figura de Goyeneche es, sin duda ninguna, el militar. Esta faceta de su personalidad será estudiada en los capitulos próximos, con ocasión de tratar de sus campañas al frente dél ejército virreinal contra los argentinos. Asimismo, tendremos oportunidad de examinar sus ideas sobre la lucha y sobre la estrategia de cada momento en particular. Con tales limitaciones, voy, pues, a ocuparme de su persona con el objeto de examinar solamente el carácter de uno de los principales Jefes realistas y su significación en el desarrollo de la lucha.

A principio de 1809 llegaba a Lima don José Manuel de Goyenéche, enviado por la Junta Central para dar a conocer en las colonias los hechos ocurridos en España y solictar de ellas ayuda en todos los sentidos para socorrer a la Metrópoli. Antes de su llegada a Lima habia atravesado todo el Continente de Sur a Norte, desde Montevideo, donde desembarcó a su llegada de la Península. En todos los lugares de su tránsito fué recibido con grandes muestras de simpatía por parte de las autoridades y vecinos. Igual recibimiento tuvo lugar a su llegada al Perú, donde el Virrey le hizo saber su decisión de mantener el Virreinato bajo la soberanía de Fernando VII y de contribuir con cuantos medios tuviese a su alcance, para lograr la expulsión de los franceses de la Península.

Sin èmbargo, la comisión de Goyeneche a Améríca se ha enjuiciado muy diversamente. Conviene,

opuesto a la causa realista como William Bennet STEVENSON, reconoce «que a su prudencia se debe la conservación de la ciudad (Lima) para la Córona de España, y que además de todos los deberés ineidentales que hubo de cumplir, aún pưdo llevar a cabo multitud de obras beneficiosas que le granjearon las simpatías de los peruanoss. (Memorias. Madrid, s. a., Bíbl. Ayacucho. Pág. 52). Igualmente MENDIBURU, en su Diccimario Histórico-Biográfico del Perí, hace ver cómo se atrajo a la sociedad perána con medidas que afectaban a las obras pubblicás, a la instrucción, etc., quie fueron los elementos que emplét el diestro Virtey para hicerse respetar y llenarse de admiradores y amigoss. (Tomo I. Lima, 1931. Păgs. 59-60). Del mismo modo podrían cítarse multitud de testimonios, conformes todos en reconocer la admirable labor de Gobierno desarrollada por el Virrey durante los años de su cargo. 
quizás, ante todo, decir que la figura de Goyeneche ha sido una de las más discutidas de este periodo, en parte debido al hecho de haber luchado al lado de los realistas, a pesar de su origen americanó, y en parte a la conducta un poco extraña observada por él en àlgunos momentos đurante el desempeñó de la comisión que le confiaran. Su estimación, por tanto, ha variado mucho, desde los que lo consideran como un general sin los más elemęntáles conocimientos militarés, hasta los que ven en él a uno de los más bríllantes personajes de la época. Es, por tanto, de gran interés valorar exactamente su personalidad (14).

Según don Carlos Pereyra, Goyeneche es un turbio negaciador y un militar conciliađor (15), idea derivada, en parte, de la afirmación sostenida por algunos, autores, que opinan que, antes de marchar a América comisionado por. la Junta Central, se había puesto en contacto con Murat, comprometiéndose con él a marchar allá para obtener la sumisión de las coloniass a José I. Según esta opinión, al llegar a Sevilla, oly̆idando su compromiso con los franceses, se puso a disposịición de la Junta, que vió en él un buen instrumerito para comísionarlo con idéntico fín al que le propusiera Murat, pero en favor de Fernando VII estầ vez. Según parrece, Goyeneche aceptó el encargo y partió hacia América con las dos proposiciones (16).

Respecto a tal afirmación, hay que tener en cuenta, en primer lugar, que no he encontrado la menor referencia documental a la supuesta duplicidad del General en ninguno de los archivos consultados, y, por otra parte, parece un poco dudoso que la Junta confiriera una misión tan delicada a un individuo

(14) Las apreciaciones sobre la personalidad de Goyeneche oscilan desde sus enemigos, como José María Paz, Miller, Araoz de La Madrid, etc que lo consideran como un ifiepto para el mando de las armas, y un seryil adulador, hasta sus, admiradores exalta. dos, coma García Camba, el mismo Torrente; y. modernamente, Herreros de Tejada.

(15) PEREYRA, Carlós, Lisistoria de la Amórica Española, Tamo VI Madrid, 1925. Pág. 346.

(16). Sostienen esta opinión, MILLER: Memorias del General Miller. Madrid, +s. a., Bibl. Ayacucho. Tomo I. Pág. 102; y más modernamente, GROLSSSAC, en su libro Santiago Liniers. Anales de Ia Bibl. Tomo II. Buenos Aires, 1904. Pág. 109. 
que, de haber estado en contacto con los franceses, eiertamente hubiera dado algo que sospechar. $\mathbf{Y}$ además', si esto no es suficiente, la conducta que observó desde el momento de su desembarco en América, famás dejó traslucir ntnguna connivencia, por minima que fuese, con el gobierno intruso de España. Por otra parte, el envio de agentes franceses a diferentes puntas de América, y, concretamente, la misión de Sassonay al Río de la Plata, hacen creer que Goyeneche era ajeno a tal finalidad, mucho más cuanto que si hubiese habido duplicidad por su parte, lo hubiera hecho saber el agente francés para procurar desprestigiarle a los ojos de los americanos.

El hecho más discutido de la actividad de Goyeneche como negoctador, es el de sus relaciones con la Corte del Brasil, concretamente con la Infanta Carlata Joaquina. He dicho más atrás cuál era la actitud de los portugueses on América respecto a las colonias españolas. Precisamente su deseo de apoderarse del territorio del Río de la Plata los habia hecho apdrecer como odjosos a los ojos de los americanos, a lo que se debtó en gran parte que sus proyectos de ahora no prosperasen. La instalación de la Corte portuguesa en el Brasil fué un acontecimiento de importancla trascendental para el desarrollo de los hechos que se sucedieron en América a comienzos del siglo XIX. Ya lo hacía notar el Virrey Abasoal, que lo califica como «uno de los acontecimientos más notables y acaso como el más peligroso a su existencia políticas (17). . Y ciertamente, desde la instalación de la Corte en Río de Janeiro se reerudeció la ofensiva politica contra los dominios españoles. No cabe duda que detrás de esta actitud de los portugueses se escondfan los manejos del representante inglés en la Corte del Brasil, Lord strangford, quien arepresentó en toda su amplitud de intención y competencia el criterio fijado por su nación en los asuntos americanos, respondiendo al sistema de lograr a toda costa el engrandecimiento del comercio» (18): Y más tarde,

(17) ABASCAL, Memoria. Tomo I. Pág, 477.

(18) RUBIO, Julián M. La Infanta Carlota Joaquina. Madrid, 1920. Pag. 180. 
cuando se planteó el problema de la independencia de las colonias, colaboró eficazmente con los sublevados, manteniendo la apariencia de una absoluta neutralidad.

Pues bien, en el momento de llevarse a cabo la abdicación de Carlos IV en Napoleón y la ocupación casi total de la Península por las tropas francesas, comenzó a manifestarse en la Corte del Brasil un deseo que poco a poco fué tomando forma; consistía sencillamente en apoderarse de las colonias españolas aprovechando la situación apurada de la metrópoli, o, al menos, ocupar aquellos territorios de la Banda Oriental que habian sido la constante preocupación de los gobernantes portugueses. La Infanta Carlota Joaquina se creyó entonces depositaria de los derechos al trono español, y comenzó a intrigar para obtener, no sólo la sumisión de los territorios americanos, sino también la Regencia de España. Para lo cual, a más de publicar su conocido manifiesto, circuló a todas las autoridades españolas de América multitud de cartas, dándoles a conocer el estado de la Península y sus derechos al trono en caso de que faltase su hermano Fernando VII, o al menos a la regencia mientras éste se encontrase en poder de Napoleón. En su propósito la secundaban su secretario Presas y el Almirante inglés Sidney Smith. Conviene, sin embargo, establecer una diferencia entre la politica seguida por la Infanta y sus colaboradores, y la de su marido y del ministro Conde de Linares. Estos últimos pretendian, siguiendo la politica tradicional portuguesa en América, apoderarse al menos de la Banda Oriental, para lo cual contaban con el valioso apoyo del embajador inglés; en cambio, la política de la Infanta tendía más bien a lograr su coronación en aquellos territorios. De aquí surgió la I1validad entre los dos bandos en la Corte, que tuvo no poca causa en el fracaso de los planes de ambos.

Esta era, pues, la situación de los dominios americanos respecto a las ambiciones de la Corte del Brasil. En toda la serie de intrigas que se desencadenaron entonces, y a raíz de ellas, se ha hecho intervenir a Goyeneche, como agente de la Infanta Carlota para el logro de sus planes.

Al desembarcar Goyeneche en América como en- 
viado de la Junta Central, se decía portador de plilegos de la misma para dar a conocer la verdadera situación de España en aquel Continente y lograr la adhesión a la causa española de todas sus colonias; asimismo, se decía portador de la misión de establecer buenas relaciones y armonía entre la Corte del Brasil y España. A este fin despachó hacia Río de Janeiro una comisión que se puso en contacto con la Infanta y le hizo saber sus propósitos (19). Como consecuencia, se estableció una correspondencia periódica entre aquélla y éste, con el fin de indicarle «cuanto observe en los dominios del Rey los sentimientos de amor y sumisión», según decía el propio Goyeneche (20), y a lo largo de la cual, la Infanta le insinuaba, algunas veces, como a las demás autoridades de América, su propósito de llegar, si las circunstancias lo exigían, «a ejercer las veces del Rey Católico con el consentimiento de la Nación; y por consiguiente, a renunciar y separarme de todo atro gobierno, en forma de aliada, of reciendo así todos los socorros que este Continente puede ofrecer a la Patria Madre, y por fin un perfecto asilo en el caso (lo que Dios no permita), que los valerosos españoles no logren en Europa sus fines honrados, como lo merecen sus esfuerzos heroicos y dignos de admiración» (21). Pero no hay ningún detalle que permita afirmar que Goyeneche se convirtiera en un agente de la Infanta, como se quiso hacer ver entonces.

Es más, se sabe que desde su llegada a Lima fué muy bien acogido por el Virrey Abascal, de quien en el transcurso de los acontecimientos llegó a ser el colaborador principal; pues bien, no parece probable que el celoso gobernante del Perú escogiese como su más eficaz auxiliar a un hombre de dudosa lealtad

(19) Arch. del Coxde de Guaqui. Caja 1. Carpeta 3. Número 65. Oficio de Goyeneche al Presidente y al Arzobispo de Charcas. Arequipa, 10, de enero de 1809.

(20) Arch. del Conde de Guaqui. Caja 6. Carpeta 2. Número 13. Copia de carta de Goyeneche a la Infanta Carlota Joaquina. Buenos Aires, 10 de septiembre de 1808.

(21) Arch. del Conde de Guaqui. Caja 6. Garpeta 2. Número 14. Copia de carta de la Infanta Carlota a Goyenediø. Río de Janeiro; 21 de octubre de 1808. 
a la Corona, lealtad que por otra parte dejó bien probada el mismo Goyeneche a lo largo de su vida militar en América.

Lo que sí es posible que ocurriera es que Goyeneche, que no era ningún genio político, creyera que quizás la solución de España en los momentos difíciles por que pasaba se podia encontrar en la persona de la Infanta Carlota; y que 'incluso no le pareciese mal la tutela de los dominios americanos por ella mientras durase la ocupación de la Península por los franceses. Pero si tal pensó, debió convencerse bien pronto de que el ánimo de los americanos no estaba dispuesto a soportar, siquiera temporalmente, ninguna dominación extraña, y menos de los portugueses, enemigos seculares de España en América (22).

A su llegada al Perú pudo darse bien pronto cuenta de que el Virrey Abascal estaba dispuesto a mantenerse a las órdenes de la Junta Central; se colocó a su lado y se ganó su confianza. Obtuvo el nombramiento de Presidente interino del Cuzco, mientras llegaba la confirmación oficial. En este intervalo tuvieron lugar los levantamientos de Chuquisaca y La Paz, primero, y poco después la sublevación de Buenos Aires. Para sofocar ambos movimientos, el Virrey no encontró otro instrumento más apropiado que el General Goyeneche, por las razones antedichas (23).

De esta actuación de Goyeneche al frente del Ejército realista durante la guerra de la Independencia, procede el juicio común que han formado de él casi todos los autores más o menos contemporáneos

(22) La pasterior correspondencia de Gayeneche desde Lima, con la Junta Suprema, el Virrey de Buenos Aires y el Intendente de Potosí, califica de esubversivas la conducta del Gabinete del Brasil, acusando al ministro Cutinho de ser el principal promovedor de las intrigas, pero salvando, por lo que se deja traslucir, a la persona de la Infanta. (Arch. del Conde de Guagui. Caja 1. Carpeta 3. Nímeros 70-71-73-74).

(23) Es muy viable la interpretación que da Rodríguez Casado al hecho de que Abascal pusiera a Goyeneche al frente de las tropas que sujetaron Chuquisaca y La Paz. Debió servir para decidir claramente la actitud del general ante las intrigas de la Corte del Brasil, luchando contra quienes precisamente lo acusaban de ser uno de sùs principales agentes. Vid, RODRIGUEZ CASADO, V., Estudio preliminar cit. Págs. LXXXVI-LXXXVח. 
con el suceso. Para los del bando patriota, fué un traidor a su patria, mientras que para los realistas fué algo asi como un hombre providencial. La actuación de Goyeneche se encuentra, sin embargo, plenamente justificada. Ya dije más atrás, al hablar de los caracteres de la lucha, que la guerra de la Independencia fué, entre otras cosas, una guerra civil entre americanos, desde el momento en que hubo americanos que lucharon en el bando realista y otros en el patriota, sin que esto quiera decir que los unos fuesen traidores y los otros patriotas. Ambos hallaban plenamente justificado su modo de obrar, y en realidad era asi, pues es innegable el sentimiento común de adhesión a la idea monárquica que existia en América, aun entre los mismos independizantes, en los primeros momentos. Por otra parte, no hay que olvidar la posición de los peruanos en general, frente a la cuestión de la Independencia. Goyeneche, educado en España en la idea monárquica tradicional, y situado al frente de uno de los distritos más importantes del Perú, se dedicó a secundar el plan de Abascal de dar una base americana a la contrarrevolución, pensando en las graves consecuencias que tendria el triunfo de los patriotas. Por tanto, dejando aparte su papel como militar, la verdadera significación de Goyeneche en el conjunto de los acontecimientos de esta primera etapa de la Guerra de. la Independencia fué la de haberse convertido en el instrumento apropiado capaz de infundir vitalidad a la causa realista y que hizo a ésta poderosa y temible hasta 1824. De aqui precisamente el odio común de los patriotas hacia el General, pues se dieron cuenta que gracias a él se logró llevar a la práctica el plan de Ab̆ascal, que de otro modo hubiera necesitado al menos de algún tiempo para que cuajara.

Otro aspecto digno de examinarse de la figura de Goyeneche, siquiera en sus lineas generales, ya que los detalles escapan al carácter de este capitulo y serán objeto de examen en los posteriores, es el de sus relaciones con el Virrey.

Ya he dicho más atrás que a la llegada de Goyeneche a Lima fué bien recibido por Abascal, quien pensó que al fin habría de tener noticia cierta de los sucesos de España. Además, debió ser un motivo de 
alegría para el Virrey la noticia que le diera Goyeneche del entusiasmo de los pueblos y ciudades de su tránsito aclamando a Fernando VII. Todas estas circunstancias, la afabilidd del comisionado y el hecho mismo de ser americano, debieron influir favorablemente para él en el ánimo del Virrey. De aquí nació una gran amistad entre ambos, que se mantuvo durante largo tiempo. Cuando estalló la guerra y Goyeneche fué colocado al frente del ejército que se estaba organizando, debió influir en la decisión de Abascal, aparte de sus ideas sobre la cuestión, la estrecha amistad que los unía. Y su colaboración no pudo serle más apreciable. En estricta Justicla, hay que decir que el virrey no hacía sino corresponderle, en parte por la propia amistad y carinho entre ambos, y en pạrte también, como he dicho antes, porque se daba cuenta de lo fundamental que era para la causa realista teher a Goyeneche al frente del ejército. A tal punto llegó esta preferencia por el Geheral, que hubo ocasión en que el Virrey detuvo el cumplimiento de órdenes del Gobierno, que sabía iban a dar como resultado inmediato la retirada de Goyeneche del mando de las tropas.

Sin embargo, hubo momentos en que llegaron a perturbarse las relaciones cordiales entre ambos. El éjecito del Perú se había organizado a base de peruanos casi exclusivamente; y, como es lógico, al llegar a las filas, ninguno tenía la menor noción del arte militar ni de la dísciplina, que sólo por una labor perseverante se les podía inculcar. Casi todos ellos Iuchaban con grati empeño por la causa del Rey, pero como por las circunstancias económicas del Virreinato, muchas veces no podian estar al corriente de sus pagas, ocurría que como hubiese algún período de inacción muchos desertaban y se marchaban a sus casas. Esta deserción casi constante y las pérdidas naturales de la lucha, hacian que Goyeneche insistiera itintertrumpidamente ante el Virrey en solicitud de auxilios. Abascal atendia las peticiones del general, en la medida de sus fuerzas, pero nunca como aquél deseara, puesto que era totalmente imposible. Sin embargo, esto era Interpretado de otro modo por Goyeneche, que creía ver en ello cierta negligencia por parte del Virrey, que no se daba cuenta de la trascen- 
dencia que tenia el mantemiento del Ejército. En consecuencia, se originaban momentos de tirantez de las relaciones entre ambos, en los que Goyeneche hacia patente al virrey su cieseo de abandonar el mando de las tropas para no hacerse responsable de la que sucediera si aquél continuaba enviándole tan pocos refuerzos: Como es patural, su insistencia llegó a molestar a Abascal; a ésto vino a unirse la derrota sufrida por el Ejército realista en Tucumán; y posteriormente en Salta, cuya causa achacaria Goyeneche a la falta de refuerzos, mientras que Abascal la atribuia a la imprevisión del general: Como conseruencia, Coyeneche presentó de nuevo la dimisión, aceptada inmediatamente por el Virrey, que enseguida trató de sustituirlo. Semejante determinación debió sentarle mal, pues se sintió lastimado en su amor propio de fundador del Ejército, lo que dió como resultado el desencadenamiento de una campaña de murmuración y resistencia, que puso en peligfo toda la obra realizada hasta entonces. Pero no sólo no paró aquí la cosa, sino que vuelto a España, Goyeneche volvió a atacar violentamente al Virrey, aunque sin éxito.

Ciertamente, las disputas entre el General y el Virrey nos hacen ver a ambos, situados en condiciones distintas, preocupados de llevar a tabo su cometido, pero con una diferencia de puntos de vista, y en algunos momentos con un poco de incomprensión. Mientras el uno; desde la capital, se preocupaba sobre todas las cosas de da marcha de las aperaclones y de evitar cuanto fuese posible para apresurar la victoria, a la par que tenia que acudir al Alto Perú, a Chile y a Quito, y en algunos momentos hasta al interior del mismo Perú, aparte de los numerosos problemas internos del Virreinato; el otro; desde el teatro de las operaciones del Alto Pervi, se daba cuenta de la trascendencia de la lucha en este sector, verdaderamente el más decisivo de todos, pero no el único: Por tanto, no se podia gcudir exclusivamente a él, pues se corria el peligro de dejar el campo libre a los sublevados en otras regiones. Esto quizás no lo comprendiera demasiado Goyeneche, casi más obsesionado con la constante amenaza de las sublevaciones del Alto Perú, que con la de los avances del Ejército argentina.

En esa discusión llega el momento en que Abascal 
está a punto de prescindir del General, pero por otra parte se da cuenta de lo valiosa que era su permanencia al frente del Ejército, como elemento de unión entre él y los soldados americanos, y decide que continúe hasta encontrar otro momento oportuno, que halló después de la derrota de Salta.

Sin embargo, todos estos detalles no empañan el mérito cierto de Goyeneche, cuya labor militar y cuyas ideas sobre la marcha de la guerra tendremos ocasión de examinar más adelante.

Queda, pues, sentado, que si Goyeneche vaciló alguna vez en su misión de negociador con que marchara a América, debe interpretarse más bien como error de un hombre inexperto en politica, que como producto de una mala voluntad por su parte. Que se hallaba completamente al lado de Fernando VI, lo demuestran sus campañas, y sus disputas con Abascal se pueden considerar como resultado de su amor propio herido al ser retirado del mando del Ejército que él organizara, y separado de sus hombres, que realmente lo estimaban.

\section{El general Pezuela.}

Don Joaquín de la Pezuela, oriundo de Santander, nació en Naval, Aragón, en 1761. Se dedicó a la carrera de las Armas, ingresando en el Cuerpo de Artillería, con el que intervino en el cerco de Gibraltar en 1782 , y en las campañas del Pirineo contra la Revolución francesa en 1793 y siguientes: En 1805 fué destinado al Perú, con el grado de coronel y -el cargo de subinspector interino de Artillería. En 1811 era ascendido a brigadier y se le confiaba en propiedad el cargo, en el que permaneció hasta su marcha como general en jefe del Ejército de operaciones del Alto Perú, en sustitución del general Goyeneehe (24).

La figura de Pezuela es bastante diferente de la de

(24) MENDIBURU, M. Op. cit. Tomo VIII. Lima, 1934. Páginas 387-388, 
su antecesor en el mando del Ejército. Hombre sereno, reposado, tranquilo en sus decisiones, no realizaba ntn-. gún acto sin haber meditado mucho las consecuencias que de él se pudieran deducir. Sus conocimientos militares no eran extraordinarios, pero sabía manejarlos hábilmente y tenía ideas claras sobre la situación.

Había pasado Pezuela siete años al lado de Abascal, en Lima, antes de incorporarse al Ejército del Alto Perú. Este tiempo no pasó en balde para el general. Al lado del Virrey, protegido por él, había ido ampliando sus conocimientos técnicos y políticos. Con su àyuda constguió organizar un potente cuerpo de artillería, perfectamente equipado y con los conocimientos suficientes, labor cuya eficacia se demostró a lo largo de la lucha. Como dice Lavalle, «Pezuela era hechura y criatura suya; el (Abascal) lo había sacado de la oscuridad, y él, que lo destinaba para que fuese su sucesor, le allanaba el camino que tenía que recorrer para ascender a tan alto puesto (25).

Cuando Abascal aceptó la dimisión de Goyeneche, no encontró a su alrededor a ningún otro Jefe-si se exceptúa a Henostrosa, de quien en seguida retiró la conflanza-que el General de la Pezuela. Recibida la orden del Virrey, inmediatamente partió hacla el Cuartel General del Perú, en donde se hizo cargo del mando del Ejército.

La situación què recogía Pezuela no podía ser más delicada. A consecuencia de las batallas de Tucumán y Salta, parecía imposible la posesión del Alto Perú para los realistas, y, sin embargo, era de vital importancia para las armas virreinales. El proplo Pezuela reconocía lo apurado del momento, mas a la par se daba cuenta de que uno de los elementos fundamentales para obtener el triunfo había de ser la reorganización y el aumento de disciplina en el Ejército. A ello se dedicá, pues, desde su llegada al Alto Perú.

Convencido de haber aumentado la efectividad de su tropa despues de una etapa de reorganización, no tuvo inconveniente en lanzarse a la lucha para des-

(25) LAVALLE, J. A. de. Abascal. Rev. de Buenos Aires. Tomo V, 1864. Pág. 406. 
pejar la situación. El resultado le fué favorable. Emprendió una serie de movimientos para impedir la unión de las fuerzas argentinas y altoperuanas. y el éxito coronó su maniobra. Las dos batallas, de Vilcapugio y Ayohuma, fueron el fruto. Al final de su campaña, con la batalla de Wiluma. consiguió la recuperación total del Alto Perú. de tal forma, que el resultado de la campaña de Pezuela no pudo ser más beneficioso para las armas realistas.

Todo esto no fué sino la consecuencia natural de la puesta en práctica de los conocimientos que poseía el general sobre la situación, llevada a cabo con la tenacidad y la firmeza que eran propios de su carácter.

Las victorias condujeron a Pezuela al gobierno del Virreinato, ya que «parecia tener el secreto de la victoria contra los generales del Río de la Platas (26). Pero no logró tampoco el resultado decisivo. La llegada de La Serna como general en Jefe del Ejército empeoró la situación, pues originó escisiones entre absolutistas y liberales dentro de las mismas filas realistas. La Serna, afiliado a una logia. constituyó en el Alto Perú, con sus oficiales allegados, un partido contrario al Virrey Pezuela. mientras éste tenia que hacer frente a la invasión del territorio peruano por las tropas de San Martín.

En situación tan inestable, amenazado por San Martín por un lado. y con la enemistad de los jefes del Alto Perú, Pezuela no podía mantenerse, a pesar de aue hacía cuanto estaba de su parte para sacar al Perú de la grave crisis por que pasaba. Pero la fuerza de los bechos era superior a la fuerza del Virrey, sobre todo, desde el momento en que no podía contar eon el apovo unánime de sus tropas. Hay que hacer notar, en mérito de Pezuela, que. a pesar de lo delicado de su posición. Jamás transigló ante el complot de los Jefes del Etército, conservando en todo momento la fidelidad hacia el Rey, aunque ello le costara el cargo (27).

Cuando Pezuela fué depuesto por la sublevación

(26) PEREYRA, Carlos. Op. cit. Tomo VII. Madrid, 1925. Página 8åre

(27) Es interesantísima a este respecto la Memoria do Go- 
de Aznapugio; aun se intentó un último arreglo entre San Martín y La Serna, según órdenes reeibidas de Madrid, pero fracasó. Desde entonces; se podía considerar liquidada la guerra, no porque el Ejército español estuviese derrotado, sino fundamentamente por las divisiones surgidas en su seno. Hasta entonces, la reacción de las tropas realistas había conseguido triunfos que hacían volvor las cosas al estado primitivo, cuando Sam Martin invadiera el Virreinato. Pero la defección de Olañeta fué un golpe mortal, mucho más cuanto que fué aprovechada por los independizantes. En esta situación tienen lugar las batallas de Junin y Ayacucho, que ponen punto final a la dominación española en el Perú.

El mérito de Pezuela durante su mando del Ejército fué conseguir darle una organización definitiva, que perduró hasta el fin de la guerra, e infundir en sus filas la disciplina, que tan relajada estuviera en los últimos tiempos de Goyeneche. Sus victorias fueron brillantes, tan brillantes que le condujeron al gobierno del Perú, cuando la Corte española se convenció de que no había otro remedio que emplear las armas como única solución al conflicto, y decidió sustituir los medios políticos del Marqués de la Concordia por el sistema militar de Pezuela.

Al decir que Pezuela no era un general extraordinario, hay que tener en cuenta que ninguno de los generales que lucharon en la guerra americana lo fué, tanto en el bando realista como en el patriota. Los generales más renombrados de los patriotas, seguramente se distinguieron más como políticos que como estrategas, sin que el haber ganado la guerra signifique una superioridad sobre sus contrarios. Antes bien, ya he dicho, y tendremos ocasión de comprobarlo, que en todo momento la técnica, la disciplina y, en una palabra, la superioridad militar, estuvo siempre de parte de los realistas. Si los americanos ganaron

bierno del Virrey Pezuela, en la que da a entender y aclara su posición frente al grupo de militares del Alto Perú, y que ha sido publicada por V. RODRIGUEZ CASADO y GUILLERMO LOHMANN VILLENA. 
la guerra, se debió a las causas ya apuntadas, pero nunca a su superioridad sobre los contrarios.

Pezuela, sin embargo, fué uno de los generales más afortunados. Su error consistió en no sacar suficiente fruto de sus victorias, que pudieron convertirse en desastres para los enemigos. Pero su caballerosidad, su lealtad hacia el monarca y su trabajo incesante por la causa realista, bastan para amnistiarle ante la Historia. 
SE GU N D A PARTE 


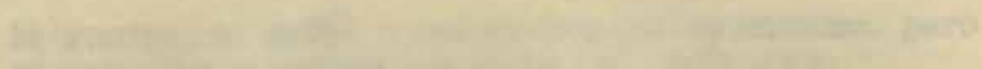

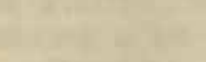

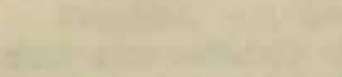

1

अ 


\section{LAS PRIMERAS SUBLEVACIONES DEL ALTO PERÚ}

\section{La sublevación de Chuquisaca.}

De todas las ciudades del Alto Perú, era Chuquisaca la más notable, por residir en ella la capitalidad de las Provincias y tener en su seno a la renombrada Audiencia de Charcas. Pero no solamente por eso era tenida como la primera entre las ciudades altoperuanas, sino también, y esto es importante, por la existencia en ella de una antigua e ilustre Universidad, de donde salieron todos los intelectuales del Alto Perú y entre ellos los futuros politicos de la revolución americana.

La Universidad de Chuquisaca era el centro intelectual de toda la América del Sur, aparte de la de San Marcos, de Lima. A ella iban a estudiar, no sólo los naturales de las provincias altoperuanas, sino también los potentados del Río de la Plata, deseosos de adquirir cultura. Y fué precisamente la Universidad la que influyó de un modo notable en los aconte- 
cimientos desarrollados en el Alto Perú, y la que dió un matiz especial a la revolución en este territorio, que la hizo separarse pronto de la argentina. Allí se formaron los universitarios que hicieron la revolución con un matiz eminentemente aristocrático, mantenido en todo momento, mientras que los que intervinieron en la del Río de la Plata, se encontraron aislados, y poco a poco fueron perdiendo sus primeras conquistas.

El otro orgullo de la ciudad era la Audiencia de Charcas, una de las más prestigiosas de América del Sur, y extraordinariamente celosa de su poder y sus privilegios. Esta Audiencia habia gozado siempre en la práctica de gran autonomía, pero al establecerse las reformas de los Borbones, por las cuales pasó a depender del Virreinato de Buenos Aires, se implantó también el régimen de la administración y el gobierno provincial con los intendentes y subdelegados, autoridades todas dependientes directamente del Virrey, con lo cual el poder de la Audiencia quedó reducido a la aplicación de la Justicia. Esto mortificaba el amor propio de los miembros del tribunal, que habían pensado que al pasar a depender del Virreinato de Buenos Aires seguirían gozando de facultades omnímodas.

Consecuencia de la nueva situación fueron los constantes choques de la Audiencia con el Virrey por asuntos de competencia, en los cuales, los oidores trataban siempre de salvar la dignidad de su Tribunal, que consideraban vejada. Procuraban, por tanto, mantener siempre una atmósfera de desafecto al centralismo de Buenos Aires, que se manifestaba en una ininterrumpida obstaculización al cumplimiento de las órdenes emanadas de aquel Virrey. Todo lo cual no era sino prueba de lo aferrados que se hallaban los miembros del Tribunal a sus privilegios.

La actitud intransigente de aquéllos fué causa de la conmoción que sufrió la ciưdad el día 25 de mayo de 1809 , con la que se abre la serie de los movimientos independizantes de América del Sur. En principio, no tuvo su origen más que en cuestiones de dignidad y en la vanidad herida de los universitarios de Chuquisaca, pero todo esto desembocó en un movimiento francamente separatista. 
Hasta comienzos del siglo XIX, a pesar de las rencillas de los oidores, se había conseguido mantener la paz en la ciudad, por encima de todo. Comenzaron a alterarse las cosas cuando surgió la enemistad entre la Audiencia y su Presidente.

Era entonces Presidente de Ia Audiencia de Charcas don Ramón Garcia Pizarro, hombre de avanzada edad y con poca energía para el mando. Debido quizás a esto las relaciones entre él y la Audiencia eran en extremo cordiales, tanto más cuanto que se limitaba a cumplir sus funciones sin afectar en lo más mínimo las prerrogativas de los oidores, antes al contrario, soportando en algunos casos desaires de sus subordinados.

Pero ocurrió un hecho que vino a alterar el «statu quos existente hasta entonces, y a desencadenar la ofensiva de la Audiencia. Fué el nombramiento del doctor don Pedro Vicente Cañete para asesor de la Presidencia. Este hombre, ingenio hábil en la intriga, había ocupado antes la Asesoría de Potosí, de donde vino trasladado a Chuquisaca. Desde el momento que tomó posesión de su nuevo cargo, se dió cuenta que el Presidente era persona fácilmente manejable, y se dedicó a imbuirle ideas de su superioridad sobre los demás miembros del Tribunal. Nada podía ser menos político, dada la situación del momento, que un golpe de fuerza por parte de aquél; esto lo sabía Cañete, y por eso procuraba robustecer la autoridad del Presidente de un modo paulatino, cercenando poco a poco el poder de los oidores. Pero la maniobra no pasó desapercibida a aquéllos, y antes de que pudiera coronar su obra, ya se le habian enfrentado. Ahora bien, el odio de los oidores recayó sobre Cañete, pero no sobre el Presidente, al que consideraban juguete suyo; y ante la intransigencia de los oidores, García Pizarro se vió obligado a sustituirlo por el doetor Gascón.

Pero mientras ocurrian las intrigas entre la Audiencia y Cañete, había tenido lugar otro hecho que merece la pena consignase como otra de las causas que contribuyeron al planteamiento de los sucesos posteriores. A la muerte del arzobispo San Alberto, le habia sustituído en la silla de Chuquisaca el arzobispo don Benito María de Moxó, hombre joven, enérgico y dispuesto a reformar el clero, cuyo estado de 
relajación conocía, por los medios que estuvieran a su alcance (1).

Desde el primer momento, fué recibido con alguna prevención en los medios religiosos, sabedores de las ideas que preconizaba y de su propósito de terminar sin contemplaciones con la situación que no habia sido capaz de superar la extraordinaria bondad del arzobispo San Alberto. Ya antes de llegar se le representaba «duro por su carácter y poco dispuesto por el trato dulce y suave a que estaban acostumbrados los de esta ciudad» (2).

Se divulgaron pronto las noticias de que el nuevo Prelado se oponía a la desmembración de la ciudad de Cochabamba en diócesis independiente, y que reprendió al Vicario de aquella ciudad por haberse mostrado públicamente partidario de la segregación, como asimismo que venía dispuesto a desbaratar «el complot de cochabambinos, que hasta entonces habia gobernado en la diócesis».

Cuando el nuevo arzobispo tomó posesión de la sede, comenzó a poner en práctica su vasto plan de reforma del clero. Tras un maduro examen del problema, puso manos a la obra. En primer lugar estableció una Junta examinadora, compuesta de doce individuos, con en el fin de juzgar el «saber e ignorancia de cada uno de los eclesiásticos en las materias esenciales de su sagrado ministerio», como tambièn para comunicarle «todas las noticias ciertas que tuviese sobre la vida y costumbres de los individuos» (3).

Las consecuencias de esta medida pueden calcularse fácilmente. Los mismos examinados se encar-

(1) Sobre el nuevo Arzobispp de Chuquisaca pueden verse el estudio de Ruben VARGAS UGARTE, S. J., titulado $D$. Benito $M a$ ría de Moxó y de Francoli, Arzobispo de Charcas, Buenos Aires, 1931 , en donde recoge los principales aspectos de su actuación en América y añade un prolijo estuảo bibliográfico; y el más reciente, de mismo autor, El Episoopado en los tiempos de la Revolución Srid-Americana. Buenos Aires, 1945.

(2) Arch. del Conde de Guagui. C. 1, C. 2, N. 37. \&Relación de un imparcial sobre los sucesos de Chuquisaca». 1809.

(3) RENE-MORENO, Gabriel. Ultimos dias coloniales del Alto Perú. II parte. Santiago de Chile, 1898. Pág. 150. 
garon de propagar todas las especies que podian tender a desacreditar al arzobispo. «Los que salían réprobos de los exámenes, eran unos tantos pregoneros de la temeridad e imprudencia de su Ilma., ya porque decian que examinaba sobre materias extraordinarias y no concernientes a la moral que habian estudiado, o ya porque su insuficiencia se hacía tanto más notoria, cuanto que su Ilma. había permitido fuesen testigos de ello todos los hombres y mujeres que asistían en calidad de mosqueteros» (4).

La enemistad del Arzobispo con la Audiencia no tardó en llegar. Fué debida al incidente que se suscitó entre el Prelado y el oidor don Agustín de Usoz, a consecuencia del cambio de residencia del último. El Oidor poseía licencia para tener oratorio en su casa, y al cambiar de domicilio quiso hacer valedera aquella licencia para su nueva casa sin necesidad de renovarla, como estaba obligado. El Arzobispo se opuso a que se celebrasen alli misas sin su previa autorización, y como Usoz no quería doblegarse a solicitarla, llegó a prohibir expresamente la celebración de misas en el oratorio. El incidente ya bastaba para enemistarse con todos los miembros de la Audiencia, que consideraban la medida del Arzobispo como un atentado contra sus derechos. Pero aún vino a agriar más la discusión, la licencia concedida por el Prelado a otro habitante de Chuquisaca para tener oratorio. Con esto se podian considerar rotas las hostilidades. Todavía colmaron la medida algunos incidentes que trajeron como consecuencia la enemistad de la Universidad hácia el Arzobispo. $Y$ aún el tejido de intrigas continuó extendiendose hasta abarcar al Presidente. Ya desde que Cañete comenzara a imbuirle las ideas de su superioridad sobre los oidores, García Pizarro quiso hacer sentir su autoridad. Fué entonces cuando comenzaron las cuestiones de competencia entre la Audiencia y el Presidente. Estas cuestiones, elevadas para su resolución al virrey Liniers, eran resueltas casi invariablemente en favor del segundo,

(4) Arch. C. Graqui. Caj. 1, Carp. 2, N. 37. «elación de un imparcial sobre los sucesos de Chuquisacas. 1809. 
de donde los togados de Chuquisaca concibieron un odio profundo hacia el virrey.

Cañete era, como dije, el que alentaba al Presidente para hacer valer su autoridad. Su remoción del cargo, conseguida por los oidores, significó bien poco en la práctica, pues continuó viviendo en Chuquisaca y aconsejaba y alentaba a García Pizarro para seguir la obra comenzada. Los oidores, molestos con su presencia, dictaron auto de extrañamiento contra él, aprovechando una corta ausencia suya de la ciudad. Pero la medida de la Audiencia fué reprobada por Liniers, y Cañete continuó en Chuquisaca; la indignación de los oidores subió de punto.

Mientras todas estas cosas iban enemistando a la Audiencia con su Presidente, ocurría un hecho que acabó de delimitar los bandos, y fué la amistad que contrajeron el Arzobispo, el Presidente y Cañete. Hasta tal punto intimaron, que siempre se les veía reunidos, circunstancia que contribuyó a hacer extensivo al Presidente el odio que profesaban los oidores al Arzobispo y a Cañete.

Los dos últimos inducían al Presidente a no ceder ante el Tribunal, antes al contrario, le hacían ver que su autoridad era superior a la de aquél. La cuestión se llevó ante el virrey de Buenos Aires, que falló a favor del Presidente, como tantas otras veces. A partir de entonces, comienza la batalla (5).

Recibidas en Chuquisaca las noticias de la Corte Española sobre la abdicación de Carlos IV, tiene lugar el reconocimiento de Fernando VII. Pero aún no habian terminado los preparativos para la exaltación del nuevo rey, cuando llegan rumores de lo ocurrido en Bayona.

El 17 de septiembre de 1808 llegaron las noticias exactas sobre lo ocurrido en aquella ciudad, y sobre la ocupación de la Península por las tropas de Napo-

(5) Sobre todos los hechos que condujeron a las enemistades que desembocaron en la sublevación de Chuquisaca, pueden verse, además de la obra ya citada de RENE-MORENO, los capítulos IX y XII del libro de HERREROS de TEJADA, El Teniente General D. José Manuel de Goyeneche, Conde de Guaqui. Barcelona, 1923. Págs. 135-151, y 175-183, respectivamente. 
león, como asimismo de la formación en Sevilla de una Junta para defender los derechos de Fernando VII. Por último, se supo también que había llegado a Buenos Aires, enviado por esa Junta, el Brigadier don José Manuel de Goyeneche, cuya visita al Alto Perú se anunciaba próxima.

El Virrey cursó las órdenes oportunas al Presidente para el reconocimiento de Fernando VII, como en efecto se hizo, pero a pesar de ello, la Audiencia, molesta por no haber recibido directamente la notificación, hizo una serie de desaires realmente inverosímiles a las personas del Presidente y el Arzobispo. Refiriéndose a este último, dice así un contemporáneo: «Hizose una Jura de estilo, y le hicieron los Oidores, con sobrado estudio, un desaire escandaloso a su Ilma., prohibiendo que ninguno tirase dinero o monedas al pueblo sin licencia del Tribunal, sólo por saber que el Arzobispo estaba dispuesto a hacerlo, y mandando igualmente que el estandarte real no pasase por la puerta del Palacio Arzobispal, donde su Ilma., con su clero y Prelados regulares, estaba dispuesta a hacer una edificante ceremonia (6).

Pero cuando las cosas llegaron a un extremo intolerable fué a la llegada de Goyeneche. Al tenerse noticias de su arribada a Buenos Aires y de que se disṕonía a continuar el viaje hacia el Alto Perú, la Audiencia se resistió a recibirle como tal diputado de la Junta de Sevilla. La tirantez llegó a su último extremo con la entrada del comisionado en la ciudad; la Audiencia no lo recibió, y cuando se convocó la reunión de los Cabildos y el Tribunal para reconocer sus poderes y que diese cuenta de la situación en que había dejado la Península, se negaron a asistir. Solamente cuando recibieron una intimación de Goyeneche, que traía plenos poderes para destituir a todos los que se resistiesen a reconocer su comisión, depusieron su actitud, aunque sólo formalmente, pues en el fondo seguían obstinados en ver en él un agente del Virrey de Buenos Aires.

Poco después de la marcha de Goyeneche ocurrió

(6) Vid. nota 4. 
la muerte del Regente de la Audiencia, don Antonio Boeto, achacada a los resultados de la Junta celebrada el 12 de noviembre, en la que se discutió acaloradamente sobre el reconocimiento de los poderes del comisionado y la legitimidad de la Junta de Sevilla.

En este estado de tensión iban propagándose los más diversos comentarios. Comenzó a correr la voz de que, tanto Goyeneche como el Virrey de Buenos Aires, se disponían a entregar los dominios americanos a la Infanta Carlota Joaquina. Basaban sus sospechas en los manifiestos circulados por la Infanta al Presidente y demás autoridades. Y decían que a su llegada a Chuquisaca, Goyeneche habia convencido al Presidente y al Arzobispo, quienes, en su odio hacia la Audiencia, se le habian entregado totalmente. Todos estos rumores se propagaban en medio de las más grandes muestras de fidelidad a Fernando VII. Igualmente se corrió la especie de que el Presidente había formado una lista de proscripción para destituir de sus cargos a todos los oidores y a todos aquellos funcionarios que se opusieran a sus planes.

Con semejantes noticias y alarmas producian el efecto deseado de enemistar al Presidente con el pueblo de Chuquisaca. Por fin, el día 25 de mayo de 1809, reunidos los ministros de la Audiencia en Acuerdo, determinaron deponer al Presidente, bajo la acusación de pretender entregar la ciudad a la Infanta Carlota Joaquina, y negaron su obediencia al Virrey de Buenos Aires, afectado también de la misma acusación.

Noticioso el Presidente de la conjuración, dispuso el arresto de los que tomaban parte en ella; pero avisados a tiempo los conspiradores, pudieron huir, de tal forma, que sólo se cumplió la orden de prisión en uno de los individuos más alejados de la cabeza de la conspiración, el abogado don Jaime Zudáñez. Pero esto bastó para que, corrida la voz entre el pueblo de que habían sido detenidos algunos miembros de la Audiencia, se lanzase a la calle pidiendo a gritos la destitución del Presidente y la libertad de los que se suponian encarcelados.

En primer lugar se dirigieron los amotinados al Palacio Arzobispal para pedir al Prelado que intercediese en favor de los detenidos. Acompañado de los 
ministros don José Vázquez Ballesteros y el conde de San Javier, se dirigió el Arzobispo a la Presidencia, en donde obtuvo la libertad del único detenido hasta entonces. No valieron, sin embargo, las razones del Prelado para convencer al pueblo de que los demás se hallaban en libertad. Como estaban escondidos y no habían aparecido aún, se los creía víctimas de las maquinaciones del Presidente, sin que se tomara en cuenta el testimonio del propio Zudáñez, que salió acompañado del Arzobispo ( 7 ).

Poco a poco fueron apareciendo los que se suponían presos, menos el Fiscal don Manuel Zudáñez. En vista de esto se dedicaron a buscarlo por aquellos sitios donde suponian que podía encontrarse. Pero como no apareciese por parte alguna, decidieron dirigirse al cuartel de las tropas de guarnición en la ciudad. Y como era de temer que resultase alguna desgracia de la presencla de tan gran multitud de gente en las proximidades de aquél, el subdelegado de Yamparaes, don Juan Antonio Alvarez de Arenales, que entonces se encontraba en la ciudad y que desde los primeros momentos del tumulto se había unido a los amotinados procurando apaciguar los ánimos, se ofreció a investigar si Zudáñez estaba detenido dentro.

En vista del resultado negativo de las pesquisas de Arenales, se dirigieron los amotinados a la Presidencia acusando de traidor al Presidente, como culpable de la muerte del Fiscal, al paso que intentaban forzar la entrada del edificio. El propio García Pizarro habló al pueblo jurándole desconocer el paradero de Zudáñez y ofreciéndose como rehén hasta que apareciese. Aún pudo detenerse un poco el tumulto gracias a la mediación de Arenales, que ofreció las diligencias precisas para dar con el paradero del Fiscal.

Ya parecía apaciguado el motín, cuando, hallándose reunida la Audiencia, se comenzó a correr la voz entre el pueblo pidiendo la destitución y entrega del Presidente, que se hallaba en el Palacio y no asistía

(7) A. G. I.-Buenos Aires, 40. Informe del Subdelegado de Yamparaes, don Juan Antonio Alvarez de Arenales, sobre los sucesos de Chuquissca. La Plata, 30 de junio de 1809. 
a la reunión que entonces se celebraba. O al menos, pedian que se le entregara la Artillería y armas que tenían los soldados de su guardia. La Audiencia accedió a la petición y comisionó para llevarla a cabo al oidor conde de San Javier y a Alvarez de Arenales. Lograron éstos su pretensión, no sin resistencia de García Pizarro, que sólo se avino a entregar las armas de sus soldados cuando se le advirtió que era el único medio que le quedaba para conservar la vida. Pero cuando se procedía a la entrega de la Artilleria, el pueblo comenzó a pedir también las demás armas, a lo que se negaron los soldados, que hicieron una descarga contra la multitud.

Este incidente provocó una conmoción más fuerte aun, y a partir de aquel momento comenzaron a pedir la destitución y encarcelamiento del Presidente. Forzaron la entrada del lugar en donde habian encerrado la artillería y la emplazaron frente a la Presidencia. En tan crítica situación, la Audiencia aceptó la petición popular y determinó oficiar al Presidente rogándole resignara el mando en ella. El Presidente se negó en un principio a entregar el mando, pero instado por tres veces por los Oidores, que en caso contrario se negaban a responder de su vida, se vió obligado a aceptar.

Con tal medida, la Audiencia se hacía cargo del poder, en medio de las mayores protestas de fidelidad a Fernando VII. El presidente quedó detenido, y mientras el pueblo de Chuquisaca hacía las mayores demostraciones de cariño ante el retrato del monarca, colgaba en una horca simbólicamente el de García Pizarro.

Antes de que ocurrieran estos sucesos del 25 de Mayo, el Presidente, sospechando los acontecimientos que se aproxitaaban, pidió secretamente auxilio al Intendente de Potosí, don Francisco de Paula Sanz. Pero su llamada no pasó inadvertida para los que conspiraban en Chuquisaca, y cuando estalló el tumulto del día 25 se daba como cosa segura la llegada de las tropas de Potosí. De tal modo se corrieron los rumores, que el día 26 se recibió aviso de que se aproximaban dichas tropas, e inmediatamente todo el pueblo se puso sobre las armas, para impedirles la entrada. Convencidos de la falsedad de la alarma, se retiraron; 
pero el día 28 volvieron a tenerse noticias de que se acercaban las tropas del Intendente de Potosí, en un total de más de doscientos hombres (8).

En vista de la veracidad de los rumores, reunida la Audiencia, destacó un emisario para obligar al Intendente a emprender la retirada. Sanz, desconocedor de los hechos ocurridos los días anteriores, acató enteramente las órdenes de la Audiencia, y no sólo se retiró, sino que convino con ella los medios de asegurar la tranquilidad de las demás provincias. La actitud del Intendente de Potosí era motivada por la aprobación que el nuevo Virrey del Río de la Plata, Hidalgo de-Cisneros, había hecho de la actitud de la Audiencia, ignorante de lo ocurrido. Es más, el propio Virrey, a su llegada a Buenos Aires, mandó al Intendente de Potosi que reuniera fuerzas para mantener la tranquilidad de las provincias del Alto Perú, pero obedeciendo las órdenes de la Audiencia de Charcas, siempre que no fueran dirigidas contra el Gobierno de España.

Entretanto ocurrian estos hechos, había tenido lugar la sublevación de La Paz, con finalidad semejante a la de Chuquisaca, y llevada a cabo con pretextos análogos. Las noticias de ambas sublevaciones llegaron juntas al Perú, cuyo Virrey se puso inmediatamente en contacto con las autoridades fronterizas de su Virreinato, con el Virrey de Buenos Aires y con el Intendente de Potosi. Desde el primer momento, Abascal consideró del mismo carácter ambos movimientos y dispuso lo necesario para sofocarlos, prescindiendo de las protestas de fidelidad hacia Fernándo VII, de que constantemente hacían gala ambas ciudades.

El Intendente de Potosí, Sanz, informó al Virrey del Perú de la actitud de la Audiencia, que no sólo no cesaba de reunir armamento, sino que le intimaba a que disolviese las fuerzas reunidas en Potosi, haciéndose cargo el Tribunal de la Audiencia de la pacificación de La Paz. Esto dió que pensar a Sanz, que llegó a sospechar de la manera de proceder de la Audien-

(8) Vid. nota 7. 
cia, que tampoco le quiso entregar la persona del depuesto Presidente García Pizarro, bajo el pretexto de que era un traidor, cyua causa se estaba tramitando para darle el castigo merecido.

Asi, la Audiencia se constituyó como único organismo gubernativo en el Alto Perú, desautorizando al Intendente Sanz y ordenando a las demás provincias que no acatasen sus órdenes. Semejante actitud puso fuera de toda duda la finalidad perseguida por los oidores de Charcas. Ante el nuevo aspecto de la situación, el Virrey Abascal no dudó del partido a seguir: las tropas del Virreinato, que había colocado bajo las órdenes de Goyeneche, entonces Presidente interino del Cuzco, habian emprendido el camino de La Paz, con el fin de ocupar dicha ciudad y sofocar la sublevación; de acuerdo con él y con el Intendente de Potosí, determinó que las tropas continuasen hasta Chuquisaca, una vez dominada la revolución de aquella ciudad.

Aún hubo un cierto tiempo en que se cruzaron abundantes comunicaciones entre Abascal y la $\mathrm{Au}-$ diencia, en las que ésta le hacía ver el derramamiento de sangre que se originaría si seguian adelante las tropas de Goyeneche, haciendo valer en cambio la aprobación que Hidalgo de Cisneros diera de lo ejecutado el 25 de mayo. Pero por aquel entonces, el mismo Cisneros habia nombrado Presidente de Charcas a don Vicente Nieto, que se encaminaba hacia allá, acompañado de tropas de Buenos Aires. Por este tiempo, La Paz fué sometida, y los sublevados de Chuquisaca vieron el peligro encima, pues Goyeneche recibió orden de continuar hasta la ciudad.

Con semejantes circunstancias adversas, los oidores de Charcas se vieron obligados a aceptar la proposición de Abascal de restituir las cosas a su primitivo estado anterior al 25 de mavo, hasta la llegada a aquella capital del Presidente Nieto. En efecto, el 24 de diciembre de 1809 , entraba el nuevo Presidente, y la ciudad, y con ella todo el Alto Perú, quedaba completamente pacificado. 


\section{El levantamiento de La Paz.}

Las consecuencias de la sublevación de Chuquisaca no tardaron en sentirse en el resto de las ciudades del Alto Perú. En Potosí, gracias a la energía del Intendente Sanz, se cortaron los primeros brotes de un movimiento que parecía tener los mismos caracteres que aquél. En cambio, en La Paz, donde encontró un ambiente propicio y los revolucionarios lograron atraerse a las clases bajas, no tardó en presentarse una situación análoga a la de aquella ciudad.

En efecto, desde que el movimiento de Chuquisaca triunfó, comenzaron a salir emisarios hacia las distintas ciudades altoperuanas, con el fin de dar a conocer lo ocurrido entre la Audiencia y el Presidente, como resultado de lo cual aquélla se había hecho cargo del mando de todas las provincias. Al mismo tiempo hacian valer la aprobación que en un principio les diera el Virrey Cisneros, antes de haberse posesionado del mando del Virreinato. Todavía se llegó a más; pues el Intendente de Potosí, que habia recibido ordenes del Virrey de Buenos Aires de estar al tanto de los acontecimientos del Alto Perú, era mirado por la Audiencia de Charcas como un traidor; se instaba a los pueblos a negarle obediencia, recabando para si toda la autoridad.

No consiguió la Audiencia su propósito, pero si obtuvo otros resultados, no menos perjudiciales para la tranquilidad de las provincias. El día 16 de Julio de 1809 estallaba la sublevación de los habitantes de La Paz contra las autoridades, en circunstancias análogas a las de Chuquisaca.

Que la sublevación de La Paz era una cosa preparada de antemano lo prueba el hecho de que antes de que se llevase a efecto se rumoreaba en la ciudad que había de ocurrir un levantamiento general en ella (9). Se habia corrido el rumor de que las autoridades

(9) A. G. I.-Lima, 625. Copia de interrogatorio a Mariano Furedis, arriero de Siguas, procedente de La Plata. Puno, 21 de julio de 1809. 
pretendían entregar los dominios americanos a los portugueses, y este fué el pretexto de que se valieron para levantar los ánimos contra ellas.

Preparado todo al efecto, a las siete de la noche del 16 de julio, asaltaron el cuartel de tropas veteranas, cogiendo desprevenida a la fuerza que en él se alojaba y apoderándose de las armas. Prendieron a su Jefe, organizaron nuevas tropas y nombraron comandante general de ellas a un tal Pedro Domingo Mưrillo, mestizo de los más significados en la revuelta.

Suerte análoga a la del comandante de las tropas sufrió el Arzobispo, Juntamente con el letrado que entonces desempeñaba la intendencia. El Cabildo tomó el mando y organizó inmediatamente una Junta, que denominó "Tuitiva», y que quería ser, a semejanza de las que entonces se formaban en España, un organismo soberano independiente del Virrey de Buenos Aires. Efectivamente, las primeras medidas tomadas por la Junta fueron actos de total soberanía: se libertaron de alcabalas los productos de las manufacturas indígenas y se desarmó a los europeos, haciéndoles jurar fidelidad al pueblo.

Una vez conquistada la capital, esparciéronse emisarios para extender la sublevación al resto de las provincias. Pero esto mismo puso en cuidado a las autoridades de los territorios confinantes con el de $\mathrm{La}$ Paz, pues a pesar de las protestas de los sublevados sobre su fidelidad hacia Fernando VII, su manera de actuar dejó mucho que pensar sobre la veracidad de tales afirmaciones.

El Intendente de la provincia de Puno, en el Perú, limítrofe de La Paz, fué el primero en sospechar de la lealtad de aquella ciudad, e inmediatamente que tuvo noticias de lo ocurrido dió cuenta simultáneamente al Virrey Abascal y a la Audiencia del Cuzco para recibir auxilios en el caso de que, como parecia, los sublevados se dispusiesen a propagar sus doctrinas con las armas.

La ciudad de La Paz pertenecía al Virreinato de Buenos Aires désde la segregación que sufriera el Perú de las provincias de la Audiencia de Charcas, motivada por la creación de aquel Virreinato. Por tanto, al Virrey de Buenos Aires correspondía tomar las medidas para sofocar cualquier movimiento que se pro- 
dujese en ella. Pero es el caso que, por su proximidad al Virreinato del Perú, toda conmoción en estas provincias podía tener su natural expansión hacia el Bajo Perú. En el caso actual, la sublevación habia corrido de Chuquisaca a La Paz, y amenazaba con extenderse a todas las provincias de alrededor. Por otra parte, el Virrey de Buenos Aires no se hallaba en estos momentos en situación de poder acudir por sus propios y únicos medios para atender a los movimientos del Alto Perú. (10)

Al tener noticias de lo ocurrido en Chuquisaca, el Virrey de Buenos Aires escribía a Abascal rogándole «estuviese a la mira» de los resultados que se pudieran derivar de tal suceso (11). Pero, como ya he dicho más atrás, cuando sus avisos caminaban hacia Lima ocurrió el levantamiento de La Paz, con lo que las noticias de ambas sublevaciones llegaron simultáneamente a la capital.

El Intendente de Puno, tomeroso de que trascendiese a su provincia la conmoción de La Paz, escribió inmediatamente a Abascal con el fin de darle cuenta de lo ocurrido y hacerle patente por otra parte la incapacidad en que se hallaba de defender la provincia en caso de ataque de los insurgentes. Toda la fuerza de que podía disponer la componían seis batallones, carentes por completo de disciplina, lo cual no era tan peligro como el hallarse en el depósito de armas «sólo el. número de doscientos ochenta fusiles, la mitad de ellos sin su correspondiente uso a falta de cajas, tornillos y demás pequeñas partes de que se componen» (12). En semejante situación, el Intendente convocó una Junta, compuesta del asesor de gobierno, oficiales de graduación, alcaldes ordinarios y ministros de la

(10) Además de las razones históricas y geográficas que pudieran existir para pensar que el movimiento de $\mathrm{La} \mathrm{Paz}$ se orientase hacia el Perú, lo confirma el hecho real de la Proclama de Morillo, dirigida al pueblo peruano, $\boldsymbol{y}$ el envío de emisarios al Cuzco y a otras ciudades del Virreinato.

(11) A. G. I.-Lima, 625. Copia de Oficio reservado de Liniers a Abascal. Buenos Aires, 18 de junio de 1809.

(12) A. G. I.-Lima, 625. Copia de Oficio de don Manuel Quimper, Intendente de Puno, al Virrey Abascal. Puno, 23 de julio de 1809. 
Hacienda, en la que se acordó no llevar a cabo ninguna medida que pudiese llamar la atención de los sublevados y mantenerse a la expectativa, para reforzar entretanto con dos compañias la capital de la provincia y poner en disposición de ser utilizado el armamento útil que existía en el depósito de armas de la misma (13).

Juntamente con estas resoluciones se adoptó también la medida de pasar noticia al Presidente del Cuzco, para recabar su auxilio en caso de un movimiento ofensivo por parte de los paceños. Recibido el aviso del Intendente en el Cuzco y consultada la Audiencia, el Presidente le contestó poniéndole de manifiesto la escasez de oficiales en que se encontraba y la imposibilidad de enviarle alguno para disciplinar sus tropas, y sobre todo, le hacia notar la falta de un jefe apto para el puesto de comandante en caso de que tuviesen que salir de operaciones, de cuya falta daba cuenta al Virrey para que diese una solución a cuestión de tanta trascendencia como ésta. En cambio, se hallaba dispuesto a proporcionarle toda la munición y gente que necesitase para organizar la defensa de su territorio (14).

El mismo día escribia el Presidente del Cuzco a Abascal y le daba cuenta de la situación. El parte le llegó al Virrey en la noche del 7 de agosto, e inmediatamente, al siguiente dia, le comunicaba Abascal haber enviado para hacerse cargo del mando de las tropas al coronel graduado, entonces Intendente de la Provincia de Huarochiri, don Juan Ramirez. Su misión consistiria en situarse en la capital de la Provincia de Puno para contener cualquier intento de alterar el orden por parte de los sublevados. Con tal fin, se le encargaba llevase desde la ciudad de su mando el suficiente número de municiones y armas, además de doscientos hombres de tropa escogida, entre ellos cincuenta de caballería. Todo este contingente, como asimismo el que ya había ordenado el

(13) A. G. I.-Lima, 625. Copia de Acta de la Junta celebrada en Puno el 22 the Julio de 1809.

(14) A. G. I.-Lima, 625. Copía de Oficio del Presidente del Cuzco al Intendente de Puno. Cuzco, 26 de julio de 1809. 
Virrey que se uniera de la Provincia de Arequipa y de la misma de Puno, comenzaría a adiestrarse en plan intensivo de tal forma, que, cuando llegase $\mathrm{Ra-}$ mirez, los encontrase dispuestos para salir de la capital a situarse en el confin de la Intendencia, en su limite con La Paz (15).

Las instrucciones que Abascal daba a Ramirez eran que marchase lo más rápidamente posible hacia Puno, y una vez alli, con las tropas preparadas, disponer las cosas «a fin de operar con acierto en ląs ocurrencias, oficiando con los jefes y autoridades legitimas para concertar el modo de restablecer el orden y tranquilidad públicos en las Provincias de Chuquisaca y La Paz, y que no se transmitan a otras los movimientos acaecidos, celando muy particularmente en las del distrito de este Virreinato para que se conserve el sosiego de que disfrutan... (16). A la par le comunicaba que escribía al Intendente de Potosí y al Virrey de Buenos Aires para concertar con ellos el plan a seguir.

Tambíén se dirigía Abascal en este sentido al Intendente de Arequipa y al Marqués de Aviles, su antecesor en el Virreinato, que entonces se hallaba circunstancialmente en esta ciudad. Al primero le encargaba extremase la vigilancia del territorio de su mando y que enviase doscientos hombres a reunirse en Puno con los demás que alli se concentraban esperando la llegada de Ramirez. Al Marqués de Avilés, en cambio, teniendo en cuenta su edad, que no le permitia ponerse al frente de las tropas, le encarecia escribiese a todos los oficiales que le merecieran su confianza para que ayradasen al Coronel Ramirez, como asimismo le rogaba cooperase con cuanto estuviese de su mano al logro de la tranquilidad en el Alto Perú (17).

Tan sólo quedaba ya a Abascal ponerse en contac-

(15) A. G. I.-Lima, 625. Copia de Oficio reservado del Virrey Ahascal al Presidente del Cuzco. Lima, 8 de agosto de 1809.

(16) A. G. I.-Lima, 625. Copia de Oficio reservado de Abascal a Ramírez. Lima, 8 de agosto de 1809.

(17) A. G. I:-Lima, 625. Copias de Oficios reservados al Intendente de Arequipa $\mathbf{y}$ al Marqués de Avilés. Lima, 8 de agosto de 1809. 
to con las autoridades del Río de la Plata. A este efecto le escribia al Intendente de Potosi y al Virrey, como he dicho antes. Al primero le referia las órdenes comunicadas al Presidente del Cuzco para que le facilitase las fuerzas que creyese necesarias, pero le hacia saber que si llegaba el caso de urgente necesidad, en que por la distancia que mediaba entre esa capital y el Cuzco se viese obligado a pedir refuerzos, podía dirigirse directamente al Coronel Ramirez, jefe de las tropas situadas en el límite del Virreinato, con lo cual se ahorraba algún tiempo. Al Virrey le notificaba igualmente las medidas tomadas, cuya copia le remitia y le advertía que para todas las resoluciones que tomase respecto a la pacificación del Alto Perú y de los auxilios que necesitase, se pusiese en contacto con don José Manuel de Goyeneche, nombrado entonces Presidente interino del Cuzco, por muerte de su antecesor (18).

También Goyeneche había recibido instrucciones del Virrey respecto a su comisión en el Cuzco. Abas cal le decia que, si lo Juzgase necesario, pasase en persona a mandar las tropas que se estaban reuniendo en Puno a las órdenes de Ramirez, y con ellas siguiese hasta La Paz, para restablecer el orden en esta provincia y en la de Chuquisaca, «obrando con la precaución, prudencia y tino que las circunstancias exigen», cacordando con esa Real Audiencia y los Gobernadores Intendentes de Arequipa y Puno y con el de Potosi, las providencias que conciernan a los interesantes fines que motivan éstas, y procediendo de acuerdo con ellos y con el Excmo. Sr. Virrey de Buenos Aires» (19). Al mismo tiempo le recomienda que imprima la mayor velocidad en el apresto del armamento y de la tropa para que se halle preparada cuando llegue el que las haya de mandar.

Como quiera que las noticias que se recibían de La Paz eran cada vez más alarmantes y se confir-

(18) A. G. I.-Lima, 625. Copias de Oficios reservados al Intendente de Potosí y al Virrey de Buenos Aires. Lima, 8 de agosto de 1809.

(19) A. G. I.-Lima, 625. Copia de Oficio reservado del Virrey Abascal al Presidente interino del Cuzco, don José Manuel de Goyeneche. 
maban los propósitos que se le atribuian a los revolucionarios, pocos días después de estas primeras medidas tomadas por el Virrey Abascal, estudiaba el mismo gobernante todo el plan de operaciones contra aquéllos. En principlo consideraba como fundamental tomar las posieiones que a lo largo del Desaguadero servian de comunicación con el Virreinato de Buenos Aires, como también el estrecho de Tiquina y las entradas de Larecaja y Omasuyos, con lo cual se cerraban los accesos al Perú. De este modo se impedía la introducción de sospechosos y de papeles que tendiesen a alterar la tranquilidad del Virreinato. Sin embargo, consideraba muy interesante Abascal tomar todas las medidas con gran prudencia, a fin de evitar que las provincias creyesen que eran ocupadas porque se dudaba de su fidelidad; de tal forma, que había que darles a entender que se dirigian sólo contra los sublevados.

Los seiscientos hombres que habia mandado reunir entre los contingentes del Cuzco, Puno y Arequipa, deberian marchar a Puno hasta la llegada de Ramirez, y entretanto permanecer a las órdenes del Intendente de Puno; de ellos se separarian los destacamentos para cubrir los puntos propuestos. Simultáneamente se debian preparar otros doscientos hombres en Puno, y otros tantos en Arequipa, para que constituyesen el Cuerpo de reserva, dispuesto a acudir donde fuese necesario, a cuyo fin daba las ordenes oportunas al Presidente interino del Cuzco y a los intendentes de las otras dos ciudades.

Aun proponia Abascal un intento de negociación con los sublevados de La Paz a la llegada de Goyeneche. Este, con el acuerdo de la Audiencia, debia tratar el asunto. Debería insistirse a la Junta de La Paz, haciéndole ver que, en caso de no avenirse a deponer su actitud, se emplearian las armas para disuadirlos, sin admitir el pretexto aducido por ellos de la distancia a que se hallaban de la capital del Virreinato, pues, como decía Abascal, dicha circunstancia no les debia dar alas para su insubordinación, "porque en semejantes casos, todos los que mandan tienen derecho, y aun obligación, de atender a cualquiera de los puntos en que se necesita su auxilio». En fin, de todas formas, recomendaba agotar todos los recursos 
de la prudencia antes de lanzarse a la lucha con las armas. Al mismo tiempo, indicaba la conveniencia de enterarse de las disposiciones en que se encontraban los enemigos respecto a su estado de armamento, municiones, disciplina, proyectos, etc., y todo aquello que pudiese interesar para el logro de sus planes (20).

Mientras el Virrey tomaba estas medidas, en la ciudad de Arequipa, recibidas las noticias de la sublevación, se reunió Cabildo abierto, en el que se acordó escribir al Presidente de la Audiencia del Cuzco, a fin de que dispusiera lo necesario para la defensa del territorio, $y$, si lo Juzgase conveniente, se hiciera cargo del mando de las tropas. Asimismo, se acordó también reunir mil quinientos hombres para acudir con ellos a la defensa, a los cuales se les uniría la artillería que se encontraba en la provincia. Por último, șe tomó la determinación de comenzar uns suscripción voluntaria para que los vecinos contribuyesen a costear el armamento del ejército que se organizaba.

Consciente, sin embargo, tanto el Intendente de la provincia de Arequipa, como el Marqués de Avilés, de la carencia absoluta de elementos en que se encontraban en el caso de una sorpresa por parte de los sublevados, acudieron al Virrey del Perú, a la par que se tomaban los anteriores acuerdos, y al comunicárselos le hacían ver la imposibilidad en que se hallaban de poder organizar las fuerzas necesarias por la falta de armas para equiparlas y de Jefes para mandarlas (21).

Aunque el Virrey Abascal había ordenado la reunión de seiscientos hombres solamente, bien que deJando un Cuerpo de reserva de cuatrocientos en Puno para acudir allí donde hiciesen falta, al recibir el ofrecimiento de la ciudad de Arequipa, lo aceptó plenamente e hizo cambiar el plan fijado. En efecto, de esos mil quinientos hombres, dispuso que marchasen

14 (2Q) A. G, I,-Lima, 625. Copia de Ofieio reservado del Virrey Abrseal al Regente de la Audiencia del Cuzco. Lima, 15 de agosto de 1809.

(21) A. G. I.-Lima, 625. Copia de Oficio del Marqués de Aviles y de don Bartolomé María de Salamanca al Virrey Abascal. Arequipa, 4 de agosto de 1809. 
mil a Puño, al mando del Intendente, quedando entretanto el mando de la provincia en manos del Marqués de Avilés. Los otros quinientos quedarian en Puno como Cuerpo de reserva. Al mismo tiempo escribia al Presidente del Cuzco notificándole que habia mandado reunir tres mil hombres en Puno, cuyo número debía completarse con los que habian salido en aquella dirección desde Arequipa y con gente del distrito de su Presidencia y de la Intendencia de Puno.

Reunida esta tropa, pasaría el propio Presidente a mandarla, estableciendo su cuartel general en Chuquito o Puno, con una vanguardia de quinientos o seiscientos hombres en el Desaguadero, con dos cañones. En caso de que fallasen las negociaciones y los sublevados no llegasen a una avenencia, Abascal le ordenaba que marchase a reducirlos, no sin antes publicar un perdón general para todos aquellos que se uniesen al ejército de Goyeneche. Verificado esto, debia comenzar su marcha hacia La Paz, teniendo en cuenta que, como los sublevados no poseían gran número de tropas, procurarian recurrir a medios de astucia en lugar de presentar batalla, y para evitarlos deberia precaverse llevando por delante de la vanguardia partidas de tropas ligeras que sirvieran para descubrir emboscadas del enemigo (22).

Antes de recibir el oficio del Virrey encomendándole el mando de las tropas, Goyeneche se disponia a enviar al Desaguadero un piquete de ochenta hombres al mando de don Fermín Piérola, Sargento Mayor de las Milicias de Urubamba, para que, apostados alli, impidiesen el tráfico sospechoso entre ambos Virreinatos y le diesen noticias del estado de la sublevación. Con lo cual pensaba estar preparado para salir de su capital con unos setecientos hombres y ocho cañones al primer aviso de aproximación del enemiga. En Puno pensaba reunirse con las tropas que viniesen de Arequipa; sín embargo, esperaría las órdenes del Virrey, para ponerse al frente de las tropas (23). Pero esta medida no la llevó a efecto, pues

(22) A. G. I.-Lima, 625. Copia de Oficio de Abascal al Presidente del Curco. Lima, 18 de agosto de 1809.

(23) Arch. C. Guaqui C. 1. Carp. 3. N. 104. Oficio de Gojeneche al Marqués de Avilés. Cuzco, 18 de agesto de 1809. 
observada la situación de La Paz, prefirió no dar pretexto a los sublevados para que pudiesen atacar al Virreinato (24).

En lugar de eso, lo que hizo Goyeneche fué ponerse en contacto con el Virrey de Buenos Aires para acordar las medidas a tomar por ambos, mucho más cuanto que, como se recordará; Abascal habia dicho a éste que se entendiera con el Presidente del Cuzco para tomar sus determinaciones respecto a La Paz. En espera, pues, de su contestación, Goyeneche se limitó a reorganizar el ejército que encontró a su llegada al Cuzco. Un ejército que, según él, «sólo tenía de militar el uniforme, sin orden ni regularidad alguna ni en lo económico, ni en la disoiplina». Cuando llegó, lo integraban cuatro compañias incompletas, llamadas veteranas, y cuatrocientos paisanos «sin vestuarios, que Jamás habian tomado fusil, durmiendo en sus casas y hace ocho meses recibían sueldo del Rey sin más funciones que las de hacer giross. Para remediar tan lamentable estado, eompletó las cuatro compañias veteranas a cien hombres, con cuatro sargentos en lugar de seis, como tenían antes. De las fuerzas de paisanos acuartelactas, destinó una compañía de Artilleria y dejó otras dos veteranas, con lo cual quedó reducído el número de tropas a seis compañias, con un total de ochocientos hombres y cien artilleros. A todos los adiestraba diariamente, sin excepción de los días festivos, con ejercicios de instrucción militar, a los cuales asistía el propio Goyeneche, para vigilarlos más directamente.

Los oficiales presentaban un aspecto semejante a la tropa, sin disciplina alguna y faltos de los más elèmentales conocimientos militares. Para corregirlos, los obligaba a trabajar activamente, haciéndolos responsables del estado de sus tropas, de lo cual dependía su permanencia en el Ejéreito. En cuanto a armamento, la situación era análoga; no había en el Cuzco «ni una bala ni un escobillón», según decía el Presidente, de tal forma que necesitaba una eficaz

(24) Arch. C. Guaqui. C. 1. Carp. 3. N. 106. Oficio de Goyeneche al Virrey del Perú. Cuzco, 17 de agosto de 1809. 
ayuda antes de comenzar cualquier empresa de tipo militar (25).

A la par que Goyeneche llevaba a cabo sus preparativos militares, no dejaba de comunicarse con la Junta de La Paz, con el fin de llegar a una solución pacifica del conflicto, tal como le ordenara Abascal. El mismo Virrey se hallaba también en contacto con ella con idéntico fin. Aun hubo un momento en que pareció estar a punto de solucionarse el problema pacíficamente. Fué a consecuencia del nombramiento del nuevo Virrey del Río de la Plata en la persona de don Baltasar Hidalgo de Cisneros. La Junta, sin embargo, difirió su reconocimiento, dando largas a la cuestión, con lo que pasaba el tiempo sin que se llegase a una determinación seria sobre La Paz. Abascal escribia entonces a la Junta pidiéndole que reconociese al nuevo gobernante e incitándola a la unión para defender los derechos de Fernando VII, mientras Gayeneche se ofrecia de mediador para los sublevados (26).

El heeho de que se iniciaran estas negociaciones no impedía que se reunieran las tropas mandadas organjzar por Abascal para marchar al Desaguadero. El propio Goyeneche debía desconfiar de la conducta de los de La Paz; pues asi se lo comunicaba al Marqués de Avilés, a quien decia que facilitase tropas a Ramírez, encargado de situarse en el Desaguadero, si se las solicitaba. Con la misma finalidad, el Presidente del Cuzco ordenaba a don Fermín Piérola, a quien antes hiciera detenerse en Sicuani, camino del Desaguadero, que marchara a situarse en Puno hasta la llegada de Ramírez (27).

Sin embargo, los planes de Goyeneche no se llevaron a efecto, pues en el intervalo se recibió el ofício de Abascal, ya mencionado, en que le ordenaba pasase a tomar el mando en persona de las tropas que se estaban reuniendo, para dirigirse con ellas hacia

(25) Arch. de Guaqui. C. 1. Carp. 3. Ns. 111 y 112. Oficio de Goyangehhe al Virrey del Perú. Cuzco, 26 de agosto de 1809.

(26) ABASCAL. Memorin. Tomo II. Págs. 21-22.

n. (27) Arch. C. Guaqui. C. 1. Carp. 3 (10). N. 118. Oficio de Goyeneche al Marqués do Avilés. Curco, 7 de septiembre de 1809. 
La Paz. Entonces pensó salir del Cuzco con ochocientos hombres, siete cañones y el suficiente número de armas para alistar más soldados en el trayecto. De allí pensaba marchar a Puno, y desde aquí lanzar un último llamamiento a los sublevados. Para su marcha sacó de la Tesorería de su capital, como Caja del Ejército, cincuenta mil pesos; nombró proveedor de la tropa al Contador de la Aduana, don Antonio Subiaga, y Auditor del Ejército a su Asesor don Pedro López de Segovia.

Con todas estas disposiciones se encontraba Goyeneche preparado para marchar mientras recibia la constante adhesión de la nobleza cuzqueña, que se ofrecía a unirse a su ejército para ir a luchar contra los revolucionarios de La Paz. El Presidente rehusó el ofrecimiento de los nobles, y aceptó solamente al Coronel don Francisco Picoaga, al Teniente Coronel Campero y al Capitán Lechuga, como jefes que podían serle útiles para el mando de sus tropas. En la capital dejaba trescientos hombres, quedando encargado del mando accidental de la misma, hasta su regreso, el Regente de la Audiencia don Manuel Pardo. También enviaba aviso al Intendente de Arequipa para que pusiese en marcha doscientos hombres al mando de don Pío Tristán, oficial conocido por Goyeneche (28).

Inmediatamente comenzaron a salir las tropas y el material del Cuzco en dirección a Puno, de manera que, en ocho días, marcharon 800 hombres, de los cua+ les, 330 eran de caballería, con siete cañones y 200 cajones de armas con fusiles, pistolas y sables. Fn el Cuzco dejaba encargado del mando de las tropas que quedaban en la ciudad, en un total de 300 hombres, nueve cañones y 40 artilleros, al Coronel don Martín de Concha.

El día 16 de septiembre, el Teniente Coronel Piérola se posesionó del Desaguadero con 80 hombres y dos cañones que tomó, y el 19 llegó a esta ciudad el Coronel Ramírez (29). El día 4 de octubre escribía

(28) Arch. C. Guaqui. C. 1. Carp. 3 (10). N. 121. Oficio de Goyenęche al Virrey del Perú. Cuzco, 11 de septiembre de 1809.

(29) Arch. C. Guaqui. C. 1. Carp. 4. N. 2. Oficio de Goyeneche al Virrey del Perr. Pucuto, 20 de eptiembre de 1809. 
Goyeneche al Virrey comunicándole su entrada en Puno, en donde se alistaron nuevas tropas de los Cuerpos de la Provincia. Desde allí dirigió dos cartas al Cabildo de La Paz con dos de sus Edecanes, para darle una última ocasión de solucionar pacíficamente el conflicto (30).

Desde Puno se dirigió Goyeneche al Desaguadero con sus tropas. Allí recibió la contestación de sus escritos al Cabildo de La Paz. Se le presentaron dos diputaciones del Ayuntamiento y del Cuerpo militar, según él, «con las expresiones más sumisas y respetuosas, poniéndose bajo de mi inmediata protección y mando y pidiéndome encarecidamente mi aproximación a liberarlos de la funesta anarquia que los oprime» (31). Con semejantes peticiones, parecia haberse conseguido el fin que en un prineipio se propusiera el Virrey Abascal y llevara a cabo el propio Goyeneche al entablar las negociaciones con el gobierno de aquella ciudad. Por todos los medios se habia procurado llegar al sometimiento pacífica de los sublevados antes de recurrir al empteo de las armas, y si ahora se habian reunido en el Desagruadero las tropas de Goyeneche, se pensaba que la sola concentración de estas fuerzas sería bastante para disolver la tormenta que se cernia sobre La Paz.

El resultado fué que los tefes de la sublevación, con Murillo a la cabeza, calcularon que, puestos en combinación, como estaban el Virrey de Buenos Aires (que enviaba hacia el Alto Perú al General Nieto, nombrado Presidente de la Audiencia de Charcas, con fuerzas a sus órdenes), y Goyeneche, que con amplios poderes del Virrey de Lima, se disponía a avanzar sobre la ciudad, sería inútil toda resistencia, y acordaron someterse a la mediación de este último. A tal efecto, enviaron diputaciones para tratar de la entrega del armamento, y estas diputaciones fueron las que acudieron al Cuartel General de Goyeneche en el Desaguadero.

El General aceptó las proposiciones ofrecidas por

(30) Arch. C. Guaqui. C. 1. Carp. 4. N. 3. Oficio de Goyeneche al Virrey del Perú. Puno, 4 de octubre de 1809.

(31) Areh. C. Guaqui. C. 1. Carp. 4. N. 5. Oficio de Goyeneche al Virrey del Perú. Desaguadero, 14 de octubre de 1809. 
los comisionados y los envió a La Paz con un oficial para recoger todas las armas de las tropas de la ciudad, que habian de encerrarse hasta su entrada. Goyeneche prometía por su parte respetar la autoridad cel Cabildo, que seguiría detentando el poder político después de ocupada la capital.

Pero cuando los diputados de $\mathrm{La} \mathrm{Paz}$ volvieron dispuestos a dar a conocer y a cumplir lo pactado con Goyeneche, se encontraron con que las cosas habian cambiado totalmente. Durante el tiempo que estuvieron conferenciando en el Desaguadero, había tenido lugar una contrarrevolución, que tuvo como consecuencia la destitución y el arresto de Murillo, que preconizaba el pacto con Goyeneche. El cabecilla del movimiento fué un tal Indaburu, que se hizo con el mando de las tropas y con el poder de la ciudad. Esta conmoción, que tuvo como principal agente a las clases bajas, se debió a la disconformidad de parte de los sublevados a entregar la ciudad sin lucha, e iba dimgida principalmente contra los europeos, que fueron detenidos en gran cantidad. En consecuencia, Indaburu se atrajo al pueblo de La Paz, y haciendo creer que Murillo había hecho traición y se hallaba en contacto con los europeos para entregar la ciudad, lo condujo a un movimiento de reacción contra cualquier avenencia con Goyeneche, que tuvo como resultado la desaparición de Murillo y sus colaboradores, dando un matiz anárquico a la última etapa del movímiento de La Paz.

En vista del nuevo aspecto del conflicto, Goyeneche, persuadido de que habían fallado definitivamente todos los recursos pacíficos, se dedicó a emprender la marcha hacia La Paz tan pronto como se hallase preparado su ejército. El mismo Virrey del Perú le escribia en este sentido diciéndole que, si al recibir su comunicación no se habian decidido los rebeldes a deponer positivamente su actitud y a reconocer las legitimas autoridades, emprendiese la marcha con sus tropas para atacarlos enérgicamente y acabar de una vez con el foco de insurrección que significaba esta ciudad (32). A Abascal le interesaba

(32) Arch. C. Guaqui. C. 8. Carp. 2. N. 29. Oficio de Abascal a Goyeneche. Lima, 26 de octubre de 1809. 
sobremanera acabar pronto con la cuestión de La Paz, porque el 10 de agosto había estallado un movimiento semejante en Quito, con la constitución de una Junta, que estudiaremos más adelante, y que le causaba una gran preocupación, pues entre la sublevación de Quito y la de La Paz corria el riesgo de quedar aislado el Virreinato del Perú, aparte de los auxilios que necesitaba enviar a los gobernantes de las provincias del Norte contra los proyectos de los quiteños. Es lógico, pues, que en esta circunstancia quisiese acabar de una vez con la revolución de La Paz, convencido, como se hallaba, de que no se lograría nada con los medios pacíficos.

Pero a la llegada del anterior oficio de Abascal, ya Goyeneche se había puesto en camino y habia coronado su empersa con el éxito. Puesto en marcha con sus tropas, tuvo noticias de que se le intentaba hacer resistencia en los alrededores de la ciudad. El día 23 de octubre llegó a tres leguas del campamento de los sublevados y se preparó para atacarlos. Distanció primero una serie de guerrillas para reconocer la situación de los enemigos. Al aproximarse el Ejército al lugar donde se hallaban situados los paceños, cundió el pánico entre éstos y se dieron a la fuga. Entonces Goyeneche se dispuso a atacarlos, para lo cual ordenó la salida de cincuenta granaderos a caballo, que los persiguieran e impidieran su reorganización, hasta la Hlegada de 400 jinetes mandados por don Narciso Basagoitia, a los que ayudó el propio Goyeneche con una columna. Al amanecer del día 25 llegaron al lugar donde se reorganizaban las tropas enemigas, cerca de la ciudad; allí fueron recibidos por algún fuego de artillería, pero no pudieron resistir el ataque de los granaderos a caballo de Tinta y de las guerrillas de Arica, que se lanzaron bruscamente contra las líneas enemigas y pusieron en dispersión a sus defensores. Desaparecida la resistencia, desplegó su eféreito sobre los bordes de los Altos de La Paz, adonde se fueron presentando inmediatamente todos los que se hallaban escondidos en la ciudad, por temor a los excesos cometidos por el pueblo en los ültimos días.

Inmediatamente organizó la entrada en la capital. Don Pío Tristán, con la mitad de la vanguardia, en- 
tró por la cuesta de Lima, mientras Goyeneche lo hacia por la de Potosi y Ramirez acampaba en los Altos con las divisiones del centro y retaguardia y la artillería.

Una vez ocupada la ciudad y alejados los restos de los sublevados, Goyeneche se dedicó a organizar la vida en ella. Inmediatamente restableció en sus destinos a los empleados públicos y subdelegados depuestos por la Junta, y mandó llamar a todos los vecinos que habían huido, como a los miembros del Cabildo; en cuyas manos permaneció el poder político, según las órdenes del Virrey Cisneros. El General se reservó el mando militar hasta tanto se hubiera pacificado totalmente el territorio. Poco a poco se normalizó la vida en la ciudad y fueron llegando los perseguidos y apareciendo los que estaban ocultos.

La ocupación de La Paz fué una empresa bastante fácil para Goyeneche. No tuvo que contar ningún muerto entre sus filas, y el hecho de que sólo encontrara en el campo de batalla cuatro muertos de los insurgentes demuestra que ni siquiera debió haber acción militar. Los sublevados volaron su repuesto de pólvora al aproximarse las tropas virreinales, e inutilizaron gran cantidad de pertrechos, a pesar de lo cual, aun pudo el General recoger bastante cantidad de cajones de balas, algunos cañones y tiendas de campaña (33).

Los rebeldes se dirigieron en su huida hacia el territorio de los Yungas, intentando situarse en el punto de Lloja. Con el fin de acabar de una vez con las conmociones en este territorio, Goyeneche organizó una expedición al mando de don Domingo Tristán, Intendente de La Paz, a quien dió amplias facultades para llevar a cabo su cometido. Los que capitaneaban a los fugitivos eran los mismos que habian mandado las fuerzas que intentaron resistir a la entrada de las tropas virreinales en La Paz: Medina, cura de Sicasica, Manuel Victorino García Lanza, Sagarnaga, Orrantía, Gabino Estrada, Castro, etc, a todos los cuales dió orden Goyeneche de considerarlos como a

(33) Arch. C. Guaqui. C. 1. Carp. 4. N. 9. Oficio de Goyeneche a Abascal. La Paz, 26 de octubre de 1809. 
«bandidos, ladrones del Tesoro público y cabezas de motín, ya que a su marcha de la ciudad se llevaron 40.000 pesos de los fondos de las Cajas Reales y Renta de Tabacos.

Antes de partir para su expedición, epilogo de la sublevación de La Paz, Tristán recibió amplias instrucciones de su jefe Goyeneche. Se mostraba el General duro con los cabecillas rebeldes, of reciendo «premios y recompensas a aquellos que los presenten», empleando en cambio las armas econ Justícia, siempre que se despleguen en la persecución, aprehensión y castigo de estos malvados». Recomendaba también la mayor precaución en las operaciones, debiendo marchar la tropa ken columna, con el frente que permite el terreno y con las partidas avanzadas de guerrillas» para tener la mayor seguridad en los movimientos. Asi debia marchar hasta Irupana, en donde conferenciaría con el Obispo y daria cuenta de su misión a Goyenoche, recibiendo de éste nuevas instrucciones.

La principal recomendación que hacía el general a Tristán era la mayor rapidez en las marchas y la pronta reunión de todas sus tropas, como asimismo, que procurase no hostilizar ni incomodar a los indios de aquel territorio (34). Las dificultades que ofrecia la expedición eran grandes, sobre todo por lo que respeeta al terreno que tenían que atravesar las tropas a marchas forzadas.

Los rebeldes se habian fortificado principalmente en los puntos de Pacallo, Chulumani e Irupana, hacia donde se encaminaban las fuerzas de Tristán. Al segundo día de marcha comenzaron a notarse las dificultades, que lentamente fueron superadas por las tropas. En dirección a Irupana llegaron a la parroquia de Taca, en donde Tristán tomó una porción de indios asalariados para que le sirviesen de espías y para evitar las emboscadas a que tan fácilmente se prestaba el camino.

El día 7 de noviembre łlegaron a la vista del pueblo

(34) Arch. C. Guaquir: C. 1. Carp. 4. N. 15. Instrucciones de Góyencehé a don Domingło Tristán, jefe de la expedición a Yungas. La Paz, 1 de noviembre de 1809. 
de Irupana, adonde, según noticias recibidas, se dirigían Lanza y Gabriel Antonio de Castro, que salian de Chulumani. Toda la noche siguieron caminando las tropas de Tristán, hasta ocupar el punto desde donde se dominaba enteramente el pueblo; que ocuparon fácilmente por haber sido evacuado por los enemigos.

Ocupado este pueblo, Tristán expidió una proclama intimando a los rebeldes a rendirse. Pero el resultado de tal bando fué completamente negativo. Antes al contrario, sabedores Lanza y Castro de la ocupación de aquel punto, se dispusieron a recuperarlo con sus fuerzas. En efecto, el día 10 aparecieron al anochecer en los alrededores y se prepararon a atacarlo. Sus fuerzas: unos 1.500 hombres, estaban integradas casi exclusivamente por indios y negros, con ocho cañones y dos morteros, a lo que se unía el gran conocimiento que poseian de aquel territorio.

Al amanecer del siguiente dia, 10 de noviembre, se dirigieron a ocupar la altura de Serropata, que dominaba el pueblo y con cuya posesión pretendían cortarle el agua y encerrar en sus rectntos a las tropas de Tristán. Ante esta perspectiva, se dispuso una salida por los puntos de Machamarque y Churiaca, para tomar el alto de Corata, hacia donde se dirigía el núcleo de los enemigos. Aquí se trabó una enconada lucha por la posesión de este punto. Tristán adelantó por Churiaca veintiún hombres al mando del tentente don Domingo Silvo, y don Francisco Solís, ayutante provisional stryo, a los que siguieron cincuenta hombres de caballería al mando de don José Ruiz Caro. Lograron situarse en posición ventajosa, pero los enemigos comenzaron a disputarles la posesión del terreno, ante lo cual envió una compañía de granaderos al mando del capitán don Pedro Murga, para que los reforzase. Al llegar Murga comenzó un fuerte fuego de fusileria, que se prolongó hasta bastante entrada la manhana, pretendiendo los insurgentes ganar la altura de los de Tristán, defendidos gracias al eficaz fuego de su artillería. En vista de ello, el comandante de las fuerzas destacó a don Pedro Barreda, mayor capitán, para que reforzase la caballería y avanzasen contra. Ios cañones enemigos. El ataque de la caballería decidió la acción, pues arrollaron los cañones contrarios seguidos de la infanteria. 
A las tres de la tarde terminaba la acción, que comenzara a las nueve de la mañana, con la total derrota de los insurgentes, que huyeron abandonando tres cañones, dos obuses, algunos fusiles con pertrechos y más de cien muertos en el campo de batalla (35).

Las consecuencias de la batalla de Irupana fueron de gran importancia para el éxito de la expedición de Yungas. A raíz de ella quedó completamente desorganizada la resistencia de los insurgentes, que emprendieron la fuga desordenadamente y perdieron la mayor parte de su artillería y armamento. Sus jefes se vieron obligados a huir y en el camino fueron perseguidos por las tropas de Tristán, quienes lograron aprehonder vivo al cura de Sicasica, Medina, y muertos a Castro y Lanza, que hicieron resistencia cuando fueron encontrados por los indios que aquél enviara en su seguimiento ( 36$)$. Por otra parte, fué de un gran efeoto moral la victoria de Irupana, pues cuando los rebeldes de $\mathrm{La} \mathrm{Paz}$ se retiraron ante la entrada de Goyeneche y Hegaron a este punto, se apoderaron de él tras una encarnizada resistencia por parte de los habitantes de la ciudad. A consecuencia de ello, la mayor parte huyb́ a los bosques contiguos ante los excesos cometidos por los invasores, que destruyeron la población casi totalmente. Por eso, la entrada de Tristán y la posterior victoria, que alejaba completamente él peligro de un nuevo ataque, animó a los vecinos, que desde entonces colaboraron eficazmente al éxito de la expedición.

Fruto inmediato de la victoria de Irupana fué también el rápido sometimiento de los indios de Ocabaya, Floripata, Churca, Chupe y Yanacachi, que se hallaban en combinación con los rebeldes para intervenir en el ataque a Irupana, que no pudkeron llevar a cabo por haberse desarrollado el combate antes del tiempo previsto. Desaparecidos los que les instigaban a

(35) A. G. I.-Lima, 1.012. Copia de parte de don Domingo Tristan a Goyeneche. Irupana; 11 de noviembre de 1809.

(36) Arch. C. Guaqui, G. 9. Carp. 2. N. 1. Relación de don Jose Marizino de Castro sobre la expedición a Xuntras, La Paz, 5 de enero de 1810. 
la rebelión se presentaron de todos estos puntos a Tristán, ofreciêndole su obediencia. Entre ellos se encontraba una gran cantidad de negros, que fueron restituídos a sus haciendas, así como los indios, al frente de los cuales fueron colocados nuevos caciques en muchos lugares (37).

Poco tiempo despues se rendian las fuerzas que ocupaban los puntos de Pacallo y Coroico, que, Juntamente con Irupana, formaban las llaves del territorio de los Yungas. Tristán marchó también a Chulumani, en donde tuvo lugar otro encuentro con los últimos restos de los insurgentes, que fueron también derrotados, con lo cual acató definitivamente la resistentia en este país.

Con el sometimiento del país de los Yungas acababan los últimos vestigios de la sublevación de la ciudad de La Paz. Y con olla terminaba también el intento de independencia de Chuquisaca. Se podía decir que el Alto Perú se hallaba completamente pacificado, de tal forma que, transcurrido menos de un mes desde el sometimiento de Yungas, Goyeneche continuaba despidiendo tropas por no juzgar necesario el sostenimiento de fuerzas para someter a Chuquisaca, hacia donde se dirigía Nieto con tropas de Buenos Aires. Pensaba mantener únicamente 1.300 hombres para sla ejeeución de algunas justicias» y la persecueión de los últimos restos de los cabecillas fugitivos. Sin embargo, Goyeneche permaneció algún tiempo en aquel territorio para arbitrar los medios de mantener la seguridad del Alto Perú, juntamente con el nuevo Presidente de Charcas, Nieto.

Se ha interpretado la sublevación de Chuquisaca como una simple «asonada promovida por el partido adverso al Presidentes (38). Sin embargo, a mi Juicio, esto pudo ser en un principio, pero creo que hay que ver algo'mús detrás de ella. Las sublevaciones de Chuquisaca y La Paz, fueron indudablemente producto de una misma causa, aunque se manifestaron con matices

(37) A. G. I. Lima, 1.012. Copia de oficio de Goyeneche al Virrey del Rerú. La Paz, 7 de ticiembre de 1809.

(3is) VARGAS UGARTE, Rubón. D. Benito Maria de Moxó $y$ de Francoli, Arzobispo de Charcas. Buenos Aires, 1931. Pág. 30. 
distintos. En ambas se utilizó el mismo pretexto, que después ha de servir a todos los independizantes del Continente, y se siguió el mismo procedimiento. La fimalidad en ambas era claramente manifiesta. Tanto los sublevados de Chuquisaca como los de La Paz se proponfan conseguir la independencia y constituir una unidad con el Alto Perú, completamente separada, tanto del Virreinato de Lima como del de Buenos Aires.

De las dos ciudades, donde tenian más acogida todas las innovaciones revolucionarias, ya se ha visto, era Chuquisaca. Las circunstancias que rodeaban a esta ciudad se han examinado también. Pero lo que no ocurrió en una tuvo lugar en la otra. Mientras la sublevación de Chuquisaca fué un movimiento llevado a cabo por los intelectuales de la ciudad, por la $\mathrm{Au}$ diencia y los abogados, debido en gran parte a la enemistad entre aquélla y las autoridades, en La Paz tuvo un carácter bastante diferente. Aquí, comenzando por su principal promotor, el mestizo Murillo, se dí gran cabida al elemento indígrena, e incluso a los negros. Fué la revolución de La Paz, como dice Cúneo Vidal, «por lo que concierne a las clases inferiores de la sociedad que ea ella intervinieron, un movimiento de raza, el cual tuvo por resultado colocar en forma amenazadora al andino frente al españolo (39). Los cábecillas de La Paz se atrajeron a los indios y excitaron su odio contra los europeos, con un resultado que se ha de manifestar a la larga, cuando comience la guerra de la Independeracia.

Sin embargo, justo es decir que sin el movimiento de Chuquisaca, seguramente no habría tenido lugar el de La Paz, pues esta ciudad se levantó por el ejemplo y la Incitación de la primera. Las causas qure pueden aducirse como móviles de estos movimientos son, en líneas generales, las mismas que después se pueden señalar en los diferentes lugares del Continente. Pero hay, que tener presente una de no pequeña importancia, ya señalada al estudiar la sublevación de Chuquisaca: el carácter peculiar de la Audiencia de Char-

(39). CUNEO VIDAL. Historia de las Insurrecciones de Tacna por la Independencia del Perí. Lima, 1921. Pág. 32. 
cas, que no se resignaba a sufrir la autoridad efectiva de Buenos Airres. Sus oidores y los doctores de La Plata estaban demasiado pagados de sí mismos y del prestigio de sus organismos para soportar la intromisión del virrey del Rio de la Plata en sus asuntos proptos. For eso, apenas encuentran una posibilidad de escapar de sus manos, la aprovechan inmediatamente, aunque para ello tengan que dejar en entredicho la autoridad y la dignidad de aquél al acusarlo de tralción a la Corona:

Pero la actitud de los sublevados era insostenible, $\exists$ se dan cuenta bien pronto ellos mismos. Por eso se apresuran a reconocer a Fernando VII, como salvaguardia de su sistema. No poco vino también a favorecerlos la defección de Elío en Montevideo y sus pugnas con Buenos Aires, pues aquél reconoció a la Audiencla de Charcas como gobernadora del Alto Perú, con lo cual le dió un arma para detener todas las obfeciones que contra su autoridad pudieran hacerse, tanto hás; cuanto que el propio Elío tildaba de afrancesado al Virrey de Buenos Aires.

Al cambiar de Virrey, el nuevo jefe del Río de la Plata recibió en Montevideo las primeras noticias de lo ocurrido en Charcas, y no es de extrañar que con esta rererencia apróbase lo alli efecutado, reforzando, sin darse olxenta, la posición de los sublevados. Pero una vez que llego a Buenos fires y tuvo noticia clara de' lo ocuptido, se retractó de lo aprobado anteriormente y se puso en contacto con Abascal, como hemos visto, para acabar con la revoluclón.

Queda, sin embargo, una cuestión por aclarar en el estudio de este conflicto, y es la intervención del Virrey del Perú, cuando se trataba, al parecer, de un asunto propio del Virreinato del Rio de la Plata. Ya he arunto algo, más atrás, en este sentido. Pero conviene insistir en él para éjar claramente la actítud del Virrey de Lima. Er primer lugar hay que tener en cuenta que la provincia de La Paz era limítrofe de la permana de.Puno, lo que Justificaría por si solo las medidas de seguridad qua tomase aquel. Por otra parte, al observar la extensión que tomaba el movimiento del Alto Perú y el peculir matiz que cobraba en la provincia de La Paz, Abascal debió recordar la no lejana sublevación te los indios de 1780, que tan- 
tos perjuicios causó al Perú, y querría a toda costa evitar una reptición de $\tan$ tristes sucesos. Como a ésto se unía lo ya indicado de la distancia a que se hallaban dichas ciudades de Buenos Aires y la poca facilidad en que se encontraba aquel Virreinato para el envío de tropas, puestos en contacto ambos Virreyes, el de Buenos Aires confió a las fuerzas preparadas en el Perú la misión de someter las ciudades altoperuanas mientras llegaban las que hacia alli se encaminaban al mando del nuevo Presidente de Charcas. Conviene recordar, además, que Abascal en todo momento ordenaba a Goyeneche que obrase de acuerdo con las órdenes que recibiera de Buenos Aires, adonde debia comunicar todos sus movimientos.

Sin embargo, a pesar del éxito de las tropas virreinales ante la primera sublevación del Alto Perú, no se puede decir que la cuestión quedara liquidada definitivamente. Los odios subsistieron y cuando tuvo lugar el levantamiento de Buenos Aires contra las autoridades virreinales, los altoperuanos se encontraron dispuestos a secundar sus propósitos, como lo prueba el hecho que observaremos de que en el momento en que tuvieron la seguridad de alzarse impunemente, llevaron a cabo la sublevación, todo lo cual viene a demostrar que el terreno se hallaba preparado. Además, el matiz especial de estas primeras sublevaciones nos servirá para explicarnos más tarde el carácter particular que tomó la revolución del Alto Perú y su posterior separación de la revolución argentina. 


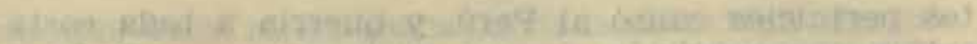

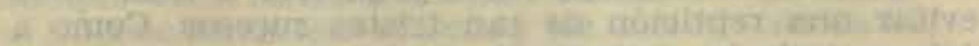

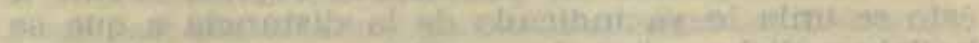

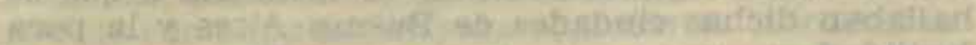

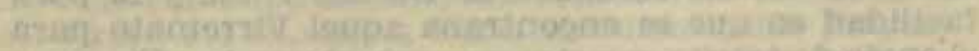

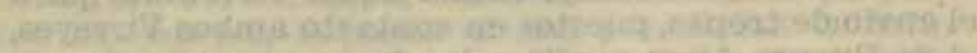

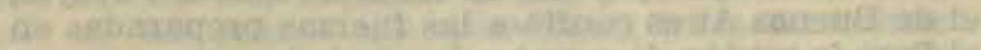

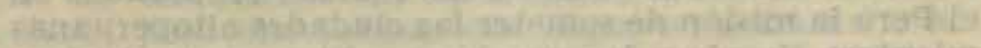

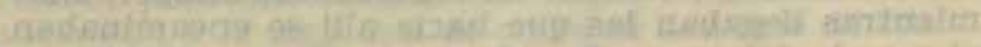
suriving

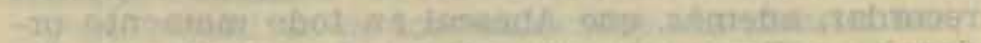

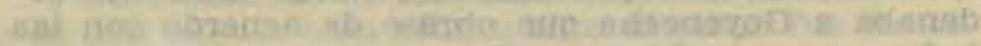

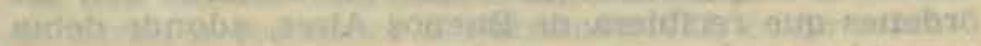

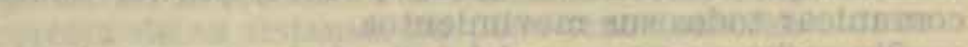

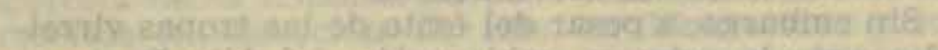

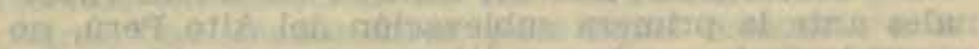

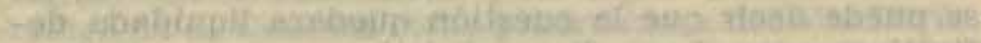

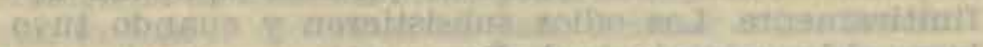

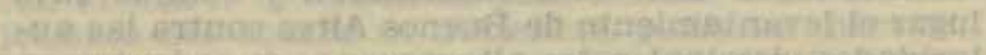

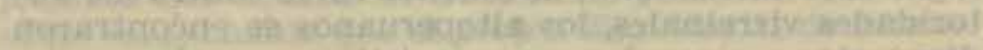

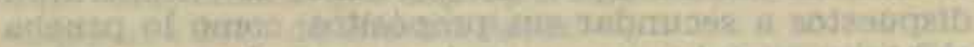
ges ou

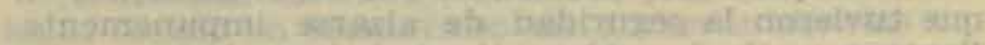

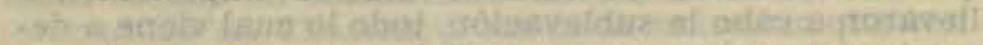

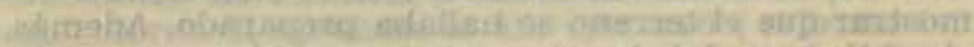

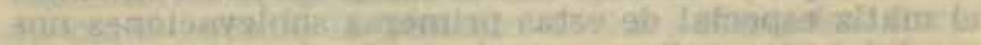

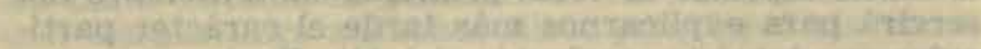

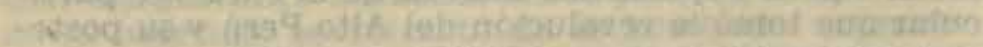

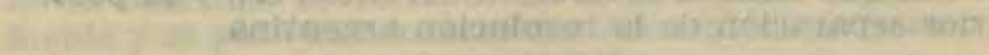

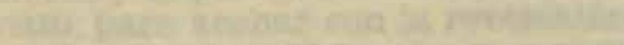

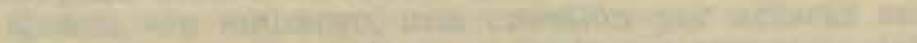

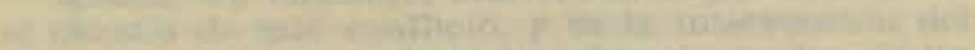

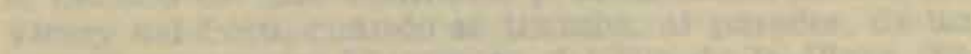

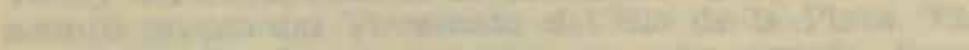

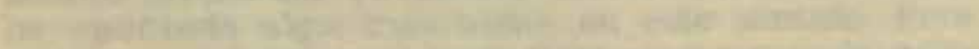

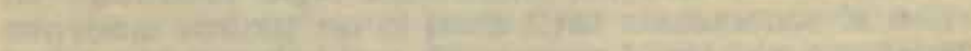

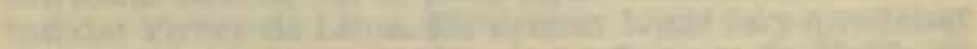

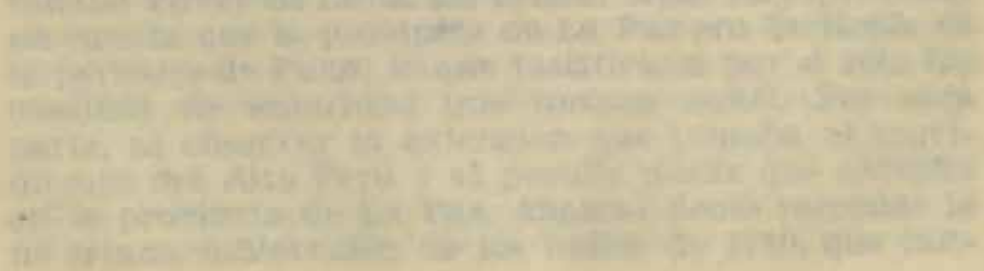




\section{CAPITULO I V}

\section{LAS REVOLUCIONES DE QUITO}

Antes de que se hubiera extinguido el eco de las sublevaciones en Chuquisaca y La Paz se le planteó a Abascal el primer problema grave de su gobierno, representado por la revolución de Quito.

Durante el siglo XVIII ya habian tenido lugar levantamientos en la ciudad contra los españoles, pero sus consecuencias habían sido prácticamente insignificantes; sin embargo, de el ánimo de los quiteños no desaparecía el recuerdo, que los predisponía a nuevas aventuras.

La ciudad de Quito era, en lo que cabe, un centro de cultura de la América Meridional. La nobleza quiteña amaba la ilustración y la ciudad era frecuentemente visitada por viajeros extranjeros como Humboldt, y los componentes de la misión francesa para medir el arco del meridiano. Estos contactos con las ideas extranjeras, las de Miranda respecto a la independencia de América, que trascendieron hasta la ciudad, y la querella planteada entre los criollos y los peninsulares desde muy antiguo, por el pago de las alcabalas, dieron como resultado su manifestación explícita en la primera ocasión que se les presentó a 
principios del siglo XIX, cuando los planes parecian suficientemente maduros.

El punto de partida tomado para llevar a cabo sus fines revolucionarios es el mismo que vemos se utilizó en el resto del Continente: la defensa de los derechos de Fernando VII durante su cautividad. A consecuencia de ello se planea la constitución de una Junta a imitación de las provincias de España, aun cuando en la práctica se tituló «Soberana».

En efecto, cuando ocurrió la invasión de la Península, gobernaba como Presidente de Quito don Manuel de Urriez, Conde de Ruiz de Castilla, hombre de mucha edad y poco ánimo, cuyas medidas sólo sirvieron en los primeros momentos para favorecer los planes revolucionarios, y después, para aumentar el confusionismo inherente a la extraña situación planteada. Su escasa habilidad y..poca firmeza fueron insuficientes para atajar el mal en sus principios, por lo que hubo de transigir, y, una vez en marcha la revolución, dejó de saberse, como ocurre siempre, dónde iba a parar.

Cuando se tuvieron noticias de lo ocurrido en España, inmediatamente surgió la idea de la creación de una Junta para salvaguardar los derechos del Monarca español y para librarse de la opresión que significaba un rey extranjero. Pero los revolucionarios quiteños tenian planes más ambiciosos, pues su finalidad era constituir una Junta Soberana, a la cual se someterian las demás Juntas Provinciales de América del Sur. El ambiente les era propicio y no habian de encontrar fuerte resistencia. Así es que se decidieron a llevarlo a la práctica.

En vista de ello, un pequeño núcleo de revolucionarios se preparó para efectuar el golpe. Este grupo estaba capitaneado por el doctor Quiroga y por don Manuel Morales, abogado de gran prestigio el primero, y ex secretario del Gobierno de Quito el segundo. A ambos secundaron el Capitán Salinas, jefe de las tropas, y el doctor Riofrío, eclesiástico que ya anteriormente había sido detenido por saspechoso de conspirar contra el Gobierno.

Preparados en todos sus detalles y contando con la cooperación de las fuerzas de la capital, en la noche del 9 de agosto de 1801 constituyeron la Junta, 
para cuya presidencia eligieron al Marqués de Selva Alegre, personaje de notable influencia en la ciudad, de gran cultura y en contacto con todos los innovadores. Aun cuando por aquel entonces se hallaba retirado en una hacienda suya cercana a la ciudad, en donde recibió la noticia de la sublevación y la de su nombramiento como Presidente de la Junta, aceptó inmediatamente sin vacilar (1).

La revolución se llevó a cabo sin dificultad y sin derramamiento de sangre. En la noche del 9 de agosto se dió a conocer a una asamblea de vecinos la cautividad del Rey, mostrándoles los peligros a que se hallaba expuesta la Monarquía. Se les hizo ver que la única medida eficaz para salvaguardar los intereses del monarca era la formación de una Junta, destituyendo a los funcionarios sospechosos de infidelidad hacia ella. A la tropa se le dió a entender de la misma forma que se trataba de escoger entre servir a las órdenes de Bonaparte o a las de Fernando VII. Naturalmente, tanto el pueblo como la tropa se decidieron por la segunda proposictón.

Con ésto quedaba consumada la revolución en Quito. A la mañana siguiente, el Conde de Ruiz Castilla recibió una nota de la Junta por la que se le hacia saber que quedaba separado de su empleo, como igualmente todos los miembros del Gobierno. A la par se remitieron avisos de lo ocurrido en la capital, con órdenes sémejantes, a todas las provincias vecinas. Pero el llamamiento de los sublevados de Quito no fú acogido como ellos esperaban, pues los gobernadores de las provincias circundantes desecharon tales avisos y se dirigieron al Virrey del Perú o al de Nueva Granada en petición de auxilios para detener cualquier intento de invasión por parte de los revolucionarios.

La noticia de lo ocurrido llegó a Lima a principios de septiembre, cuando Abascal se hallaba aún preocupado con las sublevaciones de La Paz y Chuquisaca. Sin embargo, acogió con gran interés los avisos que le venian de aquella ciudad. Quito ya tenía cierta tra-

(1) STEVENSON, W. Bennet. Memorias. Biblioteca Ayacucho. Madrid. s. a. Págs. 21-22. 
dición en lo referente a sublevaciones, pero desde la proyectada revolución de Miranda, al Norte del Continente, se hallaba bastante inquleto. $\mathrm{Y}$ ahora, con las noticias venidas de España y los amagos de sublevación en otros puntos del Continente, las novedades que se recibían de aquella capital eran del mayor interés.

Asi, pues, en vista de ello y de las peticiones de auxilio que le dirigían a Lima los gobernadores de las provincias confinantes con la de Quito, el Virrey decidió reunir un Acuerdo con la Audiencia para decretar las medidas más convenientes al caso. La posición de Abascal ante la revuelta en Quito era en este momento la de expectador interesado, dispuesto a intervenir en una ocasión propicia, preparándose mientras tanto para ello. En efecto, los resultados del Acuerdo se tradujeron en órdenes a los gobernadores de Guayaquil, Cuenca y Popayán para obtener los informes necesarios y llevar a cabo las primeras medidas de defensa contra cualquier ataque de los quiteños.

Al gobernador de Guayaquil, don Bartolomé $\mathrm{Cu}-$ calón, le previene «que esté muy a la mira de impedir la propagación de aquel desorden a esa provincia de su cargo, y que adquiera por todos los medios las noticias que pueda relativas a dichas ocurrencias, sus autores y designios, con qué número de tropas cuentan para sostenerse, qué armamento y su calidad, qué artilleria, municiones, ete. Todo lo cual, como asimismo todo lo que fuera ocurriendo debía ponerlo en conocimiento del Virrey con la mayor urgencia, «enviando desde luego a la referida ciudad de Cuenca doscientos hombres de tropa, y fusilería para armar otros tantos, con veinte mil cartuchos y ocho mil pesos en dinero, con lo demás que necesita para su defensa y ser compatible con las existencias de esa... acordando con aquel gobernador el modo más pronto y seguro de auxiliarse recíprocamente (2).

Juntamente con estas órdenes, en el mismo oficio le indicaba que en cuanto tuviese las noticias que le había pedido haria navegar hacia esa ciudad todo lo

(2) A. G. I.-Lima, 739. Copia de oficio de Abascal al gobernador de Guayaquil. Lima. 9 de septiembre de 1809. 
necesario de tropas y material para atacar a los insurgentes antes de que el conflicto tomase mayores proporciones; entretanto, con la primera embarcación que saliese del Callao le remitiría cuatro cañones con cartuchería y los útiles correspondientes para su servicio, doscientos mil cartuchos de fusil y algún dinero.

Al de Cuenca, además de advertirle que no enviase el dinero a Quito, le comunicaba que mientras durase la insurrección en la ciudad y la interrupción de la correspondencia con el Virreinato de Santa Fe, acudiese a la Audiencia de Lima en las apelaciones de Juzgados inferiores, y a él en las de asuntos de gobierno y Justicia (3).

Igualmente, al gobernador de Popayán le incluía las órdenes dadas a los otros dos, a fin de que arbitrase cuantas medidas condujesen a un eficaz bloqueo de Quito para obligar a entrar en razón a los sublevados (4).

De todas las anteriores resoluciones se deducen dos cosas: en primer lugar, la falta de noticias de los sucesos ocurridos en aquella ciudad, que sorprendieron al Virrey, y su reacción, que lo dispuso a acabar cuanto antes con aquel foco revolucionario, que podía producir funestos resultados en el Norte del Virreinato si no se lograba atajar rápidamente. De ahí las dos órdenes fundamentales impartidas a los gobernadores: la adquisición de noticias que permitiesen hacerse cargo exactamente de la situación y el envio inmediato de tropas a los confines de la provincia de Quito para organizar un cordón sanitario que aislase la revolución hasta el momento oportuno de pasar al ataque.

Todas estas medidas tomadas por un Virrey, para quien la provincia de Quito caia fuera de su Jurisdición, las encontraba Abascal plenamente justificadas por la distancia a que se hallaba el Virrey de Santa Fe, bajo cuyas órdenes se hallaban las provincias de Quito, Guayaquil, Cuenca, etc. Dada la difi-

(3) A. G. I.-Lima, 739. Cppia de oficio de Abascal al gobernador de Cuenca. Lima, 18 de septiembre de 1809.

(4) A. G. I.-Lima, 739. Copia de oficio de Abascal al gobernador de Popayán. Lima, 18 de septiembre de 1809. 
cultad de las comunicaciones, la fragosidad de los caminos y los ríos considerables, unido según Abascal, a los escasos medios de que aquél disponía para llevar a cabo la empresa, hacian que se encontrase en la obligación de tomar sobre st este cuidado (5).

A las anteriores consideraciones se unía la efectiva de la propia seguridad de su Virreinato, que Justificaba su acción. El debía pensar que el mantenimiento en la frontera del Perú de un Ejército para impedir que la insurrección penetrase en territorio peruano mientras esperaba que fuese reducida por el Virrey de Santa Fe, había de ser mucho más perjudicial para ambos que una intervención armada de sus tropas en territorio de ajena jurisdicción. Por otra parte, teniendo en cuenta la situación de Quito, en el rincón más lełano del Virreinato, adonde tardarian en llegar los cortos auxilios que su Virrey pudiera enviarle, cabía pensar que los resultados no fuesen satisfactorios. Sin embargo, Abascal procuró en todo momento marchar al unisono con el Virrey de Santa Fe, al cual comunicaba sus órdenes y a cuya autoridad sometía siempre la ultima palabra en sus decisiones.

Puestas en práctica las primeras medidas se dispuso Abascal a organizar la expedición que había de penetrar en el territorio quiteño. El mando de las fuerzas fué confiado al teniente coronel don Manuel Arredondo, a quien le comunicaba expresamente que, a su llegada a Guayaquil, se presentase al gobernador y se pusiese a sus órdenes para operar de acuerdo con él en todo lo referente a la comisión que le llevaba allí. Aquí se le reunirian las demás tropas, a las que habia de infundir la mayor disciplina antes de comenzar las operaciones. Una vez acabadas éstas, habiendo cesado el motivo de su permanencia alli, debería regresar prontamente a Lima (6).

Entretanto se preparaba la expedición de Arredondo, Abascal organizaba en la frontera trescientos fusileros que pudiesen servir de auxilio al gobernador de

(5) A. G. I.-Lima, 739. Oficio de Abaseal al primer secretario de Estado. Lima, 30 de octubre de 1809.

(6) A. G. I.-Lima, 739. Copia de oficio de Abaseal a Arredondo. Lima, 19 de septiembre de 1809. 
Cuenca, al objeto de que con estas fuerzes, las desembarcadas en Guayaquil, y las que por el Norte llegasen enviadas por el Virrey de Santa Fe, pudlesen iniciar desde tres puntos distintos la conquista del territorio sublevado.

La expedición de Arredondo salió del Callao conduciendo cuatrocientos hombres, con su correspondiente artilleria, municiones y 20.000 pesos en dinero, en dirección a Guayaquil. Mientras navegaba en aquella dirección se llevaron a cabo las órdenes del Virrey de Lima para reforzar el bloqueo de la provincia sublevada, a la par que dirigia una proclama a los quiteños para hacerlos entrar en razón antes de recurrir a las armas.

Simultáneamente, Abascal, puesto en contacto con el marqués de Selva-Alegre, le proponia como única solución al estado de cosas existente, la abolición de la Junta, la deposición de las armas y la reposición de las autoridades legítimas, admitiendo por poco tiempo una guarnición de cuatrocientos soldados. Todo lo cual habría de ejecutarse inmediatamente, pues en caso contrario, decía el Virrey, tendrán que sufrir las resultas del triple ataque que tengo dispuesto y ordeno con esta fecha se verifique inmediatamente para aprovechar la buena estación y no dar lugar a que se aumente el desorden» (7).

A la vista del giro de los acontecimientos y haciéndose cargo del peligro que les amenazaba, los dirigentes de Quito comenzaron a cambiar de conducta: 4... desde el momento que han visto algunos próceres que Popayán, Cuenca y Guayaquil ponian cerco a las provincias del centro y que sus fuerzas no serían bastantes para Fesistirlo, empiezan a planear el desenlace del drama (8). Asustado de lo que ha hecho, el marqués de Selva-Alegre se ha puesto en contacto con el conde de Ruiz de Castilla, con objeto de volver a la situación primitiva. Entretanto, el Virrey del Perú ordenaba a Cucalón se pusiese en disposición de sujetar

(7) A. G. I.-Lima, 739. Copia de oficio de Abascal al marqués de Selva-Alegre. Lima, 9 de octubre de 1809.

(8) RUMAZO, José. Guayuquil alrededor de 1809. Rev. de Indias. Número 18; octubre-diciembre de 1944. Pág. 641. 
a los insurgentes por la fuerza, en vista de que resultaban inútiles todos los intentos de conciliación.

El nombramiento del gobernador de Guayaquil como jefe de la expedición fué hecho siguiendo la voluntad de Ruiz Castilla, que lo llamó en su auxilio, voluntad que en todo momento respetó Abascal, aunque no deja de apuntar los mejores resultados que se hubiesen obtenido si, en lugar de aquél hubiese sido designado el gobernador de Cuenca o algún otro (9). Sin embargo, lo hacía asi el Virrey en su afán de no entorpecer la marcha de los asuntos y no crear zonas de fricción entre las autoridades americanas en un momento en que era fundamental mantener la unión a toda costa.

Llegadas las tropas de Arredondo a Guayaquil y celebrado Consejo de Guerra sobre las medidas más convenientes a seguir, se decidió que parte de ellas marchase a Ambato, provincia amenazada por los rebeldes, mientras el resto permanecía en Guayaquil a las órdenes del gobernador, en espera de la respuesta a las proposiciones dirigidas a la Junta por el Virrey. Igual medida tomó el gobernador de Cuenca, que también concentró sus fuerzas en Ambato, dispuesto a comenzar las operaciones.

Cuando se llevaban a cabo estos preparativos, la Junta cambió definitivamente de parecer, y el cambio dío como resultado la reposición del conde Ruiz de Castilla en el mando de la Presidencia, bajo algunas condiciones impuestas por los hasta entonces dirigentes revolucionarios, entre las que se contaba la de deJarles las armas (10). Entretanto, seguía la progresión de las tropas de Arredondo, que habian salido de Guayaquil con la vanguardia, mientras Cucalón permanecía en aquella ciudad con la retaguardia en espera de doscientos hombres que le vendrian de Panamá, y en espera también de la contestación de Selva-Alegre a

(9) ABASCAL. Memoria. Tomo II. Pág. 91.

(10) Esta capitulación de Ruiz Castilla con la Junta fué acremente censurada por el Virrey de Lima, para quien el solo hecho de entrar en negociaciones con aquella suponía un reconocimiento de la transformación operada en el Gobierno. No admitía tampoco el indulto que había aceptado el Presidente, a propuesta 
las proposiciones que para llegar a la solución del conflicto le hiciera Abascal.

Pero las comunicaciones de Selva-Alegre al Virrey no fueron tomadas en consideración por éste, que ordenaba la continuación del avance (11). Al fin, el 25 de noviembre Arrendondo entraba en Quito. El día anterior, para asegurarse y no comprometer a sus tropas, a pesar de las constantes comunicaciones de Ruiz Castilla aségurándole que obraba con entera libertad, comisionó al teniente don Agustín Zabala para entrevistarse con el Presidente; pero como sus respuestas no se conformaban con las instrucciones dadas por Abascal referentes a la entrega de las armas por lo's insurgentes, le envió otro oficio, con cuya respuesta no dudó ya en acercarse a la ciudad. Acordó con el Presidente, que salió a conferenciar con él, $\infty$ misionar a un oficial para hacerse cargo de las armas esa misma tarde, quedando licenciadas desde aquel momento las tropas que guarnecian la ciudad. Una compañía al mando de un oficial llevó a cabo el desarme a la par que se hacía cargo de la guardia del Presidente. Recibidas todas las armas, Arredondo entró en la ciudad al dia siguiente, 25 de noviembre, con el resto de las tropas, presentándose inmediatamente al Presidentè para recibir órdenes (12).

Ocupada la capital, el Gobernador de Cuenca, Aymerich, se retiró a su ciudad, convencido de la plena libertad de que gozaba el Presidente. Si hasta entonces no lo habia hecho, a pesar de las reiteradas ordenes de éste, habia sido por creer que la libertad

de la Juntâ, para los principales difjicenteg, con ánimo de no cumplirlo. ABASCAL, Mempria, t, II, págs. 99-10n.

(11) - Así se lo comunicaba el Virrey. al gobernador de Cuenca, diciêndole que cel ataque contra los insurgentes debe verificarse antes de que entren las aguas y se hagan más difíciles las operaciones, y porque conviene que con la tardanza no se dé lugar a que hagan mayores preparativos y cunda el contagio por medios de los papeles incendiarios que esparcen llenos de mentiras, suposiciones ridículas y abuminaciones que sólo pueden caber en cabezas totalmente desorganizadas». A. G. I. Lima, 739. Copia de oficio de Abascal,al gobernador de Cuenca Lima, 23 de octubre de 1809.

'(12) A. G. I.-Lima, '739.' Copia de oficio de Arredondo a Abascal. Quito, 26 de noviembre de 1809. 
de que disfrutaba era sólo simulada, y sus órdenes, intrigas de los revolucionarios (13).

Ruiz Castilla en todo momento había protestado de gozar absoluta libertad. Cuando tuvo lugar su deposición por la Junta, requirió el auxilio de Cucalón, al que nombró jefe de todas las tropas que se encaminasen hacia Quito. En la capitulación celebrada con la Junta se establecía que las fuerzas de Cuenca no entrarían en la ciudad. Pero la conducta de Aymerich le parecía bastante extraña. Había avanzado sus tropas sin comunicarle nada, y este hecho le hizo temer que se produjese derramamiento de sangre si se empeñaba en entrar en la ciudad. Los quiteños se alarmaron de tal manera, creídos que venia comisionado por el Cabildo de Ríobamba para someterlos y que traía órdenes de posesionarse de la Presidencia, que se prepararon a salirle al encuentro, con lo cual, según afirmaba el propio Presidente, «me hubiera visto seguramente en peor estado que antes, constituído por necesidad en un triste espectador de los lastimosos sucesos que ciertamente hubiesen resultado... (14). Obviado el peligro por la proximidad de las tropas de Lima, ordenaba Ruiz de Castilla su inmediata retirada a Cuenca por encontrarse en pleno uso de sus facultades, como lo demostraba el haber depuesto a Selva-Alegre y disuelto la Junta, restableciendo el orden de cosas existente antes de la revolución.

El Gobernador de Guayaquil, Cucalón, llegaba a Quito el 20 de diciembre. Justificaba el viaje alegando que habia sido llamado por el Presidente. Pero Abascal, que no las tenía todas consigo de las resultas de su presencia en la ciudad, le ordenó inmediatamente que se volviera a Guayaquil. Temía, según parece, que mal aconsejara al débil Ruiz Castilla. Asi es que, mediante la consulta del Acuerdo, se le ordenó su retirada. El Presidente, que habia elogiado

(13) A. G. I.-Lima, 803. Informe del gobernador de Cuenca al Cabildo de los efectos de la expedición practicada en los pueblos revolucionarios de la provincia de Quitos.

(14) A. G. I.-Lima, 803. Copia de oficio de Ruiz Castilla a Aymérich. Quito, 21 de noviembre de 1809. En Informe del gobernador... 
la prudencla y sagacidad con que se había manejado Arredondo para superar las grandes dificultades con que tropezó (15), criticaba la conđucta de Cucalón, que habiendo sido llamado por él para que, a la par que cortase la desavenencia surgida con el Gobernador de Cuenca le auxiliase con sus fuerzas, «debiendo encaminarse a la mayor brevedad, según el caso lo exigía, se detuvo en Guayaquil esperando estudiosamente que la tropa de Lima superase todas las diftcultades para venir a cosa hecha... (16). Un Juicio semejante merecia para Abascal la conducta del Gobernador de Guayaquil, cuando comunicaba a la Corte los sucesos de Quito recomendando a Arredondo (17). El mismo Arredondo, poco más tarde, insistía en el tema, haciendo ver que su permanencia en Quito hubiera acarreado muchos males a no haberlo mandado salir de alli Abascal. Según su opinłón, intentaba enemistar al Gobierno con el pueblo, intrigando aun con los mismos presos para entorpecer el pronto castigo de los insurgentes (18).

¿Cuál fué la causa que hizo variar tan pronto y tan radicalmente el Juicio de las autoridades españolas sobre Cucalón? En un principlo, Ruiz Castilla lo llamaba en su auxilio y Abascal le da el mando de todas las fuerzas que se dirigian contra los insurgentes al comunicar a Arredondo que se coloque a sus órdenes, y ahora vemos que unánimemente ponderan los males que podian derivarse de su conducta. Algo debió ocurrir para dar lugar a un cambio tan brusco. Ciertamente Cucalón era hombre poco reflexivo y su conducta desde el primer momento de la revolución quizás pecó algo de atolondramiento. Sus medidas contra los bienes de los quiteños en Gua-

(15) Lima, 739. Copia de oficio del conde Ruiz Castilla a Abascal. Quito, 26 de noviembre de 1809.

(16) Arek. Abascal. Copia de oficio muy reservatio de Ruiz Castilla a Abascal. Quito, 22 de diciembre de 1809. En una Relación de documentos de los informes hechos a la Corte sobre la conducta de Cucalóns.

(17) A. G. I.m-Lima, 789. Oficio de Abascal al primer secretario de Estado. Lima, 25 de diciembre de 1809.

(18) Areh. Abascal. Carta de Arredondo a Abaseal. Quito, 7 de mayo de 1810. 
yaquil fueron excesivas (19). Por otra parte, su retraso en marchan hacia Quito tampoco agradó a nadie; y cuando llegó a esta ciudad contribuyó a desprestigiarlo el hecho de que «pretendia aparecer como el pacificador de Quito y tener la comandancia general de las armas», a más del insistente rumor que se dejó correr por la ciudad de que había venido con la intención de obtener del Presídente la renuncia del cargo en su favor (20).

Abascal le hizo ver claramente su disgusto y la inutilidad de sus esfuerzos para permanecer en Quito; así es que no le cupo otro camino que volver a Guayaquil. De nuevo en esta ciudad, su conducta, un tanto irregular, levantó quejas de algunos de los vecinos más influyentes, entre otros de su propio sustituto durante su marcha a Quito, don Luis Rico. Estas quejas influyeron en el ánimo del Virrey de Lima, de quien dependía la provincia, y decretó su separación del cargo el 7 de agosto de 1810, decisión que más tarde Justificaba el Virrey en un largo escrito el Ministro de la Guerra (21). Ante la gravedad de las quejas que había recibido contra la conducta del Gobernador de Guayaquil, reunió el Acuerdo para resolver las medidas a segutr, tomando la resolución de separarlo de su cargo por mayoría de votos, nombrando como sucesor en el mismo al Coronel don Francisco Gil de Taboada.

La situación en Quito parecía completamente resuelta y la conducta de las sublevados era Juzgada por un Tribunal constituído al efecto. Pero la labor de Justicia fué extremada; aparte de los componentes de la Junta fueron aprehendidos muchos sospechosos, originando así un ambiente de temor en la ciudad, que predisponía los ánimos a cualquier otra revuelta en cuanto encontrasen momento oportuno de exteriorizar su desencanto ante la conducta de los españoles.

No tardó mucho en producirse el acontecimiento

(19) RUMAZO, José. Art. cit. Ṕ́gs. 648-644.

(20) RUMAZO, José. Art. cit. Pág. 654.

(21) I Aroh. Abascal. Oficio de Abascal al ministro de la Guerra. Lima, 23 de octubre de 1810. 
esperado por todos. La carestía que sufría la ciudad después de la pacificación debió dar lugar a que las tropas de Lima que habian quedado en ella de guarnición cometiesen algunos excesos. Esto originó el rumor de que dichos soldados se disponían a organizar un saqueo general de la ciudad, rumor que, aprovechado por los partidarios de la anterior Junta, y unido al malestar reinante, sirvió de pretexto a los sucesos que a continuación se desarrollaron.

El día 2 de agosto de 1810, a la una y media de la tarde, ałgunos soldados de la antigua guarnición de la eludad, que se hallaban en el presidio cumpliendo condena, sorprendieron la guardia y se apoderaron de sus armas. Disfrazados con los uniformes de los centinelas, y ayudados por algunos vecinos, parte de los amotinados se lanzaron repentinamerate sobre la guardia del cuartel de las fuerzas limeñas en el momento que la oficialidad se hallaba comiendo. Como los asaltantes venían disfrazados con el uniforme de soldados pudieron sorprender a la guardia, matando al centinela y apoderándose de las armas. Al ruido formado por la lucha entre la guardia $\mathrm{y}$ los asaltantes, acudió el Capitán don Nicolás Gallup, que vivía dentro del cuartel: Cuando se disponía a organizar la tropa para hacer frente a los tumultuados, fué muerto de un bayonetazo en la espalda delante de sus soldados. Al darse cuenta los que acudían de la muerte de uno de sus más queridos oficiales, subió de punto su indignación; hasta el extremo de que algunos de ellos se dirigieron contra los que intentaban forzar la entrada, y los demás se encaminaron adonde se encontraban los presas de la anterior revolución, que esperaban en los calabozos el fallo del Virrey de Santa Fe sobre sus sentencias, y a quienes los soldados ereían promotores de la revuelta. El resultado fué lamentable: trece de los allí detenidos fueron asesinados por los soldados, deseosos de vengar la muerte de su capitán, y sólo cuatro consiguieron huir, salvando con ello sus vidas.

Esparcida por la ciudad la noticia de lo ocurrido en el cuartel de las fuerzas limeñas, se reunió una gran muchedumbre contra los soldados, lo que exacerbó el furor de éstos, que se repartieron por las calles, matando a cuantos encontraban sospechosos de 
intervenir en el motín (22). Cabe imaginar los excesos que cometiera la tropa en semejante estado de excitación. El mismo virrey del Perú reconoce que «algunos desórdenes es preciso creer que se hubiesen cometido hasta reponer el orden; pero éstos Jamás deben creerse tales y tan grandes como el pueblo quiteño los abultó $\$$ ponderó... (23). Pero si bien es cierto que quizás hubo exageración por parte de los quiteños por convenir así sus fines, no lo es menos que un fondo de realidad hay que reconocer en la siguiente descripción que nos da un habitante de la ciudad de Quito: «...todos corrian a las quebradas y cerros, dejando escueta la ciudad, pues no se escapaba nadie de las balas que repartían, y al mismo tíempo rababan; no era uno libre de salir a la ventana, porque andaban como cazadores escuchando para cogerlos descuidados y hacer el tiro...) (24). No es, pues, de extrañar que, como dice el mismo testigo, la ciudad se hallase cmuy afligida y tan solitaria que no es otra cosa que sino una aldea grande, pues la gran mayoria de sus habitantes se retiró al campo.

No se puede por menos de culpar de la revuelta, dejando aparte a los asaltantes del cuartel, verdaderos promotores de ellas, a la oficialidad de las fuerzas limeñas, que no pudo o no quiso hacer entrar en la disciplina a sus desmandadas tropas. Pero si ésta fué la causa inmediata del motín y de los sucesos que le siguieron, no hay que olvidar tampoco que, cuando se produjo, se encontraba ya el ambiente propicio para ello, debido a la falta de tacto de las autoridades que sucedieron a la Junta de 1809. Si el procedimiento seguido para juzgar las causas de los rebeldes y para hacer olvidar los efectos de la primera revolución, hubiesen sido más suaves, seguramente no se hubiera llegado a los términos que precedieron a la triste jorzada del 2 de agosto.

(22) Arch. Abascal. Carta de Raiz Castilla a Abascal. Quito, 7 de aposto de 1810. A. G. I.-Lima, 740. Oficio del Virrey del Perú al primer secretario de Estado y su despaçho. Lima, 22 de octubre de 1810.

(23) ABASCAI, Memoria. Tomo II. Pág. 102.

(24) A. G. I.-Quito, 255. Carta de don Mariano Pas Miño a don Virefizs Espinosa. Quito, 22 de agosto de 1810. 
Las consecuencias de esta Jornada fueron fatales para los realistas en Quito. Para la vida económica de la ciudad significó un gran daño. No debe andar muy lejos de la verdad el ya citado comentarista de los sucesos cuando afirma que el comercio se halla muerto, pues no hay ni una tienda compuesta, porque todos vaciaron y guardaron en sus casas por los continuos robos: todo está escaso, y caros los víveres». Esto en el aspecto material y económico, pero en el aspecto político significó la anulación efectiva del poder del Presidente Ruiz Castilla. En su afán de evitar mayores males se vió obligado a transigir con las peticiones de los quiteños, que se sentian agraviados, lo cual no fué sino el primer paso hacia su total y definitiva pêrdida.

En efecto, el día 5 se publicó una convocatoria para una Junta general autorizada por el Presidente, para deliberar sobre los medios de restablecer la normalidad de la situación. En la Junta se recrimino la actitud de los «paciflcadores», que habian obligado al Presidente a faltar a la palabra empeñada de tratar con la mayor lenidad a los comprometidos en la revolucion. Esto iba dirigido directamente contra Arredondo, Jefe de las fuerzas de Lima, que se habia captado la confianza en la causa contra los sublevados de 1809. Este último era natural del Perú, 5 desde muy joven había gozado de la protección de Ruiz Castilla. Contra ambos se dirigía la acusación, quizás no desprovista del todo de fundamento, de inclinar al Presidente hacia una mayor dureza en el castigo de los inculpados.

Las resoluciones tomadas en la Junta se concreta. ban en dos extremos: la restitución a sus empleos y bienes de los que eran tenldos como reos de la anterior revolución, a los que se declaraba fieles vasallos de $\mathbf{S}$. M., y la retirada de las tropas de Lima, de las cuales, los zambos, autores de la revuelta, marcharían de alli a los cuatro días, y después el resto, sepultando en un total silencio y olvido los acontecimientos del día 2 (25).

(25) Quito, 255. In el Bando publicado como resultado de Junta del día 4, se especifica textualmente: eque de nirguna mane- 
Tenido en cuenta el parecer de la Junta, se resolvió que las tropas de Arredondo evacuasen la cludad, sustituidas por 200 hombres que, procedentes de $\mathrm{Pa}-$ namá, se hallaban en Guayaquil. Aprobada la decisión, al día siguiente comenzaron a salir en dirección a Lima. Pero notificado el Virrey de los acontecimientos que se desarrollaban en Quito, y ante la probable necesidad de una nueva intervención armada en esta provincia, ordenó a Arredondo se mantuviese en la de Guayaquil, lo más cerca posible de la frontera con Quito y dispuesto a intervenir a la primera orden que recibiese.

Ciertamente la posioión en que quedaban las autoridades españolas a la salida de las tropas de Lima era de lo más embarazosa. Ruiz de Castilla había sido repuesto en el poder por el temor de los qévoluclonarios ante el avance de estas tropas; si habia logrado superar la crisis política que significó la ereación de la Junta de 1809, fue gracias a las fuerzas de Arredondo, que eran su principæl sostén. El mismo heoho de ser tropas limeñas las que entraron en la ciudàd haciendo fracasar el plan revoluctonario, la falta de tacto de su Jefe, que gozaba del favor del Presidente, y por último, los desórdenes ocurridos de poco tiempo a esta parte, hicieron crecer por momentos el odio hacia dichas tropas, en lais que los quiteños veian el símbolo de la dominación extraña. En semejantes condiciones no ha de parecer raro que quisieran liberarse de la ocupación, aún consclentes de lo que esto significaba.

Ruiz Castilla pudo darse cuenta de que a la salida de las tropas su autoridad quedaba vacilante, tanto más cuanto que indirectamente era responsable de lo ocurrido en la revuelta del 2 de agosto. Por otra partei los ánimos estaban muy excitados, no sólo por los acontecimientos desarrollados en la ciudad, sino por

ra se proceda a la averiguación de los que promovieron, intentaron y ejecutaron la cempresa arrojadas del 2 del presentes. Ademb́s, se decide formar un batallón de la ciudad y provincia, y que se reciba con decoro a don Carlos Montúfar, comisionado por la Regencia. Copia del Bando publicado en Quito a 4 de agosto de 1810 . Como se ve, los quiteños supieron sacar buen partido a este desgraciado becho. 
las noticias que llegaban de Santa Fe y Cartagena. El Presidente, sin las fuerzas que lo respaldaban, venia a ser una entelequia que incluso podia utilizarse para los fines de los revolucionarios, como se verá que en efecto ocurrió.

El 12 de septiembre llegó a Quito don Carlos Montúfar, hijo del marqués de Selva-Alegre, que presidiera la primera Junta revolucionaria. Venía comisionado por la Regencia - según decia-, para dar a conocer los buenos deseos de ésta en su afán de encontrar una solución a los problemas americanos, y con poderes para tomar las medidas que a este efecto creyese más acertadas. Pero las noticias que sobre su actuación se tenian antes de llegar a Quito hacian dudar al Presidente de la buena fe del comisionado, que a su paso por Popayán creó una Junta de Vigilancia, sospechosa de cierto matiz independizante.

Conocedor Ruiz Castilla de la próxima llegada del comisionado hizo preparar la tropa como medida de seguridad, recomendándole hiciese su entrada en la ciudad privadamente y sin ostentación, a fin de evitar cualquier incidente. No se avino a ello Montúfar, que exigió una entrada cual correspondía a su carácter de representante del Consejo de Regencia, como en efecto hizo, rodeado de numerosa guardia y gran cantidad de gente del pueblo. Inmediatamente se puso en contacto con el Presidente y con el Obispo, quikenes enseguida le devolvieron la visita. Al día siguiente pasó de nuevo a conferenciar con Ruiz Castilla, para darle a conocer la amplitud de sus poderes y pedirle la retirada a sus cuarteles de las tropas que ocupaban diversos puntos de la ciudad. Consiguió fácilmente, no sólo ésto, sino compartír con aquél la Comandancia de las tropas (26).

Lograda la primera parte de su plan, poco trabajo

(26) A. G. I.-Lima, 740. Testimonio del expediente relativo a las rovedades introducidas en Quito con motivo de la llegada de don Carlos Mothtúfar, eomisioniado, que dice ser, por el Supremo Cansejo de Regencia para dicha ciudads.-Relación de don Simón Sáenz de Vergara, Regidor de Quito, al gobernador de Guayaquil. Guayaquil, 29 de septiembre de 1810.— — A nécdota breve de la historis de Quitos, firmada por el doctor don José María de Landa. Goenca, 29 de septiembre de 1810. 
le debió costar convencerlo también de la necesidad de convocar una Junta para decidir sobre la situación. En efecto, el 19 se reunían con el Presidente y el comisionado, el Obispo, un diputado de cada Cabildo, otro del clero y otro de la nobleza. El objeto de la reunión no era otro, según expresó el proplo Presidente, «que el de tratar de los medios y arbitrios de que debía valerse para la tranquilidad pública y sosiego de la provincia». El Procurador General, en nombre del público, expuso la situación: hizo saber que en el estado en que se hallaban, de desconfiar del Gobierno, la única solución viable era la de adoptar el ejemplo de las provincias españolas, constituyendo una Junta con voto del pueblo, previo reconocimiento del Consejo de Regencia. Sometido a votación el parecer del Proeurador General, acordaron los circunstantes lo siguiente: en primer lugar se decidió el reconocimiento del Consejo de Regencia, bien entendido que este reconocimiento tenía efectividad en tanto dicho Consejo se hallase en algún punto de la Península libre de la dominación francesa; pero que en el momento en que por la fuerza se viese obligado a someterse 0 trasiadarse a algún lugar de América, desaparecería sipso facto» el vínculp que los unía a él, y por tanto, la ciudad y provincia de Quito quedarian completamente libres de su obediencia, y, reasumiendo sus derechos, trataria de formar un Gobierno propio para lograr su independencia.

Se adoptó después la decisión de crear una Junta \$uperior de Gobierno dependiente sólo deł Consejo de Regenoia, compuesta del Obispo y del Comisionado, como vocales natos, y de un individuso de cada $\mathrm{Ca}-$ bildo, dos del Clero, otros dos de la nobleza de la ciudad y uno de cada barrio de la capital (cinco en total). La forma de elección de estos miembros era la siguiente: el clero, presidido por el Obispo, elegiria cinco electores; la nobleza, presidida por los Marqueses de Selva-Alegre y Villa Orellana, elegirían otros cinco, y cada barrio, reunidos los cabezas de familia en casa de su cura, y ante la presencia de su respectivo Alcalde, elegirían otros cuatro, a los que se uniría el voto del Cura párroco. El día destinado acudirían todos los electores a la Sala Capitular del Ayuntamiento, así como los Cabildos, para nombrar el vocal 
o vocales que los hubieran de representar. Cada uno expresania su voto por sufragio secreto, y los elegidos por este ptacediumiento constituirian la Junta Superior de Gobierno, que se haría cargo de los asuntos del mismo, quedando el Presidente actual en el ejercicio del Yice-Patronato y lo Judicial de la Hacienda.

Para que estas decisiones tuviesen el carácter público que deseaban sus promotores, se acordó someterlas al día siguiente a la decisión del pueblo medíante un Cabildo abierto, con el fin de obtener el corsentimiento y la garantia popular (27).

En efecto, el 20 se convocó a Cabildo abierto a la población de Quito. Sometida a la sanción popular el acta de la reunión del día anterior, resultó aprobada unénimemente, sufriendo una única modificación en lo referente a la constitución de la Junta, a la que se añadió el cargo de Vice-Presidente, para sustituir al Presidente en sus ausencias o enfermedades, a más del nombramiento de un secretario en la persona de uno de los vocales (28).

Conforme a lo acordado en la primera reunión y a la ratifficación del Cabildo abierto del 20, el día 22 tuvo lugar la reunión de los electores designados para constituir la Junta. El mismo día quedó designada, bajo la presidencia del Conde de Ruiz Castilla, siendo nombrado. Vice-presidente el Marqués de Selva-Alegre $(29)$.

(27) A. G. I.-Lima, 740. Copia de acta de la Junta celebra. da en Quito el 19 do septiembre. En el eTestimonio del expediente relativo a las novedades...

(28) A. G. I, - Limá, 74a. Copia de acta del Cabildo abierto, celebirato en Quito el 20 septiembre' de 1810. En el $T$ Testimonio del expediénte...s

(29) A. G. Iy-Lima, 740. Copia de acta de la constitución de la Junta Superios de Gobierno de Quito, Quito, 22 de septiembre de 181.0. En el eTestimonio del expediente... $>$ Dicha Junta la constítuían: Ruiz Cástilla y Selva-Alègré, presidente y vicepresidente, respectivamente; el Regidor'don Manuel Zambrano, representante dal Cabildo; el doctor don Franoisco Rodríguer Soto, del Cabildo Eclesiástico; el doctor don Manuel Caicodo, y el doctor don Prudencio Yáscones, por el Clero; el marqués dé Villa-Orellana y don Guillermo Váldivieso, por la Nobleza, y don Manuel la Rea, don Manue Mateos, don Mariano Marisalde y don Juan Donoso, por los berrios. Como vocales natos de ella juraron el Presidente, el Obispo y el comisionado Montúfar. 
Según se desprende de todo el proceso seguido hasta la iastalación de la segunda Junta de Quito, la de ahora, si bien tenía visos de legalidad, prácticamente tenía un carácter muy semejante al de la establecida en 1809. Como aquélla, aspiraba al título de Suprema, esta vez sobre las de la provincia, y hasta algunos de sus miembros, como los Marqueses de Selva-Alegre y Villa-Orellana, habian sido miembros de la anterior. Sin embargo, ahora se llevó a cabo el plan con más cautela. La llegada de Montúfar a Quito hizo sospechar que iban a ocurrir cambios trascendentales en la ciudad, tanto más, cuanto que era hijo del que fué Presidente de la primera Junta y se presentaba ante el pueblo celoso de los plenos poderes de que era portador. La llegada de los comisionados del Consejo de Regencia a Santa Fe fué seguida de la instalación de la Junta, provincial en aquella ciudad; no es nada extraño que al llegar a Quito, conocido el ambiente que reinaba en la ciudad, se esperase un acontecimiento semejante.

En efecto, respaldado por la popularidad adquiria , y haciendo valer sus poderes, inutilizó toda posible resistencia de Ruiz Castilla, falto de fuerza adicta en que sustentarse desde la marcha de las tropas $\mathbf{k i -}$ meñas. El resto es fácil de colegir: al Presidente no le cupo otra salida que sancionar una situación de hecho, llevado quizás en gran parte de su deseo de no provocar nuevos conflictos. Asi, los revolucionarios se encontraron con las manos libres y dentro de la legadidad. La elección de Ruiz Castilla como Presidente de la Junta fué una hábil medida para no salirse precisamente de esa legalidad, seguros como estaban de que dicho personaje habia de crearles pocas dificultades. Triunfante y puesta en marcha la revolución en la capital, sólo le restaba darse a conocer y atraerse a las demás eiudades de la provincia.

Una de las primeras medidas de Montúfar tras la elección de la Junta, y el mismo dia de ella, fué a comunicar al Virrey del Perú su disconformidad con las medidas adoptadas por éste respecto a la situación de la provincla de Guayaquil. Se mostraba sorprendido de que, consultado el Tribunal de la Audiencia, hubiese dispuesto la separación de Guayaquil del Gobierno de Quito en los asuntos de Justicia, únicos por los que 
permanecía sujeto a éste, de cuya disposición se mostraba tanto más extrañado cuanto que había tenido lugar sin previa consulta con el Goblerno de Santa Fe. Con ello, a más de haberse llevado a cabo dicha resolución sin el consentimiento de los vecinos de Guayaquil, quedaba esta ciudad privada de las medidas que obrase en su comisión. Por todo lo cual requerfa al Virrey se volviese atrás en lo realizado y conservase el estado de cosas preexistente (30).

A la par que escribia a Abascal, Montúfar informaba de su comisión y de lo realizado en Quito a las principales ciudades. El mismo 22 de septiembre se ponía en contacto con los Cabildos de Cuenca y Guayaquil, haciendo constar a este último su propósito de llevar a cabo la anulación de las medidas realizadas por el Virrey de Lima (31).

Mas no sólo a los Cabildos da cuenta de su comisión, sino que también la comunica a los gobernadores de las ciudades y al Obispo de Cuenca, a quienes anuncia su próxima llegada (32). Pero la contestación de estas autoridades fué contrarla a los deseos de Montúfar. El gobernador de Cuenca le escribía el 29 de septiembre, haciéndole notar que en su ciudad no existía la necesidad de restaurar la armonía entre el Cabildo 8 él, de que le hablaba el comisionado, ya que no se había roto Jamás; por ello le dice claramente: aperdería Usia con inutilidad el tiempo si este es el único objeto a que se dirige la partida que intenta. Es por esto por lo que Usía debe sobreseer su deseo». Le hace constar además que si en Quito el medio de solucionar los conflictos existentes fué la creación de una Junta, como en otros lugares, en Curenca no hay necesidad de recurrir a tal procedimiento, ya que no

(30) A. G. I.-Lima, 740. Copia de oficio del comisionado don Carlos Montufar al Virrey del Perú. Quito, 22 de septiemb̆re de 1810. En el \&Testimonio del expeálierte...».

(B1) A. G. I.-Lima, 740. Copiàs de ofieios de Montúfar a los Cabildos de Cuenca y Guayaquil. Quito, 22 de septiembre de 1810. En el (Testimonio del expediente...)

(32) A. G. I.-Lima, 740. Copias de oficios de Montúfar a los gobemadates de Gusyaquil y Crenca $y$ al Arzobispo de esta eirdad. Quito, 12 de septiembre de 1810. En el Testimonio del expediente... 
conduciria a otra cosa que a interrumpir su buen orden; $y$ aún no queda aquí: le manifiesta sus sospechas respecto al procedimiento empleado para erigir Juntas. «Si un jefe no es acreedor a estar al frente de una provincia, no por eso las leyes permiten que se varie el orden público establecido, sino que se dirijan reclamos a la suprema Autoridad, la que impuesta de la mala versación de sus representantes se dignará revelarlas». No duda que las instrucciones de que es portador Montúfar le permitan llegar hasta a derogar esas leyes, pero aquí surge la duda para el gobernador: «Sí es asi, ¿cómo el Perú y la Nueva España, cuya opinión debe decidir de la del resto de las Américas, han mirado y miran con odio implacable las asambleas de este género? Y ¿cóma también se adopta un sistema municipal de gobierno para este Reino cuando por su misma naturaleza ha de ser regido por el propio Código que obedecen los demás? » Tales problemas sumían en la mayor perplejidad a Aymerich, que, deseoso de contar con el parecer del Cabildo, aplaza su decisión hasta que tenga la opinión de este, cuya reunión ha convocado (33).

De un modo semejante se expresaba el Obispo. Contestaba a Montúfar claramente que no debía ir a Cuenca «por no ser en ella necesaria su presencia personal; antes por el contrario, podría acarrear su venida muchas y muy fatales consecuencias». Puesto que la ciudad se ha mantenido en todo momento fiel al Rey ¿a qué fin o con qué objeto debe venir a ella su comisionado regio, y más cuando seguro se explica viene a restablecer el orden entze el Gobierno y el pueblo? Como éste se halla tranquilo con su actual Gobierno, a nada, sino a causar perjutoios vendría cualquier innovación que se pretendiese introducir en él. Con tales y parecidas razones intenta convencer al comisionado para que desista de su proyectado үiaj'e a la ciudad, sin despreciar decirle que por las noticias que de él se tienen, por todos los sitios por donde ha ido pasando ha ido creando Juntas, como

(333) "A. G. I. -Lima, 740.Copia de carta de don Melchor de Atymerich, 'gobernador de Cuenca, a Montúfar. Cuenca; 29 de septiembre de 1810. En el sTestimonio del expediente...s 
utimamente en Quito, de la que no se ha formado en esa ciudad el mejor concepto; lo cual unido a la idea de que tenia intención de crear otra en Cuenca con subordinación a aquélla, ha hecho disponer los ánimos en contra de su viaje (34).

El día 28, Ruiz Castilla y Montúfar escribian un largo oficio al Obispo de Ouenca, detallándole las circunstancias de la creación de la Junta, e incitándolo a que cooperase al establecimiento de otra semefante en su ciuctad. Pero el mismo día, éste escribía a su vez a Abaseal notificándole las instancias de Montúfar para que se adhiriese a su sistema. El Obispo dice al Virrey: «Yo no podía en conciencia acceder a su solicitud, pues es una observación constante que no hay provincia que visite, cuyo orden público no quede entenamente trastornado: la nueva Junta que ha erigido en Quito así me lo acredita». La Junta es, a los ojo's del Obispo, una farsa, ya que gran parte de sus miembros lo fueron de la anterior Junta revolucionaria. Este hecho, la buena acogida que tuvo entre los caraqueños en tiempos de su revolución y el rumor de que la Junta de Bogotá es obra suya, completan el cuadro de la descorrfianza del Obispo hacia las planes del comisionado. Todo lo cual pone en conocimiento del Virrey para que se haga cargo de la delicada situación de Cuenca y esté sobre aviso ante cualquier emergencta (35).

En términos semejantes ponia Aymerich al Virrey de Lima en conocimiento de la situación. Le manifiesta su negativa a la instancia de Montúfar, aznque se dá cuenta de que con ello ha debido digustar a los dirigentes de Quito y no seria extraño se hallase en visperas de un romptmiento. Ante esta posibilidad recaba el auxilio del Virrey y le pide que ordene al gobernador de Guayaquil le auxilie en caso de peltgro (36).

1(34) A. G. I.-Lima, 740. Copia dé carta del Obispo de Cuenea a Montúfar. Cuenca, 29 de septiembre de 1810. En el Testimonio del expodiente...s

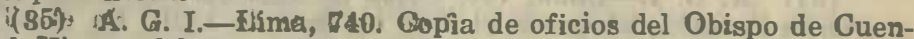
ca al Virrey del Perú. Cuenca, 28 de septiembre de 1810. En el \& Testimonio del éspediente...

(36) A: Gj+liwima, 740. Copia de oficio de Aymerich al 
Por fin el día 6 de octubre se reunió el Cabildo de Cuenca para decidir sobre el reconocimiento de la Junta de Quito. Su dictamen fué no reconocer otras autoridades legitimas que las residentes en la capital del Perú, delatando a la Junta de Quito como idéntica a la erigida el 10 de agosto de 1809 (37). Así lo hacían saber a Abascal, a quien protestaban estar unidos frente a los revolucionarios quiteños.

En situación análoga a la de Cuenca se encontraba Guayaquil, cuyo gobernador, Gil de Tabaoda, que había sido colocado por Abascal en sustitución de Cucalön, envió a Lima los pliegos que recibiera de Quito, como dependiente directamente de este Virreinato.

En Líma se planteó la situación con un aspecto semejante a la de 1809. Desde el primer momento, Abascal consideró a los integrantes de la Junta en un todo semejante a los de la anterior, influídos ahora por las ideas del comisionado, que encontró los ánimos dispuestos para las innovaciones. Antes de que tuvieran hugar los acontecimientos en Quito, ya sospechaba el Virrey de los planes de Montúfar: «Desde que don Carlos Montúfar puso pie en Cartagena, dió idea de su poco Juicio y menos reflexión, - dice el Virrey-y me hizo recelar que podría causar algunas novedades perjudiciales, como lo expuse al Ministerio de Hacienda el 8 de agosto... y efectivamente, a poco tiempo de haber llegado a Santa Fe resultó el proyecto de Junta, consiguiente deposición del Virrey y varios otros atentados, viniendo a terminar su proyecto con la de Popayán y Quito...» (38). Semejante actuación de Montúfar anulaba a sus ofos todos los poderes de que pudiera ser portador, cayendo fuera de la legitimidad todas las innovaciones introducidas en los puntos por donde había ido pasando. La Junta de Quito, pues, era ilegitima en cuanto que había supuesto la

Virrey del Perú. Cuenca, 29 de septiembre de 1810. En el tTestimonio del expediente...»

(37) A. G. I.-Lima, 740. Copia de acta del Cabildo de Cuenca, en la reunión celebrada el 6 de oetubre de 1810. En el sTestimonio del expodiente....

(38) A. G. I.-Lima, 740. Oficio de Abascal al primer secretario de Estado y su despacho. Lima, 14 de noviembre de 1810. 
ałteración de las leyes fundamentales que regian el Gobierno de América.

Como por otra parte no se le ocultaban al Virrey de Lima los proyectos independizantes que se escondian tras los cambios de formas de Gobierno, tendió desde el primer momento a cortar todos los intentos que fuesen encaminados en tal sentido. Por eso se apresuró a intervenir cuando surgió en Quito la primera Junta, y se dispone ahora a emplear igualmente todos los medios a su alcance para acabar con esta nueva tentativa de independeneia con visos de legalidad.

Se volvió, pues, a una situación semejante a la del año 1809: Quito, erigido en sede de una Junta que recababa la formación de Juntas subordinadas en las demás provincias, y frente a ella la autoridad real, representada esta vez únicamente por el Virrey de Lima, al cual se le unieron los Jefes de Guayaquil y Cuenca, a más del partido de Fußranda, de la misma provincia de Quito, y la provincia de Pasto.

Por ello, ante la extensión de la propaganda revolucionaria a través de los escritos circulados por la Junta a todas las provincias, Abascal decidio, previa reunión del Real Acuerdo, prohibir a Montúfar toda comunicación con el Perü, como medio de salvaguardar la seguridad en el Virreinato, a la par que se daban órdenes al gobernador de Cuenca para que tomase las medidas convenientes encaminadas a atajar el progreso de la revolución en los territorios limitrofes a Quito (39).

Sin embargo, las medidas del gobernador de Cuenca habia de tomarlas de acuerdo con el nuevo Presidente de Quito, don Joaquín Molina, nombrado por la Regencia en sustitución de Ruiz Castilla, y que se hallaba en Lima próximo a navegar hacia Guayaquil (40).

(a9) A. G. I.-Quito' 255; Gopia de acta del Real Acuerdo de Lima. Lima, 22 de octubre de 1810.

(40) El nombramiento de Molina como Presidente de Quito data del 29 de abril de 1810, fecha en que le era comunieado a Abascal en un oficio de la Regencia, datado en la Isla de León. A. G. I.-Quito, 255 . 
En efecto, tres días después de la reunión anterior, el Acuerdo volvió a congregarse nuevamente bajo la presidencia del Virrey, determinándose la inmediata salida de Molina en dirección a Quito, estableciendo su residencia en Cuenca, mientras durase aquel estado de cosas en la ciudad y no le fuese posible posesionarse de una manera efectiva del mando. A la par se le hacia cargo a Molina del Virreinato de Santa Fe, a consecuencia de haber quedado sin jefe por la deposición del Virrey Amar (41).

El 26 de octubre salió el Presidente para Guayaquil, adonde llegó pocos días después. Molina traía amplias instrucciones del Virrey de Lima para pacificar a Quito por medios suaves, o por la fuerza si fuera preciso; en este caso debía combinar sus operaciones con los gobernadores de Guayaquil y Cuenca para atacar por diversos puntos a los quiteños y mantener el contacto con el de Popayán, al objeto de aislar por el Norte la revolución e impedir su unión a la de Santa Fe.

A su llegada a Guayaquil, informado de la situación de la capital, envió a ella oficios dando a conocer su propósito de pasar a posesionarse del mando como Gobernador nombrado por el Consejo de Regencia. Pero entretanto recibía respuesta, se preocupó de la situación militar, seguro de que, como último recurso, habría que recurrir a las armas, a juzgar por el cariz que habia tomado el movimiento subversivo de Quito.

Antes de la llegada de Molina, el Gobernador de Guayaquil había dispuesto la colocación de tropas en Huaranda, punto vital de las comunicaciones entre esta última ciudad y la capital. Las fuerzas aqui congregadas eran las tropas de Panamá que habían sustituído en Quito a las de Lima después de su salida, y que al constituirse la Junta fueron a su vez obligadas a evacuar la ciudad. Por su parte, el Gobernador de Cuenca también organizaba las fuerzas de que podía disponer, principalmente las milicias, con objeto de defender la frontera de su territorio. Asi pues, en

(41) A. G. I.-Quito, 255. Copia de acta del Real Acuerdo de Lima, celebrado el 25 de octubre de 1810. 
la Junta de Guerra celebrada poco después de la llegada de Molina sólo se trataron estos puntos, resolviéndose mantener las tropas de Panamá en Huaranda y enviar individuos que ayudasen al Gobernador de Cuenca para disciplinar las milicias de aquella provincia (42).

Entretanto, en comunicación con la Junta de Quito, esperaba poder conseguir un resultado favorable sin necesidad de tener que recurrir a las armas. "Mi fin es usar de la persuasión y consejo-escribia Molina - : estrecharlos por medio de prudentes providencias al reconocimiento de las legítimas autoridades e inducirlos a la disolución de su ilegal Junta, empleando.toda la suavidad que fuera compatible con el decoro del empleo que debo a S. M.; pero no permitiré que en manera alguna se incremente ni extienda el fuego de la subversión a las provincias que hasta ahora se hallan libres de él, valiéndome en caso necesario de la fuerza de las armas» (43).

Pero ante la probabilidad de tener que recurrir a ellas, era necesario formar un considerable Cuerpo de tropas, que debería constar de 3.000 hombres, número que según la opinión del Gobernador de Cuenca, a la que se adhería Molina, no era exagerado, si se tenía en cuenta la necesidad de no poner en riesgo la primera acción que se sostuviese con el enemigo, ya que seria decisiva para las provincias, e incluso para el mismo Perú. Y la situación de las tropas en estos momentos era bastante precaria, pues según comunicaba Molina a Abascal, las fuerzas de Lima y Panamá habian disminuido mucho sus efectivos, y el Gobernador de Cuenca, por su parte, sólo podía proporcionar 500 hombres. Asi es que pide le remita una Compañía de granaderos del Real de Lima y oficiales̄ de Artillería para cubrir los grandes huecos que sufria el Ejército, además del envío de 60.000 pesos en

(\$2) A. G. I.-Quito, 255. Copia de acta de la Junta de Guerra celebrada en Guayaquil, bajo la presidencia de Molina. Guayaquil, 8 de noviembre de 1810 .

(48) A. G. T.-Quito, 255. Oficio de Molina a Abascal. GuaJaquil, 17 de noviembre de 1810. 
metálico para llenar las necesidades de la tropa (44).

Entretanto se llevaban a cabo estos preparativos en el campo realista mientras se esperaba la contestación de la Junta de Quito, en el campo de los quiteños tenian lugar preparativos semejantes. Reunidas sus tropas habían avanzado hasta cerca de Huaranda, llegando a constituir una amenaza para este punto. En vista de ello, el jefe de las tropas de Panamá que lo guarnecía pidió refuerzos a Guayaquil. En nueva Junta celebrada el 19 de noviembre se acordó auxiliarle con el envío de dos Compañías de pardos y cuatro piezas de Artillería, persuadidos de la importancia del mantenimiento de este punto. cuya conservación debía procurarse a toda costa. (45). Aun más, en otra Junta de Guerra posterior, de 29 de noviembre, ante el patente peligro de un ataque enemigo, se decidió que el resto de las fuerzas de Arredondo marchase a guarnecer dicho punto, dejando desocupado el de Alausi por falta de tropa, dada su facilidad de reouperaklo en un momento determinado $(46)$.

Gumplidas estas órdenes, Arredondo pasó a reforzar Huaranda con el resto de las tropas de Lima y simultáneamente se comunicaba al Gobernador de Cuenca reuniese 1.800 hombres, con las cuales debelía ocupar la provincia de Alausi, y en este caso, cortada la comunicación con Quito por este punto y por por los de Ambato y Ríobamba, que debia ocupar Arredondo, quedarían rotas las comunicaciones y anulado el comercio de Quito, completándose su aislamiento con las órdenes comunicadas al efecto al Gobernador de Popayán. De este modo, con un ejército que llegaria a 3.000 hombres se mantendría a la expectativa, en espera de las decisiones de la Junta, conservando aislado el foco revolucionario (47).

(44) A. G. I.-Quito, 256. Copia de oficio de Molina a Abascal. Guayaquil, 23 de noviembre de 1810.

(45) A. G. I.-Quito, 256. Copia de acta de la Junta de Guerra celebrada en Guayaquil, bajo la presidencia de Molina, el 19 de noviembre de 1810 .

(46) A. G. I-Quito, 256. Copia de acta de la Junta de Guerra celebrada en Guayaquil, bajo la presidencia de Molina, el 29 de noviembre de 1810.

(47) A. G. I.-Quito, 255. Copia de oficio de Molina a Abaseal. Guayaquil, 6 de diciembre de 1810 . 
Las negociaciones con la Junta habian tenido hasta entonces poco éxito. Al recibirse en Quito los' oficios de Molina en que notificaba su decisión de tomar el mando de la ciudad de una $u$ otra forma en 'virtud de su nombramiento de Gobernador de la misma, se opusieron reparos a este nombramiento, alegándose que no se hallaba en paseșión de él y que no tenía derecho a arrebatar la autoridad a la Junta. En vista de las dificultades que surgieron en el intercambio de oficios, y con el fin de obviar todos estos abstáculos, decidió Molina enviar a Quito, en calidad de comisionado, al oficial don Joaquín Villalba, para que, en contacto directo con las autoridades de allí, pudiese llegar a un acuerdo sobre la disolución de la Junta y entrada del nuevo Presidente. Pero los resultados de la comisión fueron más contraproducentes que el anterior cambio de oficios. Llegado a la capital Villalba, portador de un salvoconducto de la Junta, estuvo a pique de perder la vida en un tumulto popular que se originó a su entrada. El pueblo de Quito, tomándola por limeño, descargó en él sus iras acumuladas desde el 2 de agosto, y a no ser por la llegada de Montúfar, que lo condujo a su casa, lo hubiera pasado bastante mal el comisionado de Molina. De todos modos tampoco se alivió mucho su situación en lo sucesivo; durante toda su estancia en Quito permaneció bajo severa vigilancia por parte de las autoridades, según se decią, para librarlo de cualquier atentado.

A Villalba se le propusieron tres puntos en nombre de la Junta, como base de negociación con Molina: que se dosembargasen los bienes de los individuos de la sierra, que estaban embargados en Huranda; la libertad de comercio de la provincia, y la retirada inmediata de las tropas, comprometiéndase por su parte los quiteños a hacer lo propio. Por último, se exigia que Molina esperase el parecer de la Regencia, a quien se había comunicado la formación de la Junta: en caso de que aquélla aprobase su constitución, el Presidente se abstendría de entrar en Quito, y en caso contrario, ya se buscaria una solución para zanjar las dificultades (48). Durante el periodo de per-

(48) A. G. I.-Quito, 255. Declaración del vecino de Quito 
manencia en Quito le propusieron a Villalba que se quedase en la ciudad uniéndose a los revolucionarios, a lo que se negó rotundamente. Montúfar le dió a entender que no habia traído órdenes del Consejo de Regencia para alterar el Gobierno, pero que lo habia hecho por haberlo exigido el pueblo y parecerle que por este medio conciliaría los ánimos de sus paisanos con las autoridades, y que debido al desarrollo de los acontecimientos, en el día se hallaba comprometido a sostener dicha alteración. El Provisor del Obispado fomentaba la rebelión, y todos procuraban excitar al pueblo con una activa propaganda. En cambio, Ruiz Castilla se hallaba completamente coaccionado, no permitiéndole los componentes de la Junta abandonar su aparente mando, del que en varias ocasiones habia hecho renuncia, todas ellas completamente en vano (49).

Recibidas en Guayaquil las noticias referentes al trato concedido en Quito a Villalba, convocó Molina una Junta de Guerra para examinar la situación y obrar en consecuencia. En efecto, se determinó suspender los medios pacíficos para llegar a un arreglo, siendo de parecer los alli reunidos que se comenzase el ataque, pero reclamando antes a la Junta de Quito la devolución de la persona del comisionado. Aún se ofreció una última posibilidad con el ofrecimiento del Coronel Bejarano, que se puso a disposición del Presidente con objeto de pasar a Quito para rescatar a Villalba y ensayar por última vez un intento de solución del conflicto. Aceptada su oferta pasó a la ciudad de Riobamba, en donde se hallaba Montúfar, que se había puesto al frente de las tropas quiteñas en este punto (50).

Pero la comisión de Bejarano resultó de peores consecuencias que la de Villalba, pues a su vuelta del campamento de Ríobamba sin ningún resultado práctico en cuanto a la solución del problema, hizo cun-

don Alejandro Díaz González, huído de esta ciudad. Guayaquil, 28 de diciembre de 1810.

(49) A. G. I.-Lima, 649. Copia de informe de don Joaquín de Villalba al Virrey del Perú. Guayaquil, 6 de marzo de 1811.

(50) A. G. I.-Quito, 255. Copia de oficio de Molina a Abascal. 29 de diciembre de 1810 . 
dir la noticia de los grandes efectivos que estaban acopiando los quiteños en aquel lugar, desde donde proyectaban dirigir un ataque contra las tropas de Arredondo con objeto de cortarles la retirada. En vista de tales antecedentes, el jefe realista decidió reunir una Junta de Guerra con sus oficiales para trazar su plan de operaciones. En un principio se optó por permanecer en dicho punto y esperar el desarrollo de los acontecimientos, pero más adelante, examinadas las condiciones del terreno, decidieron abandonarlo de noche, como en efecto hicieron. Como no tenian caballerias para transportar los pertrechos y equipaje, hubieron de abandonarlos, como asimismo los cañones de que disponian, que, arrastrados por los soldados, cayeron en precipio (51).

La consecuencia inmediata de la retirada de las tropas de Arredondo fué el rápido avance de las de Montúfar, que ocuparon Huaranda sin ninguna dificultad, lo que obligó al Gobernador de Guayaquil a concentrar sus tropas sobre la linea de la frontera de su provincia. En vista de la inesperada complicación de la situación militar y de que los quiteños amenazaban continuar su avance, Molina salió de Guayaquil en dirección a Cuenca, adonde llegó el 29 de enero de 1811. El Gobernador Aymerich habia salido ya de la ciudad, marchando a Cañar, frontero a Alausi, en donde con sus tropas pensaba guardar este punto y el de Paredones. A su llegada a Cuenca, Molina envió a Aymerich los auxilios que le eran indispensables para mantenerse en aquel punto, pero como a juicio de éste aún necesitaba mayor cantidad de hombres para comenzar la ofensiva contra Quito, mucho más después del desastre de Arredondo, se dirigió al Virrey del Perú en solicitud de auxilios. Pero el Virrey no se hallaba en condiciones en este momento de enviar lo que necesitaba Molina; por ello le pareció prudente no comenzar seguidamente la ofensiva contra los sublevados, «tanto por no haberse apurado suficientemente y con la dulzura que correspondía los medios de reducirla, como por las dificultades que se

(51) A. G. I.-Lima, 649. Copia de oficio de Arredondo a Abascal. Bodega de Babahoyo, 4 de enero de 1811. 
tocaban en hacer un armamento cual Molina apetecía... (52). Insistía en que atuviese estrictamente a las instrucciones con que habia partido de Lima, encaminadas a aprovechar hasta el último resquicio de arreglo pacífico. Reunido el Acuerdo en Lima el 23 de dicfembre y examinada la cuestión de Quito, fué de parecer que Molina esperase en Cuenca el resultado de la comisión de Villalba, eapurando todos los medios de prudencia y sagacidad para restablecer el orden en aquel territorio sin necesidad de hacer uso de las armas para posesionarse de su empleo y que se le manifieste que las nuevas ocurrencias del Reino y lo avanzado de la estación no permiten se le franqueen por ahora los auxilios de tropa y dinero que pide para entrar en la provincia de su mando con la fuerza de armas...» (53): Con esto se daba a entender una vez más a Molłna quie debia desechar hasta el último momento el empleo de las armas, so pena de tener que valerse de sus propias fuerzas, pues las esperanzas que pudiera poner en Lima resultaban completamente vanas. Pero no paraba aquí la cosa, sino que en el mismo oficio en que Abascal le comunicaba el dictamen del Acuerdo, le ordenaba que las tropas de Panamá que estaban a sus órdenes debían regresar lo antes posible a su punto de origen, reclamadas por el Gobernador de aquel territorio para emplearla en su defensa ante el cariz que tomaban los acontecimientos en Santa Fe.

Pero ya no era posible un arreglo. Las negociaciones habían llegado a un punto muerto y los últimos acontecimiento militares hacían inevitable el comienzo de las hostilidades. Montúfar, al frente de 3.000 hombres y 16 cañones se sentía fuerte contra $600 \mathrm{sol-}$ dados, que era todo cuanto podía oponerle Molina por el momento; pues no cabia pensar que el Virrey de Lima pudiese enviarle muchos refuerzos cuando al mismo tiempo se hallaba preparando en el Desaguadero un ejército con que oponerse a la marea ascendente de la revolución argentina, amenaza directa del

(52) ABASCAL. Memoria. Tomo II. Pág. 119.

(5B) A. G. I.-Quito, 256. Copia de acta del Real Acuerdo de Lima. Lima, 23 de diciembre de 1810。 
Virteinato. En condiciones de manifiesta inferioridad numérica hubo pues de hacer frente Molína a las fuerzas quiteñas.

Las fuerzas realistas se hallaban en los confines de la província, en el punto de Paredones, pero atacadas por Montúfar, hubieron de retirarse de este punto al de Cañar, distante doce leguas de Cuenca, y en donde se había instalado el Cuartel General. El 18 de febrero aun hubieron de retroceder las tropas a situarse en Verdeloma, a cinco leguas de la ciudad. Montúfar dirigtó oficios al $\mathbf{C a}-$ bildo anunciando su próxima entrada tras la inminente toma de la ciudad. Convocado el pueblo a cabildo para organizar la defensa, sólo apareció un número exiguo de vecinos sín ánimo de defenderla; se hacía ver que entre la propaganda de los enemigos y el desánimo que habla cundido entre los habitantes el desenlace sería fatal para la ciudad. Ante el cariz que tomaba la situación, el Obispo, que se había mostrado en todo momento como un ferviente defensor del bando realista, abandonó la ciudad en la noche del 18.

El mismo día 18, Montúfar envió al Cabildo un oficio de la Junta de Quito en el que calificaba de falsos los poderes de Molina e invitaba a los conquenses a adherirse a su partido. Leido este escrito en el Cabildo, Molina pudo darse cuenta de que el ánimo de los capitulares era de no resistir a los quiteños, en vista de lo cual, y juzgando inútil su permanencia en la ciudad que no podía defender, pidío se le aceptase su dimisión. Su propuesta fué aceptada y al día siguiente marchó hacia el pueblo de indios denominado El Valle, distante legua y media de Cuenca. Entretanto, los enemigos habían avanzado hasta Caspicorral, en donde recibieron la contestación del Cabildo proponiendo a Montúfar pasase a la ciudad.

Pero mientras tenían lugar estas negociaciones, y a raíz de la partida de Molína, se esparcío la noticia de su marcha y de la próxima hegada de los quiteños. Ante esto comenzó a reaccionar la población, que hasta entonces había permanecido presa del mayor temor. $Y$ de tal modo fué aprovechada la reacción del pueblo de Cuenca por algunos elementos adictos a los realistas y por algunos sacerdotes, que, reunido Cabil- 
do abierto el día 22, siguiente al de la marcha de Molina, decidieron unánimemente enviarlo a llamar y colaborar todos con él en la defensa.

Ante el cambio efectuado en los ánimos de los conquenses, Molina accedió a volver y organizar la resistencia. Por su parte, Montúfar, sorprendido por el inesperado cambio de opinión, envió un nuevo ofl. cio dando tres dias de plazo para que le enviasen diputados con el fin de ajustar la capitulación. A su oficio le contestaron desde la ciudad dándole un plazo de tres horas para retirarse, decisión tomada en Cabildo abierto celebrado el 23. En vista de la alternativa, y no queriendo hacer frente a un posible ataque de Molina, emprendía la retirada, en la que, según camunicaba el Presidente, debido al mal tiempo no fué pesible llevar a cabo su perseeución (54).

La actuación de Molina en este suceso fué duramente criticada por el Virrey de Lima. En primer lugar fué acusado de haber provocado con sus eseritos la agresión de los quiteños y de no haber obrado conforme a sus instruceiones. Fué acusado asimismo de un «genio demasiado irritable» y de pocos conocimientos políticos y militares. Desde que se planteó por segunda vez el problema de Quita, se vió un marcado deseo por parte del Virrey de Lima de encontrar una solución pacifica al conflicto. Y la posioión del Virrey era lógica. Por una parte existía el natural modo de ser politico de Abascal, que en todo momento preferia recurrir al empleo de la fuerza como último argumento, y sólo cuando se habian agotado todos los intentos de composición, y por otra parte estaban aún recientes los sucesos de Chuquisaca y La Paz. Pero sobre todo se alzaba un peligro mayor, representado por la revolución argentina. Esto era lo que efectivamente impedía al Virrey dirigir del todo la vista hacia Quito, sin que por eso perdiera importancia a sus ojos el problema.

Desde su propio punto de vista parece natural que Molina quisiera apresurar los acontecimientos para entrar en posesión de su mando en la capital, to eual

(54) A. G. I.-Quito, 256. Traslado de parte de Molina a don Francisco Saavedra. Cuenca, 29 de marzo de 1811. 
no quiere decir que hiciese algo por su parte para que comenzasen las hostilidades. Cuando llegó a hacerse cargo del mando de Cuenca, ya el Gobernador de esta cludad había establecido sus fuerzas para seguridad do la provincia, como asimismo el de Guayaquil, lo cual vino a demostrar que Montúfar, sabedor de su superioridad numérica sobre Molina, intentaba un ataque para obtener sobre él una primera y decisiva viotoria que pusiese en sus manos la provincia de Cuenca, y con ella el camino del Perú, aunque cabe pensar que por entonces al menos, hubiesen parado aquí sus deseos de conquista. Por otra parte no se compaginan bien la actitud provocativa de Molina respecto a Montúfar con las constantes peticiones de auxilio de éste a Lima, por sentirse en inferioridad respecto a aquél.

Entretanto tenian lugar estos sucesos en el Sur, en la región de Popayán se desarrollaban acontecimientos análogos. Al instalarse la Junta de Santa Fe, el gobernador de Popayán, don Miguel Tacón, no reconoció la autoridad de dicha Junta. Pero casi todas las demás ciudades de la región la acataron como depositaria del Poder, de tal forma, que sólo quedaron por la causa realista Popayán, Pasto, Almaguer y Barbaeoas, tan distantes entre si una de otra que no cabia contar con un pronto mutuo auxilio, para defenderse de los rebeldes. Ante estas dificultades, amenazado por los gobernantes de Bogotá, el Cabildo y el gobernador de Popayán acudieron al Virrey del Perú, de qulen en otro tiempo había dependido la provintia. Asimismo solicitaron auxilio del Presidente electo de Quito; Molina. Conocida por ambos la situación de aquella ciudad le avisaron a su gobernador el pronto envío de auxilios. Pero los oficios fueron interceptados por la Junta de Quito, que comunicó la noticia a la de Santa Fe. Esta se apresuró a llevar a cabo sus proyectos antes de que pudiera venir el auxilio prometido a Popayán: las ciudades del valle del Cauca habian formado también una Junta en Cali, y unidas sus fuerzas, las de Neyva y la Plata, levantaron un ejército numeroso que se acercaba a la capital estrechándola y cerrándole el camino para la entrada de los víveres $y$ auxilios.

La ciudad de Pasto; ante el peligro que corría Po- 
payán, acudió en su ayuda con una compañía de milicias, y la de Barbacoas lo hizo igualmente con un piquete que no pudo llegar a su destino. En situación tan angustiosa, repiten insistemente las peticiones de auxilios al Virrey de Lima y a Molina, pero de ninguna parte llegan los esperados refuerzos. Las fuerzas enemigas, mandadas por el coronel don Antonio $\mathrm{Ba}-$ raya, se encontraban cerca de la capital, y las autoridades españolas, considerando la inferioridad numérica en que se hallaban, procuraron por todos los medios soslayar el encuentro. Pero al fín, llegó el momento en que no tuvieron otro remedio que admitir la batalla, so pena de entregar al enemigo la ciudad y la provincia sin combatir. En las márgenes del rio Palacé tuvo lugar la contienda entre ambas fuerzas el 28 de marzo de 1811. El resultado fué el que desde un primer momento se habia previsto. Los mismos soldados de Popayán, en gran número, se unieron a los revolucionarios y el resto de las fuerzas se vió obligado a retirarse a la ciudad. La situación era insostenible y en el momento en que los enemigos desencadenasen un nuevo ataque acabarian por tomar la capital. Ante lo apurado del momento, el Cabildo decidió, a las cuatro y media de la mañana del día 29, la evacuación, como en efecto se hizo (55). Tacón con sus fuerzas y el Cabildo emigraron hacia la cludad de Pasto, mientras los sublevados de las ciudades del Cauca entraban en Popayán e instalaban en ella su Junta.

Se explica perfectamente el interés, tanto de los quiteños, como de los sublevados en el Virreinato de Nueva Granada de acabar con el foco realista sostenido por Tacón. Su posición era clave para las comunicaciones entre ambos territorios. Las dos ciudades de Popayán y Pasto se hallaban situadas en el valle del Cauca, que se desliza entre las dos ramas de la cordillera andina, poniendo en comunicación la costa del Mar de las Antillas oon la región del interior, y que Juntamente con el del ría Magdalena son los dos

(55) A. G. T.-Quito, 256. Copia de una representación del Ayuntamiento de Popayán, emigrado a Pasto, al Primer Secretario de Estado. Pasto, 16 de mayo de 1811. 
grandes caminos de penetración en el Continente sudamericano. Ambos van a confluir en el Nudo de Pasto, y el camino de entrada en el Ecuador pasa por la ciudad de este nombre. De ahí el interés estratégico de ambas. Mientras Tacón se mantuvo en Popayán, la Junta de Quito se hallaba completamente incomunicada con la de Santa Fe, y el deseo de restablecer las comunicaciones entre ambas explica suficientemente la campaña contra él.

A pesar de la toma de Popayán, con la retirada de Tacón a Pasto, las comunicaciones entre aquellas ciudades quedaban aún cortadas. Lógicamente cabía pensar que, tanto los de Santa Fe como los de Quito, arreciasen sus ataques para lograr su unión, como en efecto ocurrió. Las peticiones de auxilio de Tacón se redoblaron, dirigidas sobre todo a pedir a Molina una rápida marcha sobre Quito que acabase con el peligro que significaba esta ciudad en manos de los sublevados. Por eso su desánimo fué grande cuando tuvo noticias de la detención de Molina en su camino hacia Quito. Semejante contratiempo, dice, "va a acabar de sacrificarme y hacer infructuosos todos los esfuerzos que he tenido que emplear para sostener esta barrera por el largo término de ocho meses, a fin de impedir la reunión de las fuerzas insurgentes de Santa Fe y Quito» (56).

A las angustiosas peticiones de Tacón se excusaba Molina alegando que se hallaba sin la fuerza necesaria para llevar a cabo su proyecto, a pesar de las conocidas ventajas que reportaría, por el abandono en que lo tienen las reiteradas negativas del Virreinato del Perú, adonde a su vez se ha dirigido para que le envien las fuerzas que le son necesarias (57). Abaseal, por su parte, se dedicaba mientras al arreglo de una lancha cañonera para enviarla con fuerzas y armamentos a la costa de Barbacoas y de allí a Pasto, y para que a su vuelta se trajera 50.000 pesos que ha-

(56) A. G. I.-Quito, 256. Copia de carta particular de Tacón al Gobernador de Guayaquil. Pasto, 14 de mayo de 1811.

(57) A. G. I.-Quito, 25.5 Q tario de Estado y del Despacho universal, Cuenca, 14 de julio de 1811. 
bía extraido el Gobernador de Popayán y pensaba enviarlos a Lima. Mientras preparaba el auxilio a Tacón, comunicaba a la Junta de Quito el indulto prometido por el Gobierno de España a todos lns que volviesen al acatamiento de las autoridades legitimas, e intentaba restablecer el tráfico comercial con dicha provincia sobre la base de la mutua retirada de las tropas y con el compromiso por parte de los quiteñas de no atacar tampoco a las fuerzas de Popayán.

Las proposiciones del Virrey no pudieron, sin embargo, llevarse a la práctica, pues los de Quito seguian manteniendo sus tropas en pie de guerra y en el Norte continuaba la lucha reciamente. El 19 de septiembre tuvo lugar un encuentro entre las fuerzas de Tacón y las de los quiteños en el punto de Calabozo. El dia 20, reforzados los realistas, continuó la acción: los soldados de Pasto colocaron en un aprleto a los quiteños, mandados por el Capitán Checa; pero mientras éste se defendia para abrir una brecha en las filas enemigas, la llegada del Ejército quiteño puso en fuga a los realistas. Como consecuencia del eneurentro, los quiteños ocuparon el 21 el pueblo de Taquamquer, y el 22 la ciudad de Pasto. In Teniente Coronel Tacón se vió obligado a retirarse a la costa (58).

Can la derrota de Tacón quedaba expedito el camino entre Quito y Santa Fe, por donde podrian correr los mutuos auxilios de los revolucionarios. Uno de los principales objetivos de la Junta de Quito se habia cubierto. Además, por entonces se recibieron oficlos de la Regencia aprobando la constitución de la Junta. Ambos hechos parece pudieran marcar el momento de apogeo de su poder; pero no fué así. Pues aunque aparentemente reforzaron su posición, en la práctica hay que tomarlos como el principio del fin de la misma.

En efecto, estos mismos hechos alarmaron al $\mathrm{Vi}-$ rrey de Lima, que dándose cuenta del peligro que podia representar la existencia de unos sublevados poderosos en el Norte de su Virreinato, y coincidiendo

(58) A. G. I.-Quito, 256. Copia de parte del Comandante de la expedición de tropas de Quito al sefior don Pedro Montúfar. Campo General de Yaquanquer, 22 de septiembre de 1811. 
con el momento en que las tropas del Alto Perú habian obtenido una notable victoria sobre las argentinas, se dispuso a dedicar más atención a los asuntos de Quito.

Por su parte, el Consejo de Regencia, al aprobar la constitución de la Junta, lo habia hecho con algunas restricciones, eomunicando al Virrey del Perú que dicha aprobación se coordinase con su plan para sofocar la rebelión de América. Con estos antecedentes, el Virrey escribió a la Junta solicitando le fijasen claramente su posición, y mientras esto ocurría organizaba un plan de ataque contra las fuerzas de Quito, que llevarian a cabo las de las provinclas de Guayaquil y Cuenca.

Del mismo modo panía en conocimiento de los restantes Cabildos que la condición fundamental bajo la que habia sido reconocida la Junta era el acatamiento de las autoridades legítimas, punto que en la práetica no habian acatado, ya que el hecho mismo de su constitución había significado el suplantamiento de las autoridades existentes.

Mientras ponfa en guardia a los Cabildos, remitía auxilios a Molina, cuyas peticiones, desmedidas a los ojos del Virrey, no cesaban. Pero es que temía un nuevo ataque de las fuerzas de Quito. Así la expresaba con toda seguridad: «tengo par infalible el anuncio que se me ha hecho de que en Quito se prepara contra Cuenca una fuerte combinada invasión, para la que se inventan proyectos de nueva y grande hostilidad. Este se me hace más creíble en razón de que no puede negarse que se hallan hoy con doble fuerza, pues tienen la que puede ministrarle Popayán, y que tienen dinero, pues han pagado a la tropa los sueldos atrasados... (59). En preyisión de estos posibles ataques había salido para Cuenca el sargento mayor don Antonio del Valle, al que se le habrían de reunir en aquel punto tropas de Guayaquil y las que salieran de Lima para sofocar la primera revolución y que habían sido expulsadas de Quito a raíz de los sucesos del 2 de agosto. Además de dicho auxilio, aun le pro-

(50) A. G. I.-Quito, 285. Oficio de Molina al Consejo de Regencia. Cuenca, 29 de diciembre de 1811. 
metía el Virrey el envío de doscientos hombres con sus fusiles, con los cuales esperaba socorriera a las tropas de Tacón en el Norte (60).

Entretanto tenían lugar estos preparativos por parte del Virrey y Molina, en Quito habian ocurrido también acontecimientos interesantes. La situacion de la Junta, contra todo parecer, se hacía más inestable por momentos. Quito se hallaba prácticamente aislado, pues por el Norte, si bien se había.podido establecer el contacto con las fuerzas de la Junta de Santa Fe, los fugitivos de Popayán y Pasto no habian sido eliminados totalmente y procuraban fomentar el descontento entre los indios de estos parajes, que se levantaron contra los insurgentes. En cuanto al Sur, las dos ciudades más importantes de la región, Guayaquil y Cuenca, se hallaban en poder de los realistas, que estaban dispuestos a defenderlas a todo trance. Y. este aislamiento produjo graves perjuicios a la capital, que redundaron en descrédito de la Junta. Quizás como una medida de asegurarse la revolución, la Junta tomó el partido de declarar la independencia. En efecto, el 11 de diciembre de 1811 tuvo lugar la solemne proclamación de la independencia de Quito y de todo el territorio conquistado (61). Con ello clertamente lograron un respiro, y consiguieron extenderse por la región de la costa hasta el Golfo de Tumaco, con lo que obligaron al Gobernador de Popayán, que se habia retirado a Barbacoas, a evacuar esta región y trasladarse por mar a Guayaquil. Ahora parecía completamente asegurada la comunicación con la Junta de Santa Fe.

Conseguido su objetivo en el Norte, las miras de los quiteños se dirigieron hacia el Sur, con el fin de apoderarse de Cuenea, llave del camino del Perú. Para llevar a cabo su propósito, el 15 de Junio se presentaron las tropas de la Junta en Paradones ante la avanzada de Aymerich, que rompió el fuego, entablándose un combate que duró tres horas, replegándose al cabo de ellas los realistas a la altura de Llasu,

(60) ABASCAL. Memoria. Tomo II. Págs. 142, ss.

(61) A. G. I.-Quito, 258. Copia de acta de la Junta de Quito. Quito, 11 de diciembre de 1811. 
cerca de Cañar, obligados por la caballería enemiga. Durante los dias 16,17 y 18 se mantuvieron los quiteños en los puntos de Puyal, Hato de la Virgen y Silante sin iniciar ataques. En el punto de Caspicorral los aguardaba don Antonio Maria del Valle, que habia llegado a este lugar el mismo dia 15, y a su vez, Aymerich se hizo fuerte en los cerros de Yarugaloma y Sagún. El 19, Valle tuvo noticias de avistarse el enemigo a vanguardia marchando fuera del camino real por una quebrada a la derecha del pico de Caspicorral. Valle, creyendo que iba a ser objeto de un ataque, formó sus tropas, pero en vista de que. no lo atacaban pensó en atacar a su vez a la mañana siguiente. Entonces tuvo noticias de que se dirigían a Azogues y Verdeloma, adonde marchó inmediatamente con sus fuerzas (62). El 20, los quitefinos llegaron al llano de Atar, acampando frente al puesto de Muruvrio. Alli se colocó Aymerich para impedirles la entrada al pueblo de Azogues, y de alli a la capital de Cuenca. El 21 por la mañana desfilaron por la Cuchilla del Llavasi, frente a Verdeloma y a la posición que ocupaba Ay merich. Durante los días 23, 23 y 24 hubc algunas tentativas por parte de los quiteños de abrir brecha entre las filas realistas, que fracasaron. El 25, Valle, cumpliendo órdenes de Aymerich, salió a las cuatro de la mañana a atacar a los enemigos. Atravesó el río de Cuytón, subió la loma de Pesantes y se encaminó a la Llanura de Atar. Pero detenido por el mal estado del camino llegó a este último punto ya de día y fué descubierto por sus contrarios. Desde aquí sin embargo, dominaba el campo enemigo, por lo que se destacó la Caballeria quiteña para tomar el camino de Atar, encontrándose con la vanguardia de Valle, que le obligó a retroceder. A consecuencia de esto se pudo ocupar totalmente la altura y situar en ella la artillería.

En esta situación el fuego, el enemigo se dirigió dos veces al ataque, sin éxito en ninguna de ellas. Pero con la muerte de dos soldados de una bala de cạón, empezaron a desmoralizarse las tropas de Valle,

(62) A. G, I, Quito, 257. Copia de parte de Del Valle a Molina. Verdeloma, 21 de junio de 1812. 
sobre todo sus oficiales, de tal forma que no hubo medio de organizar la lucha. En vista de ello y de que se habian consumido todas las municiones de la Artilleria, decidió emprender la retirada antes de que el resultado fuese desastroso. El repliegue comenzó con orden en dirección a Verdeloma, pero a poco de comenzar tuvo noticias de que la Caballeria enemiga venia a cortarles el camino, con lo que se aumentó de nuevo el desorden entre sus tropas, y aunque su Caballería y parte de su Infantería estaba ya desplegada, logró contenerlos y hacerles retirar.

La tarde siguiente al encuentro se observó que los quiteños variaban el campamento al sitio que ocupara Valle con sus tropas durante la batalla, y efectuaban movimientos. Entre las 10 y las 11 de la noche comenzó de nuevo el fuego en las avanzadas, que cesó pronto, y de madrugada tuvo noticias de la retirada del enemigo, que dejó en el campo abundantes municiones y artilleria (63).

Con la retirada de los quiteños se aseguraba el mantenimiento de Cuenca por Molina, y quizás ahora hubiese sido un momento oportuno para emprender una ofensiva que los alejase definitivamente de la provincia. Pero el fruto de estas acciones no iba a recogerlo el hasta entonces Presidente de Quito, que Jamás llegó a ocupar su sede, sino su sucesor en el cargo, el mariscal de campo don Toribio Montes, que, procedente de España, se hallaba en Lima disponiéndose a marchar hacia Guayaquil.

A pesar de los aparentes triunfos de las fuerzas de Quito, la situación en el interior de la región dominada por la Junta, y más concretamente en la capital, era en extremo delicada. Quito no se bastaba a sí misma, y la pérdida del importante puerto de Guayaquil, Junto con la de Cuenca, se hacía sentir notablemente en la vida del país. Por otra parte, no

\footnotetext{
(E) A. G. I,-Quito, 257. Copias de partes de Del Valle a A finerich, Verdeloma, 25 de Junio de 1812; de Aymerich al Presidente, Cuartel General de Azogues, 25 de junio de 1812. (En él transcribe un parte de Del Valle, de 25 junio, fechado también en Verdeloma), Otro parte de Arteaga a Aymerich, campo de Muruvrio, 25 de junio, y un parte de Aymerich a Molind, Cuartel General de Azogues, 30 de junio de 1812:
} 
cabe duda de que la posición de Quito, alejada del centro de la lucha de Nueva Granada, no daba lugar a forjarse la esperanza de un pronto auxilio. Todas estas circunstancias y el anuncio de una próxima ofensiva por el Sur de las fuerzas realistas, condujeron a los luctuosos sucesos que se desarrollaron en la capital y que tuvieron como resultado una serie de asesinatos, entre ellos el del hasta poco tiempo antes Presidente de la Junta, Conde de Ruiz Castilla, en junio. de 1812. Pero las revueltas sólo consiguieron aminorar el poder de la Junta cuando los realistas se apoderaban en el Norte de la ciudad de Pasto, e interceptaban las comunicaciones con Santa Fe, ayudados en gran parte por las poblaciones indígenas de aquella región.

Mientras esto ocurría en el Norte, en el Sur Montes se preparaba para marchar con su expedición. Reunió 2.000 hombres, con los que se dirigió a Guayaquil, punto elegido para comenzar sus operaciones. Alli se le reunió el ejército existente en esta provincia, y con todas sus fuerzas se encaminó hacia Quito. Las tropas de la Junta, después de su fracasado intento de apoderarse de Cuenca, se habian retirado hasta San Miguel, punto cercano a la capital, en donde se habían fortificado, dispuestos a detener el paso de los realistas. Fueron desalojados, sin embargo, de sus posiciones y se retiraron al pueblo de Mocha, como último punto de defensa de la capital. También de aquí fueron rechazados y obligados a refugtarse dentro de Quito. Aun intentaron los quiteños defender desesperadamente su ciudad, pero sin éxito; Montúfar, al frente de sus tropas, hubo de retirarse hacia Ibarra, y el día 4 de noviembre Montes entraba en Quito, haciéndose cargo de la Presidencia.

A su entrada en la ciudad la encontró casi completamente evacuada por sus habitantes. Hasta los clérigos seculares y los religiosos habían marchado de allí, y antes de que pudieran rehacerse sus enemigos envió contra ellos una división al mando del Coronel don Juan Samano, que atacó la ciudad de Ibarra y los obligó a retirarse con la pérdida de 300 hombres (64). Estas mismas tropas auxiliaron a las que

(64) A. G. I.-Quito, 257. Duplicado de oficio de Montes a la Regencia. Quito, 7 de abril de 1813. 
se defendian en Pasto contra los ataques de las fuerzas de la Junta de Popayán.

De este mado quedaba totalmente vencida la revolución en el territorio de Quito. Afianzada en él la autoridad realista y aislada de la lucha que se mantenía en el Norte del Virreinato de Nueva Granada, se mantiene en quietud hasta los momentos finales de la contienda, en que se desarrollan en su suelo las ultimas campañas. El hecho de conquistar su independencia merced a las tropas colomblanas hace que durante la primera etapa de este periodo su vida politica continue unida a la de Colombia, de la que geográficamente se hallaba desvinculada de un modo total; manteniéndose la unión hasta 1830.

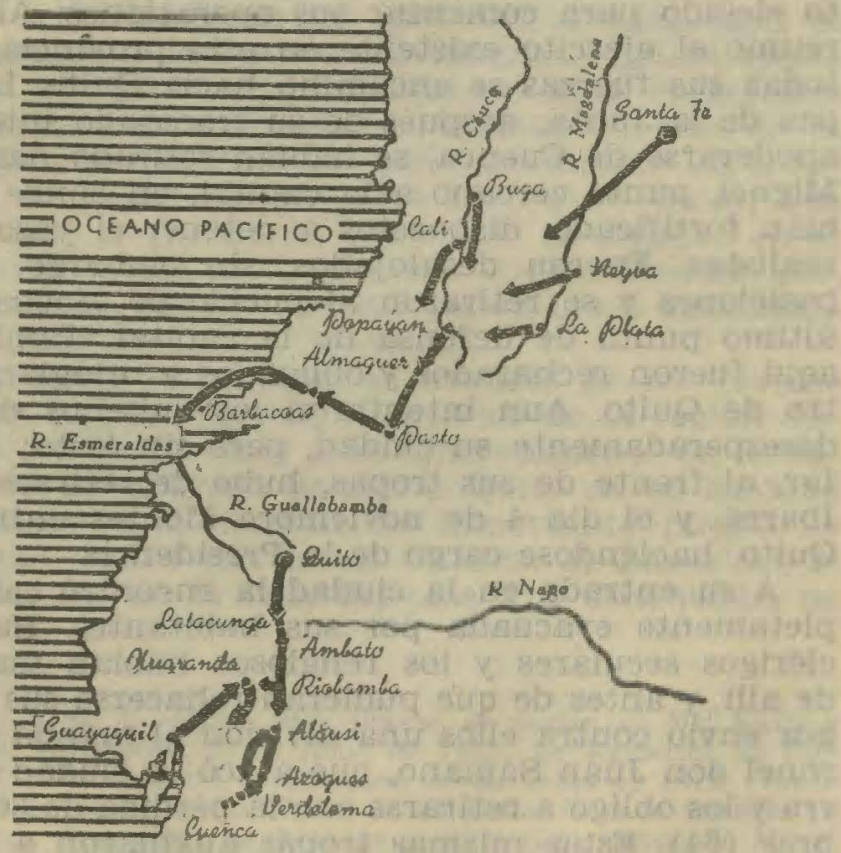

MOLINA - TACON. 

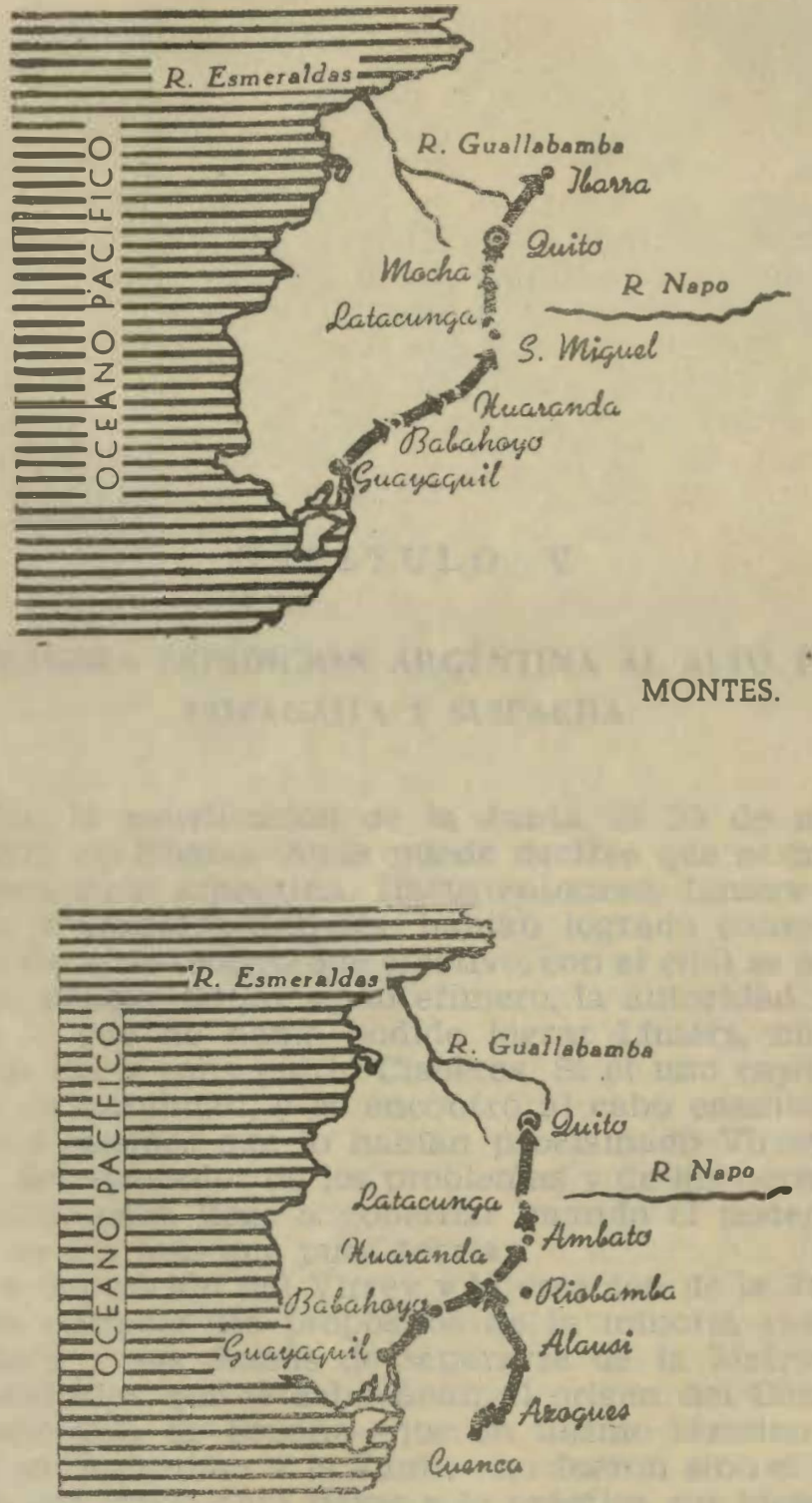

ARREDONDO. 



\section{LA PRIMERA EXPEDICIÓN ARGENTINA AL ALTO PERÚ: COTAGAITA $Y$ SUIPACHA}

Con la constitución de la Junta de 25 de mayo de 1810 en Buenos Aires puede decirse que se inicia la revolución argentina. Hasta entonces, Liniers primero, y Cisneros después, habian logrado conservar un poder más teórico que efectivo, con el cual se mantenia, aunque de un modo efimero, la autoridad real. Pero lo que no habia podido lograr Liniers, mucho menos iba a conseguirlo Cisneros. Si el uno cayó por falta de habilidad, y se encontró al cabo enemistado con los mismos que lo habian proclamado Virrey, el otro, desconocedor de los problemas y de las personas de aquel país, llegó a gobernar cuando el poder del Rey no era más que pura teoria.

La deposición del Virrey y la creación de la Junta dejan entrever los propósitos de la minoría revolucionaria y sus deseos de separarse de la Metrópoli. - Los defectos que le achacaban al origen del Consejo de Regencia de España-que en último término podian ser aplicables a la Junta-no fueron sino el pretexto que sirvió para llevar a la práctica sus ideas.

Apenas afianzada la revolución en la capital, se 
organizó un Ejército con un núcleo inicial de quinientos hombres con objeto de dirigirse a las provincias interiores y al Alto Perú. Su finalidad era dar a conocer a estos pueblos la decisión de Buenos Aires y que ellos mismos nombrasen los diputados para la Junta general de las provincias, que próximamente se habria de reunir en la capital del Virreinato. Se pensaba engrosar dicho Ejército con las levas que se hiciesen en el camino y con el alistamiento voluntario de los partidarios de la libertad del país.

El Ejército porteño, que más tarde recibió el nombre de «Ejército auxiliador del Perú», no suponía en sí ninguna grave amenaza para la existencia del Virreinato del Perú: era un reducido contingente de hombres sin una gran instrucción militar y sin noción muy exacta de la disciplina. Más que por su fuerza, el grave pẻligro que entrañaba era el ser un ejército revolucionario, con todas las características propias de tales tropas. Era, por tanto, un vehículo propagador de ideas subverstras, más bien que una poderosa máquina guerrera. Se corría, sin embargo, el peligro de que al llegar a la frontera del Perú, sublevando a su tránsito los pueblos y ciudades, presentase un contingente de hombres to suficiente numeroso para que kds tropas virreinales fuesen incapaces de detenerlo. Además, propagadas sus ideas por el Aito Perú, se facilitaba su infiltración en el Virreinato, cuyo mantenimiento en tales condiciones sería difíeil, conocida la escasez de medios que para ello dispomia el Wirrey.

Dejar avanzar las trapas hasta la frontera del Virreinato era, pues, un peligro grave: Aun cuando se Jastificaba la salida de las tropas de Buenos Aires con la liberación de las proyincias interiores y el Alto Perú, en el ánimo de todos tstaba que, logrado su otjetivo, no estaría lejana la fecha en que tuviese lugar la invasión del Virreinato.

En estas circunstancias, el Alto Perú podía convertirse en el valladar del Peru, ya que era un lugar apropiado para detener al Ejéresto invasor por su aeci- . dentado relieve que, bien aprovechado, permitia establecer la defensa estratégics de aquél. Más atrás he expuesto en lineas generajes łos oaracteres de la región y explicado su importancia estratégica, poli- 
tica y económica, que convirtieron a este pais en la presa codiciada de ambos contendientes. Pues bien, dicho territorio era el que Abascal pensaba utlizar para sus operaciones y como muralla de defensa del Virreinato, que contuviese los progresos de la triunfante revolución argentina.

Todos los sucesos de Buenos Aires eran seguidos con extraordinarioo interés, mezclado con alguna ansiedad desde el Virreinato del Perú. El trastorno de la ciudad del Plata era mucho más profundo que las anteriores revoluciones de Quito, Chuquisaca o La Paz, y de ello se daba cuenta el Virrey, que deseaba prevenirse ante cualquier contingencia.

Cuando en Lima se tuvieron noticias de la creación de la Junta del 25 de mayo y de sus intenciones independizantes, pensó Abascal que, con la deposición de Cisneros, no quedaba en América del Sur ningún otro jefe de prestigio capaz de contrarrestar el efecto de la revolución. Ante este hecho, y previendo el peligro que significaba para las colonias americanas la expansión de las ideas revolucionarias por el continente, se decidió a tomar sobre sí la ingente tarea de reducir todos los núcleos independizantes y hacer del Perú un firme baluarte del realismo que anulase la labor revolucionaria.

Las primeras providencias ante el peligro de que se acercase el Ejército revolucionario habian de ir encaminadas a poner en estado de defensa la linea de la frontera. Por el establecimiento de esta linea defensiva en la frontera sur del Alto Perú abogaban al parecer, dos razones: la estratégica ya expuesta anteriormente, y otra de tipo politico. En efecto, el 17 de Junio de 1810, el Intendente de Potosi escribia a Abascal pidiéndole que tomase bajo su mando todas las provincias altoperuanas, ya que, como le decía, «esta general subordinación a esa capital es la que en mi concepto puede sostener fiel y constante a todo ese Continente...» (1). Era lóglco que si el Alto Perú se colocaba bajo sus órdenes, Abascal no podia aban-

(1) A. G. I.-Lima, 739. Copia de Oficio del Intendente de Potosí al Virrey del Perú. Potosí, 17 de janio de 1810. 
donarlo sin lucha a la ocupación enemiga. Hubiera sido defraudar a los altoperuanos, e incluso contarlos entre sus enemigos.

Pero frente a este modo de pensar se oponía la realidad del Perú. Se ha visto el estado en que se encontraba el Ejército virreinal, incapaz, no ya de mantener una guerra en territorio alejado del Perú, sino de defender siquiera el propio Virreinato de cualquier ataque. El Virrey Amat había intentado militarizar el país en ocasión de la guerra contra la Gran Bretaña, pero su resultado fué nulo. Ahora el Virrey Abascal pretendía también dar una organización al Ejército virreinal y poner eI territorio en estado de defensa, pero los resultados no habían sido tampoco muy notables hasta entonces: la indisciplina cundia entre los soldados, poco numerosos, mal equipados y peor instruidos.

En semejante estado, no cabe duda de que la organización improvisada de un ejército destinado a cubrir la frontera del Alto Perú era casi irrealizable, y además, parecía bastante verosímil que el ejército que se creara, alejado de sus mal equipadas bases de aprovisionamiento, no podría mantenerse por mucho tiempro frente al enemigo, que si no poseía una sólida moral guerrera, contaba al menos con el entusiasmo inherente a los primeros momentos del triunfo de una revoluctón.

Por otra parte, las noticias que se tenian en el Perú de los acontecimientos de Buenos Aires eran un tanto confusas. Aunque no eran difíciles de imaginar, no se conocian exactamente las consecuencias de los sucesos de aquella ciudad, y quizás pareciera un poco aventurado tomar ciertas medidas que, a más de los gastos, suponian un rompimiento total con los sublevados, echando por tierra las esperanzas de un posible acuerdo pacífico, como hubiese sido el deseo del Virrey.

Por estas razones, la solución que dió Abascal a la situación fué semejante a la que diera con motivo de la ocupación de Buenos Aires por los ingleses pocos años antes, al recibir las peticiones de auxilio de Liniers. Dió orden al Presidente del Cuzco para que enviase al Intendente de Potosí 300 fusiles y 100.000 cartuchos, y ordenó la preparación de la Artillería 
para enviarla también en caso necesario (2). Con lo cual eonseguia estar preparado para la defensa del Alto Perú sin causar alarma en Buenos Aires.

Pero ocurrió que entretanto llegó a Lima la proposición de don Vicente Nieto ofreciendo al Virrey el mando de la Audiencia de Charcas interinamente, mientras durasen las circunstancias especiales que le obligaban a dirigir semejante petición. Se le planteaba a Abascal un problema difícil de resolver. Ya hemos visto más atrás que el Virrey del Perú se dió cuenta de la responsabilidad de su misión, desaparecida la cabeza del Virreinato del Rio de la Plata. Quedaba de hecho como único jefe de toda América del Sur, con la responsabilidad inherente, a esta posición. En conciencia, pues, debía proveer a todo lo que fuese necesario para la conservación del territorio. Ahora bien, 10 delicado de la situación obligaba a concentrar todo el poder en sus manos, según opinaba el Virrey, lo cual, sin embargo, podía dar lugar a que se desvirtuasen sus intenciones por los enemigos, que conocían su carácter absorbente, e incluso que los amigos se mostrasen un tanto reservados ante su poder absolutista.

Sin embargo, Abascal era un hombre para quien los deberes constituian un imperativo de conciencia, y no dưdó en lo que debía hacer. Después de reflexionar sobre la proposición de Nieto, a la que vimos se había anticipado la de Sanz, Intendente de Potosí, y a la que se habian unido las demás provincias del Alto Rerú, decidió aceptar el mando de dicho territoitio, cuyos recursos y valor estratégico conocía (3). No lle vó a cabo esta medida sin consultar su parecer con el de una Junta reunida al efecto. Comenta Mendiburu la reunión de esta Junta y de todas las que se celebraron durante el goberno de Abascal, en el sentido de que eran meros pretextos con los que el Virrey intentaba disfrazar su absolutismo (4). Es cierto,

(2) A. G. I.-Lima, 649. Copia de carta reservada de Abascal Gobernador Intendente de Potosí. Lima, 6 de julio de 1810.

(3) A. G. I.-Buenos Aires, 156. Bando del Virrey del Perú, por el que toma el mando de las provincias de la Audiencia de Oharcas. Lima, 13: de junio de 1810.

(4) MENDIBURU. op. cit. Tomo I. Pág. 87. 
indudablemente, el carácter absorbente de Abascal a que me he referido antes. Pero no hay que olvidar tampoco que en las Juntas extraordinarias, como en el Acuerdo, la decisión correspondía siempre al Virrey. Si consideramos ambas circunstancias y los momentos críticos en que se desarrolló su labor, no nos debe extrañar que el Virrey procurase ejercer influencia sobre la Junta o el Acuerdo en su deseo de dar una mayor eficiencia a la autoridad, que en esos momentos difíciles debía concretarse aún más en sus manos. Por otra parte, las medidas dimanadas de dichas reuniones demuestran-como más adelante se verá-que la orientación dada por el Virrey a los asuntos de gobierno no era muy errónea, y que si no logró llenar todos sus objetivos, la culpa no se debió a él solamente.

Resuelta pues, y publicada la unión del Alto Perú al Virreinato, comenzó Abascal inmediatamente a organizar la defensa de los territorios confiados a su mando.

El Presidente Nieto, a pesar de su edad, se ofreció desde un principio al Virrey para luchar contra los que él denominaba «incircuncisos de que consta la Junta Provisional» (5), aunque a la par le hacía saber sus sospechas respecto a las tropas de Buenos Aires que había traído consigo y que guarnecían las provincias, por lo que hizo traer fuerzas del interior desde Santa Cruz de la Sierra para mezclarla con aquélla y evitar toda posibilidad de sublevación.

Además del Presidente Nieto, el ex Virrey Liniers, que se encontraba en Córdoba, escribió a Abascal poniéndose a sus órdenes, recordando los auxilios que en otra ocasión recibiera de él, y le comunicaba su marcha a Potosí, en donde esperaria sus decisiones (6). Pero poco después, siguiendo el plan ideado por el Virrey, recibió aviso de permanecer en las proximidades de Córdoba y de suspender el viaje al Alto Perú, preparándose para rechazar cualquier aproxi-

(5) Arch. Abascal. Carta de Nieto a Abascal. La Plata, 9 de julio de 1810 . fecha.

(6) Arch. Abascal. Carta de Liniers a Abascal, sin data ni 
mación enemiga con el reducido armamento de cuatro cañones traídos de la frontera y ocho que se hallaban arrumbados, y que una vez reparados podían constituir un pequeño tren volante de artilleria, que, unido a 300 fusiles y al apoyo que le prestaban los rios y los bosques de la región, podian, según Liniers, detener la marcha de la columna insurgente, al menos mientras se recibieran refuerzos (7).

Poco más tarde, daba cuenta Liniers al Intendente de Potosí de su estado de fuerza y sus propósitos. En carta desde Córdoba, el 8 de julio de 1810, le decía que en ese momento tenia una fuerza de \&setecientos hombres armados, trescientos con fusiles, otro tanto de lanzas y ciento de artilleria, y aunque tendré hasta trece cañones, siendo ocho de hierro, sin embargo, de ser muy buenos, no pienso operar más que con cinco de bronce», con cuya fuerza tenia pensado un plan de ataque contra los de Buenos Aires, aunque desconfiaba que llegasen a salir siquiera de aquella ciudad. Consistía en obstaculizar al enemigo con guerrillas y retirarse antes de que se aproximaran sus fuerzas, hasta llegar a Jujuy, en donde esperaba ya haber recibido refuerzos que le permitieran recuperar la ofensiva (8).

El 25 de agosto, ante las noticias recibidas de Buenos Aires, convocó el Virrey una Junta de Guerra a la que asistieron los principales jefes militares, con objeto de resolver la situación planteada ante la salida de las tropas expedicionarias de los sublevados. En ella se decidió socorrer, aun a costa de un gran

(7) Arch. Abascal. Carta de Linierg a Abascal. Alta Grecia, 17 de Junio de 1810.

(8) Aveh, Abascal. Carta de Liniers a don Francisco de Paula Sanz. Córdoba, 8 de julio de 1810. En ella, refiriéndose a su plan ofensivo, le decía : a...si se verifica la salida de la expedición de Buenos Aires (que no lo creo), pienso salir en su dirección armando partidas de guerrillas y gente de lazos y bolas, cargadas de granadas de nueva invención mía, que se disparan como balas perdidas, y diferentes fuegos artificiales con el objeto de quemar, si pueden, las carretas, dispersar las boyadas y caballadas, etc. Al momento que se aproxime pienso ponerme en retirada siguiendo siempre la dirección del camino de Potosí hasta Jujuy, esperando que antes ya se me habrán incorporado las fuerzas que puedan Vdes. remitirme, para poder ponerme de nuevo sobre la ofensivas. 
esfuerzo, al Presidente de Charcas con 2.000 hombres, incluídos los 500 que debian haber marchado al Desaguadero, según orden dada al Presidente del Cuzco, 300 fusiles, 200 carabinas, 600 tiros de cañón y 150 resmas de papel sellado de bienios transcurridos para que en el Cuzco se hicieran cartuchos de fusil. Dichas tropas debían situarse en las provincias de Chareas - Potosí, mientras las del distrito de aquella Presidencia se dirigirían a Jujuy o Salta para socorrer a Córdoba. Para mandar las fuerzas a las órdenes de Nieto se aceptó el nombramiento que el Virrey tenia hecho en Ramírez. A la par se hace ver el deseo de Abascal de lograr una acción conjunta con las fuerzas de Mantevideo, para lo cual ordenó al Presidente de Charcas entablase correspondencia con dicha plaza, a fin de bloquear a Buenos Aires por el rio y acercar tropas a la Colonia del Sacramento. Con la concentración de fuerzas en este territorio creerian los de aquella ciudad que se intentaba un ataque desde la Banda Oriental, por lo que se pensaba distraerlos de su plan de dirigirse hacia las provincias interiores.

Se determinó también en dicha Junta conceder plenos poderes a Nieto, dado el gran perfuicio que para la marcha de las operaciones supondría el tener que estar en contacto y dependencia directa del Virrey del Perú (9).

Esta Junta de 25 de agosto es de gran interés, porque ya en ella se lleva a la práctica el plan de campaña ideado por el Virrey y aprobado por los concurrentes. Se dieron normas para la defensa de las provincias de Córdoba y Salta, bajo el mando de Nieto, aunque entregando las jefaturas de las tropas al Coronel don Juan Ramírez, más Joven que aquél y cuya aptitud para el desempeño de estas funciones conocía el Virrey (10). Ramírez habia de establecer un

(9) A. G. I.-Lima, 649. Copia de Acta de la Junta de Guerra celebrada en Lima, el 25 de agosto de 1810. A dicha Junta asistieron, además del Virrey don Toribio Montes, don Joaquín Molina, don Manuel Villalba, el conde del Valle de Oselle, don Joaquín de la Pezuela y don Gabino Gainza.

(10) El coronel don Juan Ramírez era entonces Intendente de La Paz. Ingreś en el Ejército como cadete el 14 de julio de 1773, llegando a capitán el 15 de diciembre de 1794. Sirví en el 
Ejército de observación en dicha provincia para librar a Liniers y evitar el progreso de los sublevados entretanto se llegaba a una inteligencia con Montevideo para producir un ataque contra la capital, a la vez que el Ejército situado en la provincla de Córdoba iniciaba la ofensiva. Para lograr una ayuda eficaz en la defensa de la provincia, Nieto debía ponerse de acuerdo con Liniers, y combinar entre ambos el plan de operaciones a seguir.

El plan del Virrey, a que me he referido antes, consistía, como él mismo expone en su Memoria, en que «en ninguna manera se abandonaran las provincias de Córdoba y Salta, y que reuniendo en este punto sus propias fuerzas y las que pudiesen Juntarse a la mayor brevedad de la Presidencia de Chuquisaca, Cochabamba y Potosí, y de los Gobiernos del Paraguay y Misiones, todas ellas compondrían un número muy suficiente para rechazar los 500 hombres que la Junta habia decretado internar en ellas» (11). Sin embargo, Abascal, lo mismo que Liniers, no creia en un principio que la Junta de Buenos Aires se arriesgase a enviar una expedición hacia el interior deJando desguarnecida la capital y expuesta a una reacción del elemento realista, todavía poderoso,.o a

Regimiento de Infantería de Extremadura e intervino en el bloqueo de Gibraltar y en el Ejéreito de operaciones de América de 1780 a 1783, en que pasó a Lima, donde estuvo de guarnición un año, y destinado al interior hasta 1790, en que pasó a España. Estuvo en el Ejército del Rosellón, desde el 21 de abril de 1793, interviniendo en muchas acciones durante los tres años de guerra. Hecha la paz, fué con ua Regimiento de guarnieión a la Corte, y en 1797 fué destinado al mando político y militar de la provincia de Huarochiri, siendo apresado en el camino y llevado a Inglaterra. Canjeado, se dírígió a América, en dunde. desde Montevideo, en una marcha por tierra de más de 1.000 leguas, llegó a su destino, lo que le sirvió para conocer a su paso el territorio sobre el cual más tarde habia de operar con sus ejércitos. En 1806 y 1807, con motivo de la invasión de Buenos Aires, recibió el mando de los Cuerpos de milicias acantonados en el Callao para prevenir la invasión, cuyo cargo desempeñó a satisfacción del Virrey. Posteriormente intervino, junto con Goyeneche, en la pacificación de La Paz, como hemos tenido ocasión de ver.

A. G. I.-Lima, 738. Hojas de servicios de don Juan Ramírez hasta 1797, y diversas informaciones de méritos. Vid. MENDIBURU, op. oit. Tomo IX. Pág. 294.

(11) ABASCAL. Menoria. Tomo II. Pág. 296. 
un ataque dirigido desde Montevideo, con cuyo Capitán General había intentado ponerse en contacto el Virrey al objeto de iniciar una acción conjunta.

Asi pensaba cuando se dirigía a Liniers, diciéndole que los asuntos de Buenos Aires aconviene sean tratados con más politica que fuerza para noenvolvernos en una guerra civil, que es la mayor desgracia que puede suceder» (12). Incluso en el caso de que los sublevados, olvidando los peligros a que se exponian, y en un golpe de audacia, intentasen atacarle, debia probar todos los medios pacificos antes de recurrir a las armas, e intimarlos a regresar a sus hogares o a pasarse al partido legítimo. Mas, si insistían en su error, entonces se emplearía a fondo con ellos y procuraria, con un gran escarmiento, evitar sucesivos derramamientos de sangre.

Sin embargo, poco después hubo de convencerse el Virrey de su equivocación en las apreciaciones sobre los designios de la Junta. A Lima llegaron noticias de Buenos Aires de que la expedición auxiliadora del Alto Perú se había puesto en camino. Claro está que a los ojos de los peruanos, este Ejército, cuyo carácter he señalado más atrás, y cuyos jefes, en opinión de Abascal eran «los hombres más despreciables e ineptos para el asunto que le han encargado», no había de ser considerado muy idóneo para la misión que se le encomendaba. Las noticias que en Lima se tenían de la expedictón no contribuían mucho, en verdad, a revalorizar la calidad de sus jefes: en una carta dirigida por Abascal a Liniers el 10 de septiembre de 1810, le decia que, según las noticias de Buenos Aires, «a las cinco leguas (de esta ciudad) tuvieron los soldados una camorra entre si, de que resultaron algunos heridos y bastantes desertores; pero que continuando su marcha tardaron 14 días en llegar a Luján» (13). Todo lo cual le hacia creer en una fácil victoria de Liniers si se presentaba la lucha, defendiendo el terreno palmo a palmo, ya que aprovechados los ríos y los

(12) Arch. Abascal. Carta de Abascal a Liniers. Lima, 29 de agosto de 1810 .

(13) Arch. Abascal. Carta de Abascal a Liniers. Lima, 10 de septiembre de 1810 . 
bosques podía colocar a su pequeña tropa en emboscadas que causasen una lenta, pero segura destrucción en el Ejército revolucionario, hasta que le llegasen los $\mathbf{5 0 0}$ hombres que habia mandado preparar en el Alto Perú.

Pero los consejos de Abascal llegaron tarde. Nieto no se había atrevido a avanzar hasta Córdoba: alegaba falta de hombres y material. Liniers con sus fuerzas quedó sin apoyo, dando lugar a que las tropas de Buenos Aires avanzasen más rápidamente de lo que pensara el mismo Virrey. El Presidente de Charcas se había limitado a aconsejar que Liniers, con sus escasos soldados, se retirase hasta Jujuy, en donde encontraría a la expedición que había partido en aquella dirección al mando de don José de Córdoba.

Mientras se preparaban estos planes, en Córdoba tomaban cada vez más cuerpo los deseos de unirse a Buenos Aires. El pueblo de dicha ciudad permanecía adicto al Rey únicamente por la presencia de sus tropas, pues en realidad sólo esperaba la aproximación de los de Buenos Aires para declararse abiertamente por la Junta revolucionaria. El cambio operado era debido principalmente a la actividad desplegada en favor de los sublevados por el deán Funes, de aquella Catedral, que capitaneaba el partido revolucionario.

Consecuencia del cambio de actitud de la ciudad fué la retirada de las fuerzas, constituidas jrincipalmente por los Milicias Provinciales mandadas por Liniers, el brigadier Gutiérrez de la Concha, intendente de aquella provincia, y el coronel don Santiago Allende. Emprendieron la marcha hacia el Norte, en donde esperaban encontrarse con el apoyo prometido. Al hacer ésto obraban con arreglo al plan de Nieto de retirarse hasta Jufuy, en donde encontraría a la columna de don José de Córdoba, que había mandado adelantar hasta el límite de su Presidencia, con ánimo de que en caso preciso se dirigiese en auxilio de aquella ciudad. Pero es lo cierto que por indesición o por reparo a su corto numero de hombres y escasez de armamento dicha columna no llegó a marchar fuera del limite de la Presidencia, o a lo más debió llegar a Jujuy, pues en carta de 25 de agosto, Nieto decía a Abascal que era necesario que llegase Ramírez, «estando destinado para hacerse cargo de las fuerzas, ya 
destinado a mandar la expedición y pronto a marchar el mayor general don José de Córdoba (14), a lo que añadía que su situación empeoraba por momentos, por habérsele retrasado los auxilios del Cuøco y por la propaganda revolucionaria.

Pero entretanto, Liniers, sin el apoyo de las tropas del Alto Perú, con solo una reducida fuerza de 400 hombres de Milicia, completamente contaminada por la sublevación, obligado a retirarse, y con Salta a su espalda declarada por la Junta, se encontró alslado. No le cabía otro recurso que intentar una retirada hacia el Alto Perú. Pero al llegar a un lugar denominado Chañar, la tropa le abandonó. Ante esta adversidad, fácil de presumir, se vió obligado a emprender la fuga, ya que el corto numero de soldados que le permaneció fiel no era en absoluto suficiente para oponer ninguna resistencia. Se encontraban completamente desmoralizados ante la deserción de los demás y la voladura del tren de municiones de la columna, accidente fortuito, pero que sin duda contribuyó no poco a sembrar el desorden.

En semejantes circunstancias era lógico prever el desastre: los tres jefes de la resistencia se encontraban solos y aislados en fuga hacia el Aito Perú; Salta, sublevada, les cortaba el camino, y las primeras fuerzas de la vanguardia del Ejército de Buenos Aires entraban en Córdoba, que se unió alborozadamente a los conquistadores. La situación de las provincias interiores argentimas era verdaderamente critica. En consecuencia, la captura de los Jefes de la resistencia de Córdoba no era más que cuestión de días, como efectivamente ocurrió. Fueron apresados por un destacamento enviado desde esta ciudad, y pocos dias después. siguiendo órdenes de la Junta de Buenos Aires, ejecutadas por Castellí, enviado para ello, fueron pasadas por las armas. Los fusilamientos de tan significados realistas, cuyo Juicio no voy a hacer aqui, se explican únicamente como una medida ejemplar tomada por la Junta con objeto de impedir nuevas

(14) Arch. Abascal. Carta de Nieto a Abascal La Plata, 25 de agosto de 1810. 
resistencias y de que cundiese el pánico entre los jefes de la misma en otras provincias.

Tratando de éncontrar las responsabilidadés de la situación planteada, caen todas ellas, a primera vista, sobre el Presidente Nieto, aunque no hay por qué negar que hubo circunstancias ajenas a él y que concurrieron al fracaso de sus planes.

He analizado anteriormente el plan de Abascal, que consistía fundamentalmente en no desamparar las provincias argentinas, cuya ayuda debia hacerse con las. fuerzas que se sacasen de las ciudades del Alto Perú. Las tropas asi obtenidas se repondrian inmediatamente, con el fin de no dejar desguarnecida la retaguardia. Se constituiria además una reserva de 1.500 hombres, que podrian utilizarse en caso necesario, pad ra lo eual Nieto debería concertarse con el initendente de Potosi, el más próximo a la frontera, y con los dęmás intendentes del Arto Perú, al objeto de preparar el Ejército que, unido a los refuerzos que recibiera del Cuzco, había de ser la defensa del territorio.

Pero Nieto varió fundamentalmente el plan del Virrey, en cuanto a la dífposición y coloeación de las tropas se refiere. Llevado quizás un poco de su orgullo militar, no se avino a acordar un plan de campaña con el intendente Sanz, y prefirio llevar a cabo la empresa por si mismo. Por otra parte, como no le habian llegado los auxilios que esperaba del Alto Perú, según decía en la ya citada carta de 25 de agosto, y con noticias cada vez más alarmantes de la conspiración de Córdoba, no se atrevió a alejar mucho la columna mandada por don José de Córdoba, llegando hasta Jujuy, punto verdaderamente vital para la defensa del Alto Perú y cuya posesión impedía todo intento de penetrar en dichas provincias.

Por tanto, el error príncipal de Nieto consistió en dos cosas? en no allegar auxilios a las tropas de Liniers y en no dejar tampoco guarniciones en las plazas del Alto Perú, hecho este último del que, según Abascal, dependió el resultado de la expedición (15).

Ahora bien, hay que tener en cuenta, en descargo

(15) ABA8cal. Memoria. Tamo II. Pág. 315. 
de Nieto, que sus vacilaciones fueron debidas, además de a la ya citada falta de auxilios del Alto Perú, a la poca confianza que tenía en sus tropas, como se manifiesta en toda su correspondencia con el Virrey. Era aventurado lanzarse en ayuda de la ciudad de Córdoba sin tener las espaldas guardadas y con una tropa que no merecía la confianza de sus jefes. Es lo cierto también que se precipitaron los acontecimientos al ocurrir la defección de la ciudad y el abandono de la tropa de Liniers, con lo cual no contaba el Virrey. De todo esto no tuvo noticia hasta mucho más tarde, como to prueba el hecho de que toda vía el 10 de septiembre se dirigía Abascal a Iinters, en la carta más atrás citada, con expresiones optimistas respecto a su encuentro con los porteños, cuando ya hacía quince días que aquél, con Concha y Allende, habían sido fusilados en la Cabeza del Tigro, de lo que no se tuvo noticia en Lima hasta primeros de noviembre.

Dueños los sublevados de Córdoba, y eliminadas todas las fuerzas del trayecto, se les presentaba libre el camino del Alto Perú. Al mismo tiempo que tenía lugar el avance de los argentinos por el Sur, y alentados por esta misma circunstancia, cundió la sublevación en Cochabamba, con peligro de extenderse a todo el Alto Perú. El 2 de agosto se había sublevado Quito por segunda vez, y simultáneamente el estado de Chile parecía anunciar una próxima unión de dicho territorio a los de Buenos Aires. La situación con la que se enfrentó Abascal no podía ser más crítica. Pero el Virrey, «cuyo ánimo crecía siempre en los conflictas», como dice Mendiburu (16), no perdió la serenidad ante la trascendencia del que ahora se le planteaba.

Comprendió Abascal que si no acudía a una medida rápida corría peligro todo el Alto Perú, pues la insurreeción de Cochabamba amenazaba las comunicaciones de La Paz con Potosí, adonde habían de llegar los refuerzos al mando de Ramírez. Por otra parte, Nieto no dejaba de insistir al Virrey en la poca confianza que le merecían sus tropas, constituídas a base 
de las patricios y arribeños que el año anterior trajo de Buenos Aires para sofocar la sublevación de Chuquisaca y con los cuales no se atrevía a aventurarse en el Tucumán sin haber recibido los auxilios del Cuzco (17).

Planteada así la situación, convecó Abascal una Junta de Guerra con el fin de epcontrar solución a los problemas que se le presentaban. Indudablemente, la única forma de reorganigaf el ejército era concentrarlo en el Alto Perru, en donde se podía proceder a su instacucción, a la par que le dtegaban los refuerzos, por lo cual se dió orden a Nieto de situarse en Partosí, o sea, en la frontera del Alto Perí, desamparandp las provincias argentinas. Aun en caso de verse obligado a retirarse de este punto se habría de colocar en La Paz, cuvo movimiento seria protegido por las tropas que, al mando de Ramárequire golalantaqen desde agui con dirección a Oruro, (18). Una vez reunidos, seriar arotegidos por el. ejéreito formado en el Desaguadero, cuyo mando había pasado a tomar Goyeneche; a pesar de sus peticiones de relevo. A éste, igual que a Nieto, se le daban amplies facultades para modificar o alterar el plan.

Con dichas medidas quedaba fijada la situación genoral de las tropas. Se formapía un Ejército del Desaguadero, al mando de Goyeneche, que fortificase la linea fronteriza del Alto Perú, y cuyas tropas; además de esta misión, habian de cumpolir la de reserva del que pudiéramos llamar Ejército de operaciones del Alto Perí, al mando de Nieto, cuyo engrosamiento y raorganización se pretendía.

Así como el Ejército del Desaguadero había de te-

(17) Arch. Abascal. Carta reservada de Nieto a Abascal. La Plata, 9 de septiembre de 1810. En ella. le dice: «\$i los parteños se detienen en Córdoba, como algưoo asegurą, aunque sin' mayor fundamento, llegarán a tiempo estos auxilios, y aun cuando se adelantaran más que nuestras marchas, ine darian muy poco cuidado, y podría rechazarlps, y castigarlos si no fuera tan general el fermento que advierto en estos pugblos, tan decidida su adhesión a los iqsurgentes, y tan fundada la desconfianza que tengo de mis tropas фesprinadas, y el temor de que hagan conmigo lo que con Liniers y Concha en Córdoba. Cada dia se manifiesta esto peor... (18) ABASCAL. Memoria. Tomo II. Pág. 319. 
ner como característica principal la de ser eminentemente defensivo y servir de reserva, el de Nieto habia de caracterizarse por su movilidad, pues tendria que acudir tan pronto a la defensa de las provincias contra los ataques de las tropas de Buenos Aires, como a sofocar cualquier Ievantamiento de alguna de las corrompidas ciudades del Alto Perú. Para ello contaba Nieto con un poderoso auxiliar en la persona del Coronel Ramírez, cuya rápida incorporación deseaba con objeto de entregarle el mando de la avanzada del Ejército que se encontraba en Tupiza, a las ordenes de don José de Córdobá. Pero los acontecimientos se precipitaron y Ramirez no pudo llegar a hacerse cargo de la vanguardia, porque las ciudades altoperuanas lo colocaron en una difícll texitura.

Ocupada Córdoba por las tropas de Buenos Aires, se mantuvieron estacionadas algún tiempo aquí. Pero a prímelo de septiembre, quizás por inspiración del secretario de la Junta de Buenos Aires, Mariano Moreno, se adelantó una expedición de 500 hombres, al mando del General González Balcarce, a través de Salta y Jujuy para atravesar la frontera del Alto Perú (19). Indudablemente, tan pequeña expedición no podria iniciar ninguna ofensiva contra las tropas de vanguardia de Nieto situadas en Tuplza, pero podrian servir al menos para fijarlas y alentar a las ciudades del Alto Perú a la sublevación, al imaginarse próximos los auxilios. Ciertamente consiguió ambos fines, pues obligó a Córdoba a mantenerse a la expectativa y alentó a los cochabambinos, cuya sublevación trascendió a Oruro. Nieto quedaba prácticamente aislado y sin poder recibir los auxilios de Ramirez, que se preparaba en Viocha, a cinco leguas de

(19) LEVENE, Ricardo. La Revolución de Mayo y Mariano Mareno, Buenos Aires, 192, Tomo II. Pág. 183. En un documento de Mariano Moreno existente en el Archivo General de la Nacion, Archivo de la Gobernación de Buenos Aires, tomo XXXVI-C: CXII, expresa que, esiendo uno de los principales fines de la expedición sorprender a los pueblos del Atto Perá, antes de que los réfuerzos de Lima puedan ponerlos en estádo de defensa vigorosa, sería quizás conveniente que una división de 500 hombres se adelantase a Tupiza, donde se mantuviesen hasta la llegada del grueso del Ejército». 
La Paz, ya que la linea Cochabamba-Oruro cortaba las comunicaciones del Desaguadero con la frontera argentina del Alto Perú.

Hubiera podido evitarse el aislamiento de las tropas de Nieto si Ramirez hubiera marchado antes hacia el Sur. Pero se retrasó debido a la constante obstaculización que sufrian sus peticiones de cabalgaduras y acémiles al Gobernador de La Paz, don Domingo Tristán, cuya conducta se puso de manifiesto en los sucesos que se desarrollaron poco después, cuando se colocó al lado de la Junta de Buenos Aires.

Nieto había de mantener, después, un compás de espera mientras que Balcarce recibia refuerzos, en tanto que Ramirez había de luchar por restablecer las comunicaciones y poder llevar a buen término el envío de socorros prometido. Además, el Alto Perú se hallaba materialmente anegado de papeles sediciosos y propaganda revolucionaria que encontraba ambiente propicio en todas las ciudades, lo que no es de extrañar, si se recuerda, la constante comunicación que existía entre las provincias altoperuanas y las argentinas.

Pues bien, en este ambiente de propaganda revolucionaria la labor de Ramirez se habia de multiplicar, atendiendo no sólo a la sublevación de Cocha-bamba y Oruro, sino procurando evitar su extensión a las demás ciudades, incluso a su capital, La Paz, en donđe eran bien acogidas todas las manifestaciones subversivas.

El dia 11 de octubre escribia Abascal a Goyeneche y trataba de hacerle desistir de sus intentos de abanconar el mando, haciéndole ver que no tenia a nadie para sustituirle. Apelaba a su honor militar, manifestándole el dilema en que se encontraban «de abandonar el honor, o defender, hasta exhalar nuestro espiritu, los sagrados deberes a que éste nos obligas (20). Achacaba gran parte de las causas del alzamiento de los cochabambinos al hincapié que hizo Prada, Intendente de Cochabamba, para quedarse con el armamento que tenia, en lugar de enviárselo a

(20) Arch. C. Guaqui. C. 13. Carp. 2. N. 23. Carta de Abascal a Goyeneche. Lima, 11 de bctubre de 1810. 
Nieto a Chuquisaca, suministrando así armas a los sublevados de la ciudad, que de otro modo no hubieran podido levantarse.

Le propone Abascal un medio para acabar con la sublevación de los cochabambinos, aunque los somete a su conocimiento del terreno y de las gentes. Consistia en preparar «con mucho disimulo una expedición de 1.000 a 1.500 hombres escogidos, que rápidamente pasasen a atacarlos con todas las precauciones convenientes para sorprenderlos; conseguido esto y la prisión de sus mandones, todas las demás provinciass se meterán en un puño, y sería negocio concluido, sin quedarnos otra atención que la de contener a los picaros de Buenos Aires». Para el mando de dicha expedición propone el Virrey «a Ramírez o Piérola, - mejor los dos juntos», quedando Goyeneche en el Desaguadero a la expectativia.

Cuando el Virrey escribia no debian haberle llegado noticias de las correrias de los cochabambinos hasta la cludad de Oruro, con lo que quedaba virtualmente cerrado el camino de Potosí, a través del cual tendria que abrirse paso Ramirez para llevar los refuerzos a Nieto, y era muy aventurado avanzar deJando a la espalda la ciudad de Cochabamba sublevada. Se hacia indispensable una accion contra dicha ciudad, lo que venía a cortoborar la carta del Virrey.

Para llevar a cabo el proyecto, Ramírez trazó inmediatamente el plan de ataque, que consistia en defar La Paz, cuyo mando habia extregado al Coronel Tristán. guarnecida con 500 hombres, y.con 1.000 de las provincias limitrofes del Virreinato, dirigirse a Oruro, centro vital para la comunicación con Patosí, debiendo con otros 1.000 atacar a Cochabamba, una vez sometida aquella ciudad. Al iniciar la marcha sobre Oruro destacó con la vanguardia de sus fuerzas al Coronel don Fermín Piérola, que se dirigió hacia Aroma, en donde debía esperar que se le reuniese $\mathrm{Ra-}$ mírez con el grueso del Ejército. Por su parte, Goyeneche, que se habia situado con 4.000 hombres en el Desaguadero, avanzó 1.000 de su vanguardia. 20 leguas al interior del Alto Perú, en dirección a La Paz, para sostener a Ramírez y mantener asegurada dicha 
capital e impedir a la vez que los sublevados intentasen penetrar en el territorio del Virreinato (21).

Pero a los cuatro días de marcha, el 14 de noviembre, Piérola, al llegar a Aroma, se encontró con 3.000 cochabambinos de caballería que atacaron impetuosamente sus fuerzas. Sus soldados, a pesar de defenderse denodadamente, hubieron de retirarse, batidos ante la superioridad de sus enemigos, y sin poder salvar más que la tercera parte de sus efectivos (22). El mismo Abascal, en su Memoria, refiere con Justo elogio la acción, según el parte recibido de Piérola. La primera parte de la batalla se desarrolló favorablemente para los realistas, cuyas fuerzas lograron desorganizar el centro de los cochabambinos. Ante el ataque reaccionan éstos, e intentan envolver el dispositivo de Piérola, que resistió tenazmente con la defensa de sus guerrillas. Batidos por la artillería enemiga y cercana la noche, sin que hubiese postbilidad de decidir el combate con ventaja, antes bien exponiéndose a ser envueltos y derrotados totalmente, el Coronel realista decidió replegarse hacia Sicasica, pero al encontrarla también sublevada hubo de continuar el camino hasta Viacha, en donde estaba el grueso de las fuerzas de Ramirez, sin dejar de ser perseguido por los cochabambinos (23).

Las pérdidas sufridas por las tropas de Piérola fueron graves: había sido "completamente derrotado sin poder salvar más que la tercera parte de su gente», según comunicaba el Virrey al Secretario de Estado el 14 de enero de 1811, y además había perdido todas las municiones y el armamento en la persecución que sufrió por los cochabambinos.

La derrota de Piérola era fácil de prever desde que se inició el encuentro. El número de fuerzas era extraordinariamente desigual, con gran ventaja por parte de los cochabambinos, que además poseían un fuerte Cuerpo de Caballería, que fué el elemento de-

(21) A. G. I - -Lina, 740. Oficio del Virrey del Perú al Primer Secretario de Estado y su Despacho. Lima, 14 de noviembre de 1810

(22) A. G. I.-Lima, 649. Oficio de Abascal al Secretario de Estado y su Despacho. Litha, 14 de enero de 1811.

(28) ABASCAL. Memoria. Tomo II. Págs. 326-327. 
císivo de la acción, dado el papel fundamental de dicha arma en los terrenos llanos, como la pequeña llanura de Aroma. Sin embargo, no se le puede achacar la responsabilidad al Coronel Piérola, pues al frente de sus fuerzas hizo cuanto estuvo en su mano para decidir el combate. Pero la circunstancia en que se planteó habia de darle forzosamente un resultado adverso. Se debió sin duda a la falta de auxilio por parte del Gobernador de La Paz, a que me he referido antes.

La derrota de Aroma trajo como consecuencia la suhlevación de $\mathrm{La} \mathrm{Paz}$, con su gobernador al frente, recnnociendo la Junta de Buenos Aires. Este hecho deló al descubierto la dudosa conducta del Intendente Tristán. quien si hasta entonces se habia mantenido fiel al Rey. lo había sido únicamente por el temor a la proximidad de las fuerzas de Ramírez. Ahora. al triunfar los cochabambinos, que podían prestarle ayuda, no dudó en adherirse a la Junta.

A consecuencia de la situación derivada de la batalla de Aroma y la sublevación de La Paz. Ramírez con el frente atacado por la caballería de los cochabambinos. que no cesaba de hostilizarlos. y el flanco descubierto a cualquier ataque que pudiese venir de aquélla ciudad. hubo de retirarse, no sin grandes dificultades. al Desaeuadero, para unirse al grueso del Ejército de Goyeneche.

Por tanto. auedaban comoletamente interceptadas las comunicaciones entre el Perú y las tropas de Nieto. para quien se esfumaba la posibilidad de recibir el auxilio prometido. El retardo de Ramírez $\mathrm{v}$ la batalla de Aroma decidieron la suerte del Alto Perú en esta primera cambaña. Obligado Nieto a presentar batalla a los argentinos sin el refuerzo. 7 lo que es más importante. sin la sagacidad militar de Ramirez. fué fácilmente derrotado. Los de Buenos Aires encontraron ante sí el camino abierto por la insurrección de las ciudades, y sin tropa ninguna que se opusiese a su progresión hasta el Desaguadero.

Mientras Ramírez luchaba y se replegaba en el Alto Perú. Nieto, imposibilitado, según él. de operar, esperaba la llegada de las tropas de aquél. situando su Cuartel General en Potosí y la vanguardia en Tupiza, al mando del Capitán de Fragata don José de 
Córdoba. Las fuerzas argentinas, mandadas por Balcarce, que había sustituido a Ocampo, salieron de Salta y JuJuy, y atravesando los desfiladeros de Humahuaca, se extendieron ante los campos de Yavi, llegando con sus avanzadas al río de Suipacha.

Ya he dicho más arriba que mientras Nieto aguardaba, Balcarce recibía los refuerzos que le suministraban Ocampo, Güemes y Castelli. El EJército argentino estaba mandado entonces por hombres enérgicos y decididos. A Ocampo lo sustituyó Balcarce, audaz hasta rozar la temeridad, y al doctor Vieytes le sustituyó en el cargo de diputado del Gobierno el doctor Castelli, revolucionario convencido y dispuesto a anonadar a los pueblos altoperuanos haciéndoles ver la imposibilidad de cualquier reacción.

Ante los preparativos de los argentinos, Córdoba, para quien Tupiza no ofrecía seguridades de defensa, decide retirarse a Cotagaita, como lo verificó el 13 de octubre. Dicho punto lo ofrecía el apoyo del río de su nombre, detrás del cual podría fortłficarse, como efectivamente hizo. Construyó una trinchera de 1.500 varas de largo, con cuatro reductos que ocupaban dos cañones, y a corta distancia, un pozo de la misma longitud, de 3 ó 4 varas de ancha, servía para impedir el vado del río y aun para desviarlo con el fin de acortar el agua al enemigo, si acampaba frente.

El número de fuerzas, según el parte que el 25 de noviembre daba al Virrey del Perú don Narciso Basagoitia, Comandante de 150 soldados arequipeños y 350 de Puno que habian acudido del Desaguadero en auxilio de Nieto, era de 900 hombres de fusil y 200 de lanza, con 8 cañones de a 4 , los realistas, y unos 700 , con un cañón de a 4 y un obús de a 18, los argentinos (24).

La posición de Cotagaita cerraba el camino del Alto Peru, y fuertemente defendida como estaba, era una imprudencia atacarla, sobre todo con inferior número de tropas. Pero Balcarce no reparó demasiado en ello. Ilusionado por la facilidad que había encontrado hasta entonces en su camino, y temeroso de

(24) A. G. I.-Lima, 649. Copia de parte de don Narciso de Basagoitia a Abascal. Tarapack, 25 de noviembre de 1810. 
los reproches de Castellí, que gozaba de la absoluta confianza de la Junta, se decidió a ocupar Tupiza y seguir su avance hasta el río de Cotagaita, adonde llegó el 27 de octubre.

Aunque se dió cuenta inmediatamente de la imprudencia cometida, no le cabia ya otro partido que aceptar la lucha, y comenzó la batalla. La acción, desde el primer momento, se inclinó a favor de las tropas realistas, que rechazaron los ataques de los porteños durante 4 horas y 20 minutos, lo que dió lugar a la retirada de Balcarce, efectuada con el mayor orden y sin sufrir ninguna persecución de las tropas de Córdoba, que no tuvo a bien hostigarlos. Esta pasividad les permitió retirar sus muertos y heridos y la artilleria, e incluso reorganizarse a la vista de aquéllos (25). Quizás aquí perdió Córdoba la ocasión que se le ofrecía, pues si hubiese hostilizado entonces a las tropas porteñas hubiera transformado en completa derrota un combate que tuvo un resultado un tanto indeciso, y hubiese modificado seguramente el curso de los posteriores acontecimientos.

Balcaree, a consecuencia de su irreflexiva conducta, se vió obligado a retirarse a Tupiza primero, $y$ luego a Suipacha, ante el temor de una persecución ene-

(25) De la batalla nos da la idea la descripción que hace Basagoitia en el parte antes citado (nota 24):

\$...se rompió el fuego por nuestro frente con artillería y poca fusileria, cargando esta su fuerza sobre nuestra derecha, la que fué rechazada y desalojada de su situación ventajosa por las Compañías primera y segunda de voluntarios del Rey, al mando del Capitán don José Fernando de Ontaneda, que atravesando el río a pie empezaron a subir desde la falda y montaña del cerro, y sin duda hubieran cortado mucha parte de los enemigos, si a tiempo se les hubiera auxiliado con cartuchos, por cayo defecto se vieron en la sensible precisión de volverse a bajar, no habiendo convenido el Comandante en Jefe saliese una de mis compañías a su refuerzo. Los del cerro opuesto quedaron rechazados por parte de los soldados de Puno y Potóí; duró la acción cuatro horas y veinte minutos, y el enemigo se retiró en disposición que tuvo lugar para recoger los muertos y heridos, para reunir su gente a nuestra vista, y retirar su artillería...» En realidad, la maniobra fué bien sencilla, los porteños se apoderaron de unas alturas dominantes desde donde batieron las posiciones de Córdoba, pero fueron desalojadas y resultaron inútiles sus intentos de rocuperarlas, ante lo cual, Balcarce ordenó la retirada. 
miga. La causa de la derrota se debía únicamente a su vehemencia en el deseo de vencer a los realistas y allegar socorros a los cochabambinos, de cuya sublevación le había llegado noticias, deseo que le impulsó a atacar sin haber recibido el refuerzo de hombres que le enviaba Castellí, ni las municiones, fallo este último fundamental para el curso de la batalla (26).

El día 2 de noviembre llegó Nieto con 250 hombres veteranos y 2 cañones al Cuartel General de Cotagaita. Córdoba propuso inmediatamente salir con una expedición de 500 hombres y 2 cañones para perseguir a Balcarce, pero a instancia de algunos jefes se suspendí la salida porque preveían que no había de tener muy buenos resultados, a pesar del triunfo, ya que los argentinos se encontraban perfectamente organizados y habian recibido refuerzos. Se desprendía que lo único eficaz habia de ser un ataque con todas las fuerzas de que se pudieran disponer.

Sin embargo, prevaleció la opinión de Córdoba, y el día 4 salió la expedición compuesta de 700 hombres escogidos, 4 cañones y 100 lanceros. Avanzaron sin contratiempo alguno hasta Tupiza, en donde, al revés de lo que se esperaba, no hallaron a los argentinos, encontrando al pueblo evacuado. Allí le llegaron noticias de que el enemigo habia recibido un rtfuerzo de 500 hombres, 3 cañones y un obús, y que se encontraba situado en Suipacha, 5 leguas más adelante.

Córdoba, confiado, prosiguió su avance hasta llegar al río de Suipacha, al que dió vista el dia 7. Las tropas de Balcarce se hallaban atrincheradas en espera del ataque, e inmediatamente comenzó la lucha. Córdoba destacó cuatro compañías, que, dislocadas en guerrillas, reconociesen al enemigo, al que rechazaron, aunque inmediatamente fué reforzado. No ocurrió así a los realistas, que hubieron de soportar el

26) Bartolomé MITRE, historiador generalmente poco apasionado, hablando de la batalla de Cotagaita, dice que los soldados argentinos, después de cuatro horas de fuego, fueron rechazados y obligados a replegarse, esin más municiones que las que los soldados Jlevaban en las cartucherass. (Historia de San Martín y de la emansipación Sud-Americana. Buenos Aires, 1907. Tomo I. Pág. 209). 
ataque del centro de Balcarce reforzado, sin que el resto de sus fuerzas acudiesen en su ayuda, limitado su papel casi al de meros espectadores, colocados en las posiciones sin hacer fuego, lo mismo que la artillería (27). A la hora y media de lucha, Córdoba tocó retirada ante el mal cariz que tomaba la batalla, y huyó con algunos oficiales. El desorden que siguió es fácilmente calculable, y la victoria argentina fué total. Con ella se les abría el camino del Alto Perú.

Balcarce, por su parte, demostró gran habilidad en la organización y maniobra de sus fuerzas. Preparado el dispositivo de defensa, ocultó el grueso de sus tropas de la vista de las de Córdoba, y cuando éste desplegó sus guerrillas le hizo creer que tenía la intención de contenerla con dos piezas de artillería y 200 soldados. La retirada que inició inmediatamente fué fingida, para atraer sobre el grueso de las suyas a las fuerzas realistas. En efecto, inmediatamente que se lanzaron en su persecución, la avanzada de Balcarce reforzada inició a su vez el ataque con la cooperación del grueso de los suyos, poniendo en grave trance a todas las que se dirigían algo desordenadamente contra ellos. Un ataque de los argentinos de media hora de duración decidió la batalla (28).

Al día siguiente llegó la noticia a Cotagaita, donde se encontraba Nieto con 700 hombres y 10 cañones. Pero traída por los fugitivos que primero llegaron a la ciudad, venía extraordinariamente abultada por

(27) En el parte citado en la nota 24, dice Basagoitia: \&...se empezó la acción sin que por nuestra parte entrasen en ella más que cuatro compañías; éstas rechazaron a el enemigo en superior número de gente, éste fué reforzado en aquella parte con más de cien hombres, pero los nuestros no lo fueron, manteniéndose el resto de la tropa en ala y sitios destinados sin hacer fuego, verificando casi lo mismo nuestra artillería. A la hora y media, poco más o menos de tiroteo, y cuando nuestra tropa se hallaba más acalorada, se tocó retirada y el Comandante en jefe huyó montado sin dejar orden alguna, a que siguió la total dispersión, de la que se aprovechó el enemigo, causándonos la pérdida de 100 hombres poco más o menos, entre muertos y prisioneros, no siendo de menos consideración la suyas.

(28) Vid. MITRE, op. cit. Tomo I. Pág. 210; LOPEZ, Vicente. Historia de la Repriblica Argentina. Buenos Aires, 1883. Tomo III. Pág. 242. 
las exageraciones naturales debidas al terror de la huída. Se hizo creer que todos habían sido derrotados, prisioneros y muertos, y que no había quedado fuerza alguna para retirarse. Nieto dió fe a tales exageraciones, y, temeroso de un imprevisto ataque enemigo, presa de un inexplicable temor, mandó que cada cual se salvara por donde pudiese, marchando él hacia Potosí, después de haber destruído las fortificaciones de Cotagaita.

La precipitacíón de Nieto acabó de sembrar el desorden, y amenazaba convertir en catástrofe lo que había comenzado en simple derrota. Los soldados inmediatamente marcharon, la mayoría a sus casas, y otros se dirigieron hacia Potosí, contribuyendo a aumentar la confusión en su tránsito.

En el camino de esta ciudad fueron detenidos Córdoba y Nieto, y conducidos a ella, en donde poco después eran fusilados Juntos con su Intendente don Francisco de Paula Sanz, que se resistió a unirse a los rebeldes.

Extraña mucho, al examinar los hechos, la conducta de Córdoba y la de Nieto. Ambos Jefes, que se habian mostrado siempre indecisos ante el ataque a los argentinos, se lanzaron tras ellos, deslumbrados por la victoria de Cotagaita, y fueron a parar al desastre de Suipacha. Duramente los califica Abascal, cuando dice que «semejante improvisa providencia pudo ser flaqueza de un espíritu debilitado por la edad: pero también pudo ser, y es más verosímil, efecto de la precipitación e inexperiencia de Córdoba, funesto ma-. nantial de los males sucesivos». (29).

Es indudable que no hay nada que justifique la conducta de Nieto, salvo el desconcierto que debió apoderarse de él al tener noticias exageradas de la batalła, que creyó de buena fe. Se creyó sin fuerzas para defenderse del avance inminente de los porteños y con las espaldas mal aseguradas ante el temor de un ataque de los cochabambinos, y su moral se derrumbó estrepitosamente.

En cuanto a la conducta de don José de Córdoba, puede tacharse de imprudente. Desaprovechó la oca-

(29) ABASCAL. Memoria. Tomo II. Pág. 273. 
sión de perseguir a los enemigos despuós del combate de Cotagaita, cuando se retiraban sin haber recibido refuerzos, y en cambio, se decide a marchar contra ellos una semana después con un corto número de tropas, cuando se habian preparado parn la defensa y recibido nuevos auxilios. Se puede aducír en su favor que cuando Córdoba salió de Cotagaita no tenia noticias de que los enemigos habian sido reforzados; pero sí consta que las recibió al llegar a Tupiza, cinco leguas distante de Suipacha. Más logico hubiera sido, como referia más adelante Abascal a Goyeneche, permanecer en Cotagaita «cuando tenía la experiencia de haberlos rechazado en aquel punto sabiendo que volvian reforzados, y no debía ignorar que estándolo igualmente Santiago (de Cotagaita) con las tropas que llevó Nieto y alguna más artilleria nada tenían que temer esperando el ataque en aquel puesto tal cual fortificado y procurando cubrir de antemano las alturas colaterales» $(30)$. O en caso contrario haber avanzado juntamente las tropas de Nieto con las suyas, al objeto de dar una batalla decisiva.

Sea lo que fuere, lo cierto es que Córdoba, por inexperiencia o por impremeditación pagó bien caro su intento. Incapaz de reorganizar sus derrotadas tropas, cayó prisionero de los argentinos en su huída y fué fusilado con Nieto y Sanz en la ciudad de Potosí, sublevada al tener noticia de la derrota.

Resuelta favorablemente para los argentinos la batalla de Suipacha, y facilitado su avance por el Alto Perú a consecuencia de la de Aroma, juntamente con la sublevación de las principales capitales, la ocupación de este territorio fué para ellos simplemente un paseo militar, ya que no podian encontrar ningún foco de resistencia orgallizada. La consecuencia de la batalla de Suipacha fué, pues, que se les abrió el Alto Perú a los porteños, que llegaron hasta el limite del Desaguadero.

El sometimiento de las ciudades fué cosa fácil, puesto que los cinco grandes núcleos del Alto Perú se declararon voluntarlamente por la Junta de Bue-

(30) Arch. Abascal. Copia de carta de Abascal a Gogeneche. Lima, 24 de marzo de 1813. 
nos Aires, si no lo habian hecho ya, y los pequeños pueblos siguieron su ejemplo. Es curiosa la afinidad ideológica que existía entre las provincias del Alto Perú y las del Río de la Plata. Se sentían completamente ajenas a los intereses e ideales del Perú, y en cambio se mantenian profundamente unidas al Virreinato de Buenos Aires convertido en la via natural de salida de estos pueblos hacia el mar. Tal afinidad nos da la clave para explicarnos el proceso de la posición de las ciudades altoperuanas a lo largo de la Guerra de Independencia. Permanecian fieles a los realistas mientras duraba la ocupación del territorio por sus tropas. Cuando los azares de la lucha les obligaba a replegarse, sin haber acabado de salir aún el último soldado realista, se proclamaban inmediatamente por los revolucionarios, que eran recibidos como libertadores.

Abascal quiso convertir al Alto Perú en el bastión de la defensa del Virreinato, a la vez que el camino para atacar la revolución en su centro. Prescindiendo ahora del acierto o desacierto de tal medida, hay que hacer notar que en manera alguna consiguió atraerse de corazón a los altoperuanos, y que en todas sus campañas hubo de preocuparle el imponderable que encerraba la actitud de estas ciudades. Sin embargo, los azares de la guerra, la conducta de los argentinos y la conciencia del propio valer que se iba formando en las ciudades, trazaron poco a poco una frontera entre el Alto Perú y. la Argentina, que dió como resultado la constitución de un núcleo independiente con vida propia.

Con las fuerzas recibidas de las ciudades, unidas a las que poseía el ejército revolucionario y al botín recogido en la batalla de Suipacha y lugares de su tránsito, se organizó un fuerte ejército al mando de Balcarce y Castellí, los vencedores del Alto Perú. Llegaron a los limites del Perú, frente a las tropas de Goyeneche, y acamparon a orilla del Desaguadero.

La presencia de un ejército de unos catorce mil hombres, con una gran moral de victoria y con el apoyo de los pueblos que dejaban a su espalda, era verdaderamente inquietante $y$ encerraba una grave amenaza para el Virreinato. Hacía falta urgentemente constituir un poderoso ejército defensivo, ya que 
no era posible otra cosa de momento, para evitar la progresión argentina. Pero para organizar este cuerpo de tropas hacian falta dos condiciones fundamentales: tiempo y tranquilidad. Conocida la necesidad, Abascal aprovechó la única ocasión que se le ofreció, proporcionada por la ciudad de La Plata.

El 13 de noviembre la ciudad de Chuquisaca se unía a los revolucionarios previa la reunión de un Cabildo abierto en el que se planteó la situación creada por las victorias argentinas. La decisión fué unánime: se despacharon emisarios a Balcarce para participarle la adhesión de la ciudad a la Junta de Buenos Aires, como asimismo se enviaron también a todos los puntos dependientes de la Audiencia de Charcas para darles a conocer la decisión de la capital, e instarlos a seguir su conducta. También se determinó en dicho Cabildo comunicar al Virrey del Perú, al Presidente Goyeneche, y al Coronel Ramirez «a fin de que inteligenciados de este Acuerdo $y$, de la Justicia de la sagrada causa que se apoya y declara en su tenor, se sirvan abstenerse de todo movimiento y hostilidad que pueda turbar y causar funestas consecuencias dentro del vasto territorio de las Provincias del Río de la Plata, que queda limitado en la ribera del Desaguadero», pretendiendo con ello llegar a una pacifica reanudación de las relaciones, principalmente comerciales, entre ambos territorios (31).

Duro debió ser para Abascal aceptar esta proposición. El, que había determinado desde el primer momento acabar de raiz con la revolución y que había comunicado sus ideas a Goyeneche sobre el caracter ofensivo que debía imprimir a la guerra, ya que una defensiva «al cabo siempre viene a parar en ser ruinosa» (32), no tuvo más remedio que ceder ante las circunstancias.

Serenamente pensado, era locura pretender lanzarse a una ofensiva sin contar con un ejército preparado para ella. Máxime cuando las condiciones de

(31) A. G. I.-Lima, 649. Copia del Acta del Cabildo abierto celebrado en La Plata el 13 de noviembre de 1810.

(32) Arch. C. Guaqui. C. 13. Carp. 2. N. 23. Carta de Abascal a Goyeneche. Lima, 11 de octubre de 1810. 
las tropas argentinas habian variado notablemente desde el tiempo de su salida de Buenos Aires. Poco a poco habian ido adquiriendo la disciplina de que tan faltas se hallaban en un principio, y que habian sabido imponer hombres tan enérgicos como Balcarce y Castelli. Por ello, y por doloroso que esto resultase para el amor propio del Virrey, hubo de acceder a la petición de la ciudad de La Plata, previa la reunión de una Junta de Guerra, el 10 de diciembre. Dió órdenes a Goyeneche de limitar sus actividades a la vigilancia y fortificación de los puntos ocupados, a la par que comunicaba a la Junta creada en La Plata que si habían intervenido en el Alto Perú fué debido a las solicitudes de dichas provincias; pero que pensando en el día de otra suerte esas mismas provincias, poniéndose bajo la obediencia de las Juntas de Buenos Aires, le prevengo (a Goyeneche), aprobando la respuesta que ha dado a V. S. dicho Jefe, suspenda toda operación hostil que no sea provocada, y que manteniéndose en la línea de demarcación que divide el territorio de ambos Virreinatos para rechazar cualquier tentativa que se dirija a perturbar la quietud que reina en las provincias de mi mando, observe en lo demás la conducta que se practique por parte de ese Virreinato, sin impedir por ahora el comercio reciproco, pero velando mucho el que no se introduzcan personas sospechosas y papeles incendiarioss (33). Los limites establecidos como línea de separación de ambos Virreinatos corrían desde el Estrecho de Tiquina y pasos de Larecaja y Omasuyos en la Intendencia de Puno, hasta los valles que descienden a la costa por Arica y Moquegua, en la provipcia de Arequipa: Se le daba a la vez facultad al General en Jefe del Ejército para fortificar aquellos puntos por donde, según su juicio fuese fácil de producirse una infiltración enemiga (34).

Vista la situación subsiguiente a las batallas que decidieron la suerte del Alto Perú, sólo queda, para acabar con el relato de la primera campaña de la revolución, que me refiera, siquiera de pasada, a la ac-

(33) A. G. I.--Lima, 649. Copia de oficio de Abascal a la Junta de la ciudad de La Plata. Lima, 10 de diciembre de 1810.

(34) ABASCAL. Memoria. Tomo II. Pág. 331. 
tuación de los argentinos en el territorio altoperuano, ocupado por sus tropas. Dentro de este apartado me he de referir casi únicamente a la conducta de sus Jefes con los jefes realistas aprehendidos por ellos, cuestión que ha originado algunas divergencias entre los historiadores.

Más arriba, al referirme al fusilamiento de Liniers, Concha y Allende, decía que, sin pretender Justificar la medida, a mi juicio quedaba suficientemente explicada como un hecho derivado de un primer periodo de agitación revolucionaria, con el que la Junta de Buenos Aires quería hacer ver el castigo ejemplar a que serían sometidos todos los que no la acatasen. Dicha medida se dirigía, evidentemente, a estabilizar la posición de la Junta y evitar reacciones armadas en las provincias, que pusiesen en peligro su vida.

Sin embargo, la decisión de la Junta de Buenos Aires levantó una enorme polvareda en toda América y produjo diferentes reacciones. Pero es lo cierto que, fuese cual fuese la Justicia de tal medida y las protestas levantadas, la Junta continuó en su actitud, y más tarde, cuando eran aprehendidos Nieto, Córdoba y el intendente Sanz, todos eran fusilados por orden de Castellí.

Una aclaración creo debe hacerse en principio, y es que no hay que achacar a Castelli, única y exclusivamente, la responsabilidad de tales medidas. El era un enviado, con plenos poderes-pero enviado al fin-de la Junta de Buenos Aires, la cual había de respaldar en todo instante su actuación y podía desautorizarlo en cualquier momento si sus resoluciones no agradaban, como había ocurrido con su antecesor el doctor Vieytes. El hecho de que la Junta conservase en su puesto a Castelli, aún después de los segundos fusilamientos, era señal indudable de que había encontrado en él al hombre necesario para llevar a cabo su politica y que aprobada enteramente su conducta.

El carácter de este individuo ha suscitado muchas opiniones. Unánimemente están de acuerda los historiadores del bando realista en declararle como un criminal sediento de sangre y que se dejó llevar en sus desmanes por deseos de venganzas. En cambio, los historiadores argentínos justifican su actuación considerándola necesaria en momentos tan decisivos para la 
revolución. En realidad, la conducta de Castellí no se encuentra en manera alguna justificada. Aunque no hacía sino llevar a la práctica el parecer de la Junta, se excedió un tanto en su cometido. Historiador tan poco sospechoso de simpatia hacia el partido realista como el general Miller, dice de él que era un «abogado de gran talento, era sagaz, activo y decidido, pero versatil y feroz» (35). Si es cierto que tenía órdenes para obrar enérgicamente no lo es menos que se excedió en el cumplimiento de su encargo. Castellí era un hombre plenamente convencido de las teorías revolucionarias, que estaba dispuesto a hacer triunfar por todos los medios, y entre ellos escogió el que estaba más a su alcance y le pareció más definitivo, pues aparte de eliminar a sus principales enemigos sembraba el pánico entre los jefes de la reacción y desconcertaba sus planes.

Sin embargo, la actuación de Castelli fué contraproducente para la revolución argentina. En primer lugar, su carácter violento y las ejecuciones que llevó a cabo, aprovechados hábilmente por los realistas, hicieron aparecer al ejército argentino ante los ojos de los pueblos del Alto Perú y del Virreinato de Lima como un terrible instrumento de desolación y muerte, odiada por todos. No menos sirvió la labor de Castellí para delimitar definitivamente los dos bandos en lucha. Su espíritu no admitía términos medios; no era tiempo en que se pudieran permitir vacilaciones. Para asegurar la revolución había que exterminar todo lo que a ella se opusiese; por tanto no cabían posiciones intermedias, ni incluso conservadoras dentro de la revolución. A partir de entonces comienza la lucha a muerte entre revolucionarios y realistas, convencidos ambos de que no cabe otra solución que la desaparición de uno de los dos bandos.

Por último, y no es esto lo de menos importancia, en los resultados de la labor de Castellí, creo se debe hacer notar que su vida entre los altoperuanos y el poco aprecio que hizo de sus esfuerzos en pro de la revolución, así como la actuación del ejército argentino

(35) Memorias del General Miller. Bibl. Ayacucho. Madrid. s. a. pág. 99 . 
en general, fueron uno de los primeros motivos que hicieron a aquéllos ver con malos ojos a los revolucionarios invasores, sentimiento que poco a poco fué creciendo hasta cristalizar en la formación de la República boliviana frente a las aspiractones argentinas. 


\section{CAPITULO VI}

\section{LA OFENSIVA DE GOYENECHE: HUAQUI}

La primera campaña de la revolución en el Alto Perú, cuyo final coincidió aproximadamente con el del año 1810, se liquidó con un éxito rotundo de los argentinos. En el espacio de tiempo comprendido entre los meses de Julio a diciembre habian ocupado y sometido a la autoridad de la Junta de Buenos Aires todo el territorio que va desde esta capital al Desaguadero. Bastó una sola acción victoriosa, unida a la cooperación de los sublevados altoperuanos, para que do una manera estrepitosa se derrumbase toda resistencia organizada en las provincias del Alto Perú. El resto lo hicieron las mismas ciudades al declararse abiertamente en favor de la Junta, noticiosas de la proximidad de su victorioso ejército.

Naturalmente, la facilidad del triunfo hizo concebir grandes esperanzas a los argentinos que afianzaban asi la revolución con el prestigio de los éxitos exteriores. Pero aún le quedaban muchos y duros reveses que pusieron a prueba la capacidad y el entusiasmo de sus hombres.

Es lógico que Abascal no se resignase a aceptar la derrota, pues, aunque ocurrida fuera del límite del 
Virreinato y sufrida por Jefes que no estaban colocados directamente bajo sus órdenes, repercutía sobre su propia situación. Se encontraba con la frontera del Perú amenazada por un ejército cuya moral debía ser necesariamente elevada a consecuencia de los fáciles triunfos obtenidos y de la unánime aclamación que recibian en todas partes. En el mejor de los casos si no intentaban proseguir su avance a través del Virreinato, intentarian, al menos, introducir sus ideas y atraerse a su causa a las ciudades y al ejército virreinal. Por otra parte, la situación de este ejército si el enemigo intentaba atacarlo no hacia concebir muchas esperanzas. Desorganizado, con poco armamento, con pocos oficiales capacitados para su mando, y lo que es mucho peor, con una casi absoluta indisciplina, que se traducia en constantes deserciones, disminufa poco a poco su número y amenazaba desaparecer.

Aún habia otra razón que impedía a Abascal aceptar la derrota. El pactar con los revolucionarios era sancionar de hecho una situación inadmisible. Para él eran unos individuos que se habían sublevados contra el Rey, única autoridad legítima, y a los que no cabia otra alternativa que la rendición incondicional con la disolución de la Junta y la vuelta de las autoridades virreinales. Todo lo que no condujese a esto era contraproducente, y el pactar con el enemigo era reconocerle una superioridad pelígrosa; por ello los pactos habian de ser únfcamente instrumentos para ganar tiempo, sin ningún otro valor, y en tal sentido hemos de interpretar los hechos que a continuación sucedieron.

Teniendo en cuenta lo antecedente, se desprende que si en un principio el Virrey aceptó el armisticio propuesto por la ciudad de Chuquisaca, lo hizo con la intención de ganar tiempo en el que poder preparar un fuerte ejército para atacar ventajosamente a los argentinos. Entretanto se organizaban, las fuerzas realistas situadas en la frontera cumplían simplemente el papel de un cordón sanitario ante el peligro revolucionario a las puertas del Virreinato.

De la labor de organización encargó Abascal a Goyeneche, como Jefe supremo del Ejército del Desaguadero. En poco tiempo y con un trabajo arduo logró formar un fuerte ejército y un nutrido grupo de Jefes 
y oficiales, cuya eficacia se dió a conocer a lo largo de la lucha.

La región donde se concentraron ambos ejércitos recibía su nombre del Río Desaguadero, que separa los territorios del Perú de los del Virreinato del Rio de la Plata. Dicho río es el desagüe natural de la gran cuenca del Lago Titicaca. La comunicación entre los dos Virreinatos estaba establecida a través de él por un solo punto de una anchura de 150 metros, ya que más adelante aumentaba el río en anchura y profundidad. El tránsito se hacía a través del llamado Puente del Inca, que la tradición hacia remontar a los tiempos de Cápac-Yupanqui, que lo mandó construir para facilitar la expansión de su pueblo hacia el Sur. Dicho puente constituía una curiosa construcción indígena. Estaba formado por balsas construidas con mimbre, cuerdas, una paja llamada sichu» y otra denominada «totora , y su construcción es una de las obras más notables de la Ingenieria indigena. Los haces de Juncia y enea estaban colocados transversalmente sobre dos maromas, construidas también con enea y la paja denominada ichu», y que se tendían de una a otra orilla del río. «Sobre aquellas maromas, porque no se rompan tan presto con el hollar de las bestias, echan otra mucha cantidad de enea en haces delgados como el brazo y la pierna, los cuales van asimismo por su borde cosidos unos con otros y con las maromas». Estos haces formaban la calzada del puente, y todo él era renovado cada seis meses (1).

A partir del puente, y en la orilla izquierda del ro, se extienden las alturas denominadas De Vila-Vila, y la Quebrada de Yauricoragua, que dividen la llanura en dos valles, uno al Norte, en donde se encuentran Fuaqui, Tiaguanaco y Laja, y otro al Sur, donde se hallan San Andrés y Jesús de Machaca. El valle del Norte recibe en su comlenzo el nombre de El Azafranal, . y el del Sur, el de Jesús de Machaca. La Quebrada de Yauricoragua pone en comunicación a ambos.

El valle del Azafranal, bordeando la costa Sur del

(1) GARCILASO DE LA VEGA. Los comentarios Reales de los Incas. Lima, 1918. Tomo I. Pág. 200. 
lage Titicaca, constituía el camino más frecuentado de las comunicaciones entre el Alto y el Bajo Perú. Partiendo de La Paz, adonde confluian las vías de Oruro y Chuquisaca, el camino se dirigía a través de este valle por las cludades de la Laja, Tiaganuaco y Huaqui, situadas a su entrada hasta llegar al Desaguadero, que atravesaba por el puente del Inca, y se prolongaba por toda la región peruana del Lago Titicaca. La entrada de dicho valle fué el lugar elegido por el ejésicito revolucionario para acampar., Establecieron el Cuartel General en La Raz, y sus avanzadas en el pueblo de la Laja, y más tarde en Huaqui.

Al otro lado del río Desaguadero se organiraban los realistas. Con actividad infatigable se hallaba Gayeneche encargado de su organización e instrucción. Los resultados se vieron pronto. A fines de 1810 , Goyenoche comunicaba tener uniformado siete batallones; «enseñándole el ejercicio y juegos según el moderno relamento y evoluciones del mismo, en cuya ejecución veo acercarse el más refinado sistema mis litar establecido en Europa» (2). Cada batallón estaba dotado de un Comandante, un Sargento Mayor, dos Avudantes y tres Oficiales por cada Compañia de a cien hambres.

La artállería del Desaguadero constaba de una brid gada de 260 artilleros, 8 piezas de a 4 y 2 de calibre de a 2 ; el total dol tren de artillería se componía de 20 piezas de a 4, de montaña, 8 de ellas volantes, además de las ya citadas. La caballería, arma indispensable en esta guerra, ascendía a 1.000 hombres, pero mal equipados y con malos caballos; la mayor parte habian de ir montados en mula, sin frenos y sin sillas, por lo cual la eficacia de dicha arma quedaba reducida al mínimo y se encontraba en situación de inferioridad ante el enemigo, equipado con los mejores caballos de Cochabamba (3). Una de las mayores preocupaciones de Goyeneche durante todo su mando

(2) Arch. C. Guaqui. C. 6. Carp. 4. N. 3. Estado, del Ejército de observación, reconocimiento de sus terrenos y topogräria de él». Cuartel General de Zepita, 30 de diciembre de iala:

(3) Vid. nota 2. 
en el ejército fué precisamente procurar colocar esta arina a la altura de la de sus contrarios.

Las fuerzas realistas se hallaban situadas en el Desaguadero, fortificado con una bateria de 8 piezas que batian el puente y los caminos que a él conducían desde el otro lado del río. La línea avanzada estaba guarnecida por tres batallones al mando del Coronel don Francisco Picoaga, con avanzadas en la parte limitrofe del frente, territorio que habia sido reconocido por Goyeneche con su Estado Mayor en algunas leguas, sencontrándolo invadeable en 12 (leguas) río abajo, y desde ellas hasta el Desaguadero en nuestro tecritorio una pampa fangosa intransita. ble en este tiempo de aguas, $y$ en el de secas propia para una batalla; donde el más diestro en manioiorar y la artillería de a cabalło, conseguirán la victoria por no haber en toda ella un punto de apoyo sobre que sostener una ala ni centro de ambos ejéreitoss (iz).

La vanguardia se hallaba situada a dos leguas de Zepita, y parte de ella colocada al atzo lado del río sobre la cuestá de Vila-Vila, que defendia el acceso al puente por el camino de Huaqui, úntco punto por donde se podía esperar un ataque. Su costado dierecho estaba ptotegido por otra avanzada que cubria el cerro de San 'Andrés de Machaca, con objeto de entretener cualquier avance que pudiese venir por el Valle de Jesús de Machaca. El total de la Nanguardia ascendía a unos 1.000 hoinbres.

El Estrecho de Tiquina, formado por la Península de Copacabana, estaba guardado por un destacamento de Dragones de Chumbivilcas, situado en el pueblo de Yunquijo. Estrecho, a juicio de Goyeneche; era de fácil defensa, y bastaban seguin él 50 hombres para defenderlo eficazmente (5).

Por último, el otro punto que podia preocupar al ejército realista era la entrada de la costa y del Parti, do de Larecaja, los puntos más abierto y más fáciles

(4) Vid. nota 2.

(5) Arch. C. Guaqui. C. 6. Carp. 7. N. 11. \&Memoria militar de la guerra insurreccional del Perús, por el Capitín do Ingenieros don Antonio Maria Alvarez. Cuaderno tercerio, corrépondiênte a 1811. Tupiza, 30 de enero de 1813. 
para la invasión y a los que dificilmente podía atender el ejército, cuya fuerza no era muy numerosa. Mas semejante circunstancia no preocupaba a Goyeneche, que no suponia al enemigo en condiciones de efectuar una penetración por estos puntos, puesto que inmediatamente avanzaria él amenazando la ciudad de La Paz y la espalda de los que se hubiesen aventurado a filtrarse (6).

Zepita, donde tenía instalado Goyeneche su Cuartel General, era un pequeño pueblo de las orillas del Lago Titicaca, cuya importancia hasta entonces se reducía a ser punto de paso en el camino hacia el Alto Perú. La elección que de él hizo Goyeneche se debió sin duda a su buena posición, defendido su frente naturalmente por el Lago Titicaca y a corta distancia del Desaguadero. Por lo demás, el pueblo carecía de condiciones; no poseía locales para acuartelamientos, «se mantenian varios Cuerpos bajo tiendas en un terreno húmedo; cabalmente en la estación de las aguas vigorosas en que las tormentas y frecuentes caidas de rayos se sucedian. Sin embargo, -dice el autor de la Memoria Militar de esta guerra, que convivió con las tropas allí acampadas-, no experimentábamos enfermedades y los pastos y forrajes para la caballería y bagajes del ejército, eran sobrantes con las lluvias a que meses adelante siguen los crueles frios» (7).

Lógicamente, una de las mayores preocupaciones del general habia de ser la del abastecimiento de sus tropas. Condición fundamental para evitar las deserciones que se hacian notar, sobre todo en la vanguardia del Desaguadero, era que los soldados recibiesen puntualmente su abastecimiento y sus pagas. Aun así, todavia se quejaba Goyeneche de que menudeaban las deserciones, sobre todo en la División de Piérola, situada en la vanguardia y compuesta de las tropas que tomaron parte en la acción de Aroma y de las que se le incorporaron de los Cuerpos del Cuzco, Urubamba y Real de Lima (8). Lo cual originaba que se viese obligado a imponer severos castigos para conseguir la
(6) Vid. nota 2.
(7) Vid. nota 5 .
(8) Vid. nota 2. 
disminución del terrible mal que amenazaba a su ejército.

El Virrey, ante el aumento de las fuerzas insurgentes y la poca confianza que le ofrecían las situadas en el Desaguadero, envió a Goyeneche un refuerzo compuesto de un batallón del.Real de Lima, con 680 plazas, 400 hombres del Regimiento de Pardos y 200 morenos (9).

El núcleo principal de las fuerzas que se encontraban bajo las órdenes del general procedía de la provincia del Cuzco, y el resta, de las de Arequipa y Lima, formando un total aproximedo de 6.000 hombres (10). La gran mayoría de ellos habían sido sacados de las labores del campo, lo que nos da idea de la intensidad que hubo de imprimirle a la tarea de la formación del ejército. Mas, en contrapasición a tan grandes dificultades, las tropas poseían una virtud fundamental: la lealtad hacia su jefe, como demostraron en todo momento a lo largo de la campaña. Formado el ejército en su mayoría por cuzqueños, y siendo Presidente de su Audiencia, que habia sabido captarse su simpatía en el corto tiempo que ocupaba el cargo, el que los ciirigia y arganizaba, ponían en él toda su fe, gracias a la cual le fué posible a Goyeneche alcanzar sus mejores triunfos.

En varias ocasiones habia manifestado Goyeneche al Virrey su deseo de dejar el mando del ejército, y alegaba la falta de efectivos, sin los cuales se veía imposibilitado de organizar una fuerza poderosa con la que hacer frente a los argentinos. Esto, unido a las constantes deserciones y a la desconfianza que le merecían algunos de los Cuerpos a sus órdenes, le movía

(9) A, G, I.-Lima 649. Oficio del Virrey. del Perú al Secretario de Estado y su Despacho. Lima, 14 de enero de 1811.

(10) En su Memoria de Gobierno, Abascal hace ascender estas cifras a 6.517 shombres de todas armas, perfectermente instruidos y diaciplinados». (Tomo II. Págs. 940-341). En \$p aficio de 14 de enero ya citado, la calcula en 6.000, y el Capitsp Alyarez, en su «Memoria militars, caĺcula la fuerza del ejército, en sus principiós, en más de 4.000 hombres. Parece lógico que este número fuese aumentando con la incorporación de los nuevos soldados de las provincias y los refuerzos, de Lima, hasta llegar apłoximadamente al número calculado por el Virrey. 
a pedir su relevo. Goyeneche debió darse cuenta de la dificultad y la responsabilidad de la misión que Abascal le encomendara, y no teniendo, a su juicio, los medios necesarios para llevarla a cabo, quiso eludir la responsabilidad de los acontecimientos que sucedieran, entregando el mando del ejército a algunos de sus jefes más caracterizados. La situación en sí ya era 10 suficientemente grave para preocupar a ałguien más animoso que Goyeneche. Las tropas porteñas aumentaban su número sin cesar con los contingentes que recibian de las provincias ocupadas. Todo hacia pensar que en cuatito se hallasen preparados se lanzarian a la,invasión del Virreinato sín dar tiempo a los realistas para organizar la defensa. No habia que fiar mucho de las negociaciones entabladas, pues en el ánimo de todos estaba que eran sólo un medio para ganar tiempo. La situación planteada únicamente se decidiria por las armas: mediaban muchas circunstancias y se habian originado muchos antagonismo para que se le pudiese dar una solución pacifica.

En una carta de 11 de octubre de 1810 , Abascal, refiriéndose a sus peticiones de relevo, decia a Goyeneche: «si yo fuese delicado atribuiría el arranque de usted sobre querer dejar ese mando, a una sola cosa en que he dejado de complacerle por más no poter, pero somos amigos, le amo mucho, usted lo conoce, y no cabe tal sospecha» (11). No se sabe exactamente la causa de que habla el Virrey, pues no lo aclara en la carta; pero creo lo más probable que se refiera a la falta de envío de tropas y materiales solicitados constantemente por Goyeneche. A todo respondía Abascal y procurabra mostrarle la imposibilidad material en que se hallaba de enviarle más de lo que le remitía, pues al mismo tiempo había de acudir a Quito, nuevamente sublevado, y ayudar a la lucha de la Metrópoli con el envio constante de dinero. De todas partes del Continente solicitaban a Abascal, y es que ya entonces el Perú era el único punto de toda la América del Sur en donde se mantenia de un modo firme la autoridad real. Poco a poco iba quedando aislado y, cortadas las

(11) Arch. C: Gtibiqui. C. 13. Carp. 2. N. 23. Carta de Abascal a Goyeneche. Lima, 11 de octubre dé 1810. 
comunicacianes con Montevideo; habia de obrar por su propia iniciativa. Tampoco parece probable que en caso de haberse mantenido el contacto entre el Perú y esta ciudad se hubiese llegado a un fin rápido de la guerra, Montevideo, si bien se proclamó por el Rey, estaba lo suficientemente ligada al Rio de la Plata y lo bastante alejado del Alto Peru para que se intentase desde allí una acción contra el ejército insurgente a fin de cogerlos entre dos fuegos, sabido el peligro que para dicha capital suponia dejarla desguamnecida de los pocos efectivos de que estaba dotada. A la vuelta de Elio a la ciudad con el titulo de Virrey del Rio de la Plata, a comienzos de 1811, toda su atención se dirigió hacia Buenos Aires. Mas también era muy dificil tomar esa plaza sin contar con una escuadra lo suficientemente poderosa para mantenerla en estrecho bloqueo y sin la colaboración de fuerzas en el interior. De todos modos, como se ve, no habia posibilidad de una acción mancomunada entre los dos puntos en que se aceptaba el Gobierno de Fernando VII. Montevideo tenía bastante con mantenerse frente a la fuerza creciente de Buenos Aires con el corto apoyo que habia recibido de España. Todo el peso de la lucha cayó sabre el Perú, y gracias a que contaba con la energía de un hombre como Abascal, pudo subsistir, y aun amenazar a la revolución. Si en lugar de él hubiese estado al frente del Virreinato un hombre más pusilánime o con menos energias, el Perú hubiera sucumbido en 1810. A la labor de Abascal debió España que se le mantuviera adicto y formando un bloque compacto hasta 1824 .

Volviendo al asunto de la dimisión de Goyeneche, quizás hubiese una causa que unfluyera no poco en ella. Debió ser, al decir del Virrey, el nombramiento del Brigadier don Bartolomé Cucalón para Presidente de la Audiencia del Cusco, cuyo cargo interino desempeñaba Goyeneche desde poeo después de su llegada al Perú (12). Los motivos que movieron al Gobierno español para no confirmarlo en su empleo y sustituirlo por Cucalón, no los sabemos; pero es lo cierto que esta decisión debió herir los sentimientos de Go-

(12) ABASCAL. Memorie. Tomo II. Págs. 836-337. 
yeneche. El debia considerarse acreedor a tal puesto después de su actuación contra los sublevados de La Paz en 1809, y de la confianza que ahora le había depositado el Virrey del Perú. Por el nombramiento de Cucalón, quedaria mermada su autoridad, reducida únicamente en ese caso a los asuntos puramente militares, y subordinada a la del Presidente del Cuzco. Por tanto no es difícil imaginarse que le fuera costoso resignarse a ceder los plenos poderes que el Virrey le había concedido y quedar a las órdenes de un individuo cuya conducta habia dejado tanto que desear en los recientes sucesos de Quito. Muy facilmente, pues, nos puede explicar esto la actitud de Goyeneche. Además, Abascal se dió cuenta de los motivos que impulsaban a Goyeneche, y tenía presente la anterior actuación de Cucalón, con las consecuencias que se derivarian de su colocación en puesto tan delicado como la Presidencia del Cuzco.

El Virrey decidió acabar con la causa de todos los posibles males reteniendo el nombramiento, y comunicó las circunstancias del caso al Gobierno. Estudiado el asunto, la Junta Central accedió a su solicitud. Goyeneche Pué confirmado en su actual puesto y terminaron por ahora los motivos del disgusto entre ambos (13). La actitud del Virrey, que pudo parecer de excesiva libertad, se encuentra sin embargo plenamente justificada por la conducta equívoca de Cucalón durante los acontecimientos de Quito. Abascal obró con gran prudencia a fin de evitar los roces que necesariamente habian de sobrevenir entre aquél y Goyeneche en caso de haber ocupado su puesto.

También adujo el Virrey como motivos que le impulisaron a tomar su decisión el desencanto que causó en el Cuzco y en el ejército el nombramiento de $\mathrm{Cu}$ calón. El 11 de diciembre de 1810 la Audiencia del Cuzco escribía a Abascal haciéndole ver el trastorno que se produciría con la separación de Goyeneche, en cuyo ejército estaban las familias y los hermanos de

(13) Arch. Abascal. Relación de documentos de los informes hechos a la Corte sobre Cucalóns. Oficio de Abascal de 17 de enero de 1811 al Ministro de Estado y del Despacho Universal de la Guerra, y cMemorias; Tomo II, Páġs. 156-157. 
Los cuzqueños, que estimaban de todo corazón a su General; protesta que renovó el 26 de enero de 1811, significándole que res tanta la exasperación que manifiestan sus habitantes sin el menor rebozo, que teme una catástrofe irremediables, lo que ponía en conocimínto del Virrey con el fin de descargarse de la responsabilidad por los acontecimientos que pudiesen ocurrir (14).

Junto con los escritos de la Audiencia del Cuzco se recibió en Lima otro firmado por Ramírez, Tristán, Picoada, Piérola, Lombera y demás jefes del Ejército, en el que de un modo claro hacían ver al Virrey que el Ejército del Alto Perú había tomado por dos veces las armas para defender al Virreinato contra la sublevación *que habría corrido hasta la capital de V. E. como un torrente impetuoso, si no encontrase el dique que aqui la represa». En estos términos, algo duros, resaltaban ante el Virrey que el organizador de tal dique fué únicamente Goyeneche, de cuya conservación en el mando dependía el mantenimiento del Perú. Por ello pedian a Abascal que no diese curso a tales órdenes, que significarían una verdadera catástrofe (15).

A ambas representaciones puede que no fuera muy extraño el propio Virrey, que pudo dar la idea; pero aun asi, aunque hubieran sido simplemente un medio de reforzar su actitud, los acontecimientos que más tarde se desarrollaron le dieron la razón ampliamente.

Abascal tranquilizó a Goyeneche, asegurándole su continuación en el mando a la par que le hacía ver la responsabilidad que sobre sus espaldas pesaba y en el compromiso en que se hallaban, obligados a trabaJar con toda su buena voluntad para el logro de sus objetivos. «Estamos en el caso preciso e indispensable-le dice en la carta ya citada-de abandonar el

(14) Arch. Abascal. «Relación de doeumentos de los informes hechos a la Corte sobre Cucalóns. Oficios reservados de la Au, diencia del Cuzco al Virrey de Perú, 11 de diciembre de 1810 y 26 de enero de 1811.

(15) Arch. Abascal. \&elación de documentos de los informes hechos a la Corte sobre Cucalóns. Oficio de los jefes del Ejército a Abascal. Cuartel General de Zepita, 16 do enero de 1811. 
honor, 9 defender; hasta exhalar nuestro espiritu lo8 sq́grados deberes a que este nos liga» (16).

El hecho de que la situación era oxtremadamente delicada no pasab a desapercibido a los ojos del Virxey, como asimismo la dificultad en que se hallaban para supperarle. Veia que la revolución crecía por momento: se afianzaba en Buenos Aires, rebrotaba en Quito y se extendía a Chile. A todas partes, sin embargo; atendía Abaseal con trabajo, pero desplegando una energía y actividad nada comunes. Los pximeros desgraciados reveses de las tropas del Alto Perú le hicieron ver lo crítico del momento. Los medios de que disponia no habrian de bastarle para llevar a cabo sus vastos planes; la ayuda de Montevideo era cada vez más płoblemática, y por mucho que los ejéroitos realistas pudieran resistir, conociendo su actual estada, no cabía duda que llegaria pronto el momento en que todia la resistencia del Pexú se derrumbase en los frentes, minada también la retaguardia por la propaganda revolucionaria.

De todos los teatros de la lucha el que con más cuidado atendía Abascal era el del Alto Perí, persuadido, como digo, de que en él habría de dilucidarse la swerte de toda la América del Sur. Y es ésta quizás una de las pruebas más impartante de su gran visión política, al principio pudo creer que los disturbips de la ciudad de Buenos Aires eran semejantes a los ocurridos hasta entonces en algún ptizo punta de América del Sur, pero bien pronto se percató de su trascendencia y se afirmó en su opinión al tener notigia de los tristes sucesos del Alto Perú, Por ellk, y como la causa del mal, a su entender, estaba en Buenos Aires, sus principales fuerzas se dipigen contra aquella ciudad y trata no sólo de liberar los territorios oqupados por sus tropas, sino ineluso erppjenders una acción of ensivg, llegado el mpmpata, contra la misma capital. Pero como sus medios no le bastaban se dirigía en constantes demandas de ayuda a la Península, pidiendo el envío de unos cuantas de miles de hombres a América. $\Psi$ de su opinión sobre la trass

616) Arek C. Guqqui. C. 13. Carp. 2. N. 23. Carta de Abasoal a Goyentie. Lidana:11, de octubre der,1810. 
exndencia de este auxilio nos da idea una carta dirigicta al Marqués de Casa-Irujo, entonces embajâdor de Espana ante la Corte del Brasil. En ella le décia Abascal: \&...y entiende que sin la venida de tropas de la península al virreinato de Buenos Aires y Presidencla de Chtle, ganarán mucho terreno haela la Indepertdencia que se han propuestd; por to que si V. E. thene medios de concurrir at importantísimo objeto de que por Monitevideo se introduzcan refuetzos competentess le vuego encarecidamente lo haga $\$$ me adelante los aviso's conducentes para poder yo. conformar mis medidas y combinaciones de modo que se asegure el felíz éxito que se desea y convienes (17). Aquí está todo el'plari de Abascal. Con un apoyo eficaz desde Montevideo, 'pođría comenzar la ofensiva para coger a las fuerzas insurgentes entre dos futegos; y una vez derrotadas, dirigirse hacla la capital por mar y por tierra. A esta espera de noticias de Montevideb sé debló; más que a niguna otra cosa, la inacéión del ejército dèl Desaguadero una vez térmińadó su adiestramiento. El nilismo virtey asi lo declara cuando díce: eEl ejétcito que mantengo en la raya del Virrelnato de Buenos Aires contintua en observación sin hostilizar en nada a los insurgentes, ínterin podamos tener noticia de lo que plensa ejecutar don Francisco Xavier Elio por $1 \mathrm{~d}$ parte de Montevideos. Aurique más adelante píésa que no se prolongará por thucho tiempo esta sitáación: «...creo no podrá durar está especle de netutâlidad, pues los enemigos letantan gente a toda prisa en el Alto Perú de su dóminátión y se van aproximando a nuestra vanguterdia, al paso que esparcen proclamas amenazatites;.? (29). Con 10 cital da a enterder que le van a obligar a tomar una resolución extrema, aun antes de tener noticias de Mantevitue, pues le impulsaba a ello la actitud hostil de los insurgéntés. Es interésante, sin embarbo, 'este dato part expllcarnos el desarrollo de los pástériores sucesos.

(17) A. G. I.-Lima, 649. Copia de carta de Abascal al Märqués de Casa-Irtóv. Istà, 8 de enero de 1811.

iitil12) Arok Abescall. Minuta de carta do Abastead a Pérez de Casbo. Jums, 8 de mayo de 1811. 
Entretanto, en el Desaguadero continuaba la preparación de ambos ejércitos, pues si Goyeneche preparaba el suyo para una próxima ofensiva, Cestellí y Balcarce, situados con su Cuartel General en Laja, reunian sus tropas de todas las provincias del Alto Perú pensando a su vez en tomar de nuevo la iniciativa. Es indudable que si al llegar el ejército argentino al Desaguadero se hubiese encontrado capaz de proseguir su marcha por el interior del Perú, su triunfo hubiese sido indiscutible. La resistencia que hubiera podido oponerle Goyeneche era minima, y una vez pasada esta barrera no hubiese encontrado ningún obstáculo en el resto del Virreinato. Pero los argentinos llegaron desorganizados al Desaguadero. Los triunfos anteriores habian elevado su moral, mas no habían conseguido aún su completa organización. Además, los contingentes que se le agregaban procedentes del Alto Perú, no tenian la menor disciplina, y hubiera sido aventurado lanzarse a una expedición al Perú con un ejército todavía poco preparado y tan lejos de sus bases de operaciones. Por eso, el período que medió entre la llegada del ejército argentino a la frontera del Perú y la reanudación de las hostilidades, en junio de 1811, se puede considerar simplemente como un momento de descanso y reorganización de ambos contendientes, y en manera alguna como una estabilización de la lucha. No son de extrañar, pues, las órdenes constantes de Abascal a Goyeneche indicándole que se mantuviese en una defensiva enérgica y dispuesto a atacar cuando la ocasión lo requiriera.

Se ha visto anteriormente que la suspensión de las hostilidades fué debida a la solicitud del Cabildo de La Paz, aceptada por el Virrey, a pesar de estar convencido de su nulidad, atribuida por él a la falta de representación legítima de la Junta (19). En el período que sucedió al cese de la lucha tuvieron lugar una serie de pequeños incidentes perfectamente detallados en la «Memoria Militar» del Capitán Alvarez (20), y citados todos por el señor Herreros de Te-

(19) ABASCAL. Memoria. Tomo II. Pdg. 234.

(20) Arch C. Geagui. C. 6. Carp! 7. N. 11. Memoria militar de la guerra insurreccional del Perús. Cuaderno cuarto: febrero, 
Jada (21). Por tanto, me limitaré a reseñar únicamente los más impontantes.

Los meses de enero y febrero transcurrieron con gran actividad en la organización del ejército, jperro con absoluta tranquilidad en el terreno de la lucha. Sin embargo, el 26 de febrero, al tenerse noticias de que los porteños habian avanzado un destacamento hasta el pueblo de Huaqui, y que sus pretensiones eran ocupar la cabeza de puente del Desaguadero y el territorio del Virreinato de Buenos Aires que más allá del río tenían en su poder los realistas, se reforzo la avanzada situada en el camino de La Paz, único punto por donde podían llevar a cabo sus deseos. No hubo, sin embargo, ningún intento de acupar este terreno por la fuerza, limitándose únicamente a un cambio de oficios entre el jefe de la unidad argentina que ocupaba Huaqui, y Picoaga, que mandaba la vanguardia al lado allá del rio, abandonando por fin aquéllos el pueblo de Huaqui.

El 19 de marzo hubo nuevas reclamaciones de Castellí, en las que aludía también a una exploración que con objeto de levantar un plano llevaron a cabo los realistas hasta el pueblo de Huaqui. El jefe argentina se quejaba de que con ella se había violado la paz establecida, y opinaba que debía y podía tomar posesión de la línea del Desaguadero, sin que ello significase una violación de la paz. La respuesta fué terminante y se resolvió su petición comunicándole que cualquier - intento de llevar a cabo su propósito sería tomado como el comienzo de las hostilidades.

Recibida en el campamento realista la noticia de que los insurgentes se concentraban en el pueblo de Laja y que algunos destacamentos llegaban hasta Huaqui, se reforzó aún más la avanzada del Desaguadero con un batallón de Paruro para prevenir cualquier sorpresa. Igualmente fué reforzado el Estrecho de Tiquina, en el Titicaca, y se sustituyó la caballería que se encontraba en el pueblo de Yunguyo por una compañía de fusileros.

marzo, abril y mayo de 1811. Cuarte General de Oraro, 8 de abril de) 1818.

(21) HERREROS DE TEJARA, Luis. Op, cit. Págs. 264-265. 
Parecía inevitable la ruptura de las hostilidades. Desde el momento en que de un mado extraoficial llegan noticias a Lima del desembate de Elío con 7.000 hombres en Montevideo, el Virrey cree Hegada la neasión que esperaba Convoice una Junta y advierte a Goyeneche que esté preparado para atacar transcurridos seis días, último plazo dado a los insurgentes para que se acojan al ind ulto forometido por Fdía; previa la publicación de su mantétesto: 'haciendo ver las causas que a ello le conducía; debía llevar a cabo una acción definitiva contra los sublevadosi Sin embargo, Abascal reparaba en las consecuebcias, que pudiera tener tal medida, y decía a Goyeneche: « Vd. no se le oculta'rque de los primeros pasos, bien - mal meditados, deben resultar fellces o desgraciados incidentes, y el pulso y circunspección y tino con que por esta razón se debía emprendiors. Caso de ser favorable esta pcimera acción, convenía «actuar con la mayor energía y rapidez para sujetar todo el Alto Perú antes que tengan lugar de juntarse ni reconocrsex. (28). Para llevarla a cabo le favorecia su superioridad sobre el enemigo, pives mientras sus tropas llegaban alrededor de 7.000 hombres, aquallos teháan, segun el Virrey, «en Oruro 2.000 hombres, que son sus mejones tropas; en Vireha, 1.200, cogidos tumultuariamente en La Pazs, y los que hubiesen sacado de Cochabamba. Por eso Abascal se mostraba confiado en la victoria sin dejar de preoaver las posibilidades contrarias, pues, como decía a Gozeneché, el ememigo . «no presenta un aspecta de Doder resistir la fuerza de Vd., tanto por el úmero cuanto por la disefplina, Instrucción y apresto de todo lo necesanio; pero sin embargo de todo, no lay onernigo despreciablo, y en la guerra suceden con frecueneia acasos que no puede prevenir el espínitu humbino, por cuya razón no se crebe ldesprectar la menor cosa para estar precavido contra todo lo que pueda sobreverifir (23).

in Stn embango', las resoluciones de la Junta, por

(22) Areh. C. Graqui. C. 13. Carp. 3. N. 20. Carta de Abascal a Coyenether Lima!'20, marzo de 1811.

(23) Arch. C. Guaqui. C. 13. Carp. 3. N. 20. Carta de Abascal

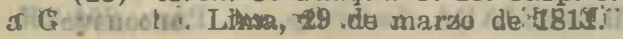


euanto interesaba aprovectiar una ocasión favorable que garantrizese el éxito, tenían un carácter relativo; Qependiendó su ejecueión de las noticias que llegasen de Elío sabre Burros Altes, de las decisiones de un Consejo de Guerra que debía celebrarse en el campamento de las tropas del Desaguadero y de los estat dosude fuerzas que se le pedían a Goyeneche, circunotancia esta última que provocó el disgusto del General y le movió a solicitar do mupro su dimisiớn (24).

Celebrado Consejo de Guerra en el Désaguadero y examinadr la situación, se decidió demorar el ataque hasta la Heigada de la época de la cosecha, en que, según costumbre, los cochabambinos desertarfan para volvers@ a sus casas y ocuparse de sus labores. A la par se dabs tiempa pasa observar los efectos del in dulto y megiorar eil estado de la Tesorería del ejércitó, cuya situación hacía ver que no era prudente aventurarse a la ofensive. Sin embargo, se determinó que si llegaban noticias de la toma de Buenos Atres por Blío, se empxesudiese inmediatamente la ofenisiva con el fin de apropechar circunstancia $\tan$ favorable; entretanto se tomaban las medidas para precaver cualquier a taque emignigo (25). Todas las resoluoio hes fueron aprobadas por una nueva Junta de Guèra celebrada en Lima, en donde se rutificaban los plemos pocieres concedidos al Jefe del Ejército del Besaguadero.

El 11 de abril los realistas efectuaror una incursión armada con un destacamento de 50 hombres en et territorto enemigo para llevar a cabo un reconocimienito en el sessino pueblo de Huarquic En los alre. dedores encerstrairon una pequeña partida ememigg; compuesta de 14 soldados y varios indios. El resultado de la escaramuza fué la retirada del grupo insturgente? que dejó 5 prisioneros y varios heridos,ipero sin más trénscendercia para la situación de ambosiejércitos. El día 14 se recibió en el Curartel General de Goyeneche un pliego de Díaz Vélez, Comandante de la vanguadidie argentina; en aure hacia constar que la int cursión hasta Huaqui habja quetera ntado la buerra

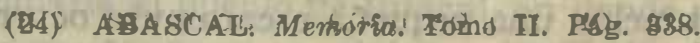

(25) ABBABCAL. Memonia: Tomo II ỉág, B41: : 
armonia existente entre los dos bandos, y que el corto número de soldados que guarneciar Huaqui, en manera alguna podía constituir una amenaza para el ejército realista. Pedía la restitución de los prtsioneros y la retirada de las tropas realistas al otro lado del Besaguadero, considerando rota la tregua en caso contrario. Aunque el pliego de Díaz Vélez daba a Coyenecho un plazo máximo de dos horas para contestarlo, no se le envió la respuesta hasta el dia siguiente y en sentido negativo. Entretanto, a fin de evitar cualquiter sorpresa de los enemigos, envió Goyeneche al Deseguadero el día 16 las divisiones del Real de Lima, Paucartambo y los Dragones de Chumbivilcas, enviando los últimos al cerro de San Andrés de Machaca para reforzar las avanzadas del valle de Jesús de Machaca. El mismo trasladó su Cuartel General al Desaguadero el día 17, y llevó consigo las compañías de zapadores minadores, de granaderos del Cuzco, pardos y morenos. La vanguardia ocupó el pequeño pueblo del Desaguadero. situado al otro lado del río en terrreno del Virreinato de Buenos Aires, y colocô sus avanzadas más al interior, en los caminos que por las montañas desembocan al río. A la vez se comenzó a abrir un camino en dirección a Huaqui, a través del monte San Cristóbal.

A partir de entonees, quedaron fijadas las postciones de los dos ejércitos hasta dos meses más tarde, que tuvo lugar el encuentro definitivo. La posición de los realistas se ha visto ya más arriba: en poco se había modificado, limitándose casi únicamente a reforzar algunos puntos o a ocupar otros con el objeto de dominar todos los caminos que condujesen al río para manterer la cabeza de puente y defenderla de cualquier ataque enemigo La más elemental estrategia hacía ver cuán valiosa era su conservación.

En cuanto al ejército argentino, ocupaba los dos puntos de entrada de los caminos que conducían al Desaguadero: al Norte habian ocupado el pueblo de Huaqui, y al Sur el de Jestis Machaca, avanzando su Cuartel General hasta Lafá.

Colocados así ambos elércitos, todo hacía pensar en un próximo e inevitable choque. Aún vino a empeorar la situación una pequeña escaramuza ocurrida en el Estrecho de Tiquina, originada por un desembar- 
co efectuado en la orilla opuesta por las tropas realistas. Fueron hostilizadas por los enemigos y se abrió el fuego entre ambas, retirándose poco después los peruanos.

Ocurrió el incidente el dia 24, y el 25 Castellí enviaba a Goyeneche una queja por la transgresión de la paz que suponian las escaramuzas de Huaqui y Tiquina, manifestando que los realistas habian sido los agresores. La contestación de éstos le hacía ver la disposición pacifica de sus fuerzas, que desde el mes de noviembre pasado no habian hecho ningún acto hostil contra los argentinos, a pesar de los esfuerzos de éstos para inquietar a los pueblos del Perú con proclamas sediciosas. En cuanto a las escaramuzas habidas, se le hacia saber que en manera alguna formaban parte de un plan militar, sino que procedian de la agresión de los suyos, que rompian el fuego «contra el celo y ardor de nuestros oficiales». Ciertamente, según parece, en las dos escaramuzas habian sido los insurgentes quienes rompieron el fuego, pero tampoco es menos cierto que en manera alguna ésto justificaba las exploraciones de los realistas por territorio enemigo. Todo lo cual viene a reforzar la opinión de que, tanto por unos como por otros, el período de paz era considerado más bien que como tal, como periodo preparatorio de una ofensiva general. Los primeros encuentros y tanteos hacian pensar en una próxima ruptura de las hostilidades, tanto más inevitable, cuanto que arreciaba la propaganda revolucionaria esparcida por los argentinos en el interior del Perú y que Castelli dirigía a todos los Cabildos del Virreinato.

En vista de la insistencia de los insurgentes en introducir propaganda subversiva, y ante el temor de un ataque por su parte, convocó Goyeneche nuevo Consejo de Guerra en el campamento el día 5 de mayo. Examinada minuciosamente la situación creada por la propaganda enemiga, se decidió tomar la ofensiva tan pronto llegasen 400 fusileros que se esperaban de Lima, aprovechándose el corto tiempo que mediase hasta entoncés para recaudar algún dinero con destino a la caja del Ejército. Recibido el material, se ocuparia el pueblo de Huaqui, en donde por última 
vez se publicaria una proclama del general invitando a los sublevados a deponer las armas (26).

En la noche del 11. llegaron al Desaguadero unos pliegos del Cabildo de Lima dirigidos a Castelli y a los Ayuntamientos del Río de la Plata. Contenían una propuesta del Cabildo de la capital dirigida a la Iunta de Buenos Aires, en la que le transmitian las once proposiciones de los diputados americanos a las Cortes, y les ofrecia la paz sobre la base de dichos puntos, aceptando la autoridad del Organismo soberano, e indicándole que cualquier acto hostil seria un crimen de lesa humanidad (27). Dicha propuesta tenia la aprobación del Virrey, que quiso encontrar con ella una solución antes de lanzarse de nuevo a la guerra.

Llegados al campamento los fusiles que se esperaban de Lima, se debia comenzar la ofensiva, según el acuerdo tomado en el Consejo de Guerra del día 5; pero dada la circunstancia de hallarse en trance la negociación ofrecida por el Cabildo de Lima, se acordó en nueva Junta celebrada el dia 12, esperar la contestación de Castelli, con objeto de evitar, si fuese posible, la renovación de la lucha, mientras quedaba preparado el ejército para ponerse en marcha en cualquier momento.

Poco se hizo esperar la contestación. El dia 14 se presentó un parlamentario argentino con un oficio dirigido al Cabildo de Lima, rechazando de plano sus ofrecimientos de paz sobre los puntos propuestos. Se le indicaba al Cabildo que lo ofrecido por él les pertenecía de derecho, y que a mucho más se había llegado en el sistema adoptado por la Junta. Decia tamblén Castellí en dicho oficio que la disposición de su ejército era la quietud «púes, sin embargo, de ir ya avanzando al campo de Lima la izquierda y derecha del ejército combinado y hallarse la vanguardia de nuestra fuerza central en Tiaguanaco en disposición de operar militarmente, y su retaguardia en la de moverse de este punto, luego que se han recibido los pliegos de $\mathrm{V}$. E. he determinado, de acuerdo con los generales

(26) - Vid. nota 20.

(27) A G. I-Lima, 741. Oficio de Ayuntamiento de Lima a la Junta de Buenos Aires. Lima, 28 de abril de 1811. Publ. en la - Gaceta de Lima n. $0^{\circ}$, de 30 de abril del mismo. 
del Ejército y demás Jefes del Estado Mayor... proponernos un armisticio de cuarenta días improrrogables; contados desde el día de la fecha hasta que, en presencia de la contestación que espero de V. E., se alejen ambos ejércitos a mayor distancia de la línea que divide ese territorio del nuestro para entrar libremente en negociaciones estables... Esta proposición de armisticio se la comunicaba también a Goyeneche, y terminaba su oficio advirtiendo al Ayuntamiento que se dirigiera a él para todo lo referente a la negociación, pues tenia plenas facultades de la Junta, asi como él por su parte se dirigiría al Ayuntamiento de Lima, único Organismo en quien reconocía la representación más legítima e inmediata de los pueblos (28).

El armisticio propuesto por Castelli a Goyeneche constaba de nueve artículos, cuyo tenor es el siguiente:

\&1. -Durante el tiempo de la tregua habrá buena fe, paz permanente, y seguridad reciproca en las estipulaciones que se pacten.

2. - -Respecto a que los campamentos de este ejército se hallan situados en la banda opuesta del Desaguadero, y que la Naturaleza parece haber marcado en sus alturas una línea de verdadero limite, diferenciada por lo establecido en pocas varas, que seria penosa su traslación, los puestos avanzados de este ejército conservarán sus posiciones sobre las cúspides y alturas de dicha serrania.

3.2-Los puestos enemigos, con su fuerza actual y Cuartel General, conservarán sus posiciones.

4. - Algunas partidas sueltas de este ejército podrán, desarmadas, adelantarse al punto donde encuentren forrajes y viveres frescos, como a distancia de tres leguas, debiendo pagar éstos en dinero contante, y por sus Justos valores, y sin que estas medidas que exigen armonía y buena inteligencia, sean motivos de reclamaciones y sorpresas, y por reciprocidad de ella franqueará el general los auxilios de esta clase, que el ejército contrario pudiese exigir en iguales materias en su territorio.

5.-Toda vejación que la indiscreción o algún otro

(28) A. G. I.--Lima, 741. Copia de Oficio de Castellf al Ayuntamiento de Lima. Cuartel General de Laja, 13 de mayo de 1811. 
estimulo de otra clase cause a los individuos que suministrasen estas especies en virtud de reclamación oficial, será indemnizadas y satisfechas a la parte reclamante.

6. - Si durante el armisticio se presentasen desertores de una y otra parte reclamando la protección de las banderas, serán admitidos, y so pretexto alguno demandados.

7. - En el mismo tiempo se prohibe a una y otra parte la internación de papeles denigrativos que atenten al decoro de las autoridades establecidas, y los correos y libre comercio serán protegidos.

8. - Siempre que las proposiciones remitidas a la capital de Lima no fuesen adoptadas, no podrán :omperse las hostilidades, sino después de cuarenta y ocho horas de la notificación por ambas partes de quedar disuelta la negociación.

9. - Estos articulos, fírmados y sellados, serán ratificados en el término de veinte y cuatro horas de su presentación, durables por término de cuarenta días, quedando copias en poder de las partes contrarias» (29).

Este armisticio fué aprobado en principio por una Junta reunida en el campamento de Goyeneche el dia 15, en tanto se recibía la aprobación del Virrey. Sin embargo, en dicha Junta hubo algunas rectificaciones en determinados artículos, que fueron aceptadas por Castellí, que las trató al dia siguiente con el Teniente Coronel don Mariano Campero, comisionado de Goyeneche. Se referían a los artículos segundo y tercero, y hacian constar que la parte del Virreinato de Buenos Aires ocupada por los realistas no se entendia en manera alguna como una nueva demarcación de límites, ofreciéndose mutuamente no mover las tropas ni efectuar acto alguno de carácter hostil o sospechoso.

De la lectura de los artículos del armisticio se deduce que lo único que pretendía Castelli al proponerlo era asegurarse la tranquilidad durante el tiempo de la negociación con el Cabildo, y en manera alguna establecerlo como preliminar de paz. Quizás hubiesen 
llegado a sus oídos las noticias de los preparativos de Goyeneche y querría acabar los suyos en este tiempo. Pero ciertamente el admitir desertores y permitir las partidas de forrajeos (articulos $4 .^{\circ}$ y $\left.60^{\circ}\right)$, eran puntos que se prestaban a posibles incidencias. En cambio, los artículos segundo y tercero no me parecen tan absurdos como se han querido hacer ver (30). A mi Juicio, no significaban en manera alguna, ni poca inteligencia de las condiciones topográficas del terreno, ni imprevisión de los jefes argentinos, como lo demuestran las reclamaciones que hasta entonces habian hecho para ocupar ese territorio. Más bien es, a mi modo de ver, el resultado de la convicción que tenia Castellí de que era inútil insistir en recuperarlo por las negociaciones, $\mathrm{y}$, en cambio, una extremada insistencia podía poner estas negociaciones en peligro y comprometer su situación.

Enviados a Lima para su aprobación el oficio del día 3, de Castellí al Ayuntamiento y los artículos del armisticio, fueron todos remitidos al Virrey. El Cabildo, al considerar los términos en que estaba concebida la respuesta del Delegado de la Junta de Buenos Aires, decidió someterlo a la decisión de aquél y dar por concluida «por ahora y para siempre esta conversación» (31).

En realidad, a partir de entonces quedaba virtualmente anulado el armisticio, aunque según su articulo $8 .^{\circ}$, dicha anulación no tendría validez hasta pasado cuarenta y ocho horas de notificado el cese de las negociaciones a ambos bandos.

Pero la anulación oficial del armisticio se llevó a cabo inmediatamente. El mismo dia en que el Cabildo contestaba a Castelli, el 1 de Junio, recibidos los papeles referentes a las negociaciones, convocaba el Virrey una Junta de Guerra en su palacio, a la que asistieron el Arzobispo de Lima, don Bartolomé Maria de las Heras; don Toribio Montes; el Regente de la

(30) LOPEZ, V. F. Historia de la República Argentina. B. Aires, 1883. Tomo III. Pág. 592, y MITRE, B. op. cit. Tomo II. Pág. 215.

(31) A. G. I. Lima, 741. Copia de Oficio del Cabildo de Lima a Castelli. Lima, $10^{\circ}$ de junio de 1811. 
Audiencia, Marqués de San Juan Nepomuceno; el Brigadier Cucalón; el Inspector de Artilleria, don Joaquín de la Pezuela; el Coronel del Regimiento Real de Lima, don Gabino Gainza; el Subinspector de Ingenieros, don Pedro Antonio Molina; Alcaldes Ordlnarios, Marqués de Torre-Tagle y don Andrés Salazar, y el Comandante de Marina, don José Pascual de Vivero. Reunidos bajo la presidencia del Virrey, examinaron todos los papeles referentes al asunto. Conocida la respuesta del Cabildo decidiendo suspender las negociaciones, fueron de opinión de considerar nula la tregua de cuarenta dias, y, «volviendo las cosas al estado en que se hallaban antes de ella, como si no hubiera sucedido, proceda el Sr. General en Jefe del Ejército del Desaguadero con arreglo a las facultades que se le tienen conferidas, según le dicte su constante celo por la Justa causa que defendemos...» (32).

La decisión de la Junta era, pues, clara y definitiva: la tregua quedaba oficialmente anulada. Los dos ejércitos se encontraban, por tanto, en estado de guelra. Asi se lo hacia constar Abascal a Goyeneche el dia siguiente al de la Junta: \&...se halla V. S. expedito para obrar ofensiva y defensivamente; según lo exijan las circunstancias y le dicte su probado y constante celo por el mejor servicio del Rey, teniendo yo la satisfacción de que ni evitará los favorables momentos de atacar y batir al enemigo, ni emprenderá operación de cuyo buen resultado no tenga prudente probabilidads (33).

A partir de este momento, Goyeneche se encontraba con las manos libres, y con completa iniciativa. Por tanto, no hacia sino obedecer órdenes del Virrey. $\mathrm{Y}$, por otra parte, parece natural que hubo suficiente espacio de tiempo entre el día 1 de Junio, en que el Cabildo consideró rotas las negociaciones con Castellí, hasta el 20, en que tuvo lugar el encuentro entre ambos ejércitos, para que llegase al Desaguadero la noticia de tal decisión. Además, el mismo Castellí debía

(32) A. G. I.-Lima, 741. Copia de Acta de la Junta de Guerra celebrada en Lima el día $10^{\circ}$ de jupio de 1811.

(33) A. G. I.-Lima, 741. Copia de Oficio de Abascal a Goyeneche. Lima, 2 de junio de 1811. 
tener la convicción interna de que sus proposiciones estaban condenadas al fracaso, desde el momento en que no aceptaba los puntos sobre los que se las hacia a su vez el Cabildo. Por consiguiente creo que, tanto Castelli como Goyeneche, estaban convencidos de que de un momento a otro tendría lugar el encuentro, aun antes de termina la tregua; e incluso es probable que aquél tuviese noticias, si no de su anulación oficial, que no es de extrañar la tuviese también, al menos de la respuesta del Cabildo, con lo que prácticamente quedaba del mismo modo anulado.

Dos thechos vinieron a unirse a estas circunstancias y contribuyeron aún más a elevar la tensión que existia entre ambos efércitos. Tuvo lugar uno de ellos en el pueblo de Huaqui, el dia 17, en que una partida del ejército realista dedicada al forrajeo, fué atacada en las cercanias de dicho pueblo en una emboscada, perdiendo algunos prisioneros y caballería. El otro ocurrió en el de Pisacoma. Algunos centenares de hombres de la caballería cochabambina sorprendieron el pueblo de este nombre; entraron en él, aprisionaron la pequeña guarnición y causaron daños en el poblado (34):

La escaramuza de Pisacoma originó una enérgica protesta de Goyeneche, en cuanto que significaba una violación del armisticio establecido unos días antes. La disculpa presentada por el General Díaz-Vélez, de que Rivero, a quien pertenecian las tropas que atacaron el pueblo, no tenia noticia del armisticio, era a todas luces insuficiente. Es absurdo suponer que la parte del ejército argentino que ocupaba. Jesús de Machaca, en donde estaba Rivero, no tuviese noticia aún de tal pacto, cuando la distancia entre este punto y Huaqui podía cubrirse en sólo unas horas.

El incidente de Huaqui no podía explicarse como consecuencia de un abuso por parte de los realistas del artículo 4. del armisticio, pues si éstos se internaron en territorio ocupado por los porteños era debido a que en dicho artículo se establecía que podrian sacar forrajes «como a distancia de tres leguass, territorio en el que estaba comprendido Huaqui. El ata- 
que porteño a esta partida no se Justificaba, pues, y quedaba como una violación de lo tratado, así como el de Pisacoma, menos disculpable aún.

Estos incidentes y los intentos de sublevación en el interior, de resultas de la propaganda revolucionaria, hicieron anular prácticamente el armisticio. Por último, como réplica a los ataques de sus enemigos, Goyeneche envió 400 hombres de infantería y 50 de a caballo en dirección de Machaca, al mando de Ramirez, que sorprendieron a su cortísima guarnición y se retiraron de nuevo.

En realidad, el armisticio, como dice Mitre, «mal observado por una y otra parte, como que la buena voluntad no presidió a su ajuste ni por una ni por otra parte, a los pocos días de fírmado estaba desvirtuado de hecho como prelíminar de paz y hasta como compromiso de guerras (35). El valor del armisticio como tal, fué, pues, casi nulo, ya que a pesar de él se mantenia la misma situación y ninguno de los dos bandos tenía mucho interés en observarlo.

Pero a mediados de Junio lo más tarde, debieron llegar a Goyeneche los oficios de Abascal anulando la tregua. Comunicados al enemigo, el General se encontraba libre de todo compromiso para tomar el partido de la ofensiva o la defensiva, según considerase oportuno.

La actividad de los argentinos hacía sospechar a Goyeneche. El 19 de Junio tuvo noticias de que se habian situado en Huaqui, Caza y Machaca. Con el movimiento de las tropas se violaba el artículo tercero del armísticio; pero no fué sólo esto, sino que, dos leguas más abajo de Machaca, los cochabambinos habian hecho un puente sobre el río y pasaron 1.200 hombres, colocados a cuatro leguas de la división de Lombera, situada a la derecha del dispositivo de Goyeneche. Al mismo tiempo llegaban noticias de los intentos de sublevación de Tacna, que en caso de triunfar dejarian cogidos entre dos fuegos al ejército del Desaguadero. Se imponia, indudablemente, una decisión ante el peligro que lo amenazaba.

El 19 de Junio, el mismo día en que se recibieron

(35) MITRE, Bartolomé. Op. cit. Tomo II. Pág. 215. 
estas noticias, convocó Goyeneche Junta de Guerra. Planteada la cuestión de atacar al enemigo, comenzó una acalorada díscusión sobre las convenlencias de adelantar el ataque al día 20. Puesto al fin de acuerdos los fełes; se preparó el ejército para la marcha que comenzó a las tres de la mañana del 20 de Junio (36).

El ejétcito, dividido en dos columnas, marchó por los dos valles que se presentaban ante él. Por el del Norte, hacia Huaqui, marchó Goyeneche con eliRegimiento del Real de LAma, 300 hombres de caballería, 40 de su guardia y 6 cañones, con los jefes Picoaga y Piérola. Aquel punto habia sido destinado para instalar en él el Cuartel General una vez conquistado.

Par el valle del Sur, hacia Caza y Machaca, se encaminó la segunda columna, mandada por Ramírez; con las batallones del Coronel Astete, del Teniente Coronel don Luis Astete y don Mariano Lechuga con 350 hombres de caballeria de Arequipa y Tinta, con 4 cañones.

La Idea de Goyeneche era desalojar al enemigo de los valles y. empujarlo hacia las llanuras de La Paz. 81.dograba llevarla a cabo de un modo enérgico, consegútría su desorganización total y el camino del Alto Perú se le ofrecería abierto. Si por el contrario la suerte le era adversa, se replegaría hasta repasar el rio, en donde le sería extremadamente fácil la defensa.

Delante del ejército en marcha, hizo desplegar una cortina de guerrillas que pronto se posesionaron de los primeros cerros en donde estaban colocadas las avanzadas enemigas, integradas por indios, soldados de caballeria y fusileros. Entre tanto, Ramírez, con los batallones de Paruro, Paucartambo y Abancay, proseguía su avance, precedido de dos partidas de caballeria para descubrir el terreno a las guerrillas y evitarles las emboscadas. Ante la noticia de la presencia de los enemigas hizo avanzar la caballería mientras colacaba en orten de batalla la división de Paruro,

(36) Utilizo fundamentalmente para estudiar la batalla de Húăư los pártes dé Gołeneche a Abascal, de 22 de Junio de 1811, y de Rathírét a Goyenedhe, dét 24 de júnio de 1811; publicados por HERREROS DE TEJADA en su obra citada, en la que se limita a transcribirlos, 
que cubria a las otras dos y a la actilteria, con la caballeria a retaguardia. Además, apresuró, el paso, intr tentando llegar al abra del camina, la Quebrada de Jaumieoragua, que pone en comurieación el valile de Huraqui con el de Machaca, adonde esperaba encontzar ya a Goyreneche. La posesión de este atura era fundamental para ambas columnas, pues era el ẃnico medio de mantener la comunicactón durante el curso de la batalla.

Pero dos leguas antes de llegar a la Quebradta se encontró con las guerriblas evemiggs, con un conjun to de doscientos hombres., No fue dura la mesistencha que te ofrecieron: tnas las primeras desoangas se replegaron al grueso de las fuerzas que axanzaban protegidas por una bateria situada en un cerro que dorainatoa el camino.

- Antes ila praximates del grueso del enemigo, cuya staperioridad exa notoria, Ramírez forma los tres batallones en columna avaozando bajo su fuztga durante tres cuarto de legua. El ataque de Ramirez en estas oondiciones fué nechazado por las tropas de viamonte, desplezadas en el camino, aporyaxias en los cerros de la derechr, D'protegidas por dos obusez, que pusia ron on grave peligro ia los realistas, desordenando su límea.

Entretanto, Goveneche, que habia aido el faego de artillexía de Ramirez aceleró la mareha con objetto de tomar el camino de Casa a Huagui y dwaitide alo Una vez acuparto, ordenó a Tristám quas, con et Real de Lima, el batallón de Piérola y una pieza, coronase la altura g esperase sus órdenes sosteniend a Ramírez. Esta fué su salvación indudabtemente: No le había sido posible romper el frénte a pesar de todos sus esfuerzos, pues si bien el enemigo se laabia retirado casi hasta el camino de Hnaqui a Cara, babía reforzado sus Fusiciones, e inciusol babía lanzado su eaballeria a. retagnardia de ias tropas de Revnoirena, eors objeto de atacat lo por la espalda y apodenarse de la artihiería

La aparición de las tropas de Tristán acabó con la resistencia de los argentinos, amenazados con un ataque de flaneco; su retirada se convirtió paco a. pọco en thige desorganicada, en el momento en que empezaron las deserciones.

Mientras Ramírez se batía con las tropas de Vla- 
monte y Díaz Véler; Croyeneche, en marcha hacia Hua dul se encontró cerrado el camino por las que mandaban Balcarce y Montes de Oca. Estas titopas, salicas de Huagmi en múmero de 2.000 hambres, con 1f plezaside artilleria, se apoyaban a su derecha por la laguna, y estaban situados sobre un morro, que lo colocaban en una posición dominante sobre el camtno. Pero, sin embargo, la parte inquierda de los cerros era mucla más asequible, y no habla do ocreada for éstos.

Colocado su dispositivo de marcha, dividió frpyeneche su columna en dos parites, una dirigida por, él personalmente y compuesta par, las Regimientos de Abarcay, del Cuzco y el batallón de Plcoaga, y otra, manoada por Tristám, con el intento de flanquear al enemigo situado en el morro. En esta disposicioun contínuó su cámino y enitró bajo el fuego enemigo, que recibió durante dos horas sin contestar, en tanto que la caballería rechizaba tres ataques en su costado izquierto.

A pesar de su avance le fué imposible' romper la jobleitis idel etiemigo, no pudiendo dominar la altura en que se hallaba' situado, ní ocupar las de sus alrededores. In vista de lo iffruetuoso de su avarice, y apereibidó de que no podria dominar la altura sin un atoque de la columna de Tristátí, envió a su edecán dan Jusé Moya con la ordéti para aquél de tomar los cenros te ste derecha. ${ }^{\prime \prime}$ desde donde debla inteiar un abaqué désesplerado do llanco contra el enethigo. Pero' Tyfst ya habia inteia do el movimiento cuando le llefto la diten de Gojenteche. Se habia dado ettenta cte lo décisito que habia de ser para el cúrso de la

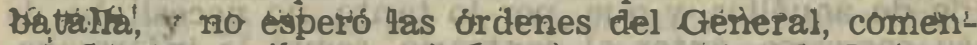
nando el ateque con el fregimiento Real de Lirina $y$ đejar elo camino eubierto con el batallóri de Piérola. con obfete de eompletar el movimiento, Gojefiectie, for' su quarte, déstacó tres compañías para que hostilizasen por el frente a los enetnigos, mientras ê, con ed cesto do las trapas, atraclaba el flanco denecho, aprovechranto es espacio quse le permitia una degua de dierrra quo se extentria a su irguierda sobre, larjagtana.

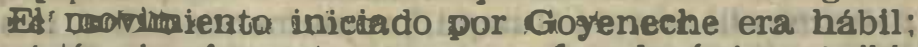
consistía cinuvetemente en aprovechar la úmica posibir lidad de penetración que ofrecia la posición enemigr 
por su flanco izquierdo, atacado por las tropas de Tristán, mientra él atraía la atención por el frente y el flanco derecho, con abjeto de facilitar a aquél su maniobra y envolyer al enemigo. Los intentos de la caballería cochabambina fueron intitiles, pues Trtstán avanzaba bajo un fuego abrumador, que obligó a retirarse a los argentinos camino de Huaqui. Fué entonces, una vez dominada la situación, icuando meschó en ayuda de Ramírez, que se hallaba en un momento verdaderamente difícil.

Desalojado el enemigo de sus posiciones en este sector, fué perseguido por las tropas de Goyeneche hasta Huaqui, que ocuparon sin la menor resistencla, cofiendo los almacenes de municiones de guerra y boca; $y$ sus hospitales, aparte del copiósp material abandonado que ocuparon en el camina, Junto con un considerable número de prisioneros.

En el frente de Ramírez, las cosas habian cambiado desde la aparición de la columna de Tristán, despues de más de cinco horas de luchar La retirada del enemigo se hizo total, aunque poco más tarde regibió noticias de que una columna de caballería cochabambina de dos mil hombres con dos cañones se aproximaba en su difección. Inmediatamente onyió axiso a Groyeneche, con objeto de que se le reuniera para detener este avance, a la par que formaba a su tropa, desorganizada en la persecución del enemige y ocupaba por siciones en la sierra. Recibida la noticia, Goyeneche reorganizo sus fuerzas $\$ se puso en camino desde Huaqui, pero a una legua de distancia del pueblo recibió aviso de Ramírez, que le comunicaba la retirada de aquéllos, y que, par lo tanto, no nocesitaba de su concurso, antes al contrario, según le informaba, Ios cochabambinos se dirigían contra él. Bl general volvió spbre sus pasos y se dirigió a Huaqui, en donde estableció sus posiciones de nuevo, para pre renirse de un ppsible ataque durante la noche.

Con ésto terminaba la llamada batalla de Eraqqui, con una total victorta de las tropas realistas. En réalidad nubo dos batallas simultáneas: una, que pudiêramos llamar de Huaqui, propiamente ddicha; la sostenide, por Goyieneche; otra, la sostentda por Ramirez contra: las fuerzas que øcupaban Jesús de Machaca; 
si bien ambas se dirigian contra un objetivo comun y constituian quizás una sola maniobra.

Las pérdidas sufridss por ambos ejércitos debieron ser graves, pues las circunstanctus de la lucha dan lugar a pensar que debí ser bastante encarnizada, con las consiguientes pérdidas considerables para los dos contendientes. Pero no poco debió influir también en el desastre final de los argentinos la deserelón que se inició en sus filas, apenas comenzó la retirada Era éste el mal fundamental de ambos ejércitos; las tropas que 10 integrabah, falta de espiritu militar, necesitaban una rigtda diseiplina para pertmanecer en sus puestos, sobre todó, en situaciones adversas, ty ésta fué una de las causas que en su origen contribuyeron a la derrota del ejército patriota en el caso presente. Castelli se habia propuesto formar un numerosisimo efército integrado por los contingentes de voluntarios que recibia de las provinicias ocupadas, sobre todo; de los cochabambinos. Y este fué su error, pues si por una parte necesitaba de su caballeria, quitrás no turvo en cuenta la necesidad de discoplinarlos debidamente. Como consecuencia lógica de tal error, en el momento en que fraqué la resistercia de las líneas, la inmensa masa de cochabambinos emprendió el camino de su ciudad con objeto de defenderla del avance de Goyeneche, abandonándolo en el combate.

Antes de eritrar en la trascendencia de la batalla

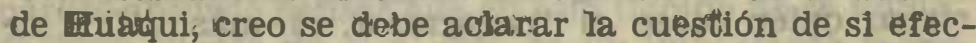
tivamerite esta batalla constituya una infraccion del armisticio estipulado y, en tał caso, quién flue el infractor.

Esta cuestión ha suscitado diverisas oplniones, producidas no pocas por un apasionada fuicfo, sobre todo entre los centemporáneos, si bien, la distancia nos permite hacer hoy un examen desapasionado de los hechos.

En cuanto al primer problema de si fué la batalla de Huaqưt una violación del armisticio, ya me he reforido antes al hablar de las comunicactones cursadas entre Castelli, Goyeneche y el Virrey. Alli decía que cuando Goyeneche se decidió el 19 de Junio a emprender la battalla, debian haberle llegado las órdenes de Abascal, anulando la tregua. Por su parte. Castellí tampoco debía hacerse muchas ilusiones respecto a la 
acentación de su propuesta Además, las esearamuzas que se sucedieron entre las partidas de ambos jércitos podran ilevar al conventeimiento de todos la nulidad práctica del arraisticio.

La prieba quigśs más palnaria de que a nadie sarprendió el movimiento del ejéreito de Goyeneche, que fué quien inició la batalla, es el hocho que cita Rada y Gamia, de que ual darse la batalla, presentó (Cratellí) sus tropas debidamente dispuestas, obteniendo hasta pataja con su caballeria (97). No es menos digna de tenerse en cuenta el hecho, también aducido por Rada y Gramin, de que en los partes de Castellí, fechados en Machaca el 28 de Junio, y de Rivero en Cachabarmba, en 19 de Julio, dinigidos a la Junta de Blienos Aires $y$, la de Potosí, respectipamente, no hay la menor alusión a que se hublere efectratdo el ataque jor sorpresa, faltando a lo estipulardo en - armisticia I como dice dicho autor nde mada ha, bxían becho más mérita Castelli y Rivero, para disculpar su der rota, que de esa circunstancia anotándola en sus oparto con todo cabrida. Ese silencio es remelador* (38t.

Por tanto quede eomprobado que si el armisticio no - taba Apulado oficialmente, en la préctica había dejado de existir, si es que alguna vez existió con viggencia efectiva.

En cranto a la segunacia cueatión, el hecha de averiguar. quién tuese laransgresor, es más difícil de aclarario, mues mituamente se cohaban las culpas ambes eantendientes. Se hace constar que primera violación partió de Goyeneche con la partida que fué atacada en Huaqui, renovacta por lo ocurisido en Jesús de Atachaca. Por otma parte se achaca esta culpa a Castralli, que colocó sus avanzadas en siruaqui, contra to prevernido en el armaticio, romo asimismo por el ataque de Pisacoma:

Indudablemente en el fondo de la cuestióm hay un intents de dartido en hacer ver ad contrarja como trangeresor de la pailatora de honor comprametida. In

(37) RADA Y GAMTO, Pedro y. El Ajzobisyd Gojeneche $y$ apuntes puma la tistoria de Pert. Rema, 1917. Pug. 51.

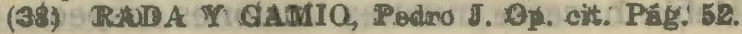




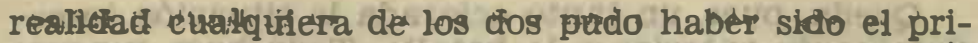
nero, dadas las eondfeiones anterlor triente exprtestas. Mitre, en su eivra citada, dice: rdetbe deeirse en horior de la verdad histórica, que los primeros que la violaron fuerom los patriotas, extendiet̀do sus correrias hasta S. Andrés de Machtea, al N. del Desaguradero (IT de mayo): y atacando en Pisacoma un destacamento peilista que observaba pereffesnente los caminós de la cóbta. Goyeneche por su parte adelantó entonees sus tebnocmientos rasta ell terreno intermedío y trató de sorpicener en dos ocasiones los puestos avanzados de los pattlutasis (39).

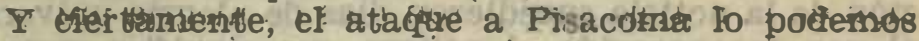
considerat como una tranditesión del ar Histicio, recor nocida por los mismos argentinos. El capitán Alvarez, en su Nemoria militar de la guerra insurreccionel del Perkx, tantas veces eitarda, affirm, que, oeurrido el imclữerite, Goyerzeetre płdió satisfacción a Díaz-Velez, queren se disculpó con la razón de que su mando correspondia al sector te Huaqui, y que el hecho había oeturitb en el sector mandatio por Rivero «a quien ya se había tequerido en razôn del último suceso». El dî̀ siguiente vito un parimentario de su ptrte haciendo saber que habian llevado a cabo esta acción por igno rar la existencia del armisticio, argumento que cae inevitablemente por su peso cuando se recuerda que dicho armisticio llevaba establecido más de un mes, y parece absurdo pensar que en este tiempo no se hubiese dado cuenta de él al jefe de un importante sector del ejército argentino.

Este y los otros incidentes que se sucedieron, obligaron a poner en guardia a ambos contendientes. Pero lo que hizo estallar la tempestad fué el paco de 1.200 hombres por el puente Machaca sobre el Desaguadero, diez kilómetros más abajo del de el Inca, con objeto de atacar la retaguardia realista. Dicho movimiento hizo adelantar los preparativos a Goyeneche, como vimos, ya que, además de una violación de lo establecido, representaba un grave peligro para su situación, a la vez que revelaba un claro intento de ataque.

(39) MITRE, Bartolom ds Opi eitu Peg. 215 
Queda, pues, un tanto aclarada la situación inmediatamente anterior a la batalla. Todo hace suponer que las primeras pravocaciones partieron del lado argentino, sin que ésto quiera decir, que, si no hubieran sucedido habria dejado de llevarse a cabo el encuentro. Se puede decir, sin temor a errar, que ambos contendientes estaban dispuestos a dar la batalla; lo único que ocurrió fué que Goyeneche se adelantó a Castellí.

La noticia de la victoria de Huaqui, llegó a Lima conducida por el teniente coronel don Juan de Ymaz, que llevaba las dos banderas cogidas a los insurgentes. El júbilo que produjo fué indescriptible. A la publicación de la noticia sueedieron días de alegria universál ad ver desaparecido el pelígro que significa para el Perú la presencia del ejército argentino, en el Des aguadero. El Virrey pudo respirar más confiado al pensar en las favorables consecuencias que para su causa podía tener dicha batalla. Felicitó inmediatamente a Goyeneche y a su ejército $(40)$, y propuso para su recompensa a aquellos que lo merecieron en dicha Jarpada, ascendiendo interinamente a muchos jefes, y regalando su sable a Goyeneche, a la par que informaba al Soberano de una victoria tan declsiva (41).

(40) Arch. C. Guagui. C. 3. Carp. 12. N. 13. Oficio de Abascal

(41) ABASCAL. Memoria. Tomo II. Pág. 253.

a Goyeneche. Lima; 12 de julio de 1811. 


\section{LA SEGUNDA SUBLEVACIÓN DE COCHABAMBA Y LA PACIFICACIÓN DEL ALTO PERÚ}

La victoria de Huaqui tuvo una gran trascendencia, tanto en el terreno militar como en el político. Militarmente supuso la pérdida de las provincias altoperuanas para los patriotas, y a consecuencia de éllo, en el terreno político, produjo una honda modificación en la estructura del régimen argentino. El balance de la primera etapa de la revolución no era nada halagüeño: «Durante el régimen presidido por Saavedra se habian perdido el Paraguay y el Alto Perú; el Uruguay quedaba en condiciones dudosas» (1). Saavedra habia fracasado y fué depuesto, simulando su alejamiento con un viaje de inspección a las provincias del Alto Perú, durante el cual recibió la noticia de su separación de la Junta, en la que se produjo un cambio fundamental. El 23 de septiembre se creó un Triunvirato, formado por Chiclana, Sarratea y Passo. El nuevo gobierno tenia como misión fun-

(1) PEREYRA, Carlos. Historia de la América española. Madrid, 1927. Tomo IV. Pág. 262. 
damental, desarrollar una labor enérgica y rápida para consolidar la revolución en peligro.

El peligro podia provenir principalmente del Alto Perú. Las victoriosas tropas de Goyeneche podian emprender el camino de Buenos Aires, en el que probablemente no habrian de encontrar una gran resistencia, sobre todo, si tardaban poco tiempo en ponerse en marcha.

Pero el mayor riesgo que se podía presentar a los gobernantes de Buenos Aires era el que se podía desprender de una posible inteligencia entre Abascal y Elio. Este último había llegado en el mes de enero con un gran contingente de tropas, e intentaba el bloqueo del puerto de Buenos Aires. El comienzo de su ofensiva había sido la señal inútilmente esperada por Abascal para lanzarse a su vez al ataque en el Alto Perú. Si ahora, triunfante éste, se ponian de acuerdo para emprender una acción común contra la capital, por mar y por tierra, la situación se haría insostenible.

Los intentos de la Junta de Buenos Aires para levantar a Artigas, en la Banda Oriental contra Montevideo, con objeto de impedir a Elio cualquier acción ofensiva contra élla, habian fracasado. A la larga, resultaron fallidos sus cálculos, pues Artigas, cuyo gran espiritu autonomista se presentaba siempre como un cbjeto de desconilanza, si bien accedió a sus planes, más tarde pactó con Móntevideo, en octubre de este año.

Sin embargo, los temores de la Junta no se llevaron a cabo; en este momento Montevideo no lograba liberarse de la presencia de Artigas, a quien ayudaban tropas argentinas, y por otra parte, Goyenechè, después de Huaquí, se dírigió de nuevo al Desaguadero, seguramente para reorganizar sus tropas antes de emprender la marcha a través del Alto Perú, que se ofrecería entonces fácil de conquistar.

Las tropas argentinas derrotadas en Huaqui emprendieron el cámino de retirada hasta Salta; no sin antes apóderarse del caudal existente en las Cajas Reales de Potosí, que ascendía alrededor del millón de pesos.

Durante el tiempo que medió entre la vuelta de Goyeneche al Desaguadero y su salida para el Alto Perú dirigió una serie de prociamás a todas las ciu- 
dades para que, libres de la ocupación insurgente, se declarasen por la causa realista. La salida se efectuó el 3 de julio con la finalidad de ocupar Oruro, punto interesante para las comunieaciones con Potosi y Cochabamba.

Entretanto, habían Hegado noticias al Desaguadero de que la ciudad de La Faz solicitaba auxilio. $\mathrm{Su}$ Intendente, don Domingo Tristán, el mismo que antes se habia declarado por la Junta de Buenos Aires, solicitaba la entrada de las tropas realistas para unirse a ellas con su ciudad, evacuada por las tropas de Rivero y sus cochabambinos. Se llevó a cabo la ocupación el 10 de agosto, marchando luego desde allí a Oruro para amenazar a Cachabamba, que, bajo el mando de Bivero, se mantenía por la Junta de Buenos Aires.

En todas las ciudades ocupadas nuevamente, Goyeneche debia atenerse a instrucciones concretas recibidas de Abascal, que se referian a tres puntos. En primer lugar debia dedicarse a reorganizar la Hacienda, a base de los tributos debidos a los indios y alguna contribución impuesta a los individuos sospechosos. con cuyo importe ayudaría al mantenimiento del ejér. cito, que a su salida del Desaguadero habia tenido que hacerto con el auxilio pecuniario ofrecido por la provincia de Puno.

Una vez logrado esto, otro punto fundamental era evitar cualquier posibilidad de nuevas sublevaciones. para lo cual debía exigir de todos los habitantes la entrega de las armas de fuego y blancas que poseyesen, sin distinción de personas, castigando con severas penas a los que así no lo ejecutaren.

Desarmadas las provincias, se hacia innecesaric dejar guarniciones en las ciudades, pues si eran pequeñas fácilmente podian ser sorprendidas, como se había demostrado, y si, por el contrario, se dejaba una gran cantidad de tropas. se debilítaba el ejercito, que habia de seguir su marcha. En cambio, recogiendo todo el armamento de que pudieran disponer, se evitaban estas contingencias.

Las instrucciones que daba Abascal a Goyeneche eran generales para todas las provincias, pero refiriéndose particularmente a la de Cochabamba, le advertia que era necesario imponerle una contribu- 
ción de caballos para remonta y repuesto del ejército, con doble finalidad: por una parte; obtener un numeroso cuerpo de caballeria, y por otra, mantener una superioridad notable en el sistema más eficaz de hacer la guerra de los cochabambinos (2).

En cuanto a los movimientos de las tropas, ordenaba Abascal a Goyeneche constituir un fuerte destacamento en Oruro, spunto céntrico de las provincias del Alto Perù», y desde allí se podria acudir a cualquier otro que lo necesitare. Con tal fin debia instalar alli un cuerpo de 1.500 a 2.000 hombres, con su correspondiente artilleria y municiones, debidamente alofados en un lugar fuera del pueblo, que le domine, y en el que debía construir una pequeña fortaleza, con su correspondiente parapeto $\mathrm{y}$ foso, con vistas a cualquier posible ataque, teniendo en cuenta para su construcción la proximidad de algún pozo, algibe, etc., que asegure el agua de la tropa (3).

Una vez efectuada la pacificación de las ciudades ocupadas en el Alto Perú; Goyeneche se dirigió a ocupar Cochabamba, partiendo de Oruro con el grueso de su ejército, y dejando como destacamento en la frontera del Desaguadero un fuerte núcleo de tropas al mando del Comandante Benavente.

Pero poco después de la marcha de las tropas en direccion a Cochabamba, se produjo en el partido de Pacajes una sublevación de indios, que se propagó a los de Larecaja, y. Omasuyos, y se extendió hasta la cludad de La Paz, a la que intentaron atacar, amenazando las comunicaciones del ejército con el Perú.

Entretanto continuaba la marcha de los realistas hacia Cochabamba, a través de un terreno bastante escabroso, y de donde los insurgentes habian procurado retirar todo posible auxilio para las tropas, para entorpecer su tránsito. En la mañana del día 13 de agosto llegaron a la altura denominada Tres Cruces, que domina la llanura del valle de este nombre. La vanguardia, mandada por Ramirez, bajó la cuesta,

(2) Arch, C. Guagui. C. 1. Carp. 2. N. 60. Carta de Abascal a Goyeneche. Lima, 12 de julio de 1811.

(3) Arch.' C. Euaqui. C. 1. Carp. 2. Ns. 60 y 61. Cartas de Abaseal a Goyenecho. Lima, 12 de julio y 21 de septiembre de 1811. 
desplegando en orden de batalla. Reunido Goyeneche con Ramirez a las tres de la tarde, y ante el temor de que les sorprendiese la noche, ya que no habia podido descender aún la retaguardia ni la caballería, resolvió dar un ataque brusco a la bayoneta para apoderarse del pueblo de Sipe-Sipe, sobre el que destacaban gruesas partidas los cochabambinos, que en número de 1.200 se hallaban situados entre el rio Amiralla y las montañas, colocada su vanguardia en aquél y su retaguardia en éstas. A la par, destacaban partidas numerosas sobre el pueblo y sobre los flancos de sus fuerzas.

Decidido el ataque, lo llevaron a cabo Ramírez por la derecha, Tristán por la izquierda y Goyeneche por el centro. El empuje de las fuerzas realistas desalojó a los cochabambinos de la primera linea de sus posiciones, abandonando el pueblo de Sipe-Sipe. Oeupado éste, y visto que los enemigos se habian situado a vanguardia del grueso del ejército, que lo apoyaba desde el otro lado del río, se ordenó un nuevo ataque. El resultado fué semejante al anterior: de nuevo fueron obligados a replegarse hacia el grueso de las fuerzas. Inmediatamente se rompió un fuerte fuego de artilleria durante tres cuartos de horas, mientras la caballería cochabambina se dividió en dos alas para envolver a Goyeneche y cortarle la retirada. Ante el nuevo viraje del combate, ordenó éste a Ramirez que permaneciese atacando al enemigo por su frente, mientras que el coronel Astete lo efectuaba por la izquierda, Tristán hacia lo mismo por la derecha, y el mismo Goyeneche, a la cabeza del Real de Lima, se dirigió a cortar por el centro la caballeria enemiga. Los resultados de la maniobra se hicieron notar pronto, pues los enemigos, acometidos por todas partes, emprendieron la retirada al otro lado del rio y abandonaron sus posiciones, en las que dejaron la artillería, dos banderas, 600 muertos y 70 prisioneros. En el lado realista, según el parte de Goyeneche, sólo hubo quince muertos y cuatro heridos, aunque es de imaginar que en realidad debieron ser bastantes más.

La noche que sucedió al dia de la batalla la pasó el ejército sobre las armas para evitar cualquier sorpresa. Al amanecer del dia siguiente, 14 de agosto de 1811, pudieron comprobar que las posiciones de los enemi- 
gos al otro lado del río habían sido también abandonadas. Durante la noche, parte del ejército insurgente, mandado por Diaz-Vélez, se retiró a Chaquisaca, mientras que el caudillo cochabambino Rivero marchó hacia Cochabamba.

Desaparecido el enemigo, el ejército realista emprendio la marcha a las nueve de la mañana de dicho día en dirección a Cochabamba, de donde recibió un parlamentario, que ofreci5 la entrega de la ciudad y de su provincia. Llegado Goyeneohe, fijó su entrada en ella para el día 16, fecha en la que la llevó a cabo triunfalmente (4).

La victoria de Sipe-Sipe fué el complemento de la de Huaqui. Con ella quedó definitivamente libre el Alto Perú de las tropas argentinas. Acabó de golpe con la resistencia de los cochabambinos, y provocó la caida de Chuquisaca y Potosí, con la consiguiente retirada de los restos de las tropas argentinas batidas en Huaqui; que evacuaron totalmente las provincias altoperuanas, en retirada hasta Salta.

Verificada la ocupación de Cochabamba, se dedicó Goyeneche a la reorganización de todos los ramos del goblerno y administración de la ciudad, y una vez acabada su misión allí, se puso en marcha de nuevo hacia Potosí. En el camino, hallándose a 50 leguas de dicha ciłdad, en el punto denominado Toracari, de la provincia de Chayanta, recibió el 3 de septiembre una diputación de aquélla, y otra de Chuquisaca, que le ofrecian la sumisión de ambas, cuya ocupación tuvo lugar inmediatamente. A su llegada a Potosi, el 16 de septiembre, recibió la triste noticia de que, al paso por la ciudad del ejército argentino, uno de sus jefes, Pueyrredón; se apoderó de cerca de un millón de pesos existentes en la Casa de la Moneda y en el Banco de $\mathbf{S}$. Carlos, so pretexto de utilizarlo para levantar tropas con las que reconquistar la ciudad. El recelo de los habitantes de Potosi respecto a las tropas argentinas aumentó al tenerse noticias de la victoria de Sipe-Sipe, y desconfiando de la veracidad de las pro-

(4) A. G. I.- Lima, 649. Parte de Goyeneche a Abasćal: Oochăbamba, 18 de agosto de 1811. Publ. en 'la Gaceta del Gobierno de Lima, de 23 de septiembre de 1811 . 
mesas de Pueyrredón, iniciaron su persecución con dos o tres mil hombres, si bien resultó infructuosa (5).

La ciudad de Chuquisaca fué asimismo ocupada por el batallón Real de Lima, a las órdenes del coronel don Mariano Campero, enviado por Goyeneche cuando se dirigia a Potosi.

Pero las noticias de la victoria de Sipe-Sipe y las de las posteriores ocupaciones de las ciudades a consecuencia de aquélla, no pudieron llegar entonces a Lima. La conspiración de indios a que me he referido más arriba habia progresado extraordinariamente. Los indios de la provincia de $\mathrm{La} \mathrm{Paz}$, movidos por dos curas y un cabecilla, y al amparo de 800 cochabambinos, se habian levantado contra el partido realista, con los consiguientes excesos de asesinatos y robos. Puestos en marcha, aprovechando la distancia a que se hallaba el ejército de Goyeneche, que les daba cierta garantía de tmpunidad, avanzaron contra la ciudad de La Paz, a la que pusieron cerco.

El peligro que significaba la insurrección de estos indios era enorme, pues aparte del trastorno consiguiente al alzamiento, con la natural inquietud que había de sembrar en las ciudades ya pacificadas, cortaba por completo las comunicaciones entre el ejército de Goyeneche y el Perú y amenazaba, incluso, con la invasión del Virrelnato, puesto que la guarnición del Desaguadero, al mando del teniente coronel don Pedro Benavente, era del todo insuficiente para contener la avalancha, sobre todo a causa de la escasez de fusiles, que Abascal no podia proveer.

En vista de lo crítico de la situación, que amenazaba entorpecer los frutos de las victorias de lar armas realistas, Abascal ordenó que los caclques de Cincheros y Azángaro, Pumacahua y Choquehuanea, cuya fidelidad se habia patentizado en muchas ocastores, sobre todo en la revolución del año 80 , se pusieran en marcha hacia el Desaguadero con sus tropas de naturales, dándole a ambos el nombramiento de coroneles del Ejército (6).

(5) A. G. I.-Lima, 649. Oficio del Virrey del Perú al Ministro de Estado. Lima, 23 de octubre de 1811.

(6) ABASCAL. Memoria. Tomo II, pág. 364, y A. G. I.-Li- 
Una vez en el Desaguadero, sus tropas se unirian a las de Benavente, de quien recibirían la instrucción que necesitasen $y$, reforzadas, se habrían de dirigir hacia La Paz con objeto de levantar el sitio de aquella ciudad, y defar libre el camino de Oruro, hasta donde se habían extendido los sublevados.

Choquehuanca llegó a Puno el 10 de octubre con 1.200 indios, de los cuales, la mitad siguió su marcha hacia el Desaguadero, y la otra mitad se dirigió a Tiquina; Pumacahua llegó también a dicha villa el 18 con tres o cuatro mil indios nobles, que el 21 debieron salir para el Desaguadero (7).

Reunidos en este punto, salieron de alli dos columnas. Una al mando de Benavente, con 1.200 hombres se dirigtó a $\mathrm{La} \mathrm{Paz}$, adonde llegó después de la victoriosa acción del Cerro de Lloco, y cuyo cerco levantó en cooperación con las fuerzas que, al mando de Lombera, había destacado Goyeneche con el mismo fin. La otra columna que salió del Desaguadero iba mandada por el coronel Pumacahua, y se dírigió hacia Oruro. Despejó el Desaguadero y demás pueblos de su tránsito, dejando asegurada su retaguardia, con el sosiego de los partidos de Pacajes y Sica-Sica (8).

Con estas acciones, libre la ciudad de La Paz y expedito el camino del Alto Perú, que-restablecia la comunicación con el ejército, se podía considerar dominada la rebelión.

Sin embargo, es curioso observar el significado de la intervenctón de los caudillos indios, Pumacahua y Choquehuanca, en el apaciguamiento de esta revolución. Con el empleo de las fuerzas de indios, asi como con la de los naturales, que formaban el núcleo fundamental del ejército de Goyeneche, pretendía Abascal una doble finalidad, pues a la par que tenia un cuerpo numeroso de tropas, disciplinado y bien instruído, lograba identificarlos poco a poco con la causa

ma, 649. Oficio de Abascal al Ministro de Estado. Lima, 23 de octubre de 1811.

(7) A. G. I.-Lima, 649. Extracto de cartas y oficios de Goyeneche a Abascal, de 26 de septiembre de 1811 y otros de Puno y el Desaguadero. Publicados en la Gaceta del Gobierno de Lima, de 6 de noviembre de 1811 .

(8) ABASCAL. Memoria. Tomo II. Pág. 366. 
que defendían, con lo cual, al cabo del tiempo, se lograría tener un poderoso partido realista formado, principalmente, a base de los naturales que militaban en el ejército, y que habian de ser el apoyo fundamental para la defensa del Virreinato en las circunstancias apuradas de la Metrópoli.

A la par que con estas medidas, procuraba Abascal atraerse a los indios, usando con ellos los medios más suaves que estuviesen a su alcance, dentro de la energía que habia de caracterizar el apaciguamiento de la rebelión. Ası́, noticiado de los procedimientos utilizados en algunos puntos contra los revoltosos por Lombera, le escribe inmediatamente a Goyeneche en términos duros: "no me gusta en manera alguna que se hayan reducido a cenizas algunos pueblos, según consta, que ha visto un oficial de la expedición; los valientes no hacen Jamás la guerra a cosas inanimadas; de esta suerte nos pareceriamos a los bárbaros de Buenos Aíres y perderiamos el concepto de humanos y comprensivos; con tan baja conducta, los pobres indios, viéndose sin albergue se exasperarán aún más y desconfiarán justamente de nosotros, queriendo antes morir que entregarse a una gente impía: hágaselo Vd. entender a Lombera y a todos los comandantes que se destaquen del ejércitos (9). Esta orden era terminante, y además de la fundamental razón de humanidad que'obligaba a observarla, existia la razón politica que presidió toda la labor de gobierno del Virrey.

Terminadas las operaciones contra los indios sublevados, y ocupadas las ciudades del Alto Perú, se podia considerar desaparecido el peligro del Virreinato $\mathrm{y}$ restablecido el orden en todo él y en las ciudades agregadas. Libre de este cuidado, podia, pues, dirigir de nuevo Abascal la vista a Buenos Aires.

Las noticias que se tenian en Lima de la repercusión en aquella capital de los sucesos del Alto Perú, así como de la aproximación de tropas portuguesas, que habian de ayudar a las llegadas de Montevideo, indujeron a Goyeneche a enviar una división de su ejército al mando del teniente coronel Barreda para

(9) Arch. C. Guaqui. C. 1. Carp. 2. N. 62. Duplicado de carta de Abascal a Gojeneche, Lima, 26 de octubre de 1811. 
situarse en Tupiza, en donde se habria de reunir a los que ya anteriormente habian sido destacados por el general. El objetivo que se perseguía era concentrar el suficiente número de hombres para reducir a los últimos insurgentes que se hallaban reunidos en Salta (10). El número de las tropas porteñas estacionadas en esta ciudad era pequeño, pero no por ello se había de déscuidar dicho punto, pues constantemente amenazaban con incursiones que turbaban la tranquilidad de la provincia.

Pero no pudo tampoco Goyeneche dedicarse exclusivamente a preparar un ataque contra los argentinos, pues dos meses después de conquistada Cochabamba a consecuencia de la batalla de Sipe-Sipe, volvía de nuevo a cundir la rebelión en su provincia, fomentada por los huidos de la ciudad y los de La Paz. No tardaron los revoltosos en apoderarse de la capital, que Jamás estuvo de corazón al lado de los realistas. Ocupada la ciudad y asegurado el golpe de mano, llevaron a cabo una expedición sobre Oruro, punto estratégico en las comunicaciones del Alto Perú. A pesar de que, según Abascal, era escasa la guarnición de esta ciudad, al mando de don Indalecio González de Socasa, fueron ahuyentados los atacantes.

Las operaciones contra los cochabambinos se limitaron, sin embargo, a mantener libres los caminos, y abierta la comunicación con el Virreinato del Perú (11).

Pero, como digo más arriba, la segunda sublevación de Cochabamba hizo modificar los planes de operaciones en la frontera del Virreinato de Buenos Aires. La reunión de un gran número de tropas aqui ofrecia el peligro de dejar desguarnecido el Alto Perú, con una insurrección en su interior, cuyas consecuencias no se podian calcular. Por otra parte, no era posible llevar a cabo ninguna acción decisiva por la proximidad de la estación de las lluvias y lo diseminado que se encontraba el ejército, que lo hacia dificil de reunir rápidamente.

(1.0) Arch. Abascal. Borrador de carta de Abascal a Pérez de Castro sin data ni fecha, y Abascal, Memoria. Tomo II. Plg. 370.

(11) ABASCAL. Memoria. Tomo II. Págs. 871-372. 
En vista de estas circunstancias se acordó en Junta de Guerra celebrada por el Virrey, de acuerdo con Goyeneche, suspender las operaciones contra la ciudad de Cochabamba, "por las diffcultades que ofrecia el paso de los caudalosos rios que circundan los valles de aquella provincia con rápida corriente en esta estación; por evitar que la común enfermedad de tercianas causase algún estrago en las tropas; y sobre todo porque esta detencion, que era favorable para la recomposición del armamento que se hallaba ya deteriorado por el continuo servicio, lo era igualmente para dar algún descanso a la fatiga de las marchas del ejércitos (12).

Efectivamente, la marcha del ejército a través de los caminos del Alto Perú había sido agotadora. Desde el mes de agosto, en que se inició la campaña para el sometimiento de las provincias, el guerrear habia sido constante, contra las tropas argentinas, contra los cochabambinos, o contra los indios. En todas partes era de esperar una sorpresa, y se imponia una vigilancia continua que producia el natural desgaste en la tropa, y el gran número de pequeñas acclones y encuentros mantenidos con los enemigos hacían com.. pletamente necesario el descanso, tanto para los hombres, como para el material.

Colocado, pues, el ejército en las ciudades del Alto Peri, podia tenerse la seguridad de su mantenimiento, pues fácilmente podria acudir de un punto a otro, ya que no eran excesivamente largas las distancias, y se hallaba jalonado por ellas el camino del Perú. Asi se podia esperar a que pasase la estación de las lluvias y aprovechar, mientras, este tiempo en la réorganización del ejército.

La posicion de las tropas de Goyeneche era en estos momentos la siguiente: Pumacahua y Benavente permanecian en Sicasica; Astete, en Chayanta; Lombera, en Oruro; y además el teniente coronel don José Francisco Moya debia pasar con dos compañias de caballeria a ocupar Llaucacóto, y Picoaga, con 500 hombres se uniria en Tupiza a la división de Barreda, con objeto de expulsar a los argentinos hasta más

(12) ABASCAL. Memoribs. Tomo II. Pág. 373. 
allá de las gargantas de Jujuy y Salta, posiciones que deberian quedar en su poder (13).

En efecto, el día 26 de noviembre salía Picoaga del Cuartel General con 470 hombres de su división, en dirección a Tupiza, con instrucciones de obrar enérgicamente. Llegados a esta villa reunió las tropas mandadas por Barreda y se informó de los preparativos de las tropas argentinas, reforzadas por Díaz Vélez, que se habia adelantado a las cercanias de Suipacha para atacar a los realistas.

A la llegada de Picoaga, los enemigos se retiraron rehuyendo presentar batalla y perseguidos a distancia por éste, que no les podía dar alcance por carecer de la caballería que aquéllos poseian en gran cantidad. Así llegó hasta el punto de Yavi, a la entrada de las gargantas de JuJuy, en donde recibió orden de suspender el avance, y noticias de haber sido reforzados los insurgentes, cuyo número llegaba a 1.300 fusileros.

La falta de datos en que se hallaba Picoaga sobre los enemigos, le hizo acceder a los ofrecimientos del Marqués de Yavi, para ir a entrevistarse con Díaz Velez, con la doble finalidad de atraerlo a razones e instruirse del estado de sus fuerzas. Llegó el Marqués al campamento enemigo, que halló situado en los lugares denominados Cangrejos y Barrios, a dos leguas del de Picoaga. La entrevista no produjo, sin embargo, los resultados pretendidos, a pesar de lo cual se dispuso que los Tenientes Coroneles Moscoso y $\mathrm{Ba}-$ rreda pasasen al día siguiente al campo enemigo para tratar con Díaz Vélez, pero en realidad, con la misma finalidad que habia ido el Marqués de Yavi. Entretanto, se daba tiempo a Picoaga a levantar el campamento y poner a salvo sus tropas, pues tenia noticias de que iba a ser objeto de un ataque en la posición desventajosa que ocupaba, en una hondonada dominada por cerros a tiro de fusil y con caminos que facilitaban el ataque.

La discusión de los enviados con Díaz Vélez fué acalorada, proponiéndose un armisticio, que no fué aceptado. Tan infructuosa como la discusión fué la obser- 
vación de las fuerzas enemigas, cuidadosamente ocultadas a los enviados.

Temiendo el ataque, a las diez de la noche del 29 de diciembre, levantó su campo Picoaga. Para evitar que las avanzadas enemigas, que se hallaban a media legra, se diesen cuenta de su marcha, tomó por una quebrada angosta y casi intransitable, por donde hubieron de comunicar las tropas durante toda la noche, hasta el dia siguiente a las cuatro de la tarde, en que despurés de andadas catorce leguas hicieron alto en Moxo. Desde alli continuaron el camino hasta llegar a Suipacha, cuyo río, que traia gran cantidad de agua vadearon con grandes difioultades .

El día siguiente a la noche en que Picoaga abandonó su posición fué atacado Yavi. Encontraron los argentinos evacuado el pueblo y empredieron la persecución de las tropas realistas con destacamentos de caballeria para hostigar su retaguardia.

Entretanto, el Coronel Garcia de Santiago, a quién Picoaga habia dado órdenes de reunirse con él llevando el resto de su división, liegaba el 1 de enero de 1812. Se estableció el campamento a orillas del ría, cerca y detrás del pueblo de suipacha. Enfrente, al otro lado del río quedaban los enemigos, situados en la ranchería de Nazareno. En la noche del 2 fueron reforzados éstos, y el día 3 extendieron sus avanzadas, originándose las primeras escaramuzas entre los dos efércitos, que se limitaron al paso del río por algunas guerrillas de ambos bandos, si más consecuencia de importancia, que los reconocimientos efectuados, $\mathbf{y}$, a veces, algún duelo de artillería

Esta situación se mantuvo durante algunos días, en los cuales, a consecuencia de las intensas liuvias, aumentó considerablemente el caudal del río. Pero el día 12 , cuando terminaba la misa en el campamento realista, fueron sorprendidos por la presencia de los argentinos que atravesaban el río en tres columnas escalonadas. De ellas, la de la derecha, que llevaba el peso del ataque, atravesó con gran rapidez el curso del río acercándose al campamento; la del centro, amparada por un denso fuego, intentaba apoderarse de su artillería, mientras la de la izquierda maniobraba simulando atacar. Mientras se desarrollaba esta acción por el frente del ejército realista, 40 Dragones 
insurgentes penetraron disimuladamente por una quebrada seca que habia a la izquierda de aquel, con objeto de atacarle por la retaguardia, pero fué frustado su intento y hubieron de retroceder.

Los momentos iniciales del combate fueron de verdadero apuro para Picoaga, ante la sorpresa producida por el enemigo; pero pronto se repuso de élla y organizó la resistencia, pasados los primeros momentos de desorden. Inmediatamente se formó la línea de las tropas realistas. \&Dispuse que $\mathrm{mi}$ segundo Llamos y mayor Barreda-dice Picoaga-sostuvieren $\mathrm{mi}$ izquierda con las compañias de Granaderos, Guerrillas de Paruro, Cuzco, Cotabamba y guardias replegadas. La derecha la mandaba el Coronel Garcia Santiago, con una compañia de mi Infanteria, las de Chichas, guerrillas de Abancay, y compañia montada de Tarifa. Yo me situé en el centro con lo restante de la división recorriendo la línea, cuya formación era en ala al borde del ríos (14).

Dos horas duró el intenso fuego de la lucha, durante la cual fueron obligados los insurgentes a repasar el río y abandonaron gran cantidad de material, defando, según la relación de Picoaga, 300 muertos y 150 heridos, aparte de los que murieron al pasar el rio arrstrados por la corriente, que debieron ser un gran número. Sin embargo, el gran caudal de aguas, fué-sigue diciendo Picoaga-lo que le obligó a retirar sus tropas que habian pasado a la otra orilla, y a no aventurarse a la persecución del enemigo.

Ey significado de esta batalla fué más bien moral que militar, pues no produjo ni la retirada total de los enemigos de las orillas del rio. Tuvo más bien carácter de revancha de la batalla del mismo nombre, sostenida poco más de un año antes en aquel mismo lugar, que significó la pérdida del Alto Perú para los realistas a las órdenes de Nieto. Se deja traslucir esta idea en la misma aRelación de Picoaga, en la que se des-

(14) Arch. A bascal. Cogian de una Relación de las operaciones de la vanguardia del ojérçito del Alto Perús, por el Brigadier don Francisco Picosga, dirigida al Virrey. Cuartel General de Potosí, 25 de agosto de 1812. In un expediente que contiene los pattes del Géneral en jefe del ejércit del Alto IPexú. 
cubre su intima satisfacción por haber vengado al general Nieto.

Cuatro días después de la batalla de Suipacha llegaron al campamento de Picoaga las primerao tropas de la columna, que, al mando de Tristán, venía en su refuerzo.

El 17, a consecueneia del intento de Picoaga de sorprender una avanzada enemiga situada a su derecha río arriba, hizo pasar alguna tropa al otro lado deI río, trabándose el combate con los patriotas situados en Nazareno. Creyendo que se trataba de un verdadero ataque, replegaron sus guardias y partidas, menos las que estaban combatiendo, y comenzó por ambas partes el fuego de artilleria. Pero cuando estaba empenada la lucha entre los argentinos \$ las guerrillas que habian pasado al otro lado del rio, recibieron los realistas orden de retirarse, a la llegada al campamento de Picoaga del Mayor General Tristán. Las razones que turviera Picoaga para dar tal orden, no se saben exactamente, aumque, según él dice, el repliegue se hizo contra la voluntad de las tropas que estaban combatiendo.

En la madrugada del día 18 comenzó la retirada de los argentinos, noticiosos quíás de la llegada de refuezzos, y temorosos de sufrir un ataque de mayor envergadura (15). Sin embargo, de todo el refuerzo que debia unirsele a Picoaga sólo lo verifieó la división de Abancay, que venía de Potosí, ye que aunque se pensó que a ésta siguiese el grueso del ejército, con su General en Jefe, le fué necesario a Goyeneche replegar las de Lombera y Astete, en vista del cariz que tomaban los acontecimientos de Cochabamba.

Y es que la revolución de Cochabamba habia aumentado considerablemente. Frustrado su asalto a Oruro, se extendieron por las provincias de La Paz y Chayanta y partidos de Paria y Mizque, cortando casi totalmente las comunicaciones con el Perú, e impulsando de nuevo a los indios a la revolución.

(15) Anch. G. Guaqui, 4. 6, Carp. 7. N. 11, Memoria militar de la segunda conquista de Cochabambas. Mayo a julio de 1812. Por Antonio Marín Alvarez. Cuartel General de Chuquisaca, 18 de julio de 1812. 
Como por entonees no parecia amenazar un gran peligro del lado de la frontera de Buenos Aires, decidió Coyeneche la separación de Lombera y Astete de la columna de Tristán, con objeto de dejar expedito el camino y restablecidas las comunicaciones del ejército entre sí y con el Virreinato.

Pero mientras habia tenido fugar el avance de la vanguardia de Goyeneche y la acción de Suipacha, habia llegado a la capital del Virreinato una noticia que puso en gran cuidado a Abascal. Extraoficialmente primero, y oficialmente poco después, se supo en Lima que el Brigadier Elío habia firmado un armisticio con la Junta de Buenos Aires, estipulado sobre la base de la retirada simultánea de las tropas argentinas y de las portuguesas que habían acudido en defensa de la ciudad. La situación de Montevideo era, en verdad, crítica. La plaza disponía de escasísimos efectivos para sostenerse contra las tropas de Buenos Aires, tanto en material de guerra, como en provisiones para alimentar al ejército defensor. El bloqueo de Buenos Aires habia resultado no sólo ineficaz, sino contraproducente, ya que únicamente consigutó exasperar a los porteños, sin conducir a ningún resultado práctieo. La derrota de Las Piedras había quitado toda esperanza de poder batir al ejército sitiador de $\mathrm{Ar}-$ tigas, a quien se le había unido Rondeau, apretando cada vez más el cerco de la ciudad, y la ayuda portuguesa tarnpoco se reveló lo eficaz que la hicieron concebir los buenos deseos de los defensores.

Pero a pesar de toda su ineficacia, la ayuda de las tropas portuguesas tuvo gran parte en la decisión de la Junta de llegar a un acuerdo con Elio, pues los argentinos no olvidaban nunca las aspiraciones de la Corte del Brasil, para quien una intervención en la Banda Oriental habia sido un deseo acariciado desde mucho tlempo atrás. Por ello, y ante el temor de un refuerzo portugués, se deciden a pactar aun cuando se les escapase de las manos una presa tan deseada. Pereyra ve en el proceder de la Junta de Buenos Aires un acto característico de la oligarquía del puerto, carente de ideas de solidaridad, que puso en grave peligro la independencia de la Banda Oriental y cuyas consecuencias la habia de padecer la misma ciudad; «el acto de Buenos Aires constituye un error, no sólo 
desde el punto de vista nacional, sino también por lo que respecta a Ios intereses locales, ya que Buenos Aires queda al arbitrio de sus enemigos y abandona la única garantía con que cuenta para defenderses (16). Isa amenaza de Montevideo contra la capital sigue en pie y los portugueses continúan amenazando la Banda Oriental. Subsiste para Buenos Aires el peligro que le impedía emprender una acción decisiva en el Alto Perú.

Sin embargo, la noticia del tratado causó gran ansiedad en Lima. No se podian calcular sus alcances en un principio, pero de todos modos se tenia la impresión de que un gran pelígro podía amenazar la frontera del Alto Perú si la Junta se veía libre de la amenaza que pesaba sobre la capital. Aun cuando Abaseal, con una extraordinaria prudencia, se abstiene de juzgar dicho pacto, no puede menos de quejarse contra él, al considerar el estado a que lo redujo, con el ejército de Goyeneche, extraordinariamente dividido en su labor de mantener las comunicaciones contra los constantes ataques de los indios y los cochabambinos, y la escasez de medios en que se encontraba, no ya para aumentar dicho ejército, sino aun para mantenerlo tal como estaba entonces. No debió, pues, exagerar cuando decia que todas estas consideraciones angustiaban su espíritu, ya bastante atormentado (17).

Pero una de Ias cosas que más preocupaban al Virrey era el peligro que podían correr las conquistas del ejército en el Alto Perú. La recuperactón de las provincias habia costado un gran esfuerzo, pero su valor los Justificaba plenamente, pues a más de su importancia económica, significaban la seguridad del propio Virreinato. Es por eso, por lo que Abascal no vacila en declarar que dicho tratado lo puede poner en un terrible compromiso, «si la Junta de Buenos Aires pretende que yo le vuelva las cuatro provincias del Alto Perú, que a fuerza de gastos y fatigas lo he conquistado y añadido a la legitima y verdadera so-

(16) PEREYRA, Carlos. Op. cit. Tomo IV. Pág. 273.

(17) ABASCAL. Memoria. Tamo II. Págs. 378-379. 
beranía (18). La razón es obvia y se reduce a la ya expuesta anteriormente. Las provincias altoperuanas en poder de los insurgentes volverían a la subversión; de ello estaba seguro el Virrey, que conocía su fidelidad. No debe, pues, extrañar qụe ésta fuese una de las causas que le indujesen a ordenar el avance de la vanguardia de Goyeneche hasta la frontera del Virreinato de Buenos Aires, con objeto de aprovechar la mala situación del ejército argentino antes de que pudiese recibir refuerzos de la capital.

Sin embargo, los temores de Abascal se esfumaron pronto, pues algún tiempo más tarde le llegaron noticias de que habian surgido dificultades para el cumplimiento del acuerdo de Elío con la Junta y que se preparaban nuevas hostilidades. La Junta debió darse cuenta de que con el tratado no se habian retirado las tropas portuguesas y se habían favorecido los planes autonomistas de Artigas en la Banda Oriental, lo que unido a los preparativos del sucesor de Elio, Vigodet, condujo al rompimiento.

Esta nueva situación debió tranquilizar el atribulado espíritu del Virrey del Perú y; le hizo concebir nuevas esperanzas de lograr sus planes en un corto plazo. Así, escribía a Goyeneche, recibidas las noticias de Montevideo: «el aspecto que por todas partes se presenta es muy favorable para la conclusión de esa guerra; pues en España se quedaban embarcando dos o tres mil hombres; cuatro mil portugueses de buenas tropas se hallan en Maldonado, y con dos mil que puede aprontar Montevideo, no tiene Buenos Aires modo de poder resistir... (19).

Todo, pues, hacía prever una nueva campaña conJunta de las fuerzas realistas del Continente contra la ciudad de Buenos Aires. Esta había sido la máxima aspiración de Abascal, que veía en ella la única manera de acabar definitivamente con la revolución en América del Sur. El primer intento había fracasado y la culpa no era suya; incluso cuando estaba en

(18) A. G. I.-Lima, 741. Oficio del Virrey del Perú al Ministro de Estado. Lima, 8 de diciembre de 1811.

(19) Arch. Abascal. Borrador de carta de Abascal a Goyeneche. Lima, 26 de febrero de 1812. 
mejor situación y tenía más probabilidad se encontró con el convenio de Elío con la Junta, que echaba a rodar todos sus planes. Por tanto no es de extrañar que ahora intentase aprovechar una nueva ocasión que se le ofrecía como única posibilidad de acabar la guerra.

Hasta entonces habían fracasado todas sus esperanzas: «con la llegada de Elío, dice Abascal, crei que me viniese a ayudar a llevar esta carga, pero lejos de ello se revolucionó el Paraguay, y los de Buenos Aires atrajeron a su partido a toda la Banda Oriental del Río de la Plata menos la plaza de Montevideo, que la pusieron en un estrecho bloqueo, obligando al Virrey a llamar en su socorro tropas portuguesas y a concluir un tratado de suspensión de armas con los insurgentes... (20). Esto nos explica la preocupación en que debía encontrarse el Virrey cuando vió que el único sitio de donde podía esperar ayuda se convertía en un nuevo motivo de inquietud. Pero pasado el peligro por la actitud de Vigodet ante el tratado, y reanudadas las hostilidades, se dispone Abascal a cooperar por su parte.

Aun cuando Abascal quisiese comenzar inmediatamente la ofensiva contra los argentinos, situados en Salta y JuJuy, tenía sin embargo en el interior del Alto Perú un grave problema que resolver con la sublevación de la ciudad de Cochabamba y de los indios del tránsito al Perú, instigados por los mismos cochabambinos. La gravedad de la sublevación se ha visto más arriba, pero aún se empeoró cuando el 25 de febrero los indios de Huánuco, en los alrededores del Cerro de Pasco, en el Perú, se lanzaron sobre aquella ciudad pidiendo la muerte de todos los españoles. La ciudad fué asaltada y sufrió el saqueo durante día y medio; al cabo de los cuales pudo conseguirse la retirada de los asaltantes. El Intendente de la provincia salió de Tarma con 400 hombres del Regimiento de aquella ciudad, que hallaron obstaculizados los caminos y destruídos los puentes, y de Lima hizo sa-

(20) Arch. Abascal. Borrador de carta de Abascal a don Francisco de Salazar. 23 de marzo de 1812. 
lir el Virrey una partida de Dragones y otra de Artillería, con buen número de municiones.

La sublevación de los indios ponía en gran inquietud a Abascal, pues amenazaba inmediatamente al Cerro de Pasco, al que éste calificaba como «la alhaja que con preferencia a otras menos interesantes debemos procurar conservar» (21); y además daba a conocer la existencia de un espiritu revolucionario en el interior del Virreinato, y en la misma capital, según decía el propio Virrey.

Junto a esto existía el peligro de que he hecho mención antes en el Alto Perú, y a él había de dedicar el Virrey su principal esfuerzo, como objetivo fundamental para consolidar su posición frente a las tropas de Buenos Aires. Hasta entonces el ejército del Alto Perú estaba extraordinariamente disgregado en razón de tener que acudir a muy diferentes sitios a la vez. Semejante situación amenazaba prolongarse indefinidamente y convertir la lucha en una guerra de sorpresas sin ningún resultado práctico para los realistas, que cada vez irían debilitando más sus fuerzas sin poder acudir a hacer frente a los argentinos, que en cualquier momento podían amenazar con una nueva invasión.

Todas estas consideraciones sobre la marcha de la guerra, unidas al estado en que se encontraba el ejército, en grave riesgo de perder la moral y los hombres por las continuas deserciones que se sucedían, empujaron al Virrey, a la par que utilizaba otros medios para detener el mal creciente entre las tropas, a comenzar una nueva campaña, dirigida en primer lugar contra Cochabamba y luego contra los insurgentes argentinos (22).

Lógicamente había de dirigirse el grueso del ejército en primer lugar contra aquella ciudad, por razones de elemental estrategia, para asegurar las comunicaciones y la retaguardia de las tropas que operasen en la frontera del Virreinato de Buenos Aires. Entretanto se llevaban a cabo estas operaciones, las fuerzas que se encontraban en dicha frontera habian

(21) Vid. nota 20.

(22) ABASCAL. Memoria. Tomo II. Págs. 381-382. 
de limitarse a un papel meramente de observación para detener cualquier intento de penetración de los argentinos, bien que ocupando algunos puntos desde donde pudiesen ejercer una mayor vigilancia. Por eso decía Abascal a Goyeneche que «poniendo a Picoaga en una fuerza de $\mathbf{2} .000$ hombres de infantería bien armados y alguna caballería, no necesita más para hacerse dueño de Jujuy y Salta, cuya garganta nos sería muy útil ocupar para quitar toda comunicación de las provincias de Buenos Aires con el Perú (23). Retirados los argentinos con la llegada de Tristán y la vanguardia del ejército a Suipacha no seria muy difícil conseguirlo.

Comienzan, pues, los preparativos para una acción decisiva contra la capital de Cochabamba, según las órdenes que transmitió Abascal a Goyeneche en carta de 24 de abril, en la que le hacía ver el peligro que encerraba la prolongada inacción del ejército. Como ya había terminado la época de las lluvias, le dice que sen esta inteligencia, la de la deserción que experimenta ese ejército y la abosluta necesidad en que nos veremos de disminuirle de fuerza o de disiparse ella misma por la falta de caudales para mantenerlo, imperiosamente nos obligan a dar fin cuanto antes a esa guerra para no vernos en un compromiso tan aflictivo. Para ésto conviene que dejando V. S. las guarniciones muy precisas en los puntos de esa villa, Chuquisaca, Oruro y avenida del Tucumán, en Suipacha u otro paraje más ventajoso, ataque con el resto de las fuerzas y con la energía que a V. S. y a esa valiente tropa le es caracteristica, a los cochabambinos y a sus secuaces en cualquier punto o puntos donde los encuentre hasta apoderarse de su revolucionaria capital y provincia, tratándolos con la severidad y entereza militar que exige la inícua conducta de unos habitantes depravados» (24). Para llevar a cabo la ofensiva le anuncia el envío por el puerto de Arica de un buque con municiones.

Durante los primeros días del mes de mayo que-

(23) Vid. nota 19.

(24) A. G. I.-Lima, 1.014. Copia de carta de Abascal a Gojeneche. Lima, 24 de abril de 1812. 
daron realizados los preparativos para comenzar la marcha sobre Cochabamba. El plan que se ideó consistía en dirigir contra dicha ciudad cinco cuerpos de ejército, que emprenderían la marcha desde diferentes puntos en dirección a aquélla, con objeto de irla estrechando y dar el ataque general.

El primer cuerpo se formaría en Chuquisaca, adonde llegaron las fuerzas de Picoaga que habían combatido en Suipacha, que a las órdenes de Goyeneche, por el camino de Misque, se dirigían contra la capital. El segundo ejército, a las órdenes del coronel Lombera, con 3.000 hombres, después de dejar guarnecido a Oruro, se dirigiría por el camino de Tapacari. El tercer cuerpo, situado en la Laguna, marcharía al frente del coronel Huici por Valle Grande. El cuarto estaría integrado por una columna organizada por el Intendente de La Paz, Revuelta, que ya antes había marchado contra el pueblo de Chayanta. Por último, el quinto cuerpo de tropas lo formaban las fuerzas que, desde Santa Cruz de la Sierra, marchasen dirigidas por el coronel Alvarez de Sotomayor (25).

El 13 de mayo salió de Chuquisaca el primer cuerpo de ejército, mandado por Goyeneche, habiendo asegurado antes el mantenimiento del orden público en dicha ciudad. El 18 salía de Oruro el segundo en la dirección de Paria y Tolapalca. Hasta fines del mes de abril, los cochabambinos habian bloqueado la ciudad de Oruro; con objeto de levantar el cerco, ejecutaron una salida los defensores de la misma, marchando hacía el pueblo de Paria sin lograr entablar una batalla formal con los insurgentes, mandados por sus caudillos Arce y Antesana, que se limitaban a retirarse a medida que avanzaban las fuerzas realistas, empuján-

(25) Areh. C. Guaqui. C. 6. Carp, 7. N. 11. «Memoria Militar de la segunda Conquista de Cochabambas, mayo a julio de 1812. Por el Capitán don Antonio María Alvarez. Cuartel General de Chuquisaca, 18 de Julio de 1812. Todos los hechos de esta campaña contra Cochabamba están relatados minuciosamente en la eMemorias. Una vez más he de limitarme a entresacar únicamente los sucesos fundamentales en el desarrollo de aquélla, pudiéndose leer un resumen de la (Memoria» de Alvarez en el ja citado libro de Herreros de Tejada, que la sigue exactamente. Vid. HERREROS de TEJADA, Luis. Op. cit. Págs. 299-ss. 
dolos en dirección a su ciudad. Asimismo emprendieron la marcha las otras columnas para aproximarse a Cochabamba y verificar las otras columnas para aproximarse a Cochabamba y verificar su unión.

Las tropas de Goyeneche llegaron sin novedad a Río Grande, límite de las provincias de Charcas y Cochabamba, y encontraron vacíos casi todos los pueblos, cuyos habitantes habian huído al tener noticias de la proximidad de los realistas. Esto facilitaba el saqueo de los pueblos por las tropas, medida reprobable ciertamente, pero a la que se exponian al dejarlos solos en manos de un ejército deseoso de vengarse de las continuas inquietudes a que estaba sometido por los insurgentes.

Sucesivamente fueron ocupados los diferentes pueblos del tránsito, hasta llegar a la ciudad de Misque el día 21, que hallaron igualmente evacuada y arruinada, pasando de largo y continuando la marcha.

Al llegar al pueblo de Pocona esperaban al ejército dos emisarios de Cochabamba, con el fin de entablar negoclaciones con Goyeneche en nombre de las Corporaciones de dicha ciudad. Pero las proposiciones parecieron improcedentes al general, que, sin tenerlas en cuenta, prosiguió su avance.

A la salida de dicha ciudad se encontraron con que los cochabambinos se hallaban en disposición de hacer frente al ejército e impedir la continuación de su marcha. En los alrededores de Pocona hay una elevada serrania, con una difícil subida, y en cuya conclusión hay un morro aislado, con dos quebradas a sus costados y un pequeño bosque en la mitad de su falda, bajo el cual era forzoso al ejército pasar para continuar su camino. Dicho morro era llamado el Queñual, y sobre él se habían colocado algunas tropas cochabambinas.

El enemigo se había colocado en tres líneas: la primera, sobre la cuesta, con dieciocho cañones; la segunda, ocupaba todo el frente del cerro, con abundante caballeria, y por último, la tercera línea componía la reserva. El total de tropas cochabambinas llegaba a un número aproxímado de 4.000 hombres.

Inmediatamente que los realistas comenzaron el avance rompieron el fuego contra ellos, a pesar de lo cual prosiguieron su marcha y los desalojaron, obli- 
gándolos a retirarse, defando en su poder toda la artillería, diez cajones de municiones, varios fusiles $\mathbf{y}$ veintinueve muertos.

Después de esta acción las tropas realistas no encontraron más resistencia en el camino hasta su llegada al valle de Clisa, en el que se hallaba asentada la ciudad de Cochabamba. A poco de avanzar en él, recibieron una diputación, que, en nombre del Cabildo y demás Corporaciones de la misma, rendian la ciudad a la discreción de Goyeneche. Admitida la rendición por el general, ordenó se constituyese en gobierno la Junta de Corporaciones, en tanto se verificaba su entrada; ordenó igualmente que se entregasen todas las armas en su Cuartel General, y envio aviso del cese de las hostilidades al coronel Lombera, que se aproximaba a la ciudad.

Dispuestas así las cosas, el efército emprendió el camino de Cochabamba, con objeto de ocuparla, según lo estipulado, cuando al llegar al punto llamado de Tamborada, se percibieron indicios de resistencia por parte de los de la ciudad. En efecto, un gran número de cochabambinos ocupaba el cerro de San Sebastián, dispuestos a cortar el paso del ejército.

En vista de tan inesperada resistencia, Goyeneche se dispuso a hacerles frente, y ordenó a Ramírez que, con dos piezas y la división de Lima, cubriese el convoy y la retaguardia, amenazada por la caballería cochabambina, entretanto se desplegaba la línea al mando de Picoaga, con el batallón de Cochabamba y 180 hombres de caballeria con ocho cañones.

La artillería cochabambina, situada en el cerro de San Sebastián, dominaba las posiciones realistas. Iniciado el avance de éstos, bajo el fuego enemigo, se dislocó la infantería en tres grupos para formar otras tantas direcciones de ataque. La disposición fué afortunada, pues en el corto espacio que duró la lucha fueron dispersos los cochabambinos, sin pérdidas para los realistas.

Entretanto, se verificaba el asalto al cerro de San Sebastián, el coronel Imaz marchó por la derecha sobre la cadena de cerros que bordean los arrabales de la población, a cuyo final los enemigos habían colocado alguna artillería, y Ramirez, con 400 hombres, pro- 
tegió la retaguardia para impedir cualquier intento de cerco.

La rápida derrota de los cochabambinos originó su desorden; que les oblígó a evacuar inmediatamente la ciudad, en la que entraron los realistas sin encontrar la menor resistencia, hallándola desierta.

Como dije mảs arriba, el 18 de mayo salió de Oruro el coronel Lombera, después de haber asegurado la ciudad, con objeto de reunirse a las fuerzas que se dirigan hacia Cochabamba. La marcha fué sin incidentes hasta llegar al pueblo de Sacasa, pues los sublevados se retiraban ante sus fuerzas sin presentar batalla. Sin embargo, en las inmedíaciones de este pueblo, un corto número de ellos le hizo frente, aunque con poca eficacia, pues pronto fueron batidos $\mathrm{y}$ obligados a replegarse. La consecuencia del encuentro fué el saqueo del pueblo de Sacasa, que hubo de sufrir la venganza de las tropas realistas.

A partir de aquí el cuerpo de ejército de Lombera prosíguió su marcha sin encontrar más resistencia organizada, deteniéndose, sin embargo en limpiar de revoltosos los territorios por donde pasaban, lo que le obligó a demorar la fecha de su unión con el cuerpo principal de Goyeneche.

El tercer cuerpo de ejército, mandado por el coronel Huicl, salió de la Laguna el 12 de mayo y tuvo que atravesar un camino bastante dificultoso, encontrando su marcha constantemente entorpecida por la hostilidad de los naturales, que hostigaban a las tropas, hasta que en el lugar denominado Alto de las Cañas entablaron batalla, en la que fueron derrotados los enemigos, dejando en poder de los realistas tres piezas de artillería y dos banderas.

Aún tưvo que hacer frente otra vez a los cochabambinos el coronel Huici. Fué al marchar a ocupar la ciudad de Valle Grande, en donde avistaron un crecido número de eaballería cochabambina, protegida por dos cañones. La accíon resultó también ventajosa para las fuerzas realistas, aunque su escasez de cabaIlería les impidíó aprovechar los frutos de la víctoria. Prosiguieron después el avance y verificaron su unión al grueso del ejército el 15 de junio en Socona.

El jefe de la cuarta columna, que procedía de La Paz, Revuelta, hubo de sostener dos acciones violentas 
contra los insurgentes; una, el 2 de Junio, que duró casi todo el día, contra un cuerpo enemigo de 1.500 hombres, que sufrió una grave derrota, en la que perdieron 140 muertos, nueve cañones y dos banderas, además de un número considerable de pertrechos, fusiles, etc.; y otra, en el partido de Yangarre, con notable éxito también por parte de Benavente, que capturó dos cañones.

En cambio, el quinto cuerpo de ejército, mandado por Alvarez de Sotomayor, no encontró obstáculo alguno en su marcha y verificó su entrada en la provincia de Cochabamba sin encontrar resistencia, quedando situado en la ciudad de Valle Grande.

La entrada de las fuerzas realistas en Cochabamba originó uno de los hechos más desagradables de esta guerra. Al ser abatidos los cochabambinos en el cerro de San Sebastián, las tropas encontraron abierto el camino de la ciudad, que, como se dice más arriba, encontraron desierta. Los soldados entraron en ella y se entregaron al saqueo, que duró hasta la puesta del sol. El saqueo del ejército realista, unido a los excesos cometidos por el populacho de la misma ciudad la noche anterior al día de la entrada de las tropas, nos pueden dar una idea del aspecto que ofreceria la población, que pagó bien cara su reincidencia. El mismo capitán Alvarez, de cuya «Memoria» ya citada son los datos que me han servido para estudiar la campaña contra Cochabamba, dice justamente horrorizado: «el ruido de nuestras armas por las calles y plazas y el conjunto de circunstancias lamentables, formaban el cuadro perfecto de la desolación y Justo escarmiento». Aún hubo más, pues al saqueo sucedió el incendio de uno de los barrios de la ciudad, lo que contribuyó a aumentar la desolación y la ruina.

Ciertamente, la conducta de Cochabamba no había sido leal para los realistas; sin embargo, en manera alguna se justifica el desorden, producido únicamente por el inmoderado deseo de venganza de una tropa difícil de mantener en la disciplina. El propio Abascal se lamenta de semejante acto de barbarie, si bien trata de sacar de él un escarmiento y ejemplo para los demás pueblos sublevados (26), La conducta

(26) ABAsCAL. Memoria. Tomo II. Pág. 392. 
de Goyeneche quizás pecó en este caso de excesiva benevolencia para con sus soldados, pues según dice la «Memoria» de Alvarez, al ponerse el sol *Goyeneohe, que se hallaba en la Plaza Mayor, dispuso suavizar y aun cesar toda hostilidad...», lo cual hace suponer que, tácitamente al menos, aprobaba los hechos cometidos hasta entonces. Sin embargo, cabe pensar en su descargo que debía ser una tarea casi ímproba impedir a las tropas cometer excesos a su entrada en la ciudad, exasperadas por la conducta de los cochabambinos.

Inmediatamente después de la toma de la ciudad, se planteaban dos cuestiones delicadas: el castigo de los culpables y la reorganización de la administración y el abastecimiento. Lógicamente tenian que ser castigados por los realistas aquellos que habian originado la sublevación, como efectivamente lo fueron a medida que cayeron en sus manos. Sin embargo, parece que en esta ocasión Goyeneche quizás en su deseo de escarmentar definitivamente a los sublevados e impedir nuevos levantamtentos, perdió un poco su serenidad acostumbrada, y se cometieron algunos excesos en el castigo de los insurgentes por la comisión militar creada al efecto.

Para resolver el otro problema, se nombraron dos alcaldes encargados de procurar el abastecimiento de viveres de la ciudad, a la par que se publicaba un decreto ordenando la entrega de todas las armas en el plazo de cuarenta y ocho horas.

Verificada la pacificación de la ciudad, emprendió Goyeneche la marcha hacia Chuquisaca, después de haber dejado una fuerte guarnición en Cochabamba, y enviado a Ramírez con las divisiones del Real de Lima y de Cotabambas en dirección a Chayanta con objeto de apaciguar dicha provincia antes de dirigirse a Chuquisaca: Igualmente, Picoaga marchó al pueblo de Paredón para castígar las partidas de insurgentes que aún permanecían por sus contornos.

A su marcha de Cochabamba, el ejército emprendió el camino a través del valle de Clisa, ocupando todos los pueblos del mismo que aún permanecían al lado de los sublevados, la mayoría de los cuales, evacuados por éstos, se rendían ante la proximidad de los realistas. 
El 24 de junio entraron en Chuquisaca las tropas de Goyeneche. Dicha ciudad no se habia sublevado durante la revolución de Cochabamba, por lo que había sido molestada por las partidas procedentes de aquélla. El caudillo cochabambino Arce, cuando se retiraba, se presentó ante ella con intención de ocuparla si no se decidia a sublevarse. Sin embargo, resultaron fallidos sus intentos, pues la guarnición, mandada por su comandante Landivar, hizo una salida y le obligó a evacuar la cuesta de Molle-Molle, en donde se habia colocado para atacar a la ciudad.

Con esta expedición y las de las columnas que acabaron de reducir las últimas partidas de revoltosos y de ocupar los últimos pueblos de la provincia, se podía considerar pacificada completamente toda la región de Cochabamba. Inmediatamente despusés de verificada la reorganización de la misma, las tropas de Goyeneche emprendieron el camino de sus primitivos destinos unas, y otras se dirigieron hacia suipacha, en donde se hallaba situada la vanguardia del ejército, con objeto de prevenirse contra la expedición que preparaban los argentinos.

La campaña contra la ciudad de Cochabamba fué quizás una de las más duras y de las llevadas con más rigor por el ejército realista. Lu ciudad y su provincia se habian manifestado desde un principio como partidarias fervientes de la revolución de Buenos Aires. Su sometimiento en agosto de 1811 lo habia sido única y exclusivamente por la fuerza de las armas: pero el corazón de los cochabambinos no estuvo nunca del lado de aquéllos, y la prueba más palpable de esta afirmación fué su segundo levantamiento.

Inmediatamente que el ejército realista se alejó de la ciudad, surgieron las primeras sublevaciones, $y$ por fin entraron los revoltosos en ella, declarándose ablertamente por la Junta de Buenas Aires. Pero lo que debió exasperar a los realistas fueron los movimientos que provocaron en los indios de los contornos, que cortaron el camino del Perú y dejaron casi aislado al ejército, colocándolo en situaciones difíciles con sus constantes ataques a las ciudades.

Todas estas eircunstancias contribuyeron a exasperar a los soldados realistas, que se veian obligados a luchar constantemente sin ningún resultado prác- 
tico. En consecuencia, todo el camino del ejército en su marcha hacia Cochabamba estaba jalonado por una gran cantidad de pueblos destruidos, en los que se hicieron fuertes los rebeldes, o que abandonaron al acercarse las tropas enemigas. Quizás esta conducta, juzgada ahora, parezca excesiva, $y$ en efecto lo sea; pero hay que tener en euenta, como he dicho antes, los hechos que la motivaron y el estado y la calidad del elércita Claro está que semejante conducta no era la más a propósito para atraerse a los naturales y a los indias; de ahí las constantes recomendaciones de Abascal a Goyeneche sobre la cuestión, que hemos cbservado más atrás. A la, par que se castigaba con mano dura a los culpables, el Virrey se daba cuenta de que, tan necesario como el mismo castigo era el empleo de un exquisito cuidado en atraerse a los naturales, puesto que de otro modo se hacia imposible el mantenimiento de las conquistas, y éste habia de ser el principal cuidada de los canquistadores.

Difícil era, sin embargo, atraerse a los cochabambinos. Casi una mes después de reconquistada la cildad, el Coronel Lombera que habia quedado de guarnición en ella al frente de su división, escribia al ViT rrey dándole notieias sobre la situzción y el estado de ánimo de la misma. La impresión que se desprende del oficio de Lombera es bastante penosa. Poco a poco se restituian a la ciudad todos sus habitantes, que habian huído a la leggada de los furras realistas. Los que volvian aparentaban su simpatía a la causa del Rey, aunque esta simpatia era puramente externa, pues el mismo Lombera nos lo explica claramente: «reina un silencio en toda la ciudad-dicengue pu- diera dar esperanzas de una segura tranquilidad; mas observados con euidado los semblantes, se advierte en ellos un aire triste $\mathrm{g}$ taimado que indica muy bien que su quietud no es la del corazón» r(27).

Semejante estado de ánimo se réflejaba en una gran resistencia pasiva a cumplir las órdenes dadas

(27) Axch. Abascal. Oficio de Lombera al Virrey de Perú. Comandarreia General de Armas de Cochabamba, 22 de junio de 1812. En un expediente de partes del General del ejércitớ del Alto Perú. Fol, 1, 
por las autoridades. Prueba de ello fueron las repetidas ordenes dadas para recoger las armas escondidas por los revoltosos, a pesar de las cuales, «si la denuncia o la viva diligencia no las descubre, ninguno las manifiesta en señal de su arrepentimiento», decía Lombera, como tampoco se apresuraba a capturar a los caudillos de la revolución, como se les había impuesto por condición al someterse. Resultado de todo, era que los caudillos, que habían escapado de las manos de las tropas al entrar éstas en la ciudad, se encontraban escondidos en los campos, adonde apenas eran molestados. No es de extrañar, pues, que diga Lombera que «el servicio de esta Plaza es de rigurosa cámpaña, no de ordinaria guarnición, y nunca será segura dejarla sin una fuerza respetable para evitar los males y desgracias de casi evidentes futuras convulsiones» (28).

Tales circunstancias obligaban a un constante estado de guerra que producía como consecuencia el natural entorpecimiento para la marcha del ejército, al que habrian de restársele las tropas, que en gran cantidad quedaron de guarnición para mantener la ciudad y su territorio. Con objetó de evitar este mal, en cuanto fuese posible, el Virrey envió instrucciones a Lombera y a Goyeneche. Recomendaba a aquel reunir las tropas en un edificio aislado y convenientemente preparado para una eficaz defensa, y quitar las caballerias a los cochabambinos, que habían demostrado tener en ella su arma más eficaz, y que habrian de utilizarse ahora para el servicio del ejército, o para su venta, invirtiendo su producto para la subsistencia de aquél (29).

De este modo se procuraba aumentar en todo lo* posible el ejército situado en la frontera de Buenos Aires para combatir a los sublevados, de quienes llegaban noticias que preparaban una nueva expedición contra el Alto Perú.

(28) Arch. Abascal. Oficio de Lombera al Virrey del Perú. Cochabamba, 9 de julio de 1812. En el expediente de partes del General del Ėjército del Alto Perú. Fol. 6.

(29) ABASCAL. Memoria. Tomo II. Pág. 395. Orden de 9 de agosto de 1812 . 


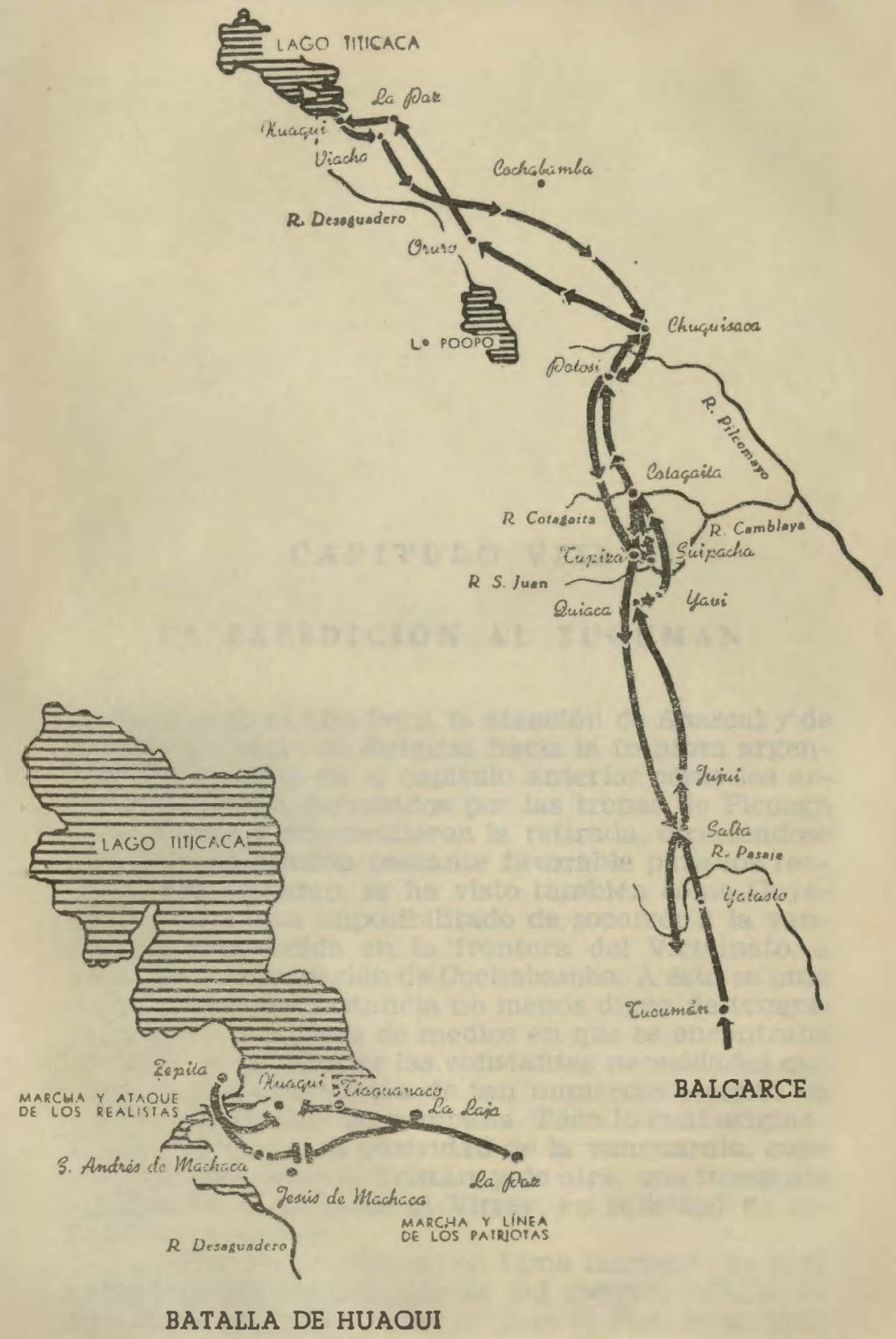


<smiles>C=CC#CC(CC(=C)C)=C(C)CC</smiles> 


\section{CAPITULO VIII}

\section{LA EXPEDICIÓN AL TUCUMAN}

Pacificado el Alto Perú, la atención de Abascal y de Goyeneche había de dirigirse hacia la frontera argentina. Se ha visto en el capítulo anterior cómo los argentinos fueron derrotados por las tropas de Picoaga en Suipacha y emprendieron la retirada, ofreciéndose con ello una ocasión bastante favorable para los realistas. Sin embargo, se ha visto también cómo Goyeneche se hallaba imposibilitado de socorrer a la vanguardia establecida en la frontera del Virreinato, a causa de la sublevación de Cochabamba. A ésto se unía además otra circunstancia no menos digna de tenerse en cuenta: la escasez de medios en que se encontraba el Virrey para atender las constantes necesidades que requería la conservación de tan numeroso ejército en permanente estado de campaña. Todo lo cual originaba, de una parte, la pasividad de la vanguardia, cuyo mando había tomado Tristán, y de otra, una incesante petición de Goyeneche al Virrey, en solicitud de refuerzos y de dinero.

La situación de Abascal en Lima tampoco era muy halagüeña. El mantenimiento del ejército solamente, significaba un gran trastorno para la Hacienda; pero 
si además se le unen las constantes peticiones que recibía de todos los lugares del Continente, y el envio obligado de dinero a la Metrópoli para mantener la guerra contra los franceses, podemos darnos una idea aproximada de la insuficiencia del Erario peruano para atender a tantos sitios a la vez, mientras le fallaban sus principales fuentes de ingreso.

A pesar de todo, ingeniándose medios para obtener dinero, acudía el Virrey a todas partes donde era necesaria su ayuda. Pero había momentos verdaderamente críticos. Por su parte, Goyeneche se daba cuenta de la imperiosa necesidad del envío casi constante de material y dinero para mantenęr la eficacia de su ejército, y asediaba al Virrey, que procuraba complacerle en la medida de sus fuerzas. No es, pues, exagerado el juicio que hace Abascal sobre su situación en una carta de 26 de febrero de 1812 , dirigida a Goyeneche. En ella le dice: «Me hago cargo del peso que Vd. tiene sobre si; pero consuélese Vd. con que no es menor el que me oprime por falta de dineto, pues me estoy viendo de un mes para otro sin arbitrios para mantener las obligaciones de este vasto Gobierno: $\mathrm{Pa}$ namá, Guayaquil, Cuenca y Puno me asaetean con peticiones urgentisimas, y anque hasta ahora las he ido contentando del modo posible, y con las mayores penalidades, llega mi aflicción a un extremo que no es fácil explicar . (1).

Se desprende que, en tal situación, el Virrey no podía atender a todas las necesidades del ejército, o al menos habría de irlas cubriendo poco a poco, lo que causaba la desesperación de Goyeneche. La perspectiva de tener que hacer frente a los enemigos del Alto Perji y a los de Buenos Aires sin contar con los medios necesarios, producía cierto desánimo en el General, que preguntaba al Virrey, después de pintarle el cuadro de la situación: ¿¿ ¿obre qué planes obro? ¿Sobre qué descansan mis insoportables tareas? 2 . La situación era muy difícil para sostenerla sin un continuo refuerzo: stenemos por enemigos cuantos ingratos hemos sometidos; la fuerza no alcanza para

(1) Arch. Abascal. Borrador de carta de Abascal a Goyeneche. Lima, 26 de febrero de 1812. 
sólo hacer callar la voz ronca de las venganzas y del odio con que nos miran; apenas las grandes poblaciones están exentas del saqueo y del robo con los batallones que las guarnecen, $y$ aún en ellas se ven clubs de tramas y asesinatos sobre que la vigilancia más contraída no puede tocar a sus exterminioss (2).

Tales son, según Goyeneche, las razones principales por las que se requería un especial cuidado para el mantenimiento del ejército. $Y$ que constituían su primera preocupación, lo demuestra el gran número de oficios dirigidos at Virrey en solicitud de auxilios. El 27 de julio de 1811 pedía a éste 100.000 pesos urgentes y necesarios para el ejército; el 6 de noviembre del mismo año le volvía a insistir en la petición, y le advertía que, si para facilitarlos no tomaba providencias extraordinarias, no podria responder de las operaciones. En el mismo mes, el 25, le pedía refuerzos de tropas. Ya en 1812, el 9 de febrero, solícitaba Goyeneche se le destinasen mensualmente 40.000 pesos de las Cajas del Perú para la subsistencia del ejército, sobre lo cual le volvía a insistir en 24 del mismo mes. Por último, en 9 de marzo, le representaba al Virrey la urgencia de los socorros en tropas y dinero que le tenía pedidos, y le indicaba que, en su defecto, le enviase instrucciones políticas para poder obrar según exigiesen las circunstancias (3).

Es lógico que Goyeneche pensase de este modo. Basta recordar que cuando escribía así, era el momento en que cundia la sublevación de Cochabamba por todas las regiones del Alto Perú y el ejército corría el grave peligro de quedar aislado. Todos los refuerzos habian de ser pocos ciertamente. Además, se encontraba solo para luchar contra todos los enemigos, pues, como decía al Virrey, Montevideo había pactado con Buenos Aires, y de España, embebida en su lucha contra los invasores, no podían enviar ninguria clase de auxilios. «Nosotros solos llevamos el

(2) Arch. Abascal. Copia de carta de Goyeneche a Abascal. Cuartel General de Potosí, 10 de marzo de 1812.

(8) Arch. C. Guagui, C. 9. Carp, 3. N. 3. \&Resúmenes de varios oficios dirigidos al Virrey de Lima, solicitando reemplazos $\nabla$ auxihos, según el extracto hecho en la Secretaría de Guerra del ejército del Alto Perús. Potosi, 4 de febrero de 1813. 
peso de la disputa contra la fuerza, contra el genio y contra las disposiclones que se proyectan para nuestro exterminio» (4). Y se quejaba de que a ninguna de sus pettciones se le había dado en la capital la importancia que tenían, porque en Lima, que había adquirido «tan considerables glorias a tan poca costa de sus peculiares recursos», quizás se hubiera pensado que las pasadas batallas habían extinguido la idea de la revolución, creencia que distaba mucho de la realidad.

Que la situación de Goyeneche fuese o no tan desesperada como él la pintaba, es cosa que se verá más adelante. Lo que sí es cierto que el Virrey, tan interesado como el General en el mantenimiento de las conquistas, hacía todo lo posible por ayudarle y le enviaba cuantos auxilios estaban a su alcance. Pero hay que tener en cuenta también la situación de Abascal, a que ya me he referido antes. Ahora se había venido a sumar a todas las dificultades anteriores la abolición del tributo de los indios, decretada por las Cortes, medida quizás política, pero de fatales consecuencias para la economía americana en tales momentos. Un millón doscientos cincuenta mil pesos importaba este ramo en el Perú, de los cuales entraban en el Erario solamente setecientos mil. El resto se empleaba en el pago de sínodos, dotación de subdelegados, el tanto por ciento de cobranza y subsistencia de hospitales de naturales; «que todos acuden a mí-decía Abascal-para que se les satisfagan sus cuotas respectivas, alegando los curas hallarse incongruos, los subdelegados sin dotación y los hospitales en término de echar a la calle a los enfermos», y solamente los gastos extraordinarios del ejército del Alto Perú y tropas de Guayaquil y Cuenca ascendían a un millón quinientos mil pesos (5). Parece natural que, desaparecido de pronto este ingreso en circunstancias tan dellcadas, se originase una grave crisis en la Hacienda con la consiguiente repercusión en el

(4) Arch. Abascal. Copia de carta de Goyeneche a Abascal. Cuartel General de Potosí, 10 de marzo de 1812.

(5) Arch. Abascal. Borrador de carta de Abascal a don Fran-. cisco Salazar. Lima, 23 de marzo de 1812. 
desarrollo de las operaciones del ejército. La situación anterior originada por la guerra ya era bastante grave, y a medida que se prolongaba iba aumentando los gastos, mientras los ingresos amenazaban disminuir.

Con objeto de hacer frente a la nueva situación, Abascal reunió una Junta de Tribunales, que ideó algunos recursos para poder extraer numerario de todos aquellos sitios de donde fuese posible sacarlo con un minimum de garantias. De las deliberaciones de la Junta se obtuvieron algunos arbitrios para obtener al año algo más de cuatrocientos mil pesos, y el proyecto de persuadir a los indios de que continuasen pagando el tributo con el nombre de única contribución. Pero lo último exigía un gran cuidado, según opinaba el mismo Abascal, pues había de tenerse un tacto exquisito para no provocar protestas.

Si se lograban dichas medidas y daban resultado, se podría cubrir un poco el déficit de la Hacienda y socorrer al Ejército del Alto Perú. Pero es que no solamente el ejército solicitaba una urgente ayuda. En 10 de Julio, Abascal decía a Goyeneche: «mi aflicción llega a un término Inexplicable, pues el Gobierno Soberano de la Nación me pide con las más tiernas instancias socorro de numerario, como por vía de limosna caritativa. El Virrey de Santa Fe me estrecha desde Panamá, donde se ha establecido, de un modo terrible, que me asegura que sin socorro mío se ve en la triste necesidad de abandonar aquel istmo; los de Cuenca me asaetean del mismo modo, y últimamente, el Gobernador de la Provincia del Rio de la Plata y el Cabildo de Montevideo me envían diputaciones en solicitud de auxilios por no tener absolutamente con qué mantener la tropa de su guarnición y la que va llegando de la Península, sin los cuales, irremediablemente se perderá aquella plaza y toda la Banda Oriental, desconfiando de algún modo de la conducta de los aliadoss (6).

Sin embargo, de todos los que solicitaban de Abascal, era Goyeneche, según declara el propio Virrey, el

(6) Arch. C. Guaqui. C. 13. Carp. 4. N. 6. Carta de Abascal a Goyeneche. Lima, 10 de julio de 1812. 
que podía salir mejor parado. Para ayudarle le había propuesto el 23 de mayo de éste año una medida, que le recuerda más tarde, y que podía sacarlo de sus apuros. Consistía simplemente en poner a contribución los pueblos que se fuesen ocupando, puesto que éllos habían dado la ocasión para el armamento y su considerable gasto. Contribuciones que podrian ser en dinero o especies que lo valgan, para así facilitar su extracción. "Ahora que las circunstancias no han variado - le decía Abascal después de la toma de Cochabamba - es forzoso repetir a V. S. que este último recurso a que no apelaría si tuviera a la mano otro más templado, no obstante que la conducta de los revolucionarios de Cochabamba y Challanta no se ha hecho en ninguna manera acreedora a esta consideración, puede bastar a cubrir sus obligaciones, y se hace cada vez más urgente y preciso, ya que mis estrecheces me ponen fuera de estado de socorrer a V. S. para que nada faltase a ese recomendable ejército... (7).

Todas las dificultades no impedian, sin embargo, la prosecución de las operaciones de guerra. Sometida Cochabamba y pacificado el Alto Perú, Abascal daba instrucciones a Góyeneche para la próxima campaña contra las tropas de Buenos Aires, que se reorganizaban con propósito de comenzar la ofensiva. Inmediatamente se debian hacer los preparativos para contrarrestar los planes de los enemigos, en tanto fuese posible tomar la ofensiva contra éllos. A este fin le indica la necesidad de continuar el camino hasta Salta, para lo cual se emplearía un cuerpo de 2.000 hombres, con otro cuerpo intermedio de 1.000 , situados en Suipacha o Moxos, según convenga kadelantando. un destacamento de 500 hombres al Ría del Pasage, desde donde pueden hacer correrias hasta S. Miguel, de cuya suerte se estrecha a Buenos Aires de un modo que, dentro de poco tiempo, no le quedarán recursos para mantener 2.000 hombres (8). Con semejante plan, el Virrey pretendia inquietar a los argentinos

(7) Arch. C. Guaqui. C. 9. Carp. 4. N. 1. Oficio de Abascal a Goyeneche. Lima, 10 de junio de 1812.

(8) Arch. Abascal Copia de aficio de Abascal a Goyeneche. Lima, 10 de agosto de 1812 . 
con correrias hasta Santiago del Estero, con el fin de perturbar toda la región hasta Córdoba, a la par que se aprovechaban sus recursos.

Precisamente para este fin consideraba Abascal necesaria la traslación del Cuartel General de Goyeneche a Potosí. Para estar más al cuidado de las novedades que pudieran ocurrit, del fomento de la mineria y del trabajo de la Casa de Moneda para activar los socorros que habrian de enviarse a la vanguardia, a cuyo frente se pondria un fefe de toda confianza.

Por su parte, los argentinos se preparaban para emprender de nuevo la ofensiva. Después de las acciones de Suipacha y Nazareno, las tropas de Buenos Aires se retiraron al pueblo de Yatasto y se mantuvieron inactivos, todo el tiempo que duró la ofensiva contra Cochabamba. Pero ahora se anunciaban nuevas operaciones. Belgrano, el caudillo argentino que había llevado la campaña del Paraguay, había sido designado por la Junta para emprender otra en el Alto Perú. Quizás la elección fué debida a un deseo de atenuar los excesos cometidos en la primera invasión del Alto Perú por las tropas de Castelli.

Efectuados los preparativos para la invasión, coincidiendo con los primeros movimientos de los reallstas, Belgrano lanzé una protelama desde su Cuartel General de Jujuy, dirigida a los habitantes de las provincias altoperuanas, a los que instaba a untrse al ejercito patriota.

Entretanto, Tristán se había puesto en camino hacia Jujuy y Salta con el fín de ocupar ambas ciudades, que según notictas recibidas, habian sido evacuadas por los argéntinos. La marcha de Tristán a través del territorio abandonado por los enemigos fué penosa. Belgrano había mandado retírar todo lo que supusiese una avuda para la progresión de los realistas, y la distancia de sus bases a que éstos operaban, les obligaba a surtirse en país enemigo. Todo lo cual originaba un considerable retardo en la marcha del Ejército, según comunicaba el Mayor General a Goyeneche (9).

(9) Arch. Abascal. Carta de Tristán a Goyeneche. Campamento de Barrios, 17 de agosto de 1812. 
Sin embargo, a pesar de las dificultades, proseguian los realistas ecercándose a Jujuy, cuya toma, Junto con la de Salta, comunicaba Goyeneche por correo extraordinario al Virrey el 4 de septiembre, a la que pedía el grado de Brigadier para Tristán, por su comportamiento en la campaña, que tan favorablemente iba desarrollando (10).

Las tropas de Belgrano se retiraban en dirección al río del Pasaje, a medida que avanzaban las de Tristán, cuya progresión era sostenida por un cuerpo de 1.000 hombres, que se organizaban en Tupiza. El avance de la vanguardia, cuya avanzada la mandaban los tenientes coroneles Llanos y Huici, estaba calculado se llevase a cabo hasta San Miguel de Tucumán. En este punto se detendrían, según ordenaba el Virrey, sin proseguir el camino hasta haberse puesto de acuerdo con Montevideo para combinar las operaciones de ambas partes. La posesión del territorio ocupado por la vanguardia de Tristán había de tener, pues, la finalidad de establecer un contacto más directo con Montevideo a través del Paraguay que, según noticias llegadas a Lima, se había unido a aquella ciudad (11). Pero lógicamente, para llevar a cabo el plan de Abascal era necesario antes derrotar a los enemigos que se hallaban en el río del Pasaje.

Llegadas noticias a la vanguardia de la expedición de que las tropas de Belgrano se hallaban situadas en el río del Pasaje, Llanos y Huici decidieron detener su avance hasta que efectuase la incorporación a sus tropas el teniente coronel Leefdael, que se había retrasado en la marcha. La detención de la vanguardia se hallaba plenamente Iustificada. Como he dicho más arriba, la progresión del ejército se encontraba supeditada al abastecimiento de víveres y de agua, problema bastante dificil de resolver. Obligado por las circunstancias, habia sido necesario desviar la ruta del camino del Tucumán, sobre el que verificaba la marcha, con el fin de dar de beber a la tropa, adentrán-

(10) Arch. Abascal. Carta de Goyeneche a Abascal. Potosi, 4 de septiembre de 1812.

( (11) Atch. Abascah Copia de carta de Abascal a Gryeneche. Lima, 10 de octubre de 1812. 
dose como una legua en el interior del monte. Desde aquí no habian encontrado más agua al reemprender el camino hasta el campamento enemigo, con el que habian de entrar en contacto, con el agravante de que, si se veían forzados a emprender la retirada, habia de ser de nueve o diez leguas necesariamente. Exponerse a una retirada con malas cabalgaduras y sin agua, era demasiado atrevido; por estas razones juzgaron prudente los comandantes de la vanguardia esperar la reunión de Leefdael, y, una vez verificada, seguir de nuevo el camino para atacar a los patriotas situados en el Pasaje, en donde harian alto hasta la reunión de las demás fuerzas que le habian anunciado (12).

Sin embargo, no se verificó el plan trazado. Se encontraron sin pastos ni ganado para abastecer a la tropa de alimentos el punto en que habian determinado esperar los reruerzos, $\$$ acordaron situarse en el rỉo de las Pledras, ocho leguas más avanzado. Alli pensaron encontrar más comodidades, y con tal fín emprendieron la marcha en la madrugada del 3 de septłembre. Continuaron caminando la mañana del día 3, y cuando se hallaban a tres leguas del rio de las Piedras, a las tres de la tarde, se oyeron tiros en la descubierta de las tropas. Reorganizada inmediatamente la columna, que había hecho alto en el río Blanco, continuaron la marcha con alguna celeridad. A medida que proseguia el avance del grueso de las tropas que se acercaban a las avanzadas, se recrudecia el fuego, más intenso por momentos, por lo cual podía calcularse un numeroso grupo enemigo, ya que el terreno montuoso impedía distinguirlo.

En vista de ello, y como la partida realista de descubierta se viese obligada a replegarse, se dispuso que una guerrilla del Real de Lima fuese a sostenerla mientras se organizaba la infantería y se acercaba el grueso de la columna de vanguardia.

Iniciado el ataque por los realistas, se retiraron los enemigos a una posición en un monte, sostenidos por

(12) Arch. Abascal. Copia de oficio de Llanos y Huici al Mayor General Jefe de la vanguardia. Campo de la Ciénaga, 1 de septiembr: de 1812. Expediente de parte del jefe del ejérrito del Alto Perú. Fol. 25. 
400 hombres y dos cañones, mandados por Balcarce y Díaz-Vélez, que rompieron el fuego inmediatamente, enfilando todos los caminos. Sin embargo, a pesar de eso, las tropas realistas se lanzaron al ataque y les cortaron la retirada, dejando sembrado el monte de más de cuarenta cadáveres. El resto fué hecho prisionero y Diaz-Vélez se retiró con la caballería, abandonando las piezas de artillería en el terreno.

Se reunieron en seguida las tropas, que se habian lanzado impulsivamente a perserguir a los enemigos y llegaron hasta su propio campamento. Se dispuso que se aproximara el resto para auxiliar a aquéllos e informar de su situación, y para proteger la retirada en caso necesario.

Las noticias que se tenian sobre el grueso de los enemigos diferían respecto a su situación en el río de las Piedras o en la Posta de Metán.

Pero entonces el enemigo, que se habla organizado, se hallaba dividido en tres sectores, con un total de unos 1.200 hombres con fusil y 500 con lanza y nueve o diez piezas de artillería. Drandose euenta de que iba a ser atacada, el enemigo destacó sus guorrillas a derecha e izquierda y comenzó el fuego hacia las seis de la tarde. Lo avanzado del tiempo y la manifiesta inferioridad de los realistas, que carecian de artillería, obligó a éstos a emprender la retirada, organizada en tres columnas, que llegaron al rio Blanco sin ser molestadas por los patriotas.

No había transcurrido la noche, cuando se oyeron disparos de la avanzada, lo que daba a entender que el enemigo estaba cerca, conocedor tal vez de la escasez de fuerzas de los realistas. Colocadas éstas en posición, se mantuvieron durante toda la noche preparadas para resistir el ataque. Una descubierta, efectuada al alba siguiente trajo la noticia de que el enemigo se movía a menos de una legua. Dándose cuenta de su evidente inferioridad, decidieron los realistas retirarse al rio del Pasaje, to que efectuaron en el mayor orden sin ser hostilizados y conduciendo el botín que habian recogido (13).

(13) Aroh. Abescal. Copia de parte de los Comandantes de la vanguardia Llanos y Huici al Mayor General Jefe de la vanguar- 
Efectuado el repliegue al río del Pasaje, en'la mañana del 5 de septiembre, les llegó el refuerzo de 500 hombres mandados por el teniente coronel don Juan Moseoso. Con dicho refuerzo, una vez descansada la tropa y las cabalgaduras, se prepararon de nuevo a marchar hacia el Tucumán, habida cuenta de que el enemigo se había retirado y padecido bastantes pér didas en los anteriores encuentros. Debido a esto parecia fácil el avance hasta dicha ciudad, adonde se habian retirado los patriotas (14).

El parte del encuentro del día 3 lo recibió Tristán camino del río del Prisefe. Efectuada una requisa de cabalgaduras en Jujay, de donde sacó 1.200 caballos en nueve días que permaneció en la ciudad, emprendió el camino para unirse a la vanguardla de Llanos y Huici, con el fin de continuar el avance con todo el grueso del ejército hasta el Tucumán para obligar a los argentinos a encerrarse en Córdoba. La finalidac perseguida en la operación está expuesta claramente por Tristán en una carta a Goyeneche de fecha 10 de septiembre. E] Tucumán proporciona abundantes $\mathbf{v}$ veres, forrajes y cabalgaduras; más allá todo es escaso y árido hasta Córdoba. La retirada de la armada. que va seguida de inmediato por $\mathrm{mi}$ vanguardia, da lugar a la deserción de todos los provineianos de esta Intendencia se reduce el ejército argentino a los pocos porteños y cordobeses que hay en él, disipándose asi su aparto de fuerza y haciéndole perdet por consecuencia muchas armas, cuya reparación es como imposible» (15). Llegados los restos del ejército patriota a Cordoba, pensaba Tristán que sus habitantes, descontentos por el trato afrentoso de que le hacían objeto, habrian de levantarse contra ellos, y conocidos por los patriotas los movimientos del grueso de la zanguardia enemiga, continuarian su retirada.

dir. Río de Pasaje, 5 de septiembre de 1812. Expediente de partes, otc . Fol. 35. Cfr. ABASCAL. TIémoria». Tamo II. Págs. 39 ss. (14) Aroh. Abascal. Copia de oficio de Llanos y Huici al Mayar General Tristán. Río de la Sierra, 10 de septiembre de 1812. En el expediente de parte, otc. Fol. 37.

(18) Arch. Abascal. Cupla de carta de Tristán a Goyeneche: Canpamehto de Cábeza de Bútey, 10 de septiembre de 1812. En el expediente etc. Fol. 38. 
Entretanto se fijaba Tristán en el Tucumán; pensaba que la provincia de Salta, completamente sometida, surtiría al Perú de mulas y ganados y reanudaría sus relaciones comerciales. Por su parte, desde el Tucumán, pensaba entrar en contacto con Montevideo, Paraguay y el Brasil. Sin embargo, para preparar las acciones posteriores y prevenir los intentos de los enemigos, creía de absoluta necesidad el envio de mil hombres que marchasen a reforzarlo, con los cuales se comprometía a destruir todos los esfuerzos de los argentinos. Este era el plan que el jefe de la vanguardia comunicaba a Goyeneche y que fué aprobado por el general. La batalla del río de las Piedras, aunque sensible para ambos contendientes y aunque obligara a los realistas a retirarse al río del Pasaje, les fué menos costosa que a los patriotas. En lineas generales, ise puede considerar la acción como un conjunto de movimientos, mejor que una batalla formal, que se pueden dividir en tres etapas. La primera tiene lugar con el avance de Llanos y Huici a partir del río Blanco, en donde se recibieron las primeras noticias del enemigo. Culmina la primera fase en el combate que se desarrolla en las cercanías del río de las Piedras, el 13 de septiembre, en el que Díaz-Vélez, comandante de la vanguardia del ejército de Belgrano, se vió obligado a retirarse. A partir de este instante, si los realistas hubiesen tenido una buena caballería hubieran podido convertir en desastre el revés que sufrieron los patriotas. Por carecer de ella se vieron impedidos de perseguirlos eficasmente, y aunque las mismas guerrillas realistas se lanzaron contra los que se retiraban, no pudieron organizar dicha persecución.

La falta de elementos para explotar el éxito, que fué quizás una de las caracteristicas fundamentales de la guerra en el campo realista, y que, unida a otras varias hizo ineficaz todos sus esfuerzos, permitió a los patriotas organizarse de tal forma que, cuando los realistas llegaron a sus inmediaciones, pudieron darse cuenta de que un combate en semejantes circunstancias les sería forzosamente desfavorable. Como consecuencia, emprendieron la retirada al punto de partida, al río Blanco, adonde llegaron sin recibir molestias por parte de sus enemigos. 
Hasta aquí puede convenirse en que la situación se decidia a favor de los realistas. Aunque frustrada su persecución y obligados a retirarse al punto de parttda, hay que concederles que, al menos, habian conseguido una victoria de la que obtuvieron bastante botín, y el enemigo no se había atrevido a atacarlos en su retirada cuando la ocasión parecía bastante propicia (16).

Sin embargo, el tercer movimiento de esta serie de acciones demuestra claramente el alcance de la operación del río de las Piedras. Indudablemente no pasó de ser un mero encuentro entre las patrullas de la vanguardia de ambos ejércitos, como lo demuestra, en primer lugar el hecho referido más arriba, de encontrar los realistas las fuerzas enemigas a su llegada al campamento patriota, y en segundo lugar, el que, retirados aquéllos al río Blanco, recibieron la misma noche la sorpresa de que los patriotas habian avanzado y se encontraban al día siguiente a menos de una legua del campo realista. El movimiento de los argentinos fué originado, sin duda, por las noticias que recibieron de algún prisionero sobre el corto número de las fuerzas realistas.

La presencia del grueso de los enemigos colocaba a las tropas de Llanos y Huici en franca inferioridad, lo que les obligó a continuar el repliegue hasta el río del Pasaje. Sin embargo, es curioso observar, que ni durante la noche ni en la retirada hasta el Pasaje sufrieron los realistas la menor hostilidad por parte de los patriotas. Semejante actitud de los argentinos es también significativa; si se hubiesen lanzado al ataque contra la avanzada de la vanguardía del ejército de Goyeneche, es casi seguro, 'o al menas bastante probable, que la hubiesen destrozado. Los aventaja ban en infantería, caballería y artillería; cabe pensar que un violento ataque contra el reducido destaca-

(16) El botín obtenido en la acción del Río de las Piedras fué el siguiente: dos cañones, más de cuarenta fusiles, cineuenta y siete prisioneros, diez carretas cargadas de hierro, cuya cantidad se calculó en quinientos quintales, y una porción de equipajes, de que se aprovechó la tropa. Arch. Abascal. Parte de tlanos y Huici de 5 de septiembre de 1,812, y ABASCAL, Memoria. Tomo II. Pág. 399. 
mento realista hubiese puesto en sus manos una victoria facil, y hasta quizás hubiese evitado por el momento la invasión del Tucamán. La causa de esta falta de iniciativa no se puede saber; quizás DíazVélez, que se había salvado milagrosamonte de caer prisionero en lá acción del rio de las Piedras, no se atrevió a lanzarse a una nuevq ducha que podía tener un resultado más decisivo que la otra, no respondiendo de la moral de la tropa con que contaba. Pero lo que más asombra es su precipitado repllegue hasta la ciudad del Tucumán al tener noticias de la proximidad de los refuerzos que se acercaban a los realistas al mando del teniente coronel Moscoso, que, con 500 hombres, se unió a Llanos y Huici en la ribera del río del Pasaje.

El inesperado repliegue del ejército patriota, Junto con la victoria obtenida en el río de las Pledras, fué lo que llevó a Tristán a concebir la ejecución inmediata de su plan de invasión del Tucumán para llegar hasta Córtaba, y desde allí ponerse en contacto con el Brasil y Montevideo con el fin de organizar la ofensiva general contra Buenos Aires.

Para llevar a la práctica el plan aprobado por Goyeneche, hacian falta dos condiciones fundamentales: un refuerzo del ejército, por lo menos de 1.000 hombres, como le pedía Tristán, y la seguridad del mantenimiento de las comunicaciones. Ambas cosas parecían logradas. Inmediatamente el General puso en camino el refuerzo para la vanguardia. El 25 de septiembre ya estaban en marcha 500 hombres desde Tupiza, y el mismo día había salido Picoaga con otros 500 para ocupar dicho punto, con el fin de estar a la vista y asegurar a Jujuy, Salta y Tarija. Y aún más: el propio Goyeneche pensaba trasladar su Cuartel General a aquella ciudad para aproximarse al teatro de las operaciones, sin perder de vista a la vez el Alto Perú (17). Con este plan, que comunicaba Goyeneche a Abascal, parecían asegurarse los dos puntos fundamentales necesarios para emprender la campaña del Tucumán.

(17) Arch. Abascal. Carta de Goyerieche a Abascal. Potósí, 25 de septiembre de 1812. 
Terminados los preparativos, Tristán comienza su avance a través de la provincia argentina. El 22 de septiembre acampó a ocho leguas de la capital en el lugar denominado Tapia, y colocó su vanguardia en el Ojo del Agua, dos leguas más adelante. Ordenó que al sigujente día toda la tropa montada y las guerrillas simulasen un ataque por el camino real de Nogales, acercándose a la población. Con este movimiento se pretendia hacer ver a las fuerzas que la guarnecian que se intentaba el ataque principal por dicho punto, tinientras Tristán, con el grueso, se desviaba hacia la derecha al lugar denominado Tafi. El día 24, bordeando la ctudad, pensaba ocupar el camino real de Tucumán a Santiago del Estero y cortar las comunicaciones entre ambas, para impedir la retirada a Belgrano (18).

Ordenado así el plan, levanta Tristán su campo. en la mañana del 24, e inicla la marcha en unión de ta vanguardia. El orden de marcha era el siguiente: la descubierta, formada por la compañla de dragones do Salineros de Tarija, la guerrilla de Abancay y velnticinco hombres montados del Real de Lima; después seguía el grueso de las tropas, con Tristán a la cabeza. Iniciado el avance llegaron a los manantiales, a dos leguas de la ciudad de Tucumán, a las nueve de la mañana. Ordenó inmediatamente destacar de la vanguardia dos compañías que sostuviesen a las partidas de caballeria enemiga, y dejando a la vanguardia frente a la cludad, se desvia hacia la derecha con el fin de envolwerla.

Sin embargo; cuando se encontraba a media legua de aquélla, se encontró con el enemigo, que le presentaba tatalla. Tristán la acepta; creyéndose a una distancia de legua y media de la cludad. Gira hacia la isquierda su dispositivo de marcha y presenta su frente al enemigo, que inmedlatamente rompe el fuego.

(18) Hrich. Abescal. Copja de parte de Tristán a Gojenechís. Cuartal Frimicipal de \$lta 161 de octubro de 1812. Expothinto de partes, etc. Fol. 65. Vid. ABASCAL. \&emoria». Tomo II. Pág. 401 y ss. Sobre la batalla de Tucumán puede verse LOZA, Emilio, Yatasto, Tucumán y Salta. Volumen V. Segunda Sec. de la Historia de la Nación Argentitha, lpubłextía bejjo la dirección de Ricardo Levene. Buenos Aires, 1941. Págs. 542 y ss. 
Entonces tiene lugar el primer fallo del plan realista. El batallón de Abancay, sin orden de Tristán, y cuando aún no estaba montada la artillería que lo protegiese, se lanzó al ataque seguido por el de Cotabaribas. Sin embargo, el General supo aprovechar este inopinado avance, apresurando la marcha de los batallones del Real de Lima y Paruro, con los que avanzó y envolvió a los enemigos por la izquierda en cortisimo tiempo. Pero cuando parecía dominada la situación por las fuerzas de Tristán, «la infantería (porteña)... de rodillas implorando clemencia y su caballeria; en un grupo que no podian ni moverse, buscaba por donde romper», comienza a retroceder la linea de los reatistas. Ante el intento de la caballeria enemiga para buscar salida, huye la de Tristán, que produce el retroceso del flanco izquierdo del batallón de Cotabambas, al que sigue el de Abancay. Esta huída de parte de las fuerzas de Tristán dejó abierto el paso a los patriotas, que se colocan a retaguardia de los realistas, y se sitúan entre éstos y la ciudad. Los enemigos saquean todo el parque de municiones y material, sucediéndose una espantosa lucha cuerpo a cuerpo que obligó al general a retirar sus tropas. El propio Tristán describe exactamente el combate: «envueltos todos, y con un fuego a quemarropa y bayoneta, empiezan a retirarse mis tropas hacia el punto donde habia señalado debíamos acampar: el enemigo aprovecha este desorden para introducir su guarnición en la plaza, llevar mi artillería de batalla y municiones y los prisioneros que hacen en el camino: ellos por un lado y nosotros por otro queda de pronto el campo sin tropa» (19).

Retirado a alguna distancia, Tristán no abandona su objetivo de ocupar la ciudad. Reorganiza sus fuerzas y recibe el apoyo de su vanguardia. Inicia de nuevo el ataque y obligan a los enemigos a refugiarse en la población, de tal forma, que a las tres de la tarde de dicho día se hallaba en posesión de sus arrabales. Sin embargo no se atreve a dar el asalto por falta de municiones, y se limita a intimar la rendición; que en

(19) Vid. nota 18. Afr. ABASOAL, Memorits. Tomo II. P6gina 403. 
tomo arrogante le es negada por Dfaz-Vélez (20). Aún se mantuvo Tristán ante la ciudad el día 25 organizanda sus tropas, curando heridos y ocupado en destruir la fábrica de fusiles.

A pesar de todo, la situación del ejército realista ante el Tucumán era bastante apurada por las condiciones en que se encontraba. Falto de municiones, era peligroso intentar el ataque, pues si no se conseguia ocuparla, como decía el mismo general, el ejéroito se podía considerar perdido. $Y$ por otra parte, com prolangar la siuación tampoco se conseguía Dingún beneficio. Ante tal dilema, la única salida que le cabe es emprenter la retirada. Pero aún ésto era peligroso: había de emprenderse un camino «de más de ochenta leguas por un país enemigo, sin caballada, ni mulas de transporte, sin víveres, sin prâcticos, con mi tropa cansada después de doscientas leguas de marcha sin descanso alguno... (21). Más no le cabía otra alter nativa. Permanecer ante Tucumán era un pedigro. Declida la refiratidi; a las tres de la mañana del 26 salió de las calles do la ciudad rconfiado en el valor, fortaleza:y sufrimiento de mis soldados, $y$ en la imposibilidad en que habia dejado al enemigo...».

La retirada de las tropas de Tristán, aunque no fué hostilizada por los patriotas no por éllo fué menos penosa. Las candiciones de la marcha eran desastrosas; no podfan detenerse más que el tiempo indispensable para el descanso de la tropa por temor de un ataque enomigo, retaguardio, Por otra garte, el toritorio que atravesaban estaba desprovisto de todo cuanto pudiera facilitar la marcha, teniendo que aprovisionarse con trabajo. Hasta el cuarto día de camino no aparecieron las primeras partidas enemigas que intentaban hostilizar su retaguardia y le intimaban la rendición. Pero al fin, pudieron llegar a Salta, en donde Tristán se estableció con refuerzos para hacer frente a los ataques enemigos.

(2p) Arch. Abarcal, Oficio de Díaz-Vélez a Tristán. Thcumán, 24 de septiembre de 1812 .

(21) Arch. Abascal. Copia đe parte de Tristán a Goveneché,

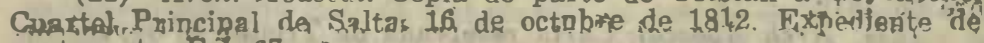
partes, etc. Fol. 67 v. ${ }^{\circ}$ 
Es inđudable que la batalla del Tucumán fué una de las más sangrientas de esta primera etapa de la Guerra de la Independencia en el Continente. Tanto los realistas como los patriotas debieron sufrir grandes perdidas, como lo demuestra el hecho de que lós unos hubieron de retirarse, evacuando toda la región, y los otros se vieron impedidos de aprovechar inmediatamente el éxito al no poder lanzarse a su persecución de un modo eficaz. El estado de ánimo de Tristán, que se deja traslucir en su correspondencia con Goyeneche inmediatamente después de la batalla, nos da una idea clara de su trascendencia. En la noche del 27 de septiembre, ya en retirada, a dieciséis leguas de Tucumán, decía al General en Jefe: «después de cinco días sin dormir, aperreado y muerto de fatiga, tomo la pluma...». «Mi cabeza perdida, mi cuerpo y mi espiritu, mis fatigas, todo me impide remitír el parte circunstanciado... (22). Tristán se encontraba aún bajo la dolorosa impresión de su fracaso cuando parecía tener asegurado el éxito. Y le era aún más difícil sobreponerse a esta idea cuando aún perduraba en su mente la sangrienta impresión de la batalla.

El mísmo nos describe la lucha con gran vigor en una carta reservada a Gojeneche: «...por milagro tienes este amigo y hay ejército; me mataron el caballo y acribillaron defándome abandonado mi tropa $\checkmark$ kiuyendo de 200 y aún de (falta un trozo de la carta) más de 600 que tenía conmigo, después de haber arrollado al enemigo, tomando su artilleria y teniéndolos a mi rodilla pidiendo perdón...» «media hora larga a quemarropa y arma blanca se sostuvo... periecteron porteños como moscas y tada ponderación es nada, pero al consumarse la obra flaqueó Cotabambas cochinamente, y Barreda, que empezó la acción sin mi order, siguió, y en este acto los mis, sin contenerse, huyen mezclados con aquéllos más de una leguas (23).

(22) Arch. Abascal. Carta de Tristán a Goseneche. Posta de Aldurralde, a 16 leguas del Tucumán. Noche del 27 'de septiembre de 1812 .

(23) Arch Abascal. Carta reservada de Tristán a Goyeneche. Sin data ni fecha. 
Este rnomento debió ser de una ansiedad y compromiso terribles para Tristán. Sus tropas, que inopinadamente habian comenzado el ataque sin esperar a recibir órdenes, se desorganizan y huyen cuando podían haber contenido a los enemigos, produciendo en su huída la confusión y el desorden entre las filas propias. Ya he dícho más atrás cómo se produjo la huída de la caballeria de Cotabambas ante el empuje de la caballeria enemiga; el mismo Tristán explica su angustla de este momento: En qué fatigas me vi con una tropa collona, con una oficialidad sin honor ni vergthenza... a no ácordarme de (falta una palabrá), me dejo arrastrar del destino que parece estaba infalibley (24).

Graclas a la columna de Llanos que lo sostuvo, aquel desorden no se transformó en catastrofe lrieparable. De todos modos, la situación én que quedaron las fuerzas de Tristán les imposibilitaba de efectuar operatón alguna: con bajas sensibles en la tropa, Jefes y ofictales, perdidos gran número de canhones $y$ el parque con parte de los equipajes, etc., debieron indudablemente su salvación a las pérdidas que sufrió también el efército patriota.

Las bajas sufridas por la vanguardia realista en la batalla de Tucumán ascendieron a 462 hombres, entre desaparecidas o prisioneros, y 152 muertos. Pero en el desorden producido en los primeros momentos, las comparias ce Tarlja y Chichas se disolvieron, desertando sus soldados, que se dedicaron a robar los equipajes y a degollar a los que encontraban a su paso, como si fuesen enemigos (25). Las pérdidas de Jêfes y oficiales fué dolorosa para el ejército, pues murieron en la acción el coronel Peralta y varios oflciales. Del Real de Lima, su coronel don Antonio Suqrez, con varios oficiales resultaron prisioneros, asi como el coronel Barreda, aunque en la confustón de los momentos posterioresva la lucha se creyeron muertos.

(24) Vid. nota 28.

(25) Arch. Abosecul. Copia de la eRelación de las bajas que ha stafrido ol Pfordito Real de Vanguardia de resulta de la sangrienta acción de 24 de septiembre en las inmediacioxes de la ciudad do 
Aú⿴ tuvo stra sonseouencia la acción del Tucumán. Llegadas las primeras noticias de la lucha a la eludad de salta con las esageraciones naturales de quitenes lasreontaban; en su mayor parte fugitivos o oesertores, se praduja una sublevación acaudiltadła por Arenales $v$ secundada por los patriotas que:iexistían en la ciudad, quienes libertaron a los prisioneros que había en ella, con la finalidad de interceptar el canino de Jujuy a la vanguardia que se retiraba. Pero aún encerraba esta revuelta un peligro mayor, y era que, siguiendo órdenes de Goyemeahe, el jefo militar de Jujuy, don Indalecio Gonzáter de Socasa, había salido con refuerzos y caudales para auxiliar a la vanguardia, y corria ahora el grave peligro de ser sorprendido por tos subleyados \$in embargo, sabedor Socasa en la Posta de los Algarrabos de los acontecimientos del Troupáan, do los que tuvo noticias muy abultadas, tar Les icomo la die que Tristán habia sido hechosprisianero, etc., se xetiró apresuradamente a Jujus. Poco después de atravesar Salta, camino de Jujuy taspo lugar la sublevación. Ins revolucionarios enviaron tropas para alcanzar las fuezas y el dinero de Socasa; pero éste logró llegá a Jujuy con el suficiente tiempo para reritario: Miemtims tanto, Goreneche ordenaba a Aistete, que se oncontraba en Tuptza, que se pusier en marcha con los quinientos hombres de su división hacia aquella ciudad Una yer rounidas lais fuertas de a) bos, jeffss se iniciarílel ataque contra los salteños para castablecer las comunigaciones con la wanguardia (26.).

Se dieponia Socasa a enviar socorros a las fuerzas de Tristion, euando tuvo noticlas de que 300 sublevados salteños avanzaban sobre la ciudad, lo que les oblıgó a estar durante ocho días en continua vigilancia. Al fira, tras una desatinada intimaclón que hicieron los salteñas, comenzó la lucha, que tuvo por escenario las, calles de Jujuy; se llegó al arma blanca y

Tucumán». Cuartel General de Potosi, 25 de octubre de 1812. Expediente de partes, etc. Fol. 72 v.

(26) Arch. Abascal. Copias de oficios de Socasa a Gpreneche. Injuy, 28 de septiambise de 1812, y de Goyeneche al Gabernador Interidente de La Paz. Potosis.4. de actubre de 1812. Expodiente de partes, etc. Folios 5.1 ₹ 52. 
por fin obligaron al enemigo a retirarse, después de tres horas de duro combate, dejando nueve muertos y siete prisioneros en las calles. Pera como se mantuvieran cerca de la ciudad, sus defensares hubieron de continuar sobre las armas, hasta que; habiéndose recibido refuerzos de la vanguardia, los enemigos se alejaron y dejaron libres las comunicaciones (27).

Indudablemente fué de una importancia extraordinaria el mantenimiento de Jukuy en poder de los realistas. Cabe pensạr cuál hubiese sido la suerte de las tropas de Tristán si al llegar a esta ciudad la hubiesen encontrado en poder de los sublevados, cerrado el paso del Alto Perú y sin posibilidad de obtener los auxilios de que tan necesitadas estaban.

Por el contrario, disipada la amenaza enemiga, quedó restablecido el contacto con la vanguardia, que tenia situadas sus a vanzadas en el punto de MonteRico, a ocho leguas de Jujky Entretanto, el coronel Astete atravesaba la quebrada de Humahuaca en dirección a esta ciudad con los quinientos hombres de su división, y Soeasa estaba preparado para salir con la plata y municiones destinadas a la vanguardia en el momento en que aquél entrase en Jujuy (28).

Así, pues, gracias al heroísmo de Socasa y al de los dofensures de Jujuy, se habia salvado la vanguardia del ejército del Alto Perú del desastre, que hubiese colmado la desgraciada expedición al Tucumán.

En resumen, la campaña del Tucumán había fracasado, y con ella el plan que Tristán ideara para dar un golpe decisivo a la revolución argentina. Las causas del desastre y de lós que le siguieran se han de ir examinaildo más adelante. Por lo pronto, basta dejar consignado que la vanguardia hubo de situarse en Salta hacla mediados de octubre, imposibilitada por el mamento de eolocarse más adelante. Lo cual hacia modificar completemente sus planes a Goyeneche, in-

(27) Arch. Abascal. Copia de parte de don Indalecio González de Socasa a Goyeneche. Jujuy, 10 de octubre de 1812. Expediente de partes, etc. Fols. 60 g 61 . Cfr. Abascal. \&Memorias. Tomo- II. Bómsir 406 y $\$ 8$.

(28) Arch. Abascal. Oficio de don Indalecio González de Socasa a Goyeneche. Jujuy, 10 de octubre de 1812 . Expediente de parte, etc. Fol. 62. 
clinándolo al pesilmismo, claramente pereeptible en sus cartas a Abascal: $k$... yo creo que toda la gente del Tucumán y Santiago se reunió a caballo a acabarnos, ¿y eran éstos los que nos aguafdaban aburridos? -Calculo la pérdida de la vánguardla en más de mil hombres, con que, ast, amigo mí, o cedamos en la lucha o apurérnosla para seguirla: es mucho el territotorio que tengo que guardar y los pueblos todos adictos a moverse, pues antes de que llegase aviso de Tristán se puso esto en una ferrnéntación de cuidado y mis precauciones y serenidad lo han entonado; pero él es contra nosotros y acabarnos: si V. E: no hace esfuerzós no bespondo de conservar esto, y dimito el mando si no hay la fuerza necesaria para sostenerme: si V. E. le parece, que venga Henestrosa a relevarme y de jefes de división Cucalón y Valdehojós y algunoós oficiales de artilleria; mire $\nabla$. E: que arge el remedio: Buenos Aires no cede, nos engañan con decirnos que agontza... mi final propuesta es: o refuerzos o mi dimisión» (29). Rntretanto, las órderię que da a Tristán son las de limitarse a rehacerse sobre las gargantas de Jujuy y Salta, manteniéndolas a tođa cósta; - y situar un destacamento en el río del Pasaje en espera de ulteriores acontecimientos (30).

Goyeneche, que ya venía maniféstándo desde mu cho tlempo atrás al Virrey su opinión sobre la uirgente necesidad de refuerzos, extrema su actitud ante las noticias que le llegán del Tucumán; hasta colocar al Virrey en la alternativa que se acaba de ver: o envío de refuerzos o dimisión. En las anteriores ocasiones en que el General había solicitado su separación del ejêrcito, el Virré̀ no aceptó su petición y le contestaba siempre con el envio de los auxilios que estaban a su alcance, con los que procuraba cubrir sus necesidades. Pero el fracaso de la campaña del Tueumán, de la que en parte se sentia téspósable, debió hacer sqariat de opinión al General respecto al curso posterior de la guerra, como se verá más adelante.

(29) Arch. Abascal. Carta reservada de Goyeneche a Abrocal. Fotoks, (6) octubre de 1812 .

(80) Arch. Abascal. Crita de Goyeneche a Abaseal. Potosí, $\theta$ de octubre de 1812. 
La primera necesidad del ejéreito después de las pérdidas sufridas era una urgente reposiclón de tropa y oficialidad; «...son ahora más que nunca necesarias los refuerzos que anteriormente he pedido a V. E.decia Goyeneche a Abascal - Si la suerte ha proporcionado la llegada a esa eapital del navio de guerra "Salvador», en que se nos tha dicho venian 600 hom. bres de tropa, es de indispensable necesidad el que sin pérdida de momento me los dixije $\forall$. E. armados,... (31). Tan urgente era el envio.de tzonas como el de oficiales. En el misano ofieio decia Goyeneche a este respecto que le enviase los oficiales kqua pueda proporcionar esa capital, de graduación, conocido valor y. pericia militar, pues como sabe $\mathrm{V}, \mathrm{E}$. en éstos debe descansar mi esperanza por el buen éxito de mis planes, el del buen orden, ejemplo y discipling que conduce al soldado a la gloriaw. Las divisiones de vanguardia habian quedado sin jefes y. urgia su reemplazo.

A estas angustiosas peticlónes de Góyeneche contestaba Abascal procurando el envio de tropas, oflciales y auxilios para la reorganizateión del Ejército 8 aprovecha la ocasión para hacerle ver la uttlidad del plan que anteriormente le trazara. Para allegar tropas dió las órdenes necesarias al Cuźco, Punó y el Desaguadero, ante la imposibilidad de sacar soldados de la capital, en donde sófo existía como tropa veterana el resto del Régimiento fifo de la nilsma, con 400 a 450 plazas, aparte de la artilleria. Por otra parte, falló también la esperanza de Goýeneche del desembarco de los 600 hombres que transportaba el navio *Salvador», pues st blen desembarcaron en el Continente, to hicieron en Montevideo, en lugár de en el Callao, como se pensaba.

Al darle estas nóticiás; le repite Abascal lo que en ćtto tiempó le recómeridara como medio eficaz para mantener sơmetidas las cludades y sacar suficientes trópas para el ejêrcito de óperaciones. ¿Si V. B.; como creo, ha hecho despojar a los cochabambinos y a los

(81) Arch Abascal. Copia de un oficio reservado de Goyeneche a Abascal. Guartel General de Potosi, 6 de octubre de 1812. Expediente de partes, etc. Fol 44. 
demás habitantes de estas provincias de sus armas y caballos, habrá poco que temer de que se vuelvan a sublevar, por falta de medios con qué sostenerse, y en caso de que lo intentasen, sería prontamente escarmentados de nuevo sin necesidad de sostener en los pueblos capítales guarniciones que pasasen de 500 hombres, siempre que éstos vivan con la disciplina y cuidaido de no ser sorprendidos». (32). Dichas guarnicionés, como le habia dicho en otros momentos, debían ser alojadas en un solo edificio aislado, aspillado, y con una estacada que circundase la puerta, con un rastrillo de comunicación.

Juntainenfe con la tropa que disponia enviar a Ctołeneche, Abascal procuró poner a su disposición los oficiales necesarios para sustituir a los que habian sido muertos o hechos prisioneros en la batalla del Tilumán. En efecto, inmediatamente se pusieron en màrcha el Brigadier Marqués de Valdehovos: los coroneles don Franctsco Gil $\nabla$ don Miguel Tacón (éste último que tanto se habia distinguido en la defensa de Popayán y. Pasto contra las tromo,s de los sublevados del Virreinato de Nueva Granada). y los tenientes cororieles don Nicolás Cevallos v don Francisco Javier Mendizábal. Con estos jefes le enyiaba también un gran respresto de pótvara y municiones (33).

No sebió ser tarea fácil para el Virrey reunir los jefes y oficiales que debian marchar al Alto Perú, pues él mismo dice que sesto que parecia lo más sencillo y que menos obstáculos debia presentar. no fué la menos embarazoso en aquellas circunstancias, ocasionándiome el mayor disgusto la displicencla con que algunos de los nombrados, olvidando de las obligaciones de la carrera, manifestó el poco amor que la tenías (34). Tal modo de esquivar el cumplimiento de su deber por quienes precisamente debian dar ejemplo a los demás en estos momentos era imperdonable. y justamente sacaba de quicio al Virrey, en el que lu-

(32) Arch. Abascal. Copia de oficio reservado de Abascal a Goyeneche. Lima, 28 de octubre de 1812.

(33) Aniki Abascal. Copia de oficio de Abalscal a Goyeneche. Litidi, 28 dé octubre de 1812. Expediente de prontes? etc. For. 50.

(31) ABASCAL. Memoria. Tdmo II. Pág. Mita. 
chaban dos sentimientos encontrados: por un lado su noción del deber y de la responsabilidad, exaltada al sumo grado por su profesión militar, y por otra parte la situación critica en que se hallaba, en la que más veces habia de emplear una fina politica que las medidas espontáneas dictadas por su conciencia. Algo debió compensar su disgusto el hecho de que, contrariamente a éstos, algunos otros oficiales se le presentaron voluntariamente para marchar al Alto Perú, haciéndole ver que aún subsistian jefes y oficiales con dignidad en el ejército virreinal, y que los otros casos eran solamente excepcionales.

Tomadas las medidas para su socorro, Abascal pasa inmediatamente a fijar el plan de campaña a Goyeneche. «El punto del rio del Pasaje-le dice-es muy yentajoso, y debe conservarse todo lo posibles, y la razón es clara, "para que suene que estamos posesionados, cuando no del todo, de una gran parte del Tucumán, próximos a operar de concierto con las fuerzas del Paraguay y Montevideo, cuya comunicación no creo sea dificil abrirse por el río Colorados. Pero no basta esto; para apoyar el frente del Pasaje convenía mantener el fuerte de Cobos: «el fuerte de Cobos es fácil restablecerle con mejor̀as de lo que fué; en cuyo caso seria un excelente punto de apoyo en todo evento para la avanzada del Pasaje y para cubrir la confluencia de los caminos de Salta y Jujuy». Este último punto tenía a los ojos de Abascal la máxima importancia: «es verdaderamente la puerta del AIto Perú, que es indispensable conservar a toda costa en cualquier trance», para lo cual «es preciso construir una fortaleza de campafla con un foso de dos varas y media a tres de profundidad, tres o cuatro de ancho y sus flancos correspondientes aplicados a la localidad del sitio que se elija, libre de dominación» (35).

Las instrucciones del Virrey, en cuanto al establecimiento de posiciones defensivas en la frontera del Alto Perú, en manera alguna excluía, a su tiempo, la ofensiva. Para Abascal no significaba la actual situa-

(35) Arch. Abascal. Copia de oficio reservado de Abascal a Goyeneche. Lima, 28 de octubre de 1812. Expediente de partes, etc. Folios 44-45. 
ción otra cosa que un compás de espera en el que habría de reorganizarse el ejército manteniendo firmemente la entrada del Alto Perú, mientras llegaba la ocasión de emprender de nuevo la lucha, que sería «en recibiendo noticias de la parte oriental del Río de la Plata» (36). Para llevarla a cabo, contaba el ejército del Alto Perú, según los cálculos del Virrey, con 11 ó 12.000 hombres perfectamente equipados y disciplinados.

No es de extrañar, pues, que habiendo recibido la carta reservada de Goyeneche en la que le proponía su dilema de "refuerzos o dimisión» (37), le hiciese saber que, en su sentir, «dista mucho de pensar siquiera en ceder en la lucha, expresión que no puedo significar a $\mathrm{V}$. cuánto me ha admirados; y respecto a su alternativa, le parece que «es terrible, pero es Vd. mi amigo y no hago alto sobre ello» (38). Abascal piensa que la crisis que temporalmente parecia afectar al General no duraría mucho, pues 10 conocía bien, y por otra parte se daba cuenta de que no era la ocasión más oportuna para que se retirase. Sin embargo debió influir este punto de vista de Goyeneche en las posteriores relaciones entre él y el Virrey.

Ya he dicho más atrás que el fracaso de la expedición de Tristán hizo variar al Jefe del Ejército en su modo de pensar respecto a la guerra. No quiere decir esto que la batalla del Tucumán y la posterior retirada le hiciesen modificar totalmente sus ideas sobre el curso y el final de la contienda, inclinándolo a pensar en un desastre inminente, ni mucho menos. Lo que ocurrió fué que este revés le aferró aún más en su creencia sobre la imposibilidad de acabarla con éxito por falta de medios y le hizo pensar en que se imponia la necesidad de llegar a un entendimiento con el enemigo antes de que fuese tarde y sobreviniese una catástrofe. En otras palabras, Goyeneche no dudaba del éxito de la lucha si recibia los refuerzos que

(36) Arch. Abascal. Copia de carta de Abascal a Goyeneche. Lima, 28 de octubre de 1812.

(37) Vid. nota 29.

(38) Arch. Abascal. Copis de carta de Abascal a Goyeneche. Lima, 28 de octubre de 1812. 
necesitaba, pero no respondía de su resultado en caso contrario.

Quizás el informe que dirigio a la Regencia sobre la situación del ejército del Alto Perú el 20 de octubre de este año, sea el documento donde más clara y extensamente se deja traslucir su desencanto. En él expone todos sus cuidados en la guerra, sus temores acerca del final de la misma y sobre su actual situación, e intenta encontrar un remedio a todo ello, presentando su dimisión si no se aceptan sus consejos.

Una de las cosas de que más se queja el General en dicho informe es de haber carecido siempre de instrucciones o plan a seguir. Gracias a su entusiasmo habia conseguido la organización de un fuerte ejército, integrado por hombres sin las menores aptitudes militares y con los cuales llevó a cabo dieciséis batallas campales esin haber recibido, cuando más lo necesitaba, ni de la Corte ni del Superior Gobierno de Lima unas instrucciones de simples iniciativas para obrar según las circunstancias, ni otros recursos que la facultad de buscarlos en las provincias que he reconquistado, al propio tiempo de carecer enteramente de comunicación con las tropas combinadas de Montevideo y el Brasil en la distancia inmensa de 600 leguas ocupadas por pueblos adictos a la independencia, con un ejército a mi mando que no pasa de 8.000 hombres sin arbitrios para aumentarlo por falta de armas y caudales" (39).

En realidad, esta era una falta de que siempre había adolecido el ejército. La carencia de recursos no era nueva. Desde los primeros momentos de la revolución se había dejado sentir la dificultad de formar un ejército idóneo y preparado para hacerle frente. Ya he insistido varias veces en las peticiones constantes de Goyeneche al Virrey y cómo Abascal procuraba por cuantos medios estaban a su alcance, satisfacer sus necesidades de todo orden. En el año de 1812, Goyeneche ya se lo había notificado en las siguientes ocasiones: el 9 de enero; el 24 de febrero; el 9 de mar-

(39) Arch. C. Guaqui. C. 5. Carp. 7. N. 4. \&Informe en el que el General del Ejército del Alto Perú expone a S. A. la situación». Potosí, 20 de octubre de 1812. 
zo; el 10 de marzo, en que da cuenta del ajuste de Buenos Aires y Montevideo, con el peligro que de ahí podría sobrevenir para el Alto Perú; el 13 de marzo, insistiendo en lo anterior; el 22 de abril con motivo de la expedición de Cochabamba; otro oficio del mismo día en el que demostraba el gasto del ejército; el 6 de junio; el 2 de julio; el 19 de julio, en que dice que si no llegan los auxilios se paralizarán las operaciones; el 25 de julio, y por último el 6 de octubre y sucesivos a que me refiero últimamente (40). Pero esta insistencia no quiere decir que sus peticiones no fuesen atendidas; antes al contrarlo, ya he dicho repetidas veces que el ejército del Alto Perú atraía la máxima atención del Virrey, y aún se verá demostrado más adelante este interés. Poco antes de la batalla del Tucumán se le enviáron 160.000 pesos y 1.002 quintales de azogue, parte del pago de las libranzas que se extendían por el General contra la Tesorería de Lima. Además, se le aumentó el armamento con 500 espadas y 10 quintales de cuerda de mecha, 1.200 lanzafuegos, 12 estopines, y para paco después se preparaba el refuerzo en hombres (41).

Por lo que respecta a la carencia de instrucciones, se ha podido ver a lo largo de la campaña, como el Virrey iba dando las líneas generales-en muchos casos hasta el detalle -, de las operaciones que habían de llevarse a cabo. Es lógico que estas instrucciones. generales hubieran de irse adaptando al desarrollo particular de la lucha en cada momento. Los puntos en que se basaba el plan de Abascal y que por no poderlos conseguir hasta ahora le habían impedido llevar a cabo, eran la inteligencia con Montevideo y el auxilio de la Península, para conseguir una operación combinada contra Buenos Aires. Mientras no se lograse ésto era un poco problemática la victoria. Sin embargo, como hasta ahora no lo realizara, se limitó a mantener un ejército poderoso, con el que pudiese

(40) Arch. C. Guaqui. C. 9. Carp. 3. N. 3. aResúmenes de varios oficios dirigidos al Virrey de Lima solicitando reemplazos y auxilios según el extracto hecho en la Secretaría de Guerra del Ejéreito del Alto Perú». Potosí, 4 de febrero de 1813.

(41) ABASCAL. Memoria. Tomo II. Pág. 408. 
contar para llevar a cabo la defensa del Virreinato y asegurar las comunicaciones maritimas del mismo, estableciéndose así las dos bases fundamentales para su mantenimiento frente a la insurrección.

Pero a todo lo anterior venia a unirse un nuevo factor, un imponderable, que constituia, quizás, el más grave de los peligros que podía correr el efército $\mathrm{y}^{\mathrm{b}}$ lo que éste representaba. Era la actitud de los pueblos americanos. Goyeneche, además de natural de aquel país, tuvo bastantes ocasiones de vivir junto a éste pueblo; y expresa claramente el sentimiento de rebéldía que latia en todos ellos: "dado que el trastorno del reinado precedente hizo perder a los pueblos las sencillas ideas de que estaban imbuidos sobre la santidad de nuestras leyes y la beneficencta del Gobierno español, parecian ya unas naciones diferentes que no trataban sino de vivir para si sólo, sin unión con la Metrópoli... y por esto anhelan únicamente su libertad por todos los medios por donde creen que podrán lograr sus deseos, interesándose con los mayores esfuerzos en destruir todos los estorbos que les impiden conseguir estos fines. (42).

En semejantes circunstancias, el problema se complicaba considerablemente: ya no es solo contra Buenos Aires y sus tropas contra quienes habia de luchar el Ejército realista, sino que a la par que hace frente a éstos, había de contener a los pueblos y ciudades que quedaban a su retaguardia, lo que le obligaba a diseminarse entre infinidad de puntos, haciendo ineficaz su labor frente a los enemigos porteños, cada vez más seguros de sí, a medida que se daban cuenta de que tenian el apoyo de los pueblos del interior. Este hecho se lo hizo notar constantemente Goyeneche al Virrey. «Tenemos por enemigos cuantos ingratos hemos sometido», habia dicho Goyeneche, y demostraba que ni aún las poblaciones en donde existía una guarnición realista después de haber sido arrojados de ella los sublevados, se veian libres de conspiraciones e intentos de nuevos alzamien-

(42) Arch, C. Guaqui. C. 5. Carp. 7. N. 4. sInforme en el que el General del Ejército del Alto Perú expone a S. A. la situación». Potosí, 20 de octubre de 1812. 
tos (43). Y aún últimamente, la sublevación de Salta, en ol momento en que se alejaron de élla las tropas, venía a confirmar su Juicio.

Solamente la fuerza era capaz, según el, de mantener la tranquilidad, pero aún al cabo resultaba ineficaz, pues los pueblos «con cuanta mayor violencia fueran arrasados de su carácter, otro tanto más dispuestos están a recobrarlo en el momento que desaparece la fuerza que los contiene» (44). Y aún tal sistema suponía el mantenimiento de un ejército con el que no cabia contar. Por otra parte, tampoco podia utilizar tropas sacadas de dichos pueblos, pues se exponía a quedar a merced de sus enemigos en un momento determinado, comprometiendo quizás la existencia del efército. "Estos pueblos se han vuelto tan inmorales con el mal ejemplo de los porteños, dice Goyeneche, que nunca podré confiar en ellos para armarlos en defecto de las tropas que traje del Collado. Se han viciado en la rebelión y debemos recelar que, vendiéndose esta vez a los caprichos de su soñada independencia, fácilmente emplearian contra nosotros en cualquier novedad las armas que tantas veces he hecho triunfar en honor del Rey y en servicio del Imperio español» (45).

Abascal, ya se ha visto, recomendaba insistentemente el total desarme de las poblaciones, con lo cual podria reducirse bastante su guarnición, con el consiguiente aumento de la tropa combatiente. Perao aun asi, resultaba insuficiente el ejército para mantener bajo su mano tan inmenso territorio. En la dilatadisima región que se extiende desde el Desaguadero a Jujuy, con trescientas leguas de exteasión; desde Santa Cruz de la Sierra a las fronteras de los chiriguanos del Este, con más de doscientas, habian, según escribe Goyeneche, nueve ciudades, ciento ochenta y un pueblos de indios tributarios, quince misiones, y las dos provineias de Moxos y Chiquitos; y tan enorme territorio lo ocupaba con cuatro mil hombres, a

(43) Arch. C. Guaqui. C, 9. Carp. 4. N. D. Informe de Goyeneche al Virrey del Perú. Potosí, 10 de marzo de 1812.

(44) Vid. nota 42.

(45) Vid. nota 42. 
los que procuraba mantener en cierto contacto entre sí y con su Cuartel General; el resto de la fuerza, hasta ocho mil, lo tenía en Potosí o en otros puntos como vanguardia en la frontera (46).

Esto en cuanto al territorio ocupado se refiere; pero respecto a la guerra en sí, la lucha contra los sublevados porteños, no cabía pensar que pudiera tener éxito en tales circunstancias. Por otra parte no se llegaba a una coordinación de las fuerzas realistas en el Continente y sus aliadas las brasileñas: «Tampoco puedo contar con las tropas combinadas de Montevideo y el Brasil, porque intermedian 600 leguas ocupadas por los enemigos, "que nos impiden comunicarnos para poder continuar planes juiciosos y reciprocos socorros. Yo ignoro absolutamente - decía Goyeneche- las órdenes con que se halla el general Vigodet, y asimismo creo que no las tiene el Virrey de Lima, una vez que no me las ha participado, ni penetro los designios de las tropas portuguesas en la Banda Oriental del Río de la Plata, pero me consta que únicamente han formado hasta ahora una barrera defensiva que nada puede servir para auxiliar los proyectos ofensivos, que tal vez hubiera indicado yo para la disolución de Buenos Aires» (47).

Esta total desconexión de las fuerzas contrarrevolucionarias del Continente, de la que he hablado más atrás, era fatal para la marcha de la guerra, sobre todo teniendo en cuenta que el Perú por sí solo, sin la llegada de auxilio de la Península, no podía dominar la sublevación. La situación es clara para Goyeneche, que no oculta su pesimismo ante ella: «Estoy viendo -dice en el citado informe-, que la gran máquina de América del Sur se va precipitando a su ruina porque no tiene bastantes fuerzas para mantener su enorme peso... En la crisis planteada, y ante el peligro inminente se ve precisado a dirigirse directamente a la Regencia para salvar su responsabilidad, presentando la renuncia a su cargo en caso de que no se encontrase una solución, prefiriendo retirarse a ser testigo de las desgracias que inevitablemente habian de sobrevivir.

(46) Vid. nota 42.

(47) Vid. nota 42. 
En lineas generales, puede decirse que la actitud de Goyeneche en este momento decisivo de la contienda es la de un hombre que, al cabo de algo más de dos años de lucha entusiasta contra los enemigos y las dificultades, se da cuenta de que en la práctica, el resultado ha sido minimo, por no decir nulo. La idea de la revolución está mucho más arraigada de lo que él pudiera haber pensado en un principio, y tan solo hay un sistema eficaz para contrarrestarla, el de la fuerza. Pero aun éste.le fallaba, pues no contaba con los medios ni con la colaboración necesaria para crear un instrumento que mantuviese la seguridad del Continente. Se perdió la ocasión en un principio, y ahora era cada vez más difícil encontrar una solución. En todo lo cual vino a confirmarlo la retirada del Tucumán, que le obligó a colocarse de nuevo en observación en la frontera argentina sin poder llevar a cabo ningún movimiento ofensivo contra los patriotas, exponiéndose a eternizar la lucha, con tanta mayor ventaja para éstos, cuanto más tiempo durase.

Precisamente entonces tuvo lugar un hecho que dió ocasión a Goyeneche para exponer al Virrey todas sus ideas sobre el problema de la revolución. El 18 de octubre, Belgrano escribía un mensaje al General con objeto de hacerle ver sus pocas posibilidades de éxito, y le incitaba a una avenencia entre ambos que acabase con una guerra civil «que poco a poco nos ha devorado y de la que al fin no habremos sacado más ventaja que nuestra total ruina» (48). Le hace ver el estado en que se encuentra el ejército patriota, como se lo ha demostrado la reciente acción del pasado 24 y le llama la atención sobre el equivocado concepto que de tal ejército se tenia.

Le indica el equivoco en que se encontraba al creer tranquilo al Perú y las provincias sobre que se hallaba. De todas partes, decia Belgrano, «me llaman a gran prisa en su socorro, no sólo de esa provincia en que V. S. se halla, sino de las de Lima, de Lima mismo, y lo que es más, de su propia patrias. Ante un panora-

(48) Arch. Abascal. Copia de oficio de Belgrano a Goyeneche. Campamento General, 18 de octubre de 1812. Expediente de partes, etc. Fols. 81 v. ss. 
ma tan grave para las armas reallstas, incapaces de contener por mucho tiempo el ataque de las tropas dé Buenos Aires y la sublevación del interior, le ofrece la paz y la unión sobré la base de que los pueblos elifan sus diputados para constituir el Congreso que decidiese la suerte dél Continente.

El oflclo de Belgrano fué una confirmación para Goyeneche: El habia advertido al Virrey en otra ocasión que lo engafiaban al decirle que Buenós Aires agonizaba (49); por su parte, no nabia creido nunca en tal cosa, y por lo que le daba a entender el general argentino, sus tropas se hallaban dispuestas a continuar la lucha hasta el final.

Si se tienen en cuenta las ideas de Goyeneche sobre la marcha de la guerra, sobre este momento en particular, y sus posibilidades, ya expuestas, no debe extrafiar la resolución que tomó. Inmediatamente envio a Lima a su ayudante de campo, don José Pobil, con el mensaje de Belgrano y plenos poderes para decidir juntamente con el Virrey. Así se lo comunicaba a Abascal, diciéndole que Pobil le informaría de cuanto interesase, pues se hallaba perfectamente enterado de todo "para que V. E. conferencie con él como conmigo y delibere sobre las solicitudes de Belgrano y más para asegurar la Américas; pero a la par le indicaba, o dejaba traslucir al menos, su punto de vista: "debiendo asegurarle que no hay que contar con tropa ni soldado alguno de estas provinclas, pues si no desertan en acciōn se nos declaran enemi gos» (50). Con objeto de no dar a entender a nadie la finalidad del viaje de Pobil, cuya misión no conocían ni los mismos Jefes del Cuartel General, aparentó marchar a Lima para negocios propios.

Sin embargo, los intentos de llegar a una inteligencia entre ambos bandos no eran nuevos. Días antes, "đurante su retirada, recibió Tristán un oficio de Díaz-Vélez en el que le proponía una entrevista entre ambos o entre dos oficiales de cada ejército para llegar a un convenio sobre la suspensión de hostili-

(49) Vid. nota 29.

(B0) Areh. Abascal. Carta de Goyenech a Abrscal. Potosí, 28 de octubre de 1812. 
dades. Con tal motivo se cruzaron varios oficios entre los dos generales, pero sin conseguir llegar a un acuerdo, por no admitir Díaz-Vélez como mediador al que le proponía Trístán (51). Mas ahora, Goyeneche quiere dar una solución al problema aprovechando la coyuntura que le ofrece Belgrano para obtener una transacción si no era posible otra fórmula. La misión de Pobil en Lima era clara en este sentido. Había de procurar el envío de dos mil hombres al ejército del Alto Perú; en caso contrario, decía Goyeneche, «no queda otro recurso sino el que V. E. acuerde los mediọ y modos más racionales de ajustar una transacción ventajosa y decente a virtud de la propuesta de Belgrano, para cuya ejecución dígnese V. E. destinar comisarios de luces, carácter, probidad y experiençia, dignos de su entera confianza, que vengan por la posta, bien instruidos, con facultades plenipotenciarias» (52). Caso de que la gestión de Pobil fracasase, Goyeneche ponía a disposición del Virrey el mando del Ejército, que resignaba para no ser testigo de los males que habian de sobrevenir.

Sin embargo, hay que hacer constar que Goyeneche sólo propone el acuerdo con Belgrano en último extremo, obligado por las circunstancias, y a pesar del tono más bien pesimista de su correspondencia, siempre ofreee continuar la lucha si se le envian los medios necesarios para ello.

Pero el Virrey veía las cosas de diferente modo que el General. Aunque las noticias que llegaban a Lima sobre la fuerza de los argentinos y la situación de Buenos Aires y Montevideo eran un tanto confusas, calculaba que el total de las situadas en Santa Fe, Buenos Aires y Uruguay no pasaban de cuatro a cinco mil hombres, de los que lógicamente no podria sacarse ninguno para el auxilio de Belgrano. Este, por su parte, debió quedar bastante castigado en la operación del Tucumán, como lo demostraba el hecho de que

(51) Arch. Abascal. Copias de oficios cruzados entre Tristán y Díaz-Vélez, 4, 5, 7 y 8 de octubre de 1812. Expediente de partes. Fols. 69 v. ss.

(52) Arch Abasoal. Oficio de Goyeneche a Abascal. Cuartel General de Potosí, 28 de octubre de 1812. 
no molestase a Tristán en su retirada. En tal caso no era difícil precaverse. Las llamadas que habia dicho Belgrano recibía de las provincias y que podian encerrar un peligro para su conservación, por ser un sintoma de la existencia de un partido revolucionario, se neutralizarían fácilmente. Para ello recuerda las repetidas órdenes dadas por él de desarmar las poblaciones. Por otra parte, la posible amenaza que representaban las tropas enemigas quedaba conjurada colocando en buen estado de defensa a Jujuy, Salta y el Fuerte de Cobos, con lo que se cerraban todos los pasos practicables hacia el Alto Perú, cuya entrada y salida quedaban completamente controladas por los realistas. Un destacamento de 400 a 500 hombres, situado en el río del Pasaje, completarían el plan y serviría para cualquier tentativa de penetración desde el Tucumán, a la par que podía efectuar de vez en cuando incursiones para alarmar a las fuerzas enemigas (53).

Siguiendo el plan propuesto por el Virrey, podria tomarse el tiempo necesario para saber lo que hacian las fuerzas de Montevideo y obrar en consecuencia. Entretanto, Abascal le da orden terminante de mantener el terreno adquirido y defenderlo palmo a palmo, si hubiese necesidad de ello.

La proposición de Goyeneche de llegar a un acuerdo con el enemigo sobre la base indicada por Belgrano, es completamente rechazada en Lima. El sólo hecho de entrar en discusión con el general argentino indignaba a Abascal, que con toda energía dice a Goyeneche: (Siquiera) cuando tuviesen algún fundamento las razones con que parece se inclina $\mathbf{V}$. S. a la afirmativa, no debían ser aún suficientes para separarnos en lo menor del verdadero camino que hemos tomado... (54). No cabe, pues, lugar a dudas. Abascal estaba dispuesto a continuar la lucha con todas sus consecuencia. Por su parte, no daba tanta importancia a la acción del Tucumán como para decidir el curso de aquélla, y así se lo hacia saber a Goyeneche,

(53) Arch. Abascal. Copia de Abascal a Goyeneche. Lima, 14 de diciembre de 1812 .

(54) Vid. nota 53. 
a pesar de lo cual habia tomado las medidas necesarias para auxiliar al ejército.

Para el Virrey, las opiniones y la actitud de Go. yeneche carecian de razón de ser; todo lo cual debió contribuir no poco a cambiar el concepto que, pese a sus posteriores declaraciones, tenía formado enton. ces del General.

A los ojos de Abascal, sus angustiosas peticiones y su decisión extremada para solucionar el conflicto, no eran más que producto de una gran falta de cálculo de sus posibilidades y de su deseo de salvar la responsabilidad que sobre el pudiera caer en caso de una contingencia desgraciada. La exactitud o el error de este Juicio se verá más adelante. 


\section{CAPITULO IX \\ LA BATALLA DE SALTA Y LA SUSTITUCIÓN DE GOYENECHE}

Fracasada la ofensiva de Tristán contra el Tucumán, la vanguardia de las tropas realistas se vió obligada a retirarse a Salta, conforme a las órdenes que posteriormente recibiera del Virrey. En un principio todo hacia creer que las consecuencias de la batalla y del repliegue no iban a ser graves; pero los hechos se encargaron de demostrar lo contrario.

El mismo Virrey, cuando tuvo noticias de los sucesos, no les dío una importancla clesmesurads, en parte, quizás porque estuviera convencido de ello, y cambién por su deseo de tranquilizar a Goyeneche, que, como se ha visto, le instaba cada vez con más apremio solicitando ol envío de las fuerzas necesarias para detener a los parteños. La manera como se desarrolló la batalla hacía dudar al Virrey. El hecho de haberse mantenido Tristán durante sesenta horas en el campo de la lucha después de haber perdido sus equipajes, así como el caso insólito de que los enemigos no hubiesen hostilizado su retaguardia durante la retirada, le parecían un tanto curiosos.

Sin embargo, esta misma circunstancia hacía pen- 
sar a Abascal que se tratase de un engaño de los argentinos con el fin de sorprender a las tropas de Tristán, ya que podían haber proseguido su marcha por el camino de carretas por adelantarse al General que iba por el de postas. En tal caso corría el grave peligro la vanguardia de ser sorprendida en manifiesta inferioridad, pues carecia de municiones; ahora bien, si no se confirmaban las sospechas del Virrey, la situación variaba totalmente, pues se daba tiempo a que las tropas realistas llegasen al río del Pasaje, en donde podrian reunirse. Entonces, la situación no sufriría cambio notable, pues desde aquí se podría iniciar, en el momento oportuno, una nueva ofensiva contra el Tucumán (1).

De todas formas, creia el Virrey que el ejército conservaba aún la suficiente fuerza para poder rechazar a los enemigos que llegaban a presentarse ante él. Sin embargo, el Virrey se equivocaba al calcular la cantidad de hombres sobre las armas. Si bien no poseía un estado general del ejército, falta que constantemente echó en cara a Goyeneche, calculaba su total en unos 11 ó 12.000 hombres, con los cuales, indudablemente se podría, no sólo defender el territorio de JuJuy a Salta, sino también emprender la ofensiva. Pero un estado de fuerzas de fecha 25 de noviembre de 1812, fijaba en 7.540 hombres el total de las fuerzas de vanguardia y las guarniciones del Alto Perú (2).

Este número de hombres era del todo insuficiente, a Juicio de Goyeneche, y de ahí las constantes peticiones al Virrey, quien por su parto ordenó se le enviasen refuerzos del Desaguadero, Cuzco y Puno, por ser de los únicos puntos de donde podía sacar tropas. Pero tales envíos no satisfacían las peticiones del General.

Tristán llevó a su término con éxito el repliegue sobre Salta y Jujuy. El 9 de noviembre daba parte

(1) Arch. Abascal. Copia de carta de Abascal a Gogeneche. Lima, 28 de octubre de 1812.

(2) Arch. Abarcal. Copia de un estado de fuerza del Ejército Real del Perú en la línea desde el Desaguadero hasta las avanzadas de vanguardia. Cuartel General de Potosí, 25 de noviembre de 1812. 
Goyeneche al Virrey de que su Mayor General le comunlcaba haber llegado el día 31 del mes anterior a Salta con el grueso de su división, mientras que las tropas argentinas mandadas por Diaz-Vélez, que le habían hostilizado en la última parte del camino hasta la ciudad, habían sido rechazadas a doce leguas más allá del río del Pasaje, y dejado libre las inmediaciones del Tucumán (3).

Fortificadas JuJuy, Salta y el fuerte de Cobos, y situado un destacamento en el río del Pasaje, se podrían sacar, al menos, los mayores frutos del forzado repliegue.

El valor estratégico de la provincia de Salta era innegable. Constituye geográficamente la transición del Alto Perú hacia la pampa argentina y participa, por tanto, de los caracteres de ambas regiones, con predominio de la montaña sobre la llanura. Es la vía natural de comunicación entre las cuencas del Plata y las montañas del macizo boliviano. De ahi deriva su fundamental importancia, como punto de enlace de dos mundos distintos. Estos caracteres, traducidos al terreno militar, significaban la defensa o la invasión del Alto Perú, según lo poseyesen uno u otro de los bandos contendientes.

Pasado el río Suipacha, se extiende la llanura de Yavi, que poco a poco se va estrechando hacia el sur hasta encajonarse en la Quebrada de Humahuaca, para desembocar en JuJuy, primera etapa del camino de Tucumán. La posesión de dicha ciudad era, pues, necesaria para asegurarse el dominio de los valles que se dirigen hacia el sur, en la provincia de Salta. La topografía de esta provincia es bastante accidentada. Es una sucesión ininterrumpida de valles, llanuras y. desfiladeros, entre los cuales estaba emplazada su capital.

Al sur de la ciudad de Salta se extienden una serie de valles, tales como los de Lerna, Calchaqui y San Carlos. A través de dichos valles se ponía en comunicación la provincia con el Tucumán por un camino de carretas, remontando simplemente la co-

(8) Arch. Abascal. Copia de oficio de Goreneche a Abascarh Guartel General de Potosí, 9 de noviembre de 1812. 
rriente del rio Guachipás por el valle de este nombre. El camino real de Salta hacia el Tucumán se extendía al oriente de aquél, al otro lado del macizo montañoso, a través del río del Pasaje. El tal rio se orlgina por dos pequeños riachuelos que nacen en Santa Maria y San Carlos, que en su confluencia recibe el nombre de Guachipás, del valle antes citado, por el que corre en dirección sur-norte. A la salida de dicho valle tuerce hacia el este, y recibe el nombre de Pasaje, constituyendo el limite entre las provincias de Salta y Tucumán. En esta dirección corre un corto trayecto, y se inclina hacia el sur, en donde va a unirse al Paraná, despues de haber recorrido la llanura del Tucumán y de Santiago del Estero con el nombre de río Juramento.

Dicho rio, que servia de limite entre ambas provincias, era el escogido por Abascal para establecer la linea avanzada de los realistas en dirección al sur. Pero la colocación de las avanzadas aquí ofrecia un grave inconveniente, y era que, a través de los valles occidentales, por los caminos de herradura que ofrecían, podía avanzarse sobre Salta sin necesidad de vadear el río del Pasaje, con solo seguir el curso del Guachipás, con lo cual se desembocaba sobre dicha cludad, y a la vez se amenazaba el flanco y la retaguardia de las tropas acantonadas en el Pasaje. También ofrecia otro peligro por el lado oriental, pues como a dístancia de seis leguas del paso príncipal del río existía otro camino que terminaba en un vado llamado de Mirallores, al cual se llegaba por un rodeo a través de la región del Bstero, pero desde donde podían atacar también por retaguardia a las fuerzas de la orilla del río e impedirles la retirada sobre el fuerte de Cobos, en el camino de Salta. Dicho fuerte; cuyo restablecimiento habia sido ordenado por el Virtey, se hallaba situado cerca de la confluencia de los caminos de Salta y JuJuy, y se pensaba sirvlese como punto de apoyo para la guarnición del río $\mathrm{Pa}-$ saje, a la vez que cubría la confluencia de ambos caminos.

De todos estos puntos, el que más interesaba al Virrey era la ciudad-de Jujuy, que a sus ojos const1trúa la llave del Perú, ya que si los enemigos lograban apoderarse de ella tenían franco el paso por la 
Quebrada de Huamahuaca para desembocar en los campos de Yavi.

Sin embargo, esta posición de las tropas en Cobos y en el río del Pasaje, para proteger las ciudades de Salta y Jujuy, barreras del Alto Perú, tenía sus inconvenientes. Todos ellos se los hacía ver Tristán a Goyeneche, que a su vez lo comunicaba al virrey. De lo expuesto anteriormente se deduce que el fuerte de Cobos quedaba prácticamente inutilizado, para proteger la retirada de las tropas del Pasaje, ya que podía a su vez ser sorprendido. Por eso, el sistema que adoptó Tristán no fué el de destacamentos, que podian ser atacados por sorpresa, sino el de partidas volantes que recorriesen el país (4). Noticioso el Virrey de tales inconvenientes, aceptó dicho plan, recomendando se tuviese un especial cuidado para la conservación de las dos cludades, reforzando sus guarniciones (5). De estos dos puntos, como ya he dicho antes, el que más interesaba a Abascal para su conservación era Jujuy, llave del Perú, por lo cual era necesario protegerla mediante una fortificación. La posición de la ciudad estaba favorecida por la existencia a su espalda del río Grande, punto de apoyo para el caso de una retirada. Por ello opinaba Abascal que de la guarnición de dicha plaza debía extraerse un cuerpo de quinientos hombres que, colocados en las riberas del río, sostuviesen su paso y la reunión de las tropas en caso necesario, y si por desgracia se viesen en tal coyuntura, aun el mismo río podía servirles para sostener un contraataque por parte de los realistas.

En evitación de posibles sorpresas recomendaba que no se dividieran las fuerzas entre las dos ciudades, cuya comunicación, a través de un camino de dieciocho leguas podía ser cortada fácilmente (6). Claro está que para reforzar las guarniciones de ambas habia que sacar tropas de las provincias del inte-

(4) Arch. Abascal, Copia de oficio de Goyeneche a Abascal. Cuartel General de Potosi, 18 de diciembre de 1812.

(5) Anch. Abascal. Copia de oficio de Abascal a Goyeneche. Lima, 25 de enero de 1813.

(6) Arch. C. Guaqui C. 9. Carp. 5. N. 31. Oficio de Abascal a Goyeneche. Lima, 24 de marzo de 1813. 
rior, pero esto no preocupaba tanto al Virrey mientras se tuviese la vanguardia reunida en Salta o Jufuy.

Tristán, en su retirada, no fué más allá de Salta, que pensaba defender a toda costa. Pero poco después de asentarse en la plaza, se tuvieron noticias de que los enemigos trataban de reforzar sus fuerzas e iniciar una ofensiva contra sus tropas. Ante el nuevo peligro, Goyeneche trató por todos los medios de aumentar su vanguardia, a la vez que ordenaba situarse una columna en el paso de Humahuaca, con objeto de asegurarse el tránsito hacia el Alto Perú (7). La causa de su temor era una carta confidencial escrita por Tristán el día 7 de diciembre, en la que se mostraba convencido de que los portugueses de la Banda Oriental habían llegado a un acuerdo con Buenos Aires, en cuyo caso era de esperar que los argentinos trasladasen a Salta las tropas que hasta entonces habían estado en aquel territorio, ya que Montevideo les daba bastante poco cuidado. Dichos temores se los transmitía a su vez Goyeneche al Virrey (8), advirtiéndole además que, a la par que estos hombres eran retirados y transportados a la frontera del Alto Perú, se hacian levas en las provincias argentinas para aumentar sus fuerzas, que podían llegar, según sus cálculos, a 15.000 hombres (9). Sin embargo, a pesar del peligro, Tristán se mostraba optimista y resaltaba la moral de sus tropas frente a la desmoralización que reinaba en el campo enemigo.

Los rumores de los preparativos argentinos llegaban hasta Lima. El 7 de enero de 1813, el Virrey comunicaba por un extraordinario a Goyeneche las noticias que le llegaban de Buenos Aires por vía de Chile. Se desprendía de ellas que los argentinos habían destinado 500 negros, 300 patricios y 200 arribeños para reforzar el ejército de Belgrano, aparte del gran contingente de voluntarios y tropa irregu-

(7) Arch. Abascal. Carta de Goyeneche a Abascal. Potosí, 24 de diciembre de 1812.

(8) Arch. Abascal. Carta de Goyeneche a Abascal. Potosí, 26 de diciembre de 1812.

(9) Arch. Conde Guaqui. C. 9. Carp. 5. Oficio de Goyeneche al Virrey del Perú. Cuartel General de Potosí, 31 de enero de 1813. 
lar reclutada en las provincias. Tales preparativos hacian pensar en un próximo ataque contra Salta y JuJuy; para detenerlo Juzgaba preciso el Virrey sacar 1.000 hombres de Tupiza y Cotagaita, que reforzasen la vanguardia. También Juzgaba conveniente que Ramírez, entonces Presidente de Charcas, y Picoaga, que mandaba las tropas avanzadas del grueso del ejército, pasasen a los puntos amenazados para hacerse cargo del mando de las fuerzas (10).

La insinuación de Abascal de que Ramírez tomase el mando de la vanguardia, disgustó a Goyeneche hasta el punto de hacerle saber al Virrey que si aquél se hacia cargo de dichas tropas, él, por su parte, renunciaba al suyo de todo el ejército. En primer lugar alegaba como grave dificultad para su cumplimiento los inconvenientes que Ramírez habia de encontrar en el mando de una unidad desconocida para él, sin los conocimientos y noticias que poseía Tristán en orden a la situación, a los habitantes, $\theta$ incluso a la tropa y conductos de información sobre el enemigo (11). Aducía más tarde en favor de su opinión, una serie de argumentos al retratar a Ramírez. Era para Goyeneche un buen militar, honrado, subordinado y capaz de mantener en disciplina a sus tropas, pero carecía de algunas cualidades necesarias para todo el que ostenta el mando supremo de una tropa. Según él, carecía de cálculo, era irresoluto en sus decisiones y carecía del tacto y la política necesarios para ganarse las voluntades de los oficiales y la tropa. Todas estas razones, reforzadas por ejemplos, inclinaban al General a mantener a Tristán como jefe de la vanguardia, ya que no encontraba en el ejército otro capaz de sustituirlo (12).

Goyeneche pretendía hacer ver que, en manera alguna, el parentesco que le unía a Tristán era la causa de su mantenimiento al frente de la vanguardia, antes al contrario, aseguraba al Virrey que en

(10) Arch. Abascal. Copia de oficio de Abascal a Goyeneche. Lima, ๆ de enero de 1813.

(11) Arch. C. Guaqui. C. 9. Carp. 5. N. 26. Oficio de Goyoneche al Marqués de la Concordia. Potosí, 1 de febrero de 1813.

(12) Arch. Abascal. Carta de Gojeneche a Abascal. Potosí, 24 de febrero de 1813. 
el momento de hallar algún sustituto sería relevado; pero de lo que no le cabía duda ninguna era de que no se encontraba, desde luego, en la persona de Ramírez. Compara a dicho fin la retirada de éste en Aroma con la de Tristán en Tucumán. A pesar de todo, hay que hacer notar, en descargo de Ramírez, que ambas acciones difieren fundamentalmente; mientras Ramírez hubo de emprender una retirada sobre el Desaguadero a toda prisa, tras la derrota de la columna de Piérola, en manifiesta inferioridad ante la caballería cochabambina, que podía perseguirlo, y con la amenaza de encontrarse cortada las comunicaciones por la inminente sublevación de La Paz, Tristán, después de una batalla, que quedó indecisa, como lo demuestra el hecho de haber permanecido bastante tiempo frente a Tucumán después de la lucha, pudo emprender una retirada sin ser molestado y con las comunicaciones aseguradas.

No significa ésto que Tristán no estuviese tan capacitado como Ramirez para el mando de la vanguardia. Ambos eran buenos militares. Pero hay que tener en cuenta que Tristán había fracasado en su ofensiva, quizás por imprudencia y por avanzar confiadamente; no es extraño, pues, que ahora que se iba a decidir la suorte del Alto Perú, el Virrey quisiese sustituirla por otro jefe cuyas cualidades le merecían a él particularmente más confianza, en contra de la opinión de Goyeneche, que en el fondo habría de entenderse mejor con su pariente que con Ramirez. Sin embargo, continuó aquél en el mando, ante la amenaza de Goyeneche de retirarse también si Tristán el'a removido de su cargo.

Ante la inminencia del peligro, Goyeneche había movido sus tropas. La división que se hallaba guardando el paso de Humahuaca avanzó hasta JuJuy; Picoaga se mantenía en Tupiza como reserva, a la par que imponia respeto a los partidos de, Chichas, Cinti y Tarija, que no podrían sublevarse y cortar las comunicaciones. Ramírez, en Charcas, aseguraría los partidos limítrofes de Santa Cruz y Chayanta, evitando las irrupciones de los chiriguanos de aquella frontera, y Tristán era reforzado con caballería (13).

(13) Arch. Abascal. Oficio de Goyeneche al Virrey del Perú. Cuartel General de Potosí, 1 de febrero de 1813. 
No parecía posible, sin embargo, que los argentinos atravesasen 사 río Pasaje en esta época en que se hallaba crecido; más cabía la posibilidad de que se dirigieran por Santa María y San Carlos a través de los valles occidentales, para cuyo evento habia que estar preparado, aunque Goyeneche no esperaba acción alguna durante el periodo de las lluvias.

Pero los rumores sobre la aproximación hacia Salta de los argentinos seguían insistentemente. Su número lo calculaba Tristán en 3.500 ó 4.000 hombres. Pero el Mayor General confiaba, quizás excesivamente de nuevo, en sus tropas, cuya magnífica disposición hacia patente a Goyeneche, "Mientras V. S. no me ordene otra cosa, yo he de sepultarme en ésta con honor, aunque viniesen las fuerzas todas de la infame Capital: asi lo he Jurado con mi tropa, y veo en todos un ánimo resuelto a cumplirlo (14). Ciertamente, Tristán se hallaba en un doble error: no daba la debida importancia a las tropas enemigas, y fiaba excesivamente en las propiag. Los resultados de su equivocación habian de ser funestos e iban a arrastrar con ellos al propio Mayor General.

En efecto, el 20 de septiembre se presentaron los argentinos ante Salta. Alli tuvo lugar un sangriento combate en el que los oficiales realistas no supieron imponerse a sus tropas. El enemigo habia marchado a la derecha de la ciudad, colocándose entre ésta y Jujuy, a legua y media de la primers. Todos los intentos de abrirse paso hacia aquella ciudad por parte de las tropas de Tristán fracasaron, y al fin, cundiendo la desmoralización entre los realistas, y aumentando el desorden, que no supieron atajar sus oficiales, se vieron obligados a encerrarse en la ciudad, y se acogieron a la capitulación como único medio de salvar los restos del ejército (15).

El mismo día, desde el campo de batalla de la propia Salta, Tristán escribía lleno de consternación a

(14) Arah. Abascal. Copia de Oficio de Tristán a Goyeneche. Cuartel General de Salta, 13 de febrero de 1813.

(15) IOZA, Emilia. Yutasto, Tucumán y Salta. Tomo V. (Sec...2.) \& la Historia de la Nación Argentina publicada bajo la dirección de Ricardo Levene. Buenos Aires 1941. Págs. 559 ş. 
Goyeneche: «Mil veces he sentido no haber perecido cuando tuve que defenderme sable en mano de entre los enemigos que me rodearon, pues me es más sensible darte estos pesares y noticias que el dejar de existir» (16). La culpa la achaca a los «ignorantes Jefes y malos oficiales», que no supieron mantener la disciplina, merced a lo cual, el desorden hizo pronto presa en las filas realistas, que, a pesar de tres horas de lucha, hubieron de capitular.

Un Consejo de Guerra, celebrado en Salta, dió poderes al coronel don Felipe de la Hera para que, acompañado del teniente coronel don Juan Bautista Estéllez, entrase en negociaciones con Belgrano. La proposición de que era portador el coronel de la Hera consistía en el abandono por el ejército realista de la provincia de Salta y todo el territorio al Norte de esta ciudad hasta Tupiza, respetando las propiedades y la seguridad individual de los habitantes, y sin perJudicar a nadie por sus opiniones (17).

Belgrano, en su contestación, aceptaba la proposición de Tristán y concedía los honores de guerra a su ejército a la salida de Salta; pero al llegar a tres cuadras de distancia de la ciudad habia de rendir las armas y entregar los fusiles, artilleria y municiones. Asimismo, el general y los demás jefes y oficiales prestarian juramento de no volver a tomar las armas de nuevo contra las Provincias Unidas del Río de la Plata, y los soldados quedarían como prisioneros. Por último, exigía la devolución de todos los oficiales argentinos prisioneros de los realistas. Aclaraba convenientemente que en las Provincias Unidas del Río de la Plata comprendia a las de Potosí, Charcas, Cochabamba y La Paz. Por su parte, Belgrano se comprometia a respetar las propiedades y a perdonar a todos los vecinos de Salta que hubiesen tomado las armas contra su ejército (18).

(16) Arch. Abascal. Carta de Tristán a Goyenecde. Salta 20 de febrero de 1813.

(17) Arch. Abascal. Copia de la proposición de armisticio comunicada por don Felipe de la Hera a Belgrano. Campo de Salta, 20 de febrero de 1813.

(18) Arch. Abascal. Copia de Oficio de contestación de Belgrano a don Felipe de la Hera. Tablada de Salta, 20 de febrero de 1813. 
La aceptación de las condiciones exigidas por el General argentino caían fuera de las facultades del comisionado la Hera, por lo cual, enviadas a Tristán, fueron discutidas en un nuevo Consejo de Guerra reunido al efecto. La respuesta sólo tendía a modificar tres puntos. Hacía saber a aquél lo doloroso que era para los jefes realistas que sus soldados, por el simple hecho de ser de inferior condición, quedasen prisioneros, mientras ellos quedaban en libertad bajo juramento; por lo cual solicitaban de él les concediese la misma suerte que a sus Jefes. Otro punto tocado en el Consejo era la devolución de los prisioneros argentinos, que había de entenderse afectaba únicamente a los que se hallaban entonces en la ciudad, los únicos de quienes Tristán podía responder, $y$, por último, se rogaba que a los vecinos de Salta se les considerase como a los soldados del ejército, respetándole sus propiedades. En cuanto a los demás puntos de la capitulación podía entenderse para ello con el coronel la Hera (19).

Al fin, aceptadas por Belgrano las modificaciones propuestas por los realistas, fué confeccionado el documento de la capitulación en los términos siguientes:

«El Sr. General don Manuel Belgrano, Jefe del Ejército de Buenos Aires, y el Coronel don Felipe de la Hera, encargado por él de la vanguardia del Perú, han acordado (a consecuencia del papel anterior) lo siguiente:

Artículo 1.-ㅌ Ejército del Perú saldrá mañana a las diez, de la Plaza de Salta, con todos los honores de la guerra, quedando ahora en la posición que ocupan las tropas de las Provincias Unidas del Río de la Plata; a las tres cuadras rendirán las armas y se entregarán con cuenta y razón, como igualmente artillería y municiones.

Artículo 2.0-El General, los Jefes y demás oficiales prestarán juramento de no volver a tornar más las armas, y por todos los soldados del Ejército (a

(19) Arch. Abascal. Copia de Oficio del Consejo de Guerra celebrado en Salta para contestar a las condiciones propuestas por Belgrano. Salta, 20 de febrero de 1813. 
quienes concede el Sr. General Belgrano que puedan restituirse a sus casas), contra las Provincias Unidas del Río de la Plata, en las que se comprenden las de Potosi. Charcas, Cochabamba y La Paz.

Artículo $30^{\circ}-$ Se conviene el Sr. General Belgrano en que se les restituyan los oficiales y soldados prisioneros que hay en la Plaza y territorio que se evacua, y pide que el General Tristán estimule a su General en Jefe para el canje de los prisioneros hechos en las diferentes acciones de guerra, desde la del Desaguadero, inclusive.

Artículo $4 .^{\circ}-$ Serán respetadas las propiedadess, así de los individuos del Ejército, como de los vecinos, y a nadie se molestará por sus opinlones políticas, en que se incluyen los oficiales o vecinos de cualesquiera otro pueblo.

Artículo 5. - Los caudales públicos quedarán en Tesorería balo de cuenta y razón que deberán prestar los Ministros de Hacienda.

Artículo 6. - El cuerpo de tropa que se halla en Jujray deberá retirarse sin perjuicio alguno en su tránsito al interior, llevando sus armas.

Artículo 7. - El General Belgrano conviene en que el General Tristán haga un expreso a su General en Jefe remitiéndole copla de este tratado, y para su ma.vor validación lo tirmaron en la Tablada de Salta, a 20 de febrero de 1813.-Manuel Belgrano.-Felipe de la Hera) (20).

El mismo día 20 fueron ratificados por Tristán los artículos de la capitulación.

La noticia de la derrota y capitulación de la vanguardia de su elército le llegó a Goyeneche el día 27, runto con la carta confidencial a que me he referido antes (21), y un papel escrito en francés de puño y letra de Tristán, en el que le decía que calculaba la fuerza de los enemigos en 4.000 hombres con armas de fuego, que iban en su busca, ante lo cual debía retirarse a Oruro, pues no los detendria nada.

Sin más noticias sobre la situación, Goyeneche

(20) Arch. Abascal. Copia de la Capitulación firmada en Salta el 20 de febrero de 1813 por Belgrano $y$ el Coronel la Hera.

- (21) Vid. nota 16. 
convocó un Consejo de Guerra en Potosi, compuesto por los jefes de la guarnición; cuatro coroneles; un teniente coronel; el auditor, conde de Vallehermoso; el fiscal de la Audiencia, $y$ el secretario de Guerra, con el fin de tomar partido sobre los acontecimientos. Carentes como se hallaban de otras noticias que las contenidas en las cartas de Tristán, ya que el portador de ellas tampoco pudo informarles, por haber sido relevado en Tupłza el que éste enviara, el Consefo fué de parecer que se evacuase Potosi, en donde sólo tenian 400 hombres de guarnición.

Las razones que abonaban la evacuación de la ciudad fueron varias: en primer lugar, el General hizo saber a la Junta la escasez de medios de defensa en que se encontraba con la pequeña guarnición existente, que no bastaba a cubrtr los puntos de la misma. Por otra parte, la noticia enviada por Tristán de que el enemigo se dirtgía rápidamente contra Potosi, hizo pensar a Goyeneche que podian enviar una gruesa columna de caballeria por el camino llamado del Despoblado, que se extendía a la izquierda del real dél Tueumán, favorecido su avance por el camino sin altibajos y por mucha caballeria que traian de esta región, aparte de la que tomaran a Tristán. En semejantes condiclones, los enemigos podían desbordarlo por la izquierda y, dejándolo a retaguardia, interceptar sus comunicaciones con Oruro en el pueblo de Ancacato, donde desemboca dicho camino. Fácilmente podrian desde aquí introducir la sublevación en Cochabmba y Chayanta; con lo cual llegaria a encontrarse Goyeneche totalmente aislado, con el consiguiente desaliento de la parte del ejército que quedaba al Norte, de la que no era aventurado suponer que acudiese en su auxilio.

Tampoco le pareció conveniente al General hacer frente a los argentinos con el núcleo de tropas que pudiese reunir inmediatamente. Cualquier pérdida sufrida podia disminuirla considerablemente, cuando su interés era reunir el ejército, en el que comenzaban a introducirse la murmuración y las deserciones. No le parecía tampoco suficiente apoyo el que pudiera ofrecerle la guarnición de Jujuy en su retirada, de la que no tenía noticias, y cuya salide, pensaba, podían retrasar los enemigos para sorprenderle. 
Otro argumenta aducido por Goyeneche en favor de la evacuación fué la imposibilidad en que se hallaban de reunir las tropas en Potosí antes de que Hegasen a esta ciudad los enemigos, cuyo avance, según las noticias de Tristán, era rapidísimo. El Desaguadero se hallaba a ciento treinta leguas y con poca guarnición; La Paz, a cien diez leguas, necesitaba su guarnición para sostener el partido de Yungas, constante amenaza de aquel territorio. La única que podía proporcionarle ayuda, especialmente en caballeria, era Cochabamba, pero distaba de Potosí noventa y cinco leguas, y, según el cálculo de Goyeneche, tardaría la tropa do menos cuarenta días en reunírsele en esta ciudad, en donde no encontrarian forraje. En cambio, en Oruro, de donde distaba Cochabambá sólo treinta leguas, lo encontraria en abundancia.

Por último, no poco influyó ! para abandonar la ciudad el recuerdo del general Nieto y del intendente \$anz, victimas de la sublevación popular ante la proximidad de los argentinos.

Todas estas razones decidieron al jefe de las tropas realistas y a los miembros de la Junta por él convocada a ordenar el repliegue sobre Oruro. A la par se ordenaba a Picoaga, situado en Tupiza y que corría el peligro de ser atacado por los argentinos, que se retirase sin entrar en Potiosí, cuya inquietud hostil hacia temer un mal desenlace (22).

Para poder llevar a cabo con cierta tranquilidad la evacuacion, propuso a Belgrano, con la aprobación de los demás jefes del ejército, un armisticio de cuarenta días. Durante estos dias, detenido el avance argentino, y con un territorio bastante extenso entre ambas fuerzas, podría efectuar su plan de evacuación de Potosí $y$ concentración en Oruro para defender las restantes provinciais del Alto Peru. Así se lo comunlcaba al Virrey el mismo día que recibió las noticias de Salta (23).

(22) Areh. C. Graqui. Cb 9, Carg, 6. N. 1. Memorial de Goyeneche a S. M. Quinta de Pacallar, 30 1 de marro de 1814.

(23) Arch. Abascal. Carta de Goyeneche a Abascal. Potosi, 27 de febrero de 1813. 
Mucho debió preocupar a Goyeneche, a juzgar por lo que insiste en ello, el estadi) de sorda hostilidad, que se hizo patente en Salta. Conservaba en su imaginación la conducta veleidosa de sus habitantes, que ya tenian experiencia de estas situaciones. Como he dicho, recordaba lo sucedido a Nieto y a Sanz, asi como también tenia en la memoria que, un año después de la muerte de ambos, el mismo pueblo de Potosí perseguia a Pueyrredón, que con sus derrotadas tropas evacuaba la ciudad llevándose el dinero del Banco. Muy bien podía ocurrir por tercera vez este caso, y ahora en su persona y en sus tropas. Cabe pensar, por tanto, hasta qué punto influyó esta idea en su decisión de evacuar Potosi. A mi juicio, debió ser uno de las angumentos decisivos, y el que hizo imprimir más velocidad a la evacuación.

El mismo nos dice que el día 28, siguiente al de la llegada de la noticia, se vió imposibilitado de hacer ningún movimtento para la evacuación por la actitud del pueblo. Por fin, aquella noche, a la una, comenzó la extracción de fondos de la Casa de la Monoda, en total más de 350.000 duros, operación que quedó terminada al rayar el dia. Pretendió, aunque sin conseguirlo, hacer lo mismo con la Cafa Nacional y iel Banco.

El día 1 de marzo la intranquilidad popular subió de punto: el pueblo se agrupaba por las esquinas $y$ plazas de Potosi, hasta que, a media mañana, una comisión se dirigió a Goyeneche. Solicitaba la entrega de los prisioneros argentinos existentes en la ciudad. Hubo un momento difícil, salvado por la enérgica actitud del general, e inmediatamente se organizó la evacuación total, efectuada con gran normalidad (24). El dia 12 llegaban las fuerzas a Oruro; daba cuenta de ello al Virrey en una carta con pormenores de la evacuación, y explicaba los motivos que le obligaron a dejar 50.000 pesos en el Banco de Potosí, que no pudieron extraerse por falta de mulas.

El camino habia sido agotador, bajo frecuentes granizadas, acampando al aire libre y en la precisión de vivir de la çaza, el Ejército llegó diezmado a Oruro,

(24) Vid. nota 22. 
debido en no pequeña parte a la deserción constante en el trayecto. Estas deserciones eran reflejos de su estada, pues comenzaba a cundir la voz del cese de las operaciones, por todos deseado (25).

El total de las fuerzas que Goyeneche pensaba reunir en Oruro era de 3.300 hombres, con los de Picoaga, que senían de Tupiza, los de Lombera, de Cochabamba, y los suyos propios. Allí se dedicó a reorganizar la tropa y el material, a pesar de lo cual escribía al Virrey pidiendo el rápido envio de soldados o el inmediato cese de la lucha. Caso de no serle posible llevar a cabo ninguna de las dos soluciones, ponía a su disposición el mando del Ejército (26).

nis 22 de marzo recibía Goyeneche la contestación de Belgrano a su petición de armisticio, solicitada desde Potosí. Con el fin de discutir las proposiciones y resolver en consecuencia, convocó una Junta de Guerra a la que asistieron Ramirez, como segundo del Ejército; el capitán de la Armada, Tacón; los coroneles Lombera, Campero, Santiago, Conde de Casa Real, Revuelta, Vallivian, Benavente, etc.

Leída la contestación del general argentino, se vió que accedía al armisticio por cuarenta días, durante los cuales sus tropas no pasarian de la provincla de Chichas, en espera del establecimiento de negociaciones para terminar las hostilidades definitivamente. Ante la oferta de Belgrano, y después de una discusión en la que se presentó el estado de fuerzas y se sometió a la consideración de los alli reunidos la situación de las provincias y la falta de auxilios, acordaron proponer la prórroga del armisticio a sesenta o setenta días, para elevar a conocimiento de la superioridad las necesidades del Ejéreito, con el fin de remediarlas o recibir instrucciones para el cese de la lucha. Durante este período de tiempo, las tropas de Buenos Aires llegarian hasta la provincia de Chichas, pero Potosí y Charcas quedarían neutrales, sin ocupación alguna por parte de los dos bandos. Por el con-

(25) Ařch Abréscal. Carta de Goyeneche a Abascal. Oruró, 13 de marzo de 1813.

(26) Arch. Abascal. Oficio de Goyeneche a Abascal. Oruro, 23 de marzo de 1813. 
traxio, las provincias de Cochabamba y La Paz habian do quedar bajo la protección de las armas del Rey, la primera sin guantición. Ambos jefes habían de procurar el establecimiento de toda clase de relaciones entre los respeativos territorios, pero sin permiltir el desorden.

A la par que se ultimaban estos puntos con el general argentino, se decidio en la misma Junta enviar por extraordinarlo al Virrey una copia del acuerdo, kexigiendo de sus altas facultades el envio de 3.000 hombres, necesarlos para continuar la lucha, o el avenimiento con los argentinos para suspenderla (27).

Lia retirada a Oruro fué para el General Goyeneche la única solución que le cabia. Las causas que le indujeron a llevarla a cabo han sido expuestas anteriormente. Pensaba que, una vez preparado y disciplinado el Ejército, podriallanzarse de nuevo a la lucha, un1dos los que se concentrasen en la ciudad $y$ los contingentes que el Virrey enviase.

Sin embargo, Abascal no pensaba de la misma manera. La noticia de la capitulación de Salta fué para él una verdadera sorpresa. En primer lugar le sorprendio que los argentinos se hubiesen aventurado a atravesar el rio del Pasaje en la estación de las aguas, que lo hacia crecer hasta convertirlo en invadeable, eorriendo; por tanto, el grave lesgo de defar aisladas a sus tropas con la crecida. Pero lo que le causaba admiración, lindante con el enojo, era el desorden en que, según se traducia por las notielas recibidas, se desarrolló la acción.

Todo el plan anterior a la batalla de Salta, desde el comienzo de la ofensiva de Tristán contra el Tucumán, es criticado severamente por el Virrey. En primer lugar, y como afirmación fundamental de su atgumentación, manifestaba que, aunque ni la acción det Tucumán ni la de Salta podian influir mucho en la seguridad del Contmente, ambas fueron dadas contra sus órdenes. El había mandado que no se adelantasen del Pasaje más que algunas partidas para alarmar el Tucumán; pero Tristán, lejos de ate-

(27) Arch. C. Guaqui. C. 9, Carp, 5, N. 1. Acta de la Junta de Guerra celebrada en Ororuro el 22 de marzo de 1813. 
nerse a sus órdenes, se adentró con todas sus fuerzas en desorden y sin tomar las más elementales precauciones, con lo que comprometió el éxito de la campaña. Consecuencia de su imprevisión, fué dar la batalla del Tucumán en un llano, con inferioridad notable en la caballería y sin tener montada aún la artilleria.

Indudablemente, el Virrey llevaba razón. Las órdenés dadas a Tristán eran claras y terminantes. El Mayor General se dejó llevar de la facilidad con que efectuaba el avance en un principio, y creyó que con esta campaña se podría conseguir el fin de la guerra. El mismo Goyeneche así lo reconoció, aunque se excusaba de la responsabilidad que sobre él pudiera recaer demostrando que, cuando tuvo noticias del avance por el territorio del Tucumán, ya llevaba Tristán yarios días de marcha. Confiado en los buenos informes que recibiera, convino con el plan del Jefe de la vanguardia, pero con su aquiescencia se hizo también responsable, en parte, de las consecuencias (28).

Pero lo que más molestaba al Virrey era la desobediencia de Tristán. Después de la batalla del Tucumán comunicó él a iGoyeaeche que se construyese una fortificación en Jujuy cerse Tristán, y otra en el fuerte de Cobos, como más atrás se ha visto, para lo que le envió los medios necesarios. Pero «ninguna de estas disposiciones acomodó a Goyeneche ni a Tristán, el que se mantuvo en inacción en Balta, que es un puesto a trasmano y de difícíl comunicación con Jujuy por la aspereza del camino... (29). En sealidad, el ataque a Salta por los argentinos cogió de sorpresa a Tristán, que no podia pensar que atravesasen el rio del Pasaje entonoes. Pero también es obligatorio reconocer que el mismo Virrey, al tener noticias de la posición de Triotán, una vez terminado el repliegue, ordenaba la conservación de las dos ciudades de Salta y Jujuy, aunque prefiriendo siempre la segunda a la primera $(30)$.

(28) Vid. nota 22.

(29) Arch. A bascal. Oficio del Virrey de Perú al Secretario de Eutada. Lina, 14 de abril de 1813.

(30) Vid. nota 6. 
Es cierto que si Tristán se hubiese establecido en Jaujuy en lugar de Salta, hubiéra quizás asegurado más su posición; pero indudablemente, no debió pensar nunca que iba a ser objeto de un ataque repentino, y por otra parte, como ya se ha visto, confiaba, tal vez demasikido, en sus tropas. Cuando se apercibió de su verdadera situación, ya estaba aislado, cortadas sus comunicaciones con Jujuy, y no le cabía otra solución que rendirse o luchar hasta morir.

El momento en que Abascal recibió la noticia de la derrota y capitulación de Salta, así como la decision de Goyeneche de abandonar Potosí, era un instante crítico. Coincidió con los preparativos para las elécciones de diputados, «dias eríticos, que, puestos en calor y movimiento los pueblos, no debía manifestarse en ellos ni dar al público estos sucesos» (31). Por esta razón, y para evitar cualquier alteración del orden, escribió inmediatamente a Goyeneche desaprobando su manera de proceder. El armisticio convenido con Belgrano no tenía ante sus ojos ninguna valider, por carecer Tristán de facultades para concertarlo, ya que este jefe solamente podia decidir sobre la suerte de las tropas a su mando.

En cuanto a la evacuación de Potosí, ordenaba el Virrey que no se llevase a cabo hasta tanto se reuntesen los dispersos de Jujuy, y aun entonces debia enviarse por delante el dinero, dado el caso que, evacuada aquella ciudad, a Juicio de Abascal, habria de continuarse el repliegue hasta el Desaguadero a falta de algún punto intermedio con cuya seguridad pudiese contar; «pero en llegando a aquél es necesario defenderlo con toda la energía que exige su importancias, para lo cual daba órdenes de acopiar cuantos hombres y material tuviesen a su disposictón (32).

Según opinaba el propio Virrey más tarde, ni aun hubiera sido necesario evacuar Potosi, con lo que se hubieran evitado las consecuencias de la derrota de Salta. Bastaba haber efectuado en aquella ciudad la reunión de fuerzas que Goyeneche ordenó se verifi-

(31) ABASCAL. Memoria. Tomo II. Pág. 415.

(32) Arch. Abascal. Copia de Ofieio del Marqués de la ConConcoftid a Gojeneche. Lima, 26 de marzo de 1818. 
case en Oruro y, de alli, reunido con las que se netiraban de Jujuy y Tupiza, marchar contra Belgrano (33). Sin embargo, más atrás quedan expuestas las razones que movieron a Goyenech a la evacuación. Indudablemente, tenidas en cuenta las circunstancias del momento, era lógico que, en el estado de incertidumbre e indecisión en que se hallaba el General, no encontrase otra solución mejor.

Transcurridos los agitados días de las elecciones, el 1. de abril reunió el Virrey una Junta de Guerra para resolver sobre la situación planteada por la derrota de Tristán y su capitulación. En ella manifestó Abascal el estado de las operaciones y leyó su correspondencia con Goyeneche: Examinados todos los datos se tomaron las resoluciones concretadas en los puntos siguientes:

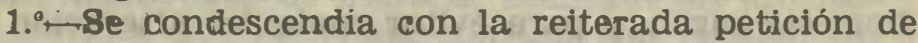
Goyeneche de entregar el mando de las tropas, que debía efectuar én la persona de su segundo, el brigadier don Juan Raminez, mientras el Virrey en persona, o aquél a quien él designiase, se hacía cargo de las fuerzas. Esta decisión se comunicaría a las provincias del Curco, Puno y Arequipa.

2. - se anulaba todo lo que excedía de las facultades de don Pío Tristán en la capítulación que llevó a cabó, que sólo podía referinse a las tropas bajo su mando.

3. - Igudmente se anulaba todo trato o capitulación que pudiera pactar Goyeneche con los argentinos, ya que tampoco se encontraba autorizado para ello sin la anuencia del Goblerno de Lima.

4. - Be ordenó al cacique Pumacahua que pasase con 1.000 ó más de sus indios a defender el camino de La Paz al Cuzco por el Partido de Larecaja.

5: - Con objeto de no levantar sospechas y mantener asegurado el orden público, debia declararse la finalidad de la Junta, así como igualmente anunciar al comercio la conveniencia de reunir en Lima los caudales y efectos que tuviesen en las provinclas.

$6 .^{\circ}$ - Por último, como medio preventivo para evi-

(33) Arah. C. Guaqui. O. 9. Carp. 5. N. 15. Oficio del Yirrey del Perú al Secretavio de Estado. Lima, 14 de abril de 1813. 
tar cualquier intento de ataque desde el mar, se decidió colocar un teniente de Gobernador en la Plaza del Callao, con los conocimientos necesarios.

Mas, como para poder llevar a cabo todas las medidas que habian de realizarse hacia falta gran cantidad de dinero como factor fundamental, el Virrey y los demás vocales de la Junta habrian de discutir en otra reunión el modo de conseguirlo, a la vez que se daba cuenta al Goblerno del estado del Virreinato.

Por ultímo, se dictó una medida, sugerida seguramente por el Virrey, con objeto de abreviar los trámites para deshacerse de los individuos revoltosos que se hallasen en el Virreinato. Como la formulación de un juicto llevaba consigo una gran pérdida de tiempo, se determinó que dichos individuos se remitiesen en los buques que salian para la Península o algún otro lugar donde su permanencia no constituyese un peligro, sin necesidad de cumplir aquel requistto, que prolongaba interminablemente su estancia en el. V1rreinato. Medida diriglda a concentrar más la autoridad en manos del Virrey, cuyas facultades habia Ido ampliando poco a poco Abascal (34).

Ciertamente, la resolución de más trascendencia adoptada en esta Junta fué la sustitución de Goyeneche. Con objeto de disimular lo que en efecto era una destitución, se adoptó el criterio de condescender con la reiterada solicitud del señor Goyeneches. Aứn más: unos días después de celebrada la Junta, Abascal escribía al General en estos términos: «La inclinación de la Junta de entregar V. S. el mando se debe entender si insiste en separarse de el, pues no hay razón para violentarle en un asunto tan delica-

(84) Arch. Abascal. Copía de Acta de la Junta de Guerra celetmada en Lima el $40^{\circ}$ de abril de 1813. A dicha Jputa, preaidida por el Virbey, agistieron el Tenionte Goneral don Juan de Hepestrosa, Subinspector de los Éjércitos; don Joaquín de Molita, Jefe de Escuadra de la Armada; el Conde del Valle de Oselle, Mariscal He Canfpo; 'Jos' Brigadieres don Josiqua de Alós; don Joaquín de la Pezuela, Subinspector de Artillería; don Pedro Molina, del Cuerpo de Ingenieros; don Gabino Gaínza, Coronel del Regimiznto de Infantería de Lima; el Coronel don Mariano Osorio, Comandante de la Brigada de Artilleria de Lima, y el Capitán de Navio don José Pascual de Vivero, Comandante del Apostadero del Callao. 
do (35). Pero en caso de continuar, le exigía el Virrey el alejamiento de su lado de Tristán y del doctor Cañete, su asesor.

Las razones de la remoción de Goyeneche nos las da el Virrey en su Memoria; se reducían a las siguientes: La manera «en que abiertamente y sin el menor disimulo pretendio evadirse de la responsabilidad de su cargo, a pretexto de falta de auxilios yi socorros de toda especie, de los cuales, muchos se le habian remitido, § manifestándole la imposibilidad de realizarlo en otros; la declarada connivencia en los negocios referentes al comandante Tristán, de cuyas resultas procodieron en su mayor parte la falta de cumplimiento a las órdenes de esta Superioridad y, sobre toda, el decaimiento de ánimo y abatímiento a que lo redujo la esquela del mismo Tristán, escrita en el desorden de la pérdida de la acción de Salta; en términos de pasar al Jefe de la revolución el más humillante oficio y proponerme la bajeza de negociar con el mismo la cesación de hostilidades o su relevos (36). En resumen, tres eran los motivos que Abascal daba para Justificar la separación de Goyeneche: la constante petición de auxilio, inmoderada a su Juicio; la falta de cumplimiento a sus órdenes por su declarada amistad con Tristán, que le cegaba, y, por último, el abatimiento a que había llegado, que le impulsó a tratar con los enemigos.

La primera de las razones no era nueva. A lo largo de la campaña se ha podido ver cómo Goyeneche solicitaba auxilios constantemente. Al salir con su ejército del Desaguadero después de la batalla de Huaqui, indudablemente se hallaba en situación ventajosa para luchar contra los argentiños. Pero a medida que avanzaba a través del Alto Perú, la guerra cambió repentinamente de carácter. Las mismas ciudades que acogieron alborozadamente a las tropas revolucionarias, recibian con igual alegria a los realistas. Semejante voluble conducta era suficiente para hacer dudar de su buena fe. Ya he dicho anteriormente (37)

(35) Aritr. C. Guaqui. C. 9. Carp. 5. N. 3. Ofieio del Marqués de la Corleordia a Goyeneche. Lima, 5 de abril de 1813.

(36) ABASCAL. Memoria. Tomo II. Pág. 420.

(37) Vid. pág. 10. 
que el comportamiento de los argentinos durante su ocupación de las ciudades del Alto Perú originó un sentimiento común de hostilidad hacia ellos; pero no quiere decir esto que dichas ciudades renunciasen a sus ideas de independencia. Antes al contrario, se mantenía viva aún frente a los argentinos, y a pesar de la ocupación de los realistas. Así se explica la necesidad en que se encontraban éstos de mantenerse en continua vigilanola para evitar ser sorprendidos. Eógicamente, la anterior circunstancia traía como consecuencia un fraccionamiento del ejército en los diferentes puntos vitales del Alto Perú, sobre todo en aquellos que mantenian las comunicaciones con el Virreinato. Y precisamente ahora, al sustituir la Junta de Buenos Aires a Castellí por Belgrano, aureolado de una fama de hombre probo y Justiciero, se pretendía restañar el mal llevado a cabo ten 1810 y restablecer el contacto entre los revolucionarios altoperuanos y los argentinos, a punto de lograrse. - Al lanzarse a la ofensiva los argentinos, Goyeneche, temeroso de una insurrección a sus espaldas, redobló las peticiones de auxilios, $\boldsymbol{y}$ con ellos la situación parecía sostenorse, e incluso los obligó a retirarse; pero cuando tuno lugar el fracaso de la ofensiva de Tristán y el avance de Belgrano hasta Salta, pensó que, desaparecida totalmente la varguardia y avanzando victorioso el Ejército argentíno hasta el mismo Alto Perú, la catástrofe era inevitable.

El número aproximado de la fuerza que poseía Gayeneche, oscilaba alrededor de los 8.000 hombres, de los cuales tres mil y pico estaban situados en la vanguardia; los argentinos, según los cálculos que se hacían, no debian pasar de los 4.000. Sin embargo, hay que tener en cuenta la disgregación del ejército realista a que me he referido antes. $Y$ ciertamente debía tener razón Goyemeche al exponer la pérdida de tiempo que significaba la reunión de las tropas en Potosí para detener a los argentinos, cuyo ejército había engrosado en el camino, y de los que se esperaba un rápido avance.

El Virrey, por su parte, no cesaba de enviarle auxilios en cuanto estaba a su alcance. Pero se había llegado a un momento en que casi no se podían extraer más saldados, y Goyeneche pédía 2.000 hombres 
de refuerzos. El plan que le propustera de sacar soldados de las guarniciones no le ofrecia garantlas al Genesal, a pesar de que al fin se vió obligado a hacerlo. ¿Se encontraba, pues, preparado Goyeneche para hacer frente con ventaja a los enemigos? Desde luego, inmediatamente después de la batalla y capitulación de Salta, no. Ahora bien; ¿hubiese cabido precaver esta situación, o haber llevado la campaña de otro modo que como él la llevó? Con esto entramos en el segundo de los argumentos aducidos por el Virrey.

Que Goyeneche sentía especial predilección por Tristán, es inctiscutible. Razones de parentesco o de simpatfa personal debieron influir no poco en el ánimo del General, aparte de las innegables dotes militares de aquél. Basta para demostrarlo la correspondencia entre ambos, y por si fuera poco, la carta más atrás comentada, de 1 de febrero de 1813 , en que Goyeneche expone su jutcio sobre Tristán y Ramirez, no deja lugar a dudas. No es mi ánimo negar la capacidad militar de aquél ni asegurar que su preeminencia en el efército fuese debida única y exlusivamente a la preferencia que por él sentía el General; pero hay que tener en cuenta un hecho indudable. El fracaso de la ofensiva del Tucumán fué debido fundamentalmente a Tristán. Las causas ya se han visto y no hay que insistir en ellas. Por otra parte el plan ideado para llevarla a caboy a pesar do la buena voluntad que manifestaba, encerraba una desobediencia a las órdenes del Virrey. Claro está que, al avanzar la vanguardia, se necesitaban más hombres, y sabre todo, después de la derrota del Tucumán se hacian tmprescindibles. No hay que decir, pues, que la situación creada por la capitulación de Salta cuyas consecuencias no se podian prever en aquel momento se hiciese sostenible para Goyeneche, con bastantes visos de verosimilitud.

Pero aqui interviene el tercer argumento de Abascal. Tampoeo er\& repentino el estado de ánimo deprimido de Goyeneche, que se apoderó de él, o se acentuó más bien, después de la derrota de Salta. En el capitulo anterior se ha visto como influia en el General la marcha lenta e inacabable de la guerra. Quizés, tanto él como Abascal, no pensaron al co- 
menzar la lucha, que se inauguraba la guerra a muerte entre el antiguo régimen y las nuevas teorías. Pero si en un principio no tuvieron esta idea, los! hechos hubieron de demostrárselos, y pronto pudierous calcular la trascendencia de la contienda. La manera como el Virrey enfocó la situación no nos interesa ahora; tan sólo examinaré la actitud de Goyeneche. Durante la primera parte de su actuación todo hacfa concebir un éxito rotundo. Tras la preparación del ejército y la derrota de Huaqui vino la ocupación total del Alto Perú, que, exceptuada Cochabamba, no ofreció resistencia a los realistas. Pero las sublevaciones que sufrieron poco después le obligaron a pensar que hacía falta algo más que la ocupación de las lineas de ctumunicación con el Virreinato: era absolutamente imprescindible la permanencia de tropas en todas las ciudades y purtos de alguna importancia del Alto Perú, si se quería asegurar la tranquilidad y progresión del resto del efércita. La prolongada resistencia pasiva de las oiudades y los intentos, abortados unos y trianfantes otros, de nuevas sublevaciones produjeron cierto decaimiento en el ánimo del General, que veia su obra en un equilibrio inestable. De ahí las constantes peticiones de auxilios con el fin de asegurar lo conquistado y prewenir el derrumbamiento por alguna cireunstancia desgraciada.

No es de extrañar, pues, que tal estado de ánimo del General se agudizase al conocer lo ocurrido en Salta a su más adicto y fiel colaboradar. Con pocas y confusas noticias, con la advertencia de Tristán de que venían sobre él los enemigos, con la pequeña guarnición de la ciudad, y habida cuenta de su estado de espíritu al no recibir refuergos, nos encontramos perfectamente oxplicadas, a duicio, las decisiones que tomó en consecuencia. $Y$ por cierto, que a mi modo de ver, más errado estuvo Goyeneche al permitir el avance de la vanguardia a través del TucuJoán, que en las posteriores resolueiones para hacer frente a sus resultados.

Precisamente, para juzgar éstos últimos convocaba nueva Junta de Guerra el Virrey el dia 8 de abril. Tres días antes había escrito a Goyeneche, calificando su retirada a Oruro como una «resolución precipitada», que podía haberse ahorrado acercán- 
dose Picoaga hacia Jujuy para recoger a los que de aquí se retiraban. Una vez efectuada la unión, pensaba que podían haberse hecho firmes en Humahuaca, Buipacha, o algún otro punto de fácil defensa. Pero como ya debía haber efectuado el repliegue, le instaba a remediar esa falta, «regresando a ocupar a Potosí y seguir al encuentro de los enemigos, si se les considera con menos fuerzas» (38):

Conocido el modo de pensar del Virrey, se puede calcular cuál había de ser el resultado de la Junta. A tres cuestiones se reduce todo lo tratado en ella: a la retirada de Potosi, al armisticio propuesto a Belgrano y al envío de refuerzos con el sustituto de Goyeneche.

La retirada de Potosí fué calificada por la Junta de edemasiadamente precipitada, y se aducía en favor de este Juicio el hecho expresado por el General de los ruegos y lágrimas que la evacuación produjo en los habitantes de la cludad. Dichas circunstancias debieron moverle precisamente a demorar la salida hasta el último momento, con lo cual se hubiese facilitado el orden de la retirada. No quiere decir esto que con la reconvención sobre la marcha precipitada, la Junta reconociese una situación de hecho y lá aceptase como única solución. Antes al contrarlo, se renuevan a. Goyeneche las instrucctones enviadas por el Virrey en su oficio del día 5 sobre la necesidad de volver a ocupar Potosi, con tanta mayor insistencia, cuanto que las noticias llegadas a Lima aseguraban haber disminuído notablemente las fuerzas argentinas en la batalla de Salta y quedado los realistas en superioridad manifiesta.

Aprobado el primer punta, se desprende lógicamente que fuese rechazado de plano el armisticio propuesto por Goyeneche. El cese de las hostilidades sólo había de tener lugar «cuando las circunstancias obliguen a ello, en las cuales no se hallaba el Ejerctto Real». Por tanto, debian suspenderse toda clase de negociaciones con los patriotas, y emprender la marcha hacia Potosí.

Pará poder llevar a eabo victoríosamente la con-

(38) Vid. nota 35. 
traofensiva, se dispuso la organizactón en la capital del refuerzo necesario de tropa, artilleria y municiones que permitiesen las circunstancias para salir en un plazo breve en buques preparados al efecto por el Yirrey en dirección a uno de los puertos más inmediato a la ciudad de Arequipa, desde donde continuarian su marcha a través del camino del Alto Perú. Al frente de la expedición de refuerzos iria el teniente general don Juan de Henestrosa, designado por la Junta para suceder a Goyeneche en el mando del ejército (39).

La noticia de su sustitución se ta comunicó el Virrey a Goyeneche en carta de 10 de abril con la mayor suavidad de que era capaz, para evitar cualquier motivo de roce: «...como se haya V. ya tan disgustado en ese ejerciclo, y su salud vaya tan en disminución, como las almas verdaderamente grandes no deben amilanarse en los contratiempos, sino antes desplegar toda la extensión de su energia y recursos, la Junta de Guerra ha venido en conceder a Vd. el retiro que desea...» A la par, como preveia que la separación de Goyeneche podia dar lugar al disgusto de la tropa, trataba de cortar el mal, advirtiéndole: «Vd., en ejercicio del esclarecido honor y fidelidad que le caracteriza, hará cuanto considere conveniente para que esta resolución a que nos ha precisado Vd., con sus repetidísimas instancias y los males que le aflijen, no cause en la tropa novedad notable, tratando de infundirle la confianza y el amor hacia un jefe que ha humillado tantas veces la altivez y la insolencia de los franceses en España... Asi, pues, si Vd. considera que su presencia en este teatro es necesaria interin se da a conocer Henestrosa y sus talentos militares le adquieren le adquieren el lugar que debe ocupar, hágalo por su Patria, y sea éste el últi-

(39) Arch. Abascal. Copia de Acta de la Junta celebrada en Lima el 8 de abril de 1813. Dicha Junta fué presidida por el Virrey y asistieron a ella los mismos jefes que a la del día 1 del mismo mes (Vid. nota 34), con la única alteración de la ausencia de don José Paseual de Vixero; sustituídó por el Brigadier don Bartolomé Cucalon. 
mo sacrificio con que concurra Vd. a su libertad y triunfo» (40).

Quizás una de las cosas que más temía el Virrey al separar el mando a Goyeneche era el malestar que podía originar su marcha. Por esta causa procura que su separación aparezca en todo momento como una decisión a que le han obligado las repetidas instancias del general para retirarse a descansar, en vista de su falta de salud para continuar en el mando. Esta misma razón es la que le impulsa a rogarle que continúe en el Ejército hasta que Henestrosa se haya familiarizado con los Jefes y soldados.

La causa del posible descontento es clara y nos la explica el mismo Virrev: a...porque como era hifo de la Patria y había organizado aquellas tropas poniendo a la cabeza de los batallones caballeros de las provincias limítrofes, muy adictos a su persona, en el momento se hubieran disgustados sobremanera, atribuyendo la Providencia a rivalidad por ser americano, y era de esperar tomasen un partido violento... (41). Ciertamerite', la presencia de Goyeneche al frente del Ejército había servido de mucho al Virrey, y en este sentido pecan de alguna exageración sus f:גicios sobre el papel que en dicho puesto desempeñara. La circunstancia que más le favoreció de todas fué la de ser americano, gracias a la cual consiguió reunir alrededor de su persona a una serie de Jefes, oficiales y soldados naturales del pais, que formaron el núcleo del ejército. Abascal estaba convencido de ello y supo aprovecharlo como una de las piezas fundamentales de su juego político. Así nos lo dice de un modo bastante claro: «...tal vez no se hallará ejemplar de que ningún jefe hasta ahora se haya visto en el compromiso en que el general Goyeneche me ha tenido de dos años acá, pues por una parte me era insufrible su petulancia, amor propio, y exaltado engreimiento en que a cada paso tropezaba con faltas de subordinación y un procedimiento arbitrario; pero por la otra me hallaba ligado a acariciarle y conser-

(40) Archs C. Gingui: C. 13. Carp. 5. N. 4. Carta resroada de Abascal a Goyeneche. Lima, 10 de abril de 1813.

(41) Vid. nota 33. 
varle en el mando del Ejército, pues si lo separaba, contemplaba infalible su disolución...» (42).

Esta actitud de Goyeneche, que critica Abascal, no fué más que resultado del viraje de la guerra a partir de mediados del año once. Desde entonces insiste cada vez con más energía en sus solicitudes de refuerzos, y como no puede ser complacido totalmente, se encuentra con cierto derecho a modificar los planes del Virrey. Pensaba que era un general americano y si se habia hecho querer de sus subordinados, se había hecho odioso a todos los pueblos sometidos: no es de extrañar, pues, su preocupación por el final ce la contienda, que había de serle funesto, si por cualquier circunstancia le resultaba adversa. Desde este punto de vista creo que debe explicarse gran parte de la actitud del general.

El Virrey, sin embargo, no podia permitir que se salliese de sus planes. Pero lo que hirió más profundamente su susceptibilidad fué la acusación de abandono y poca preocupación por el Ejército, lanzada contra él. Esto, que podía repercutir sobre su reputación, achacándole negligencia en el desempeño de sus obligaciones, no se lo perdonaba: «Cuando este general no hubiera tomado por fundamento de sus interminables quejas el abandono y falta de auxilios de este Gobierno, dejaría correr sin contradicción la brillantez que atribuye a sus acciones, sus ponderados trabajos y fatigas, y el abultado rlesgo en que suponía al Ejército; ensalzaría su mérito, y lo colmaría de elogios como hasta aquí». Pero Goyeneche, que por sí solo no hubiera podido organizar un ejército, sin armamento, hombres y caudales, habia recibido todo ésto del Virrey. «...de manera que no ha tenido más que presentarse a mandar estos Cuerpos, dándoles a lo más una corta disciplina». (43). El Virrey disminuye ahora la labor de Goyeneche para hacer resaltar la suya propia. En realidad, Goyeneche hizo algo más que disciplinar superficialmente a las tropas. Si la deserción fué un mal constante a lo largo de sus campañas, hay que tener en cuenta que tampoco des-

(42) Vid. nota 33.

(43) ABASCAL. Memoria. Tomo II. Pág. 425. 
apareció más adelante, una vez que ya había abandonado el mando; y este mal no se daba solamente en el campo realista, sino que ocurría de un modo semefante en el patŕtota. Teniendo en cuenta el carácter de la guerra y la calidad de los soldados cabe decir que el ejército formado por Goyeneche, si no ejemplar, fué en todo momento eficierite, y desde luego, superior técnicamente y en dísciplina al de los patriotas. A mi modo de ver, el gran valor de Goyeneche reside; más que en sus vietorias, que nunca demostraron ser producto de un extraordinario genio militar, en la formación de este núcleo de tropas adiestradas a la lucha, y que constituyeron la médura de la reststencia peruana contra la revolución hasta Ayacucho. 


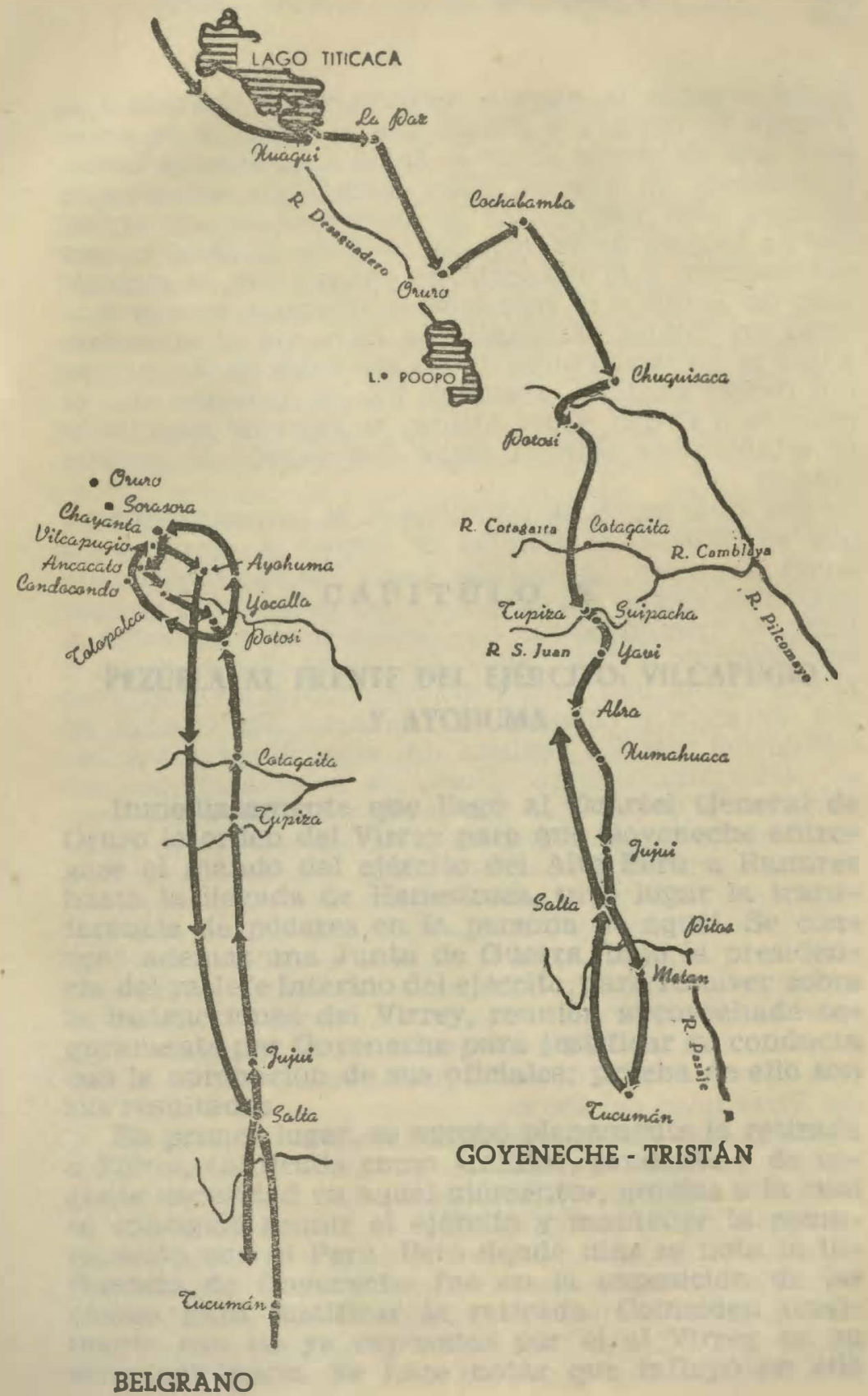





\section{PEZUELA AL FRENTE DEL EJERCITO: VILCAPUGIO Y AYOHUMA}

Inmediatamente que llegó al Cuartel General de Oruro la orden del Virrey para que Goyeneche entregase el mando del ejército del Alto Perú a Ramirez hasta la llegada de Henestrosa, tuvo lugar la transferencia de poderes en la persona de aquél. Se convocó además una Junta de Guerra, bajo la presidencia del ya Jefe interino del ejércitc, para resolver sobre la instrucciones del Virrey, reunión aprovechada seguramente por Goyeneche para Justificar su conducta con la aprobación de sus oficiales; prueba de ello son sus resultados.

En primer lugar, se aprobó plenamente la retirada a Potosi, calificada como «militar, prudente y de urgente necesidad en aquel momentos, gracias a la cual se consiguió reunir el ejército y mantener la comunicación con el Perú. Pero donde más se nota la influencia de Goyeneche fué en la exposición de las causas para Justificar la retirada. Coinciden totalmente con las ya expuestas por él al Virrey en su correspondencia. Se hace notar que influyó en ella 
decisivamente la esquela redactada en francés que Tristán le enviara a Potosí con el aviso de la amenaza que se cernía sobre él si no abandonaba inmediatamente la ciudad. Con semejante advertencia hubiera sido antimilitar la conservación de Potosí por su escasez de fuerzas, la falta de noticias acerca del enemigo y la carencia de datos sobre la guarnición de Jujuy y el repliegue de Picoaga, que se hallaba en Tupiza. Asimismo se hace ver la distancia a que se hallaba Potosí de las ciudades de donde podía recibir auxilios, distancia que se acortaba con la retirada a Oruro, y por último, se pone de manifiesto el estado poco tranquilizador del pueblo de aquella ciudad.

Por otra parte, se patentizaba la imposibilidad en que se hallaba el ejército de tomar la ofensiva en aquel momento. La marcha hacia Potosí era del todo imposible. Según los cáliculbs efectuados sobre el enemigo, se hacían elevar sus fusiles a más de 6.000 , y sus bompres a unos 3:000, de tropas disciplinadas a lo que habia que unir los contingentes de las levas que llevaban a cabo en el Tucumán. En cambio, el estado del ejército realista era lamentable y las deserciones aumentaban; ahora las detenía un poco el amor hroje coyseneche quse sentian sus soldados, pero todb acabaria en el momento on que se dejara trashoir la decisión de marohar hacia el enemigo, ky aun el espeparlos con la actual fuerza con la determinaeich de dar una batalla que decidiese de miestra acturl constituoín, sería aventurarlo tado, y que no curmpllender con sus deberes se verificase ia disolueión de este ejérgito, el sacrificio inútil de sus jefes y demás sufetos de horor que se hallan acogidos a él, y la total pérdiatu do estas provingias, y acaso de las del Virreinato del Perú».

Rodes las anteriores congideraciones persuaden a loo all reunidos a tomar «la prudente y segura resolucion de observar en este punto los movimientos del enomigo, conservanse en reunión mientras que por el Excmo. St. Virroge se provee do tropas de entera confianza y necesapio axmamento... $Y$ en el caso de que los eremigos avancen prevalidos de sus ventajas antos de que-puecian llegart esos refuerzos, se acordará la resolueión. que convenga a 12 seguridad y decoro 
de las armas del Rey..., (1). Es declr, piensan segulr el plan trazado anteriormente por Goyeneche: esperar en Oruro el envio de refuerzos sin atacar al enemigo; y si éste por su parte se lanzaba al ataque antes de que llegasen los auxilios, se adoptarían las medidas del caso, que dejan entrever una retirada, para mantener el decoro de las armas del Rey».

Como se desprende de las decísiones de la Junta, a joesar de la entrega del mando, Góyeneche seguia prácticamente como General en Jefe. El mismo dia de la entrega; los jefes del ojército, enterados de su restgnación del mando en la persona de Rathíréz, le enviaron una petición firmada por fodos ellos en la que le solicitaban continuase de fefe ejército, como efectivamente continuó durante veintisiete dias, hasta su marcha (2).

Ramírez da idea del ambiente que reinaba entonces entre los jefes del ejertito. Un poeo grotescamente reflere el momento en que Gbyeneche recibió la noticia de su separacton. Se hallaban reunidos en tertalta los jefes y ofictales, eltando entró el portador de los pliegos del Virtey. El Geheral los ileyó inmediatamente y «conclurco, difo: búenas tioticias; se paseó ₹ todo fué tan desconcertado que todos conocieron no le había gustado. Llegada la hor a se déspidieron, y deteniendo a los jefes y a $\mathrm{ml}$, nos entramos a lo ulitimo de la casa, sacó su ofieio, lo léý, y sin contestar nada, él solo habló blłśfemias, disparates y delirios: brincó en el aire más de cuatro veces, rompió la faja y se turó de los pelos. Al fín tomó la pluma, hizo su dejación, y anuncio lo que había de procla-

(1) Anets Guaqui, C. 9. Crtp. 5. 19ún. 17. Acta de la Junta celebreda bajo la presidongcia de Ramáres en Qrura, el 25 de abril de 1813. Bajo la piesidencia del Brigadier Ramírez, Jefe intering del Efército def Alto Perú, se reumferon los siguientes jefes:- El Brighadier Prebaga; Conde de Valle Hermose, Audítor Ae Guerra; lof. Dorqneles; Tacón, Lombera, Camparó:Conde de Cafa Real de Moneda, García de Santiago; los Tenientes Coroneles Valdés y Mendizábal, y los jefes de Milicias Carasa, Moya, Bálcome, Vallibián, Revuelta y Estévez. Aunque no figura en el Acta, es de su-

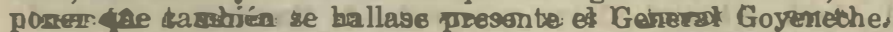

(2) Arch. C. Guaqui. C. 9. Carp. 6. N. 1. Memorial de loger neche a S. M. Quinta de Pacallar, 30 de marzo de 1814 
mar, que en sustancia era alarmar y conmover los corazones con su tierna y artificiosa despedidas (3). A pesar de las posibles exageraciones de Ramírez, indudablemente debió ser un momento de extraordinaria violencia. Según él, todo fué una farsa montada por el General: «Entonces yo-dice Ramírez- acordándome de las instrucciones de V. E., y viendo que había artificio hasta en callar los favoritos, les gané por la mano para rogarle y serenarle, que era lo que queria. Al punto hicieron lo mismo los otros, y se acordó lo que llevó el Correo, con lo que se tranquilizó y se acabó la comedia» (4). Quizás Goyeneche no se esperaba la resolución de la Junta de Guerra celebrada en Lima el $10^{\circ}$ de abril y pensase que el Virrey no iba a atreverse a dar un paso tan decisivo como era su separación, que indudablemente podía traer malas consequencias por las causas indicadas en el capítulo anterior. Por otra parte, le debía resultar bastante doloroso separarse del ejército en las condiciones que lo hacia. corriendo el riesgo de quediar en entredicho ante la Regencia, el Virrey y la oflinión pública. A pesar de sus respetidas instancias de retiro, debió eogerle de sorpresa la rápida condescendencia que para ella mostró ahora la Junta. No es, pues, extraño que en los primeros momentos cediera a su disgusto y se dejara llevar de su genio inspulsiyo, aunque pronto se tranquilizase ante los consejos de Ramirez y los demás jefes.

Pero también debia contribuir a su disgusto, según este último, el engreimiento a que llegó, halagado por una serie de jefes que se habian convertido en sus mayores aduladores: «Tenga V. E. entendido que siempre sucederá lo mismo, porque nunca se hace sino lo que quiere este niño engreído. A V. E. se le aparenta que es más importante en el Ejército que la pólvora, pero éste está lejos ce pensarlo asi, y sólo es artificio de cuatro o seis que sostienen asi su comercio y monopolio, al paso que acechan grados y recomendaciones. Este es un complot cuzqueño, que sólo

(3) Arch. Abescal. Carta reservada de Ramírez a Abascal. Oruro 29 de abril de 1813.

(4) Vidi nota 8. 
videndolo se entiende: $3 n t r e$ ellos anda siempre la máquina .. (5). Es lógico, por otra parte, que los Jéfes, en su mayoria naturales de America, viesen con disgusto la marcha de su genteral, con quien debian estar tastante compenetrados y de quien en su mayor parte habian recibido grandes recompensas. Es natural que a su vez Goyeneche los favoreciera por el hecho de ser paisanos suyos y además por haber aportado al Ejéruto el importante núcleo de sus tropas Indigenas. De aqui resultaba cierto apartamiento de los europeos, con perjuiclo incluso de las órdenes del Niswey de que Ramirez se queja.

Por últindo, trata Ramtrę de la correspondenua que se mantenia con los argentinos, que le hacia sospechar y le llevaba a graves supostciones: «...y lo que es más raro, que en 20 de lebrero, Tristán capitula y Goyeneche pronostica la percuda tal cual ella sucedió. Dios quiera que los pronósticos no se repitan, pues los favoritos andan dicieido que lo que conviene es paces y transacciones; y si se hace Junta, sin duda pronostico yo también que tenemos paces, porque este es un eco de estos congresos cebemonialess.

A partir de la derrota de Salta debió comentarse entre las tropas y los oficiales la idea, por lo dem 4 s no muy nueva, de que era necesario llegar a una paz sí no se recibian refuerzos. Como el general, debian pensar todes; o la inmensa mayoma de los jefes, con lo cual se corria el peligto de que, poco a poco, cundiese el desafliento, y ante la imposibilidad de envíbs immeciatos, se impusiese el partido pacifista. A mi juicio, sin embargo, esta tendencia hacia la paz no quiere decir que los jefes del Ejército se hallasen cansddos de la lucha y dispuestos a acabarla fuese como fuese; que esto es asi, lo prueba el hecho de que, una vez vuelta a empezar algún tiempo más tarde, todos sin Wistinción continuaron batiéndose con el mismo ardor que hasta entonees. Parece que lo que Ramírez quiere avisar al Virrey, es el peligro de que triunfe y se imponga el criterio pacifista de Goyeneche, entre los jefes americanos a sus órdenes.

Altkque se debe tener en cuenta que las relacio-

(5) Vid. nota 3. 
nes entre Ramírez y Goyeneche no eran ded todo cordiales, no resulta extraño pensar que, tento en las decisiones de las Juntas como en las demás cosas, se imponía el criterio de éste, y tampaco es exsgerado suponer, que el manifiesto firmado por los jefes pidiendo la continuación del general duranteri algún tiempo al frente del Ejército; a modo de justificacián de su eonducta, fuese sugericho por el propto general, o bien fuese ideado por sus mejores amigos.

El día 6 de mayo se recibiexon en Oruro las copias de actas de las Juntas de Guerra celebradas en Eima para tratar de la retirada de Gajeneches y otra copiardel oficio de 5 de abrił; en el que se le ordenaba entregar el mando a Ramírez que ya se thabía recibido par extraordidario el 25 de dictho nes. Inmediatamente se reunió una nueva Junta, en la ourd Gro yeneche afirmó que continuaba al frente del Đjérchto por los ruegos de sus subordinados araque astaba dispuesto a ceder definitivamente el mando a su segundo. Pero al reiterársele la orden de entrega ssuplicabas, a los allí reunidos, que consideraran como ineludible la ejecución de dicha orden. A pesar de la resistencia de Ramirez, partidario de que cantinuase en el mando hasta la llegada de Henestrosa, los jefes se mostraron unánimes en efectuar la entrega, con la condición de que se mantuvtese el general con todo su «carácter y distincioness. Goyeneche accedió a la solicitud de los Jefes y prometió, no sólo permanecer en el Cuartel General, sino también exhortar a las tropas a mantener la fidelidad debida hacia su nuevo jefe, e incluso salir al frente del Ejército al encuentro de los enemigos, si se aproximaban.

En este momento cedió la presidencia de la Junte al nuevo general en jefe interino del Ejército, bajo cuya dirección se diseutieron dos puntos tratados en la de 8 de abril en Lima. En realidad, los resultadas de esta Junta son en todo semejantes a los de la celen brada en Oruro el 25, Se vuelve a insistir en la necesidad de abandono de Potosi, basado, como la otra vez se hizo, en los avisos de Tristán, la poca fuerza de la plana y el aspecto poco tranquilizador de la misma. En la mañana del día de la evacuación se advirtieron indicios de que ciertos elementos intentaban conmover al pueblo, cuyo ánimo se exaltaba a medida 
que atafizabá la conspiractór, detenida gracias a la entetgle del generat. Obligados por tal circunstanclit, cuvieton que evacuar la ciludad antes de lo displiestio, a pesar de to cual se inslste en que aún tuvo tiempo para Hacetlo con orden $\mathrm{y}$ para que se incorporisen al Ejeréito los particulares que lo desearan.

in suanto al armisticio - otro de los puntos tratados en la Junta de Limá-, manifestaron la opinión ce se llevo a efecto a consecuencia de las noticias de 1 istén; en manera alguna se adoptó para entrar en négoclaeiones, sino para detener la marcha del eqenirgo y tener tiempo para la reunión del Ejército, él avregli de su zartimento, y, sobre todo, para recibir del virrey las instrucciones necesarias y obrar en consecuencia:

Uná vez más piden también en la Junta que se haga ver al Virrey la necesidad del envio de refuerzos, por las noticias que se tenian del enemigo, cuyas fuerzas iban en aumento. Por todo esto se consideraba antimilitaf e impracticable cualquler intento de salir a hacer frente al enemigo en aquellas clrcunstaneias. Firialmente, y en refuerzo de la anterior opinfót, se intentaba destruir la creencia errónea del Virrey de que existiesé stipterioridad en fusiles de los realistas sobre sus eniemigos, con lo cual terminó la Junta (6).

Claramente se puede ver en está reunión de jefes del Eijército cómo se séguía imponiendo el criterio de thy theche. Ahora bien, si tanto las conclusiones de la Junta de 25 de abril como de la del 6 de mayo, celebradas en Oraro, eran una maniobra para obligar al Virrey a que continuase Goyeneche al frente del Ejército y quiuedara a sálvo su responsabllidad, ciertamente que no lograron su objetivo.

(6) Areh. C. Gmagry C. 9. Carp. 5. N. 18. Acta de la Junta celebrada bajp la presidencia de Ramirez en Oruro, el día 6 de mayo de 1813. Eistuvieron preséntes en élla, además de Ramfrez y el General Goyerieche, el Brigadíer Pieoag'd; el Auditor de Guerra, Condé de esllt Hermoso; Corotreles Camperv; Lombera, Conde de Casa Roal de Moneda y Ganór dé Santiago; el 'Intendento del Ejército del Alta Perú don Antamia do Zupjiagai los Tenientes Coroneles Fáldẻs y MTendizábal, y los jefés de Milicias Cazasas, Bálcome, Urbina; Rertedta, Vallibian, Moya, Benavente, Estévez, Zabala g Mendiżáball. 
En Lima se habia decretado la sustitución de Goyenectie por Henestrosa, y Abascal debia estar dispuesto a que aquél no continuara en el mando, temeroso de un total fracaso. Y en esta opinión habian de reafirmarlo las noticias confidenciales que recibia por İanure,z, que cada vez ip inclinaban mas on cuntra del general.

Así, al recibirse en Lima el acta de la Junta celebrada en Oruro el 25 de abril, que encerraba una repulsa al criterio y a las instrucciones del Virrey, reunlo inmediatamente a su vez una nueva Junta: En ella se debió tratar con toda minuciosidad el problema de la separacion de Gopreneche. Par una parte se piceseontó el acta de la Junta de Qruro, en la que los dieciséis individuos que la componian se mostraban en un todo conformes con la actuación del general: acemás, se layó una reprasentación de los mismos individuos en la que hacian yer las graves consecuenciass que sobrevendrian del cambio de jefe; otra del Mayor General Tacun, y los comandantes de Ingenieros y Artillexía don Francisca Mendizábal y don Casimuira Valdés, en donde, en términos semejantes a la anterrior, juzgaban inevitable la disolución del Ejér Gito si se seppraba a Gryenphe. Frente a todos estos argymentas se lesó un oficio del propia Goyeneche, en el que insistia de nuevo en su retiro, $\$$ alegaba su estado de debilidad fásica como abstáculo insuperable para poder continuar en el Ejército, y junțo con èl una carta confidencial en la que reiteraba el misno deseo.

Ante argumentos tan contradictorios, Abascal pudo pensar que se trataba de una maniobra para justificar a Ģoyeneche; pero con lo que no podia transigir. su carácter era con el resultado de la Junta celebrada en Oruro. Así, pues, examinados todos los hechos, como va se habia determinado la separación del General, "por exigiflo asi la huthanidad y.el interés del setrulcio en conservar la salud de nuestro jefes, se râsolvíó esperar su contestación al oficio del día 10 de abril, en que se le comunicaba dicha medida. Se pensaba que al celebrarse la Junta el 25 en Oruro, podin no kaber llęgađo aưn el oficio del Virrey en el que cepsurána la rápida evíciractón de la cłpdad, el abandono de la plata de las Cajas Reales, la voladura 
de las municiones; y la reproghaba que por eumDlir la oapitulación de Triştán, iba a perder los frutos de tres años de lucha y tres millones de pesos gastados, a la par que le advertia la próxima marcha de Henestrosa para ponerse al frente del Ejército (7).

En espera de la contestación de Goyeneche, aunque reafirmándose en la decisión tomada anteriormente, se concluyó la Junta (8). Pero la contestación al oficio del Virrey y el acta de la Junta celebrada, en Oruro el 6 de mayo llegaron doce días después a Lima. Los resultados de esta Junta se han examinado más axtiba, y a su acta venia unido un oficio de Goyenethe acompañada de una certificación de su estado de salud firmada por siete médicos y una carta confidencial dirigida al Virrey, en la que le comunicaba que padecia un ataque de nervios, por cuya razón se veía obligado a guardar cama y, a entregar el mando a Ramírez.

Con objeto de examinar tales documentos, convocó Abascal una Junta de Guerra el día 25 de mayo. Con gran asambro del Viffey se debió examinar el acta de la Junta de Oruro del 6 de mayo. Una vez más insistían las allí reunidos en el acierto de la retipada, fundada en la esquela de Tristán, razones que al Vịrrey parecian sialen débiles e insuficiantes para haber tomado aquel partido, cuyas consecuencias pueden y deben ser funestass. Manifipsta asimismo el Virrey que los datos en que se fundaba la Junta de Orura para justificar su dictamen no eran los que reflejaban los estados de fuerzas remitidos por el General. En tin todo venía a demostrar a los ojos del Virrey la equitocación en que habían incurrido los Jefos del ejérclto al dar su asentimiento a los planes de Goyeneche, pues los enemigos,

(7) Arch. C. Guagui. C. 13. Carp. 5. N. 4, Oficio de Abascal a Goyeneche. Eima, 10 de abril de 1813. Más adelante, en su ya citado Memorials de 30 de marzo de 1814, Goyeneche calificaba de falsa la acusación de Abascal de haber dejado abandozados en las Cajas de Potosí 60.000 pesos.

(8) Aroh. C. Guaqui. C. 3. Garp. 14. N. 21. Acta de la Junta celebrada en Lima 12 de mayo de 1818. Presididos por el Virrey, se reunieron Henestrasa, Molina, Cucalón, don Joaquín de Alos, Gaisza, don Pedro Molina, Oonandante del Guerpo de Ingenieros; Osorio, y don Pascual de، Virezo. 
debieron pesader mudhìgente en la batàlla de Saltắ, * para recuperarse tendrian que saearla del Tuct-

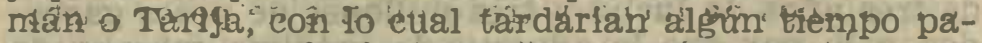
ra ponerla en eśtado de luchar, kreflexiones que no han hecho Ids's vécalés de la Junta».

- El resultado de la Junta de Lima es análogo al de las antériories. En vista de la aetittad de los Jefes del Ejértêtc, se decidé äplazar toda resoluclón hasta que E1 nuevo Genetal en Jefe se haga cargo del mismo. For eso, los teisistentés se linitiaba a dar las graeias

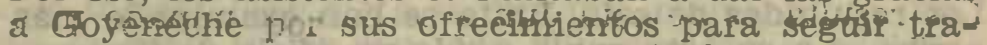
bajarido por la causa del Rey, y'a ordenar se le diesen itsprucelones con la mayor mitruclosidad y brevedad" ar Brigbaler dón Jợưứn de la Pézièla designado últhromérite como jefe del ejêrcíto del Alto Perú en lugdr de Fenestrósa" (\$).

En la Juntà teunida en Lima el 8 de abril fué elegido para jefe del ejército el teniente general don Jún de Heliestrósá, que a lá zazón se hallaba en

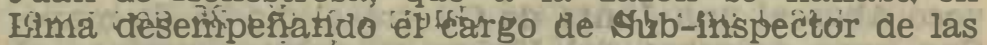
fuerzás del Virtefithato. Era por entonces uno de los milititares de 'mảs alt'a graduádón' que tenía a sus ór-

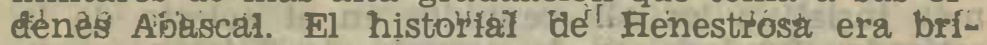
Hante. Habia infervelaldo con gran fortun en la guerta té la hrodétendencia Española, en donde ría bfá tomala párté en las batallas de Medellín y. Tala

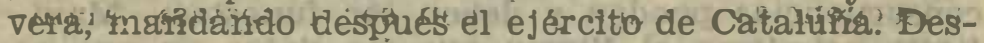
de 1812 tleséńpeñaba el cargo que ocưpaba al ser nonibiado General en Jefé del ejerctio del Alto Péril, y el mismo día que recibió la aectsión de la Junta', acéptó su nuevo éŕnpléo (10).

Comenzados los pregarativos para el embarque de las tropás que habia 'de' lievar consigo, \ recibidas del Virrey las instrucciónes y noticias necesarias para el desempeño de sus funciones, le dió a conocer Henestrosa su pensamiento de no abandonar el anterlor cargo de sub-iníspector que hasta entonces ocu-

atrir (9) Aroh. Aboiscal. Colpia de Actá de la Junta de Guerra celebrula en Lima el 25 de mayo de 1813. Compusionan esta Juinta las zhisnios voeater que la del 12 de dicho mes.

(10) Aroh. Abuscal. Oficios de Abascal a Henestrosa y contestación de éste. Lima, 8 de abril de 1813. 
para, y que pensaba continuar desempeñanda desde el punto en que se situaso en el Auto Pari. Inmedja tamente surgió la oposición del Virrey. Le pusa de manifiesto las dificultades gue supondrian para el desempeño de su cargo el alejaniento de Lima, ż nor otra parte, le parecía totalknenta imposible simultanear esta función con la de jefe del ojéfeitą Alegaba además Alaascal la práptica observada hasta entont ces en casos semedantes, segúp la cus I asimia para sì el cargo de Subinspector y dejoba unicansonte en manos del Geperad da Subinspección de das provin-

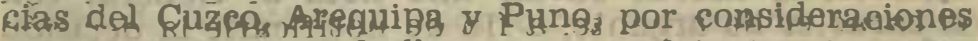
a su persona y por hadlarse cerfa del toatigo de la lucha (11). Р РБо había otka razba de gran peqQ para que el Virrey no atitorizara la preteenoión de Henes+ trosa, y era que al dejaf eomisionado en bima a un aficial con la misión de enyiar los asuntos y las fir-

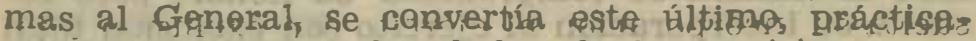
mente, en mero refrendador de las deqisiones quie

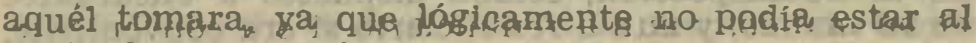
tanto de los negocios,

Aun asi insistía Henestrasa en aantimpar. con la Subinspección, a do que una ver más se pegó retundamente el Virrey. Se le indicó el día 22 de abril parra su salida hacia el Alto P,exú, con las instrucoiones convenientes al efecta. Caso de que Goyeneche hubiese continuado su retirada hasta el Despgy dero. se le ordenaba defender a toda costa dicho punto. En kaso contrario debia aqquirir los datos necesarios y, una vez estudiados, emprender la ofensiva, ai así lo jug gaba conwaniente, para a rojar al enemigo hasta Jujuy. o bien manteneres a la defensiva si lo estimaba oportuno, Tonavia más adelante do indicaba que señatass un jefe para hacerse qafge do la Subinspección durante el tiempo de su estancia en el ejército, a lo cual respondió Henestrosa nombrando al propio Virrey, para demostrarle que no le causaba el menor recelo verl'o desempeñando el eargo que le correspondía a él (12).

(11) Arech Ahrasear. Corpia dey, Qficio de Henestrosa al Virfey. Lima, is de abril de 1813, Contestación del Viarer. Irimax.20 de abril de 1813.

(12) Arch. Abascal. Copia de Oficio de Abascal a Henegtrosa. 
Semefante contestación hizo subir de punito la indignación de Abascal, que inmediatamente reunió una Junta de Guerra para tratar de la conducta del General. Examinadas todas las comunicaciones cursadas entre Henestrosa y el Virrey, y la actitud de aquẻl, se resolvió que pasase enseguida a tomar el mando del ejertito, sin la Subinspección siquiera del Curco, Arequipa y Puno. Y con objeto de dar un final rápido a una situación que amenazaba prolongarse frdelinflamente con el consiguiente đaño para el efertuito, se acordó enviar una nota al General con el caradter de urgente, a fin de notificarle la decisión de la Junza, exigiéndole un inme dista respuesta, ya que continuaba reưnida hasta saber su resolución. La respuesta de Henestrosa manifiesta claramente su quego. Decía que al Instársele a una rápida contestaclón se trataba de comprometer su honor; pero restuita su incorporación al ejército con exclusión total de la Srubinspección, estaba đispuresto a encargarse te su mando, y aun a renunciarlo si era conveniente, - pero haciendo siempre responsable a la Junta de esta tropelia nunca vista» (13).

Examinada la contestación, se resolvió por los ctrctunstantes sustituir a Ienestrosa por Pezuela en el mando cel ejército. El nuevo General en Jefe salió el 29 de abril con rumbo al puerto de Qullca, en la fragata Caritabria» (14).

En realidad, resulta extraña la actitud de Henestrosa firente a las repetidas órdenes del Virrey. No parece adecuada otra explicactón que la de su poco iriterés en marchar a ponerse al frente del ejéreito, de cuvas vicisitudes no podria hacerse responsable sin los auxilios que Juzgaba necesarios. A todas sus dificultades se procuró hallar solución, «allanándole

Linea, 20 de abril de 1813. Oficio de Henestrosa a Abroseal, 23 de abril de 1813.

(13) Arch. Abascal. Copia de Oficio de Henestrosa al Virrey. Lima, 24 de abril de 1813.

(14) Arch. Abascal. Copia de Acta de la Junta de Guerra celebradé en Litna el 24 de abril de 1818. Asistierun a ella el Pirrey, don Joaquín Molina, el Conde del Valle de Oselle; Cucalón, AK6s, Pezuela, Gaínza, Molina, Osorio, y el Comandante del A postadevo de Evurine. 
documentos, noticias $y$ aun dinero, que era 10 más daflcultoso, excusando reflexionàr sobre muchas de las necesidades que aparentaba, dándoles un aịre dé grávedad y de importancla que no merecian: s (15). Pero ciertamente, el Virrey tenía raźon al pretender desglosar los dos cargos que queria reunir en su persona el General.

Encargado interinamente del mando el general Ramirez, se puso al frente del ejército en un momento difícil. Dos peligros graves se oponian a su labor. Por un lado la deserción constante entre las tropas, cada vez más extendida a medida que se alargaba el periodo de inactividad; por otro, el partido formado por los jefes y oficiales adictos a la persona de Goyeneche, que introducian la indisciplina amenazaban con disolver el ejército. A ambas dilicultades hizo frente el General, dedicado preferentemente a su resolución, más que a efectuar una acción sèria contra el enemígo.

Con objeto de evitar la escisión entre los jéles, que necesariamente se derivaria de la retirada de Goyeneoné, procutó Ramírez retardarlá lo más posible. De ahí su resistencia a tomar el miando en las Juntas de Guerrá celebradas en Orưo, a pesar del interés de aquél en éntregárselo. Preferia ganar tiempo hasta la llegata de Pezuela, qué soluctonase todos los problemas peridientes, porque las diferencias entre los Jefes se traducian en malestar en la tropa; lo cual, uni a a las deserciones, aumentadas desde la evacuación de Potosí, condúciria fatalmente al desastre.

No son, pues, de extrañar las quejas de Ramirez sóbre álgunos oficiales que, desde el momento de la eftrega del mando, se dedicaban a sembrar el malestar y el descontento entre los soldados; y respecto a los cuales se hallaba imposibilitado de tomar medida enérrgica alguna para hacerlos entrar en orden. Lo que ocurrió poco deșpués era ineyitable, con motivo del estado de ánimo de la tropa, y creó una situación de tírantez, resuelta gracias a la actitud. de Goỳeneche.

In la mañana del día 10 de mayo, cuando la tropa

(15) ABASCAL. Memória. Tòmo II. Pags. 429-430. 
del batallón de Ricoaga, compuesto en su mayoria de cuzqueños, muy adictos a la persona de su General, volvía de sus acostumbrados ejercicios, se extendió el rumor de que éste había abandonado la ciudad al entregar el mando del ejército. Como una avalancha se dirigieron todos los soldados por las calles de Oruro hacia la casa en que habitaba Goyeneche, al paso que manifestaban su descontento y aseguraban se marcharian todos a sus casas si era cierto el rumor. Daba la casualidad que el General hahia salid.o de paseo, por lo que estuvieron esperándolo durante tres cuartos de hora para verle al regreso; mas, en vista de que no volvía, y convencidas por las razones del ayudante de Picoaga, se restituyeron pacífieamente a sus cuarteles.

La actitud tumultuosa de las tropas cuzqueñas era indudablemente un infracción manifiesta de la disciplina militar; pero más interesante es el hecho de que nos deja ver claramente el peligro que encerraba la situación, conjurado momentáneamente gracias a Goyeneche. Cuando el General regresó a su casa y tuvo noticias de lo ocurrido, reunió a las jefes y afeó la conducta de la tropa y la de los oficiales, que no la detuvieron al ir a realizar tales actos. Inmediatamente publicó una proclama en la que incitaba a la obediencia a su sucesor, y mientras éste se hacía eargo del mando a la persona de Ramírez (16); 10 cual, unido a la actitud del jefe de las fuerzas; $\mathbf{P}_{\mathbf{i}}$ coaga, hizo calmar los ánimos y restablecer el ordęn, a pesar de lo cual Ramírez ofreció el pasaporte para sus casas a todos aquellos que no quisiesen seguir bajo sus órdenes (17). Conocido el hecho por el V1rrey, publicó a su vez otra proclama alentando a las tropas (18).

(16) Arch Abuscal. Copia de una Proclama de Goyeneche al Ejércitó. Oruto, 12 de mago de 1813.

(17) Azrh. Abascal. Copia de Informe de Ramirez al Marqués de la Conoordia! Guartel General de Oruro, 13 de mayo de 1818. Copia de Informe de don Manuel de Helguero al Virrey del Perá, Oruro, 13 de mayo de 1813 (Helguero ora Capitán y habia sído érviato al tyjército por Abascal con la misión de informarle sobre su situación).

(18) Arch. Abascal. Copia de una Proclama del Marqués de laConcordia al Ejército del Alto Perú. Lima, 9 de junio de 1813. 
En estas condiciones, no es de extrañar que Ramirez no quisiera aventurarse a librar una batalla con el enemigo, cuyos resultados, en el mejor de los casos, serían inciertos. Se mantenia en observación de sus movimientos, a la par que procuraba mantener el orden en sus tropas.

En cuanto a la desereión, aumentaba por momentos, de tal modo, que Ramírez opinaba se debian separar a los principales agentes de insidias de que se hallaba dotado el ejército, que no hacian sino rebajar la moral de la tropa y abatirle el ánimo.

Aún tuvo lugar otro hecho que pudo complicar más las cosas. En la madrugada del 22 de mayo, Goyeneche salió ocultamente de Oruro acompañado de algunos jefes, entre ellos los coroneles Conde de Casa Real y García Santiago. Tan inesperada marcha, después de haber prometido permanecer en el Cuartel General hasta la llegada de Pezuela, cogló de sorpresa a Ramírez, que temió fuese a tener alguna repercusión en la tropa, cuyo estado de ánimo se ha visto anteriormente. Por todos los medios políticos y de habilidad intentó atraerse a los soldados y a sus jefes, a pesar de lo cual decía al Virrey: «...no puedo asegurar a V. E. el haberlo conseguido. La simulada conducta de unos pocos de los primeros y segundos (se refiere a los jefes y oficiales) me envía fundadas sospechas de que, olvidados de los sentimientos de gratitud al Rey y al Estado, que los ha condecorado y mantenido en abundancia, instigan secretamente a la disolución de estas tropas, inspirándolas temor y desconfianza en la continuación de sus deberes» (19). El Virrey le indicaba la conveniencia de separarlos del ejército con cualquier pretexto y enviarlos destinados a comtsiones en puntos donde no pudiesen promover la intranquilidad de la tropa, a pesar de lo cual Ramírez prefirió aguardar a lá llegada de Pezuela para decidir sobre tales sujetos.

Ante la noticia de la entrada en Potosi de DíazVélez con 500 hombres, avanzó tres Compañías sobre

(19) Arch. Abascal. Copia de Informe reservado de Ramírez a Abreceall Cuartel General de Oruro, 29 de mayo de 1813. Contestación reservada de Abascal. Lima, 26 de junio de 1813. 
el camino de dicha ciudad, con el fin de observar sus movimientos. Pero en atención a las circunstancias en. que se hallabs, ell ejéxcito, no ereyó conveniente iniciar ninguna operación. Así se lo hacia saber también el Virrey a Rawirez. Puesto que habia pasado el momento oportuno de iniciar un atraque para recuperar Potosi antes de que Belgrano se hubiese posesionada de ella, lo que convenía era mantenerse a la defensiva con las avanzadas que había cobocada. Así debia continuar hasta la llegada de Pezuela con los refuerzos de que era partador (20).

Ramírez habia organizado ya su dispositivo de defensa. El 5 de mayo salía de Oruro hacia el pueblo de sorasora el Brigadier Picoaga con un batallón y el nombramiento de jefe de la vanguardia acogiendin bajo sus órdenes a las avanzadas que, al mandoidel teniente coronel don Pedro Antonio do Olañeta, se haltaban situadas en el pueblo de Condoconda, a 35 legizo: de Orarp en dirección a Potosí.

- ilas fines perseguia Ramírea al jlevar a cabo dicho movimiento. En primer lugar, sorecaver cualquier ińtento de sorpresa por parte del enemigo, y. en segundo tominoryy ésto era para él tał importante o más que lo primero-observar la reacción do dos soldados.

En vista del buen resultado canseguido y de que sus recelas no se viefon justlficados, dispuso que a Picoaga aiguiese el teniente coronel Estévez; que marché a situarse en Venta y Media, cinco leguas adelante de Sorasora, y por último, el coronel Lombera se unió con sus fuerzas a las de Picoaga. Preparado de este modo el dispositivo, el mismo Ramírez proyectaba abandonar Oruro y trasladarse también a spragora, dejando en la capital al coronel don Joaquin Reyuelta.

- Fl trastado del Cuartel General favorecía el deseo de Ramírez de sacar a la tropa de un modo definitiyo de Orum, en donde necesariamente habrian de encontrax más motivos de xalajación que en el pequeño pue- 
blo de Sorasora. Aqui, al tenerla más concentrada $y$ menos expuesta a la indisciplina, pensaba aprovechar también la primera ocasión que so le presentase, caso de que los enemigos continuaran su avance, para dar una acción que pudiera resultarle ventajosa y elevar el espiritu de sus decaídas tropas (21).

Poco desppués, el 9 de junio, recibía noticias de que los enemigos avanzaban más allá de Potosí en dirección a Condocondo. Inmediatamente ordenó a Olañeta que reuniese todas las avanzadas y se replegase a Poñas, a diez leguas de distancia de Venta y Media, para establecer una comunicación más directa con Estévez. Caso de adquirir informes de que avanzase el enemigo con gran superioridad ce fuerzas; debía continuar su repliegue hasta unirse con éstoj si por el contrario, se presentaba en inferioridad numérica y habia posibilidad de intenter un ataque ferliz, debia lleyarlo a caloo.

Colocadas así sus tropas J;aprobada la disposicion por el Virrey ante las balagîñas. notileias llegadas al Cuartel Gerzeral sobre la situación de los enemigos, estacionados en Potosi, con sus azanzadas en vtlcapusio: y Ancacato, tras una deliberación en Junta de Guerra celebrada el 12 de mayo, Olañeta avanzó en dirección a aquella ciudad. Al llegar al pueblo de Challapata encontró un corto número de argentinos, que fueron dispersados fácilmente. Para su persecución destacó una partida hasta el pueblo de Ancacato. Pero a dos leguas de dicho pueblo encontraron una avanzada enemiga y allí hubieron de sostenerse hasta la llegada de refuerzos a las órdenes del capitán Marquiegui. Conducidos por Olañeta, tomaron la contraofensiva y los arrojaron hasta la Angostura, en donde hicieron fracasar un intento enemigo de emboscada que tenia dispuesta una columna de Infanteria. A pesar de ello $\$$ ante el temor de que se rehicieran, Olañeta juzgó más oportuno emprender la retirada. Que dicha, decisión fué acertadí lo prueba el hecho de que, comenzada la marcha por los realistas, fueron

(21) Arehti Abascal. Copia de Oficio de Ramirez al Marqués de la Concordia Cpartél Genoral de Qruro, 13 de junio de 1813. 
hostilizados y perseguidos por los argentinos hasta Huancani (22).

El dia 22 de Junfo salía Ramirez de Sorasora con sus fuerzas, tras las de Picoaga, que lo hicieron el día anterior, en dirección a Challapata, con un total de fuerzas de 3.146 hombres. Sin embargo, Abascal se mostraba partidario de colocarse en una situación ventajasa y esperar alli la llegada de Pezúela, quien con los refuerzos aseguraria la victoria, indecisa de otro modo, ya que no se poseían unas noticias exactas sobre la situación ni el número de los enemigos. A este fin continuó Ramirez sus marchas hasta el pueblo de Condocondo. Como a su llegada aqui encontrase inexactos algunos de los informes que habia recibido, decidió no continuar su avance para no arriesgar la tropa al saber que el camino seguido hasta entonces, la rata del Despoblado, se convertía en un terreno quebrado y árido en las inmediaciones de Potooi, sin viveres ni forrajes. Prefirio permanecer alli para tomar noticias ciertas sobre los porten̆os, a la par que se aseguraba del camino a seguir en el momento oportuno.

Evacuado todo el territorio por los argentinos, que se habian retirado a Potosi, colocó Ramirez sus avanzadas en Torapalca y Vilcapugio, y avanzó en sus descubiertas hasta Lagunilla, a veinte leguas de aquella ciudad. (23). En esta situación esperaba la incorporación de Pezuela, aunque poco después se vió obligado a retirarse a Challapata por la falta de viveres y forrajes.

El viaje de Pezuela sufrió varios retrasos debidos a diferentes circunstancias. A fines de abril se embarcó en el Callao con 270 hombres de tropa veterana de Lima, que iban de refuerso al Alto Perú. Llegó al Puerto de Quilca a los cuarenta y dos dias de navegación, đespués de una penosa travesía. Durante el recorrido hizo escala en Arica, donde entró en contacto con algunos de los jefes acógidos a la capitula-

(22) Arch. Abascal. Copia de Parte de Olañeta a Ramírez. Huancani, 20 de junio de 1813.

(23) Arch. A úascal. Copia de Parte de Ramirez a Abascal. Cuártel "General de Condocondo, 11 de juljo de 1818. 
ción de Salta, que se hallaban allí y habian comprometido su palabra de no empuñar de nuevo las armas contra los argentinos. En un principio parecian todos dispuestos a embarcarse con el General para volver al frente y alegaban que si se acogieron a la capítulación fué por el mal trato y despreçio sufrido. Pero es lo cierto que a última hora fallaron las negociaciones y solamente se le incorporaron dos oficiales.

Desde Quilca se dirigió Pezuela a Arequipa, en donde recibió urgentes avisos de Ramirez, para que acelerase la marcha y se incorporase pronto al Ejército. Pero aún hubo de detenerse para esperar a las tropas que se le habian de reunir aquí. De Arequipa marchó hacia el Desaguadero con objeto de revistar las guarniciones de esta región y allegar recursos y tropas para el Ejército combatiente. Sin embargo, se vió entorpecida la marcha por las constantes deserciones que experimentaban las tropas que llevaba consigo.

En el Desaguadero pudo comprobar el poco espiritu de la guarnición, integrada por soldados \&uramentados» en Salta, que desertaban constantemente o pedían el retiro a sus casas. En vista de lo cual dispuso su relevo por tropas venidas de las provincias de Puno, y envió a aquéllos a La Paz, de donde sacó nuevos hombres para el Ejército.

El día 27 de julio llegó Pezuela a Oruro, anticipándose a las tropas que le acompañaban. El primero de los problemas que se le plantearon fué el de la carencia de víveres para el Ejércita, que había influído notablemente en la retirada de Ramírez desde Condocondo a Challapsta. Para remediar tan delicada cuestión ordenó que se hiciese un constante envio de víveres desde La.Paz, Puno y todos los contornos, ya que no habia. medio de acudir a la fértil provincia de Cochapamba, sublevada por tercera vez, y con la que estaban cortadas las comunicaciones:

El otro aspectp de la Labor de Pezuela en Oruro es el de la reforma y reorganización del Ejército. La retirada del Tucumán y la evacuación de Potosí dejaron honda huella en las tropas. A esto vino a unirse la marcha de Goyeneche, con todas las circunstancias de que se rodeó. Todo ello se tradujo en una gran desmoralización del ejército, con el consiguiente re- 
lafamiento de la disclplina y el aumento de las deserciones. Para este tipo de ejército, la deserción era uno de los males endẻmicos, y el largo periodo de inactividad en las poblaciones del Alto Perú habila de serle fatal. He aquí lo que Ramirez habla intentado evitar al iniciar la marcha tan pronto como le fué posible.

Al examinar Pezuela la situación militar, observaba que presentaba un aspeeto nada satisfactorio. A su modo de ver, se había perdido la ocasion de recuperar Potosí, que hubiera sido un gran impulso moral y material para las tropas. Según su punto de vista, si se hubiera atacado la ciudad un mes antes de su llegada, tal vez no hubiera podido resistir. Pero Ramírez había dejado pasar el momento y las cosas habian variádo ya. Los enemigos aumentaron sus fuerzas a medida que disminuian las realistas, y la déserción era prueba además de que existía una gran tibieza en sus filas y un buen número de agitadores. Todos estos males no se pudieron subsanar porque aún existian los roces originados entre los jefes a consecuencia de la retirada de Goyeneche,

Era préciso vencer todos los obstáculos antes de decidirse a una acción de envergadúra contra los argentinos. En primer lugar habia de tratarse el punto fundamental del aumento de tropas. Ya se hạn visto más arriba las dificuitades con que tropezó Pezuela al intentar reunir genté en su camino hacla Oruro. En total pénsaba ineorporar al ejército del Alto Perí un contitigente de 600 hombres $y$ su corresporidiente artilleria. Juntamente con ellos llevaba más de 50.000 pesos sacados de los ingresos de la deuda pública para costear sus necesidades (24). Pero de la tropa que sacó de Lima, en total 270 hombires, solo le quedaban al llegar a La Paz 150; de aquil sacó 300, de los que apenas llegaron la mitad, y de Oruro solo pensaba conseguir unos 100. De tal forma, el total de hombres que incorporó al ejércitö apenas igualaría al que sacó de Lima. Agregado tan pequeño refuerzo a las tropas existentes, sumaríar, según los cálculos de Pe-

Al24) Arín. Abdiscal. Copia de Oficio de Pezuela a Abascal. Désagtradérb, 11 de Julio de'Y813: 
zuela, un total de poco más de 3.000 hombres, con lo cual quedaba aún con menos fuerzas que los enemigos, cuyo número se calculaba como mínimo en 4.500 . Según un estado de la fuerza existente en el Cuartel General el día 26 de julio, ascendía el ejército a un total de 3.157 hombres entre infanteria, caballería y artilleria(25).

Aun la inferiorilad numérica frente al enemigo hubiese causado poco cuidado a Pezuela si sus tropas se hubieran hallado siquiera con un mediano entusiasmo. Pero la situación ora muy diferente a lo que deseaba el General. Sin embargo, se hallaba dispuesto a remediarla, y como se hacía necesario preparar al ejército para la lucha, se propuso emplear todo el vigor de los castigos contra aquellos que intentasen perturbar el orden y la disciplina. Era el remedio más eficaz, aunque desagradable, que pensaba utilizar para salvarlo (26).

He dicho más atrás que, al poco tiempo de haberse situada en Condocondo, con sus avanzadas en Toropalea y Vilcapugio, Ramírez se vió obligado a evacuar dichos puntos y situó su Cuartel General en Challapata. A Pezuela le causaba extrañeza que el entonces jefe del ejército hubiese dejado pasar la ocasión de reconquistar Potosí, y mucho más le extrañaba el repliegue a Challatapa. Pero Ramírez -lo aclaraba convenientemente con una razón fundamental, que es la cifra de toda su actitud durante el tiempo que ostentó el mando: su objeto no habia sido *otro que el de conservar este resto del ejército, único apoyo de la seguridad y defensa de la América (27). Con tal argumento se encuentra aclarada su actuación, y si a ello unimos las circunstancias que lo rodearon, nos explicamos perfectamente sus decisiones.

Hay que tener presente que Ramirez estaba dis-

(254) Arch. A,bascal: Estado de fuerzas del Ejéreito Nacional del Pexí, reunido en el Cuartel Generals, Cuartel General de Challapata, 26 de jullo de 1813.

(26) Arch. A bascal. Copia de informe de Pezuela al Marqués de la Concordia. Oruro, 28 de julio de 1813.

(23) Arch. Abascab. Copia de carta de Ramírez a Pezuela. Cuartel General de Condocondo, 15 de julia de 1813. 
puesto por encima de todo, a mantener el decoro y el honor de las armas que mandaba; he aqui por qué evacuó Oruro; como he dicho antes; y se decidió a cortar todo atisbo de insubordinación. Pero la marcha hasta Potosí no era posible por la cisminución que sufría el ejército y las pocas posibilidades que of recía el camino del Despoblado, por donde se dirigia; $y$ además, la entrada \& la oluad era difícil a causa de los desfiladeros $y$ el terreno quebrado que la rodeaban. Por esta razón y tras la deliberación de una Junta de Guertra, se situó en Condocondo. Colocado aqui pensaiba que, con la pronta incorporación de Pezuela y con su corrsejo, pouría encontrarse una solución. Pero como Pezuela retrasase su llegada, se hizo sentir la falta de viveres para los hombres y de forraje para el ganado, que le obligó a retirarse hasta Challapata, como asi mismo hubo de retirar sus avanzadas de Toropalca y Vilcapugio hasta Ancacato, a causa de las enfermedades que en ellas: empezaron a manifestarse. También contriburyeron al repliegue de Ramirez, las notícias que llegaron a Oruro sobre las actividades de los sublevados đe Cỏchiabamba. Lögicamente, por su posicion, está provincia limitrofe con la de Chayantá y 'él libre comunicación con ella constituia en todo momento un peligro para la retaguardia del ejetcito, que podia verse amenazado y coftadas sus comunieaciones. $Y$ precismente poco tiempo después llegaban noticias a Oruro, desmentidas más tarde, de que los cochabamłrios se encaminaban hacla dicha ciudad con objeto de asediarla, lo cual hizo precipitar la marcha de Ramirez hacia Challapata, para estar más cerca de aquélla y prevenir cualquier contingencia (28).

Indudablemente, como decia Pezuela, habia pasado el momento de tomar Potosi, pues entretanto, Belgratio habia llegado con nuevas fuerzas a la ciudad; pero la conducta de Ramirez es perfectamente explicable. En su calidad de Jefe interino del ejército preferia entregar a Pezuela un núcleo de tropas saneado, a lanzarse a una ofensiva cuyos resultados

Misus8) Aron. Abascal. Copia de Oficio de Ramirez a Abascal. Cuartel General de CHallapata; 26 de julio de 1813. 
eran dudpsos. Y como no cabe pensar que hiciera ésto por falta de valor, conocida su actuación anterior, pueden muy bien aceptarse sus razones.

Taxapoco el mismo Vixrey era muy partidario de lanzarse \& la ventura sin suficientes probabilidades de éxito. Según noticias llegadas de Lima en la Gacétar se preparaba en Cádiz la salida de una expedición de 4.000 hombres con destino a Montevideo, fijada para fines de marzo o principios de abril. Esta cra, la. for en esperanza de Abascal, con lo que esperaba equilibrar la situación y: lanzarse a la ofensiva general. Por lo tanto, mientras tenía efecto tan esperató acontécimiento, recomendaba al mismo $\mathrm{Pe}-$ zuela mantenerse a la defensiva sin dejar de reunir génté de las provincias, en vista de la situación de Iós enémigos en Potosí y sin que esto significase que Pezuela dejara pasar cualquier ocásión de vencerlos si se le ofrecía la oportunidad con las debidas garantias. Y29Y.

Al fin, el 7 de ágosto negó Pezuela al Cuartel General de Ancacato para hacerse cargo del mando efectivo del ejército del Alto Perú, cuya transmisiỏn se efectuó al día sigulente. El General se lievó una penosa impresión de las fuerzas y de sus equipajes; pero lo que más le preocupó fué el estado de la caballeria. Ya he dicho varias veces que la caballerla era un arma fundamental en esta guerra, y ahora, al hacerse cargo de las fuerzas, se encontraba Pezuela que, después del trabajo que habia supuesto reunir los caballos que poselan actualmente, estaban a punto dé perderlos por la escasez de forraje, imposible de remediar. En su camino habla dado disposiciones para su envio, pero aún tardarian en llegar.

El número de hombres del ejército se elevaba exactamente a 3.177, divididos en 282 de artillería, 659 de caballeria y 2.236 de infanteria, con $576 \mathrm{mu}-$ las de earga. Aparte de dichas fuerzas, escalonadas en las diferentes ciudades del tránsito existian sus corfespondientes guarniciones. Todas las fuerzas aptas para combatir las habia organizado Pezuela antes

(29) Arch. Abascal. Copia de Oficio de Abascal a Pezuela. Lima, 8 de agosto de 1813 . 
de iniciar ningun movimiento. Redujo los diferentes Cuerpos del ejército a dos Regimientos de Infanteria, constituido cada uno por dos batallones de cinco companias y un batallón de reserva, de cuatro; un Regimiento de Caballería, de tres escuadrones, y tres coanpañus formadas por los diferentes cuerpos y partidas sueltas en un cuerpo de cazadores, de tres compañia de infanteria y una de caballeria para hacer el servicio de aranzada. La artillería la organizó en tres brigadas de a pie con cuatro cañones cada una, y otra volante de seis (30).

Pronto comenzaron algunas escaramuzas con los enemigos. Una partida enviada a recoger forraje para la caballeria sufrió el ataque de un pequeño contingenté enemigo. Inmediatamente que tuvo noticia de lo ocutrido, disputso el General la salfda en su socorro del teniente coronel Olañeta, que al segundo día de marcha encontró a los argentinos, y sostuvo con ellos un pequeño tiroteo. Pronto se volvió al campamento, pues aunque acometió su persecución no pudo alcanzarlos.

Terminado el período de reorganización y preparación del ejército, llegaron rumores de que las tropas de Belgrano "se ponian en mavimiento. Pezuela pensá en un principio en una retirada hasta Oruro, no confiando demasiado en sus tropas y sabedor de la gran cantidad de fusiles y caballos de aquéllas. Pero se dió cuenta de que podja cundir el desaliento entre los suyos al recorrer en una nueva retirada el camina de Oruro, y por otra parte ofrecia gran dificultad el transporte de la artilleria y el material por la falta de mulas. Pero aún sobre todo existía un tercer inconveniente, y era que, conocida por los de Cochabamba y Chayanta la retirada de Pezuela y el avance de los argentinos, era casi segura su unión, que le colocaría en una situación bastante apurada. En consecuencia, decidió permanecer en la quebrada de Vilcapugio, donde se hallaba-a la sazón. Dicho punto presentaba la ventaja de su fácll defensa, pero

(30) ABASCAL. Memoria. Tomo II. Pág. 447. 
por el contrario tenia el inconveniente de que ofrecia escasa cantidad de síveres y forrajes.

Pero en vista de que el enemigo continuaba su avance, y había indicios para creer que actuarian confumtamente con ellos los cochabambinos y chayanteños con objeto de aislar a Pezuela, no le quedaba atra soluesón a éste que retirarse a un punto en donde tuviese más ampllo espacio para colocar sus tropas y emplearlas en una acción decisiva. En vista de la cual, se trasladó a Condocondo, donde una angostura entre un cerro que se extendía a su izquierda y una laguna a su derecha, le olrecta una excelente posición con una explariada en doncte podria evolucionar la infantería y colocar a su espalda la artillería. El traslado de una a otra posiclón se efectuó con gran trabaja Como habia pocas mulas, se utilizaron llamas, y burtos, pues a pesar de todos los intentos llevados a cabo por Pezuela para obtener caballos no puda conseguirlo (31).

Aún no se podia mirar la situación con exagerado optimismo. Las tropas realistas habian podido ser aumentadas por las últimos reclutamientos hechos por Pezuela hasta un total aproximado de $4.000 \mathrm{y}$ pico de hombres, sometidos a una intensa preparación militar; pero unida a la carencia de víveres, había una gran escasez de dinero para mantener en pie toda la máquina gueerrera. El total de fondos existentes en la Tesoreria del Ejército al hacerse cargo Pezuela del mando; ascendia, entre lo que existía en el momento y lo traido por 1 , a 112.500 pesos. Con semejante cantidad tendría suficiente para mes y medio aproximadamente, en el que quedaria invertida en sueldos y gastos. Era necesidad fundamental reunir más dinero, como efectivamente se propuso el Virrey, destinando para ello el de las Cajas de Huamanga, Arequipa, Cuzco, Puno, La Paz y Oruro (32).

Sin embargo, en la situación en que se encontraba el Ejército podía con ventajas hacer frente a los ene-

C. "s1) Arch. 'Abáscal: Copía de informe de Pezuela a Abascal.

Cuant General de Cóndocondo, 27 de septiembre de 1813.

132) ABASGAL. Memori . Tomo II. Pág. 450. 
migos. Dos posibilidades cabian sobre el proyectadt ataque de éstos. $O$ bien se podia esperar un ataque frontal, en cuyo caso serian hostilizados al desceider por el estrecho camino que conducía al llano donde se ballaba situado Condocondo, o bien intentarían un mokimiento envolvente sobre las fuerzas de Pezuela, divioidas las suyas en varias fracciones $\mathrm{g}$ - caminando partsa de ellas por Ancacato y Challapata para caer sobre la espalda de los realistas.

En el primer caso se podia prevehir la sorpresa con ta colocación en las avanzadas de las fuerzas de Ołañeta, $\theta$ inclusa con el establecimiento de un cuerpo intermedín entre éstas y el grueso de las tropas; y en cuanto al segundo lo habia prexenido Fezuela con la colocición de partidas destacadas en los caminos de Vilicapugio, Chayanta, Aroma y de la Costa.

dita 27 de septiembre llegaron. las tropas de Belgrano en su avance hasta los llanos de Vilcapugio, mientras que numerosas partidas de indios y cochabambinos se acercaban a Ancacato El mismo día recibió noticias de un encuentro sostenido por la avanzada situada en Pequereque, a espalda de Condocondo, contra 2.400 indios. Dichos Indios se hallaban en contacta con Belgrano, y par la documentación que se les recogió, se vino en conocimiento de que el reoeral argentino se hallaba tambien en relaciones con otros caudillos indios con el fin de que todos antos atacasen a Pezuela por la espalda, mientras él lo bacía de frente con sus tropas.

Conocidas estas noticias, camo asimisma la de que 4.000 cochabambinos se hallaban ya en marcha hacla Condoconda, se optó por librar una batalla que decldiese la situación En vista de ello ordenó Pezuela a Olañeta que se replegasè con sus avanzadas, y el día 30 , a las doce de la mañana, se puso en movimiento el ejército realista, en dirección a Vllcapugio con el fin de atacar a los enemigos por sorpresa antes del alba del siguiente. La marcha se llevó a cabo por un camino de llamas, elevado, ásperory fmo, que tenía la ventaja de reunir tan pésimas condiciones, que no era fácil hallar situados en él a los enemigos.

La mafcha fué accidentada, pues habienda huido los arrieros, los soldados de artilleria hubieron de efectuar las funciones de aquéllos, cujo resultado se 
tradujo en un ligero retraso de la maniobra. Desembacados al fin en el llano de Vilcapugio, frente al campamento enemigo, hubo de varlar el dispositivo de ataque (33). El mando del ala derecha lo ostentaba Ramírez; de la izquierda el Mayor General Tacón, y el del ceatro Pezuela. Aof; preparados, comenzaron el a taque contra el enemigo.

Los argentinos, en numbero de unos 5.000 hombres de infantería y 650 de caballería, con 14 cañones y dos obuses, se hallaban preparados para luchar, apoyada su retaguardia sobre una montaña, defendida por gran canticted de indios y cochabambinos.

La batalla fué dura para ambos ejércitos y presentó aígunas altermativas, que pusieron en peligro a los realistas, que, en un total de $\$ 3.000$ hombres de infantería y 480 de caballería con doce cañones se henzaron contra los enemigos en una acción que duró desde las ocho y media de la mañana hasta las tres de la tarde. Comenzado el ataque por la izquierda, hubo un prither momento de retroceso argentino, gracias al rual los realistas ganaron terreno aunque lentastrente, sobre tollo por la parte derecha; llegando a estrecharlos contra la montafia que les servía de base. Pero dicho retroceso era un movimiento ordenaro, lo que nizo darse cuenta a Pezuela de que el efercito patriota poseia un fuerte contingente de tropas disciplinaidas y no estaba integrado por reciutas, como se habia hecho creer.

Con un violento forcejeo continuó la batalla hasta media mañana, en que, heridos o muertos ta mayoría de los jefes que mandaban el ala izquierda realista; comenzó a eeder, contragiándose el centra, a pesar de

(33) La colocación de las tropas de Pezuela era la siguiente: Picoaga, con un Regimierto, cuatro piexás de Artíllería y el Cuerpo dc Cazadores de Olañeta, dcupaba ta lerecha. Lombera, con'otro Regimiento, cuatro cañones, un Ouerpo del Coronel Lahera y un Escuadrón de Caballería, la irquierda. Estévez, con su Batallón, un Escuddrón de Caballería desmontada y cuatro cañones, ocupaba el centro. La reserva la formaban el Batallón de Azángaro, que había llegado dos días antes de la batalky dos Escuadrones de Csballería y dos piquetes del Cuzco y La Paz. Anch. Abascal. Copia de Parte de Feruela a Abascak Guartel General de Condocondo, 6 de octubre de 1818. 
los esfuerzos que por evitarlo hacia Tacón. Como el ala derecha continuaba firme y empujaba a los argentinos, aprovechó Pezuela este momento para reunir a los dispersos y reforzar la izquierda, conseguido lo cual les obligó a ayanzar, haciendo retroceder a los argentinos hacia la montaña, a pesar de sus violentos contraataques. Al fin, hacia las tres de la tarde, se retiraron las fuerzas de Belgrano, y Pezuela quedó dueño del campo. En él dejaron gran cantidad de muertos y prisioneros, calculados por el general realista en unos 600 de los primeros, y más de 1.000 heridos, aparte de 137 prisioneros. Además, perdieron gran cantidad de artilleria y municiones. Por su parte, los realistas tuvieron 153 muertos, 257 heridos y 61 dosaparecidos (34).

Como recompensa a su actuación, fueron ascendidos al grado de Mariscal de Campo, en el campo de batalla; y propuestos para su aprobación por el Virrey, Ramírez y Picoaga, y Lombera y Tacón al de Brigadier, aparte de otros muchos jefes y oficiales. Todos ellos fueron después confirmadas por Abascal (35).

La inmediata consecuencia de la batalla de Vilcapugio fué la dispersión de las fuerzas argentinas. For una parte. Díaz-Vélez, con 400 hombres, marchó a Potosí para defender la ciudad; por otros lados había diferentes grupos de fuerzas, más o menos numerosos, que se dirigian todos hacia el Sur, y por último, Belgrano, con 1.500 hombres, se hallaba situado entre Macha y Chuquisaca.

De todás estas fuerzas, la que mayor preocupaolón podía causar a Pezuela era la de Belgrano, pues su situación era a propósito para atacar su flanco si continuaba el avance hacia Potosi, y aún podia tam-

(34) Arch. Abaroal. Copias de Partes de Pezuela a Abascal de 1 y 6 de octubra Parte de Ramirez a Pezurela de 4 de octubre, y de Tacón a Pezuela de 2 de octubre. Copias de Inventarios de Artillería, municiones y pertrechos tomados a los insurgentes en da batalla de Vileapugio y Estado de muertos, heridos y dispersos del Ejército Nacional y de prisioneros hechos por éste de los días 12 y 5 de octubre de 1813, respectivamente.

(35) La noticia de la victoria llegó a Lima el 27 de octubre y fué celebrada con népique general, fiestas neligiosas y un baile ofrecido por los oficiales de la guarnición, al que asistio el Virrey. 
bién sublevar a los pueblos situados a su espalda. En vista de ello decidió concentrar su esfuerzo sobre di.cho punto, sin olvidar a Potosí. Contra esta ciudad marcharon Olañeta y Castro por el camino del Despoblado y el de Postas respectivamente, sostenido el primero por 500 hombres de la división de Ramírez. El plan de Pezuela consistía en arrojar a Belgrano hacia el Sur y marchar luego a Potosí para ocuparla. Con ello se lograría la liberación de todo el Alto Perú, pues las ciudades de Cochabamba y Chuquisaca, aunque sublevadas contra los realistas, podrian ser dominadas fácilmente una vez que no tuviesen posibilidades de ayuda.

La situación de Pezuela no era lo ventajosa que se podía esperar después de la batalla de Vilcapugio, debido a la pérdida de 1.500 caballos y mulas de transporte que habia sufrido su ejército por la escasez de forrajes y la inclemencia del tiempo. Lógicamente, esto se traducía en una gran lentitud de movimientos, ocasionada por la falta de medios de transporte, o por tenerse que hacer sobre asnos o llamas, extraordinariamente lentos, y aún a veces hubo de conducirse la artillería a brazo. Tal circunstancia permitió a los argentinos retirarse en orden y colocarse en los puntos ya dichos para reunir y reorganizar sus tropas.

La situación encerraba, pues, una amenaza para Pezuela y podian incluso echarse a perder los frutos de Vilcapugio, a poco que tardase el general realista en ponerse en marcha. Por esta razón, el 30 de octubre, se puso en movimiento, después de haber ordenado reunirse con sus tropas a las que se hallaban en camino de aquella ciudad, para dirigirse al encuentro de Belgrano, al que se le había unido Díaz-Vélez desde Potosí.

El primer día de marcha recibió un parte del Comandante Militar de Oruro, que le daba cuenta de que Belgrano habia enviado una gruesa partida integrada por tropas, indios y cochabambinos al pue-blo de Sicasica. Dicha expedición tenía un doble obJeto: atacarlo, y sublevar los pueblos de la región, con la idea de llegar hasta La Paz para interceptar la comunicación del ejército realista con el Virreinato y entorpecer sus movimientos. Pero el peligro 
pasó pronto, pues Pezuela comisiono para hacer frente a los argentinos al coronel Imaz, que a su llegada se encontró con que ya había sido disuelta la partida enemiga.

Tras una marcha dificułtosa, llegó Pezuela el 12 de noviembre a las alturas del Taquiri, distante dos leguas de la posición de los argentinos en Oyohuma, al otro lado del río, al que llegó el día 14. La posición enemiga, naturalmente ventajosa, había sido reforzada con construcciones de ingenieria, y habian hecho de ella un punto fuertemente defendido y de dificil aceeso. El plan de Belgrano consistía en detener el avance realista ante sus posiciones, que cortaban el camino y aprovechas este momento para atacar por la derecha. Pero su plan fué desbaratado ror Pezurela, que hizo variar la marcha de sus tropas y reforzó el costado derecho con más infantería y artillería, mientras que por su izquierda ocupó una loma que dominaba la derecha de los argentinos. Así preparados, avanzó todo el ejército y comenzó un violentísimo fuego de cañón para proteger la maniobra de su izquierda.

La primera fase del combate fué afortunada para los realistas, pues su columna de la izquierda tomó la altura, y su derecha reforzada frustró todos los ataques de la caballería argentine. En vista del éxito, Fezuela ordenó proseguir el avance de tódas sus fuerzas, protegidas por la artillería, para atacar de frente al enemigo, mientras sus alas intentaban envolverlo. Pero en este momento tuvo lugar una reacción de los argentinos. Sus tropas, que habían aguantado a pie firme el nutrido fuego de los cañones readistas, a pesar de los claros que producian en sus filas, iniciaron un piolento ataque, combinado de la infantería y de la artillería. Se sucedieron catorce minutos de angustia, en los que el impetu de los atacantes chocaba con la firmeza de las tropas de Pezuela, hasta que al fin, literalmente machacados por la artillería de éste, no tuvieron otra resolución que la retirada (36).

(36) Arch. Abolocil. Copia de Parte de Pezuela a Abascal. Cuartel General de Macha, 15 de noviembre de 1813. 
Las dos batallas de Vilcapugio y Ayohuma significaron el fin de la expedición de Belgrano y la total evacuación del Alto Perú por las fuerzas argentinas. La segunda fué complemento de la primera, pues, derrotados los patriotas en Vilcapugio, aunque sus fuerzas se retiraran, la retirada fué lo suficientemente ordenada para permitirles permanecer en una posición ventajosa cerca de Macha, en Ayohuma. Desde alli volvian a amenazar a los realistas y les impedian toda ofensiva contra Potosí. De tal modo se hacía necesaria una nueva acción, que sin ella se hubieran inutilizados los resultados de la primera, tanto más, cuanto que Belgrano había dado órdenes de reunírsele a las tropas que se hallaban en Potosí, para marchar junto contra los realistas.

Al decir esto último, puede creerse que la batalla de Vílcapugio fué de carácté secundario, a juzgar por sus fresultados. Nada más lejos de la verdad. Vilcapugio fué una batalla de gran trascendencia, pero a la que no se le pudieron sacar los frutos, debido a la carencia de caballería y de provisiones en el ejército realista. Aun en Avohumma se dejó sentir la falta, pues, retirados los argentinos, no se pudo continuar la persecucion durante mucho trayecto, debido también a la causa antedicha.

Hay en estas dos batallas algunas diferencias con las dadas por Goyeneche. Gran parte de la variación era debida al ejército argentino. No cabe establecer una comparación entre las fuerzas que se le opusieron a Goyeneche en Huaqui o Sipe-Sipe, y las que se le enfrentaron a Pezuela en Vilcapugio y Ayohuma. En las dos primeras se trataba de grandes masas de hombres, con poca disciplina y casi ninguna experiencia militar; en las segundas el número había cedido en beneficio de una mayor organización y de un aumento del espíritu militar.

Ciertamente creo que, al menos en los primeros momentos de la guerra de la Independencia americana, el ejército argentino no resiste la comparación con el realista. En todo momento, como dice Mitre, la organización y los mayores talentos militares estuvieron de parte de éstos (37). Mas no hay que des-

(37) MITRE, Bartolomé. Op. cit. Tomo I. Pág. 225. 
prectair por eso el valor guerrero de las tropas argentinas. Belgrano supo infundirles el espíritu de que tan faltos se hallaban en los primeros tiempos. $Y$ esto nos lo demuestra su actuación en Vilcapugio y Ayohuma, en donde resistieron los ataques de Pezuela, e incluso hubo momentos en que pusieron en peligro a su ejército. Si al final la victorla fué para los realistas, se puede decir que correspondio a su mayor experiencia y a la mejor preparación de sus tropas, no a otra cosa.

Libres los caminos del Alto Perú, Pezuela pensó tomar las dos ciudades más cercanas que se hallaban en poder de los enemigos, Chuquisaca y Potosi, y dejar a Cochabamba para una posterior operación. Para tomar las dos primeras envió sendas columnas al mando de Lombera y Ramirez, respectivamente. Ambos ocuparon las dos ciudades casi a la par.

La principal meta de estas operaciones era la ocupación de Potosí. A dicha ciudad llegó Ramírez el 19 de noviembre y la encontró evacuada por los argentinos. Antes de marchar, Belgrano envió a Pezuelá una comunicación para proponerle un armisticio, que fué totalmente rechazado (38). $Y$ ante la negativa, y en la imposibilidad de defender la ciudad, se retiró hacia Salta. Algo semejante le ocurrió a Lombera en Charcas, que encontró también abandonada.

(38) Arch. Abascal. Copia de Oficio de Belgrano a Pezuela. Cuartel General de Potosí, 18 de noviembre de 1813. Contestación de éste. Cuartel General de Macha 22 de noviembre de 1813. 


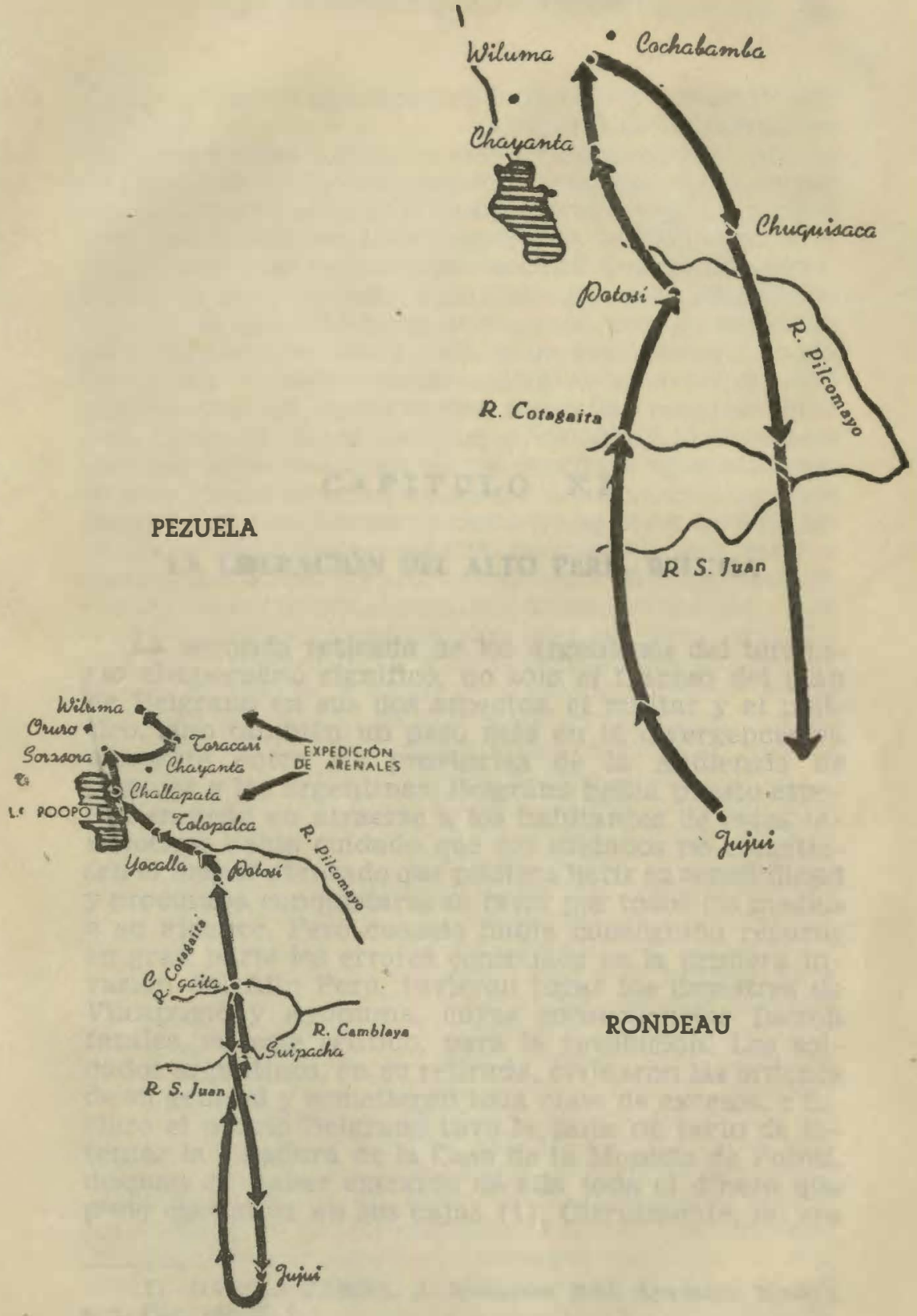


<smiles>C=CCC(C)CC1(C)CCCC1</smiles> 


\section{LA LIBERACIÓN DEL ALTO PERÚ. WILUMA}

La segunda retirada de los argentinos del territorio altoperuano significó, no sólo el fracaso del plan de Belgrano en sus dos aspectos, el militar y el politico, sino también un paso más en la divergencia ya existente entre las provincias de la Audiencia de Charcas y las argentinas. Belgrano habia puesto especial empeño en atraerse a los habitantes de estos territorios; había cuidado que sus soldados no cometiesen el menor atentado que puciera herir su sensibilidad y procuraba conquistarse su favor por todos los medios a su alcance. Pero cuando había conseguido reparar en gran parte los errores cometidos en la primera invasión del Alto Perú, tuvieron lugar los desastres de Vilcapugio y Ayohuma, cuyas consecuencias fueron fatales, en este sentido, para la revolución. Los soldados argentinos, en su retirada, olvidaron las órdenes de su general y cometieron toda clase de excesos, e incluso el propio Belgrano tuvo la falta de tacto de intentar la voladura de la Casa de la Moneda de Potosí, después de haber extraído de ella todo el dinero que pudo encontrar en sus cajas (1). Ciertamente, no era

(1) GARCIA CAMBA, A. Memorias. Bibl. Ayacucho. Madrid. s. a. P\&g. 160. T, I. 
éste el mejor medio de dejar un buen recuerdo de sus ocupantes en el Alto Perú.

Sin embargo, lo anterior no quiere decir que en los peruanos se operase como reacción un movimiento de simpatía hacia los realistas ni mucho menos. Desde 1809 se sucedían en sus ciudades los levantamientos revolucionarios y habian transcurrido tres años desde la primera invasión argentina. Ambos factores determinaron, en gran parte, el arraigamiento de la tendencia independizante en el Alto Perú. Ahora bien, esta idea, que en un principio nació-dejando aparte las sublevaciones de La Paz y Chuquisaca en 1809-, como una secuela lógica de la sublevación de Buenos Aires, con la que se mantuvo en estrecho contacto durante los tres años, aunque no fúera permanente la ocupación de su suelo por las tropas argentinas, sufrió poco a poco una desviación fundaméntal. Ios acontecimientos ya referidos fileron una de las causas principales por las que los argentinos llegaron a ser casi tan odiados como los realistas en las provincias altoperuanas. Consecuencla de ello es el cărăçter peçuliar que a partit de entonces adquirió la guerra en el Alto Perú. Surgen ahora los caudillos que, como Arenales, Carnes o Gưémes, dieron lugar a las «montoneras» o «republiquetaș», grupos de guerrilleros que luchaban independientemente unos de otros, sin reconocer autoridad súperior, y que trabajaban todos por la libertad del Alto Perú. Su misión consistia, fundamentalmente, en obstaculizar las comunicaciones y hacer imposible Ia ocupación del territorio a las fuerzas enemigas.

Durante su estancia en Potosí, Belgrano no tuvo ningún plän de operaciones determinado, ni le era factible tenerlo, dadas las condiciones de sus tropas. Solamente pudó aprovechar la inactividad de los realistas para llevar a cabo sus propósitos. Pero entretanto, utilizó cuantas ocasiones se le ofrecieron para ponerse en contacto con los revolucionarios e indios de estas provincias. Aunque sabia que no podía esperar gran cosa de los últimos, en cuanto a su adhesión permanenț a la causa de la independencia, procuraba aI menos exaltar su espiritu de tribu frente a la dominación española. Sin embargo, su apoyo no fué todo lo eficaz que pudiera haber pensado el general argentino, debido en gran parte a la desconflanza 
de los indios hacia los patriotas, y a su poca eficacia guerrera. Mucho más en contacto se mantuvieron los indios con los caudillos revolucionarios del Alto Perú durante todo el tiempo de la lucha por la independencia, que con los argentinos, en quienes vieron siempre al invasor, casi tan odiado como los realistas.

Ya con unos o con otros, es lo cierto que las correrias de los indios y las sublevaciones comenzadas en Cochabamba y Chuquisaca, eran motivos de constantes preocupaciones para Pezuela. Por ello, desembarazado de los enemigos más temibles, se dedicó a la pacificación del territorio que ocupaba.

Después de las batallas de Vilcapugio y Ayohuma sus fuerzas se hallaban divididas en tres partes. Una de ellas, mínima, era la encargada de cubrir las guarniciones de las ciudades; otra, la que al mando de Lombera se dirigió a Chuquisaca para sujetar las provincias de Charcas y Cochabamba, y una tercera, la más nutrida, aquélla cuya vanguardia mandada por, Ramirez acababa de ocupar Potosí. Los objetivos de los tres núcleos de fuerzas eran igualmente importantes, pues si a Pezuela le interesaba avanzar hacia Jujuy y Salta, camino del Tucumán, igualmente le era preciso mantener en sus manos el control de las ricas provincias altoperuanas.

El mejor, o quizás el único modo de someter todo el Alto Perú, era mantener la posesión de las ciudades insurreccionadas. De ahí la expedición de Lombera a Chuquisaca, cuya ocupación se realizó rápida y fácilmente. Pero el núcleo de la resistencia lo constituía Cochabamba. Basta recordar las dos sublevaciones anteriores para confirmar este juicio. Pues blen, una vez dominada la segunda sublevación, tan pronto como dicha ciudad se vió libre de la presencia del ejército peruano, se levantó de nuevo y obligó a huir al Intendente y al Arzobispo, que hubieron de refugiarse junto a los realistas. La difícil situación del Ejército impidió a Pezuela dedicarse al problema con la atención que requería, y se limitó exclusivamente a mantener las comunicaciones con el Virreinato. Pero una vez evacuado el territorio por las tropas argentinas, se decidió a emprender una expedición de castigo contra la ciudad y su provincia. Dispuso el envio de 600 hombres al mando de don Martín de Jáuregui, 
gobernador político y militar de Oruro. En un príncipio colocó en Chayanta 250 hombres de caballería, mientras se ultimaban los prepárativos, y una vez terminados éstos, Jáuregui se reuniría a ellos para marchar contra la ciudad, y con él irian el Intendente y el Arzobispo, que le asesorarian con sus conocimientos (2).

Pronto se tuvieron noticias del feliz resultado de la expedíción. Arenales, hecho gobernador de Cochabamba por Belgrano, se encontraba despravisto de municiones y material por haberlo enviado todo al Ejército de aquél antes de la batalla de Ayohuma. Ante la presencia de las fuerzas realistas no le cupo otra solución que la huída, y se dirigió, a través del Valle Grande, a Santa Cruz de la Sierra. Evacuada la capital por las tropas, sus habitantes enviaron una diputación a Jáuregui con el ofrecimiento de su rendición incondicional. Ocupada la cludad, el Jefe realista dividió sus tropas en dos partes: una destinada a la ocupación de la provincia. y otra, q e sł dirigió contra Arenales hacia Santa Cruz de la Sierra (3). Se originó entonces una campaña bastante trabajosa para los realistas y que impidió a Pezuela moverse hacia Jujuy, como pretendía el mes de mayo de 1814.

En el lado de los patriotas fué llevada la lucha por Arenales. Este personaje es quizás uno de los tipos más característicos de los caudillos de la revolución en el Alto Perú. Espíritu aventurero, pero con grandes recursos, fué el más eficaz colaborador de Belgrano en sus operaciones. Promovió la sublevación de Salta en tiempos de la batalla del Tucumán, como se ha visto, y mantuvo viva la insurrección en el Alto Perú, mientras Belgrano se hallaba en sus fronteras. $Y$ aún, después de derrotado en Vilcapugio y Ayohuma, le debió en gran parte el general argentino la facilidad que encontró para llevar a cabo su retirada.

Tomada Cochabamba por los realistas, se retiró hacia Valle Grande, tras un fallido intento de sostenerse en el Valle de Mizque, y allí, en comunicación

(2) Arch. Abascal. Copia de Oficio de Pezuela al Marqués de la Concordia. Cuartel General de Macha, 23 de noviembre de 1813.

(3) ABASCAL. Memoria. Tomo II. Págs. 466-467. 
con Santa Cruz de la Sierra, se preparaba para hacer frente a la proyectada expedición contra dicho territorio al mando del coronel Blanco.

Reforzado Aremales, y extendida la sublevación a todos los valles de la cordillera oriental, presentó batalla el 4 de febrero a la columna realista en el lugar denominado San Pedrilło, con 400 hombres de infantería y otros tantos de caballería. El combate fué duro, y después de tres horas de lucha, se decidió al fin por aquéllos. Arenales hubo de retirarse hacia Santa Cruz de la Sierra. Sin embargo, los realistas no pudieron continuar su avanee. Reforzado el caudillo altoperuano por Warnes, a pesar de los piques de éste por cuestiones de autoridad, consiguió mantenerse en Valle Grande. Y no sólo sostuvo su posición, sino que propagó la rebelión en La Laguna y entre los indios chiriguanas, con lo que obligó a Pezuela a enviar contra ellos una columna de 200 hombres al mando del coronel Benavente. El flanco izquierdo de los realistas estaba seriamente amenazado, y con la insurrección de los indios de Pilcomayo, los sublevados del Alto Perú podían entrar en un contacto más directo con los argentinos. Por otra parte, en las provincias limítrofes a Cochabamba comenzaba a surgir de nuevo la rebelión.

La finalidad de las columnas de Blanco y Benavente era, ante todo, empujar a Arenales y a los indios al otro lado de la cordillera oriental, más allá de Santa Cruz de la Sierra, para privarlos de todos los posibles puntos de apoyo y aislarlos de los argentinos. Pero tenían en contra lo accidentado del terreno y el clima malsano de aquellos territorios. Precisamente por eso es aquí donde Arenales y Warnes querían a toda costa dar la batalla a los realistas y defender los desfiladeros que les mantenían abiertas las entradas hacia Santa Cruz de la Sierra.

La lucha se polariza ahora principalmente en dos puntos: en los desfiladeros de Valle Grande e inmediaciones de Santa Cruz de la Sierra, y en el partido de La Laguna, en la provincia de Chuquisaca; lo cual no quiere decir, sin embargo, que se circunscribiera únicamente a dichos puntos. El mismo carácter de la contienda, llevada a cabo con partidas poco numerosas y contando con el terreno como uno de los 
factores principales en su desarrollo, le dan una movilidad extraordinaria, que se traduce en lo poco provechoso de sus resultados.

Asi comienza una serie de acciones, en las cuales el principal empeño de los realistas era actuar con todas sus fuerzas reunidas, mientras los patriotas ponían todo su interés en mantener la división entre aquéllas; $y$ aún aumentaban las dificultades para los realistas con el nacimiento de nuevas rebeliones a su espalda, que les obligaban a luchar en medio de una gran inseguridad.

Teniendo en cuenta estas circunstancias, el relato minucioso de las campañas en el Alto Perú sólo serviría para complicar mucho más el cuadro, ya de por si amplísimo, de la lucha total. Basta recordar como hitos fundamentales en su desarrollo, en primer lugar el combate de la Angostura, cuyo resultado fué la ocupación de Santa Cruz de la Sierra por los realistas, y el de La Florida, desgraciado para éstos.

Dispersado Warnes por las fuerzas de Blanco, se unió a las de Arenales, y juntos lo esperaron a orillas del rio Piray. Blanco habla ocupado Santa Cruz de la Sierra tras el encuentro de la Angostura, y, posesionado de la ciudad, envió a Udaeta a perseguir a los que se retiraban con 300 hombres, mientra él se dírigta con el résto de las fuerzas hacia la misión de La Plórida. Alli le encontraron Warnes y Arenales y el resultado del combate fué adverso para los realistas.

Indudablemente, la causa fundamental de la derrota de Blanco hay que buscarla en su inferioridad de fuerzas. Al desprenderse de la columna de Udaeta quedó en manfifiesta inferioridad ante los enemigos, que, además; supteron aprovechar hábilmente las condiciones del terreno. Muerto el Jefe realista en la batalla, el resto de sus tropas se dispersaron, y al cundir la sublevación en la provlncia de Santa Cruz de la Sierra, la pequeña guarnición que Blanco deJara en la capital hubo de evacuarla rápidamente (4).

(4) ABAscat Memória. Tomo II. Págs. 478-ss; GARCIA CAMBA, op. cit. Tomo I. Pág. 163 y ss; MITRE, op. cit., Tomo I. Pig. 284 -ss. 
A partir de aqui, el resto de la lucha se mantiene con alternativas, impulsada en todo momento por los argentinos.

Entretanto, en el Sur, como dejé dicho más atrás, las fuerzas de Ramirez entraron en Potosí y se disponian a seguir su avance en territorio de la provincia de Salta. Según las instrucciones del Virrey, debía continuar hasta el rio del Pasaje y colocar el Cuartel General en Suipacha (5). En dicho punto aguardarían a que transcurriese la estación de las aguas, y entretanto procuraría informarse de la situación de Montevideo.

Los patriotas se hallaban fortificados en Cobos; mientras Ramírez avanzaba hasta Jujuy y Salta con sus primeras tropas. Con ellas les hizo desalojar sus posiciones, en vista de lo ctral, Pezuela adelantó su Cuartel General hasta Tupiza.

Después de la batalla de Ayohuma, Bełgrano creyó peligrosa la permanencia de su ejército en la frontera del Alto Pérú, y si se detuvo en Cobos fué por la imposibilidad de atravesar el río đel Pasaje en la estación de las aguas. Pero ante la proximidad de la vanguardia realista, tuvo que continuar' la retirada hasta el Tucumán. El mando de Belgrano no había sido afortunado para el ejército argentino. Se hizo cargo de él en una situación difíeil, cuando parecia inminente la derrota total de las fuerzas revolucionarias. Sus primeros pasos fueron extraordinariamente felices.

Las batallas de Tucumán y Salta afianzaron definitivamente los resultados de la revolución e hicieron presagiar fáciles triunfos sobre el desmoralizado ejército realista. Pero la falta de medios para continuar su avance dió lugar a que el Virrey del Perú sustituyese al jefe de su efército, y con él varió todo el plan estratégico.

Indudablemente, Belgrano no tuvo nunca un plan de operaciones fijo, como en muchos casos tampoco lo tivieron los generales realistas. Dada la superioridad de sus enemigos, hubo de supeditar a éstos sus movimientos. Aun cuando los hubo vencido y llegó

(5) ABA SEAL. Memoria. Tomo II. Pág. 464. 
hasta Potosi, se ví́ obligado a detenerse por falta de medios. Entonces se dió cuenta de que el sistema más eficaz para triunfar sobre los realistas en el Alto Perú, dada su propia imposibilidad, era fomentar y mantener la sublevación en las ciudades. de este territorio, mientras él, a la defensiva, estaba atento a la mejor ocasión que se le presentase para obrar en combinación con las ciudades altoperuanas (6).

Su fracaso es fácil percibirlo. En el momento en que avanzó prescindiendo de una ayuda directa e inmediata de las ciudades, se encontró con un fuerte núcleo de tropas enemigas reorganizadas a toda prisa por Pezuela, que, libre momentáneamente de los altoperuanos, pudo emplearse a fondo contra los argentinos. El resultado no se hizo esperar. En dos batallas casi consecutivas se derrumbó definitivamente todo el fruto de sus anteriores victorias. La invasión del Alto Perú estaba condenada al fracaso.

No hay que negar que Belgrano fué uno de los hombres más inteligentes de la revolución argentina; pero lo que no se puede admitir, observando su actuación, es que fuese un general excelente. El mismo Mitre lo reconoce así: «Belgrano, el vencedor de Tucumán y Salta, bien que dotado de altas cualidades, carecía de los conocimientos técnicos y de la inspiración de la guerra.... (7); y su colocación al frente del ejército argentino fué débida exclusivamente a la falta de otro jefe más caracterizado que él. Pero esto no basta para explicarnos su fracaso, si a ello no le unimos que hubo de enfrentarse con un enemigo técnicamente superior, mandado y organizado por militares profesionales.

Cuando Belgrano se hizo cargo del mando del ejército, se encontró ante tres problemas a resolver: «remontar el personal y la moral de un ejército desorganizado, infundiéndole aliento nuevo; proveer las necesidades imperiosas que reclamaba el miserable estado de su material de guerra, y lo que era más arduo, levantar el espíritu de los pueblos abatidos o enconados, y atraerlos a la causa de la libertad, comprometiéndolos en la revolución. (8). Los tres pro-

(6) LOZA, Emilio. Op. cit. Pág. 533.

(7) MITRE, Bartolomé. Op. cit. Tomo I. Pág. 189. 
blemas eran difíciles de resolver, pero en la medida de sus fuerzas los llevó a cabo con entera fortuna, sobre todo el último. Cuando se retiró, después de Ayohuma, dejó tras sí la estela de la insurrección en el Alto Perú, aunque con las características apuntadas más atrás.

Pero frente a él había un ejército mucho más experto y organizado, consciente de su poder (a mi modo de Juzgar, un exceso de confianza en este poder fué la causa de las derrotas de Tucumán y Salta) para igualar el cual hacían falta grandes condiciones militares, que no podían suplir la buena voluntad y los escasos, aunque bien aplicados conocimientos de Belgrano. Aun así, y éstos son a mi juicio sus dos grandes triunfos en lo militar, hizo ver a los realistas la vitalidad de la revolución argentina, obligándolos a variar en su modo de pensar $\mathrm{y}$ de obrar en relación con el ejército patriota, y dejó afianzada definitivamente la revolución en el Alto Perú.

Tras la derrota de Ayohuma y la subsiguiente retirada al Tucumán, Belgrano insistió en su separación del mando del ejército, alegando la enfermedad que padecía. Es cierto que se encontraba enfermo, pero no creo menos cierto su interés en desaparecer del teatro de la guerra tras el fracaso, antes de que el propio Gobierno lo relevara. En efecto, a mediados de enero de 1814, San Martín se incorporaba al ejército patriota del Alto Perú, primero como segundo jefe, y poco después, como general en jefe del mismo.

San Martín poseía más dotes militares que Belgrano, de quien le diferenciaban peculiares matices, y llegaba al ejército en un momento crítico para su existencia (9). El fracaso de la segunda invasión del Alto Perú había producido general desilusión, y este territorio había ahondado las diferencias con las Provincias Unidas del Río de la Plata. El efército tan minuciosamente organizado por Belgrano, estaba a

(8) MITRE, Bartolomé. Historia de Belgrano y de la Independencia Argentina. Tomo II. Buenos Aires, 1877. Pág. 59.

(9) Sobre el carácter de S. Martín y su paralelo con el de Belgrano, vid. MITRE, B. Historia de Belgrano y de la Independencia Argentiza. Tomo II. Buenos Aires 1887. Págs. 275 ss; y del mismo tutor, Historia de S. Martin y de la emianoipación SurAmericana. Tomo I. Buenos Aires 1907. Págs. 191 ss. 
punto de desorganizarse de nuevo totalmente, y si los realistas emprendian una ofensiva a través del Tucumán, esta vez sería difícil contenerlos. No quedaba más que una solución: impedir que los realistas continuasen su avance creándoles obstáculos en su retaguardia en el Alto Perú. Como para Belgrano, para San Martín el primèro y principal objetivo es mantener la revolución en aquel territorio para obstaculizar los planes de Pezuela.

Pero aún vino a favorecer la idea de San Martín un nuevo acontecimiento: la insurrección de la provincia de Salta, mantenida por Güemes y sus gauchos. Estos hábiles Jinetes, organizados por un caudillo con ribetes de demagogo, atacaban constantemente las comunicaciones e interceptaban el abastecimiento del eqército realista (10). Fueron los peores enemigos que encontraron aquellos al invadir el territorio argentino. Formaban la vanguardia del ejército de San Martín, que nombró jefe de ella a Gliemes, y con sus correrias, impidieron a Ramírez continuar el avance en la provincia de Salta, tanto más, cuanto que la situación del Alto Perú no se presentaba nada favorable. El general argentino los utilizó para mantener la vigilancia sobre el Pasaje y el Desfiladero de Gauchipás, mientras reorganizaba sus fuerzas en Tucumán. En esta nueva modalidad de la lucha ha visto Mitre el origen de una nueva práctica empleada por San Martín, cuya orig1nalidad consiste en que, con un campo circunscrito a mantener, y un objetivo fijo que atacar, tuvo una base, una forma y una línea de operaciones dentro del perímetro de los mencionados valles (se refiere a los valles de la frontera con el Alto Perú), con proyecciones metódicas y atrevidas fuera de su radio; con comunicaciones estratégicas para el ataque y para la defensas (11). En realidad la originalidad de este sistema de guerra se reduce a la utilización de las guerrillas populares como elemento auxiliar en el conjunto de las maniobras militares, caso similar a lo ya

(10) GARCIA CAMBA, A. Op. cit. T. I. Pág. 166.

(12i) , MITRE, B. Historia de S. Martín. Tomo I. Buenos Aires, 1907. Pág. ?f4. 
ocurrido anterlormente en España. Pero el nuevo método de lucha no podía convertirse en definitivo. Había de ser untcamente un medio de ganar tiempo y contemer a los realistas mientras San Martín organizaba su ejercito.

Por su parte, Pezuela hacía lo propio con el suyo. La dispersión que significaban las diferentes expediciones a las ciudades sublevadas dèl Alto Perú, hábía de suplirla con nuevos reclutas y con la incorporación de tropas de diferentes puntos. Tales dificultades le impedian aprovechar los éxitos anteriores; por eso limitó su actividad a la persecusion de los gauchos y al abastecimiento de sus tropas (12). Entretanto, había trasladado su Cuartel General a Tupiza, más cercano a los valles de donde partían las correrias de los gauchos, y adonde llegó el 8 de febrero, estableciendo parte de sus fuerzas en Suipacha.

Colocados aqui, se dispuso Ramirez a avanzar sobre Salta, para lo cual ordeno la progresión de sus avanzadas hasta las postas de la Cabaña y de la Caldera. Pero ante la noticia del avance de dos partidas enemigas sobre Salta, hubo de detener su marcha. Los enemigos se dirigían hacia la ciudad a través de los dos caminos que confluian en ella: el Camino Real, atravesando el Pasaje, y el del Despoblado, por el valle de Guachipás.

Poco tiempo atrás habian tenido lugar algunos choques entre los partidarios de Güemes y las tropas de las avanzadas de Ramírez situadas en Salta a las ordenes del coronel Castro. A mediados de marzo, el Jefe realista avanzó por el valle de Lerma para obtener caballos, tan necesarios para sus tropas. Pero los gauchos le obligaron a regresar sin cumplir el objetivo de su expedición, y pocos días más tarde tenía lugar otro encuentro, también desfavorable para los realistas, en el Valle de Guachipás. El mismo Güemes con sus gauchos atacaba constantemente Salta y producia pérdidas continuas en su guarnición (13).

Los continuos ataques de los sublevados de la

(12) ABASCAL. Memoria. Tomo II. Págs. 469 y 472.

(13) MITRE, B. Historia de S. Martín. Tomo I. Buenos Aires, 1907. Págs. 266 y ss. 
provincia de Salta debieron ser, sin duda, los que indujeron a Ramirez a avanzar para proteger la ciudad y dar una batida en todos los valles de sus alrededores. Pero teniendo noticias de la proximidad de los enemigos, decidió suspender el avance y enviar una columna de exploración a las órdenes del coronel Marquiegui, entretanto recibia los refuerzos que $\mathrm{Pe}-$ zuela le enviara. Sin embargo, sus temores resultaban injustificados y no se verificó ningún ataque de los patriotas. En vista de lo cual y como coincidiese con la entrada de las tropas realistas en Santa Cruz de la Sierra, de que he hablado antes, dispuso el avance del Cuartel General hasta JuJuy, con el fin de estar más cerca de Salta, sobre cuya guarnición se temía un nuevo ataque de Güemes.

Para prevenirlo dispuso Pezuela la concentración de la vanguardia al mando de Ramírez en el fuerte de Cobos, desde donde se podrian destacar columnas para impedir el avance enemigo. Mas, antes de lanzarse a una operación conjunta sobre la provincia de Salta, le interesaba al general tener noticias exactas de la situación y del número de fuerzas de sus contrarios. Para lograrlo destacó dos expediciones, al mando del coronel don Antonio María Alvarez, una, y al de Marquiegui, otra.

La primera, partiendo de Salta, marchó por el curso alto del río del Pasaje y penetró en el valle de Lerma hasta llegar al pueblo de Somalao. Alli se encontró con la infanteria enemiga, con la que trabó combate. Durante la primera parte consiguió rechazarla, pero protegida ésta por los bosques, cambió el aspecto de la lucha y Alvarez fué obligado a replegarse. Cuando se retiraba, recibió aviso del avance de nuevas fuerzas patriotas que llegaban del Tucumán, en vista de lo cual, dispuso su regreso a Salta (14).

La otra expedición, al mando de Marquiegui, marchó por el otro camino, hacia el fuerte de Cobos para atravesar el río del Pasaje. En este último lugar encontró a Güemes, preparado para hacerle frente. Los intentos de Marquiegui de arrojarle al Sur del río se estrellaron contra la caballería gaucha y se vió obli-

(14) ABASCAL. Memoria. Tomo II. Pág. 483. 
gado a retirarse: como consecuencia tuvo lugar el avance de Güemes hasta Salta, que volvió de nuevo a sufrir sus ataques (15).

No acabaron aqui, sin embargo, las expediciones de reconocimientos enviadas por Pezuela al territorio enemigo. Trasladado a Jujuy, y mientras se operaba la concentración de sus fuerzas en Salta, organizó una nueva columna a las órdenes de Marquiegui, gran conocedor de aquellos terrenos. Dicha columna tenía por objeto adquirir noticias de los enemigos y alarmarlos con ataques inesperados. Se encaminó por la frontera del Chaco, desde donde podría a su vez conseguir el doble objetivo de ayudar a las columnas de Blanco, que operaban en el Alto Perú, y obtener ganados. Desde allí se habia de dirigir a atravesar más abajo el río del Pasaje y sorprender las posiciones patriotas por la espalda, proyecto atrevido y que, en parte, fué coronado por el éxito, pues ocupó los fuertes de Santa Bárbara, Río del Valle y Pitos, aunque en ninguno de dichos lugares encontró el ganado que buscaba. En cambio, en Pitos tuvo noticia de la'rendición de Montevideo, que unida a la de que Güemes había sido reforzado con 200 hombres, le hizo retirarse (16).

En un principio, las noticias recogidas por Marquiegui sobre la rendición de Montevideo no fueron aceptadas. Se las hacía pasar por un ardid del enemigo para hacer vacilar el ánimo de los realistas. A hacerlas más increíbles contribuia la información llegada por el navio «Asia», arribado al Callao, según la cual, una numerosa expedición estaba a punto de embarcar en Cádíz con rumbo a aquella ciudad. Pero los informes de Marquiegui tenían todo el carácter de ser veraces. Montevideo se hallaba estrechamente bloqueada por la escuadra mandada por el inglés Brown, y el ejército argentino a las órdenes de Alvear la rodeaba por tierra de tal forma que su caída era inminente. Había triunfado entre los gobernantes de las Provincias Unidas la idea de que mientras Mon-

(16) MITRE, B. Historia de S. Martin. Tomo I. Buenos Aires, 1907. Pág. 269.

(16) MITRE, B. Historia de S. Martin. Tomo I. Buenos Aires, 1907. Pág. 269; ABASCAL, Memoria. Tomo II. Pág. 482. 
tevideo estuviese en manos realistas, la revolución tenía frente a si una grave amenaza, y de acuerdo con este pensamiento, estaban dispuestos a conquistarla. El resultado de la lucha no se hizo esperar.

Ante una noticia con tantos visos de verosimilitud, Pezuela se dió cuenta de que, por ahora, habia fracasado el plan de la invasión del Tucumán; y no sólo éso, sino que también pensó que quizás sería mucho más conveniente retirarse a posiciones en donde se pudiera establecer con mayores garantias que en las actualmente ocupadas.

Aun como medida precautoria, puesto que todavia no se tenia confirmación oficial de la pérdida de Montevideo, el Virrey dió amplias instrucciones a Pezuela sobre la situación y sus posibilidades y le autorizó a «disponer el repliegue desde Jujuy a Cotagaita, y aún más adelante si era menester, escogiendo en todo los parajes más defensibles que presenta el camino de estas sierras: pero que en último evento nunca debería cederse sino palmo a palmo y por partes el terreno hasta el Desaguadero, que son los términos de ambos Virreinatoss (17). Para lo cual le encargó dispusiese lo necesario en los puntos del trayecto con el fila de no entorpecer el movimiento de las tropas y tener preparados los abastecimientos.

A este motivo de indecisión víno a unirse un peligro real. A partir de la derrota y muerte de Blanco, la insurrección cundió de nuevo en Santa Cruz de la Sierra, desde donde se propagó a otros puntos, principalmente a los partidos de Cinti, Valle Grande y La Laguna. Semejante perturbación desarticuló totalmente los planes para someter a los sublevados del Alto Perú, que llegaron a ser una gran amenaza para la retaguardia de Pezuela.

Así, pues, en vista de las adversas circunstancias externas y de la deserción que se hacía notar en el ejército, dispuso el general realista la retirada de sus fuerzas a Cotagaita, en donde, si bien de un modo provisional, podria hacer una enérgica defensa sobre el río de su nombre. En efecto, el 3 de agosto salía de 
Jatay en dtrecetón a aquel punto, y el 21 llegaba a Suipæecha (18).

En el camino de su retirada, Pezuela adquirió noticias ciertas sobre la rendición de Montevideo y sobre otro suceso de mucha mayor e inmediata gravedad: la sublevación del Cuzco. En primer lugar, al extenderse los sublevados hacia el Desaguadero en su intento de tomar La Paz, cortaban totalmente las comunicaciones del ejército y aislaban el Alto Perú. Por otra parte, si lograban apoderarse de aquella cindad, como parecla probable, cabia pensar, como consecuencia inmediata, en el total alzamiento de las demás ciudades altoperuanas, algunas de las cuales estaban amenazadas por los sublevados de sus provinucies; tal era el caso de Chuquisaca y Oruro. Esto sin contar eon las repercusiones que dicho movimiento pudiera tener en el Virreinato del Perú, en donde ya se habian dado casos de sublevaciones semejantes en algunos puntos aislados. Agravadas todas las anteriores circunstancias con el carácter peculiar de la revuelta, la situación de Pezuela, de delicada, se tornaba en critica, y el movimiento que en un principlo comenzara a titulo de precaución, se volvía ahora una medida necesaria e inaplazable.

Con toda su gravedd se planteó la situación en una Junta de Guerra celebrada en Lima el 30 de agosto, en la que, examinadas las posibilidades, se optó por aprobar la retirada de Pezuela y procurarle el envío de refuerzos, sacados de las tropas que luchaban en Chile. Con tal fin se cursaban órdenes al Jefe de dichas tropas, don Mariano Osorio, para que enviase el batallón de Talavera y uno de Chiloé, que luchaban a sus órdenes, hacia el Alto Perú por Arica u otro punto, caso de que hubiese conseguido sujetar a los rebeldes chilenos; en caso contrario se le facultaba apara celebrar un convenio cuyas estipulaciones fueran las más ventajosas que pudiese conseguir, para que, dirtgléndose con la fuerza total de su expectición, hlenasen el objeto de salvar el ejército del Alto Perús (19).

(18) GARCLA CAIMBA, A Op. cit. T. I. Pag. 169.

(19). ABASAAL. Memeria. Tomo II. Pág. 492. 
Es decir, que de todos los problemas que en este momento tenia planteados Abascal, el más importante para él, y objeto de sus preferencias, era el mantenimiento del ejército del Alto Perú. Pensaba que mientras se mantuviese un fuerte núcleo de tropa en esa región, estaría defendida la integridad del Virreinato. No importaba que estallasen revoluciones como la del Cuzco, graves en sí, pero que, sin entrar en contacto con los enemigos de fuera del Virreinato, tarde o temprano, estaban condenadas al fracaso. Por eso no vacila en aconsejar a Osorio la contemporización que antes desautorizara a Gaínza. Cree más conveniente llegar a un pacto con los chilenos, que abandonar a su propia suerte al ejército de $\mathrm{Pe}-$ zuela. Indudablemente, Abascal llegó a temer un alzamiento general del Alto Perú, cuyo resultado inmediato había de ser la disolución y la derrota del ejército realista. De ahi todo su interés en precaver semejante desgracia.

Aún amenazaba a Pezuela otro mal. Se recordará que el núcleo principal del ejército organizado en un principio por Goyeneche lo constituian los naturales del Cuzco, que siguieron nutriendo sus filas durante los cuatro años de lucha, y aunque siempre habian dado prueba de su fidelidad al Rey, era de temer que ahora, en que moralmente derrotados se retiraban hacia sus antiguas posiciones, sabedores de la sublevación de su ciudad, y minada su voluntad por elementos perturbadores, se declarasen en rebeldía o desertasen de sus filas, con lo cual colocarían en una situación apurada a su general.

Una prueba del peligro existente fué la abortada conspiración del coronel Castro. Don Saturnino de Castro, coronel salteño, que se había distinguido en la batalla de Vilcapugio, ante la sublevación del Cuzco y la proximidad del ejército argentino, concibió la idea de sublevarse al frente de sus tropas y atraer a las demás, para con todas ellas pasarse al enemigo. Su plan consistía en ganarse a los cuzqueños del ejército realista y, con su influencia, sublevar los demás Cuerpos. Para garantizar, pues, el éxito entró en relaciones con el jefe argentino, entonces Rondeau, que habia relevado a San Martín, para que se acercase a sus posiciones; así pensaba asegurar el triunfo con 
la proximidad de aquellas fuerzas. Sin embargo, el plan no estaba del todo determinado. Para llevarlo a cabo, pensaba, o bien apoderarse de la persona del general español y de su Cuartel General y sublevar después al ejército, o bien marchar a Moxos, donde se hallaba la vanguardia, para apoderarse de ella por sorpresa, y efectuada la primera parte del plan, intimar la rendición a Pezuela ,(20).

El proyecto de Castro fué descublerto a tiempo por el general; pero como aquél se apereibiese, decidió adelantarlo. Mas su intento fracasó. Sus propios soldados no le siguieron completamente, y sus intentas de atraerse a los cuzqueños no tuvieron éxito. Detenido y sometido a juicio, fué fusilado poco después (21).

La conspiración de Castro no tendría importancia alguna, y no pasaría de ser una intriga más, común a todos los períodos revolucionarios, si no se hubiese dado las circunstancias que la hicieron fracasar. De haber triunfado, a más de cambiar el curso de la guerra, hubiese significado el fracaso del sistema de Abascal, no sólo en su aspecto militar, sino también en el político. El hecho de que los cuzqueños del ejército no ya rechazasen la insinuación de rebelarse para luchar al lado de sus paisanos, sino que, antes al contraria, pidieran voluntariamente ir a combatirlos, es, a mi juicio, el más alto triunfo de la política seguida por Abascal en su gobierno, secundada eficazmente por sus colaboradores.

Recibidas las noticias sobre los proyectos de los sublevados del Cuzco, Pezuela reunió una Junta de Guerra en Suipacha, con el fin de tomar las medidas necesarias Se determinó que Ramírez marchase contra los cuzqueños con dos batallones, dos escuadrones y cuatro piezas de artillería, en un total de unos 1.200 hombres; de esta fuerza se haria cargo Picoaga, una vez que llezase al teatro de la lucha. Mientras tanto, el resto de las fuerzas efectuaría un repliegue hasta Cotagaita, en donde les sería más fácil dete-

(20) MITRE, B. Historia de Belgrano. Tomo II. Buenos Aires, 1887. Pág. 386.

(21) GARCIA CAMBA, A. Op. cit, T. I. Pág. 175. 
ner al eaemigo, cuyas avanzadas se hallaban en Yavi (22).

Fué entonces, una vez que se supo lo resuelto en la Junta respecto a la columna expedicionaria al Cuzco, cuando el primer Regimiento de las fuerzas de Pezuela, compuesto de cuzqueños, se ofreció voluntariamente a ir contra los sublevados. Dicho Regimiento era el mismo que Castro incitara a la sublevación.

Indudablemente, fué medida de habilidad la de Pezuela al aceptar el ofrecimiento de sus soldados. Es curioso hacer notar cómo estos soldados del Cuzco, que llevaban ya varios años de lucha desesperanzada contra los patriotas, se mantienen en todo momento fieles al Rey, y en cambio, los que estaban en su ciudad, menos en contacto con los sublevados argentinos, empuñan las armas contra los españoles, diferencia interesante de resaltar. Conviene también recordar, como ya dije más atrás, que el núcleo del Ejército Virreinal, el que constituyó el eje de la resistencia española hasta Ayacucho, estaba formado por los indigenas del Perú, y que en su mayor parte el elemento perturbador y dado a la deserción, lo constituian los procedentes de las provincias del Alto Perú, incorporados al ejército durante la ocupación del territorio. En esta identificación de los peruanos con la causa realista hay que hacer notar la habilidad del Virrey Abascal, a que ya me he referido en la primera parte de este trabajo. Sus soldados, de tal forma se unieron a la causa del Virrey, que no le abandonaron Jamás; y sus jefes les eran tan queridos que basta recordar al efecto la fermentación producida en los campamentos realistas con motivo de la separación de Goyeneche.

Enviado, pues. Ramírez con sus tropas hacia el Cuzco, comenzó Pezuela el replieguie hacia Cotagaita. El 15 de septiembre salía de Suipacha, y el 19 llegaba a aquel punto, en donde se dispuso a fortificarse.

Entretanto se desarrollaban todos los anteriores acontecimientos en el campo realista, en el argentino

(22) GARCiA CAMBA, A. Op. cit. T. I. Págs. 175-176. 
habia tenido lugar un cambio de jefes. A Sah Martín habia sucedido en el mando del ejército el general' don Jasé Rondeau, quiž́s el menos hábil de todos los jefes que turo el ejército patrlota en esta ejoéa. Mantenido al frente de las tropas contra las órdenes del Goblermo, no supo imponerse a los jefes que lo sostuvieron, y sus platnes militares carecieron de originalldad (23). Un testigo de sus operaciones, quie le profesaba gran afecto; no puede inenos que decir acerca de 11: El GenerdI Rondeau era un perfecto caballero, adomado de virtudes y prendas estimables como hombro privato; pero de ningunas aptitudes para un unairdo militar, principalmenté en circunstancias a:fielles, como lais en que se hallaba» (24).

Sin enibarigo, se prepató para comenzar una nueva campaña contra Pedtela; sin auda, quérla aprovéehais - trastorno que pórodujo la pevolución del Cuzcó. El éjercilo árgéntino habia sido seforzadó últimiamente, aunque hay discrepancia sobrè el numéro exácto de sus solatados. Abascil lo fija en 3.000 hombres; en: eambid. Mitre los elefá a més de 4.000 de las tres armás, + García Cambá, a 6.000. Por lo menos debia óscillar su nưmero de 4 a 5.000 hombrès.

De todás formass, al comenzar la ófensiva las ventajas que se le ofrécian a los patriotais erán grantes: se habian apoderado de la entrádá ál Alto Pèrú, se hanabian en contźcto con los sublevaidos de dicho teriftotio y con los del Cuzcb. y poseian un ejército sut perfot en numero al de los reallistus. Intretántó, éstos habian de atender a la vez a la deserión, a las sublele vaciones de su retaguardia y a la enorme revolución del Chrco, mlentras que habian de estar a la mira de los posibles ataques argentinos.

Sin érnbargo, Rondeaù dejo pasar la ocasión, ya fueta borque no estuviese seguro de sus tröpas, o porque juigase muy aventirađio adentrarse en el Alto Perty. Se limitó a colocar sus avanzadas en Yavi, a las órdenes de Guernes, y a apoyar el resto de su van-

(23) MITRE, B, Historia de Belgrang Tamo II. Buenos $\mathrm{Ai}_{\text {, }}$ res, 1887. Págs. 3877-388.

(24) PAZ, J. María. Memorias póstumlds. Bibl. Ayácucho. Madrita. B. a. Pag. 269. 
guardia a lo largo del desfiladero de Humahuaca. Pensó llevar a cabo un plan semejante al de Belgrano, que consistiria en fomentar las sublevaciones para obligar a Pezuela a una retirada hasta el Desaguadero, sin necesidad de combatir con él, o al menos, combatiendo en una minima parte. $Y$ es que todos los generales argentinos pensaban que un factor imprescindible para expulsar al ejército realista del Alto Perú era la sublevación de sus ciudades. Sin ella la conquista de este territorio era del todo imposible. El camino de los conquistadores se alargaba extraordinariamente y crecían las dificultades para el abastecimiento y la reposición de las tropas. En cambio, contando con el pueblo adicto, quedaban obviadas las dos dificultades. He aqui, pues, la clave de la estrategia de los generales argentinos ante el problema de la guerra en el Norte. He aquí también la explícación de por qué una guerra que empezó por parte de los argentinos con el fin de liberar las provincias altot peruanas y se convirtió en lucha a muerte contra los realistas, degeneró en una guerra de movimientos sin ningún resultado definitivo. Sin embargo, hay que tener presente la idea de que el sistema utilizado por los generales patriotas era el único que cabía seguir en el camino hasta entonces utilizado por la estrategia de la revolución argentina.

El error de Rondeau no residió, pues, en seguir esta táctica, sino en no aprovechar sus resultados, simultaneándola con el avance de sus fuerzas en el primer momento de desconcierto realista. En lugar de ello, les dió tiempo de retirarse y prepararse para detenerlo, y el resultado varió completamente, a pesar de que estuvo cerca del triunfo.

Ya he dicho anteriormente que la delicada situación de Pezuela le obligó a replegarse a Cotagaita: desde allí podía continuar su retirada hasta el Desaguadero, según le autorizara el Virrey. En un principio, al asomar las avanzadas argentinas en Yavi, quizás pensara en proseguir el repliegue; pero en vista de que no se movían de aqui, prefirió fortificarse en aquel lugar. Además, y no poco debería contribuir en el general a tomar semejante determinación, el Virrey le notificaba las órdenes cursadas a Osorio para que atravesase los Andes por Mendoza y marchase so- 
bre Córdoba, a la par que Pezuela iniclaba el avance; por otra parte las notícias de la expedición de Morillo, dirigida al Kio de la Plata, hacian pensar que se aproximaban días difíciles para la revolución argentina.

Con tan halagueñas noticias, se decidió Pezuela a hostigar la vanguardia de Rondeau. Las incursiones de Marquiegui obligaron a Güemes a evacuar Yavi. Además, tuvieron lugar encuentros en los pueblos de Rinconada, El Tejar, etc.; en los que si los realistas sufrieron pérdidas, no permitieron a los argentinos ningún movimiento de avance (25).

Pezuela, que pretendía contener a los argentinos hasta que se sofocase la sublevación del Cuzco o rectbiese nuevos refuerzos de tropas, quizo aprovechar un momento, que al parecer se le ofrecia para terminar decorosamente la lucha. En un combate sostenido por las tropas de don Antonio Vigil en El TeJar, fué hecho prisionero un coronel argentino, apellidado Rodriguez. Dicho coronel se dispuso a aprovecharse de su situacion, y considerando el precarlo estado del ejército de Pezuela, se propuso llevar a cabo un plan que redundase en su beneficio particular y en el de sus partidarios. Comenzó a dar noticias falsas sobre la sttuación y fuerzas de los argentinos, a la par que hacla creer al general realista en la falta de deseos de independencia en los mismos revolucíonarios. La rovolución, según decía él, había surgldo por la negativa a someterse a un rey extranjero, pero una vez repuesto el legítimo soberano, los argentinos no tendrian inconveniente en aceptarlo como monarca (26).

Confiado en las declaraciones de Rodriguez, y deseoso de aprovechar la ocasión que se le presentaba, Pezuela entró en negociaciones con Rondeau, a la par que pedía envios de refuerzos a los Intendentes de las provincias y preparaba lo necesario para una postble retirada hasta Oruro.

El motivo de la última medida fué la declaración del prisionero sobre la fuerza y designios de los enemigos. También pusieron en cuidado a Pezuela los movimientos de los indios a su retaguardia. Estas ra-

(25) ABASCAL. Momoria. Tomo II. Págs. 501 y. 508.

(26) GARCIA CAMBA, A. Op. cit. T. I. Páq. 200; 
zones le hagón pensar en la convenlencla de conthnuar l lepliegue hasta Oruro. Efectiramente, los indios, de acuerdo con Rondeau, surgían de nuevo en sus correrias y amenazaban su retaguardia Contra ellos se diefon las acciones de Palca Grande, de la cuesta del Inca, del Cerro de Carretas, etc.

Mientras se intentaba sujetar a los indios, proseguín las, negociablones con Rondeau; sólo que al tratar el general argentino se supo gue rio existía por su parte pinguna proposición para llegar al final de las hostilidades, simo solamente la de efectuar un canji, de prigipnerog: De aquí se vino a saber que todo la ofrecida ponselnownonel Rodriguen fue un ardid para Foeolarar su libertad; como efectivamente lográ, bajo el título de modiador cerca de Rondeau, Ir asustar a los reglistas con los pretendidos.movimientos de las trapas ple éste.

nis Fracasa do el intento de llegar a La Paz, no le queqaba a Pezuela otra alternativa que esporar los refuerzos pididos, mientras ppocuraba sostener a la Fan 4 ardia . enemiga con constantes incuranes en an territorio. Pero poen después ocurriexton algunos acontecimientos que le hicieran variar de modo de penser. En grimer lugar, una de las partidas mandadas por Jáduregui y, Esenarro fú derrotada, y pocos días caspłzés gtre, mandada nor don Antonio Vigit, fué igualugento batida en el Puesto del Marqués: Inmodiatamente Raradeau; puso en movimiento todo el efército la ciá Yavi (27).

- Olañetas que mandaba la vanguardia realista, comanicaba estas desgracias a Pezuela y. le hacia saber que emprendia la retirada ante la superioridad del enemiga Pero como coincidiese con, el hecho de que los shofos, de las provineias de Rotosi, Charcas y. Cochabamol comunicaban igualmente al general el atat que a sus respectivas capitales por los sublevados, todo

(27) ABASCAL Mémoria. Tomo II. Págs. 514 y 520; GAR.

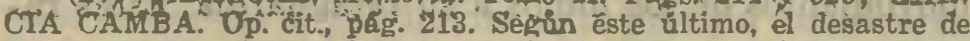
Vigil, que tuvo lugar el 17 de abril de 1815, ocurrió durante un plazo de ocho días señalados por Pezuela a Rondeau para que le

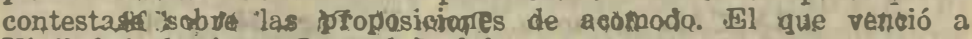
Vigil fué al tnimana Coranel Rodorigaez. 
vino a contribur la idea que se formó éste de que se preparaba un ataque general de los argentinas. en co- Laboración con Jos revolvcionarios del Alto Perú (28).

Inmediatamente conłocó en su Cuartel General una Junta de Gnerra, cuya opimión fué la de retirar. se a Oruro, "no estimando prudente aventurar una batalla, cuya posible pérdida arrastraria la total del Perú...) ‘(29). Dicha decislón fué aprobadta por el Vírrey, que, como se recordará, en otro tienipo ya había axtorizado a Pezuela esta medida.

La primena etapa det replicgue se hizo hasta el puteblo de Choulapata. El día 21 de abril salienton las fuerzas de Gotagaita por el camino real haspa quidbe. De aquí siguienon par el del Despoblado hasta Chadapater adondo legaro el 9 de mayo Desde Quirbe envió Pézuela elguna fuerza a Rotosí para retirar la guarøición de la plaza:st. de exitraer los caudales y las máquinas do la Casa de la Moneda. Igualmente fué evaouada Ghupuisaca, y las guarniciones de ambas ciudades se incorpararon al grueso del ejército (30),

Pero lo que nas preooupaba a Rezuela en su tetirada era la suerte de) Cochabamba. Más atrás se ha visto cómo ol cạdillio Arenales conotikula el alma de la nesistencia en el Alta Perú contra los españoles. Quxectó expuesto allíicómo dospués de una victoriosa expedir ción de los realtstas por los territorios de Cochabamba; Valle Grande y. Santa Cruz de la Sierra, se yió bbligado a retiranse temporaimente del campo de la bucha. Pero su ausencis no: tba a duxar mucho tiempo Con su tenacidad caracteristica y la constante ayauda de los argentinos; reavivó de nuevo la insurreceióx, "y en este momento lo vemos amenazando una vez más las ciudades de Potosí, Chuquisaca yl Cochabamban.

Verificada la retirada de Pezuela a Challapata, los argentinos ocuparon Potosí y Chuquisaca. Liberadas de la aeupabión realista ambes; ciudades; Arenales se dirigió con sus fuerzas zacia Cochabamba, amenazada. $5 a$ por otros caudillos insurgentes. Apercibido del peligro que esto suponía para la ciudad, el generait

(88) ABASCAL. Memorio. Tömo II. P\&g. 520.

(29) GARCIA CAMVBA, A. Op. cit! T. İ Páss, 218-214.

(30) GARGIA CAMBA, A. AR, ait, T. I. Rág. 214. 
realista destacó una columna de 350 hombres, que, al mando del Sargento Mayor don Francisco Javier Aguilera, y a marchas forzadas, se dirigió a evitar el proyecto de los sublevados. Sin embargo, Arenales les llevaba ventaja y ocupó la ciudad antes de la llegada de Agnilera.

La ocupación de la ciudad no fue operación de gran trabajo para Arenales. Al frente de 400 hombres de infanteria y 300 montados, se presentó ante Cochabamba, que se encontraba casi indefensa. Unos dias antes había tenido lugar una reunión de los jefes de dicha ciudad, en la que se acordó llamar al coronel Velasco, que con su división de tropa destinada a la guarnición de la cludad, se hallaba en Totora para batir a los indios. Pero el gobernador Goyburu se opuso a ello, al parecer, por cuestiones de rivalidad personal. A pesar de todo, Velasco se retiró hacia Cochabamba, en donde entró el 15 de mayo. El mismo día se recibió un emisario de Arenales intimando la rendición. El gobernador le dió a entender que, con condiciones decorosas, evacuaría la provincia, y reunió al efecto un Consejo de Guerra para tratar la cuestión. Pero los vecinos y los oficiales no se conformaban con su parecer y salieron al campo al mando de Velasco, con siete cañones. En tales circunstancias, llegó un nuevo enviado de Arenales y se preparó la entrevista entre los comisionados de ambos bandos.

Sin embargo, Velasco no acepto lo tratado en las reuniones, y tuvo varios eneuentros con las tropas de aquél, que le obligaron a emprender la retirada. El dia 22 se encontraba con las de Aguilera. Este último Jefe tenía órdenes de Pezuela para replegarse inmediatamente y con el mayor orden a Oruro, en caso de que, al aproximarse a Cochabamba, tuviese noticias de su ocupación por los insurgentes. A tal efecto; envió Pezuela el batallón del centro, al mando de Benavente, a colocarse en Sorasora, para estar a la vista de la situación de Oruro. Igualmente prevenia a don Rafael Maroto, coronel del Cuerpo de Chile que se dirigía al Alto Perú, para que acelerase sus marchas, con el fin de llegar a dicha ciudad.

Mas, a pesar de las ordenes del general, relunidas las columnas de Velasco y Aguilera, decidieron sus Jefes volver sobre Cochabamba, y llegaron a unas seis 
leguas de distancia de la capital, pero no se atrevieron a atacar, en vista del estado de desorden en que venia la tropa, y, previo un Consejo de Guerra, tomaron la resolución de retirarse y dar parte a Pezuela solicitando el envío de refuerzos; aun así, todavia en el camino hacia retaguardia tuvieron lugar algunos encuentros con los.indios.

Recibidas estas noticias, el geral ordenó a Aguilera que tomase bajo su mando'a su columna y a la de Velasop, que, reunidas, ascendian a 665 hombres. Todos debian estar preparados para emprender la marcha en un momento propicia al primer aviso de Pezuela, que ya les enviaba tropas de refuerzos. Cuando se hallaban casi terminados los preparativos de la expedición en ayuda de la columna de Aguilera, tuvo noticias de que Rondeau pensaba salir con todas sus fuerzas para marchar sobre los realistas, ante cuya posibilidad ordenó la suspensión de dicho movimiento. La columna, que marchaba al mando del coronel Lavin, y se hallaba en el punto de Paria, recibió orden de detener su marcha y permanecer a la expectativa en espera del resultado de los acontecimientos en el Sur. Si los rumores esparcidos no se convertian en realidad, prosegairia su marcha; en caso contrario, se había de dirigir hacia Sorasora para reunirse allí con las tropas de Pezuela, que juzgaba a aquél como el único punto para presentar o aceptar batalla con el enemigo (31).

Según noticias llegadas al Cuartel General de Challapata, los argentinos, cuyio general se trasladó a Potosi, habian colocado sus avanzadas en Yocalla, y esto era lo que hacia temer a Pezuela un ataque simultáneo de Rondeau y de los caudillos altoperua-

(31) Arch. Abascal. Interrogatotio de don Tomás Manuel de Gá ndiamo y dón Miguel de las Rivas, enviádos de Velaseo A Aguilera, 5 de junio de 1815. Parte de Pezuela a Abascal. Cuartel General de Challapata, 8 de julio de 1815. Oficio de Pezuela al Brigadier Tacón, Presidente de Oruro. Cuartel General de Challapata, 19 de mayo de 1815. Asimismo, los partes de Aguilera y Velasco a Pezuela. Campamanto de Oputani, 29 y 30 de maro de 1815, respectivamente, e instrucciones de Goyburu a los enviados con el Tratado firmado con Arenales. Campamiento de Tamborada, 18 de mayo de 1815, y Haejenda de utocta, 16 de majo de 1815. 
nos. Hasta ahora el refuerzo recibido era escaso. Se recordará que Abascal habia ordenado a Osorio acabas promto la campasa de Ghile para enviar tropas al Mlto Peria, por Árica; o bten, atravesando la cordiHera psra atacar las cludades argentinas. Igualmente, se pensabal qua Ramirez, sofocada prontament la rebelión del Cuzco y ocumada la ciudad, podría paner en movimiento sus fuerzas haola el Alto Pert y unirse de nuevo a Pezuela. Y por último, y sobre todas estas esperanzas, estaba la de la próxima llegada al Rfo de la Plata de la expetiolón de 10.000 hombres al mando del genaral Morillo.

De todos los planes anterlores, hasta ahora sólo se habia converticto en realidad el auxilio de 314 hombres venidos de Onile, al manto de Matoto. El total de fuerzas de que disponita Peztrelas: ascendia a 2.452 hombres de infanterite - 555 de caballeria, con 20 cañones. Aparté, habla 598 hombres más de infanteria, 317 de caballería y 4 cañones, que fotmaban la $00-$ lumna enviada contra Cochabambi al mándo de Agullena (32). Indudablemente, su ejerdito era inferior en número al del enemigo, cuvo total se cifraba en unos 4.000 hombres; peto habia una difereneia ontre ambos, que en trualdad de condiciones hublera ruesta en un plan de sluperiorladi a los realistas: Eistos formaban una "masa efeotivalmente inferior en en himero, pero muy saperiot en tisciblina $y$ en disposición para obrar en aquíllos climas a la que pudíera of oner él enemigo con el mayor esfuerzos (33). Sin embargol las circtristaridas del momento en el Alto Perús ya referidas anteriomente, redundatán en una gran desventida pära ella.

Poco despulios se reclbierón noticias en el Cuartel General de que don José Ballesteros había desembarcado en Arica al frente de una división auxiliar procedente de Chile, compuesta de 441 hombres (34). Con ellos se elevaba el número de las tropas de Pe-

(82)). Ariek. Abascal Oficia de Pezuela al Matquas de la Concondias Güartel Gerreral de Challapataj 9 de junjoido 1815.

(33) ABALCHE. Memorio Tomo II. Pág. 525.

(34) Anoh Abasbal: Oficia de Ballesteros al Marques de la Coneordia, Ouartel de Aricás 5 de fínio de 1815: 
zuela hasta el punto de hacer creer al Virrey que en este estado saldría al encuentro del enemigo (35).

En vista de la proximidad del nuevo refuerzo y del que procedía del Cuzco, unido a las noticias sobre los preparativos enemigos, Pezuela convocó una Junta de Guerra en su Cuartel General. Según los informes recibidos, Rondeau había situado alrededor de 3.500 hombres en Potosí y Yocalla, con 14 cañones de diversos calibres. Por su parte, los realistas tenian en el Cuartel General 3.000 hombres de fusil y 20 cañones, aparte, por supuesto, de los 1.000 hombres de infantería y caballerla que, a las órdenes del coronel Lavín, habian sido enviados a Cochabamba, y recibieron órdenes en el camino de detenerse en Paria hasta ver el giro de los acontecimientos.

En la Junta, Pezuela informó del estado de su tropa y de los próximos refuerzos, cuya llegada a Oruro pensaba tendría lugar hacia fines del mes de Junio o principios del siguiente. Expuesta así la situación, se sometió a la consideración de los reunidos la conveniencia de dar una batalla al enemigo con la fuerza actual del ejército, o replegarlo a las inmediaciones de Oruro, con el fin de unirse a los auxilios que hacia alli venían. Juzgadas las posibilidades de ambas opiniones, determinó al fin la Junta «que el ejército permanezca en esta provincia de Challapata hasta el preciso momento de saberse con certeza que el enemigo ha salido de Potosí, y que en este caso se repliegue todo al pueblo de Sorasora.... (36). Aquí se le unirian las tropas procedentes de Chile y las situadas en Paria y formarían un grueso contingente capaz de hacer frente y detener al enemigo, e incluso, según la opinión de Pezuela, se podría obtener «una muy completa victoria que acaso disipe para siempre nuestros cuidados en orden a la provincia de Potosí

(35) ABASCAL. Memoria. Tomo II. Pág. 526.

(36) Arch. Abascal. Acta de la Junta de Guerra celebrada en el Cuartel General de Challapata el 16 de junio de 1815. Formaron aquella Junta, Pezuela, Tacón, Olañeta, Mendizábal, Valdés, Maroto, Alvarez, Benavente (Sebastín'), Rolando, Valle, Irareburu, Vigí y Arrieta. Todos ellos formaban el cuadro de jefes del ejército de Pezuela. 
y todas las aemás situadas a espaldas de ella...8 (37).

Hasta ahora no se tenian noticias exactas de que los \&rgentinos no hubiesen comenzado a avanzar. La Hegada de una pequeña partida a Vilcapugio hizo creer que se habian puesto en marcha; pero Marquiegui, que se hallaba en Condocondo con las avanzadas realistas, destacó a su vez otra partida de observación, gue llegó hasta Torapalca en persecución de aquélla. Fisto era un indicio de que no se trataba de los preliminares de un ataque.

Poco después tuyo lugar la incorporación de las tropas de Ramírez, que volvían del Cuzco. Se unieron al ejército de Rezuela 1.500 hombres con el vestuario, dinero y material de que eran portadores. Con dicho refuerzo parecía lógico que el general se lanzase a la ofensiva contra Rondeau, cuyas tropas permanecian estacionadas en Yocalla. Incluso las órdenes de Abascal iban dirigidas en ese sentido y aconsejaban un inmediato ataque (38).

Pero la gran preocupación de Pezuela la constituía el estado amenazador del Alto Perú. Las campañas que periódicamente comenzaban Arenales y Warnes, y que culminaron con la poupación de Cochabamba, eran un peligro constante a espaldas del ejército. Y una de las cosas que más temía Pezuela era quedar aislado del Perú por la posible caída de Oruro en poder de los sublevados. De ahi la determinación de retirarse a Sorasora tan pronto se tuviesen noticias de que las argentinas se ponían en marcha. Quería evitar a toda costa, aun a trueque de entregarles el territorio sin lucha, una aoción conjunta enemiga, que colocaría a su ejército entre dos fuegos.

Así, en el momento en que se tuvieron noticias en el Ouartel General de los movimientos de Arenales y demás caudillos altoperuanos en el partido de Chayanta, Pezuela previó un ataque de éstos sobre Oruro en cuanto entrasen en contacto con Rondeau. Inmediatamente reunió una Junta de Guerra para dell-

(37) Arch, Abascal. Oficio de Pezuela al Virfey, Marqués de lá Concardia, Cuartel Generál de Challapata, 23 de junjo de 1815.

(38) Arch. Abascal. Oficio de Abascal a Ramírez. Lima, 11 de agosto de 1815 . 
berar sobre la nueva situación. El problema a diseutir era si convénía salir en busca del enemigo y déat a Oruro con su sola guarnictón ante la posibilldad del ataque argentino, o si era preferible retardar la bitalla hasta la llegada de las tropas de la expedidión do Morillo, en cuyo caso se imponia el repliegue hacia Oruro.

La deliberación de la Junta dió por resultado la orden de retardar el ataque hasta la llegada de los peninsulares. Se hacían ver los peligros apuntados anteribruente, y el que se habría de derivar de la ocupación de los parques de armamento y municiones de Oruro por los sublevados, además del gran prestigio que adquiririan por este hecho, y como última comseeuencia, interceptarian las líneas de comunicaciones del ejército, anulando así todas las ventajas que se obtuvieran sobre los argentinos (39). Así pues, se imponía el repliegue a sorasora, a pesar de que el Virrey no era partidario de dicha medida; para él, el interés de batir al enemigo no contrapesaba al riesgo de exponerse a perder aquello mismo que deseaba conservary (40).

Pero la opinión de Abascal Hegó tarde, ya que poco después de celebrada la Junta, el $10^{\circ}$ de septiembre, las tropas realistas iniciaban su salida en dirección a Oruro $y$ colocaban las avanzadas en Venta y Media, y el Cuartel General en Sorasora. \&La posición de somasora ofrecia mayores ventajas para proteger la villa de Oruro y el partido de Sicasica, amenazados ambos puntos por grandes reuniones de indios alzados, y cubría al mismo tiempo a La Paz y la línea del Desaguadero, quedanda ez general Pezuela, como se proponta, en mejor disposición de proporcionarse los recursos de que carecía, paralizar las tentativas del ejército enemigo, y aun atacarlo con prontitud si presentaban una ocasión favorable» (41). Esta ocasión pensaba encontrarla Pezuela cuando se le incorporasen las tropas de la expedición de Morillo.

(189) GARCIA CAMBA, A. Op, cit Tomo I. Rágs. 2823-224. Agistibron a esta Junta, celebrala el 26 de agosto, Pezuela, Ramirez, Tacón' Maroto, Valiés y Mendizábal.

(40) ABASCAL. Memoria. Tomo II. Pág. 532.

(41) GARCIA CAMBA, A. Op.'cit. Tomo I. Pág. 226. 
A principios de agosto se supo que dichas tropas habian variado de destino. En lugar de desembarcar en el Rio de la Plata, lo harían en Costa-Firme, desde donde parte de ella se dirigiría hacia el Alto Perú. Con dicho fin, Abascal envió a Panamá los buques necesarios para su transporte. En ellos irían al Perú 1.600 hombres, de los cuales, una parte, la cuarta división, se dirigló al Callao, pero la segunda de Cádiz, formada por los batallones de Ordenes Militares y Voluntarios de Navarra, destinados al puerto de Arica para incorporarse al efército de Pezuela, cambió de destino y no arribó al Perú (42).

En consecuencia, debía modificarse completamente el plan trazado. Las fuerzas llegadas al Callao serian destinadas a guarnecer la capital del Virreinato y las Provincias, y Pezuela no recibiría los refuerzos. El Virrey se excusa ante el giro de los acontecimientos. - A poderse prever este último incidente que me privó del auxilio ofrecido-dice-, hubiera hecho pasar la cuarta división del ejército de Morillo en auxilio del general Pezuela, sujetándome a vivir en la amargura y cuidados en que quedé con la deshecha guarnición de la capital en ocasión que era preciso se aumentasen con el restablecimiento de la contribución extinguida por las Cortes, pues ni podía tener tropas sin que reconociesen los naturales esta Justa obligación, ni ella se hubiera reconocido Jamás sin exponerse a grandes alborotos en los partidos; lo cual ha evitado el respeto de las tropass (43). La inseguridad que a los Jefes de las Provinoias les ofrecían sus distritos, hacia que constantemente solicitasen auxilios al Virrey, que había de dárselos de la única fuerza que entonces tenía en Lima, para cuya seguridad nece-

(42) Se componían las tropas que llegaron al Perú formando la cuarta división al mando del Brigadier don Juan Manuel Pereira, del Regimiento de Extremadura, mandado por don Ma'riano Ricafort, en el que iba de oficial don Baldomero Espartero; del cuarto escuadrón de Húsares de Fernando VII, mandados por don Josquín Germán; del cuarto escuadrón de Dragones de la Unión, al mando de don Vicente Sardina; una Compañía de zapadores y otra de artilleros a ple. (GARCIA CAMBA, A. Op. cit. Tomo I. Pág. 242).

(43) ABASCAE. Memoria. Tomo II. Págs. 535-536. 
sitaba también de cierto número de tropas. De todos modos, aún cabe preguntarse si no hubiese podido enviar entonces, siquiera parte de ellas al Alto Perú.

Seguramente el Virrey no consideraba de extrema necesidad estos nuevos auxilios a Pezuela. Se recordará que antes de la llegada de las tropas españolas le habia aconsejado no sólo dar una batalla al enemigo, sino que la diese sin una retirada previa, coma pretendía el general. Su plan consistía en colocarse en «una situación fuerte y abundante, donde con marchas y contramarchas sobre uno y otro flanco, procurase sacar al enemigo del punto interesante de Yocalla que ocupaba, hasta llevarlo a paraje más a propósito para batirlo», para lo cual no consideraba necesaria la retirada a Sorasora anunciada por $\mathrm{Pe}$ zuela (44).

El cambio de destino de la expedición de Morillo fué sin duda un error del Gobierno español. Si en lu gar de marchar a desgastarse en las tlerras pantanosas de Cotombia y Venezuela, se hubiera dirigido al Río de la Plato, hubiese originado una grave crisis a la revolución argentina. El avance de Sur a Norte hubiese sido más fácil que el que se intentaba efectuar a través del Valle del Magdalena y demás territorios andinos. $Y$, por último, un fuerte golpe asestado contra los argentinos, hubiese sido de mucha más trascendencia para los fines realistas que la pretendida dominación en la parte septentrional del Continente. Además, aun cuando hubiera conseguido el éxito en el Norte, le quedaba que enfrentarse con un enemigo mucho más poderoso en el Sur; no hubiera ocurrido asi en el caso contrario, en que, dirigiendo sus esfuerzos contra la revolución chilenoargentina, les hubiera sido más fácil después de vencer al aislado foco neogranadino. El mismo Virrey del Perú tenía ideado un plan para atacar a los sublevados del Norte una vez acabada la lucha contra el Sur. Lo dice claramente: *...por lo que correspondía al Reino de Santa $F$ e, tenla trazado mi plan, de que, luego que se tranquilizasen las provincias del Río de la Plata, hacer navegar desde el Valparaíso a

(44) ABASCAL. Memoria. Tomo II. Pág. 532. 
Guayaquil la parte necesaria de la fuerza que quedara disponible para dirigirse por Quito y Popayán, aumentando su número con las que hubiese en ambos puntos, para atacar y reducir al llamado Reino de Cundinamarca (45). Unidas las fuerzas de Morillo a las del Virrey, el contingente de tropas realistas se hubiera encontrado en condiciones de acabar con la sublevación de Bolivar.

Pero no ocurrió así, y los planes del Virrey hubieron de modificarse. De ahi su constante insistencia para no demorar el ataque contra los argentínos. Cuanto más tiempo se perdiera, se les ofrecian más posibilidades de éxito, pues, desembarazados del peItgro de las tropas de Morillo, podrian a su vez reforzar las de Rondeau, mientras Pezuela no recibiría ningún auxilio.

Mas, como tardaron en llegar al Cuartel General las notlcias sobre la expedición de Morillo, nos encontramos explicada la opinión de la Junta del 26 de agosto, a la que Pezuela no quiso oponerse. Esto debió đisgustar a Abascal, partiđario de una acción Inmediata desde tiempo atrás, y mucho más ahora, conocedor de que no iba a recibir refuerzos inmediatamente, como se suponia.

La insistencia del Virrey y su critica a las decisiones de la Junta molestó a Pezuela, que se había retirado a Sepulturas poco después de su llegada a Sorasora, a causa de un quebranto en su salud, producido por una intensa nevada que le cayó al ejército a la subida de Challapata (46). Sin embargo, poco después le vemos de nuevo, a principios de octubre, encargado del mando. Es entonces, al recibir las quefas de Abascal, cuando expone su parecer sobre el momento y sus posibilidades de éxito. En primer lugar, hace saber al Virrey su intención de haberse lanzado al ataque tan pronto hubiera recibido los refuerzos de Chile y las tropas de Ramirez; con todas ellas contaba aumentar las suyas en $\mathbf{2 . 3 0 0}$ hombres, pero cuando llegaron, sólo se encontró con 1.800 , de los cuales, 800

(45) ABASCAL. Memoria. Tomo II. Pág. 534.

(46) Arch. Abascal. Oficio de Pezuela al Marqués de la Concordia. Sepulturwar 26 de deptieanbre de 1816. 
eran reclutes, mal equipados y peor instruidos. Aun así, cuando se disponía a levantar el campo y marchar contra el enemigo, recibió la orden del Virrey de que se le incorporase la columna del coronel Lavín, que se encontraba en Paria para contener a los sublevados del Alto Perú. Esto fué lo que le impulsó a reunir la Junta de Guerra, pues, al decir del general, se consideraba a consecuencia de dicha orden «envuelto por ella en una grave responsabilidad: de falta de obedecimiento si no la cumplía literalmente y era batido por desgracia, de falta de previsión, si, por cumplirla materialmente, abandonaba la plaza de Oruro y su gran repuesto de municiones a discreción de Arenales, Lanza, Lira y otros caudillos que la amagaban de cerca... (47). El ataque a Oruro le parecía inminente, y si se llevaba a efecto, dudaba de su resistencia frente a las tropas de Arenales.

Con semejante argumento y el de sacar a las tropas de Rondeau de sus posiciones de Yocalla con su retirada a Sorasora, a la par que se acercaba al esperado refuerzo de las tropas peninsulares, explicaba Pezuela su modo de obrar. Se dejó ver en él, como he dicho más atrás, su constante preocupación por la suerte de Oruro, punto vital para la subsistencia del ejército, preocupación que se nota en el curso de los posteriores acontecimientos. Incluso pensaba el general, una vez que se le reunieran los peninsulares, enviar una fuerte columna contra los altoperuanos, y con el resto de las tropas marchar contra Rondeau, en una operación simultánea de ambos contingentes.

En espera, pues, de ellos, ninguno de los reunidos en la Junta de Guerra dudó del arribo del refuerzo. La única dificultad que subsistía era el peligro de que Rondeau lo recibiese a su vez. Pero según los avisos del Virrey, aquél llegaría a mediados de septiembre, $\Varangle$ por las conjeturas que se podían deducir, el Gobierno de Buenos Aires no podría socorrer a su general antes de noviembre, con lo cual la ventaja estaba de parte de los realistas.

Pero una vez convencido Pezuela de que esperaba

(47) Arch. Abascal. Informe de Pezuela al Marqués de la Concordia. Cuartel General de Sorasora, 19 de octubre de 1816. 
en vano la llegada de tropas, debió comprender la insistencia de Abascal: «Ya hoy han variado las cosas-le dice-: no dista el tiempo en que por mis cómputos debe recibir Rondeau sus refuerzos de Buenos Aires: me contemplo desahuciado de que le lleguen tropas de Espanfa y de que V. E. ni me habla: veo enteramente agotados todos los recursos de dinero para la manutención de las tropas, ni en la Caja Militar hay un peso para la buena cuenta del mes próximo, habiendo quedado varios individuos, y yo entre ellos, sin percibir los sueldos del presente y anterior; y finalmente, si hube de tener por ordenes de atacar, las indicaciones de las precedentes cartas de V. E., con mayor razón debo graduar de una orden terminantísima de ejecutarlo lo que se sirve V. E. decirme... pues aunque han variado las cosas de entonces acá, ha sido más bien en favor nuestro, por habérsenos aproximado los enemigos y situándose menos ventajosamente que antes» (48).

En realidad, tal como pinta la situación Pezuela, no le cabía otra salida que ponerse en movimiento, so pena de ver deshacerse su ejército, sin refuerzos y sin sueldos. Sin embargo, el paso era arriesgado y de graves consecuencias: «avistados los ejércitos, no hay alternativas para éste entre el vencer y el perecer». Habia que arriesgarlo todo: una retirada ordenada era punto menos que imposible, habida cuenta del estado de ánimo del Alto Perú: r...las tropas del Rey no encuentran amigos fuera de sus cuarteles; todo indio es espia de los contrarios; éstos nos aventajan siempre en caballería, y habiendo de caminar por lugares casi estériles, campos devastados y poblaciones desiertas, en vano es pensar en proveerse de viveres y forrajes luego que se consuman los que podamos transportar (49). He aquí explicado el recelo de Pezuela a entrar en batalla abierta con el enemigo; tanto más, cuanto que la diferencia entre el número de sus tropas y las de éste era escasa. Según un estado de fuerzas realistas del 12 de octubre, el ejército de operaciones ascendía a 4.955 hom-

(48) Vid. nota 47.

(49) Vid. nota 47. 
bres (50), mientras el de los patriotas oscilaba alrededor de 4.500, sin contar con el apoyo que pudieran recibir del Alto Perú.

La escasez de tropas hacia desconfiar al general realista de un éxito rotundo y definitivo: \&...aun en el supuesto de que todas sean ventajas a medidas de nuestros deseos, el expresado miserable resto de las tropas victoriosas, apenas podría alargarse hasta Tupiza o Suipacha para permanecer alli por sólo el tiempo que acomodase a los vencidos, porque por fatal que les sea la acción, es regular salven alguna gente de ella; lo es también que no tardarán en recibir los auxilios de la capital... y en el peor caso bajarian a Jujuy o Salta a rehacerse y volver a los pocos días para hacernos replegar más o menos lejos, según la disposición de los pueblos de nuestra espalda y las fuerzas que trajesens (51).

La opinión de Pezuela sobre este momento concreto de la lucha es por demás aplicable a toda ella. Aunque he insistido sobre el asunto, se debe hacer notar la realidad que encierran tales palabras. Con un exiguo contingente de tropas, como el de que disponía el general, no era posible obtener una victoria aplastante; sus tropas apenas podrian pisar el territorio argentino, y, una vez en él, les tocaría esperar el momento de ser arrojadas de alli nuevamente hacla el Alto Perú. Era, pues, de todo punto necesario, ya que no cabía pensar en un desembarco en el Río de la Plata, el envío de una numerosa tropa disciplinada, si se quería asegurar un éxito que fuese un jalón definitivo en el camino hacia un fín victorioso de la guerra. He aquí reflejada una consecuencia del error cometido al cambiar de destino a la expedición de Morillo.

A pesar de todo, Pezuela se dispuso a marchar al encuentro de los enemigos. Pero antes de ponerse en movimiento, en la madrugada del 20 de octubre, tuvo lugar un choque entre las avanzadas de ambos ejér-

(50) Arch. Abascal. Estado de las fuerzas, artillería ₹ armamento del Ejército Real del Perús. Mayoría General del Ẻjército. Cuarte General de Sorasora, 12 de octubre de 1816.

(51) Arch. Abascal. Informe de Pezuela al Marqués de la Concordia. Cuartel General de Sorasora, 19 de octubre de 1815. 
citas en el pueblo de Venta y Media. Los argentinos, en número de 500 hombres, creyeron de igual número o inferior a las trodas realistas situadas aquí, mandadas por Olañeta, y eompuestas de 900 hombres. Hacia las cuatro de la mañana del 20 de octubre tuvo noticia el jefe realista de una infiltración enemiga por el costado izquierdo de sus avanzadas. Inmediatamente puso sobre las armas a todas sus fuerzas y ordenó el repliegue de su izquierda. Olañeta creía que el Brigadier Rodríguez, jefe de la columna enemiga, habría sido detenido por las tropas que cubrian su retaguardia, por lo cual ordenó destacar un batallón para mantener la protección de aquélla, y un escuadrón desmontado para apoyar la avanzada que había sufrido la infiltración. Pero la avanzada de la retaguardia había sido arrollada, y el batallón que iba en su auxilio fué envuelto. Olañeta, al frente del resto de las tropas, marchó en su ayuda hasta colocarse a su izquierda, desplegando ante la columna enemiga. Aún no le había dado tiempo a ésta de colocarse para hacerle frente, cuando todas las fuerzas del jefe realista se lanzaron al ataque y arrollaron a las argentinas. Las pérdidas de los patriotas fueron numerosas: 150 muertos, 158 prisioneros, 325 fusiles, 130 bayonetas y otros efectos de guerra. Por su parte, los realistas sufrieron 42 muertos y 32 heridos (52).

Durante el combate hubo un momento difícil para los realistas, debido seguramente, como opina Garcia Camba, a la falta de pericia militar de Olañeta. Este, que según dicho historiador «era un hombre de valor conocido, pero imperito en el arte militar», peçó de imprevisión al enviar uno de los batallones que tenia a sus órdenes, «sin saber la fuerza con que contaba el enemigo, a consecuencia de lo cuąl, dicho batallón se vió en grave apuro de ser aniquilado, como efectivamente hubiera ocurrido a no ser por la pronta aparición del propio Olañeta con el resto de sus fuerzas (53).

(52) Arch. Abascal. Parto de Olañeta a Pezuela. Cuartel General de Venta y Media, 20 de octubre de 1815.

(53) GARCIA CAMBA, A. Op. cít. Tomo I. Pág, 230. Conviene, sin embargo, para juzgar tal apreciación, tener en cuenta 
Sin embargo, la llegada de auxilio fué tan oportuna, que puso en total desorden a los enemigos. Un testigo del lado argentino lo explica así: «...el enemigo se habia contenido y se agrupaba y remolineaba en el mayor desorden, cuando en la cresta de la segunda altura se dejó ver de improviso otro batallón que, tomándonos a boca de Jarro, nos abrasó con sus fuegos. Ya no tuvimos más remedio que zafar des-ordenadamente por entre los dos cuerpos enemigos para descender la loma por el otro costado del que la. habian subido» (54). Un último intento de los argentinos fracasó de nuevo y completó su derrota.

Pero el éxito no pudo ser aprovechado como hubieran deseado los realistas. Su carencia de caballos les impedía explotarlo. Si los hubiesen tenido, el triunfo hubiera sido aplastante. El mismo testigo antes citado dice a este respecto: «Es seguro que si se hubiese empleado esta arma (la caballería) para completar nuestra derrota, hubiéramos escapados muy pocos...8 (55). Una vez más se echa de ver la falta de que en todo momento adoleció el ejército realista.

Animado Pezuela por el primer éxito, y desoso de aprovechar sus efectos, decidió emprender la marcha en busca de las tropas de Rondeau. Se hallaban éstas situadas en Chayanta, pero ante los rumores de su aproximación, se retiraron en dirección a Cochabamba. Por una parte, el general argentino quizás quisiera con ese movimiento evitar el choque con los realistas, pero no es extraño que pensara también reunirse allí con las tropas de Arenales, Lanza, etc., y, una vez reforzado, lanzarse a un ataque sobre Oruro.

Pezuela salió de Sorasora el primero de noviembre en dirección a Chayanta. Al segundo día de marcha sufrió una fuerte nevada en la estancia de Bombo, que le obligó a detenerse. Y esa fué la salvación de Rondeau, que, en caso contrario, se hubiera visto obligado a aceptar batalla en condiciones sumamente

que Qlañeta fué el General que más tarde se sublevó en el Alto Perú contra el Virrey La Serna, a cuyas órdenes se mantuvo, por el contrario, García Camba, autor de las Memorias.

(54) PAZ, J. María. Op. cit. Pág. 310.

(55) PAZ, J. María. Op. cit. Pág. 312. 
desventajosas. En cambio, ahora tuvo tiempo de retirarse hacia Cochabamba y esquivar la lucha.

El temporal hizo temer a Pezuela el paso de la cordillera para llegar a Chayanta, y como a la par tuvo noticias de la retirada de los enemigos, hubo de variar su dirección de marcha. Dirigióse entonces por la quebrada de Tapacari hacia Cochabamba, con el fin de proteger a Oruro en su movimiento contra la amenaza de los patriotas, y cortarles el camino de aquella ciudad. El 21 de noviembre llegó a Tapacari, en donde permaneció hasta el 24. De allí, desviándose ligeramente hacia la izquierda, llegó el día 26 a los Altos de Chacapaya, las últimas eminencias de la cordillera, que distaban dos leguas del punto en que Rondeau tenía instalado si campamento.

El sitio en que estabar $r$ jlocados los argentinos era una gran llanura rodeada de montañas, con una serie de lomas en el centro, al pie de un plano inclinado que domina la llanura. En vista de que la bajada al llano por la quebrada de Chacapaya era muy difícil y que la salida del desfiladero estaba dominada por los patriotas, se corrió Pezuela hacia su izquierda para efectuar el descenso por los Altos de Wiluma. La posición de los realistas en este punto era inmejorable, «porque además de presentar el terreno unas lomas suavemente tendidas hacia el llano, por las que en caso necesario podía descender la infantería con bastante frente, ofrecía a media cuesta una pequeña mesa, donde colocada la artillería, hubiera alejado a los enemigos que se aproximasen al pie de la cuesta» (56). El descenso desde aquí hasta la llanura se llevó a cabo con bastante dificultad bajo el fuego enemigo; pero al fin consiguieron los realistas situarse en el llano. Con ésto terminó la primera etapa de la batalla.

Al día siguiente, 29 de noviembre, el ejército realista desplegó sus fuerzas frente al río Sipe-Sipe, de tal forma que las tropas argentinas que guardaban la entrada de la quebrada de Chacapaya quedaban con su flanco derecho descubierto, lo que les obligó a efectuar un cambio de frente y a colocarse en los bosques

(56) GARCIA CAMBA, A. Op. cit. Tomo I. Pág. 258. 
que bordeaban el rio. Los realistas decidieron llevar a cabo un ataque oblicuo sobre las posiciones argentinas a través del rio. El primer choque fué de bastante dureza, pues las tropas de Rondeau resistieron firmemente los ataques realistas, que, poco a poco, fueron progresando.

Obligados a retroceder, los patriotas hubieron de retirarse a una segunda posición, divididas sus fuerzas a ambos lados de las lomas centrales del llano. Aún aqui, fuertemente cargada su derecha, se vieron obligados a replegarse a una tercera posición, en donde se inició la retirada general (57).

El número de pérdidas habidas por los argentinos en esta acción no se ha podido fijar exactamente. Mitre compara los diferentes Juicios emitidos por varios actores de la misma e historiadores posteriores, y por su parte apunta como el número máximo de pérdidas posibles el de 1.000 hombres (58). Por el contrario, las pérdidas realistas se fijan en cinco oficiales, 32 soldados muertos y 198 heridos.

Las causas de la derrota argentina hay que buscarlas, en gran parte, en la ineptitud de Rondeau. La dirección de la batalla correspondió en todo momento a Pezuela, cuyos errores no supo aprovechar el general argentino. El hecho citado por Garcia Camba, de que desplegase sus fuerzas para avanzar por el flanco argentino bajo el fuego de la artilleria y que no fuese atacado, ni molestado siquiera por éstos, demuestra la poca iniciativa de sus jefes (59).

Efectuado dicho movimiento felizmente, la batalla estaba decidida. «Pezuela avanzó resueltamente y, desplegado en batalla, sufrió el fuego de artilleria; desalojó a los tiradores patriotas del barranco (en donde se apoyaba la derecha argentina), se lanzó

(57) Arch. Abascal. Parte de Pezuela a Abascal. Cuartel General del Campo de Wiluma, 29 de noviembre de 1815.

(58) MITRE, B. Historia de Belgrano. Tomo II. Buenos Aires, 1887. Pág. 30日; nota 18. Confronta el pareeer de Pezuela, que suponen 1.500 muertos y 500 prisioneros, además de 500 heridos, con el de García Camba, que calcula 500 muertos, 800 prisioneros y 1.000 heridos, y el de Torrente, con 1.200 muertos, 300 prisioneros 600 heridos.

(59) GARCIA CAMBAy A. Op. cit. Tomo I. Pág. 262. 
sobre la derecha de la posición, que, tenazmente defendida al principío, hubo de ceder al fin a su empuje. Mientras tanto, la derecha realista se corría en desfilada a lo largo del indicado barranco y vigorizaba el ataque a la vez que amagaba a la izquierda argentina. Rota la derecha de los patriotas, y en inacción su lzquierda, la batalla estaba completamente perdida (60).

Quizás esta pasividad del ejército argentino, que en todo momento concibió la maniobra como un movimiento defensivo, era resultado de la poca disciplina que reinaba en sus filas y que todos los historiadores están unánimes en afirmar. Un protagonista de la luoha, nada sospechoso de parcialidad hacia los realistas, afirma que el ejército argentino que intervino en la batalla estaba «desmoralizado y vencido desde antes, por el desorden y la anarquía en que lo había constituido la insubordinación de los jefes» (61). $\mathrm{E}$ indudablemente ésto no era sino el resultado de la poca firmeza de carácter del general, unido al hecho de haberse apoyado en los jefes del ejército para mantenerse con el mando en contra de la voluntad del Gobierno de Buenos Aires.

En el campo realista. Pezuela, como mérito a su comportamiento en la batalla, ascendío a Ramirez al grado de Teniente General; a Tácón, a Mariscal de Campo; a Brigadieres, a Valdés, Olaf́eta y Alvarez; y a otros más que se distinguieron aquel día.

La batalla de Wiluma tuvo graves consecuencias para el ejército argentino. Aparte de la desorganización consiguiente, supuso la pérdida definitiva del Alto Perú para el Gobierno de las Provincias Unidas del Rio de la Plata. Inmediatamente después de la batalla, las tropas se retiraron a Moraya, en donde pretendieron hacerse fuertes, pero pronto hubieron de evacuarla ante el avance realista. Por su parte, los sublevados del Alto Perú se retiraron a Santa Cruz de

(60) MITRE, B. Historia de Belgrano. Tomo II. Buenos Aires, 1887. Pág. 397.

(61) PAZ, J. María. Op. cit. pág. 323. Son curiosos a este respecto los casos que cita el autor y que demuestran palpablemente el grado de relajación a que se había llegado, principalmente entre jeles $y$. oficiales. Pags. 314 y 315. 
la Sierra, a cuyos alrededores limitaron sus actividades.

Abascal quiso aprovechar el momento favorable que se le ofrecía, en el que la revolución parecia pasar por un periodo de crisis militar $\mathbf{\nabla}$ politica. Sus armas victoriosas habian sofocado la revolución de Chile y aplastado la sublevación del Cuzco, a la par que por el Norte, las tropas de Morillo amenazaban terminar con la sublevación en Santa Fe. De ahí las órdenes que dió a Pezuela para perseguir a los derrotados hasta el Tucuman, con objeto, no sólo de causarles mayor perjuicio, sino tambien para alejar todo posible peligro de seducción de los pueblos del Alto Perú por los invasores.

En primer lugar, Pezuela destacó una columna al mando de Olañeta, comandante de la vanguardia, para ocupar Potosí, como llevó a cabo el 16 de diciembre, entrando en una ciudad desolada por los horrores de la guerra (62). Igualmente se destacó otra columna mandada por Ramírez para ocupar La Plata, pero antes de la llegada de las tropas había sido evacuada la ciudad por los insurgentes, de forma que, cuando Ramírez se presentó ante ella, no encontró la menor dificultad para ocuparla. A la par, el general había marchado para Cochabamba, que también ocupó sin dificultad, y estableció en ella su Cuartel General hasta que más tarde lo trasladó a Potosí, y luego a Santiago de Cotagaita. Del mismo modo, una columna mandada por el coronel Aguilera salió en dirección a Santa Cruz de la Sierra, en donde se habían refugiado gran cantidad de fugitivos de Cochabamba y de los otros puntos del Alto Perú.

En tal situación, parecía posible que el ejército virreinal emprendiese una ofensiva tal como el Virrey proponia, para liberar definitivamente de nuevas invasiones el Alto Perú. Sin embargo, los propósitos de Abascal no pudieron llevarse a cabo. El ejército realista constaba entonces de $\mathbf{7 . 3 4 0}$ hombres, de los cuales 3.800 estaban destinados a guarnecer aquellos puntos que sufrían las correrías de los grupos de insurgentes

(62) Arch. Abascal. Parte de Olañeta a Pezuela. Potosí, 16 de diciembre de 1815 . 
dispersos por aquel territorio, de forma que, sólo poco más de 3.500 quedaban disponibles para llevar a cabo cualquier operación contra los argentinos (63). De ahí, que poco después de la batalla de Wiluma, el propio Pezuela se dirigiese una vez más al Virrey en demanda de refuerzos, aunque fuese de tropas de la guarnición de Lima. Pero el Virrey no podía desprenderse de ellas, y se vió imposibilitado de continuar su avance y obligado a mantenerse en el limite del Alto Perú. De esta forma, una vez más, por falta de tropas, se malograban las prometedoras posibilidades de un éxito logrado con gran trabajo.

(63) ABASCAL. Memoria. Tomo II. Pág. 545. 


\section{CAPITULO XII}

\section{LA REVOLUCIÓN DE CHILE: RANCAGUA}

La estrecha faja costera que se extiende al Sur del Perú y se prolonga hasta el Estrecho de Magallanes, entre el mar y la inmensa muralla andina, constituía desde 1797 la Capitanía General de Chile, segregada del Virreinato del Perú. La vida en este país, eminentemente agrícola, transcurría sin graves problemas para sus habitantes. Su organización diferia fundamentalmente de la del resto del Continente. «Dominaba en el reino un cierto número de familias, respetadas por el recuerdo de sus antepasados, poderosas por sus riquezas, por sus relaciones, por la multitud de sus dependientes, estrechamente ligadas entre sí, y con una organización patriarcal» (1), y estas familias monopolizadoras de la vida del pais, pocas en cantidad, ejercian una influencia enorme en la marcha de los negocios del mismo. Tal peculiaridad en la forma de vida de la colonia ha de influir más tarde extraordinariamente para dar un matiz especial a su movimiento emancipador.

(1) AMUNATEGUI, y VICUNA MACKENA, M. L. y B. La Dictadura de O'Higginв. Bibl. Ayacucho. Madrid, s. a. Pág. 42. 
El otro elemento poderoso en la vida del país lo constituia el Cabildo. No hace falta insistir en la influencia del Cabildo en el gobierno de toda la América española. No es de extrañar, pues, que la fuerza del de Santiago fuese extraordinaria. Por tanto, si tenemos en cuenta estos dos elementos, el poder absoluto repartido entre unas cuantas familias, y la preponderancia del Cabildo, nos hallamos ante las dos fuerzas principales promotoras de la revolución en Chile.

Desde el momento en que dichas familias se enfrentasen con el Gobierno colonial, el germen de la sublevación estaba lanzado. Lo demás, teniendo en cuenta las circunstancias, vendría determinado en gran parte por la inercia del primer movimiento. $Y$ lo primero no era difícil. «Ya hemos visto que la fuerza pública estaba en manos de los criollos. Les faltaba sólo quererlo para adueñarse del Poder público. Este tránsito de la subordinación a la rebeldia iba efectuándose en las conciencias de los hombres independientes y aun en las de los que estaban más o menos ligados con la jerarquía oficial» (2).

Ahora bien, precisamente por ser la nobleza criolla la detentadora del poder y la que puso en marcha el principio de la revolución, va a tener un matiz completamente diferente al que tuvo en las provincias del Plata. Allí se inicia con tendencias claramente democráticas; aquí, en cambio, se inicia con un claro matiz aristocrático y conservador. Sin embargo, quizás esta misma característica hace que la revolución se desenvuelva dentro del más perfecto orden, sin efusión de sangre y sin alteraciones profundas en la vida del país.

Así pues, el elemento criollo, que aumentaba sus deseos de independencia a medida que entraba sin obstáculos en la gobernación del país, fué echando los cimientos de la revolución. Lo demás no se iba a hacer esperar. El contacto con Buenos Aires y con los medios extranjeros que llegaban a Chile, comple-

(2) PEREYRA, Carlos. Op. cit. Tomo VIII. Madrid, 1924. 
taron la obra. No faltaba más que la causa ocasional que pusiese en movimiento todo el plan.

El motivo se halló bien pronto. Se encontró en la pugna entre el Cabildo y el Gobernador. La Audiencia, a quien Jamás fué simpático este personaje, se mostró en un principio indecisa, e incluso llegó a favorecer al Cabildo; cuando se dió cuenta del peligro que encerraba su actitud ya era tarde, la revolución estaba consumada. $Y$ es que dicho organismo vió frustrado sus planes para la elección de Presidente y Gobernador a la muerte de Muñoz de Guzmán. La elección de don Francisco García Carrasco produjo el descontento entre los Oidores, y el nuevo Presidente tampoco supo captarse sus simpatías durante su mando. Los roces y desavenencias a que dió lugar tan violenta situación contribuyó en gran manera a establecer un estado de tirantez de relaciones entre las autoridades españolas y el elemento criollo.

A dicha circunstancia vino a unirse poco después la noticia de la invasión de la Península por Napoleón. Se originó un estado de opinión semejante al que existia en las provincias del Plata. Al ser sometida la Península a un poder extraño, las colonias quedaban en libertad de acción para evadir su sometimiento a una autoridad ilegal. Estas ideas, fomentadas por don Juan Martínez de Rozas y don Bernardo O'Higgins iban poco a poco haciendo mella en la opinión pública chilena. Y lógicamente, el Cabildo de la capital, constituido en gran parte por chilenos, era el foco de ellas.

El Presidente Carrasco era hombre poco ducho en cuestiones politicas, y ante el peligro inminente que se le presentaba creyó encontrar una solución definitiva que atemorizase a los conspiradores. Don ínsé Antonio de Rojas, don Juan Ovalle y don Bernardo Vera, personajes principales de la conspiración, fueron remitidos al Callao sin más formalidades de Juicio, con una simple carta al Virrey. Tan arbitraria medida exasperó al elemento criollo, y puso claramente de manifiesto la oposición entre éste y el Gobernador.

De la pugna anterior entre la Audiencia y el Presidente, quien salió beneficiado fué el Cabildo, que ahora se enfrenta con él. Carrasco se encontraba solo 
y sin esperanza de ayuda. Por eso, el triunfo rotundo del Cabildo no se hace esperar. Por su parte, la Audiencia fluctúa entre su odio hacia el Presidente y el vago presentimiento de un grave peligro. Pero con su conducta no hace sino confirmar el triunfo del Cabildo. El Presidente se ve obligado a ordenar la vuelta de los detenidos; pero cuando se da la orden se hallaban ya camino de Lima, y la indignación sube de punto.

Sin embargo, la Audiencia quiso aún solucionar la cuestión y halla un término medio entre las dos opiniones que contentase a ambos. Con tal fin, tiene lugar la elección de un Presidente chileno en la persona del marqués de la Conquista, que por otra parte, debido a su edad no había de ser un gran obstáculo para los planes de los reformadores, evitando la deposición de Carrasco, que parecía inevitable.

En esta situación, se planteó el problema del reconocimiento del Consejo de Regencia. El Cabildo lo reconoció en un principio (3); pero pronto surgieron las discrepancias y se pretendió la reunión de un $\mathrm{Ca}-$ bildo abierto para lograr la tranquilidad y el orden que parecían perturbados por los partidos. La Audiencia se opuso a ello; pero ni la Audiencia ni el Presidente conservaban realmente el Poder, que en la práctica había pasado a manos del Cabildo.

Celebróse, pues, el Cabildo abierto el dia 18 de septiembre de 1810. En él, el Presidente que en la práctica carecia ya de toda autoridad, y ante la situación creada por el Cabildo, hizo entrega a éste đel mando, y lo convirtió así en cabeza de la revolución. Tal hecho significa, desde luego, el completo triunfo de la idea revolucionaria; el primer paso estaba dado. Los hechos posteriores se desprenden lógicamente de aquél.

La primera medida del Cabildo al recibir el mando del Presidente, fué el nombramiento de una Junta a imitación de las de la Península y la de Buenos Aires. Dicho organismo, presidido por el mismo marquẹs de

(3) MEDINA, J. Toribio. Actas del Cabildo de Santiago (1810-1814). Santiago, 1910. Acta correspondiente al Cabildo del 14 de agosto de 1810. Pág. 35 y 88. 
la Canquista, había de ser únicamente una solución transitoria hasta la reunión de los diputados de las provincias, a fin de nombrar al que había de tomar el Poder de un modo definitivo (4).

Pero si la revolución estaba en marcha, pronto surgen las primeras dificultades. La existencia de la oligarquia nobiliaria a que me he referido antes, traía consigo una constante pugna entre las familias que se repartían el Poder. Como consecuencia de ello, la rivalidad se traduce en el nacimiento de diferentes partidos que se disputaron el mando (5). En primer lugar estaba el partido del Cabildo, de matí moderado y sostenido por la gran masa de la aristocracia, de ideas conservadoras: su ceritro estaba en Santiago: Frente a él surge el partido capitaneado por Rozas, que se había retirado a Concepción y que abogaba por la completa independencia y el establecimiento de un Gobierno nacional: su centro se hallaba en Concepción. Y lógicamente, aparte de ambos partidos, y frente a los dos, se encontraba el que pudiera llamarse partido realista o español, que propugnaba la restauración de las legítimas autoridades, y que se hallaba capitaneado por los Oidores de la Audiencia.

La escisión entre los revolucionarios se puso pronto de manifiesto en la convocatoria del Congreso que se llevó a cabo después. Al principio la revolución se hizo por los moderados, pero pronto sus enemigos encontraron el medio de hacerse con el Poder. Se les presentó con la conspiración de Figueroa, merced a la cual, Rozas halló la ocasión para deshacerse de los principales enemigos realistas y disolver la Audiencia, su principal baluarte.

Pero en la elección del Congreso el triunfo correspondió a los moderados. Rozas y los suyos, insatisfechos se retiraron a Concepción para preparar una acción por su cuenta. Pero entonces aparece en escena un hombre que simboliza el cambio de rumbo que

(4) MEDINA, J. T. Op. cit. Acta correspondiente al Cabildo de 18 de septiembre de 1810 . Pág. 60 y ss.

(5). AMUNATEGUI y VICUNA MACKENA. Op. cit. Página 45. 
poco tiempo después iba a sufrir la revolución: Josẻ Miguel Carrera.

Carrera unía a toda la ideología exaltada de Rozas y los suyos, su carácter de militar y su extraordinario ímpetu. Había luchado en España contra la invasión francesa y llegó a Chile cuando ya la revolución estaba en marcha. Pronto se puso al frente del partido turbulento radical, y, tras el levantamiento del 4 de septiembre de 1811 , los radicales se hicieron de nuevo con el Poder. Pero en su triunfo olvidaron a aquél por quien habían llegado a la altura, y eso no lo podía sufrir Carrera. El prestigio obtenido en el golpe del 4 de septiembre le hacia considerarse como postergado, y para reivindicar sus derechos pensó en una nueva revolución. Los realistas estaban confiados en él, pues creian ver en su descontento para con la facción gobernante un punto de partida para la restauración. Carrera, por su parte también lo daba a entender así para obtener su apoyo. Pero una vez que hubo probado suerte y le sonrió el triunfo el 15 de noviembre en una repetición de la asonada de septiembre, se desentendió de ellos y procuró, al contrario, atraerse a sus enemigos radicales. Ahora bien, no consiguió su propósito, pues sus enemigos Jamás le perdonaron el asalto al Poder. «Chile tuvo así dos gobiernos de hecho: el de Santiago, que era una dictadura de sable, representada por Carrera, y el de Concepción, en donde dominaba el doctrinarismo, que, disponiendo de las tropas fronterizas y de las milicias del Sur, amenazó con un avance para la restauración del Congreso (6). A tal punto llegó la hostilidad entre ambos partidos, que hubo un momento en que sus fuerzas se encontraron frente a frente separadas por el río Maule.

Sin embargo, ninguno de los dos deseaban llegar a la lucha. Así es que la contrarrevolución de Valdivia vino a llenar sus deseos y se concertó la paz entre ambos. Sin embargo, a pesar de la paz rel país estaba dividido en dos diferentes gobiernos. Desde Atacama hasta el Maule, dominaba una Junta de gobierno, o más.bien, don José Miguel Carrera, que la presidía.

(6) PEREYRA, Carlos. Op. cit. Tomo VIII. Madrid, 1924. Página 218. 
Desde el Maule hasta el Biobio imperaba la Junta de Concepción, que tenía por Jefe al doctor Rozas. En Valdivia estaba triunfante la reacción realista. Chiloé quedaba sometido a la dependencia del Virrey del Perú (7). La naciente revolución pasaba por un momento difícil y la primera preocupación de Carrera fué la de conseguir el dominio total del territorio. Le fué fácil desentenderse de Rozas, no enviándole el dinero para el pago de sus tropas; la consecuencia inmediata fué su caída llevada a cabo por sus mismos soldados. Carrera se encontraba dueño de casi todo el pais, desde el desierto de Atacama hasta el Biobio.

Entretanto, el Virrey del Perú, cuyo pais se hallaba vinculado económicamente en gran parte al Reino de Chile, se mantenía en una actitud expectante hasta ver el transcurso de los acontecimientos, aunque con la debida vigilancia para evitar cualquier contacto entre los revolucionarios chilenos y las provincias peruanas. Esta táctica del cordón sanitario es la misma que en un principio empleara contra la revolución argentina. Por su parte, la Junta de Chile tampoco se propasaba en sus relaciones con el Virrey, quien si bien la calificaba de eco de la de Buenos Aires, no podía menos de reconocer que su tendencia era mucho más moderada que aquélla, y que, en cuanto a sus relaciones con el Virreinato, no había cortado el comercio, ni siquiera la correspondencia epistolar (8). Todo ello, unido a las órdenes recibidas de la Peninsula para reconocer como legítima a la Junta de Chile, hacían que el Virrey adoptase una actitud de prudente reserva.

Sin embargo, Abascal se daba cuenta que tras la actitud de la Junta de Santiago se escondía un verdadero propósito de independencia, como había tenido ocasión de observar anteriormente con la conducta semejante mantenida por la de Buenos Aires. Si bien en un principio se colocó, como digo, en una posición

(7) BARROS ARANA, Diego. Historia de América. Tomo II. Santiago de Chile, 1908. Págs. 373-374.

(8) Arch. Abascal. Minuta de carta de Abascal a Pérez de Castro. Sin data ni fecha. 
meramente expectante, a medida que transcurria el tiempo y se traslucían más claramente los propósitos de los chilenos, comenzó a elaborar un plan de ataque contra este país, con objeto de lograr su pronta pacificación y evitar que en un plazo más o menos corto se convirtiese en una nueva amenaza para el Virreinato del Perú, que, unida a la de Buenos Aires, hubiera significado su total ruína. Ahora bien, para ello había una dificultad fundamental, que era la inexistencia de un ejército capaz de emprender las operaciones en territorio chileno.

Ya se ha visto la situación del ejército virreinal al comenzar la revolución de Buenos Aires. A duras penas logró el Virrey obtener un corto número de soldados, carentes casi por completo de instrucción, con los que hacer frente a la marea ascendente de los revolucionarios. Por otra parte, hasta despues de la batalla de Hurqui, la situación del Virreinato era delicada. Todas wus energías habian de concentrarse en las orillas del Desaguadero, amenazado con la invasión de las fuerzas de Castellí de un momento a otro. Gracias a la constancia de Goyeneche y sus oficiales y al tenaz esfuerzo de Abascal, se pudo superar aquella crisis. Aun así, hasta después de dominado todo el Alto Perú, no cabía la posibilidad de emprender una acción secundaria, que divirtiese el esfuerzo principal.

Pasada, pues, tan angustiosa situación, Abascal se dirigió inmediatamente hacia el Reino de Chile, cuya revolución seguía un camino ascendente, y que ahora, con la subida de Carrera al Poder, se apartaba de las disquisiciones doctrinarias para prepararse en el terreno de las armas. No es, pues, de extrañar que, dominada la situación en el Alto Perú, se dirigiese a Goyeneche en estos terminos: Como esas cuatro provincias están absolutamente tranquilas, he pensado que de las guarniciones que han quedado en los pueblos grandes se pudiesen extraer 3.000 hombres que caminasen a Salta o al Tucumán y podrian hacer una expedición desde este distrito por el camino que más acomodare para que de repente pasase la cordillera y se echase sobre Copiapó y Coquimbo, a fin de introducir la consternación en el Reino de Chile, 
y haciendo, por consecuencia, pensar racionalmente a la Junta insurgente de Santiagos (9).

Sin embargo, la idea del Virrey no prosperd. Goyereche le contestaba poco después y le advertia que era imposible la realización de tal proyecto, pues el atague por la costa era irrealizable, ya que toda ella se encontraba Jalonada de desiertos sin agua ni wiviente alguno. Según el general, no existía otro punto para la penetración en el territorio chlleno que. Mendoza, en lo cual se anticipaba a la idea que más tarde Hevó a la práctica San Martín (10).

El Virrey se encontraba entonces précticamente imposibilitado de realizar sus planes sobre Chlle, ya que en las circunstancias que decia Goyeneche no le era posible llevarlo a cabo. Pero pronto se le presentí una ocasión favorable, que no quiso desaprovechar. Fué a causa de la contrarrevolución de Valdivia, a que me he referido antes. Tan pronto tuvo noticias de ella, así como de la acaecida de un modo semejante en Osorno, previa la reunión del Aoverdo, der oretó la sacorporación de dichos territorios al Virreinato del Perú, como asimismo de la pnowincia de Concepcióni cuya disidencia respecto al Gobierna de Santiaga quiso aprovechat en beneficio propio (11).

jnmediatamente, con objeto de llevar a la práctica la incorporación, inició los preparativos de una expedición que se dirigiese a tierras de Ghile mantada por el Brigadier de Marina don Antonio Paraja, nombrado gobernador de la provincia de Concepolón. Pero el Virrey no pocia separarse de la tropa que tanta falta le hacia: así es que Pareja recibió órdenes de reuzir y adiestrar las tropas veteranas y de milieias que encontrase en estas regiones, para lo cual llevaba numerosos oficiales y 6.000 pesos; además del correspondiente vestuario para dichas fuerzas.

Mas, a pesar de todo, las órdenes que Pareja recibiera de Abascal no eran, ni mucho menos, las de co-

(9) Arch. Abascal. Copia de carta de Abascal a Goyeneche. Lima, 10 de octubre de 1812.

(10) Arch. Abascal. Carta de Goyeneche a Abascal. Potoss, 9 de noviembre de 1812.

(11) ABASCAL. Memoria. Tomo II. Págs. 165-166. 
menzar inmediatamente la lucha. Antes al contrario, sus indicaciones se encaminaban a lograr una conclliación con los sublevados, para lo cual el Brigadier reconocería los Cabildos y respetarta a las personas que ocupaban los puestos púbilteos; por el lado contrario, a éstos sólo se les exigia el juramento de fidelidad. La razón es obvia, y se desprende de lo apuntado más arriba: la necesidad de organizar un poderoso ejerclto para eilriglrlo contra Buenos Alres, objetivo principal de toda su labor (12).

La expedición llegó a su destino, al puerto de San Carlos de Ancud, en las islas Chiloé, el 18 de enero de 1813. Alli se dedicó Parela a organizar sus tropas, y una vez que hubo completado su instrucción, se dirigió a Valdivia. La ocupación dé la ciudad no le ofreció dificultades, y de aquí siguio navegando hasta San Vicente, punto próximo a Concepción, y el más indicado para llevar a cabo el desembarco. Una vez efectuado, en lugar de dirigirse directamente hacia la plaza, fué a ocupar Talcahuano, con lo cual aquêlla quedaba rebasada y privada de recibir cualquier posible auxilio del Norte. La ocupación de ambas fué Iácil, favorecida en gran parte por la deserción de los enemigas. Efectuada la primera parte de las operaciones, Pareja se dispuso a avanzar hacia el Norte para llegar lo antes posible a Santiago.

Entretanto, la alarma había cundido en la capital. Pero ante el peligro exterior cedleron las desavenencias entre los partidarios y se dispusieron a hacer frente a las tropas realistas. José Miguel Carrera fué elegido unánimemente general en lefe del ejército chlleno, y se dispuso a organizar la lucha, marchando a cortar el paso al ejército de Parela, que continuába mientras tanto su avance hasta llegar a los alrededores del río Maule. Alli, como a unas siete leguas del rio, instaló su campamento en un punto denominado Yerbas Buenas, el 26 de abril. En la madrugada del día 27 fué sorprendido por una columna patriota de 600 hombres, que consiguieron en un principio desorganizar a sus tropas. Sin embargo, pronto se im-

(12) BARROS ARANA, Diego. Historia General de Chile. Tomo IX: Sartitago dé Chtle, 1887. Pét. 10. 
puso la reacción de los realistas, $y$, tras una corta lucha, hubieron de retirarse los chilenos.

El encuentro con los patriotas parecia carecer de toda importancia. Su falta de plan les impidió sacar alguna ventaja militarmente, pero en cambio, tuvo el poder de desmoralizar a las fuerzas de Pareja. Cuando, rehecho de la sorpresa, se dispuso a continuar la marcha hasta Talca, se encontró que sus tropas, desalentadas y desmoralizadas, se negaron a seguirle. Ante el inesperado aspecto de los acontecimientos, el general se vió obligado a emprender la retirada el 10 de mayo.

La causa del desaliento de las tropas al primer choque con el enemigo, es dificil de explicar. En realidad no cabe otra explicación que la falta de disciplina, poco asentada en el corto tiempo de instrucción que habian tenido. No.debía tampoco ser ajeno a esta. circunstancia el hecho, señalado por Abascal, del descubrimiento de una serie de individuos confidentes de los chilenos descubiertos en el efército por su general (13).

En vista de la actitud de sus soldados, Pareja se retiró a Chillán, no sin haberse visto obligado a contener el avance de los patriotas, con quienes sostuvo algunos encuentros. Pero al encerrarse en Chillán, quedó aislado el ejército realista, pues Talcahuano y Concepción, los dos puntos por donde podian recibir los auxilios, no tardaron en caer en manos de los chilenos, que se encontraron con el camino de la costa completamente libre, y ante cuyas fuerzas no pudieron resistir las cortas guarniciones que en ellas habian permanectdo, e incluso llegaron a sitiar a Chillán (14). El poder realista quedaba reducido a este punto, I sus enemigos tenian verdadero interés en aprovechar el momento de entusiasmo producido por la retirada de los españoles.

La ciudad de Chillán se hallaba defendida por el

(13) ABASCAL. Memoria. Tomo II. Pág. 171.

(14) Consecuencia de tan rápida ocupación de los puertos por los chilenos, fué la captura por éstos de la fragata eTomáss en Talcahuano, adonde acdbaba de arribar, portadora de auxilios para las tropas. 
capitán don Juan Francisco Sánehez, a quien hizo entrega del mando de la plaza el Brigadiér Pareja, cuya enfermedad se acentuó con las fatigas del trabajo hasta el punto de morir poco después de su llegada aqui. Frente a ella se hallaba mandando el sitio José Miguel Carrera, que antes había ocupado las otras dos ciudades. Pero Chillán resistia todos los ataques ehilenos, hasta el punto de que los sitiadores llegaron a encontrarse sin viveres ni municiones para seguir manteniendo el cerco. No les cupo entonces otra solución que retirarse ante la vista de los españoles.

La retirada de Chillán tuvo un hondo sismifioddo, tanto para los realistas como para los patriotas. Para éstos significó el fin del mando de Carrera. «Durante su auseneia, sus adversarios polfticos se habian rehecho en la capital y ejercian grande influencia en el Gobierno. Si algo difexía la caida de don José Migued era el prestigio de la victoria. Un revés como aquél iba a precipitarla y a suministrar a sus émulos la coyuntura que atisbaban» (15). Y aún más; para mucho arrera era el único responsable de todas las desgracies ocunridas: Pero en todos existía el temor de que no:se aviniese a entregar el mando al coroned Q'Higgíns, como ordenó la Junta de Bantlago. Sin embarga bien pronto pudo darse euenta el jefe chileno de que ni los soldados ni la mayoría de sus compatriotas estaban de 'sis parte; no le cabía opción, $\boldsymbol{y}$ hubo de tesignar el mando. $\mathbf{Y}$ no pararon aquí las desgracias de Carrera: al dirigirse junto con su hermano Juis hacia Santiago, fué sorprendido por una partida realista, que los hizo prisioneros en Penco Viejo y los trasladó a Chillán.

Para los realistas significó el ansiado respiro de que tar necesitados estaban. Aparte del consiguiente aumento de moral al ver desaparecor al ejército sitiado sin haber conseguido su óbjetivo. En resumen, se puede decir que sla suspensión del. sitio de Chillán, al paso que dejó libres a los realistas para extender sus operaclones, fué el principio de una especie de

(15) 'AMUNATEGUI y IVIGUNAA MACKENA. Op. cit. Página 76 . 
desquicianajento del ejército pațriota, quo comenzó a perder terreno en todas partes, ya por la sublevación de Araucp, ya por la actividad y la audacia que desplegaron los realistas ensanchando el campo de sus operaciones». (16).

Induçablemente, la culpa del fracaso cae de lleno sobre Carrera, cuya falta de iniciativa se puso de manifiesto en varias ocasiones a lo largo de la campaña. Una de ellas, la más importante, fué cuando al intentar Pareja pasar el Maule, repuesto de la sorpresa de. Yerbas Buenas, se encontró con la insubordinación de sus tropas. Entonces era el momento más a propósito para una acción a fondo contra los realistas, a puntp̣ de desaparęcer. Dasaprovechó el momentro, y más tarde, cuando llegaron éstos a Chillán, con la enfermedad del general $y_{4}$ el ambiente desmoralizador que reinaba entre sus soldados, se encontró con otra ocasión aportuna, de haberlos seguido de cerca, los dejó reorganizarse, y cuanda intentó llevar a cabo el ataque a la ciudad se encontró can que la situación había variado considerablemente y las posibilidades de éxito habian disminuido. El resultado final fué que se consiguio lo que Jamás se hubiera pensada: el robustecimiento del poder de los realistas.

Con tan adverso mesultado, no era de extrañar, pues, la caída de Carrera cuya dictadura no había sido nunca grata a los demás revolucionarios. Si tal vez en su desgracia aumentaron las acusaciones en contra de la conducta por él observada, no es menos cierto que, apartado el posible apasionamiento de estos juigips, queda en pie el hecho de que desaprovechó las mejores acasiones que se le ofrecieron.

Su sucesor en el mando de las tropas patriotas fué, como dije antes, don Bernardo Q'Higgins, que, a partir de ahora, entra como primera figura en la historia de Chile. Hijo del que fué, Virrey del Perú y marqués de Vallenar, don Ambrosio O'Higgins, devoto partidario de Rozas, bien pronto figuró a la cabeza de uno de los partidos de la revolución chilena. Su ellevación al mando del ejéroito le granjeó la enemistad de Carrera,

(16) BARROS ARANA, Diego. Historia General de Chile. Tomo IX. Santiago de Chile, 1887. Pág. 176. 
que, como se vera, trajo funestas consecuencias para la causa chilena. El resentimiento de éste, que por segunda vez se creia infustamente pagada, se concentrớ en la persona de su sucesor al frente de las tropas, por quien se creyó preterido.

A consecuencia del nuevo aspecto de la lucha, tuvieron lugar hechos de importancía para el curso de la misma, tanto en el campo realista como en el patriota. En Santiago fué depuesta la Junta y se nombró a una sola persona que concentrase en sus manos todo el Poder, como única solución para superar tan crítico momento en la historia de la revolución: esta persona fué el coronel don Francisco de la Lastra.

Por el contrario, en el campo realista habían mejorado las cosas. El hecho del levantamiento del cerco de Chillán alentó extraordínariamente a los allí encerrados, que inmediatamente comenzaron à extender sus correrías por el Sur. Pero no paro ahí, sino que pronto recibieron un numeroso refuerzo enviado por el Virrey del Perú al mando del Brigadier don Gabino Gaínza.

Este militar español, que hasta entonces había estado mandando el Regimiento Veterano de Lima, recibió de Abascal unas instrucciones minuciosas antes de ponerse en marcha (17): Hacían referencia a dos puntos principalmente, a la reorganización del efército y a las líneas generales del plan a seguir.

En relación con el primer punto, Abascal especifica la conducta a seguir con el ejército, cuya disclplina habian de reforzar y cuyos defectos tenía que remediar (art. 5). Además; procuraría enterarse de la suficiencia de los jefes con quienes contaba y del número de fuerzas propias y enemigas para decidir lo más conveniente respecto a las futuras operaciones (art. 6 al 11). El plan a seguir se encontraba especificddo en sus lîneas generales: efectuado los

(17) ODRIOZOLA, M. Documentos históricos del Péri: Tomo IIf. Lima, 187\%. Pbig. 201. Apéndice al *Pensidor del Perús: eInstrucción que deberá observar el Sr. Brigadier D. Gabino Gaínza en el mando del ejército de la Concepción de Chile, a que va destinado, en relevo del Coronel don Francisco Sánchezs. Lima, $10^{\circ}$ de enero de 1814. Son 24 artículos, firmados por el Marqués de la Concordia, 
cálculos y pesadas las posibilidades, quedqba a la iniciativa del general resolver si convenia «hacer la guerra solamente defensiva, o emprenderla con energía ofensivamente atacando con rapldez en detalle, si los enemigos estuviesen dixididos en porcknnes separadas: o en el todo si sus fuerzas las tuviesen reunidas; pero defando siempre un competente numero de guarnición en Ghillán con la artillería suficiente para conservar en todo evento aquel importąnte punto, y mantener la existencia e intereses de aquellos fieles habitantes» (art, $\left.{ }^{\circ} 11\right)$.

Entrado en contacto con los enemigos, si la lucha adquiría un aspecto favorable para los realistas, el primer objetivo de las fuerzas de Gaínza debia ser la ocupación del puerto de Talcahuano, punto por donde podria asegurarse el envío de refuerzos desde Chiloé, conseguido lo sual, continuarian la progresión hasta el Maule para amenazar más directamente a los de Santiago, cuyas fuerzas deberían ser atacadas a la atra orilla del río, sí las condiciones fuesen favorables (art.॰ 12 y 13 ).

Ocupada la orilla del Maule, cuyo paso debía tonerse asegurado en todo momento, Gaínza se dirigiría al Gobierno de Chile instándole a deponer las armas, en cuyo caso se le trataría con todo miramiento, y le haría ver las consecuencias que para él se derivarian de su negativa. En el caso de que accediese a la deposición de las armas, le ofrecería el perdón general y olvido de todo lo pasado, a cambio de que jurase inmediatamente la Constitución, efectuado lo cual, el general se haría cargo del gobierno político y militar del territorio. Pero si la Junta pretendiese entrar en pactos en otros términos, especifica Abascal que «sólo le podrá conceder la suspensión de armas, conservando el país ocupado, y el Gobierno de Chilo el suyo, hasta que, dándome parte de lo que se haya tratado, reciba mi contestación» (artículos 18 y, 20).

No paraban aqui las instrucciones del Virrey, sino que, hambre minucioso en la concepción de sus planes, advertía que si se consiguiera someter a los sublevados de Chile, desaparecia el motivo que obligaba a mantener en el,país la fuorga que actualmente existía en él, en cuyo caso, parte de ella pasaría la 
Cordillera por alguno de los caminos que la atraviesan para desembocar en el territörio argentino, a fín de efectuar álgunas correrias por Mendoza (art. ${ }^{\circ} 20$ ).

A la par que ordenaba el plan de opéraciones, también se daba cuenta Abascal de la importancia que para ellas tenía la adhesión a la causa realista de los indios araucanos. Por eso, y a fin de mantenerlos a sú lado, recomienda a Gainza les dé en su nombte y en el del Rẻy las más exprèsitras gräcias y algunós pirésentes, estimulándolos a continuar firmes Junto al Soberano (art. ${ }^{\circ} 3$ ).

Con las anteriores instracciones partió rumbo a Chile la expedición de Gainza. A fines de enero de 1814 desembarcaba en la costa de Aráuco, e itimediatamente se preparaba para empiender la ofensíva. «El ejército patriota estabá dividido en dos cuerpos, uno acantonado a la orilla norte del Itata, en el sitio denominado Membrillar, a las órdenes del coronel don Juan Mackena, y el otro en Concepción, bajò el mando de O'Higginss (18). El objetivo de Gaínza era apoderarse del camino de Saritiago, a cuyo fín, $\forall$ con el de separar a ambos jefés thilenos, se dirlgio a Talca: el camino dé Santiago quedaba abierto, y su suerte dependía de una batalla solamente. El intento de recobrar la ciudad por los patriotis đió como resultádo su nueva derrota en CanchaRayäda.

A pesàr del revés que sufrió Gaínza en su ataque a las fuerzas de Mackena en el Membrillar, pronto pudo reponerse y marchar esta vez sobre Santiago direetamente, a pesar de dejar atrás a las fuerzas de' O'Hingins y Mackena, quieries; sabedores del plan dè Gainźd: se dirigieron también hacia el Norte, con el fin de cortarle el paso a la cludad. El camino de ambos ejércitos hasta su llegada a la Hacienda de Quecheregua, fué una desénfrenađa carrera, con el fin dé obtener ventafa sobre el adversario. Al. llegar aqui, los patriotas habían obtenido la delantera y se hallaban interpuestos entre los realistas y Santiago. Todos los intentos de Gaínza para abrirse paso hacia

4hin (18) BARROS ARANA, Diego. Historiá de Amovicai Tomo $\mathbf{I I}$. Santiagt, 1908. Pág̨ 382. 
la capital fueron inútiles y al final hubo de retirarse a Talca. $\mathrm{Su}$ intento habia fracasado.

El alejamiento de las tropas realistas de Chillán, punto principal para su aprovisionamiento y donde tenían establecido su Cuartel General, unido a las deserciones y al desánimo consiguiente al fracaso de su plan, sin esperanza de poder llevarlo a cabo, influyó poderosamente en el espíritu del general y determinó en gran parte su conducta posterior.

Mientras Gaínza se dirigía con sus tropas hacia Chile, Abascal celebraba conferencias en Lima con el Comodoro inglés Sir James Hylliar, comandante de la fragata británica «Phoebe», que, juntamente con la corbeta «Cherub», navegaban por el Pacifico para proteger el comercio inglés de los ataques de los navíos estadounidenses, con cuya nación se hallaba en guerra Gran Bretaña. Arribado al Callao, el marino inglés se puso en contacto con el Virrey de Lima y se prestó voluntariamente a servir de mediador en el conflicto entre éste y el Gobierno chileno.

Abascal, que aunque había enviado a Chile a Gaínza con tropas y armamentos para continuar la lucha, tenia gran interés en solucionar el conflicto chileno, entrevió una posibilidad con el ofrecimiento del marino inglés. Inmediatamente puso en su conocimiento las bases sobre las que se podría llegar a un acuerdo entre ambos bandos. Se reducían, naturalmente, como ya había indicado a Gainza en sus «Instrucciones», a que los chilenos «ratifiquen el reconocimiento que han hecho de Fernando VII, que en su ausencia y cautividad reconozcan la soberanía de la nación en las Cortes generales y extraordinarias, y reciban y juren la Constitución española hecha por las mismas» (19), en cuyo caso el Virrey se obligaba a un total olvido de lo pasado, con un perdón general para todos aquéllos que hubiesen tenido mayor o menor parte en la revolución. Para mover al Gobierno chileno a entrar en las negociaciones le hacia ver los

(19) ODRIOZOLA, M. Op. cit. Tomo II. Lima, 1872. Pág. 222. Artículo 10 de las Apuntaciones dadas al Capitán de la fragata de S. M. B. Phoebes, que zarpó de este puerto del Callao para el de Valparaíso con la corbeta *Cherub», el 11 de enero de 1814 . 
recientes y notables triunfos de las armas realistas, tanto en la Peninsula como en el continente americano, en donde las tropas del Virrey acababan de inflingir dos graves derrotas a los argentinos en los campos de Vilcapugio y Ayohuma.

La situación ciertamente era delicada para los rebeldes de Chile. Sus esperanzas se iban apagando poco a poco al observar cómo las tropas francesas evacuaban la Península, y pronto se habrían de poner de manifiesto sus propósitos independizantes con la vuelta al Trono de Fernando VII. El matiz de la Junta se iba a poner al descubierto a poco que el Monarca recabase su acatamiento. $Y$ entonces era de temer una acción ofensiva de las fuerzas peninsulares que, libres de la lucha en España se podrian muy bien dirigir a América. Por otra parte, la ayuda de Buenos Aires era en estos momentos bastante problemática, pues los reveses que acababa de sufrir le imposibilitaban de todo punto para enviar tropas a Chile. Así, pues, no es extraño que los dirigentes chilenos acogiesen en principio con agrado la idea de una transacción, siquiera como una fórmula provisional.

En el ánimo de los gobernantes chilenos pesaban dos sentimientos dispares: por una parte, el referido más arriba; por otra, la idea, arraigaba al cabo de tres años de vivirla, de una independencia más o menos efectiva. Se sentían comprometidos con la revolución, y por otra parte veían las consecuencias de la guerra y las que podian venir más adelante. Por tanto no debia estar muy lejos de su modo de pensar el llegar a una transacción en la que quedasen a salvo los principios fundamentales de sus doctrinas y que condujese a un pronto término de las hostilidađes. *Lo que en tales circunstancias y en semejante disposición de ánimo podría cuadrarles mejor era el sistema de un gobierno nacional y constitucional, más o menos sometido al Rey; algo parecido a lo que habían sido las colonias inglesas de la América del Norte antes de su emancipación» (20).

En cambio, Abascal no podía permitir otro arreglo

(20) AMUNATEGUI, M. L. y V. La Reconquista española de Chile en 1814. Bibl. Agacucho, s. a. Pág. 34. 
que el reconocimiento pleno de la soberania del Rey por el Gobierno de Chile y la sumisión a las órdenes emanadas del Consejo de Regencia y de las Cortes. $\mathrm{Su}$ posición estaba claramente definida y no se hallaba dispuesto a volverse atrás, y mucho menos ahora, cuando las tropas virreinales se extendian por todo el Alto Perú y habian rechazado la segunda invasión argentina. Así se lo expuso claramente a Hyllíar en las "Apuntaciones» que le dió, haciéndole constar, de todas formas, sus buenos deseos de llegar a una avenencia sobre esta base.

Inmediatamente que Hylliar llegó a Chile, se puso en contacto con el Director Lastra, por quien fué bien acogido. Se nombraron para llevar a cabo las negociaciones por parte del Gobierno de Chile, a don Antonio José de Irisarri y don Camilo Henriquez. Las bases sobre las que habian de fundarse fueron determinadas por el Senado chileno, y eran las siguientes: «suspensión de las hostilidades, evacuación del territorio por las fuerzas de Lima, reconocimiento de la soberanía del Rey de España, conservación de las autoridades nacionales o chilenas hasta que, por medio de diputados, se conviniera con el Supremo Gobierno de la Península el modo de conciliar las actuales diferenciass (21).

Como puede verse, las bases para las negociaciones caían fuera de los poderes concedidos a Hylliar por el Virrey, que le habia hecho contar claramente que, en caso de llegarse a la avenencia por él propuesta, debia «admitir la Audiencia, Gobierno y empleados por la soberania, como lo estaban antes, con la sola diferencia dictada por la propia Constitución, y que para el resguardo de las personas, propiedades y sostén de la administración de Justicia, han de recibir la guarnición necesaria de tropas chilotas, interin se organizan otras de todo el distritos (22).

Sin embargo, Hylliar las aceptó como punto de partida para díscusiones posteriores, con la mejor buena voluntad, pero sin apreciar, quizás, la gran

(21) AMUnategui, M. L. y V. Op. cit. Págs. 37-38.

(22) Artículo 10 de las eApuntaciones... de Hylliar. (ODRIO. ZOLA. Op. cit. Pág. 222). 
diferencía que existía entre una y otra posición. Así es, que con ellas se dirigió al lugar en donde se encontraban los dos ejércitos, a fin de conseguir su propósito. Entretanto, el Director Lastra escribia, informando a O'Higgins de las negociaciones en curso, para inclinar su ánimo a aceptarlas, aunque a la par le decia: "Usía, como testigo ocular, y por mil otros motivos, sabe bien cuánto hemos perdido en esas desoladas provincias; la parte que de ellas ocupa el enemigo, la fuerza con que la sostiene e intenta invadirnos, si sigue la guerra; si le aprovechará la suspensión y si separado algún tiempo podrá rehacerse y regresar con dobles y mejores tropas; si las nuestras están hoy en estado de atacar con ventaja, acabar con aquéllas y entorpecer o dificultar que venga otro repuesto capaz de hacernos sucumbir después de victoriosos» (23). Nada como este trozo nos da idea de que el fin perseguido por el Gobierno chileno era obtener una tregua con la que ganar tiempo para reorganizar sus fuerzas con el fin de que, si fallaban las negociaciones propuestas con el Gobierno de $\mathrm{Ma}-$ drid, se encontrasen en franca superioridad sobre sus adversarios. No es de extrañar, pues, que, fijos en su idea, no diesen importancia al hecho de insertar en el tratado algunas frases que se contradecian con su conducta.

O’Higgins aceptó la idea del tratado, y así se lo comunicó a Hylliar, que se trasladó al campamento realista para dar a conocer a Gaínza las negociaciones que se llevaban a cabo y proponerle la discusión de las mismas con el jefe del ejército enemigo, a fin de convertirlas en tratado de paz.

Se ha visto más atrás el estado de ánimo de Gaínza, consiguiente al fracaso de su plan de ocupar Santiago de Chile. Obligado a retirarse a Talca, veía desaparecer la ocasión, quizás única, que se le ofrecia de acabar la guerra. Para él no cabian más posibilidades: alejado de Chillán y con el ejército de O'Higgins enfrente, no podía recibir auxilios, y además

(23) Oficio del Director Lastra al General en Jefe del Ejército de Chile, OTHiggins. Santiago, 22 de abril de 1814. (AMUNATEGUI. Op. cit. Pág. 44, nota). 
veia amenazado su repliegue. Inactivo y en espera de un ataque de los enemigos, vió en el posible tratado una ocasión de salvar sus tropas sin perfuicio de volver más adelante con refuerzos e iniciar una campaña. No es extraño, pues, que acogiese con gusto la proposición de Hylliar de entrar en contacto con los generales chilenos. Sin embargo, aún tuvo sus vacilaciones antes de marchar a entrevistarse con sus contrarios, pues se dió cuenta de que las proposieiones de Hylliar no entraban dentro de la «Instrucción» que le habia dado el Virrey de Lima. Por ello le propuso llegar a un tratado provisional que sería sometido a la aprobación del Virrey (24). La respuesta estuvo a punto de romper las negociaciones, pero ante el pelígro, Gaínza, hombre irresoluto, se decidió a entrar en tratos.

El día 3 de mayo se entrevistaron Gaínza y el asesor Rodríguez Aldea, del lado de los realistas, con O'Higgins, Mackena y Zudáñez, del chileno. También se hallaba presente Hylliar, aunque parece que no intervino en la discusión. Al fin, tras un debate larguísimo, se firmó el Tratado conocido con el nombre de Tratado o Convenio de Lircay, por haberse firmado a orillas del río de este nombre, punto medio entre los dos campamentos y lugar elegido por Hylliar para la entrevista (25).

En el Tratado se convenía la evacuación por las tropas realistas del territorio chileno, evacuación que habría de llevarse a cabo en Talca, donde se encontraban las fuerzas de Gaínza, a las treinta horas de recibirse la aprobación del Tratado por el Gobierno de Santiago, y en la provineia de Concepción, en el término de un mes a partir también de dicho momento. Para facilitar la retirada de los realistas, el gobierno chileno pondría a su disposición «los auxiHos que estuviesen al alcance de Chile y dicte la regularidad y prudencia» (art. ${ }^{\circ}$ 2). Hasta que se verificase dicha evacuación se entregarian en rehenes

(84) AMUnategui. Op.. cit. Pág. 50.

(25) ODRIOZOLA, M. Op: cit. Pág. 225 y ss. eConvenio celebrado entre los Generales dé los ejércitos titulados Nacional y det Gottierno de Chilet. 
por el ejército nacional dos coroneles, y otros dos por el de Chile (art. ${ }^{\circ} 12$ ).

El ejército de Chile, por su parte, mientras se efectuaba la evacuación, se obligaba a conservar la posición que tenia en el día, sin aproximarse más a Talca, pudiendo únicamente retirarse a algún otro sitio más alejado de la ciudad en caso de temporal (art. $\left.{ }^{\circ} 8\right)$. También se restituirian los prisioneros de ambos ejércitos «sin excepción alguna, quedando enteramente olvidadas las causas que hasta aquí hayan dado. los individuos de las provincias del Reino comprometidos por las armas con motivo de la presente guerra, sin que en ningún tiempo pueda hacerse mérito de ellas por una ni otra parte (art. ${ }^{\circ} 3$ ).

El Gobierno de Chile nombraría diputados con plenos poderes para sancionar la Constitución que las Cortes habian formado y para hacer oír sus representaciones, \&...y se compromete a obedecer lo que entonces se determinase, reconociendo como ha reconocido, por su monarca al señor don Fernando VII y la autoridad de la Regencia, por quien se aprobó la Junta de Chile, manteniéndose entretanto el Gobierno anterior con todo su poder y facultades y el libre comercio con las naciones aliadas y neutrales, y especialmente con la Gran Bretaña... (art. $\left.{ }^{\circ} 16\right)$. Por su parte, Chile daría a España todos los auxilios que estuviesen a su alcance, arreglados al deterioro que nabia sufrido su territorio durante la guerra (art. ${ }^{\circ}$ 5), y satisfaria 30.000 pesos como parte del pago a algunos vecinos de Concepción por los gastos que había hecho el ejército de Gaínza (art. ${ }^{\circ} 10$ ).

Las relaciones mercantiles de Chile con las demás regiones de la Monarquía española continuarian de igual manera que antes de la guerra (art. $\left.{ }^{\circ} 4\right)$. Por último, si por cualquier circunstancia no se llegase a aceptar el Tratado, el Jefe del Ejército de Chile quedaba obligado a esperar la contestación de esta noticia, que deberia comunicar al Jefe realista antes de reanudar cualquier actividad bélica (art. $\left.{ }^{\circ} 13\right)$. En caso contrario, si se aceptaba el Tratado, como prueba de la buena fe del Gobierno chileno, se ofrecía a entregar tres personas distinguidas en calidad de rehenes, entre las que figuraría el propio O'Higgins, que se habia ofrecido voluntariamente, salvo en caso de ser elegido 
diputado para las Cortes, en cuya circunstancia sería sustituído por otro individuo de semejante representación (art. $\left.{ }^{\circ} 11\right)$.

Como puede observarse, de la lectura del Tratado se desprende, en primer lugar, que dicho Tratado era nulo, porque ninguno de los representantes realistas tenía poderes para firmar un pacto en tales condiciones. Por otra parte se observa también que todo lo aprobado en el Tratado era lo propuesto por el Gobierno chileno, aún con algunas ventajas sobre las bases iniciales de las discusiones, sin que el general español hubiese logrado ninguna por su parte. En resumidas cuentas, que el único beneficiado con el Convenio era el bando chileno, que se encontraría con su territorio evacuado de enemigos, con el Gobierno reconocido por el de España y con una representación en las Cortes, aparte de las ventajas comerciales.

La responsabilidad del Tratado cae por entero sobre Gaínza, que poco después debió darse cuenta del paso que había dado, y el día siguiente al de de la conclusión del Convenio quiso retractarse, según él mismo dice, "con la precisa condición (secreta y acordada con los jefes) de evacuar a Talca con sorpresa, y que habiendo sido inverificable aunque se intentó» no pudo menos que desistir de su proyecto (26).

En realidad, no creo quepa pensar en un doble papel interpretado por Gaínza en las negociaciones. «Entró en tratos para evitar un desastre que creía inevitable y aceptó condiciones que sus instrucciones le mandaban rechazar y que ni él mismo ni los oficiales de su ejército se proponían cumplir» (27). Pero su intento no era engañar a los chilenos, sino que, su obsesión era evitar, de la manera que fuese, un desastre, sègún él inevitable. Su inactividad en Talca, origen de todos sus males, la explica detalladamente: «Consistiendo ya entonces el ejército enemigo de algo más de 2.000 bayonetas (es un hecho), con caballería robusta y descansada, la tropa acabada de pagar y

(26) Arch. Abascal. Carta de Gaínza a Abascal. Concepción, 15 de octubre de 1814.

(27) BARROS ARANA, Diego. Historia General de Chile. Tomo IX. Santiago, 1887. Pág. 453. 
vestir, alentada de verse en su terreno y con la posibilidad de recibir todo género de auxilios, al paso que el mío sólo tenía 1.475 bayonetas y de ellas 73 plazas en el hospital, fortificada Talca y de consiguiente necesidad de conservarla como punto único defensible, y que si se perdia era va difícil retomarla, que con mi caballeria endeble y muy gastada, si me quedaba en la campaña no podría proporcionarme subsistencias, amenazándome ya los aguaceros que habian dado principio y siéndome inverificable el repaso del Maule con el enemigo encima y superior, entiendo no debía empeñar acción que era tan expuestas (28).

En esta situación, el único medio de salvar su ejército era reforzarlo con los auxilios que le pudiesen llegar, según su Juicio, y como no cabía pensar que llegasen, encontró como única salida la del Convenio, pensando que, si bien no estaba autorizado a aceptarlo en tales condiciones, Abascal no Juzgaría muy severamente su conducta, ya que le había permitido salvar a todo el ejército de Chile.

Sín embargo, no ocurrieron las cosas como juzgaba Gaínza. El día 13 de mayo daba cuenta a Abascal en una carta de la conclusión del Convenio. En ella le explicaba su decisión: "me entregué ciegamente a la fe del primer artículo del Convenio y sobre él establecí la paz como el bien más conveniente al Estado en general y a este Reino en particular (29). El deseo de paz y la excesiva buena fe del general eran evidentes. Pero si sus deseos de paz eran compartidos también por el Virrey de Lima, no lo eran los de una paz en tales condiciones. La noticia del Tratado fué una gran sorpresa para Abascal, cuyo estado de ánimo debió llegar a tal punto de excitación que, según deja traslucir el mismo Gaínza en una carta posterior, en la que intenta justificarse, debió calificarlo hasta de cobarde, en presencia de su esposa (30).

No es de extrañar, pues, que, inmediatamente de

(28) Arch. Abascal. Carta de Gaínza a Abascal. Concepción, 15 de octubre de 1814.

(28) Arch. Abascal. Carta de Gaínza a Abascal. Chillán, 13 de mayo de 1814 .

(30) Arch. Abascal. Carta de Gainza a Abascal. Talcahuano, 31 de octubre de 1814 . 
recibida la noticia, convocase un Acuerdo en el que se desautorizó a Gaínza y se desaprobó el Convenio. Juntamente con ello, se determinó que, a la mayor brevedad, se reuniese el suficiente número de tropas para salvar la situación de Chile y llevar a cabo la reconquista del país. Pero la situación del Perú era bastante critica, pues las múltiples exigencias que requerian la ateneión del Nirrey le habian obligado a dispersar las fuerzas hasta el punto de que en la actualidad se encontraba sin tropas y sin medios para atender las necesidades de Chile. Al fin, pródigo en recursos, logró organizar el auxilio. «El Regimiento de Talavera, acabado de venir de España para guarnecer el punto de esta capital-dice el Virrey-r, me facilitaba lo primero: el obrador de artillería y la fábrica de pólvora empleadas en una continua labor podian también allanarme lo segundo, aunque con inmensos trabajos: pero como para todo era inexcusable el primer agente, que es el dinero, y éste no lo habia, recurrí al arbitrio de pedirlo, como otras veces al Consulado, euyos fondos y su crédito, apurados por repetidos suplementos, me lo allanó al fin en la mus precise cantidad para los gastos de la nueva expedición».(31).

Como jefe de la expedición, designó el Virrey al único soficial de concepto e inteligencia que entonces tenía disponible a sus órdenes, el comandante y Subinspector interino de Artillería don Mariano Osorio, militar de más decisión que Gaínza, y de quien esperaba pusiese un punto final victorioso a la guerra.

Con objeto de indicarle su norma de conducta le dió nuevas instrucciones (32). En ellas le indicaba, en primer lugar, que observase la conveniencia de fortificar los puntos de Concepción y Talcahuano, con objeto de cubrir la mayor cantidad posible de terreno de aquella provincia (art. ${ }^{\circ} 2$ ). Verificado este punto, debía dirigirse a Chillán, en donde, al hacerse cargo del mando del ejército, debía revistar cada uno

(31) ABASCAL. Memoria. Tomo II. Pág. 181.

(32) ODRIOZOLA, M. Op. cit. Tomo III. Pág. 229 y ss. aInstrucción que debérá observar el Coronel don Mariano Osorio en el mando del Ejército Real de Concepción de Chile, a que va destinados. Lima, 18 de julio de 1814. 
de los cuerpos que lo componían, cuyo estado de instrucción y disciplina debía remitir a la mayor brevedad al Virrey (art. ${ }^{\circ} 4$ ).

Aún ofrecía el Virrey una nueva posibilidad al Gobierno chileno, a quien debía dar a conocer Osorio su deseo de llegar a la paz con un olvido general para todos los que renovasen el juramento hecho al soberano y durante su cautividad Jurasen la Constitución española y el Gobierno de las Cortes. En este caso deberia Osorio pasar a la capital con la tropa necesaria para imponer en ella el orden y hacerles observar a sus soldados la más rigida diseiplina, a fin de que no maltratasen a nadie (artículos 6 y 7).

Cotejados los estados de fuerza del enemigo que poseía el Virrey y los de las propias, remitidos por Gainza, resultaba que las realistas eran muy superiores a las patriotas, sobre todo con el refuerzo del batallón de Talavera; «por cuya razón conviene romper las operaciones luego que la estación de aguas lo permita, atacándolos enérgicamente donde se les encuentre, sin darles lugar a rehacerse en caso de ser derrotados, persiguiéndoles incesantemente hasta disiparlos y continuando su marcha hasta apoderarse de la capital»; y si entonces el Gobierno de Chile pidiese la paz que antes rehusó, se le concedería con \&las menores ventajas para él que exige su obstinación y el estado de ambos ejércitos (arts. 8, 10 y 11).

Efectuada la toma de la capital, Osorio debía poner en segura prisión a todos los que hubieran tomado parte en la revolución y a los miembros del gobierno revolucionario, que remitiria inmediatamente a la isla de Juan Fernández, a la par que a todos los realistas, europeos o americanos que se hallasen desterrados por los insurgentes se les facilitaria la vuelta a sus casas y se procuraría formar con ellos un Regimiento de voluntarios de la Concordia chilena, semejante al que existía en Lima (arts. 13 y 15). Conseguido el orden en la capital, debería procurar también el restablecimiento de la Audiencia, como asimismo debía conseguir el orden en los demás puntos del país (arts. 14 y 16).

Una vez efectuada la total pacificación del Reino, debía dejar en la ciudad de Santiago y demás puntos necesarios la suficiente cantidad de tropas para man- 
tener el orden, y con el resto del ejército deberia formar una expedición que, a través de la Cordillera, se dirigiese hacia Mendoza para propagar el pánico en las provincias del Rio de la Plata y aliviar al ejército del Alto Perú. Con tal finalidad adelantaría algún cuerpo hasta Córdaba, y en caso de descubrir fuerzas enemigas, emprenderia la retirada si fuesen superiores, o las atacaría si fuesen inferiores. Para ello, el Jefe de la expedición debía ponerse en contacto con el general del ejérçito del Alto Perú, como igualmente el propio Osorio, cuando hubiese terminado la ocupación del Reino de Chile (arts. 21 al 23). Para llevar a cabo la expedición, dada la escasez de fondos del Erario, el Virrey facultaba a Osorio para que impusiese una contribución general en todo el Reino de Chile, con dicho fin y con el de contribuir también al sostenimiento del ejército que debía subsistir en él (art. $\left.{ }^{\circ} 12\right)$.

Como se ve por estas instrucciones, cuyo espíritu es semejante a las dadas anteriormente a Gainza, el Virrey no permitía otra alternativa a los chilenos que el acatamiento de la soberanía española, o la reanudación de la lucha, de cuyo final victorioso tenia poderosas razones para estar seguro. E incluso pensaba en uno de sus planes favoritos: el franqueamiento de la Cordillera por el ejército victorioso de Chile para coger por la espalda al argentino.

Con las anteriores instrucciones salió Osorio del Perú con 150 hombres del Regimiento de Talavera, 45 artilleros, sus oficiales y dos obuses de siete pulgadas, además de las correspondientes municiones y los naturales auxilios en dinero (33). Por fin, el 13 de agosto desembarcó en Talcahuaco y se dispuso a prepararse para la nueva ofensiva.

En el interin de estos acontecimientos habian ocurrido hechos trascendentales en el campo chileno. No cabe duda que conocido por el Gobierno de Santiago el modo de pensar del Virrey del Perú y lo acontecido por los sublevados de Buenos Aires, no podía, en buena lógica, pensar que las condiciones impuestas a Gaínza fuesen aceptadas por aquél ni por el Gobier-

(33) ABASCAL. Memoria. Tomo II. Pág. 182. 
no español. Otra cosa bien distinta es la cuestión de si el Gobierno de Santiago estaba dispuesto de buena fe a cumplir lo estipulado en Lircay, o sea, si estaba dispuesto a llevar a cabo el retroceso que para sus ideas revolucionarias significaba dicho pacto. En cuanto a lo último, me inclino a creer que los dirigentes de Santiago estaban íntimamente convencidos de que su meta final era la independencia, a semeJanza de los de Buenos Aires, $\boldsymbol{\nabla}$ que, al proponer un término medio, creyeron hallar un «modu vivendis, que en la práctica los hiciese independientes, aunque de un modo nominal estuviesen sujetos a la soberania del Rey de España. Pero esto fué un error de los gobernantes chilenos, que perdieron la ocasión de emplearse a fondo contra los realistas, en un momento en que no les hublera sido extremadamente difícil arrancarles la victoria: Entonces se hubieran encontrado en franca superioridad para pactar, si lo hubiesen Juzgado necesario. Más no lo hicieron así, y las consecuencias le fueron fatales, pues a nadie agradó el Tratàdo, antes al contrario fué utilizado por el partido enemigo del Gobierno como arma politica, pa $\downarrow$ ra echarles en cara el haber llegado a una transac ción con el enemigo.

Inmediatamente que cundió la desilusión, al tenerse noticias del Tratado, el pensamiento popular se fijó en el antiguo caudillo que tanto impulso diera a la revolución y que la puso en estado de medir sus armas con los realistas: en José Miguel Carrera. Las circunstancias vinieron a convertir en realidad este anhelo.

Se recordará que los dos hermanos Carrera habian sido hechos prisioneros en Penco Viejo, después de su destitución por el Gobierno de Chile, y trasladados al Cuartel General de los realistas en Chillán. Ahora, por el Tratado de Lircay, en Justicia, debían habèr sído puestos en libertad, según el artículo tercero de dicho Tratado, en el que se establecía la restitución reciproca de todos los prisioneros que se hubiesen hecho por ambas partes asin excepción alguna». Pero el Gobierno de Chile, que no tenía el menor interés de enfrentarse con sus más temibles adversarios en el interior, estipuló un artículo secreto en dicho Tratado, con el fin de que los dos hermanos les fue- 
sen entregados, seguros de que su libertad supondría la alteración del estado de cosas existente, y quizás, su propia caída. Parece que en primer lugar se dispuso fuesen enviados a Lima, pero que después se determinó pasasen a Río de Janeiro (34).

Pero a pesar de este artículo, y antes de que pudiera cumplirse lo estipulado, ambos hermanos emprendieron la fuga y se dirigieron hacia Santiago. Inmediatamente que se supo en la Capital la fuga de los hermanos Carrera, el Director Lastra dictó auto de prisión contra ambos, y dió comienzo la búsqueda de los proscritos por todo el territorio chileno.

La medida de Lastra puso una vez más de manifiesto su falta de tacto político, pues con ella solo consiguió reunir alrededor del popular caudillo a todos los descontentos y a la mayor parte del ejército, que nunca habia llegado a olvidarle. Si bien uno de ellos fué detenidó, el otro pudo ensayar su procedimiento favorito: el 22 de julio de 1814 una sublevacíón militar en Santiago colocó otra vez en el poder a Jose Miguel Carrera.

Ocupada la capital, quedaba por saber la actitud de O'Higgtins y su ejército ante el golpe de Estado. Pero su posición era clara: se mantenía al lado del Directorio, y se díspuso a emprender la marcha sobre Santiago para restaurarlo. La enemistad entre Carrera y O'Higgins iba a desencadenar la guerra cívil entre los mismos chilenos. Aquél organizó a toda prisa un núcleo de fuerzas para hacer frente al ejêrcito que venia de Talca, y se dispuso a defender la capital. Aún tuvo lugar una escaramuza entre la vanguardia de ambos ejércitos, y ya estaban las fuerzas preparadas para lanzarse a la lucha, cuando se recibieron noticias del desembarco de Osorio con la orden del Virrey de Lima de desaprobar el Tratado de Lircay y continuar la guerra.

Ante el giro de los acontecimientos, Carrera, que había obtenido algunas ventajais en el primer choque, propuso a O'Higgins la unión contra el peligro común. Aceptada por éste, se dispuso el ejército de ambos para luchar contra Osorlo, que distaba sólo sesenta

(34) AmUnategui. Op. cit. Pág. 90. 
leguas de la capital, favorecido su avance por las discordias entre los Jefes chilenos, que motivó la marcha de O'Higgins hacia Santiago. Ante la proximidad de aquél, O'Higgins, que después del acuerdo con $\mathrm{Ca}-$ rrera habia quedado como segundo en el ejército patriota, se hizo cargo de la vanguardia, y con ella se situó en Rancagua, a fin de detenerlos, en tanto que Carrera organizaba las fuerzas necesarias para acudir en su socorro y obligar a retirarse a los realistas.

Entre los jefes patriotas existia, sin embargo, disparidad de criterio respecto al punto donde se debía hacer la resistencia a los enemigos, pues mientras Carrera era partidario de replegarse a la Angostura del Paine si las fuerzas enemigas eran superiores, O'Higgins se declaraba por una defensa a toda costa de Rancagua. Prevaleció por fin el criterio de este último, y se situó en ella el 30 de septiembre.

Al día siguiente, $10^{\circ}$ de octubre, se presentó Osorio ante la ciudad. Su llegada se llevá a cabo casi por sorpresa, y los enemigos hubieron de retirarse a toda prisa al interior. El centro de la población era la parte que O'Higgins pensaba defender; constituido por una gran plaza cuadrada, habia fortificado todos sus accesos. El sitio de la plaza fué terrible. Durante todo el día se luchó denodadamente por ambos bandos, sin conseguir que se decidiese la situación por ninguno de ellos. Los realistas atacaron furiosamente las posiciones patriotas, pero todos sus ataques fueron rechazados con gran energía. Al amanecer del día 2 se renovó la lucha. Los patriotas habian sufrido enorme cantidad de pérdidas y escaseaban de municiones. Por otra parte, los realistas, a quienes la presencia del ejército de Carrera en socorro de la ciudad hacía buscar un final rápido, arreciaban sus ataques. La situación se iba haciendo cada vez más insostenible, y la suerte de los defensores de Rancagua estaba decidida, a no ser que Carrera iniciase un movimiento para sorprender la retaguardia realista. Pero el esperado ataque no se llevó a cabo, pues, tras un leve contacto con sus enemigos, el Jefe chileno se retiró hacia la Angostura del Paine, punto que a su Juicio debiera haberse defendido a toda costa. 
Y esto fué lo que decidió el combate definitivamente: ante la imposibilidad de seguir resistiendo por sus propios medios, O'Higgins decidió dar una carga contra las tropas realistas, y salir de la ciudad.

Ocupada Rancagua, el mantenimiento de Santiago en manos de los patriotas era imposible. Asi lo comprendió Carrera, marchándose de allí, y con êl todos los comprometidos en la revolución. Muchos de ellos marcharon a territorio argentino para librarse de caer en manos de los realistas, y otros, con Carrera a la cabeza, se retiraron hacia el Norte; pero su permanencia alli no podia prolongarse mucho: sin ejército disciplinado y sin medios para organizar una seria resistencia, se vieron obligados, al fin, a pasar los Andes $\mathbf{y}$ acogerse a territorio argentino.

Durante la marcha de Osorio por el territorio chileno, y antes de su llegada a Rancagua, recibió oficios del Virrey de Lima en los que le comunicaba los desgraciados sucesos que se hábian desarrollado dentro y fuera del Virreinato. Dichos acontecimientos eran la rendición de Montevideo, el recrudecimiento de la insurrección del Alto Perú, que había obligado a Pezuela a retirarse hacia Cotagaita, y las insurrecciones del Cuzco y Huamanga. La situación originada en el Virreinato por estas circunstancias era bastante delicada, como se ha tenido ocasión de ver. No sólo había que desechar la idea de un posible envio de refuerzos a Chile, sino que todos los cuidados habian de dirigirse hacia el Alto Perú. En su consecuencia, el Virrey habia convocado en Lima una Junta de Guerra, con el fin de tomar las medidas necesarias para atajar el peligro. Allí se acordó «prevenir a Osorio que, estipulando si fuese dable una racional convención con los chilenos, se pusiese prontamente con todas las tropas voluntarias que pudiese recoger, la artillería, armamento y municiones a bordo de los buques existentes en el puerto y se dirigiese a uno de los intermedios para amparar y proteger su retirada» (35). Esta decisión, más que ninguna otra, nos da una idea de la angustia que debía reinar en aquellos momentos en Lima, cuando el

(35) ABASCAL. Memoria. Tomo II. Păg. 184. 
Virrey, que poco antes habia rechazado de plano todo trato con los insurgentes, a no ser que tuviese como base el reconocimiento del Monarca español y la restitución de las antiguas autoridades, se avenía ahora a indicar la necestdad de una "racional convención con los chilenos», sabiendo que, por muy ventajosa que fuese, siempre lo había de ser menos que la impuesta por las armas. La necesidad de socorrer al ejército del Alto Perú, de cuyo mantenímiento se daba cuenta que dependía el de todo el Virreinato, le okligó a amoldarse a las circunstancias.

Sin embargo, no se llevó a cabo lo dispuesto por el Virrey. Ni Osorio entró en tratos con los chilenos, ni envió sus fuerzas al Alto Perú. Pero la actitud de Osorio, que encierra una desobediencia a las órdenes del Virrey, se encuentra perfectamente explicada. Poco después de su llegada a Chile se halló con que habia surgido la división en el bando patriota, cuyas fuerzas amenazahan con llegar a las armas entre si, lo cual favorecia extraordinariamente sus planes, pues, como se ha visto más atrás, al retirarse O'Higgins hacia Santiago para reponer al Directorio en contra de Carrera, Osorio se encontró con el camino abbierto, y asi pudo llegar con toda facilidad hasta Raneagua, sin encontrar la menor resistencia. En estas condiciones debió recibir las citadas órdenes de Abascal, y comprendió que podía dar en Rancagua una batalla decisiva que, en caso de ser yictoriosa, le valdría la posesión de la capital y con ella la de todo el Reino. Valía la pena esperar al resultado de la accion y no perder a tan poco precio el territorio ya conquistado. Los resultados dieron la razón al general; y cabe incluso pensar en que si el propio Virrey hubiese tenido noticias detalladas de cómo marchaba la situación en Chile, no hubiera dudado en aprobar el plan de Osorio. Por otra parte, el misma ejército, formado en gran parte de chilenos, se mostraba reacio a abandonar el país, y mucho más en las condiciones en que la evacuación había de hacerse. Todo lo cual obliga a pensar indulgentemente sobre la desobediencia de Osorio, y se puede concluir afirmando que, si existió, se halla plenamente justificada por las circunstancias del momento y por la libertad de acción de que está dotado todo jefo de ejército. 
La ocupación de la capital por las tropas realistas tuvo lugar inmediatamente después de la victoria de Rancagua: El 5 de octubre entraba en ella el primer contingente de dichas tropas. Poco después eran ocupados los demás puntos importantes del país, aunque como decia Osorio al Virrey, no podía contar con sus moradores «hasta que desaparezcan (si es posible conseguirlo), las ddeas de independencia radicadas en los corazones ( 86$)$; que le obligaban a dejar guarniciones en las plaztas; con lo que disminuia la fuerza de su éjército y aumentaban sus petíciones de refuerzos a aquel.

La situación del Reino después de ocupado por los realistas era todavía bastante delicada. Las partidas de instirgentes continuaban hostilizándolos y sus habitantes se mostraban recelosos de ellos. Así lo daba a entender el propio Osorio cuando eseribía a Abascal y le decía: k...en una palabra, este Reino no está todayia tranqułlo ni lo estábá en mucho tiompo; la indeperidenciá esta arraigada en los corazones, y sólo la recta jedstreia, el olésinterés $\$$ una conducta efemplas pueden arrancar y destruir estas ideas (37). Citertatinente, el plan i'propuresto en esas líneas por Osorio era el único medio eftcar de atraerse a los chslenas. $Y$ segliramente que hizo cuanto estuvo de su parte para Mevarto a cabo. Hambre laborioso, trabafador infatigable, procuraba Imponerse de todos los asuntos del Goblerno, cuyo desconocimiento en muchos casos intentaba subsanar con su buena voluntad y el. consefo de personas autorizadas.

Daránte todo el año 1815 continuó Osorio en el mando de Chtle, y si su Gobierno no se caracterizó como el de un gran politieo, al menos puso en práettca las ideas que tenia respecto a la gobernación de un terrtorlo, aunque le faltaba el tacto político necesarlo para gobernar un pais convaleciente de la grave crisls por la que habia pasado.

Con el Gobierno de Osorio y la reconquista de

(36) Arch. Abascal. Garta de Osorio a Abroaal. Guartel Ge neźal en la Quinta de Sánchez, media lequa de Santiago, 13 de octubre de 1814.

(37) Areh. Abascal. Cartá de Osorio a Abascal. Valparaiso, 22 de betubre de 1814. 
Chile termina la primera etapa de la lucha en este país. Al terminar, la situación se ofrecía inmejorable a los españoles. Cuando ocurrieron en el Perú los desgraciados sucesos ya mencionados, Abascal ordenó a Osorio que, realizando una avenencia con los chilenos, procurase pasar al Alto Perú para llevar a Pezuela el auxilio de que tan necesitado estaba. El refuerzo podia haberse transportado, o bien en barco hasta algún puerto desde donde continuara la marcha por tierra, hasta llegar a unirse con las demás tropas realistas, - bien a través de la Cordillera. Aún ya antes, si se recuerdan las «Instrucciones» dadas por el Virrey a Gaínza, primero y después a Osorio, se puede observar esta idea del Virrey del paso de los Andes por el ejército realista de Chile. El fin perseguido por Abascal era claro: sorprender la retaguardia del ejército argentino, que se encontraria así entre dos fuegos, y con ello franquearse el camino de Buenos Aires.

Osorio no llevó a cabo el plan de Abascal porque las condiciones de su ejército después de la lucha no se lo permitieron. El corto auxilio que pudo enviar a Pezuela era harto exiguo para emprender la aventura, y hubo de tomar el camino del mar. Cuando terminó su campaña tampoco se creyó lo suficientemente fuerte para intentarlo, y, por último, cuando a fines de 1815 se preparaba, quizás, para llevarlo a cabo, vino su relevo y ya no se volvió a hablar más del proyecto, pues su primer promotor, el Virrey Abascal, también fué sustituído a mediados de 1816. Es curioso, sin embargo, observar cómo este Virrey concibió un plan que, de haberse conseguido, hubiera retrasado indefinidamente el triunfo de la revolución en América del Sur. Pensó realizar, en sentido inverso, la marcha que más tarde efectuara San Martín, que entonces se preparaba en Mendoza. Si las condiciones del ejército de Chile y de su Jefe hubieran respondido a las necesidades del momento y Osorio se hubiese dado cuenta de la trascendencia de los planes del Virrey, no cabe la menor duda de que el curso de la guerra hubiese cambiado notablemente, ya que, en aquel momento, San Martín no se encontraba preparado aún para hacer frente a la invasión desde el territorio chileno. De haberse llevado a efecto, no cabe duda de que hubiese significado el mo- 
mento de más aguda crisis para la revolución argentina, y aún, sin temor a exagerar, quizás el principio de un fin posible e inmediato.

Pero no se llevó a eabo, y con él se perdíó la última ocastón de asestar un fuerte, golpe a la idea de la independencia en el Continente. Mas no fué sólo eso, sino que a Osorio sustituyó en el gobierno de Chile un personaje incapaz de realizar ningún plan de envergadura: D. Francisco Casimiro Marcó del Pont. Si el primero se había mostrado algunas veces duro en castigar a los patriotas, éste aumentó la dureza hasta límites extremados, y contribuyó indirectamente a favorecer los planes de San Martín. Por lo demás, no cabía pensar que fuese capaz de medirse con el general argentino; asi, cuando más tarde sus tropas sufren la derrota de Chacabuco, infligida por el ejército de San Martín una vez atravesados los Andes, no tomó otra solución que la retirada inmediata. $Y$ cuando el entonces Virrey del Perú quiso echar mano de Osorio, no pudo repetir su hazaña de 1814. Entonces se debió dar cuenta del error que cometiera al no realizar el plan que le trazara Abascal. 


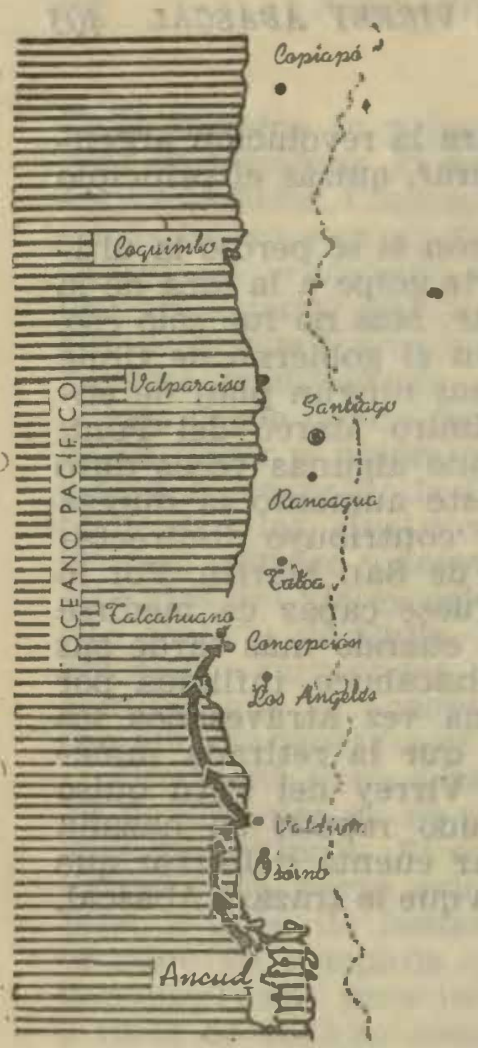

PAREJA
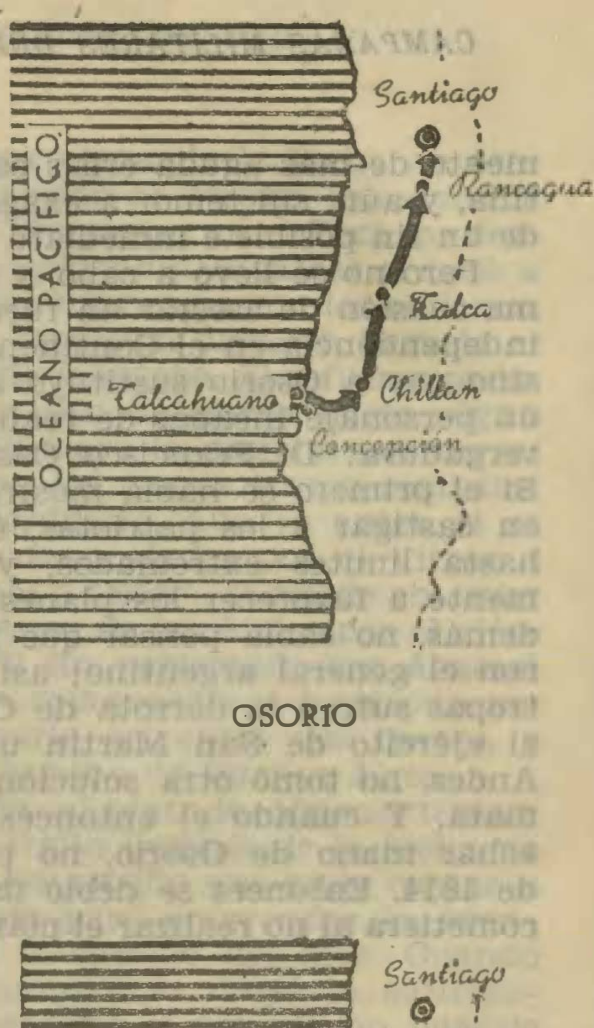

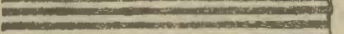

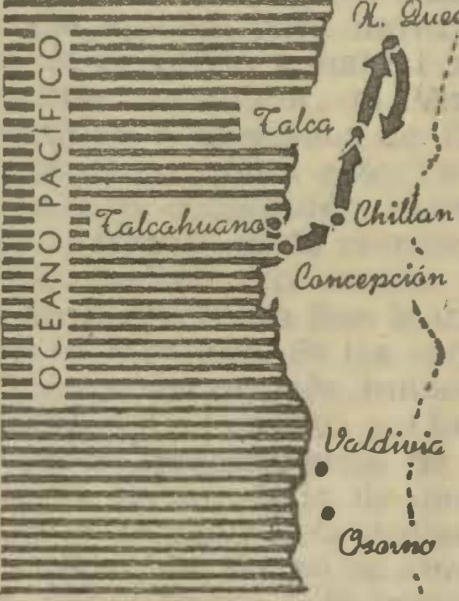

GAINZA 
F UE N T E S 


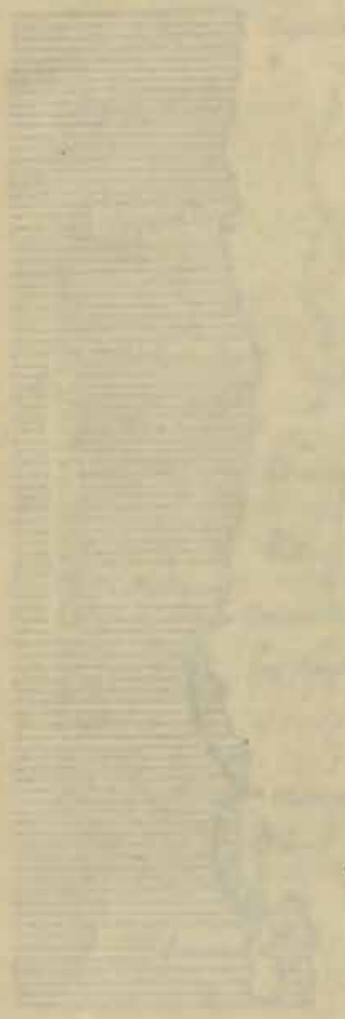

2 3 T ด 3 บ.
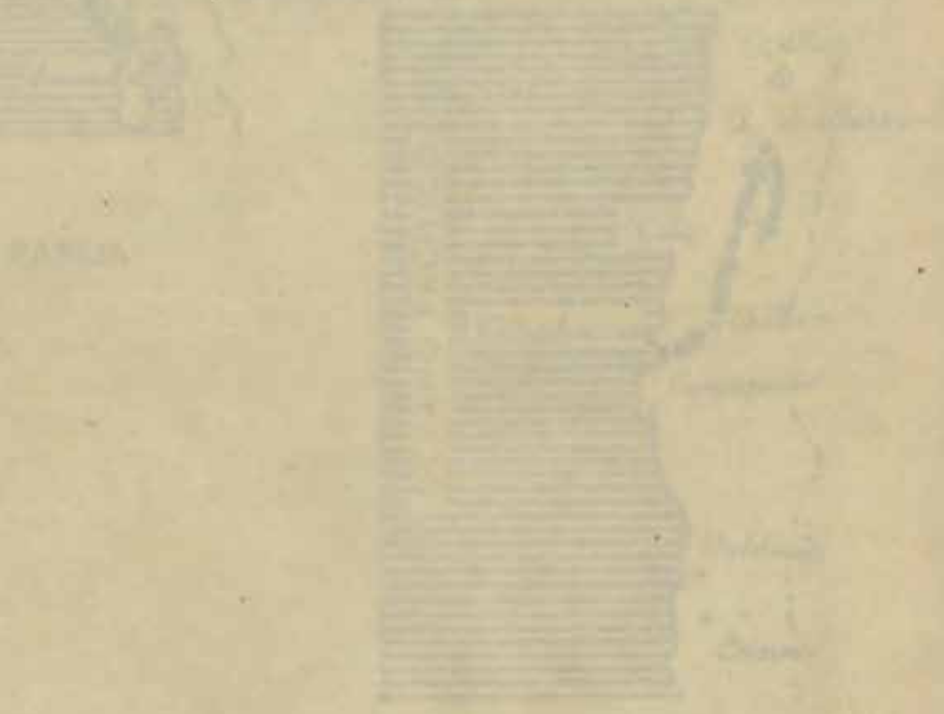

zusketh 


\section{Archivo General de Indias}

Quito 235. Asuntos de Popayán y correspondencia con los residentes de Quito. 1816.

Quito 237. Correspondencía con los Gobernadores de Gusyaquil. 1862-1814.

Quito 238. Cosrespóndencia con los Gobernadores de Popaýán: 1734-1817.

Quito 255. Duplieada del Presidente. 1808-1810.

Quito 256. Id. 1811.

Quito 257. Id. Id. 1812-1813.

Quito 258. Id. Id. 1814-1815.

Quito 259. Id. $\quad$ Id. $1816-1817$.

Lima 585. Inventarios de Decretos. 1760-1816.

Lima 600. Consulta al Consejo. 1799-1807.

Lima 601. Id. Id. 1807-1811.

Lima 602. Id. Id. 1812-1817.

Lima 608. Remisiones al Consejo. 1805-1824.

Lima 609. Materias Gubernativas. 1555-1819.

Lima 610. Id. Id. Id. Id.

Lima 613. Informes sobre materias gubernativas 1806-1821.

Lima 624. Provisiones de emplobs. 1805-1807.

Lima 625. Id. Id. 1808-1811.

Lima 626. Id. Id. 1812-1815.

Lima 641. Burrespondencias de Virreyes. 1797-1815.

Lima 648. I I. Id. 1800-1808.

Lima 649. Id. Id. 1809-1820.

Lima 734. Duplicados del Virrey. 1805-1806.
Lima 735 .
Id.
Id. Id. Id.
Lims 736 .
Id.
Id. 1807-1808.
Lima 737.
Id. 1808.
Lima 738.
Id.
Id. 1800-1809.
Lima 739 .
Id.
Id.
Id. 1809-1810.
Lims 740.
Id.
Id. 1810 .
Lima 741.
Id.
Id. 1811 . 


$\begin{array}{llllr}\text { Lima } & 742 . & \text { Duplicados del } & \text { Virrey. } & 1812 . \\ \text { Lima } & 743 . & \text { Id. } & \text { Id. } & \text { Id. } \\ \text { Lima } & 744 . & \text { Id. } & \text { Id. } & 1813 . \\ \text { Lima } & 745 . & \text { Id. } & \text { Id. } & \text { Id. } \\ \text { Lima } & 746 . & \text { Id. } & \text { Id. } & 1814 . \\ \text { Lima } & 747 . & \text { Id. } & \text { Id. } & \text { Id. } \\ \text { Lima } 748 . & \text { Id. } & \text { Id. } & \text { Id. } \\ \text { Lima } & 749 . & \text { Id. } & \text { Id. } & 1815 . \\ \text { Lima } & 750 . & \text { Id. } & \text { Id. } & 1816 . \\ \text { Lima } 751 . & \text { Id. } & \text { Id. } & \text { Id. } \\ \text { Lima } 752 . & \text { Id. } & \text { Id. } & \text { Id. } \\ \text { Lima } 753 . & \text { Id. } & \text { Id. } & \text { Id. } \\ \text { Lima } 754 . & \text { Id. } & \text { Id. } & \text { Id. } \\ \text { Lima } 755 . & \text { Id. } & \text { Id. } & \text { Id. }\end{array}$

Lima 764. Duplicados de Gobernadores e Intendente. 1803-1817. Lima 769. Duplicados de Ministros y Particulares. 1805-1808. Lima 770. Id. $\quad$ Id. Lima 771. Id. $\quad$ Id. $\quad$ Id. 1810. Lima 772. Id. Id. $\quad$ Id. $1811-1813$. Lima 773. . Id. Id clbnt ab Id. Lima 778. Correspondencia con los Gobernadores de Huancavéli-

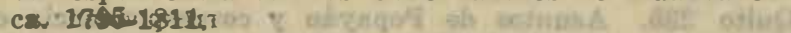

Lima 788. Reales Cédulas e Informes de la Audieneia. 1683-1817.

Lima 793. Cartas Budientes del Presidente y Oidores. 1796-1813.

Lima 794. Cartas Fupdientes del Presidente y Oidores. 1814-1817.

Lima 798. Sec de Gobierno. Nézociado Política y de Inīstrucción. 1789-1822.

Lima 799. Elocdionea de Ayunthmientos y Diplatados a Cortes. 1813-1814:

Lima 800. Exp̉ddenito sobre Vtantaniento del Perú. 821.

Lima 801. Reales . Cadulas' !y. Erivilogios a Ciudadis. 1621-1818.

Lima 802. Expedientes de-Cabildes Eeculares: 1739-1811.

Lima 803. Id. Itef To II. Id. Id. 1812-1813.

Lima 804. Id. Mtat. Id. Id. 1813-1819.

Lima 975. Expedientes resneltos. 1814-1815:

Lima 981. Expedientés pendieates de informes. 1798-1818.

Lima 982. Indices de Expobientes. 1760-1832.

Lims 1.010. Expedientes e instrneias de partes, 1804-1812.

Lima 1.011. Id. Id. Id. 1808.

Lima 1.012. Id. Id. Id. If 1809-1810.

Lima 1.013. Id. Ititatst Id. Id. 1811.

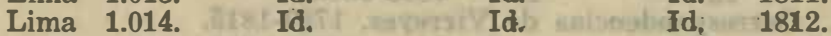

Lima 1.017. Id. Id. Id. 1814-1815.

Lima 1.018-A! Id. Id. Id. 1816-1818.

Lima 1.018-B. Id. Id. Ily ti. Id. Id. Id.

Lima 1.027. Gacetas poribdicos. $812-1814$.

Lima 1.068. Informes de'Trieienda. 1613-1822.

Lima 1.069. Id. Id. I613-1824.

Lima 1.115. Duplicado del Visitador e Intendentes de Hacienda. 1788-180x

Lima 1.116. Duplicados del Visitador e Intendentes de Hacienda. 1811-1822. 
Lima 1.120. Correspondecia con los Intendentes. 1776-1829.

Lima 1,121. Id. Id. Id. Id. Id.

Lima 1.122. Reales Cédulas e Informes del Tribunal de Cuentas. 1621-1818.

Lima 1.124. Expediente sobre arreglos del Tribunal de Cuentas. 1800-1813.

Lima 1.131. Tribunal de Cuentas y Oficiales Reales. 1785-1812.

Lima 1.441. Asuntos de Hacienda. 1806-1808.

Lima 1.442. Id. Id. 1809-1812.

Lima 1.443. Id. Id. 1813-1816.

Lima 1.462. Instancias de partes de la Real Hacienda. 1806.

Lima 1.463. Id. Id. Id. Id. 1807-1809.

Lima 1.465. Expedientes de Hacienda. 1812-1814.

Lima 1.466. Id. Id. 1814-1816.

Lima 1. $₫ 67 . \quad$ Id. Id. 1816-1817.

Lima 1.482. Patentes y Nombramientos Militares. 1627-1817.

Lima 1.483. Asuntos de Guerra. 1778-1814.

Lima 1.504. Revistas, Libretas y Ajustes Militares. 1791-1810.

Lima 1.539. Duplicados del Consulado. 1782-1818.

Lima 1.549. Expedientes del Consulado y Comercio. 1801-1811.

Lima 1.550. Id. Id. Id. 1812-1819.

Lima 1.553. Expedientes del Consulado sobre Préstamos al Virrey. 1769-1817.

Lima 1.557. Expedientes sobre la captura de la fragata angloamericana \&PEGASUS». 1803-1819.

Lima 1.566. Estado de las iglesias en el Perú. 1767-1820.

Lima 1.568. Cartas del Arzobispo y Cabilde Eclesiástico de Lima. 1724-1819.

Lima 1.570. Iglesia de Arequipa. 1770-1823.

Lima 1.572. Cartas del Obispo de Arequipa. 1736-1817.

Lima 1.577. Cartas del Obispo de Huamanga. 1786-1819.

Lima 1.588. Expedientes e Instancias. 1801-1810.

Lima 1.589. Id. Id. 1811-1814.

Lima 1.590. Id. Id. 1815-1818.

Cuzco 2. Duplicados de Gobernadores. 1784-1814.

Cuzco 3. Correspondencia y Duplicados de Autoridades y Particulares. 1782-1824.

Cuzco 7. Duplicados del Presidente y Oidores. 1795-1812.

Cuzco 8. Id. Id. Id. 1810-1816.

Cuzco 28. Expedientes e Instancias de Partes. 1791-1833.

Buenos Aires 40. Correspondencia con los Virreyes. 1804-1815.

Buenos Aires 47. Correspondencia con los Gobernadores de Montevideo. 1810-1813.

Buenos Aires 97. Duplicados del Virrey. 1809-1810.

Buenos Aires 155. Expedientes y Noticias sobre la sublevación de Buenos Aires y sus incidencias. 1808-1822.

Buenos Aires 156. Id. Id. Id. 1808-1822.

Buenos Aires 532. Asuntos Militares. 1787-1824.

Charcas 434. Correspondencia con los Gobernadores. 1788-1817.

Charcas 436. Correspondencia con los Gobernadores de Cochebamba y La Paz. 1790-1824.

Charcas 441. Duplicados de Gobernadores, 1799-1812.

Charcas 447. Cartas, Expedientes y Duplicados de la Audiencia. 1800-1830. 
Charcas 454. Cartas y Expedientes de Cabildos Seculares. 18081812.

Charcas 583. Expedientes e Instancias de Partes. 1804-1814.

Chile 207. Duplicados de los Presidentes. 1815.

Chile 315. Papeles sobre sublevaciones y levantamientos polfticos. 1781-1815.

Chile 187. Correspondencias de Presidentés. 1773-1817.

Chíle 222. Duplicados de Particulares. 1773-1815.

\section{Archivo del Conde de Guaqui}

En dicho Archivo, propiedad del Excmo. Sr. Conde de Guaqui (Madrid), he visto todos los documentos que se hallan depositados en él, los cuales se refieren fundamentalmente al General Goyeneche Primer Conde de Guaqui. Se hallan reunidos en cajas y agrupados dentro de ellas en carpetas, numerado cada documento, cuya cita corresponde al Catáogo existente en dicho Archivo. En su mayor parte son cartas, partes, memoriales, borradores, etc., interesantísimos para estudiar la figura de Goyenache y enjuiciar sus campañas.

\section{Archivo del Virrey Abascal}

El Archivo del Virrey Abascal, prapiedad de su descendiente don Manuel Pavía Pereira, se halla depositado en la Escuela de Estudios Hispano-Americatos de Sevilla. Se compone de siete cajas de documentos sin catalogar, que contienen gran cantidad de documentación oficial y privada del Virrey. Toda ella ha sido estudiada por mi y es verdaderamente fundamental, no ya para el presente trabajo, sino para el elaborar la historia del Perú desde 1806 a 1816. En las citas de documentos me he limitado a sefialar los que pertenecen a dicho Archivo, sin más puntualización, ya que por no existir un Catálogo, su actual distribución es puramente pravisional.

En dicho Archivo se guatda la Memoria de Gobierno del Virrey Abascal, recientemente publicada por V. Rodxiguez Casado y J. A. Calderón, que es la que he manejado y cuyas citas he acomodado a dicha edictón.

\section{Bibliografía}

ACUERDOS del extinguido Cabildo de Buenos Aires. Barcelonai, $1888-1930$.

ALBERDI, J. $\mathbf{B}_{\text {, }}$ \&a cultura argentipa-interpretación económica de la Historla Política Argentina y Sur-Amtericainas.

ALTAMIRA, R. RResumen Histótico de la Independẹncia dè la Amiérica Españolas. Buenos Aires, 1910.

ALVAREZ, Aleiandro. \$La Diplomacia de Chile durante la emancipaciónz. Madrid, s. a.

AMUNATEGUI, M. L. y V. \&La Reconguista Española de Chile en 1814 . Bibl. Ayacucho. Tomo LXIII. Madrid, s. a. 
AMUNATEGUI, Domingo. «Virreinato del Río de la Platas. Rev. Humanidades XXV. 1936.

AMUNATEGUI, M: L. \&Los precursores de la Independencia de Chile». Santiago de Chile, 1909.

AMUNATEGUI, y VICUNA MACKENA, M. L. y B. KLa Dictadura te O'Higginss. Bibl. Ayacucho. Tomo XIX. Madrid, s. a.

AMUNATEGUI SULAR. \&La Sociedad Chilena en el siglo XVIII. Sastiago de Chile, 1901.

ANDRE, Marius. \&El fin del Imperio Español en América». Cultara sispafiola. 1939.

APUNTES sobre la Revolución de 1809 en Buenos Aires. Rev. de Buenos Aires. Tomo XV. 1868.

ARAOZ de la MADRID, Gregorio. Extracto sacado de todas mis campañas... desde 1811๖. Rev. de Buenos Aires-XXIII y XXIV. $1870-1871$.

ARAUJO, Oreste. \&eografía económica de Uruguay». Montevideo, 1910.

ARCE; Luis. \&Iniciativas y comienzos de la Guerra de la Independencia Sur-Americana». Santiago de Chile, 1908.

ARCHIVO GENERAL DE LA NACION. Archivo de Gobierno de Buenos Alires, 1810.

ARDISSAC, Romualdo. La forma del territorio de los Estadosensudo de Geografía Políticas. Rev. Humanidades. XXIII-1932.

ARGUEDAS, Alcides. *Pueblo enfermos. 1909.

ARGUEDA:, Alcide. QHistoria General de Bolivia (1809-1921)s. La Paz, 1922.

AUNOS, Đauardo. «C6mo se perdi6 Américas. Buenos Aires, 1942.

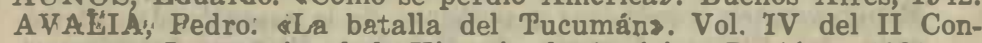
greso Internacional de Historia de América. B. Aires, 1938.

BARBAGELATA, Hugo de. RL'influence des idees française dans la revolutión et dans l'evolutión de l'Amerique Espagnoles. París, 1917.

BALLESTEROS. Rev, de la Guerra de la Independencia de Chile.

BALLIVIAN, Manuel V. \&Noticia Política, Geográfica, Industrial y Estadística de Bolivias. La Paz, 1900.

BAELIVIAN y ROXAS, V. de. \&Archivo Boliviano, Colección de documentos relativos a la Historia de Bolivia durante la época colonialy". Paris, 1872.

BANADOS ESPINOSA, Julio. eLa batalla de Rancaguas. Sanst tiagol de Ghile, 1884 .

BARBAGELATA, Hugo de. Artigas y la Revolución Americana». París, 1930.

BARREDA Y LAOS, Felipe. \&Vida intelectual de la Colonia». B. Aires, 1937 .

BARRERA, Isaac J. \&Memoria de la Academia Nacional de la Historia : Quito Colonial, siglo XVIII, comienzos del siglo XIXs. Quito, 1922.

BARROS ARANA; Diego. \&Historia General de la Independencia de Chiles. Santiago de Chile, 1854.

BARROS ARANA, Diego. «Historia General de Chile». Santiago de Chile, 1887.

BARROS ARANA, Diego. «Historia de Américas. Santiago de Chile, 1908. 
BASADRE, Vicente. Memoria histórica-político-geográfica relativa a la Independencia de la América Españolas. La Coruña, 1822.

BATALLAS de la Guerra de la Independencia Altoperuanas. La Paz, 1913.

BECQUER, Gerónimo. \&Las provincias Hispano-Americanas en los últimas años del siglo XVIIIs. Rev. de Geografía Col. y MercXII. 1915.

BELGRANO, Mario. eliniers y Napoleón». Boletín del Instituto de Investigaciones Históricas. Tomo XIX. 1935.

BELTRAN AVILA, Marcos. ¿Cápítulo de la Historia Colonial de Oruro». La Paz, 1925.

BELTRAN Y ROZPIDE. \&La Independencia de Américas. Bol. de la Real Academia de la Historia. Tomo LXXX. 1922.

BENAVENTE, J. de. Memorias de las primeras campañas de la Guerra de la Independencia de Chiles. Santiago de Chile, 1845.

CAILLET-BOIS, R. eEnsayo sobre el Río de la Plata y la Revolución francesas. Buenos Aires, 1929.

CALVO, Carlos, «Recueil complet des traites, conventions, capitulations, armistices... de tous les etats de l'Amerique latines... depuis l'annee 1493». Besançon, 1862.

CALVO, Carlos. Anales históricos de la Revolución de la América latina. París, 1864.

CAMACHO, J. María. \&istoria de Bolivias. La Paz, 1906.

CAPPA, Ricardo. «Estudios críticas». Madrid, 1889.

CARBIA, Bómulo de. sLa Revolución de mayo y la Iglesias. Buenos Aires, 1945.

CESPEDES DEL CASTILLO, Guillermo. \&Lima y Buenos Aires. Repercusiones económicas y políticas de la creación del Virreinato del Platas. Escuela de Estudios Hispano-Americanos. Sèvillà, 1947.

CEVALLOS, Pedro Fermín. «Resumen de la Historia del Ecuador desde su origen hasta 1845». Lima, 1870.

CONWAY, M. The bolivian andess. New-York, 1901.

CORDOVA Y URRUTIA, J, María. «Las tres épocas del Perú, o compendio de su Historia».

CORNEJD, Atilio. Apuntes históricos sobre Saltas. Buenos Aires, 1937.

C.UNEO-VIDAL, R. «Historia de la insurrección de Tacna por la Independencia del Perú». Lima, 1929.

D'AVIS, Julio Alberto. «El estado boliviano y la unidad peruanas. Cachabamba, 1944.

DELLEPIANE, Carlos, «Historia militar del Perú». Buenos Aires, 1941.

DENIS, P. a Amerique du sud (II partie). T. XV de la Geographie Universelle de V. Lablache». París, 1927.

DESSALINES D'ORBINY, A. EDescripción geográfica, histórica y estadística de Bolivia. 1846.

DOCUMENTOS del Virreinato existentes en la Biblioteca Nacional de Limas.

DOCUMENTOS para la historia Argentinas. Buenos Aires, 1920-1921.

DOCUMENTOS para la historia del Río de la Platas. Buenos Aires, 1913. 
DUFEY, P. F. Resume de l'histoire des revolitions de l'Amerique Meridionales. París, 1826.

ENSAYO histórico (Volumen CXXIX de la Biblioteca del OficialCírculo Militar-. Buenos Aires, 1929).

ESTRADA, Santiago de. «...y la casa fué destruídas. Rev. Sol y Luna. N. 5. Buenos Aires, 1940.

FRIAS, Bernardo. Historia del General don Martín Huemes y de la provincia de Saltas. Salta, 1902.

FUNES, Gregorio. Ensayo de la Historia civil del Paraguay, Buenos Aires y el Tucumáns. Buenos Aires, 1816-1817.

GANDIA, Enrique de. Eistoria de Santa Cruz de la Sierra-una nueva república en Sur-Américas. Buenos Aires, 1935.

GARCIA AL-DEGUER. Historia de la Argentinas. Madrid, s. a.

GARCIA CAMBA, A. Memorias para la historia de las armas españolas en el Perús. Madrid, 1846.

BIBLIOTECA AYACUCHO. Madrid, s. a.

GARCIA DE LOYDI. El Marqués de Sobre Montes. Buenos Aires, 1930.

GARCIA PAZ. «Memorias del General Garcis Paz». Bibl. Ayacucho. Tomo XVI. Madrid, s. a.

GARCIA ESCUDERO, José María. «Un viraje en la interpretación de la independencia americanas. Rev. de estudios políticos. Volumen V. N.॰ X. 1943.

GELPI Y FERRO. Estudios sobre la América, conquista, colonización, gobiernos coloniales y gobiernos independientess. $1864-1866$.

GIMENEZ FERNANDEZ, Manuel, eLas doctrinas populistas en la Independencia de Hispanoaméricas. Escuela de Estudios Hispano-Americanos. Sevilla, 1947.

GRENON, P. EDe la primera revolución del Alto Perú en 1809. Documentos en Córdoba, Boletín del Instituto de Investigaciones Históricas. 1925.

GROUSSAC, D. Santiago Liniers (Anales de la Biblioteca).

HERNANDEZ, Alfonso J. El Virreinato del Perús. Madrid, 1945.

IBARBUREN, Federico. La tradición hispánica en nuestra emaneipaeión políticas. Rev. Sol y Luna, N.³.

IZCUE, J. Augusto de. Los peruanos y su independencias.

JANE, Cecil. LLibertad y despotismo en la América Españolas. Madrid, 1931.

CRAMER, Pedro. Historia de Bolivias (incompleta). 1899.

LAMA, Tomás. «Historia de la Guerra de la Independencias.

LA VALLE, J. A. Abascals. Rev. de Buenos Aires. Tomo V. 1864.

LAVALLE, J. A. Rev. de Lima, 10 de septiembre de 1860.

LEGUIA, Jorge Guillermo. LLa ciudad de Lima en el siglo XVII (Mercurio Peruano. Tomo IV). Lima, 1920.

LETURIA. La emancipación hispano-americana en los informes episcopales a Pío VII». Buenos Aires, 1935.

LENENE, Ricardo. La política económica de España en América y la revolución de 1810s. 1914.

LEVENE, Ricardo. eHistoria de la Nación Argentinas, publ. bajo su dirección. B. Aires, 1941. (5 tomos publicados):

LEVENE, Ricardo. Ensayo histórico sobre la revolución de mayo y Mariano Morenos. B. Aires, 1920-1921. 
LLWFENA, Ricardo. \&uecciones de historia artentinas. Buenos Aires, 1934.

LAPER M Mnued. *Recuerdos históricos de la gurerra de la independencia de Colombia-Perú (1819+1826)>. Bib1. Ayacucho. tromo.XI.

LOPEZ, Vicente. «Historia de la República Argentinąs: Buenos Aire: 1833.

LOPEZ, V. «eografía histórica del territorio argentinos. Rev. de 1 : Buedos Aires. Tomo XX. 1869.

LORENTrE, Sebastián. «História deł Perú bajo los Borbones» (1700-1881)\%. Lima, 1871.

MANCIAI, Jules. Bolivar et l'emaneipation des colonies espagnolies, des origines a 1815. Paris, 1912.

MARDA.NI, J. W Wirrey don Baltasar Hidalgo de Cisneross. Rev. Humanidades. Tom XX XX. (Segunda Parte). 1936.

MARIATEGUI OLIVA, Ricardo. «Historia del Perú». Lima, 1939.

MARIATEGUI, F. J. \&Ahotariones a la historia del Perú independiente de don M. Paz Soldán». Lima, 1869.

MEDINAs J. Toribio. Expediatón en Corso del Comodoro Guiliermo Brown (1815-1816).

MEDINA, J. T. S. Colección de documentos para la historia de Chiles.

MEDINA, J. T. RActas del Cabildo de Santiago (1810-1814)s. Santiago, 1910.

MENDIBESRU, Manuel de. Eiccionario histórico-biográfico del Perús. Lima, 1931.

MIRRO. «Ivas casacas de Goyeneches. La Naci6n'. Suplemento al núm. 19.571: 7 de marzo de 1926. Tomo II. N..॰ 37. Pâg.' 4.

MITRE, Bartolomé. «Historiz del General Belgrano y de la Inindependezcia Argentina*, Parí, 1887.

MIT,RE, B, Ensayos históricos: IL emancipación Sur+Americanas. B. Aires, 1918.

MITRE, B. Historia del General San Martín y de le emancipación Súr-Ámericanas. B. Aires, 1907.

MITRE, B. ¿Compróbaciones históricas». B. Aires, 1882.

MONFERINI, J. L. Historia de la Nación Argentinas. Buenos Aires, 1940

MQN,OGRAFIAS históricas sobre la ciudad de Limay. Lima, 1935.

MUNOZ OLAVE, Reinaldo. \&El centenario de la batalla de Yerbas Buenas, (1813-1913) . Santiago de Chile, 1916.

MUSEO MITRE. \&Documentos del Archivo de Belgranos.

NOBOA ZUNARRAGA, Horacio J. KLas sociedades porteñas y su acción revolucionaria». B. Aires, 1939.

PATRON, Pablo. \&studio crítico acerca del Perú Colonials. Limä, 1894.

PAZ, Luiș, «Historia General del Alto Perú, hoy Bolivias. Sucre, 1919.

PAZ SOLDAN, Mariano Felipe. \&Historia del Perú independiente, primẹr períodos. Lima, 1858.

PAZ SQLDAN, Mariano IFelipe، \&Diceionario geográfico estadístico del Perú». Lima, 1880.

PAZ SOLDAN, J. Pedro. La ciudad de Lima bajo la dominatión espat̃olas. Lima, 1908. 
PFhRYRA, Carlos, aHistoria de la América Españoza: Madrid, 1925

PINILLA, Sabino. eLa oresción de Bolivias. Bibl Ayacucho. Madrid, s. a.

PINTO, Manuel. \&La revolución de la Intendencia de La Paz en el Virreinato del Río de la Plata, con la ocurreneia de Chu(1800,1810). B. Aires, 1909.

PRADO Y UGARTECHE, J. \&studio social del Perú durante la dominación españolas. Líma, 1894.

PRUVONENA. *Memorias y documentos para la Historia del Perús. IParis, 1858.

RADA Y GAMIO, Redro J. «El Arrobispo Goyeneche $\mathrm{y}$ apuntes . para la Historia del Perús. Roma;'1917.

RAVIGNANI, Emilio. \&La personalidad de Manuel Belgranos. Publieaviones de la Facuitad de Eilosofía y Letras N. V. Buenos Aires, 1912.

RENE-MoRENO, Gabriel. \&Bolivi y Perú. Más notás históricás y bibliográficass. Santiago de Chile, 1905 .

RENE-MORENiO, G. RUltimos días! coloniales en el Alto Perús. Santiago de Chile, 1897-1898.

REVOLUCION, sLa de La Pas en 1809: doeamientos históricos». Buenos Aines, 1897.

RIVA AGƯERO, José de la. \&El Perí hastôrico y artísticos. Santenter, 1981.

RIVA AGUERO, José de la $\&$ D. José Baquijano de Brascea y $\mathrm{Ca}$ rrillo de Córdoba, tercer conde de. Vista Florida en el Pérús. 1751-1818. Revistas del Arch. Bibl. y Museo. Octubre-Diciembre, 1985:

RIVA AGtrERO, José de la. kLa Historia del Perú». Eima, 1910.

REBERTS! Carlos tLas inysaiones inglesas del Río de la Plata (1806-1807) y la influencia inglesa en la independencia y organización de las provinciass Río de la Platás. Buenos Aires, 1928.

ROBERTSON y PARIS, J. G. \&La irgentiná en la époea de la revolucións.

RODRIGUEZ CASAADO, Vicente, y J. A. Calderón Quijano. «Mèmoria de Gobierno del Virrey Abascals. Sevilla, 1944. Con un estudio preliminax.

RODRIGUEZ PEDRO, Manuel. \&Memarias sobre las causas que prepararon la Independencia del Petris. Lima, 1877.

RODRFGUEZ. VILIA. \&El Teriente Coronel D. Pablo Morillos. Bibl. Ayacucho. Tomo LIII-LIV. Madrid, s. a.

ROMERO, Emilio. «Geografía económica del Perús. Lime, 1944.

ROMERO, Emilio. sHistoria económiea y finánciera del Perú. Antiguo Perú y Virreinato. Lima, 1937.

ROMERO. C. A. «Memoria del Vi trey del Perú, Marqués de Avilés. Limaa, 1801.

RUA DE ESTASIN, José. «El General Elío». Madrid, 1940.

RUBIO, David. aLa Universidad de San Marcos de Litha, durante la colonización españolas. Madrid, 1983.

RUBIO. Julián María. sLa Infanta Carlote Joaquina y la politica de España en América (1808-1812). Madrid. 1920.

SAGI. sLos cuatro últimos años de dontinactón española en el Río de lá Platas. Buenos Aires, 1874. 
SALAVERRIA, J. María. Bolivar el Libertadors. (Vidas españolas e hispanoamericanas del siglo XIX), 1930.

SAN CRISTOVAL, Evaristo. eLos precursores de la Independencias. Lima, 1923.

SANCHEZ DE VELASCO. Memorias para la Historia de Bolivia desde el año de 1808s. Sucre, 1988.

SARAVIA, Carlos M. a eSalta en la Independencia, y la acción de Güemess. Buenos Aires, 1923.

STEVENSON, William Bennet. eMemorias». Bibl. Agacucho. Tomo XV. Madrid s. a.

TORATA, Conde de. Eocumentos para la historia de la guerra separatista del Perús. Madrid, 1884-1898.

TORRENTE, Mariano. RHistoria de la revolución hispanoamericanas. Madrid, 1829.

UNANUE, Hipólito. \&Guía política, militar y eclesiástica del Perú para el año 1794, s. l. Imp. R. de Niños Expósitos, 1794.

URBINA, A. F. de (Marqués de Rozalejos). eliniers y Napoleóns. Rev. Estudios Políticos. Vol. XIII. Núm. 24. 1945.

VALEGA, J. M. «La gesta emancipadora del Perús. Lima, 1940-1944.

VALEGA. El Virreinato del Perús. Lima, 1939.

VARELA ORBEGOZO, Luis. eApunte para la historia de la sociedad colonials. Lima, 1905.

VARGAS UGARTE, Rubén. eD. Benito María de Moxó y Francolí, Arzobispo de Charcas». Buenos Aires, 1931.

VARGAS UGARTE, Rubén. «El Episcopado en los tiempos de la revolución Suramericanas. Buenos Aires, 1945.

VAZQUEZ MACHICADO, H. Ra efervescencia libertaria en el Alto Perú de 1809 y la insurrección de esclavos en Santa Cruz de la Sierras. Rev. Kollasuyo. La Paz. Año II. Núm. 14. Febrero de 1940.

VELAZQUEZ, J. «Historia del Reino de Quitos.

VICUNA MACKENA, Benjamín. «El ostracismo de los Carreras». Santiago de Chile, 1857.

VICUNA MACKENA, B. QVida de Sucres. Madrid, s. a.

VICUNA MACKENA, B. La revolución de la Independencís del Perús. Lima, 1924.

VILLAMIL. Reseñas de los acontecimientos políticos y militares de la provinoia de Guayaquil desde 1818-1824s.

VILLANUEVA; Carlos A. RLa Monarquía en Américas.

VIVERO, Domingo de. *Galería de retratos de los Gobernadores y Virreyes del Perú (1582-1824,). Texto de J. A. Lavalle. Barcelona, 1909.

WEBSTER, C. K. eGran Bretaña y la Independencia de la América Latinas. Buenos Aires, 1944.

WIENNER, Carlos. \&Peŕ́ y Bolivias.

WIESSE, Carlos. «Historia del Perú Colonials. Lima, 1931.

YRAIZOS, F. El Sur Oeste de Bolivias. La Paz, 1901.

ZINNY, Antonio. $2 D$. Juan Martín de Pueyrrodóns. Rev. de Buenos Aires. Tom XIV, 1867.

ZINNY, Antonio. aditamento al bosquejo de la revolución argentinas. Rev. de Buenos Aires. Tomo XVI, 1868.

ZINNY, Antonio. Historia de los Gobernadores de las provincias argentinas desde 1810 hasta la fechas. Buenos Aires, 1879. 
DE LA

\section{ESCUELA DE ESTUDIOS HISPANO-AMERICANOS}

Series en publicación:

x." Anuario.

2." Monografias.

3. Memorias, relaciones y viajes.

4." Ensayos.

5." Manuales de estudio.

6." Colecciones de documentos.

7." Ediciones y reediciones de libros raros y curiosos.

EDICIONES A LA VENTA:

1 ANUARIO DE ESTUDIOS AMERICANOS. Tomo I, 1944. $24 \times 17 \mathrm{cms.}$. XII +844 páginas, 17 ilustraciones; rística.Noventa pesetas.-AGOTADO.

2 Florentino Pérez Embid: EL ALMIRANTAZGo DE CASTILLA HASTA LAS CAPITULACIONES DE SANTA FE. $-24 \times 17$ cms., XVI+186 págs. y 4 ilustraciones; rústica, con sobrecubierta.-Veinticinco pesetas.

3 Manuel Giménez Fernández: LAS BULAS ALEJANDRINAS DEL 1493 REFERENTES A LAS INDIAS. $-24 \times 17$ cms., XVI+258 págs. y 5 ilustraciones; rística, con sobre cubierta.-Veinticinco pesetas.

4 MEMORIA DEL GOBIERNO DE JOSE FERNANDO DE ABASCAL Y SOUSA, VIRREY DEL PERU.-Edición do Vicente Rodriguez Casado y José Antonio Calderón Quijano; estudio preliminar de V. Rodríguez Casado.-Dos tomos de $20 \times 13 \mathrm{cms}$., CLII+1.084 págs., 15 láminas; tala, con sobrecubierta.-Setenta pesetas.

5 José Antonio Calderón Quijano: BELICE, 1663 3-1821.-Prólogo de Vicente Rodríguez Casado.-22×16 cms., XIV+504 págs., 32 láminas; tela, con sobrecubierta.-Setenta pesetas.

6 P. Venancio D. Carro, O. P.: LA TEOLOGIA Y LOS TEO. LOGOS JURISTAS ESPANOLES ANTE LA CONQUISTA DE AMERICA.-Dos tomos de $22 \times 16$ cms., 934 págs.; tela, con sobrecubierta.-Setenta pesetas. 
7 Antonto Ruméu de sAmas: COLON EN BARCELONA$24 \times 17$.cms., XII + 86 págs.; rústica.-Doce pesetas.

8 Emiliano Jos: INVESTIGACIONES SOBRE LA VIDA Y OBRAS INICIALES DE DON FERNANDO COLON. $24 \times 17$ cms., XVIII+164 páginas, 6 ilustraciones; rústica.-Veinticinco pesetas.

9 ANUARIO DE ESTUDIOS AMERICANOS.-Tomo II, 1945. $24 \times 17$ cms., XVIII + 936 páginas, 88 láminas; rústica.-Noventa pesetas.-AGOTADO.

10 P. Constantino Bayle, S. J.: EL PROTECTOR DE INDIOS. $24 \times 17$ cms., VIII +176 págs.; rústica.-Veinte pessetas.

11 Manuel Gutiérrez de Arce: LA COLONIZACION DANESA EN LAS ISLAS VIRGENES. $-24 \times 17$ cms., VIII +152 pḱginas, 6 láminas; rústica.-Veinticinco pesetas.

12 Guillermo Lohmann Villena: EL ARTE DRAMATICO EN LIMA DURANTE EL VIRREINATO $-22 \times 16$ centímetros, $\mathrm{XX}+648$ págs.; tela, con sobrecubierta.-Sesenta pesetas.

13 P. Luis Alonso Getino, O. P.: INFLUENCIA DE LOS DOMINICOS EN LAS LEYES NUEVAS. $-24 \times 17$ centímetros, VIII + 94 págs.; rústica.-Dieciséis pesetas.

14 LAS LEYES NUEVAS, 1542-1543. Reproducción fotogrạ́fica. Transcripción y notas de Antonio Muro Orejón.-24 $\times 17$ cms., XXV +26 págś.; rústica.-Veinte pesetas.

15 Guillermo Céspedes del Castillo: LA AVERIA EN EL COMERCIO DE INDIAS. $-24 \times 17 \mathrm{cms}$., VIII+188 págs., 8 láminas; rústica.-Veinticinco pęsetas.

16 Antonio Matilla Tascán: LOS VIAJES DE JULIAN GUTIERREZ AL GOLFO DE URABA. $-24 \times 17$ cms., VIII + 84 págs., 4 láminas; rústica.-Dace pesetas.

17 Vicente Palacio Atard: EL TERCER PAGTO DE FAMILIA. Prólogo de V. Rodríguer Casado-22 $\times 16$ centímetros, INIII 380 págs., 8 láminas; telą, con sobrecubierta.-Sesenta pesetas.

18 José Luis Múrquiz de Miguel: EL CONDE DE CHINCHON, VIRREY DEL PERU. $-22 \times 16 \mathrm{cms.,} 336$ pátrs., 16 láminas; tela, con sobrecubierta.tCincuenta pesetas.

20 Alvaro del Portillo y Diez de Sollano: DESCUBRIMIENTOS Y EXPEDICIONES EN LAS COSTAS DE CALIFORNIA. $22 \times 16$ cms., 542 págs., 24 láminas; tela, con sobrecubierta. Hoventa pesetas.

21 MEMORIA DEL GOBIERNO DE MANUEL AMAT Y JUNIENT, VIRREY DEL PERU.-Edición y estudio preliminar de Vicente Rodríguez Casado y Florentino Pérez Embid. $20 \times 13$ cms., CXII +846 págs., 12 láminas; tela, con sobrecriblerta.-Ciento diez pesetas.

22 F. Javier de Ayala: IDEAS POLITICAS DE JUAN DE 
SOLORZANO. $-22 \times 16 \mathrm{cms}$., XVI+584 págs.; tela con sobrecubierta.-Sesenta pesetas.

23 Gaillermo Lohmann Villena: EL CONDE DE LEMOS, VIRREY DEL PERU. $-22 \times 16 \mathrm{cms}$., XVIII+474 págs.; 11 láminas; tela, con sobrecubierta.-Setenta y cinco pesetas.

24 Domingo Lázaro de Arregui: DESCRIPCION DE LA NUEVA GALICIA.-Edición y estudio de François Chevalier. Prólogo de John Van Horne. $24 \times 17$ cms., LXXIV+164 páginas, 4 láminas; rústica.-Treinta y cinco pesetas.

25 Fray Miguel de Agía: SERVIDUMBRES PERSONALES DE IDIOS.-Edición y estudio preliminar de $F$. Javier de A yala. $-24 \times 17 \mathrm{cms}$., LIV +144 págs.; rústicą, con sebrecubierta.-Treinta y cinco pesetas.

26 MEMORIA DE GOBIERNO DE JOAQUIN DE LA PEZUELA, VIRREY DEL PERU.-Edición y prólogo de Vicente Rodríguez Casado y Guillermo Lohmann Vitlena.$20 \times 13$ centímetros, XLVI +912 págs., 3 Jáminas; tela, con sabrecubierta. Noventa y cinco pesetas.

28 Ernesto Schäfer: EL CONSEJO REAL Y SUPREMO DE LAS INDIAS.-Tomo II: LA LABOR DEL CONSEJO DE INDIAS EN LA ADMINISTRACION COLONIAL. $-25 \times 17$ cms.; XVIII+680 págs.; 1 lámina; tela, con sobrecubierta.

29 José Rumazo: LA REGION AMAZONICA DEL ECUADOR EN EL SIGLO XVI.-24X17 cms., XII+268 págs.,12 láminas; mistica.-Cuarenta ppsetas.

30 Vicente Palacio Atard: ARECHE Y GUIRIOR, OBSERVACIONES SOBRE EL FRACASO DE UNA VISITA AL PERU. $24 \times 17 \mathrm{cms}$.,VIII+106 pég̨.,5 láminas; rústica.Dieciséis pesetas.

31 ANUARIO DE ESTUDIOS AMERICANOS.-TOMO III, 1946. $-24 \times 17 \mathrm{cms} ., \mathrm{XVI}+1.306$ páał., 59 láminas; rústica.

32 Julia Herreez $S$. de Escáriche: DON PEDRO ZAPATA DE MENDOZA, GOBERNADOR DE CARTAGENA DE INDIAS. $-24 \times 17 \mathrm{cms}$., VIIII+138 págs., 6 láminas; rística.Dieciocho pesetas.

33 Manuel Giménez Fernández: LAS DOCTRINAS POPULISTAS EN LA INDEPENDENCIA DE HISPANOAMERICA. $-24 \times 17$ cms., VIII +156 págs.; rústica.-Veinticinco pesetas.

34 Guillermo Céspedes del Castillo: LIMA Y BUENOS AIRES. REPERCUSIONES ECONOMICAS Y POLITICAS DE LA CREACION DEL VIRREINATO DEL PLATA. $24 \times 17$ cms., VIII+216 páginas; 6 láminas; rústica.-Treinta y cinco pesetas.

35 Antonio Rumeu de Armas: LOS VIAJES DE JOHN HAWKINS A AMERICA (1562-1595). $-22 \times 16 \mathrm{cms}$., $\mathrm{XX}+486$ 
páginas; 26 láminas; tela, con sobrecubierta.-Ochenta pesetas.

36 Diego Angulo Iñiguez: EL GOTICO Y EL RENACIMIENTO EN LAS ANTILLAS. ARQUITECTURA, ESCULTURA, PINTURA, AZULEJOS, ORFEBRERIA.-24 $\times 17$ centímetros, VIII+102 págs.,81 ilustraciones; rústica.-Treinta y cinco pesetas.

37 Fernando Díaz Venteo: LAS CAMPANAS MILITARES DEL VIRREY ABASCAL。 $-22 \times 16 \mathrm{cms}$., VIII+416 páginas; tela, con sobrecubierta.

\section{EDICIONES EN PRENSA:}

19 Florentino Pérez Embid: LOS DESCUBRIMIENTOS EN EL ATLANTICO HASTA EL TRATADO DE TORDESILLAS.

27 Vicente Rodríguen Casado y Florentino Pérez Embid: CONSTRUCCIONES DEL VIRREY AMAT.

38 ANUARIO DE ESTUDIOS AMERICANOS.-Tomo IV, 1947.

EDICIONES DEL ANTIGUO CENTRO DE HISTORIA DE AMERICA:

Ernosto Schäfer: LAS RUBRICAS DEL CONSEJO REAL Y SUPREMO DE LAS INDIAS DESDE LA FUNDACION DEL CONSEJO EN 1524 HASTA LA TERMINACION DEL REINADO DE LOS AUSTRIAS. $-31 \times 22$ ems., 64 páginas, con láminas y texto explicativo; rústica.-Treinta y cinco pesetas.

Ernesto Schäfer: EL CONSEJO REAL Y SUPREMO DE LAS INDIAS.-TOMO I: HISTORIA Y ORGANIZACION DEL CONSEJO Y DE LA CASA DE LA CONTRATACION DE LAS INDIAS. - $25 \times 17 \mathrm{cms}$., XVII +436 págs., 4 láminas; tela, con sobreeubierta.-Se vende con el tomo II, editado por la Escuela.

ESCUELA DE ESTUDIOS HISPANO-AMERICANOS

PUBLICACIONES

ALfonso XII, I2.SEVILLA 





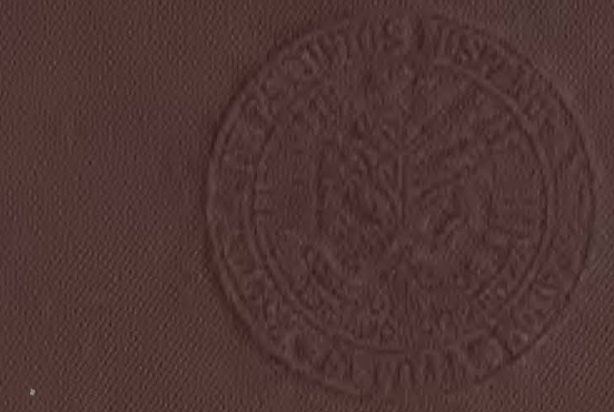


D) $A=$ WENT ES

CAMEAMA:

MIU I

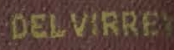

An ASCHA

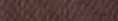

